\title{
Resocialisatie en detentie
}

Citation for published version (APA):

Nelissen, P. P. (2000). Resocialisatie en detentie: een onderzoek naar de houdingen van gedetineerden en gevangenispersoneel ten aanzien van de voorbereiding van de terugkeer in de samenleving. [, Maastricht University]. Universiteit Maastricht. https://doi.org/10.26481/dis.20000928pn

Document status and date:

Published: 01/01/2000

DOI:

10.26481/dis.20000928pn

Document Version:

Publisher's PDF, also known as Version of record

\section{Please check the document version of this publication:}

- A submitted manuscript is the version of the article upon submission and before peer-review. There can be important differences between the submitted version and the official published version of record.

People interested in the research are advised to contact the author for the final version of the publication, or visit the DOI to the publisher's website.

- The final author version and the galley proof are versions of the publication after peer review.

- The final published version features the final layout of the paper including the volume, issue and page numbers.

Link to publication

\footnotetext{
General rights rights.

- You may freely distribute the URL identifying the publication in the public portal. please follow below link for the End User Agreement:

www.umlib.nl/taverne-license

Take down policy

If you believe that this document breaches copyright please contact us at:

repository@maastrichtuniversity.nl

providing details and we will investigate your claim.
}

Copyright and moral rights for the publications made accessible in the public portal are retained by the authors and/or other copyright owners and it is a condition of accessing publications that users recognise and abide by the legal requirements associated with these

- Users may download and print one copy of any publication from the public portal for the purpose of private study or research.

- You may not further distribute the material or use it for any profit-making activity or commercial gain

If the publication is distributed under the terms of Article $25 \mathrm{fa}$ of the Dutch Copyright Act, indicated by the "Taverne" license above, 


\section{RESOCIALISATIE EN DETENTIE}

Een onderzoek naar de houdingen

van gedetineerden en gevangenispersoneel ten aanzien van de voorbereiding van de terugkeer in de samenleving

\section{PROEFSCHRIFT}

ter verkrijging van de graad van doctor aan de Universiteit Maastricht, op gezag van de Rector Magnificus,

Prof. dr. A.C. Nieuwenhuijzen Kruseman, volgens het besluit van het College van Decanen,

in het openbaar te verdedigen op donderdag 28 september 2000 om 16.00 uur

door

Peter Philippus Nelissen 


\section{Promotores:}

Prof. mr. G.P.M.F. Mols

Prof. dr. J.P.S. Fiselier (Rijksuniversiteit Groningen)

\section{Co-promotor:}

Mr. dr. M. Moerings (Universiteit Utrecht)

\section{Beoordelingscommissie:}

Prof. mr. E. Prakken (voorzitter)

Mr. G. de Jonge

Prof. mr. C. Kelk (Universiteit Utrecht)

Dr. M.M. Kommer (Ministerie van Justitie) 
Voor mijn ouders 


\section{Voorwoord}

Halverwege de jaren negentig bleek, althans in Nederland, de aandacht voor resocialisatie in het penitentiaire beleid en in het wetenschappelijk onderzoek aanmerkelijk verminderd te zijn. Het was een onderwerp, zo bleek bijvoorbeeld bij het aanvragen van subsidie voor dit onderzoek, dat van belcidswegen geen prioriteit genoot. Resocialisatie was, zo werd mij van sommige zijden wel eens te verstaan gegeven, een achterhaald onderwerp, waaraan in beleidsmatige en wetenschappelijke zin eigenlijk niet zo veel eer meer te behalen viel. Dit denkklimat had uiteraard ook gevolgen voor de wijze waarop ik dit promotie-onderzoek ging verrichten. Het was vooral een kwestie van het optimaal benutten van de tijd die mij restte na mijn gewone dagelijkse werkzaamheden. Het was met name in de periode van de voorbereidingen van het veldonderzoek ook een kwestic van haast maken. Je kon in die periode immers nooit weten welke gevolgen de versobering van de gevangenisregimes had voor het ondervragen van de doelgroep over bepaalde activiteiten. Voor het overige was het schrijven van dit proefschrift voor mij toch vooral een plezierige en spannende bezigheid, met name op de momenten waarop zich via het computerscherm orde en systeem begon af te tekenen in een betrekkelijk onontgonnen terrein.

Dit proefschrift zou niet geschreven zijn zonder de ondersteuning en het onvoorwaardelijke vertrouwen van mijn promotoren. Allereerst gaat mijn dank uit naar Gerard Mols die als cerste promotor de richting van het onderzoek steeds op het juiste moment wist te bepalen. $\mathrm{Zijn}$ vertrouwen in het slagen van deze onderneming heb ik steeds als bijzonder waardevol en inspirerend ervaren.

Martin Moerings dank ik voor zijn adviezen die mij in staat stelden eenvoud en orde te scheppen in het onderzoeksmateriaal. Dankzij zijn visie op het onderzoek kreeg ik grip op de materie. Jan Fiselier wil ik bedanken voor zijn commentaar op methodologisch, inhoudelijk en tekstueel gebied, commentaar dat hij mij altijd op bewonderenswaardig voortvarende en nauwgezette wijze deed toekomen.

De leden van de leescommissie wil ik danken voor hun bijzonder waardevolle opmerkingen. Hun commentaar heeft bijgedragen aan de leesbaarheid en evenwichtigheid van het proefschrift.

Verder dank ik drs. A. van Gemmert van de Dienst Justitiële Inrichtingen voor zijn medewerking bij het verkrijgen van toestemming voor het verrichten van dit onderzoek.

In de drie inrichtingen waar het onderzoek in 1996 plaatsvond, kreeg ik veel ondersteuning van het personeel bij de afname van de vragenlijsten. Mijn dank strekt zich uit tot alle medewerkers die mij met raad en daad terzijde stonden. In het bijzonder wil ik hier noemen Jacques Gorissen, indertijd algemeen directeur van P.I. De Geerhorst, Monique Vroemen, unit-directeur van P.I. Oosterhoek te Grave, Nico Plitscher en Leon Hoeben respectievelijk algemeen directeur en hoofd detentiezaken van P.I. Roermond.

Een bijdrage leverde ook Richard Gullikers die als stagiaire van de opleiding Sociaal Pedagogische Hulpverlening een deel van de interviews met gedetineerden en personeel voor zijn rekening nam.

Verder wil ik hier ook de gedetineerden bedanken die bereid waren om mee te werken aan dit onderzoek.

Mijn collega's van de afdeling scholing en vorming van P.I. de Geerhorst te Sittard hebben steeds veel belangstelling getoond voor de vorderingen van mijn proefschrift, waarvoor mijn dank.

Jeanine Schreurs wil ik bedanken voor haar hulp bij het redigeren van het proefschrift. 
Dit proefschrift zou niet zijn geschreven zonder de ondersteuning van mijn vrouw, MarieLouise Schreurs. Vanuit haar betrokkenheid als partner en vanuit haar ervaring met het schrijven van een proefschrift overtuigde zij mij op momenten van twijfel telkens weer van de haalbaarheid. Van haar leerde ik tevens de kunst om met een juiste dosis aan lichtvaardigheid en relativeringsvermogen te werk te gaan. Hoe valak heeft zij nict gezegd: "Het is maar cen proefschrift...".

Tenslotte wil ik hier mijn kinderen Sophie, Izaak en Irene noemen die mij steeds weer op tijd achter de computer vandaan wisten te halen. 


\section{INHOUDSOPGAVE}

1. Achtergrond en probleemstelling van het onderzoek

1.1. Inleiding

1.2. Resocialisatie als doelstelling van het strafrecht

1.2.1. Resocialisatie als intrinsieke en instrumentele doelstelling van het strafrecht

1.2.2. De noodzaak van een gelijktijdig nastreven van doelstellingen

1.2.3. Conflicten tussen doelstellingen van het strafrecht

1.3. Relevantie van het onderzoek vanuit de ethisch normatieve betekenis van de resocialisatie-gedacht

1.3.1. Desillusie omtrent een ideaal

1.3.2. Functionalistische argumenten versus normatieve overwegingen

1.3.3. De rationalisering van de strafrechtspleging.

1.3.4. Implicaties voor het onderzoek.

1.4. De relevantie van het onderzoek vanuit de optiek van de penologic 10

1.4.1. Penologie

1.4.2. Nothing Works: Niets werkt?

1.4.3. De nadruk op recidive-cijfers

1.4.4. Het functioneren van de voorzieningen tijdens de detentie

1.4.5. Implicaties voor het onderzoek 16

1.5. Relevantie van het onderzoek vanuit het perspectief van de gevangenis als samenleving en organisatie

1.5.1. Resocialisatie in de context van een schadelijke omgeving

$\begin{array}{ll}\text { 1.5.2. De pychosociale kwaliteit van de detentie } & 18\end{array}$

1.5.3. Resocialisatie in de context van personeel en organisatie 20

$\begin{array}{ll}\text { 1.6. Probleemstelling van het onderzoek } & 21\end{array}$

$\begin{array}{ll}\text { 1.7. Opbouw van het boek } & 24\end{array}$

2. Resocialisatie en het beleid van het Nederlandse gevangeniswezen 27

\begin{tabular}{ll}
2.1. & Inleiding \\
\hline
\end{tabular}

$\begin{array}{ll}\text { 2.2. Het begrip resocialisatie } & 27\end{array}$

2.2.1. Het begrip resocialisatie en aanverwante begrippen $\quad 27$

$\begin{array}{ll}2.2 .2 \text {. Een omschrijving van het begrip resocialisatie } & 28\end{array}$

2.3. Het streven naar zedelijke verbetering door eenzame opsluiting in

2.4. Resocialisatie in de twintigste eeuw 33

2.4.1. Het ontstaan van het verbeteringsstreven als speciaal-preventieve doelstelling $\begin{array}{ll}\text { van het strafrecht } & 33\end{array}$

2.4.2. Ontwikkelingen na 1945: de resocialisatie-opdracht van art. 26 Beginselenwet 36

2.4.3. Ontwikkelingen in de jaren vijftig en zestig 38

2.4.3.1. Resocialisatie en de humanisering van de detentie $\quad 39$

$\begin{array}{ll}\text { 2.4.3.2. De Utrechtse School } & 40\end{array}$

2.4.3.3. Verklaringen voor het humaniserende karakter van het resocialisatie-streven 41

2.4.4. De teloorgang van het resocialisatie-ideaal in de jaren zeventig en tachtig 44 
2.4.4. I. De minder ambitieuze invulling van de resocialisatic-opdracht: de nota Taak en Toekomst

2.4.4.2. Humanisering van de detentic

2.4.4.4. De ontwikkeling van het strafrechtelijk klimaat in de loop van de jaren tachtig verharding en verzakelijking

2.4.5. Het penitentiaire beleid in de jaren negentig: matschappelijke integratie en de veiligheid op lange termijn op lange termijn.

2.4.5.1. Uitgangspunten van Werkzame Detentie

2.4.5.2. De nadruk op het punitieve en vergeldende karakter van de straf

2.4.5.3. Het standaardregime

2.4.5.4. Maatschappelijke integratic

2.4.5.5. De terugkeer van recidive-vermindering als succescriterium voor maatschappelijke integratie

2.4.5.6. Werkzame Detentie: pragmatisch detentiebeleid?

2.4.5.7. De praktische uitvoering van Werkzame Detentie

2.5. De voorzieningen ten behoeve van resocialisatie: overzicht en inhoud 60

2.5.1. De voorzieningen ten behoeve van resocialisatic: een overzicht 60

2.5.1.1. Individualisering en differentiatie 60

2.5.1.2. Fasering en regionalisering van de detentic 61

2.5.1.3. Het penitentiair programma en maatschappelijke integratic programma's 62

2.5.1.4. Het regimesactiviteiten-programma $\quad 63$

2.5.2. Regimesactiviteiten en deconcentratic 65

2.5.3. De regimesactiviteiten en hun relevantie voor het onderzoek 66

2.5.4. Het penitentiair onderwijs 68

2.5.4.1. Historische ontwikkeling 68

2.5.4.2. Penitentiair onderwijs: doelgroepen, leergebieden en randvoorwaarden 69

2.5.4.3. Recente ontwikkelingen 71

$\begin{array}{ll}\text { 2.5.5. Kunstzinnige vorming } & 72\end{array}$

$\begin{array}{ll}\text { 2.5.5.1. Historische ontwikkeling } & 72\end{array}$

2.5.5.2. Doelstellingen van de kunstzinnige vorming $\quad 73$

2.5.5.3. Kunstzinnige vorming in de jaren negentig van de twintigste eeuw

$\begin{array}{lll}\text { 2.5.6. Het penitentiair reclasseringswerk } & 75\end{array}$

2.5.6.1. Psychosociale hulpverlening in de inrichting $\quad 75$

2.5.6.2. Het penitentiair reclasseringswerk: historische ontwikkeling 76

2.5.6.3. Recente ontwikkelingen in het penitentiair reclassingswerk 78

2.5.6.4. Doelstellingen en kenmerken van het penitentiair reclasseringswerk 79

2.5.7. De gestichtsarbeid 81

2.5.7.1. Historische ontwikkeling 81

2.5.7.2. De rol van de arbeid in de nota Werkzame Detentie $\quad 82$

2.6. Samenvatting en discussie 83

3. Houding ten aanzien van resocialisatie: een literatuuroverzicht $\quad 89$

$\begin{array}{ll}3.1 . & 89\end{array}$

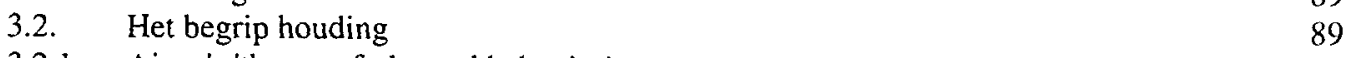

3.2.1. Ajzen's 'theory of planned behavior' $\quad 91$

3.3. Resocialisatie: het denklimaat in de jaren negentig 93

3.4. Meningen van Nederlandse gedetineerden over detentie 95

3.5. Onderzoek van de opvattingen van gedetineerden over de resocialisatiedoelstelling 96 
3.6. Gedetineerden en hun beleving van de activiteiten: een overzicht van het onderzoek

3.6.1. De beleving van de activiteiten in de context van de detentie-situatic

3.6.2. De beleving van de activiteiten in de context van de persoonlijke ontwikkeling en (toekomstige) levensssituatie

3.6.3. Beleving van ontwikkelingsactiviteiten: resultaten van recent onderzoek

3.6.4. Beleving van hulpverleningsactiviteiten

3.7. Samenvatting en conclusies

4. Theoretische achtergronden van het onderzoek

4.1. Inlciding

4.2. Naar een interactionistisch conceptueel model:uitgangspunten

4.2.1. Verklaringsmodellen

114

4.2.2. Het begrip interactic

115

4.2.3. De aanpassing aan de detentie als interactie tussen individu en omging

4.2.4. Een interactionistische benadering van houdingen ten aanzien van resocialisatie

4.2.5. Detentie, stress en coping

4.2.6. Het begrip programma-integriteit

4.3. Een interactionistisch conceptueel model

4.4. De objectieve ongeving: de -people-changing- organisatie, inrichtingsideologie en beleid

4.4.1. De gevangenis als people-changing organisatie

4.4.2. Inrichtingsideologie

4.5. De subjectieve omgeving en het perspectief van het prisonisatie-onderzoek

4.5.1. Subculturen in Nederlandse inrichtingen

4.5.3. Orde- en gedetineerdengerichte regimes, prisonisatie en de effecten op de houdingen van gedetineerden

4.5.4. De effecten van verblijfsduur en detentiefase 136

$\begin{array}{ll}\text { 4.6. De invloed van persoonsgebonden factoren } & 139\end{array}$

4.7. Recente kritick op het prisonisatie-onderzoek 141

4.8. Coping en houdingen ten aanzien van resocialisatie 143

4.9. Het activiteitenprogramma en de kwaliteit van implementatie: programma-integriteit 148

4.10. Een overzicht van de geselecteerde variabelen 150

4.11. Vraagstellingen naar aanleiding van het verklarend deel van de probleemstelling 151

4.12. Samenvatting en conclusies

5. Opzet en uitvoering van het onderzoek onder gedetineerden 155

5.1. Inleiding 155

5.2. Dataverzameling, procedure en respons 155

$\begin{array}{ll}\text { 5.2.1. De onderzoeksgroep en de inrichtingen } & 155\end{array}$

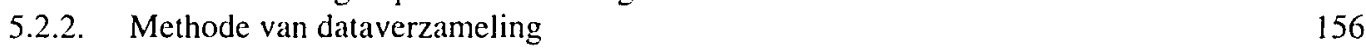

$\begin{array}{ll}\text { 5.2.3. Procedure } & 157\end{array}$

5.2.4. Respons in de inrichting te Sittard 158

5.2.5. Respons in de inrichting te Grave 158

5.2.6. Respons in de inrichting te Roermond 159

$\begin{array}{ll}\text { 5.3. Een beschrijving van de onderzoeksinstrumenten } & 159\end{array}$

$\begin{array}{ll}\text { 5.3.1. Opvattingen over resocialisatie } & 160\end{array}$

$\begin{array}{ll}\text { 5.3.1.1. Belang van Resocialisatie } & 160\end{array}$ 
5.3.1.2. Scepsis ten aanzien van de gevangenis als resocialiserend instituut 161

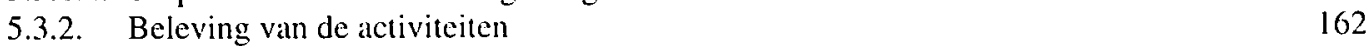

$\begin{array}{lr}\text { 5.3.2.1. Beleving van onderwijsactiviteiten } & 162\end{array}$

$\begin{array}{ll}\text { 5.3.2.2. Beleving van kunstzinnige vorming } & 163\end{array}$

$\begin{array}{ll}\text { 5.3.2.3. Beleving van de hulpverleningsactiviteiten } & 164\end{array}$

$\begin{array}{ll}\text { 5.3.2.4. Arbeidssatisfactic } & 165\end{array}$

$\begin{array}{ll}\text { 5.3.2.5. Vrije tijdsbesteding } & 165\end{array}$

$\begin{array}{ll}\text { 5.3.3. Deelname aan de activiteiten } & 166\end{array}$

5.3.4. De subjectieve ongeving: regimesevaluatie 166

5.3.5. Achtergrondkenmerken van persoonlijke, strafrechtelijke en penitentiaire alard 167

$\begin{array}{ll}\text { 5.3.5.1. Persoonskenmerken } & 167\end{array}$

$\begin{array}{ll}\text { 5.3.5.2. Strafrechtelijke en penitentiaire kenmerken } & 168\end{array}$

$\begin{array}{ll}\text { 5.3.6. De kwaliteit van de implementatic } & 169\end{array}$

$\begin{array}{lr}\text { 5.3.6.1. Informatie } & 169\end{array}$

$\begin{array}{ll}\text { 5.3.6.2. Ervaren ondersteuning en begeleiding } & 170\end{array}$

$\begin{array}{ll}\text { 5.3.6.3. Materiaal en middelen } & 170\end{array}$

$\begin{array}{ll}\text { 5.4. } & \text { Beschrijving van de onderzoekspopulatie en representativiteit }\end{array}$

$\begin{array}{lr}\text { 5.4.1. Leeftijd } & 172\end{array}$

$\begin{array}{lr}\text { 5.4.2. Burgerlijke staat } & 172\end{array}$

$\begin{array}{lr}\text { 5.4.3. Culturele achtergrond } & 173\end{array}$

$\begin{array}{ll}\text { 5.4.4. Recidive } & 174\end{array}$

$\begin{array}{ll}\text { 5.4.5. } & \text { Opleiding } \\ 5.4 .6 . & 174\end{array}$

$\begin{array}{lr}\text { 5.4.6. Werkervaring } & 175\end{array}$

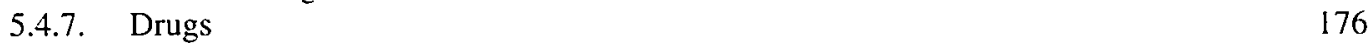

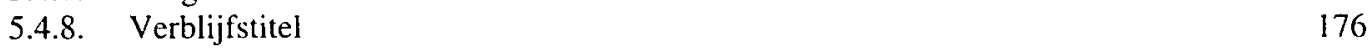

$\begin{array}{ll}\text { 5.4.9. Verblijfsduur ten tijde van het onderzoek } & 177\end{array}$

$\begin{array}{lr}\text { 5.4.10. Strafduur } & 178\end{array}$

$\begin{array}{lr}\text { 5.4.11. Strafrestant } & 179\end{array}$

$\begin{array}{lr}\text { 5.5. De inrichtingen } & 180\end{array}$

$\begin{array}{lr}\text { 5.5.1. Inrichting te Sittard ten tijde van het onderzoek } & 180\end{array}$

$\begin{array}{ll}\text { 5.5.2. Inrichting te Grave ten tijde van het onderzoek } & 183\end{array}$

$\begin{array}{ll}\text { 5.5.3. Inrichting te Roermond ten tijde van het onderzoek } & 185\end{array}$

$\begin{array}{lr}\text { 5.6. Samenvatting en conclusies } & 187\end{array}$

6. Houdingen van gedetineerden: beschrijving van de onderzoeksresultaten 189

$\begin{array}{lr}\text { 6.1. Inleiding } & 189\end{array}$

$\begin{array}{lr}\text { 6.2. Opvattingen over resocialisatie } & 190\end{array}$

$\begin{array}{ll}\text { 6.2.1. Belang van resocialisatie } & 190\end{array}$

6.2.2. De mate van scepsis over de gevangenis als resocialiserend instituut 191

$\begin{array}{ll}\text { 6.3. Deelname aan de activiteiten } & 193\end{array}$

$\begin{array}{ll}\text { 6.3.1. Deelname aan het onderwijs } & 193\end{array}$

$\begin{array}{ll}\text { 6.3.2. Hulpverleningscontacten } & 194\end{array}$

6.3.3. De deelname aan de kunstzinnige vorming 195

$\begin{array}{lr}\text { 6.3.4. Bibliotheekbezoek } & 195\end{array}$

$\begin{array}{ll}\text { 6.3.5. Sportbeoefening } & 196\end{array}$

$\begin{array}{ll}\text { 6.4. Beleving van de activiteiten } & 196\end{array}$

$\begin{array}{lr}\text { 6.4.1. } & 197\end{array}$

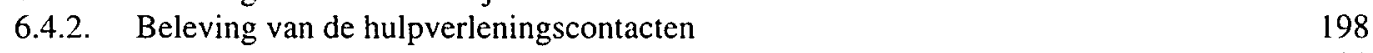

$\begin{array}{ll}\text { 6.4.3. Beleving van de kunstzinnige vorming } & 200\end{array}$ 
6.4.4. Tevredenheid met de vrije tijdsbesteding 201

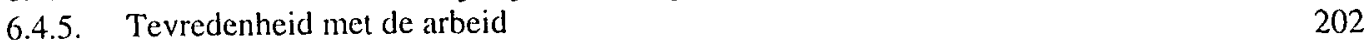

6.5. De houdingen t.av resocialisatie: vergelijking tussen inrichtingen en afdelingen 203

6.5.1. Opvattingen, deelname en beleving vergelen voor drie inrichtingen 203

$\begin{array}{ll}6.5 .1 .1 . & 203\end{array}$

6.5.1.2. Deelname aan de activiteiten 204

$\begin{array}{ll}\text { 6.5.1.3. Beleving van de activiteiten } & 207\end{array}$

6.5.2. Opvattingen, deelname en beleving vergeleken voor afdelingen 208

6.5.2.1. Een vergelijking van opvattingen, deelname en beleving voor afdelingen in de
inrichting te Sittard

6.5.2.2. Een vergelijking van opvattingen, deelname en beleving voor afdelingen in de inrichting te Grave 211

$\begin{array}{ll}\text { 6.6. Samenvatting en conclusies } & 213\end{array}$

7. De onafhankelijke variabelen:

kenmerken van de omgeving, gedetineerden en programma-integriteit 219

$\begin{array}{ll}7.1 & \text { Inleiding }\end{array}$

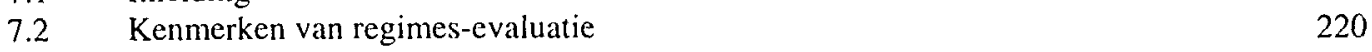

7.3 Kenmerken van contacten met medegedetinecrden $\quad 222$

$\begin{array}{lll}7.4 & \text { Kenmerken van toekomstverwachtingen } & 224\end{array}$

\begin{tabular}{ll}
7.5 & Kenmerken van programma-integriteit \\
\hline 7.5 .1$. & 225
\end{tabular}

$\begin{array}{ll}\text { 7.5.1. Informatieverstrekking } & 225\end{array}$

$\begin{array}{ll}\text { 7.5.2. Ondersteuning en begeleiding } & 225\end{array}$

$\begin{array}{ll}\text { 7.5.3. Materiaal en middelen } & 225\end{array}$

\begin{tabular}{ll} 
7.6. & Samenvatting en conclusies \\
\hline
\end{tabular}

8. Determinanten van de houdingen van gedetineerden ten aanzien van $\begin{array}{ll}\text { resocialisatie } & 229\end{array}$

$\begin{array}{lll}8.1 & \text { Inleiding } & 229\end{array}$

8.2. De relaties tussen opvattingen, beleving en deelname $\quad 230$

8.2.2 Relaties tussen belevingsvariabelen 231

8.2.3 Relaties tussen deelname variabelen $\quad 232$

8.2.4 Relaties tussen opvattingen en deelname $\quad 232$

8.2.5. Relaties tussen opvattingen en beleving $\quad 233$

8.2.6. Relaties tussen deelname en beleving 234

8.3. Relaties tussen omgevingskenmerken, persoonskenmerken, kenmerken van

8.3.1. Relaties tussen omgevingskenmerken en opvattingen ten aanzien van resocialisatie 237

8.3.2. Relaties tussen persoonskenmerken en opvattingen ten aanzien van resocialisatie 238

8.3.3. Relaties tussen kenmerken van programma-integriteit en opvattingen ten aanzien van resocialisatie

8.3.4. Causale modellering van relaties tussen opvattingen en variabelen met betrekking tot de omgeving, persoon en programma-integriteit

$\begin{array}{lll}\text { 8.3.4.1 Resultaten van de causale modellering bij de opvattingsvariabelen } & 241\end{array}$

8.3.5. Relaties tussen omgevingskenmerken en deelname aan de activiteiten 244

8.3.6. Relaties tussen persoonskenmerken en de deelname aan de activiteiten 245

8.3.7. Relaties tussen programma-integriteit en deelname aan de activiteiten 246

8.3.8. Deelname aan de activiteiten en de modellering van de relaties met omgevings- en persoonsgebonden variabelen en programma-integriteit 
8.3.9. Relaties tussen omgevingskenmerken en de beleving van de activiteiten

8.3.10. Relaties tussen persoonskenmerken en de beleving van de activiteiten

8.3.11. De relatie tussen kenmerken van programma-integriteit en beleving van activiteiten

8.3.12 De beleving van de activiteiten en de modellering van de relatie met omgevings- en

8.4. Beantwoording van de verklarende onderzoeksvragen

8.5 Samenvatting en conclusies

9. Houdingen van het personeel ten aanzien van resocialisatie

9.1. Inleiding

9.2. Houdingen van het personeel ten aanzien van resocialisatie: een literatuuroverzicht

9.2.1. PIW-ers en hun opvattingen over de resocialisatie-doelstelling

9.2.2. Detentiedoelen en de takopvattingen van de PIW-er

282

9.2.3. De bewaarder als begeleider van activiteiten: de crea bewaarder

9.3. Overige personeel: de professionele staf en inrichtingsdirectie

9.3.1. De professionele staf

9.3.2. De leiding van de inrichting

9.4. Opzet en uitvoering van het onderzoek onder het personeel 294

9.4.1. Dataverzameling

9.4.2. Respons

295

9.4.3. Methode van onderzock

296

9.4.4. Meetinstrumenten

296

9.4.4.1. Opvattingen over resocialisatie

296

9.4.4.2. Opvattingen over de zin van de vrijheidsbeneming in het algemeen 298

9.4.4.3. Scepsis ten aanzien van de gevangenis als resocialiserend instituut 298

9.4.4.4. Activiteiten

299

9.4.4.5. De gepercipieerde motieven en motivatie van gedetineerden

9.4.4.6 De waargenomen effecten van de kunstzinnige vorming

9.4.4.7. Persoonlijke ontwikkeling

9.4.4.8 Sociale ontwikkeling

9.4.4.9. Hantering van de detentiesituatie door gedetineerden

9.4.4.10 De kunstzinnige vorming en programma-integriteit

9.4.4.11 Taakopvatting: orde-versus gedetineerdengerichtheid

300

300

301

301

302

9.5. Resultaten van de enquête onder het personeel $\quad 302$

9.5.1. Houdingen van de PIW-ers: de opvattingen over de resocialisatie-doelstelling 302

9.5.2. Meningen van PIW-ers over de zin van vrijheidsbenemende sancties 304

9.5.3. Meningen van PIW-ers over de activiteiten in het algemeen

9.5.4. PIW-ers en hun visie op de begeleiding van de activiteiten

9.5.5. PIW-ers en hun mening over de motieven en motivatie van gedetineerden 309

9.5.6. PIW-ers over de waargenomen effecten van de crea-activiteiten 309

9.5.7. PIW-ers over de randvoorwaarden van de activiteiten 311

9.5.8. PIW-ers en hun visie op de omgang met gedetineerden 313

9.5.9. Houdingen van PIW-ers ten aanzien van een orde-gerichte taakopvatting 314

9.5.10. Houdingen van PIW-ers ten aanzien van een gedetineerdengerichte taakopvatting

9.6. Relaties tussen opvattingen van PIW-ers over resocialisatie en de houdingen t.a.v. de taakuitoefening en activiteiten

9.7. Relaties tussen opvattingen van PIW-ers over resocialisatie en de houding ten aanzien van de activiteiten en hun effecten 
9.8. Relaties tussen opvattingen over resocialisatie, taakopvattingen en scepsis enerzijds en het oordecl over randvoorwaardelijke aspecten anderzijds

9.9. Verschillen in houdingen van bewaarders tussen inrichtingen

9.10 Resultaten van de enquête onder de leden van de staf en inrichtingsdirectie

9.10.1. Houdingen van onderwijzers, penitentiair reclasseringswerkers en leden van het management-team: de opvattingen over strafdoelen

9.10.2. Onderwijzers en penitentiair inrichtingswerkers over de effecten van hun werk

9.10.3. Onderwijzers en penitentiair reclasseringswerkers over de randvoorwaarden van hun werk

9.11. Samenvatting en conclusies

10 Samenvatting en conclusies

10.1. Inleiding

10.2. Samenvatting en conclusies van het onderzoek onder gedetineerden

10.2.1. Resocialisatie in historisch perspectief

10.2.2. Instrumenten ten behoeve van resocialisatie

10.2.3. Opvattingen van gedetineerden over resocialisatie

10.2.4. De deelname van gedetineerden aan de activiteiten

10.2.5. De beleving van de activiteiten

10.2.6. Verschillen in houding tussen inrichtingen en afdelingen

10.2.7. De determinanten van de opvattingen ten aanzien van resocialisatie

10.2.8. De determinanten van de deelname aan de activiteiten

10.2.9. De determinanten van de beleving

10.2.10 De rol van prisonisatie

10.2.11 De rol van stress en stresshantering

10.3. Samenvatting en conclusies van het onderzoek onder het personeel

10.4. Wetenschappelijke relevantie van het theoretisch en methodologisch kader

10.5. Slotbeschouwing: mogelijkheden en beperkingen van het resocialisatiestreven

10.5.1. Resocialisatie als aspect van een humaan detentiebeleid

10.5.2. Integratie van de intramurale en extramurale zorg

10.5.3. Naar een juiste beoordeling van doelmatigheid van penitentiaire interventies

10.5.4. Het belang van een multimodale aanpak

10.5.5. Aanpak van criminogene factoren

10.5.6. Het belang van vroegtijdige cognitief/gedragsmatige interventies 357

10.5.7. Resocialisatie tijdens voorlopige hechtenis 358

$\begin{array}{ll}\text { 10.5.8. Motivatie } & 358 \\ \text { 10.5. } & 358 \text {. }\end{array}$

10.5.9. Resocialisatie en de psychosociale kwaliteit van de detentie 359

$\begin{array}{ll}\text { 10.5.10 De invloed van de gedetineerdencultuur } & 360\end{array}$

10.5.11. Verbetering van randvoorwaarden in de organisatie 361

10.6. Aanbevelingen

Literatuur

Bijlagen 


\section{ACHTERGROND EN PROBLEEMSTELLING VAN HET ONDERZOEK}

"Empirical detail can help us appreciate the strengths and the weaknesses of past and present strategies for penal reform". (De Haan, 1990, p. 150)

\subsection{Inleiding}

Al bijna een halve eeuw geeft de wet het Nederlandse gevangeniswezen nadrukkelijk de opdracht de tenuitvoerlegging van de vrijheidsstraf mede dienstbaar te maken aan de voorbereiding van de terugkeer van gedetineerden in de samenleving. Deze opdracht die voor het eerst in 1951 werd vastgelegd in de Beginselenwet Gevangeniswezen, beoogt het behoud en herstel van de maatschappelijke positie van gedetineerden. In de nieuwe Penitentiaire Beginselenwet (PBW) die in 1999 in werking trad, heeft de wetgever het resocialisatie-beginsel gehandhaafd.

In het Nederlandse gevangeniswezen tracht men dit resocialisatiebeginsel onder meer te realiseren door het aanbod van voorzieningen op het gebied van educatie en psychosociale hulpverlening. Gedetineerden zijn niet verplicht van deze voorzieningen gebruik te maken. Het gebruik dat gedetineerden van deze voorzieningen maken is primair afhankelijk van hun eigen initiatief tot maatschappelijk en persoonlijk herstel.

Het streven naar resocialisatie in Nederlandse gevangenissen staat of valt derhalve in belangrijke mate met de houding van gedetineerden. Daarnaast is de houding van het gevangenispersoneel van belang. Het gevangenispersoneel dient immers gedetineerden tot resocialisatie aan te moedigen en hen verder te ondersteunen bij hun inspanningen ten behoeve van een betere toekomst.

In dit onderzoek staat deze houding van gedetineerden en gevangenispersoneel ten aanzien van de resocialisatie-opdracht en de verschillende voorzieningen waarmee men dit doel tracht te verwezenlijken centraal. De uitvoering van de resocialisatie-opdracht wordt in empirische zin onderzocht vanuit het perspectief van de opvattingen en beleving van gedetineerden en personeel. In dit onderzoek worden de meningen van gedetineerden en personeel over het streven naar resocialisatie weergegeven. Hun meningen worden niet alleen beschreven. Het onderzoek richt zich ook op de factoren met betrekking tot de persoon van de gedetineerde en factoren in de detentieomgeving die mogelijk van invloed zijn op hun mening.

Een onderzoek van resocialisatie vanuit een dergelijk perspectief is, blijkens een gang door de onderzoeksliteratuur, tamelijk uitzonderlijk. De vraag hoe gedetineerden en personeel in een Nederlandse penitentiaire inrichting denken over resocialisatie en hoe zij hun betrokken- 
heid bij dit streven beleven, is tot op heden geen voorwerp van alzonderlijke empirische studie geweest.

Als de houdingen van gedetineerden ten aanzien van bepaalde voorzieningen en behoeve van resocialisatie in empirische zin werden onderzocht, dan gebeurde dit voomamelijk in het kader van een breder onderzoek naar de beleving van het regime (Van der Linden, 1981). Dergelijk onderzoek uit de jaren tachtig van de twintigste ceuw levert slechts in summiere zin informatie op over de houdingen vall gedetineerden (en personeel) ten aanzien van het resocialisatiestreven.

Het onderzoek van de jaren negentig levert evenmin vecl betrouwbare informatie op over de opvattingen en beleving van gedetincerden en personeel ten amzien van resocialisatie. In de meeste bronnen treft men overwegend veronderstellingen aan die niet of onvoldoende aan de empirie zijn getoetst.

Zo veronderstelt men in de nota Werkzame Detentic $(1994$, p.53) op grond van een peiling onder gevangenispersoneel dat een meerderheid van de gedetineerden niet of in geringe mate gemotiveerd is om iets van de detentie te maken. Andere, meer betrouwbare bronnen gebaseerd op een peiling onder de gedetineerden zelf, bleken bij verdere naspeuring cenvoudigweg te ontbreken. Niet alleen over de motivatie van gedetinecrden voor inspanningen ten behoeve van een betere toekomst is weinig bekend. De motieven van gedetineerden voor deelname aan de verschillende activiteiten ten bchoeve van hun terugkeer in de samenleving zijn evenmin in empirische zin onderzocht. Ook hier is veclal sprake van veronderstellingen op basis van impressies. In de Nederlandse onderzoeksliteratuur treft men bijvoorbeeld de veronderstelling aan dat voor gedetineerden en personeel het verminderen van de spanningen die het gevolg zijn van de detentiesituatie het voornaamste doel zijn geworden van activiteiten die oorspronkelijk groei en ontwikkeling in de levenssituatie beogen (Melk, 1985, p.753-757; 1993, p.780-784). Voorts wordt gewezen op het postulaat van orde en rust dat prevaleert vanuit het perspectief van het personeel en organisatic en waaraan het ideële doel (resocialisatie) ondergeschikt is (Melk, 1985, p.752; Kelk, 1993, (1), p.56).

Het buitenlandse, overwegend Anglo-Amerikaanse onderzoek levert in vergelijking met het Nederlandse onderzoek jets meer betrouwbare informatie op over de houdingen van gedetineerden en personeel ten aanzien van resocialisatie. Met name over de beleving van het penitentiair onderwijs door gedetineerden is in empirische zin meer bekend. Toch geldt ook voor het Anglo-Amerikaanse onderzoek dat specifieke studies naar de houdingen van gedetineerden en personeel ten aanzien van resocialisatie betrekkelijk schaars zijn.

Het beeld dat zowel de binnen- als buitenlandse literatuur met betrekking tot het onderwerp van deze studie oplevert, is dat van een braakliggend terrein. En deze constatering geldt in het bijzonder voor het empirisch wetenschappelijk onderzoek van de houdingen van gedetineerden en personeel ten aanzien van de voorbereiding van de terugkeer in de samenleving
in Nederlandse inrichtingen.

Sinds jaar en dag maken Nederlandse gedetineerden gebruik van het penitentiair onderwijs, kunstzinnige vorming en psychosociale hulpverlening maar tegelijkertijd weten we niet wat het nu precies voor gedetineerden betekent om een cursus bij het onderwijs te volgen, bezig te zijn met kunstzinnige activiteiten of regelmatig een gesprek te hebben met de medewerkers van de reclassering. Hoe passen deze activiteiten in hun toekomstbeeld? Speelt die toekomst in een detentiesituatie wel zo'n belangrijke rol? Welke betekenis heeft de resocialisatiedoelstelling als zodanig voor gedetineerden en personeel? Al bijna vijftig jaar geldt de resocialisatie-opdracht aan het gevangeniswezen als een belangrijke opdracht en toch zijn

deze vragen zijn door de penologie eigenlijk nooit in uitgebreide zin beantwoord.
De vraag is echter of het nog wel de moeite waard is resocialisatie vanuit een dergelijk
perspectief te onderzoeken perspectief te onderzoeken. Over resocialisatie en de gevangenis lijkt zo langzamerhand alles 
wel duidelijk. Van een gevangenisstraf wordt niemand beter. De gevangenis werkt juist averechts als het om het welzijn en de toekomst van gedetineerden gaat. Het recidiveverminderend effect van de voorzieningen gericht op een betere toekomstige maatschappelijke positie is nog steeds niet indrukwekkend.

Bovendien is in het afgelopen decennium twijfel gegroeid over de zin en het nut van een breed en, volgens de nota Werkzame Detentie (1994, p.14), een te weinig geclausuleerd en doelgericht aanbod van deze voorzieningen. De twijfels gelden bovendien de ontvankelijkheid van de huidige gedetineerdenpopulatie voor het resocialisatie-streven.'

Onder meer op grond van deze twijfels is het penitentiaire beleid in het afgelopen decennium restrictiever geworden ten aanzien van de mogelijkheden om de terugkeer in de samenleving voor te bereiden. De ruimte binnen de detentiesituatie voor persoonlijke groei en toekomstgerichte perspectieven is ingekrompen. Aandacht voor de persoon van de gedetineerde en zijn perspectief op een betere toekomst zijn, als verworvenheden van een humaan detentiebeleid, steeds meer onder druk komen te staan.

In dit hoofdstuk zal worden uiteengezet dat ondanks deze verminderde aandacht het nog wel degelijk de moeite waard is onderzoek te doen naar resocialisatie, in het bijzonder naar de houdingen van gedetineerden en personeel ten aanzien van dit streven.

In de eerste plaats omdat het hier een streven, of liever, een beginsel betreft dat in de Penitentiaire Beginselenwet van 1999 onverkort is gehandhaafd en dat behoort tot wat Kelk (1993, (2), p.196) noemt:

"een strafrecht met een menselijk gezicht, d.w.z. dat oog heeft voor de individuele noden en behoeften teneinde een individu dat zich misdroeg nieuwe kansen te bieden en dat maatschappelijk van een ongehoorde betekenis is".

Bezien vanuit deze optiek van een humaan strafrecht, is het bieden van een toekomstperspectief aan gedetineerden vooral een kwestie van ethiek, van normen en waarden. In een fatsoenlijke strafrechtspleging mag aan de mens die zich misdroeg, een nieuwe kans in beginsel niet worden onthouden. Een strafrechtspleging waarin men een dergelijk beginsel hoog houdt, heeft baat bij kennis die de humane, ethisch-normatieve betekenis van dat beginsel zichtbaar maakt en benadrukt. Die kennis laat mogelijk zien hoe resocialisatie, als aspect van een strafrecht met een menselijk gezicht, zijn humane strekking waarmaakt. Onderzoek van de houdingen van gedetineerden en personeel ten aanzien van resocialisatie lijkt bij uitstek geschikt om een bijdrage te leveren aan dergelijke kennis.

Een onderzoek van de houdingen van gedetineerden en personeel ten aanzien van resocialisatie is in de tweede plaats zinvol vanuit het perspectief van het penologisch onderzoek waarin men de recidive-verminderende effecten van resocialisatie-programma's probeert vast te stellen.

\footnotetext{
' Over de gedetineerdenpopulatie uit de jaren negentig en hun ontvankelijkheid voor de voorzieningen gebaseerd op de detentie-visie uit de voorgaande decennia merkt de toenmalige gevangenisdirecteur Helgers op: "Met de vervolmaking van deze detentievisie uit de jaren ' 60 en ' 70 , was Justitie ook in de recente periode nog druk aan de gang. Alleen de doelgroep waarvoor deze plannen geschikt waren. bleek nauwelijks meer voorradig binnen onze muren. Onze klei-cursus bleek ongeschikt om de Marokkaanse verslaafde te bewegen zich netjes te gedragen. Onze training sociale vaardigheden beklijfde onvoldoende bij de Turkse beroepscrimineel toen hem netjes gevraagd moest worden uit de speciaal voor hem gelande helikopter te stappen. Hij vloog gewoon weg! De lummel." (bron: NRCHandelsblad, maart 1993).
} 
Met het verrichten van dit type effectivitcitsonderzoek is men met name in de Verenigde Staten en Canada, ondanks het verbleken van het resocialisatie-idealal in de laatste twee decennia van de twintigste eeuw, onverminderd voortgegaan. Sindsdien is het inzicht in de factoren die van invloed zijn op het succes van resocialisatie-programma's langzaam maar zeker toegenomen.

Het staat inmiddels wel vast dat men bij het beantwoorden van de vraag wat werkt op het gebied van penitentiaire interventies niet voorbij kan gaan aan de vraag hoe de interventie in een detentiesituatie werkt. Dit pleidooi voor een vermeerdering van procesmatige kennis impliceert de bestudering van het verloop of het functioneren van resocialisatie-programma's onder meer vanuit het perspectief van de beleving en opvattingen van de participanten. Een onderzoek van de houdingen van gedetineerden en personeel ten aanzien van resocialisatie ontleent zijn relevantic dus tevens aan een groeiende behoefte aan procesmatige kennis bij de evaluatie van de effecten van resocialisatieprogramma's.

Een derde belangrijke reden voor onderzoek van de houdingen van gedetineerden en personeel heeft betrekking op de organisationele optiek van het resocialisatie-streven. De resocialisatie-opdracht dient op een adequate, verantwoorde en optimale wijze te worden uitgevoerd in een omgeving of organisatic die min of meer haaks staat op het streven naar een betere toekomst.

Het verblijf in een gevangenis kan immers gepaard gaan met schade voor het (toekomstige) welzijn van gedetineerden. Bovendien dient de zorg voor cen adequate terugkeer in de samenleving plaats te vinden in een organisatie met een bureaucratisch en beveiligingsgericht karakter.

De gevangenis als organisatie of samenleving kent kortom tal van potentiële belemmeringen voor een adequate en optimale zorg voor de terugkeer in de samenleving. Een optimale zorg veronderstelt kennis van belemmerende factoren in de gevangenis als gemeenschap en organisatie. Dergelijke kennis kan met name worden verkregen door onderzoek van de houdingen van gedetineerden en personeel ten aanzien van de resocialisatie-doelstelling. Vanuit een ethisch normatieve, penologische en organisationele optiek blijken er dus geldige redenen aanwijsbaar voor een onderzoek naar de houdingen van gedetineerden en personeel ten aanzien van resocialisatie. Die redenen zullen in dit hoofdstuk verder worden toegelicht.

Hieraan vooraf gaat een korte uiteenzetting over resocialisatie als doelstelling van het strafrecht. Ter besluit van dit hoofdstuk wordt de probleemstelling van het onderzoek geformuleerd en een overzicht gegeven van de opbouw dit boek.

\subsection{Resocialisatie als doelstelling van het strafrecht}

\subsubsection{Resocialisatie als intrinsieke en instrumentele doelstelling van het strafrecht}

Uitgangspunt bij de beschouwing over de relevantie van het onderzoek vormt het onderscheid tussen resocialisatie als instrumentele doelstelling en resocialisatie als intrinsieke doelstelling van het strafrecht.

De term 'instrumenteel' betekent volgens Denkers (1976, p.99-100) dat "de doelstellingen voor het strafrecht een instrument zijn voor het meest algemene en abstracte doel van het strafrecht: de ordening van de samenleving (in een bepaalde sector) en de reductie, of regulatie van criminaliteit." Het object van beïnvloeding bij de instrumentele doelstellingen hebben, aldus Denkers, steeds betrekking op iets of iemand anders dan het strafrechtelijk apparaat en zijn functionarissen: een fictieve orde, daders, potentiële daders, slachtoffers en hun naasten, het publiek. 
Bij resocialisatie als instrumentele doelstelling tracht men via een bepaalde interventie het gedrag van justitiabelen, in casu gedetineerden, in positieve zin te beïnvloeden. Men tracht tijdens de detentie iemands persoonlijkheid of maatschappelijke positie op dusdanige wijze te beïnvloeden, dat de kans op toekomstig crimineel gedrag kleiner wordt.

Het resocialisaticdoel behelst echter meer dan een functioneel streven naar vermindering van toekomstig crimineel gedrag van justitiabelen. Men kan het bieden van nieuwe kansen aan gedetineerden ook zien als een doel waartoe wij, afgezien van de vraag wat het uit het oogpunt van gedragsbeïnvloeding oplevert, in humane, morele of juridisch normatieve zin zonder meer zijn gehouden. Vanuit deze visie is behoud of herstel van de (maatschappelijke) positie van gedetineerden een principe van behoorlijke strafrechtspleging en niet zozeer een kwestie van nut in termen van beïnvloeding van het gedrag van justitiabelen. De leidende gedachte is hier in essentie dat de burger door een detentie niet volledig buiten de samenleving wordt gesteld. Gedetineerden dienen volgens deze visie tijdens en na een detentie zoveel mogelijk deel te blijven hebben aan de samenleving en aan de waarden die wij in die samenleving centraal hebben gesteld. Aantasting van de integriteit van de gede-tineerde als (mede)mens of, vanuit een juridische optiek, als rechtsgenoot dient derhalve te worden beperkt. Een dergelijk streven naar (rechts)bescherming van gedetineerden kan voortvloeien uit humane motieven van solidariteit en sociale gevoelens, de rechtsmoraal, het idee van de rechtsstaat, (grond)rechten van de mens en wettelijke rechtsbeginselen (Kelk, 1993, (1), p.34 en 35).

De resocialisatie- opdracht in de Penitentiaire Beginselenwet (art.2 lid 2) en in de oude Beginselenwet (art. 26, in werking getreden in 1953) is zo'n wettelijk beginsel. Het draagt, met handhaving van het karakter van de straf, op tot het mede (art.26 Beg.wet) of zoveel mogelijk (art.2 lid 2 PBW) dienstbaar maken van de vrijheidsstraf of de vrijheidsbenemende maatregel aan de voorbereiding van de terugkeer van de gedetineerde in de maatschappij.

Volgens Kelk (1993, (1), p.34) tendeert dit wettelijk resocialisatie-beginsel naar participatie van de gedetineerde in het recht, dus naar diens rechtsburgerschap, in het bijzonder naar diens sociale medeburgerschap (zie voor een meer uitgebreide bespreking van deze opdracht, hoofdstuk 2).

Dit wettelijk resocialisatie-beginsel heeft dus vooral een juridische, rechtsbeschermende dimensie. Dit blijkt ook duidelijk uit het feit dat de opdracht gericht is aan de functionarissen van het gevangeniswezen. $\mathrm{Zij}$ zijn het object van beinvloeding. Bij de resocialisatiedoelstelling in instrumentele zin daarentegen, zijn de justitiabelen het object van beïnvloeding.

Het resocialisatiestreven draagt dus een tweezijdig karakter. Naast een instrumenteel element is er tevens sprake van een ethisch, normatief en rechtsbeschermend element. Waar de bescherming van justitiabelen op grond van het recht, opgevat als een systeem van intrinsieke wąarden in het geding is, draagt het resocialisatie-streven tevens het karakter van een intrinsieke doelstelling van het strafrecht (Denkers, 1976, p.100-107). In het penologisch debat over straffen en resocialiseren wordt deze intrinsieke, ethisch-normatieve dimensie van het resocialisatie-streven veelal genegeerd. De aandacht is doorgaans gericht op een vermeend, gering effect in termen van recidive-vermindering.

Het gevangeniswezen geeft gestalte aan het resocialisatiebeginsel door middel van bepaalde instrumentele doelen. Die doelen kunnen in enge zin zijn geformuleerd en louter betrekking hebben op recidive- vermindering. $\mathrm{Zij}$ kunnen ook in ruime zin zijn geformuleerd en betrekking hebben op andere gedrags- of houdingsveranderingen (bijvoorbeeld betere sociale redzaamheid in de samenleving of bepaalde houdingsveranderingen tijdens detentie).

Deze instrumentele doeleinden verwezenlijkt men onder meer met behulp van bepaalde voorzieningen op het gebied van educatie en psychosociale hulpverlening. 
Die realisering voltrekt zich niet in het luchtledige maar in de organisatorische context van een stratrechtelijk apparaat. In en door middel van het strafrechtelijk apparaat krijgen de eigenlijke intrinsieke en instrumentele doelstellingen van het stratrecht gestalte. De organisatic zelf is strikt genomen ecn middel en geen doel. Ondat de organisatic zelf tal van complexe problemen met zich meebrengt en het zoeken van oplossingen daarvoor als een zelfstandige doelstelling worden gezien kan men in de context van de organisatic toch spreken van organisationele doelstellingen (Denkers, 1976, p.108).

\subsubsection{De noodzaak van een gelijktijdig nastreven van doelstellingen}

Een wezenlijke eigenschap van het strafrecht in het algemeen is de noodzaak van het gelijktijdig nastreven van intrinsieke, instrumentele en organisationele doelstellingen (Denkers, 1976, p.84). Aan alle typen doelstellingen moet in beginsel recht worden gedaan. Deze eigenschap manifesteert zich ook bij de verwezenlijking van de resocialisatiedoelstelling.

Zo is het niet verstandig resocialisatie enkel en alleen in het teken van het instrumentele doel van gedragbeinvloeding te zetten. Dit kan een gevaar opleveren voor de rechtsbescherming van justitiabelen. Een voorbeeld: gedwongen castratie van zedendelinquenten is uit speciaalpreventieve overwegingen wellicht zeer effectief, malar uit het oogpunt van cen humane strafrechtspleging en van rechtsbescherming van de delinquent niet toelatbaar. Een ander voorbeeld: het afschaffen van resocialisatie enkel vanwege het geringe effect op (toekomstig) crimineel gedrag staat op gespannen voet met een humane strafrechtspleging die de ontspoorde mens een nieuwe kans biedt.

Omgekeerd is het onmogelijk resocialisatic enkel en alleen in het teken te zetten van humanitaire en ethische overwegingen en de vraag wat men ervoor terug krijgt in de vorm van bepaalde effecten, te negeren. De overheid moet immers bij het streven naar maatschappelijke veiligheid aan de samenleving bepaalde resultaten kunnen tonen. Men kan daarom niet voorbij gaan aan de vraag naar de (toekomstige) effecten van resocialisatie.

$\mathrm{Er}$ is, zo blijkt uit deze voorbeelden niet alleen sprake van een noodzaak van gelijktijdig nastreven. Er treedt ook onvermijdelijk een spanning op tussen de intrinsieke, instrumentele en organisationele doelstellingen van het strafrecht.

\subsubsection{Conflicten tussen de doelstellingen van het strafrecht}

De spanning of het conflict tussen de verschillende typen doelstellingen vormt eveneens een wezenlijke eigenschap van het strafrecht. De verschillende categorieën doelstellingen kunnen onderling conflicteren en binnen een bepaalde categorie conflicteren.

$\mathrm{Bij}$ het resocialisatie streven is in art. 2 lid $2 \mathrm{PBW}$ (voorheen art.26 Beginselenwet) een belangrijk conflict ingebouwd. Het artikel draagt weliswaar op de tenuitvoerlegging van de vrijheidsstraf mede in het teken van resocialisatie te stellen, maar hierbij dient het strafkarakter van de vrijheidsbeneming gehandhaafd te blijven.

Handhaving van het strafkarakter in de aanhef van het artikel impliceert het nastreven van een instrumenteel doel namelijk, opzettelijke leedtoevoeging omwille van vergelding. Het tweede deel van het artikel geeft de opdracht tot resocialisatie van gedetineerden. Vergelding en resocialisatie conflicteren hier met elkaar. Bovendien hoe meer vergelding des te minder resocialisatie en omgekeerd.

Conflicten tussen de resocialisatie-doelstelling en de overige doelstellingen van welk type dan ook kunnen zich in tal van combinaties en gedaantes voordoen. Echter één type conflict namelijk dat tussen de humaan-ethische overwegingen en/of gecodificeerde rechtsbeginselen (de intrinsieke doelstellingen) enerzijds en de instrumentele en organisationele doelstellingen 
van het strafrechtelijk apparaat anderzijds geldt als cen bijzonder fundamenteel en groot conflict waarvan het strafrecht als totaal systeem doortrokken is (Denkers, 1976, p.134).

Dit conflict is van alle tijden. In het recente beleid van het gevangeniswezen wordt het conflict onder meer zichtbaar in de manier waarop men over straffen en resocialiseren denkt. In deze manier van denken spelen instrumentele en beheersmatige doeleinden van het justitiële bedrijf een dermate prominente rol dat resocialisatie, opgevat als een doelstelling die tevens verwijst naar een intrinsiek systeen van ethische-normatieve waarden niet alleen steeds minder zichtbaar, maar in zekere zin ook kwetsbaar is geworden.

In de volgende paragrafen wordt de relevantie van dit onderzoek belicht vanuit:

1. deze spanning tussen resocialisatie als intrinsieke doelstelling en het instrumentalisme als heersende denkvorm in het strafrecht en het strafrechtelijk beleid;

2. cen instrumentele optiek die is toegespitst op het penologisch onderzoek van de speciaalpreventieve effecten van resocialisatie;

3. een organisationele optiek, waarbij de realisering van de resocialisatie-opdracht in de gevangenis als organisatie en samenleving centraal staat.

\subsection{Relevantie van het onderzoek vanuit de ethisch- normatieve betekenis van de resocialisatie-gedachte}

\subsubsection{Desillusie omtrent een ideaal}

Op een symposium over het straffen in een moderne samenleving dat halverwege de jaren negentig werd gehouden, merkt een van de sprekers op dat in deze tijd nog maar weinigen geloven in resocialisatie. (Symposium: Straffen in de moderne samenleving, Junger-Tas, 1994, p. 40)

Deze scepsis aan het eind van de twintigste eeuw vormt het sluitstuk van een ontwikkeling die veelal wordt beschreven als een geschiedenis van een desillusie omtrent een ideaal. De desillusie betreft primair de mogelijkheid om de vrijheidsstraf te gebruiken voor de verbetering van de gedetineerde. Die vrijheidsstraf resocialiseert niet, zo bleek steeds duidelijker in de jaren zeventig van de twintigste eeuw. De gevangenis verhindert juist zelf het optreden van positieve gedragsveranderingen door de stigmatiserende en ontwrichtende effecten van de detentie op het persoonlijk leven van de gedetineerde.

In de jaren tachtig en in de loop van de jaren negentig van de twintigste eeuw trekt men conclusies uit deze inzichten. De legitimering van de vrijheidsstraf wordt niet meer in het teken gesteld van een toekomstgericht verbeteringsdoel. De vrijheidsstraf vindt zijn rechtvaardiging dan nog hoofdzakelijk in het verleden (vergelding) of in doelen die op het heden (verwijdering uit en beveiliging van de samenleving) zijn gericht. Deze veranderde inzichten omtrent de verbetering van gedetineerden resulteren in het gevangeniswezen van de jaren tachtig van de twintigste eeuw tot een beleid met minder ambitieuze doelstellingen ten aanzien van de voorbereiding van de terugkeer in de samenleving (zie de nota Taak en Toekomst, 1982, p.21).

Vervolgens vermindert de aandacht voor de resocialisatiedoelstelling nog verder in het penitentiaire beleid van de jaren negentig zoals dat in 1994 werd vastgelegd in de nota Werkzame Detentie.

\subsubsection{Functionalistische argumenten versus normatieve overwegingen}

Resocialisatie, in de nota Werkzame Detentie (1994) aangeduid als maatschappelijke integratie, is geen hoofddoelstelling van het beleid meer: zij valt onder de noemer van het 
begrip maatschappelijke veiligheid op lange termijn. Effectieve maatschappelijke integratieprogramma's dienen de veiligheid te bevorderen door recidive-vermindering. Verbetering wordt niet alleen verbonden met het instrumentele beveiligingsdoel, zij wordt daaraan ondergeschikt gemaakt. Deelname aan maatschappelijke integratie-programma's is slechts voorbehouden aan een kleine minderheid (ongeveer 20\%) van de gedetineerden die blijk geven van een duidelijke motivatie. De overige $80 \%$ worden geplaatst in een standaardregime waar men, bij gebleken motivatie, gebruik mag maken van minimale voorzieningen op het gebied van bij voorbeeld basiseducatie (nota Werkzame Detentie, p.16). Een belangrijke reden voor deze regimaire beperkingen op het gebied van de voorbereiding in de terugkeer van de samenleving is de grotere nadruk op het punitieve en vergeldende element van het straffen (nota Werkzame Detentie, p.11). Een andere reden is gelegen in de randvoorwaarde van doelmatigheid (nota Werkzame Detentie, p. 15).

Over resocialisatie wordt louter nog in instrumentele zin gesproken, als intrinsieke doelstelling zoals vastgelegd in de vroegere Beginselenwet in art. 26 en in de huidige Penitentiaire Beginselenwet in art.2 lid 2, lijkt het resocialisatie-streven nauwelijks nog invloed op het penitentiaire beleid van de jaren negentig van de twintigste eeuw uit te oefenen (van Swaaningen en de Jonge, 1995, p.33).

Wees staatssecretaris Scheltema in 1982 in de nota Taak en Toekomst nog op het grote belang van de wettelijke resocialisatie-opdracht (nota Taak en Toekomst, p.25), in de nota Werkzame Detentie wordt over het beginsel met geen woord meer gerept.

Over deze tendens tot veronachtzaming van de ethisch-normaticve aspecten van het straffen en de overheersende rol van instrumentele en organisationele doeleinden in de jaren negentig merkt 't Hart (1993, p.17) op:

"De gevangenis moet beoordeeld worden op rendement. En zoals kenmerkend is bij zo'n instrumentalisme spelen waarden geen rol. Waarden zoals de morele plicht van de samenleving om de medemens die ontspoord is telkens weer nieuwe kansen te bieden, en de morele verantwoordelijkheid voor de menselijkheid en leefbaarheid van een regiem komen niet aan bod."

In wezen beschrijft 't Hart hier een conflict tussen enerzijds resocialisatie als intrinsieke doelstelling en anderzijds instrumentele en organisationele doeleinden van criminele politiek. Ook op andere terreinen van de strafrechtspleging zoals het strafvorderingbeleid en de strattoemeting lijken fundamentele waarden zoals aandacht en respect voor de persoon van de dader (Janse de Jonge, 1990) steeds meer te worden verdrongen door organisatorische, op efficiëntie en uniformiteit gerichte beperkingen, bijvoorbeeld in de vorm van de richtlijnenstelsels.

De humaan-ethische en normatieve aspecten van het straffen in het algemeen en van de resocialisatiegedachte in het bijzonder zijn door deze recente instrumentalistische en technocratische tendensen in de strafrechtspleging (Franke,1990, p.719) niet alleen uit het zicht geraakt, zij zijn door deze ontwikkeling in zekere zin ook kwetsbaar geworden. Het in diskrediet geraken van het resocialisatie-ideaal in de jaren zeventig en begin jaren tachtig van de twintigste eeuw illustreert deze ontwikkeling.

Toen in de jaren zeventig en tachtig duidelijk werd dat resocialisatie in technisch zin, dat wil zeggen als instrumentele doelstelling niet bleek te werken, was het besef van de humaanethische en normatieve waarde van dit streven niet stevig genoeg verankerd in het bewustzijn van het publiek en strafrechtelijke beleidsfunctionarissen om een beleidsmatige aftakeling van deze doelstelling te voorkomen (Garland, 1990, p.186). Het falen van de resocialisatiegedachte werd niet in verband gebracht met een ondeugdelijk normatief beginsel maar met de constatering dat resocialisatie als speciaal preventief instrument 'niet werkt'. Normatieve 
overwegingen legden nauwelijks gewicht in de schaal, functionalistische argumenten voerden de boventoon.

Conrad (1981, p.1725) meent dat de eenzijdige functionalistische oriëntatie van penologen en beleidsmakers op de als maar uitblijvende effecten in termen van recidive-vermindering, in de Verenigde Staten althans, enorme schade heeft aangericht. Vrijwel iedere poging om gevangenen tijdens hun detentie in psychosociale of educatieve zin bij te staan is daardoor zo langzamerhand verdacht geworden. Deze functionalistische denkwijze komt volgens Conrad in essentie neer op een simpele 'alles of niets' redenering: resocialisatie werkt niet dus waarom zouden we er nog langer mee doorgaan?

\subsubsection{De rationalisering van de strafrechtspleging}

Het verminderde zicht op de ethisch-normatieve basis van het straffen en de grote nadruk op functionalistische argumenten in het strafrechtelijke apparaat lijken op het eerste gezicht vooral door nood te zijn ingegeven. De toename van de criminaliteit in de afgelopen vijfentwintig jaar en de eisen die als reactie hierop vanuit de samenleving aan de strafrechtspleging werden gesteld, gaven voor de beleidsmakers aanleiding tot het voeren van een punitiever, slagvaardig en efficiënt beleid ten aanzien van de misdaadbestrijding. Als gevolg van deze ontwikkelingen staat de tenuitvoerlegging van de detentie in de jaren negentig van de twintigste eeuw vooral in het teken van de maatschappelijke veiligheid. Herijking van het beleid acht men noodzakelijk vanwege problemen met betrekking tot de beveiliging van de inrichtingen, de celcapaciteit en de beschikbare financiële middelen en vanwege de verzwaring van de gedetineerdenbevolking.

Toch ligt de verklaring voor een sterker functionalistische karakter van de strafrechtspleging niet uitsluitend in externe maatschappelijke ontwikkelingen. Volgens Garland (1990, p.180190) liggen de oorzaken vooral ook in de ontwikkeling van het strafrechtelijke systeem zèlf besloten. Het systeem heeft in de afgelopen twee eeuwen een proces van rationalisering ondergaan dat zich vooral manifesteert in de vorm van voortschrijdende centralisatie, bureaucratisering en professionalisering.

Met name aan de professionalisering en bureaucratisering van het straffen kent Garland een belangrijke rol toe:

"the professionalization of the punitive process has, in the twentieth century, reached a point where penal professionals have been able to redefine the social meaning of punishment. To the extent that penal measures have become professionalized they have also been removed from direct public participation and involvement and have been cast in a form which de-emphasizes their moral content."(ibid., p.184)

Het proces van bureaucratisering en professionalisering werkt een eenzijdig rationele visie op het straffen als een vorm van social engineering in de hand. Binnen deze visie is straffen vooral een neutrale, amorele en technisch wetenschappelijke activiteit waarbij volgens Garland humane en morele waarden en gevoelens steeds meer worden geschuwd.

Het valt buiten het bestek van deze paragraaf de schaduwzijden van deze ontwikkeling uitputtend te behandelen. Ik beperk mij tot een belangrijk aspect dat door ' $t$ Hart (1993, p.1719) wordt genoemd, namelijk het gevaar dat één instrumentalistische visie het strafrecht monopoliseert en zich niet meer als interpretatie presenteert maar zich voorstelt als de werkelijkheid zelf. Er dient volgens 't Hart ruimte te blijven bestaan voor concurrerende interpretaties waarin wordt gewezen op het recht als een systeem van intrinsieke waarden of beginselen die betrekking hebben op de bescherming van justitiabelen. Strafrechtsfunctionarissen hebben tevens de taak deze rechtsbeginselen waaronder het resocialisatie- 
beginsel te realiseren. Aandacht voor deze taak en zijn ethisch normatieve oorsprong lijkt geboden in de hedendaagse strafrechtspleging die steeds meer wordt gemodelleerd naar een bedrijfsmatig productie-proces waarin aandacht voor de persoon van de dader het steeds meer moet opnemen tegen het streven naar efficiency en uniformiteit.

\subsubsection{Implicaties voor het onderzoek}

Deze conclusie heeft tevens implicaties voor het (empirisch) wetenschappelijk onderzoek van resocialisatie. Hedendaags onderzoek van resocialisatie dient niet uitsluitend gericht te zijn op de instrumentele aspecten van dit streven, met name in de vorm van de (uitblijvende) effecten op de recidive. Het impliceert tevens een type onderzoek dat is gericht op de detentiesituatie en dat vanuit het perspectief van de opvattingen en beleving van gedetineerden en personeel de humaan-ethische betekenis van het resocialisatie-streven zichtbaar maakt.

Dergelijk onderzoek is in essentie gebaseerd op het uitgangspunt dat resocialisatie in de context van de detentiesituatie veel meer positieve functies vervult dan het louter voorkomen of verminderen van recidive. In de volgende paragraaf zal blijken dat deze eenzijdige nadruk op recidive-verminderende effecten van penitentiaire resocialisatie-programma's onderhevig is aan een aantal belangrijke beperkingen

Samenvattend kan worden gesteld dat het resocialisatie-streven alleen al op grond van haar ethisch-normatieve betekenis aandacht verdient van wetenschappelijke zijde. Het betreft hier tenslotte een belangrijk beginsel dat hoort bij een humane strafrechtspleging. In het verlengde van dit belang van het resocialisatiebeginsel ligt de noodzaak van en behoefte aan kennis van haar directe (humanitaire) werking binnen de muren van de gevangenis. Met het oog op deze kennis is een onderzoek van de houdingen van gedetineerden en personeel ten aanzien van het resocialisatie-streven in de eerste plaats relevant.

\subsection{Relevantie van het onderzoek vanuit de optiek van de penologie}

In de vorige paragraaf kwam bij de bespreking van de ethisch-normatieve betekenis van de resocialisatie-doelstelling vrijwel onvermijdelijk ook de instrumentele betekenis van dit streven aan de orde. De bespreking van beide betekenissen vond plaats in de context van het strafrechtelijk beleid. In deze paragraaf wordt de instrumentele betekenis van het resocialisatie-streven louter onderzocht vanuit het perspectief van de empirische wetenschappen, in het bijzonder het penologisch evaluatie-onderzoek. Voor een meer uitgebreide bespreking van resocialisatie als instrumentele doelstelling van het strafrechtelijk beleid van de afgelopen decennia wordt de lezer verwezen naar Hoofdstuk 2.

In deze paragraaf wordt de relevantie van de voorliggende studie besproken vanuit het perspectief van het evaluatie-onderzoek van de speciaal preventieve effecten van resocialisatie-programma's.

\subsubsection{Penologie}

De penologie kan men beschouwen als een specialisatie van de criminologie. In enge zin bestudeert de criminologie de oorzaken en gevolgen van criminaliteit min of meer los van het strafrechtelijk beleid. De penologie legt de verbinding met het strafrechtelijk beleid. In penologisch onderzoek bestudeert men het functioneren van het strafrechtelijk apparaat met behulp van de kennis uit de criminologie en andere sociaal- en gedragswetenschappelijke disciplines. Tot de penologie behoren studies over de effectiviteit van sancties, de besluitvorming van de rechterlijke macht, openbaar ministerie en politie en studies over de gevangenis. 
In deze paragraal komt het penologisch onderzock naar de effectiviteit van penitentiaire interventies aan de orde. Dit onderzoek noemt men ook wel evaluatie-onderzoek, waarbij het vooral gaat om de beantwoording van de vraag of een bepaalde interventie aan zijn doelstellingen beantwoord. Bij evaluatie-onderzoek naar de effecten van resocialisatie gaat het doorgaans om de vraag of een (penitentiaire) interventie van meer specifieke aard (bijvoorbeeld een therapeutisch of educatief programma) of van meer algemene aard (bijvoorbeeld cen bepaalde detentievorm) tot vermindering van crimineel gedrag na detentie leidt. Zowel in Nederland als daarbuiten, met name in de Verenigde Staten, is dit type onderzoek naar de speciaal preventieve werking van resocialisatie-programma's verricht. Het begrip speciale preventic verwijst, in het kort gezegd, naar het voorkomen van recidive bij personen die met Justitie in aanraking zijn geweest.

Een van deze evaluatie-onderzoeken uit de jaren zeventig geldt tot op de dag van vandaag als een van de meest geciteerde studies over resocialisatie. Het betreft hier Martinson's publicatie, 'What Works?'-Questions and Answers about Prison Reform (1974), een studie die tot op heden wordt aangevoerd als bewijs dat resocialisatic niet werkt. De wetenschappelijke discussie naar aanleiding van Martinsons studie en de ontwikkeling van het evaluatie-onderzoek in de jaren tachtig en negentig laten echter zien dat de conclusie dat 'niets werkt', ook wel alangeduid als de 'Nothing Works'-ideologie, op zijn minst voorbarig is.

\subsubsection{Nothing Works: Niets werkt?}

Onderzoekers in binnen- en buitenland concludeerden in de jaren zeventig en begin jaren tachtig van de twintigste ceuw dat resocialisatie geen effect heeft op recidivecijfers. Nederlandse onderzoekers (Fiselier, 1969; Caminada, 1973; Dijksterhuis, 1973; Van der Linden,1981; Berghuis, 1981) onderzochten het recidive-verminderend effect van de strafmodus (open versus gesloten inrichtingen) en verschillende soorten regimes. De strafmodus en het regime, zo bleek uit dit type onderzoek, hadden hooguit een gunstig effect op de korte termijn. Effecten op de lange termijn traden niet op.

De conclusies van het evaluatie-onderzoek in de Verenigde Staten luidden niet veel anders.

Een van de Amerikaanse evaluatie-studies, namelijk die van Martinson (1974) wordt in het algemeen beschouwd als de studie die de definitieve genadeklap voor het resocialisatie-ideaal betekende. Martinson concludeerde na evaluatie van de effecten van een groot aantal resocialisatie-programma's dat niet één type programma in algemene zin, dat wil zeggen voor de daderpopulatie in zijn totaliteit, een methode oplevert die de recidivecijfers terugdringt. Resocialisatie als instrument van criminele politiek bleek te falen. De gedachte dat resocialisatie als een panacee zou kunnen werken voor alle of bijna alle delinquenten werd met Martinsons onderzoeksresultaten ernstig in twijfel getrokken. Aanvankelijk werd zelfs publicatie van Martinsons studie verboden door de opdrachtgever The New York State Governor's Special Committee on Criminal Offenders. Het onderzoek werd potentieel ondermijnend geacht voor de bestaande programma's en werd pas voor publicatie vrijgegeven nadat een advocaat het rapport opeiste als bewijsmateriaal in een rechtzaak (Van Emmerik, 1983, p.7).

Het is evenwel opmerkelijk dat Martinson's studie eigenlijk niets nieuws toevoegde aan de bestaande kennis omtrent de effectiviteit van resocialisatie-programma's. Evaluatieonderzoek uit de jaren vijftig en zestig leverde dezelfde bevindingen op. Toen leidde dit in het algemeen tot de conclusie dat de verschillende resocialisatie-methoden moesten worden verbeterd. In de jaren zeventig echter werd de 'Nothing Works'-conclusie door voorstanders van een meer punitief straf-rechtelijk beleid aangegrepen als een belangrijk argument in een campagne waarin resocialisatie als een verwerpelijk streven werd afgeschilderd.

Cullen en Gilbert (1982, p.112) merken in dit verband op: 
"( ) 'nothing works' became a code word for the more sobering belief that rehabilitation camnot work".

Van Voorhis (1987, p.60) concludeert in de jaren tachtig dat als er één les valt te leren uit de periode na het onderzoek van Martinson het wel deze is: onderzockstesultaten worden selectief gebruikt door politici en beleidsfunctionarissen ter ondersteuning van bepaalde ideologische stellingnamen.

Het onderzoek van Martinson ontketende cen discussie in de penologie walardoor na verloop van tijd de mogelijkheden en beperkingen van het resocialisatie-streven toch meer vanuit hun juiste proporties werden beschouwd.

De bevinding van Martinson dat er voor resocialisatie als instrument van criminele politiek geen enkel type interventie is aan te wijzen dat in algemene zin, dat wil zeggen voor een breder samengestelde groep daders, resulteert in een substantiële recidivevermindering, ondervond vrijwel geen kritiek. De kritiek betrof vooral de conclusie die hieraan werd verbonden, namelijk dat niets werkt. Die conclusie kon eenvoudig niet worden getrokken vanwege de geringe methodologische kwaliteit van de onderzochtc evaluatie-rapporten (Palmer, 1975; Sechrest et al.; 1979, p.34; Gendreau en Ross, 1979, p.462 e.v.; Martin et al., 1981, p.22-27,).

Voorts wezen onderzoekers op de zeer grove maatstaven van het onderzoek van Martinson. Hij negeerde de positieve resultaten en in het bijzonder de vraag waarom een interventie succes oplevert bij het ene type delinquent en bij het andere type niet. Deze onderzoekers bepleitten een onderzoeksaanpak in termen van de vraag wat heeft succes voor welk type gedetineerde onder welke omstandigheden (Palmer, 1975, p.150). Deze benadering wordt in de literatuur aangeduid als het 'differential treatment' perspectiel.

Een belangrijke conclusie die in het Anglo-Amerikaanse evaluatie-onderzoek naar aanleiding van Martinsons studie werd getrokken is dat de progranma's zowel naar hun inhoud als methodologische kwaliteit dienen te worden verbeterd (Sechrest 1979; Martin et al., 1981; Palmer, 1975).

Die conclusie werd getrokken door onderzoekers die het de moeite waard vonden om, ondanks het falen als instrument van criminele politiek, in wetenschappelijke zin aandacht te blijven besteden aan het resocialisatie-streven (zie voor een overzicht van de ontwikkeling van het effectiviteitonderzoek in de jaren tachtig: Palmer, 1991).

Het onderzoek naar de effectiviteit van interventies in de zin van de verschillende overheidsreacties op het criminele gedrag (sancties, behandelingen en resocialisatie-programma's) werd in de jaren tachtig en negentig, met name in de Verenigde Staten en Canada, onverminderd voortgezet.

Nieuwe (gecombineerde) vormen interventie werden beproefd en de evaluaties die vanaf het begin van de jaren zestig waren verricht, ondergingen een hernieuwde analyse in de vorm van kwalitatief (beschrijvende overzichten) en kwantitatief onderzoek in de vorm van metaanalyse.

Het valt buiten het bestek van deze inleiding in uitgebreide zin bij de resultaten van het effectiviteitonderzoek stil te staan. De conclusie die onderzoekers in de jaren negentig uit de resultaten in vrij algemene zin trekken is dat de stelling dat 'niets werkt' onjuist is (Andrews et al., 1990 (1); Lösel, 1996; Palmer ,1994; Bol, 1995; Antonowicz en Ross, 1994). Interventievormen hebben, ongeacht het type, onder bepaalde omstandigheden en voor bepaalde groepen delinquenten een recidive-verminderend effect, zij het in matige zin. De effect-grootte is vooral afhankelijk van het soort interventie dat men aanbiedt (Lösel,1996). Sommige interventie-typen (bijvoorbeeld cognitieve/ gedragsmatige) lijken in dit opzicht een 
belofte in te houden. Er is echter nog steeds geen categorie aan te wijzen die tot aanzienlijke recidive-vermindering leidt bij de meerderheid (tweederde) van de afzonderlijke interventies (Palmer, 1994).

Ondanks de onhoudbaarheid van de stelling dat 'niets werkt' blijven sommige beleidsfunctionarissen en wetenschapsbeofenaren resocialisatie afschilderen als een achterhaald streven.

\subsubsection{De nadruk op recidive-cijfers}

Zo stelt de Amerikaans hoogleraar strafrecht Haen Marshall in 1994 dat:

"Morele heropvoeding, rehabilitatie door het verschaffen van een betere scholing, het leren van een vak, het aanleren van sociale vaardigheden, of het afkicken van hard drugs, dat zijn anno 1994 vrijwel allemaal achterhaalde idealen warin alleen de grootste optimist nog gelooft. Na een kritische evaluatie van een groot aantal rehabilitatie-programma's concludeerde de Amerikaanse onderzoeker Robert Martinson zo'n 20 jaar geleden heel pessimistisch dat 'nothing works'."

\section{Verder merkt Haen Marshall nog op:}

" Het is onrealistisch te verwachten dat enig rehabilitatieprogramma ( hoe goed bedoeld het ook mag wezen) in de korte tijd dat men opgesloten zit, echt een wezenlijk verschil kan uitmaken in het leven van een mens. De meeste gedetineerden zijn ook weinig gemotiveerd iets van hun detentie te maken" ( NRC-Handelsblad, 8-9-94).

Kenmerkend voor dit soort uitspraken is het 'alles of niets' karakter waarmee het resocialisatie-streven wordt benaderd. Resocialisatie voor gedetineerden werkt niet als middel in de bestrijding van de misdaad dus is het achterhaald of alleen maar een streven voor optimisten die al even onverbeterlijk lijken te zijn als de gedetineerden. .

Op grond van de teleurstellende recidive-cijfers wordt vervolgens elke poging om gedetineerden een perspectief op een betere toekomst te bieden als zinloos beschouwd.

$\mathrm{Bij}$ dergelijke redeneringen wordt veelal voorbij gegaan aan de resultaten van effectiviteitonderzoek waaruit naar voren komt dat penitentiaire interventies onder bepaalde omstandigheden wél effectief kunnen zijn qua recidive-vermindering. Voorts lijken de sceptici nogal veel van de gevangenis te vragen. Impliciet ligt in het scepticisme ten aanzien van resocialisatie veelal de verwachting besloten dat delinquenten met een enkele residentiële interventie weer tot oppassende burgers kunnen worden gemaakt. En als dat vervolgens niet lukt wordt het nut van voorzieningen die gedetineerden een maatschappelijk perspectief bieden, eenvoudigweg in twijfel getrokken. Dat men zich voor wat betreft de effectiviteit van penitentiaire (residentiële) interventies bescheiden dient op te stellen, blijkt ook uit het empirisch onderzoek.

Gunstige effecten van penitentiaire interventies zijn veelal van korte duur.(Van der Linden,1981; Berghuis, 1981). Die effecten zijn van vluchtige aard onder meer vanwege de omstandigheden en gebeurtenissen in het leven van de ex-gedetineerde in de periode na afloop van de detentie. De invloed van de stigmatiserende en ontwrichtende gevolgen van de detentie voor het persoonlijke leven van de gedetineerde speelt hierbij vermoedelijk een belangrijke rol. In dit verband wordt in de literatuur gewezen op het belang van een goede nazorg (Lösel, 1997, p.119).

Cloward (1969, p.89) beschreef dit van nature beperkte bereik van de gevangenis aangaande recidive-vermindering als volgt:

"But here we have the basic dilemma of the prison: No matter how lofty the goals to which the prisoner aspires and no matter how succesfully he acquires the values, knowledge, and skills he needs 
to make the transition to higher status, the prison canno make available legitimate means of acces 10 the goals he has been led to scek: for his public identity remains unchanged, even though he may have undergone a moral regeneration. The society in which he secks to become integrated continues to reject him ('once a con always a con') and thus perpetuates his inferior status."

Volgens Cloward ligt het mislukken van resocialisatie niet uitsluitend bij het gevangenissysteem of de gedetineerde, maar vooral ook in de maatschappelijke omstandigheden na detentie.

Op de post-detentiefase en de criminogene werking van stigmatiseringprocessen heeft de gevangenis geen directe invloed.

In de gevangenis kan men waarschijnlijk wel een basis leggen voor een proces van gedragsverandering. Een proces dat na ontslag met ondersteuning in de vorm van nazorg wellicht tot een goed einde in de zin van daadwerkelijk persoonlijk en maatschappelijk herstel is te brengen. In de praktijk van het gevangeniswezen in de jaren negentig vindt deze visie op resocialisatie als een omvangrijk proces waarvan de fase van de penitentiaire interventie slechts een deel bestrijkt, langzaam maar zeker meer ingang In recente maatschappelijke integratie-projecten van het gevangeniswezen tracht men immers door middel van trajectbegeleiding al tijdens de detentie een verbinding te leggen met de fase van nazorg. Vanwege deze visie op het resocialisatieproces als een meer omvangrijk, detentieoverstijgend proces waarvan de gevangenis vooral het voorbereidende deel bestrijkt, lijkt het niet erg logisch het eventueel tegenvallende eindresultaat in termen van recidive uitsluitend aan de gevangenis toe te schrijven. Het is evenmin erg juist om, op grond van deze toerekening, vervolgens de inspanningen van gedetineerden en gevangenispersoneel ten behoeve van een betere toekomst als zinloos af te schrijven. Een dergelijke benadering gaat eenvoudigweg voorbij aan de complexiteit van de terugkeer van gedetineerden in de samenleving en het proces van voorbereiding dat eraan voorafgaat.

Recidive als maat voor de effectiviteit van strafrechtelijk ingrijpen kent bovendien een reeks problemen die betrekking hebben op de operationalisatie (arrestatie, nieuwe veroordeling, veroordeling to gevangenisstraf), de periode waarover recidive wordt gemeten en de kenbaarheid van het feitelijk delictgedrag. Verder blijft het een probleem het effect in termen van recidive toe te schrijven aan de interventie. Het al dan niet recidiveren kan immers tevens samenhangen met factoren in de post-detentiefase die geheel los staan van de interventie tijdens de detentie.

\subsubsection{Het functioneren van de voorzieningen tijdens de detentie}

De bezwaren tegen de hiervoor beschreven 'alles- of niets' redenering met betrekking tot resocialisatie worden nog duidelijker als men het feitelijk verloop van het resocialisatieproces op de werkvloer onder de loep neemt.

Conrad (1981, p.1722-1724) merkt in dit verband op dat gedetineerden niet zozeer deelnemen aan resocialisatie-programma's om later 'niet-recidivist' te worden. $\mathrm{Zij}$ nemen veeleer deel omdat zij iets willen leren waar zij later iets aan hebben, omdat zij hun tijd nuttig willen doorbrengen en om de spanningen van de detentie te verlichten.

Door alleen maar te kijken naar de recidive-uitkomsten gaat men voorbij aan het veelal langdurige, complexe en moeizame karakter van elk individueel proces van zelfherstel. Gedetineerden komen de inrichting vaak binnen met een verleden dat rijk is aan problemen. De doelen die gedetineerden en personeel met betrekking tot (zelf)verbetering nastreven zijn 
daardoor noodzakelijkerwijs van bescheiden en realistische aard ${ }^{2}$. Men is bij wijze van spreken allang blij als men erin slaagt een proces van zelfherstel op gang te brengen. De succes-criteria die gedetineerden en leden van de professionele staf hanteren, hebben vooral betrekking op het proces van persoonlijke groei tijdens de detentiefase en niet op recidivevermindering na ontslag uit de gevangenis. De vooruitgang op het gebied van motivatie, zelfinzicht, sociale vaardigheden en studieprestaties, kortom de directe effecten van de voorzieningen zijn voor gedetinecrden en personeel van cruciale betekenis.

Warren (1977) beschouwt het negeren van groei in sociaal en educatief opzicht als een van de belangrijkste beperkingen van recidive-maten als succescriterium voor resocialisatieprogramma's.

De grote nadruk op het rendement in termen van recidive gaat dus veelal gepaard met het veronachtzamen van het feitelijk karakter en het verloop van het resocialisatieproces."

Sinds het begin van de jaren tachtig is bovendien het inzicht gerijpt dat kennis van dit feitelijk verloop onontbeerlijk is voor verbetering van de kwaliteit van resocialisatie-programmma's.

Kennis over dit feitelijk functioneren bleek bij de evaluatie van de meeste resocialisatieprogramma's in de jaren zestig en zeventig volledig te ontbreken. Deze kennis is echter essentieel voor het inzicht in de factoren die het succes of falen van het reintegratie-proces kunnen verklaren.

Een van de eerste onderzoekers die op het belang van het feitelijk verloop van resocialisatieprogranma wees, is Quay (1977). Geringe effectiviteit van resocialisatie-programma's, zo liet Quay zien, hangt voor een deel samen met de gebrekkige wijze van implementatie in en door de organisatie. De interventie dient echter in de praktijk zoveel mogelijk te worden geimple-menteerd zoals oorspronkelijk bedoeld in theorie en ontwerp. Dit duidt men ook wel aan met het begrip programma-integritejt.

Na Quay hebben ook andere onderzoekers gewezen op het belang van kennis van het feitelijk functioneren van programma's in de inrichting in relatie tot de kenmerken van de participanten en van de organisatie (Sechrest et al, 1979; Krisberg, 1980; Conrad, 1981; Palmer,1991; Lösel, 1996)

\footnotetext{
2 De inspanningen van onderwijzers, hulpverleners, PIW-ers en gedetineerden zijn met name in de beginfase van het proces van zelfherstel gericht op het bescheiden, maar voor gedetineerden niettemin heel belangrijke doel van het aanleren van basale vaardigheden (zich leren concentreren, geduld oefenen, versterken van motivatie en zelfvertrouwen en het herwinnen van een zekere emotionele rust en regelmaat in het leven)

Conrad (1981,p. 1723) merkt in dit verband op: "There are few people for whom two or three years of any kind of treatment will suffice to move them from the bottom of the social barrel, or to endure quietly the prospect of the rest of their lives spent on the bottom."
}

${ }^{3}$ De eenzijdige aandacht voor het rendement van resocialisatie in termen van recidive is niet alleen het gevolg van een instrumentalistische visie op resocialisatie. Ook de door Garland (1990) en Franke (1991) beschreven ontwikkeling van het straffen waarbij het publieke karakter van de tenuitvoerlegging geleidelijk aan plaats maakt voor een tenuitvoerlegging in de beslotenheid van de gevangenis als totale institutie, lijkt een rol te spelen.

Binnen dergelijke instituties bestaat de neiging om buitenstanders te weren (Kelk,1993,(1), p.4len42). Het zijn voor publiek en onderzoekers bijzonder ontoegankelijke plaatsen. Het besloten karakter van de gevangenis is wellicht tevens een oorzaak voor het feit dat penologen het resocialisatie-streven zo zelden van binnenuit de penitentiaire organisatie en vanuit de binnenwereld van de participanten hebben onderzocht. Hun evaluaties van resocialisatie zijn wellicht om deze reden op afstand, dat wil zeggen buiten de muren van de gevangenis verricht en beperkt gebleven tot het radplegen van recidive-uitkomsten in justitiële dossiers. 
Van den Hurk (1998) constateert na een inventarisatie van het recente effectiviteitonderzoek dat de tekortkomingen vooral een gebrekkige beschrijving van de kenmerken van delinquenten en staf betreffen. Meer kennis van de proceskant van interventies is noodzakelijk, zo luidt een van de conclusies van van den Hurk (p.170-172).

Naast de programma-integriteit en de kenmerken van het personeel of de cliënten noemt men in overzichtsstudies uit de jaren negentig met betrekking tot het feitelijk verloop van programma's nog een andere factor namelijk, de setting van het programma. Onder dit begrip verstaat men het karakter van de omgeving waarin het resocialisatie-programma wordt uitgevoerd. Deze kan van penitentiaire of niet-penitentiaire aard zijn.

Bol (1995) constateert in het effectiviteitonderzoek een opvallend gebrek aan aandacht voor deze setting waarin de interventies plaatsvinden. Volgens Palmer (1994) is de aard van de setting niet eens zo heel belangrijk voor de gevonden verschillen in succes. De verschillen zijn eerder een gevolg van 'wat' er gebeurt dan 'waar' het gebeurt.

Vanuit de invalshoek van het penologisch effectiviteitonderzoek wordt derhalve gewezen op het belang van het vermeerderen van wetenschappelijke kennis van het feitelijk verloop van het reintegratie-proces. De boodschap is korton dat als wij willen weten wat wel of niet werkt wij ook dienen te weten hoe het binnen de context van een detentie-situatie werkt.

$\mathrm{De}$, in de inleiding gesignaleerde kennisleemte vormt dus ook vanuit dit empirisch-wetenschappelijke perspectief van het effectiviteitonderzoek een probleem dat de moeite van het onderzoeken waard is.

\subsubsection{Implicaties voor het onderzoek}

Op grond van de voorgaande paragraaf kunnen we het volgende concluderen. De conclusie van het penologisch onderzoek uit de jaren zeventig van de twintigste eeuw dat resocialisatie van gedetineerden uit het oogpunt van recidive-vermindering niet werkt, is vanwege de geringe kwaliteit van het evaluatieonderzoek nogal voorbarig geweest. Voorzover penitentiaire resocialisatie-programma's uit het oogpunt van recidive-vermindering effect sorteren, is dit effect veelal van korte duur. Deels duidt dit op de belangrijke functie van extramurale vervolgvoorzieningen, deels duidt het ook op de beperkte mogelijkheden en een beperkt bereik van de gevangenis waar het de beïnvloeding van gedrag na een detentie betreft. Op grond hiervan en op grond van het complexe en veelal moeizame karakter van het proces van zelfherstel ligt het weinig voor de hand om penitentiaire interventies uitsluitend af te rekenen op een falende recidive-vermindering. Voorzover men penitentiaire interventies beoordeelt op hun toekomstige speciaal-preventieve effectiviteit in termen van recidive-vermindering lijkt het wenselijk om dit oordeel in termen van een (indirecte) bijdrage te formuleren. Hoe resocialiserende voorzieningen in een penitentiaire inrichting in dit opzicht een optimale bijdrage kunnen leveren is een vraag die in de penologie tot nog toe nauwelijks is beantwoord. In de penologie is inmiddels wel het inzicht gerijpt dat kennis van het feitelijk functioneren van resocialiserende voorzieningen tijdens een detentie onontbeerlijk is voor progressie van het effectiviteitonderzoek. Het onderhavige onderzoek waarin het functioneren van het resocialisatie-proces vanuit de opvattingen en beleving van gedetineerden en personeel wordt onderzocht, ontleent zijn relevantie dus tevens aan de optiek van het penologisch (effectiviteits)onderzoek van resocialisatie. 


\subsection{Relevantie van het onderzoek vanuit het perspectief van de gevangenis als samenleving en organisatie}

Bij het resocialisatie-streven spelen niet alleen ethisch- normatieve overwegingen of overwegingen met betrekking tot de speciaal preventieve effectiviteit een rol. Het is een streven dat gestalte krijgt in de organisatic en samenleving van de gevangenis. Dit gegeven van een sociale en organisatorische context heeft zowel voor gedetineerden als voor het gevangenispersoneel die beiden vorm geven aan het resocialisatie-streven, tal van consequenties.

\subsubsection{Resocialisatie in de context van een schadelijke omgeving}

Het staat inmiddels wel vast dat het ondergaan van een gevangenisstraf gepaard kan gaan met tal van schadelijke gevolgen voor het welzijn van gedetineerden.

De beschrijving van Goffman (1961) van het verblijf in een gevangenis als totale institutie toont de negatieve invloed van een proces van mortificatie op gedrag en houdingen van gedetineerden. Het is een proces waarbij het ego van de gedetineerde langzaam maar zeker teniet wordt gedaan. Het inrichtingsleven dat volgens een strak schema en strikte regels verloopt impliceert in belangrijke mate het prijsgeven van de eigen identiteit, eigen initiatief en autonomie van de gedetineerde. Het lijkt om deze redenen een allesbehalve geschikte omgeving om een proces van zelfherstel of resocialisatie te initiëren. De spanningen waarmee de detentie gepaard gaat zijn volgens sommige onderzoekers (zie bijvoorbeeld Melk, 1985; 1993) voor de gedetineerden zo groot dat zij de activiteiten gericht op persoonlijke groei en ontwikkeling voornamelijk nog gebruiken om de lasten van het bajesleven te verlichten. Onderzoekers zoals Clemmer (1940) en Sykes (1958) wijzen voorts op de negatieve invloed van de gedetineerdencultuur. Zij menen dat de gevangenis in het algemeen een destructieve invloed heeft op het welzijn van gedetineerden. Er is sprake van een proces van vernedering van gedetineerden in een omgeving die het karakter heeft van een totale institutie. Als vorm van aanpassing aan of reactie op deze negatieve omstandigheden ontwikkelen zij een eigen subcultuur met normen en waarden die haaks staan op de regels en voorschriften van het gevangenissysteem. Men veronderstelt dat gedetineerden naarmate zij sterker betrokken zijn bij deze oppositionele gedetineerdencultuur, zij minder gemotiveerd zijn voor resocialisatie. Een veronderstelling die overigens nauwelijks in empirische zin is getoetst. Of dit proces van aanpassing aan de pijnlijke omstandigheden van een detentie onder het merendeel van de gedetineerden daadwerkelijk tot negatieve houdingen ten aanzien van resocialisatie leidt, is onduidelijk.

Ook over het proces van aanpassing aan de pijnlijke omstandigheden van de detentie in het algemeen is in empirisch wetenschappelijke zin nog niet alles gezegd. De desastreuze psychosociale en fysieke gevolgen zijn wel beschreven maar het is niet duidelijk hoe de effecten zich verhouden tot bepaalde modererende factoren van persoonlijke en organisationele aard (Lösel, 1996).

Men kan eigenlijk nog niet goed verklaren waarom, ondanks het uniforme restrictieve karakter van de gevangenisomgeving, gedetineerden toch verschillende reacties op die ongeving vertonen (Zamble en Porporino, 1988). Het is bovendien onduidelijk welke functies de voorzieningen ten behoeve van resocialisatie in het kader van die aanpassingsreacties hebben. Voor sommige gedetineerden zijn voorzieningen gericht op resocialisatie een cruciaal middel om zich gedurende een jarenlange detentie staande te houden. Andere gedetineerden keren zich na verloop van tijd volledig af van dergelijke voorzieningen en gebruiken blijkbaar een andere strategie om de detentie door te komen. Kennelijk geven gedetineerden blijk van een verschillende en wisselende behoefte aan zorg. 
De volgende sub-paragraal is gewijd aan het streven in het Nederlandse Gevangeniswezen om in het kader van de detentickwaliteit zoveel mogelijk aan te sluiten op deze zorgbehoefte van gedetineerden.

\subsubsection{De psychosociale kwaliteit van de detentie}

In het Nederlandse gevangeniswezen spreckt men nadrukkelijk over een zorgbehoefte van gedetineerden (Verhagen,1999). Die zorg heeft betrekking op hun fysicke en geestelijke gezondheid. Gedetineerdenzorg is voor een deel gericht op het voorkomen of beperken van de schade die de detentic onvermijdelijk oplevert voor de geestelijke en lichamelijke gezondheid van gedetineerden.

In Nederlandse gevangenissen is sinds 1982 (zie de nota Taak en Toekomst, 1982) het voorkomen of beperken van de schade van de detentie een van de officiële doeleinden van het penitentiair beleid. Het is cen doelstelling die zowel in de nota Taak en Toekomst als in de nota Werkzame Detentie (1994) in het verlengde ligt van cen andere doelstelling, namelijk een humane of menswardige tenuitvoerlegging van de detentic.

Door een hulpaanbod tracht men de verslechtering van het welzijn van gedetineerden als gevolg van de detentic tegen te gaan. De voorzieningen op het gebied van educatie en psychosociale hulpverlening staan voorts in meer positieve zin in het teken van persoonlijke groei en het bevorderen van (toekomstig) welzijn. Zorg voor de geestelijke gezondheid van gedetineerden heeft immers ook betrekking op het bieden van perspectief in het leven.

Het hulpaanbod ter realisering van deze doelstellingen stond in de jaren tachtig en begin jaren negentig van de twintigste eeuw sterk in het teken van het scheppen van een gunstig psychosociaal klimaat (Dhondt, 1989) waardoor de kwaliteit van de detentie blijft gewaarborgd. In Nederland tracht men het psychosociale klimaat niet alleen te bevorderen door middel van een hulpaanbod van deskundigen op het gebied van educatie en psychosociale hulpverlening. Ook aan het regime en aan de manicr waarop dit in de contacten tussen PIW-ers en gedetineerden 'gestalte krijgt, wordt cen cruciale functie toegekend. Tot hun taakstelling behoort immers tevens het begeleiden van gedetineerden bij het oplossen van hun psychosociale problemen.

Voorts worden speciale regimaire voorzieningen getroffen met het oog op groepen gedetineerden die extra aandacht behoeven zoals bij voorbeeld gedetineerden met psychische stoornissen en drugsverslaafden die hun drugsgerelateerde levensstijl willen doorbreken.

De wijze waarop aan de kwaliteit van de detentie in het bijzonder aan het psychosociale klimaat vorm wordt gegeven vertoont verschillen per inrichting. Het is het resultaat van drie decennia van voortschrijdende differentiatie en decentralisatie, waarbij de inrichtingsdirecties grote invloed hebben op de cultuur en het klimaat van de inrichting. Er bestaat, aldus Boin (1999), evenwel geen consensus over de definitie en inhoud van het begrip detentiekwaliteit. Evenmin bestaat consensus over de manier waarop de kwaliteit gestalte dient te krijgen. ${ }^{4}$

4 Boin stelt dat sinds de inspecties ter plekke zijn afgeschaft, de beleidsmakers in Den Haag grotendeels afhankelijk zijn van 'softe' informatie: klachten van gedetineerden; berichten in de krant: de geruchten uit het circuit (p.30).

Deze afhankelijkheid van 'softe' informatie is in zekere zin ook kenmerkend voor het recente beleid met betrekking tot de resocialisatie van gedetineerden. Binnen het kader van dit beleid zoals vastgelegd in de nota Werkzame Detentie (1994) wordt de motivatie van gedetineerden om iets van hun detentie te maken laag ingeschat op basis van impressies van gevangenispersoneel en niet op grond van een empirisch onderzoek onder gedetineerden. 
Controle op de detentickwaliteit is gering, bovendien is onderzoek van het detentieklimaat, behoudens enkele gouvernementele klimaatschaal-studies in de eerste helft van de jaren negentig schaars (zie bijvoorbeeld Herbschleb en Zorge, 1992).

Toch is de behoefte atan onderzock in het gevangeniswezen bijzonder groot blijkens de recente uitspraken van het hoofd Beleidsinformatie van de Dienst Justitiële Inrichtingen Verhagen (1999, p.23). Hij merkt het volgende op:

"Het hebben van veel detentievormen betekent dat er gekozen en geselecteerd moet worden: welke wijze van tenuitvoerlegging past het best. Omdat er van de selectie zovecl afhangt, moeten de selectiecriteria expliciet zijn. Willen die criteriat up to date blijven, dan zal er voontdurend onderzocht moetes worden hoe het de gedetineerden tijdens, en ook na, hun detentie vergat. Daar ligt de grote onderzocksuitdiging voor het gevangeniswezen. Wat gebeurt er met gedetineerden in verschillende detentievormen tijdens de detentie, hoe vergat het ze na de detentie en om een stap terug te maken, hoe kwamen $z$ de detentie binnen? (......) Wat heeft de detentie met de gedetineerde gedaan. wat hebben \%e geleerd. zijn ze beter voor de wereld uitgerust? Kijken naar recidive is cen mogelijkheid. matr recidive is een zeer grove mat voor succes van detentie. De cxit-conditie die gedetineerden hebben bij het verlaten van de inrichting is een betere mat."

Verhagen wijst verder nog op de noodzaak van een adequaat en verantwoord gebruik van middelen en van een goedc aansluiting van het aanbod van de inrichtingen op de noden van gedetineerden.

In het licht van het voorgaande is een onderzoek van de houdingen van gedetineerden ten aanzien van de voorbereiding van de terugkeer in de samenleving relevant.

Gedetineerden berciden hun terugkeer in de samenleving voor in een schadelijke omgeving die vanwege deze schadelijkheid juist hakas lijkt te staan op het streven naar een betere toekomst. Het beleid van het Nederlandse Gevangeniswezen is erop gericht de schade voor het welzijn zoveel mogelijke te beperken en te voorkomen. Men probeert bovendien het welzijn van gedetineerden te bevorderen door hen kansen en mogelijkheden te geven op het gebied van resocialisatie. Men tracht een psychosociaal detentieklimaat te scheppen dat alansluit op de behoeften aan zorg van gedetineerden onder meer op het gebied van de voorbereiding van de terugkeer in de samenleving. Er is kortom sprake van een noodzaak die zorg op een adequate. optimale en verantwoorde manier gestalte te geven. Dit laatste veronderstelt empirisch-weten-schappelijke kennis omtrent de behoefte aan maatschappelijk perspectief en de wijze waarop gedetineerden het toekomstgerichte aanbod van zorg beoordelen en beleven.

Het voorliggende onderzoek kan een bijdrage leveren aan dit streven door:

I. Vermeerdering van kennis omtrent de betekenis die ontwikkelings- en hulpverleningsactiviteiten hebben voor gedetinecrden, personeel en organisatie;

2. Vermeerdering van kennis van de wijze waarop voorzieningen ten behoeve van resocialisatie qua moment, inhoud en omstandigheden kunnen worden afgestemd op de behoeften van gedetineerden, personeel en organisatie;

3. Vermeerdering van kennis ten behoeve van het expliciteren van doelcinden, middelen en evaluatie-criteria, hetgeen weer kan bijdragen aan de rechtvaardiging van het resocialisatie-streven;

4. Vermeerdering van kennis ten behoeve van een vorm van straffen waarbij de gestrafte zich, aldus Tulkens (1994, p.250) "verantwoordelijk gesteld, maar ook bemoedigd weet ten behoeve van zijn of haar maatschappelijke toekomst". 


\subsubsection{Resocialisatie in de context van personeel en organisatic}

Het verwerven van kennis van de houdingen van gedetineerden en in het bijzonder van het personeel ten aanzien van resocialisatie is tevens van belang als men het aanbod van voorzieningen ten behoeve van resocialisatie bekijkt vanuit een organisatie-sciologisch perspectief.

Het scheppen van een humaan. schadebeperkend detentieklimat watarin het (toekomstig) welzijn van de gedetineerden voorwerp van zorg is, vindt plaats in cen organisatie die tevens in het teken staat van het beveiligingsdoel. De taak van het gevangeniswezen is primair het tenuitvoerleggen van een vrijheidsbenemende straf op grond waarvan gedetineerden voor kortere en langere tijd uit de samenleving worden gehouden. Het gevangeniswezen moet delinquenten opsluiten en opgesloten houden; voorkomen moet worden dat zij zich aan de detentie onttrekken. Het opsluiten dient bovendien op een rustige, ordelijke en veilige wijze te verlopen. Deze doelstelling van de ongestoorde tenuitvoerlegging van de gevangenisstraf heeft volgens onderzoekers een grote invloed op het handelings- en beslissingspatroon van gevangenisfunctionarissen. Kelk (1993, (1), p.41-43) meent dat de, in wezen bureaucratische gevangenisorganisatie met zijn hiërarchische gezagsstructuur resulteert in een mechanisme van starheid, onveranderlijkheid en voorspelbaarheid van gedrags- en beslissingspatronen. Voorts leidt het primaat van orde en rust tot het ontkennen van problemen, conflicten en belangentegenstellingen. Dit beveiligingsgerichte en bureaucratische karakter van de gevangenisorganisatie kan in conflict geraken met het resocialisatie-streven. De realisering van de resocialisatie-doelstelling veronderstelt immers dat de individuele behoeften en mogelijkheden van gedetineerden voldoende aandacht krijgen en dit lijkt niet bijzonder gemakkelijk in een organisatie waarin bedrijtsmatigheid en beveiliging een dominante plaats innemen.

Sommige onderzoekers menen dat vanwege het grote belang van het orde- en rust principe men feitelijk niet eens meer toekomt aan doeleinden als groei en ontwikkeling in de levenssituatie van gedetineerden.

Zo stelt Melk $(1985 ; 1993)$ dat het orde- en rustprincipe in platats van een middel tot iets in feite is veranderd in het totale doel van de organisatie. Van hoog tot laag is het personeel voornamelijk bezig met de detentie-situatie en het lenigen van nood en verminderen van spanning die het gevolg is van deze situatie. Voorzieningen oorspronkelijk gericht op persoonlijke groei dienen door het primaat van orde en rust voornamelijk nog maar één doel namelijk, het rustig houden van gedetineerden.

Binnen deze visie heeft de resocialisatiedoelstelling het definitief afgelegd tegen het orde- en rustprincipe en is in feite aan dit principe ondergeschikt gemaakt.

Ook andere onderzoekers (Moerings, 1992; Cullen en Gilbert 1982; Denkers, 1976; Hamm en Schrink, 1989; Patterson,1988; Tulkens, 1988) gaan ervan uit dat de mogelijkheden van het personeel om daadwerkelijk gehoor te geven aan de persoon van de gedetineerde en zijn behoeften aan perspectief in het leven aan beperkingen onderhevig zijn juist vanwege de bureaucratische structuur van de gevangenisorganisatie.

Melk (1985, p.750) meent in dit verband dat er zo langzamerhand zelfs sprake is van een filosofie of geloof in de onmacht van de gevangenis en de onverbeterlijkheid van gedetineerden. Ook wetenschapsbeoefenaren, zo stelt hij, zijn veelal gefixeerd op de negatieve kanten van de gevangenis. Zij hebben zich meer gericht op het terugdringen van de gevangenisstraf en veel minder op de verbetering van de gevangenis. Zij gaan uit van een axioma van de onveranderlijkheid van de gevangenis, een gedachtengang die het streven naar een serieuze oplossing van de aanwezige problematiek van gedetineerden tegenhoudt. 
Een belangrijk probleem met betrekking tot deze en dergelijke veronderstellingen over de onmacht en onveranderlijkheid van het Nederlandse gevangeniswezen is dat zij grotendeels gebaseerd zijn op impressies en een empirisch wetenschappelijke basis missen.

Hoe in Nederlandse penitentiaire inrichtingen de PIW-ers, gevangenisdirectie en de leden van de professionele staf de resocialisatie-opdracht beoordelen en welke zin of betekenis zij aan de verschillende voorzieningen ten behoeve van deze doelstelling toekennen, is tot op heden nooit in uitgebreide, empirische zin onderzocht. De vraag is of deze functionarissen, ondanks de vermeende beperkingen van de gevangenisorganisatie nog steeds geloven in de taken die zij uit hoofde van de maatschappelijke integratie van gedetineerden dienen te verrichten. De vraag is verder of zij die beperkingen als zodanig ervaren en beoordelen. Huldigen zij eveneens een defaitistisch beeld van de onveranderlijkheid en onmacht van het gevangeniswezen en de fundamentele onverbeterlijkheid van gedetineerden, of zien zij nog mogelijkheden om de psychosociale problematiek van de gedetineerden binnen de organisatie van de gevangenis op een serieuze en adequate wijze tegemoet te treden? Deze, grotendeels onbeantwoord gebleven vragen met betrekking tot het resocialisatie-streven in de context van organisatie en personeel verdienen een antwoord en een vertaling in systematisch, empirisch onderzoek.

Het is immers van belang te weten hoe het personeel deze en andere problemen met betrekking tot de voorbereiding van de terugkeer in de samenleving beoordeelt. Het personeel behoort immers samen met gedetineerden op een adequate wijze gestalte te geven aan het proces van zelfherstel. Voorts staat of valt het behoud van een detentie waarin, behalve voor veiligheid, rust en orde, ook aandacht is voor de persoon van de gedetineerde en zijn perspectief op een betere toekomst, met de houding van het gevangenispersoneel ten aanzien van een dergelijk streven.

Het gaat om het verkennen en optimaliseren van ruimte voor het resocialisatie-streven binnen de marges van een, in essentie beveiligingsgerichte organisatie. Het feit dat er over het functioneren van de voorzieningen ten behoeve van de terugkeer in de samenleving in empirische zin weinig bekend is, vormt derhalve ook vanuit deze optiek van de organisatie een probleem dat de moeite van het bestuderen waard is.

\subsection{Probleemstelling van het onderzoek}

In de inleiding van dit hoofdstuk werd in verband met resocialisatie een gebrek aan empirische kennis vastgesteld met betrekking tot de houdingen van gedetineerden en personeel ten aanzien van dit streven. Geconstateerd werd dat het in empirische zin grotendeels onbekend is hoe gedetineerden en personeel over de resocialisatie-doelstelling als zodanig denken, noch is het duidelijk hoe het feitelijk streven naar resocialisatie in een inrichting door hen wordt beleefd.

Er werd betoogd dat deze kennisleemte een probleem vormt dat vanuit een ethisch normatieve, (instrumenteel) penologische en organisationele optiek de moeite van een onderzoek waard is.

Het gesignaleerde hiaat in de kennis van het resocialisatie-streven komt in feite neer op een vraagstelling naar de aard en de oorsprong van de houdingen van gedetineerden en personeel ten aanzien van resocialisatie. Voor een goed begrip van deze aard en oorsprong van die houdingen is kennis van de historische ontwikkeling van de resocialisatiegedachte in het Nederlandse Gevangeniswezen van essentiële betekenis. De historisch-sociologische, beleidsmatige en juridische context van het verschijnsel resocialisatie zal in de eerste plaats dienen te worden onderzocht. Deze onderzoeksvraag naar de (historische) context van de 
resocialisatic-gedachte en de vraagstelling naar de alard en oorsprong van de houdingen van gedetineerden en personeel kunnen als algemene problemstelling als volgt worden geformuleerd:

Wat houdt het resocialisatie-streven in het Nederlandse Gevangeniswezen precies in, hoe beoordelen gedetineerden en personeel dit streven en door welke factoren wordt hum oordeel beïvloed?

Deze probleemstelling bevat zowel een beschrijvende en verklarende component. De vraag naar de factoren die van invloed zijn op de houdingen ol het oordeel valn gedelinecrden en personeel impliceert cen verklarende anpak. De beantwoording van de vraag natar de inhoud van het resocialisatie-streven en van de vraig naar het oordeel van gedetineerden en personeel hierover impliceert een beschrijende alanpak.

Deze beschrijvende component van het onderzoek bestaat uit vijf onderzocksvragen:

1. Wat houdt het begrip resocialisatie precies in?

2. Op welke wijze heeft men totnogtoe de resocialisatie-doelstelling in het Nederlandse gevangeniswezen gestalte gegeven?

3. Hoe denken gedetineerden en personeel over de resocialisatie-doelsielling als zodanig?

4. Op welke wijze en in welke mate zijn gedetineerden en personeel betrokken bij de activiteiten gericht op de voorbereiding van de terugkeer in de samenleving?

5. Op welke wijze beleven gedetineerden en personeel de verschillende activiteiten gericht op de voorbereiding van de terugkeer in de samenleving?

Deze vijf beschrijvende onderoeksvragen worden hieronder verder toegelicht.

1. Wat houdt het begrip resocialisatie precies in?

In de eerste platats dient het begrip resocialisatie te worden verhelderd. In het kader van de terugkeer in de samenleving van gedetineerden worden behalve het begrip resocialisatie ook begrippen gebruikt als reclassering, rehabilitatie en maatschappelijke integratie. Sommige begrippen bestrijken het gehele proces van reintegratie. weer ander begrippen hebben betrekking op een deel van het proces. Op grond van deze begripsbepaling wordt ten behoeve van het onderzoek het begrip resocialisatie in operationele zin gedefinieerd.

\section{Op welke wijze heeft men tomogtoe in het Nederlandse gevangeniswesen de resocialisatie} doelstelling gestalte gegeven?

De resocialisatie-opdracht aan het Nederlandse gevangeniswezen en de voorzieningen die men ten behoeve van deze opdracht heeft geschapen zijn in essentie het resultaat van ecn ontwikkeling in de strafrechtspleging waarin men steeds meer aandacht kreeg voor de persoon van de dader of gedetineerde. Voor een goed begrip van de hedendaagse positie en betekenis van het resocialisatiestreven in de strafrechtspleging is cen historischsociologische, juridische en beleidsmatige beschouwing van deze ontwikkeling onontbeerlijk.

3. Hoe denken gedetineerden en gevangenispersoneel over de resocialisatie-doelstelling als zodanig?

Een beschrijving van de houdingen dient in de eerste plaats aansluiting te zoeken bij het simpele gegeven dat gedetineerden en personeel een mening hebben over de resocialisatiedoelstelling als zodanig, los van de vraag of men op enigerlei wijze actief betrokken is bij de verschillende voorzieningen ten behoeve van deze doelstelling. Of men zich met betrekking tot resocialisatie nu actief opstelt of afzijdig houdt, gedetineerden en personeel hebben altijd 
cen bepaalde mening over de zinvolheid van de resocialisatie-gedachte. Men kan resocialisatie als doelstelling zinvol achten, matr tegelijkertijd ook zeer sceptisch zijn over de mogelijkheden daartoe tijdens een detentie. Het denken van gedetineerden en personeel over resocialisatie kent mogelijk bepaalde nuances die men dient te beschrijven.

4. Op welke wijze en in welke mate zijn gedetineerden en personeel betrokken bij de activiteiten gerich op de vorbereiding ran de terugkeer in de samenleving?

Athankelijk van hun visies op resocialisatic raken gedetineerden en personeel al dan niet betrokken bij de concrete uitvoering van de resocialisatic-opdracht. Deze betrokkenheid kan men voor de gedetineerden in de eerste plaats beschrijven in termen van de frequentie van hun deelname aan de verschillende activiteiten. Men neemt bovendien niet alleen met een bepaalde frequentic deel aan de activiteiten. Men makkt ook een keuze voor bepaalde aspecten van het aanbod op het gebied van educatie en hulpverlening. De betrokkenheid heeft ook een bepaalde vorm die kan worden beschreven. Ook voor het personeel kan de wijze waarop cen bepaalde betrokkenheid gestalte krijgt, worden beschreven.

5. Op welke wijze beleven gedetineerden en personeel de verschillende activiteiten gericht op de voorbereiding van de terugkeer in de samenleving?

Is men als gedetineerde of als personeelslid actief betrokken bij activiteiten die het resocialisatie-doel dienen, dan zal men ook een bepaalde kijk op deze activiteiten hebben. Bij sommige gedetineerden staat de deelname sterk in het teken van de ongemakken van de detentiesituatic. Men neemt deel om, zoals dat in het gevangenisjargon heet, 'niet achter de plank te hoeven zitten' of om de spanningen van de detentie af te reageren. Bij sommige gedetineerden spelen wellicht ook andere verder gelegen doeleinden een rol zoals persoonlijke groei en verbetering van de toekomstige levenssituatie.

Het bewarend personeel, ook wel Penitentiaire Inrichtingswerkers (PIW-ers) genoemd, vervult een rol bij de begeleiding van de activiteiten. Ook hier kan men verschillen verwachten in motieven en motivatie. De beleving of de perceptie van de activiteiten door gedetineerden en personeel wordt naar alle waarschijnlijkheid gekenmerkı door aspecten die te naken hebben met de detentiesituatie, de wijze van implementatie van de activiteiten in de inrichtingsorganisatie en met bepaalde intenties ten aanzien van de persoonlijke ontwikkeling en toekomstige levenssituatie.

Met deze vijf onderzoeksvragen die betrekking hebben op het beschrijvende deel van de probleemstclling komt bij uitstek de procesmatige kant of het feitelijk functioneren van resocialisatic binnen een penitentiaire inrichting tot uitdrukking.

Deze beschrijvende onderzoeksvragen vormen de leidraad voor zowel het onderzoek van de literatuur als voor het empirische onderzoek dạt in het kader van deze studie werd verricht.

Doel van dit onderzoek is niet alleen het beschrijven van de aard van de houdingen. In de probleemstelling wordt tevens de vraag gesteld naar de factoren die mogelijk van invloed zijn op de houdingen ten aanzien van resocialisatie. De oorsprong of achtergrond van de houdingen is evenzeer voorwerp van onderzoek. Een dergelijk verklarend perspectief impliceert dat de houdingen ten aanzien van resocialisatie vanuit een theoretisch kader worden onderzocht.

Er is tot op heden zowel in Nederland als daarbuiten geen onderzoek verricht waarin vanuit een theoretisch perspectief de invloed van bepaalde factoren op houdingen ten aanzien van resocialisatie aan de orde komt. Wel is er sprake van studies waarin op basis van impressies het karakter van de houdingen ten aanzien van resocialisatie post hoc wordt verklaard. 
Bij deze post-hoc verklaringen gaat men veelal uit van de veronderstelling dat het gedrag en de houdingen van gedetineerden vermoedelijk dienen te worden verklatard vanuit de aanpassing atan een belastende en depriverende detentie-omgeving. Een omgeving kortom, waarin gedetineerden worden geconfronteerd met tal van (potentiële) stressoren en daaruit voortvloeiende spanningen.

Studies waarin de aampassing van gedetineerden aan de detentie worden onderzocht, laten tevens zien dat ondanks het uniforme, restrictieve karakter van de gevangenisomgeving, gedetineerden toch heel verschillende reacties kunnen vertonen op die stressvolle omgeving. De restrictieve omstandigheden van de detentie zijn over het algemeen niet zo dominant en determinerend dat zij uniforme effecten op het gedrag teweeg brengen. Evenmin zijn individuele kenmerken of disposities dermate sterk dat zij, ongeacht de kenmerken van de omgeving, de houdingen of het gedrag van gedetineerden bepalen. Blijkbaar worden houdingen van gedetineerden niet alleen beinvloed door de depriverende kenmerken van de omgeving, persoon(lijkheid)skenmerken lijken eveneens een rol te spelen.

Het ligt derhalve voor de hand bij een onderzoek van de factoren die van invloed zijn op de houdingen van gedetineerden een onderzoeksmodel op te stellen waarin wordt gekeken naar de invloed van zowel omgevingsfactoren als van bepaalde persoonskenmerken ook wel predetentiefactoren genoemd.

Een belangrijke functie van een dergelijk integratie-model is het ordenen of het aanbrengen van structuur in mogelijk relevante variabelen. Een dergelijk model dat als 'kapstok' dient voor potentieel relevante variabelen zal alleen worden ontwikkeld ten aanzien van de houdingen van gedetineerden. Voor de houdingen van het personeel ten aanzien van resocialisatie zal een dergelijk model niet worden ontwikkeld. Een dergelijke poging zou op zich zelf reeds het onderwerp kunnen zijn van een promotic-onderzoek. Het onderzock van de houdingen van het personeel draagt vooral een exploratief karakter, hetgeen overigens niet betekent dat hier een verklarend perspectief geheel ontbreekt.

Het verklarend deel van de probleemstelling kan men op grond van de voorgaande uiteenzetting toespitsen door middel van de volgende twee vraagstellingen:

6. Zijn er bepaalde persoons-en omgevingsgebonden factoren die, eventueel in onderlinge samenhang, van invloed zijn op de houdingen van gedetineerden en personeel ten aanzien van de voorbereiding van de terngkeer in de samenleving?

Deze vraag wordt in hoofdstuk 4 waarin de mogelijk relevante factoren aan de hand van de theo-retische literatuur worden onderzocht, verder uitgesplitst in een reeks specifieke onderzoeks-vragen

Een verklaring van de houdingen van gedetineerden ten aanzien van resocialisatie zou nict volledig zijn indien de onderlinge relaties tussen opvattingen, deelname en beleving buiten beschouwing blijven. Dit geeft aanleiding tot de volgende vraagstelling:

6a. Hoe hangen opvattingen, deelname en beleving onderling samen?

\subsection{Opbouw van het boek}

Hoofdstuk 2 bevat een verheldering van het begrip resocialisatie en een beschrijving van de wijze waarop de resocialisatie-gedachte zich in het Nederlandse gevangeniswezen in de loop der tijd heeft gemanifesteerd.

In hoofdstuk 3 wordt de literatuur onderzocht op relevante gegevens omtrent de houdingen van gedetineerden ten aanzien van resocialisatie. 
In hoofdstuk 4 wordt vanuit een theoretisch kader gekcken naar de factoren die mogelijk van invloed zijn op de houdingen van gedetineerden ten aanzien van resocialisatie. De veronderstelde samenhangen worden weergegeven in een onderzoeksmodel. Dit hoofdstuk wordt afgesloten met een atutal specifieke onderzocksvragen.

Hoofdstuk 5 behandelt de opzet en tuitvoering van het onderzoek en geeft een beschrijving van de onderzochte gedetineerdenpopulatie en van de inrichtingen waarin het onderzoek werd uilgevoerd.

Hoofdstuk 6 geeft de resultaten van het onderzoek voorzover het een beschrijving betreft van de aard van de houdingen van gedetineerden ten aanzien van resocialisatie.

Hoofdstuk 7 geeft de onderzocksresultaten weer met betrekking tot de typering van de onderzoekspopulatie op een aantal omgevingskenmerken, persoonskenmerken en kenmerken van programma-integriteit.

In hoofdstuk 8 worden de resultaten beschreven die betrekking hebben op de relatie tussen de houdingen van gedetineerden ten aanzien van resocialisatie enerzijds en omgevingskenmerken, persoonskenmerken en kenmerken van programma-integriteit anderzijds.

In hoofdstuk 9 wordt de probleemstelling van het onderzoek onder het personeel toegespitst en geeft een overzicht van de relevante literatuur. In dit hoofdstuk komen vervolgens de opzet en uitvoering van het onderzoek onder het personeel en de resultaten van dit onderzoek aan de orde.

Hoofdstuk 10 bevat tenslottc een algehele samenvatting, conclusies en aanbevelingen naar aanleiding van het onderzoek. 


\section{RESOCIALISATIE EN HET BELEID VAN HET NEDERLANDSE GEVANGENISWEZEN}

"In het strafrecht is de marge watrbinnen wee of meer doelstellingen kumnen samengaan conder dat zij elkatrs realisering in ernstige mate frustreven, veel kleiner:

Winst voor de one doelstelling beteken al heel ganw verties vor de andere. Toch moet aan alle doelstellingen worden rechtgedam. Het gevolg is dat het strafrecht eigenlijk nooit iets goed kan doen." (Denkers. 1976, p.122)

\subsection{Inleiding}

Het streven naar verbetering van delinquenten in het kader van de tenuitvoerlegging van een vrijheidsbenemende straf kent al een vrij lange geschiedenis. Reeds in de $16 \mathrm{e}$ eeuw probeerde men in de Amsterdamse tuchthuizen. ook wel de rasp-en spinhuizen (resp. van 1596 en 1598). door dwangarbeid het gedrag van delinquenten in bepaalde mate te beinvloeden. Als in de loop van de $19 \mathrm{c}$ eeuw de vrijheidsbeneming de belangrijkste sanctievorm wordt. krijgt de verbinding tussen het streven naar verbetering van delinquenten en de vrijheidsbenemende sanctic een steeds duidelijker inhoud.

In dit hooldstuk word deze ontwikkeling van de verbeterings-of resocialisatiegedachte in het Nederlandse gevangeniswezen beschreven vanuit de optiek van het strafrechtelijk denken over misdaad en straf. de wetgeving en het penitentiaire beleid.

Deze beschouwing wordt afgerond met een beschrijving van de historische. juridische en beleidsmatige achtergrond van de huidige voorzieningen op het gebied van het penitentiaire onderwijs, kunstzinnige vorming, hel penitentiaire reclasseringswerk en de gestichtarbeid.

Alvorens de ontwikkeling van de resocialisatie-gedachte in het Nederlandse gevangeniswezen te beschrijven wordt het begrip resocialisatie verduidelijkt.

\subsection{Het begrip resocialisatie}

\subsubsection{Het begrip resocialisatie en aanverwante begrippen}

Het begrip resocialisatie is van betrekkelijk recente aard. Het stamt uit het begin van de jaren vijftig toen "de voorbereiding van de terugkeer van gedetineerden in het maatschappelijk leven" in de Beginselenwet van 1951 als nevendoel aan de gevangenisstraf werd verbonden. In de wet zelf treffen we nergens het woord resocialisatie aan. De term resocialisatie werd in de praktijk gebruikt ter aanduiding van het streven naar de voorbereiding van de terugkeer in de samenleving. Het begrip resocialisatie drukt in globale zin een streven of een doelstelling 
uit. De precieze betekenis van resocialisatie is afhankelijk van de manier waarop men deze doelstelling in het Nederlandse gevangeniswezen heeft verwezenlijkt.

Resocialisatie wordt in de Penitentiaire Beginselenwet van 1999 (art.2 lid 2) nog steeds omschreven als de voorbereiding van de terugkeer van de gedetineerde in de maatschappij.

De wettelijke omschrijving van resocialisatic vertoont sterke gelijkenis met de omschrijving die men in van Dale's woordenboek van de Nederlands taal (1995) aantreft: "resocialiseren is het weer geschikt maken voor een aangepast leven in de maatschappij, (in het bijz.) de terugkeer van een gedetineerde (of een zieke. gehandicapte) in de samenleving voorbereiden".

In deze omschrijving ligt volgens Derks (1991, p.275) de veronderstelling besloten dat:

-het een verwijdering uit of een scheiding van de samenleving over een langere periode betreft;

-het resocialiseren niet verder reikt dan de voorbereiding op ontslag, het is niet gericht op begeleiding na ontslag;

-het resocialisatieproces alleen betrekking heeft op het te resocialiseren individu en niet zozeer op de gemeenschap. Deze is geen onderdeel van het resocialisatie-proces;

Het begrip resocialisatie wordt ook wel geassocieerd met activiteiten die eerder zijn te beschouwen als vormen van reclassering en rehabilitatie.

Reclasseren heeft vooral betrekking op begeleiding na ontslag, terwijl resocialiseren vooral verwijst naar de voorbereiding op het ontslag.

Rehabilitatie wordt in van Dale's woordenboek omschreven als herstel in eer en goede naam, waarbij vooral de samenleving een actieve rol krijgt toebedeeld. Het is de samenleving die uiteindelijk beslist of men in eer en goede naam wordt hersteld (Derks, 1991).

In de nota Werkzame Detentie (1994) spreekt men niet meer over resocialisatie maar over maatschappelijke integratie. Het begrip maatschappelijke integratie lijkt een ruimere betekenis te hebben dan resocialisatie in de zin van de voorbereiding op het ontslag. Het is vergeleken met de overige begrippen veel minder specifiek. Maatschappelijke integratie bestrijkt alle aspecten of preciezer, alle fasen die samenhangen met de terugkeer in de samenleving.

Omdat het begrip resocialisatie vooral betrekking heeft op de voorbereiding van het ontslag uit een inrichting en deze voorbereidende fase van de terugkeer in de samenleving in dit onderzoek een centrale plaats inneemt, wordt in deze studie steeds het begrip resocialisatie gehanteerd.

\subsubsection{Een omschrijving van het begrip resocialisatie}

De wettelijke resocialisatie-opdracht heeft, zoals in het vorige hoofdstuk bleek, de strekking van een intrinsieke doelstelling die de (rechts)bescherming van justitiabelen beoogt.

Het gevangeniswezen voert deze opdracht uit door middel van het penitentiaire beleid. In de concrete uitvoering is resocialisatie een doelstelling van instrumentele aard.

Er bestaan verschillende opvattingen over de vraag wat dit resocialisatie-doel in instrumentele zin precies inhoudt. Zo beschouwt men in de jaren vijftig en zestig het veranderen van gevangenen in burgers die in sociaal opzicht beter functioneren en minder gauw zouden terug-vallen in een criminele levensstijl, als het belangrijkste doel van resocialisatie. In de jaren tachtig geldt als doel dat de gedetineerde eerder geaccepteerd wordt door de samenleving en wellicht zich daarin beter weet te handhaven dan voorheen het geval was ( nota Taak en Toekomst, 1982, p.21). Het omvormen van gedetineerden tot betere mensen die zich voortaan zullen onthouden van crimineel gedrag wordt als doelstelling verlaten. Het zich beter weten te handhaven in de samenleving dient men vooral op te vatten 
als het verbeteren van de sociale redzaamheid van gedetineerden.

In de jaren negentig, in de Nota Werkzame Detentie (1994), krijgt een beperkte interpretatie van het resocialisatie-doel hernieuwde aandacht. In het kader van de maatschappelijke veiligheid ligt de nadruk weer op het verminderen van recidive. Maatschappelijke integratie dient voor daartoe gemotiveerde gedetineerden een duidelijk rendement in de zin van minder terugval op te leveren.

Er kan ook een verschil van inzicht bestaan over de vraag hoe, dat wil zeggen, met welke middelen het gestelde resocialisatiedoel dient te worden verwezenlijkt.

Al naar gelang het vigerende penitentiaire beleid is in de afgelopen decennia bij de verwezenlijking van het resocialisatic-doel het accent gelegd op bijvoorbeeld: het doorbreken van het besloten karakter van de inrichtingen teneinde vervreemding van de gedetineerden van het leven in de samenleving tegen te gaan, het geven van meer verantwoordelijkheden, het leggen van zo normaal mogelijke menselijke contacten en het scheppen van een goed psychosociaal detentieklimaat en het vinden van betaald werk na detentie

De technieken of interventievormen waarmee men resocialisatie tracht te bereiken kunnen van velerlei aard zijn, bij voorbeeld individuele- en groepstherapie, bepaalde vormen van (basis)- educatie, training van sociale- en arbeidsvaardigheden, gezinstherapie, cognitieve therapie, gedragstherapie, milieutherapie e.d..

Sechrest et al., (1979, p.19) hanteren de volgende definitie van resocialisatie als instrumentele doelstelling van het strafrecht:

"Resocialisatie is het resultat van een geplande interventie gericht op de reductie van toekomstige criminele activiteit via beïnloeding van de persoonlijkheid, gedrag, vaardigheden, houdingen, watden of andere factoren".

Deze definitie sluit vormen van interventie uit die andere doelen nastreven dan recidivevermindering. De onderzoekers merken niettemin op dat dergelijke interventiedoeleinden wel degelijk de moeite van het evalueren waard kunnen zijn (ibid., p.19).

Sechrest et al. gaan er blijkbaar vanuit dat resocialisatie meer kan zijn dan het louter voorkomen van recidive. Zij sluiten een definitie van resocialisatie in ruime zin dus niet uit.'

Het niet meer recidiveren als gevolg van een interventie met een bruut en intimiderend karakter beschouwen zij niet als resocialisatie, maar als afschrikking. Het planmatige karakter impliceert dat spontane verbetering zonder de aanwezigheid van een interventieprogramma, bijvoorbeeld als gevolg van bepaalde maturatie- en ontwikkelingseffecten evenmin als een vorm van resocialisatie kan worden beschouwd.

De houdingen ten aanzien van resocialisatie worden in deze studie onderzocht in relatie tot de doelstellingen van resocialisatie als zodanig en in relatie tot de middelen dat wil zeggen de concrete voorzieningen waarmee men deze doeleinden tracht te verwezenlijken. De doeleinden in instrumentele zin kunnen zowel betrekking hebben op recidive-vermindering als op andere houdings-of gedragsveranderingen zoals het streven naar persoonlijke groei,

\footnotetext{
' Opvattingen over resocialisatie waarbij men het verminderen van criminele tendenties als het enige juiste doel van dit streven acht, kan men aanduiden als opvattingen in enge zin. Opvattingen waarbij men ook andere, niet direct op recidive-vermindering gerichte functies als legitieme doeleinden van het resocialisatiestreven beschouwt ( bijvoorbeeld humane bejegening en beperken van detentieschade, veranderingen in houding. persoonlijke groei, betere sociale redzaamheid), kan men aanduiden als opvattingen in ruime zin.
} 
een groter welbevinden of betere sociale redzaamheid.

Respondenten krijgen bovendien uitspraken voorgelegd watarin resocialisatic meer de strekking heeft van een intrinsieke doelstelling. dat wil zeggen als een opdracht waartoe men. afgezien van de eventuele (toekomstige) effecten, is gehouden om humane redenen.

De concrete voorzieningen hebben in het empirisch gedeclte van deze studie met name betrekking op educatieve activiteiten, hulpverlening en arbeid.

Het begrip resocialisatie kan men voor deze studie in operationele zin derhalve omschrijven als: het streven dat is gericht is op zoncl behoud en herstel ram het (toekomstig) psychosociale welaijn van gedetineerden als op vermindering van hun toekomstig crimineel gedrag door middel van voorieningen warbij de persoonlijke onwikkeling centraal staat. Deze operationele definitie dekt de mogelijke betekenissen watrin het begrip resocialisatic in het literatuuronderzoek en in het empirische gedeelte van deze studic aan de orde komt.

\subsection{Het streven naar zedelijke verbetering door eenzame opsluiting in de negentiende eeuw}

"Het stelsel ran cellalaire opshatiting dat met enkele verachatingen van de cenaamheid. tot na de Tweede Wereldoorlog in Nederland gehandhadt bleef. behoort tot cen ran de meest ragische misrekeningen in de historie van de criminaliteitsbestrijding." (Franke. 1991. p.351)

Het streven naar verbetering in het kader van de vrijheidsbenemende straf kent al een vrij lange historie. In Nederland werden misdadigers naast andere 'ommaatschappelijken' vanat' het einde van de zestiende eeuw opgesloten in huizen van correctic ook wel de rasp- of spinhuizen genoemd. In deze inrichtingen probeerde men delinquenten door middel van dwangarbeid te laten wennen aan een leven van orde en regelmaat.

Opsluiting van delinquenten was in deze periode zeker niet de belangrijkste sanctievorm. De nadruk bij de bestraffing van delinquenten lag op de toepassing van liji-en doodstraffen. Bovendien zijn de pedagogische bedoelingen die men aan de opsluiting in de rasp- of spinhuizen verbond veel minder uitgesproken dan die van de latere, negentiende-ecuwsc gevangenisstelsels.

In het begin van de negentiende eeuw groeit de afkeer tegen het publieke vertoon van de executie van deze straffen. Het openbaar pijnigen en ter dood brengen van delinguenten werd steeds meer gezien als een praktijk die in wezen onbeschaafd was.

Franke (1990) en Garland (1990) beschouwen het in onbruik geraken van deze lijf- en doodstraffen en de geleidelijke vervanging van deze straffen door de vrijheidsbenemende sanctie in de eerste helft van de negentiende ceuw vooral als een uitvloeisel van een omvangrijk en autonoom civilisatieproces in de Westerse samenleving. En belangrijk facet van dit civilisatieproces is een toenemend vermogen zich te verplaatsen in het leed en de pijn van andere mensen. Franke spreekt in dit verband over een toegenomen identificatie met de 'gevallen' medemens door de maatschappelijke bovenlagen.

Franke (p.135) zegt hierover:

" de geselslagen die misdadigers op het schavot werden toegebracht. zouden als het ware meer en meer als striemen op het eigen lichaam gevoeld worden".

Deze gevoeligheid of sensibiliteit voor het leed van anderen strekte zich aan het begin van de negentiende eeuw ook uit tot het lot van delinquenten. Vanwege de toegenomen afkeer van 
de lijf-en doodstraffen werden deze allengs vaker bestraft in de vorm van gemeenschappelijke opsluiting in tucht-en correctiehuizen (Franke, 1990, p. 776).

De groeiende belangstelling van mensen uit de bovenlagen van de maatschappij voor de behandeling van gevangenen ging gepaard met nieuwe denkbeelden over het doel van hun opsluiting. Totnogtoe werden met de opsluiting in de tucht- en correctiehuizen vooral vergelding, afschrikking en wraak beoogd. Maar juist doordat men gevoeliger was geworden voor het leed van gevangenen werden vergelding en wraak steeds meer in verband gebracht met primitieve driften.

Ter rechtvaardiging van dit leed was vergelding en afschrikking alléén niet langer aanvaardbaar. De gevangenis moest nict alleen afschrikken maar tevens bijdragen aan de zedelijke verbetering van delinquenten. Franke concludeert dat de toenemende gevoeligheid voor het leed van anderen in belangrijke mate bijdroeg tot de verbinding van dit 'nevendoel' aan het straffen (ibid., p.783).

De oorsprong van het verbeteringstreven in de context van de gevangenisstraf ligt dus historisch gezien voor een deel in humanitaire motieven, hoe zwak en pril die aanvankelijk ook geweest mogen zijn.

Garland's (1990) omschrijving van deze verandering in de houding ten aanzien van delinquenten als 'the extension of sympathy to the offender' geeft die humanitaire strekking goed weer. 2

Dat men zich in de eerste helft van de $19 \mathrm{e}$ eeuw reeds in enigerlei mate bekommerde om de omstandigheden waaronder gevangen hun straf uitzaten, blijkt bijvoorbeeld uit de oprichting van het Genootschap tot Zedelijke Verbetering der Gevangenen in 1823. De oprichting van dit genootschap was een particulier initiatief met een filantropische doelstelling.

Enige jaren daarvoor, in $1821 \mathrm{kreeg}$ de aandacht voor de positie van gevangen ook in wettelijke zin gestalte met het Koninklijk Besluit houdende de Organisatie der Gevangenissen. Dit besluit had expliciet tot doel de kosten van het gevangeniswezen te drukken door een regeling van de gevangenisarbeid. Impliciet had het besluit echter ook tot doel de ergste wantoestanden in de gevangenissen tegen te gaan. Klachten van welgestelde burgers over de erbarmelijke omstandigheden van de huizen van correctic waarin zij tijdens de Franse Bezetting om politieke redenen waren opgesloten, vormden mede aanleiding voor het Koninklijk Besluit. Bij de eerst volgende bezetting door een vreemde mogendheid in de twintigste eeuw herhaalt zich, zoals we elders in dit hoofdstuk zullen zien, een dergelijke geschiedenis van grotere betrokkenheid en verontwaardiging van burgers uit de maatschappelijke bovenlagen die een verblijf in een strafgesticht aan den lijve hadden ondervonden.

In het Koninklijk Besluit werden voeding, kleding, hygiëne e.d. aan een aantal minimale regels gebonden (Franke, p.46). Ook werd door een betere classificatie van de gebouwen gepoogd een scheiding aan te brengen tussen verschillende categorieën gedetineerden (veroordeeld, onveroordeeld, mannen, vrouwen, kinderen en volwassenen). De voorschriften werden overigens maar zeer ten dele in de praktijk gebracht'(Franke, p.47).

\footnotetext{
2 Ook Garland kent een grote betekenis toe aan deze toegenomen sensibiliteit voor het leed van gevangenen: "Thus the gradual but undeniabele lowering in the intensity of punishment, the extension of charity to prisoners and offenders, the provision of social welfare measures in the twentieth century, the amelioration of prison conditions in most states and even the legal recognition of prisoners' rights in some of them, might all be understood as aspects of this more general movement in sensibilities." (p.236)
} 
Terwijl betekenis van de lijf-en doodstraffen in de eerste helft van de $19 \mathrm{e}$ ecuw geleidelijk aan afneemt en de vrijheidsbenemende straf steeds vaker wordt toegepast, krijgt intussen ook het denken over de manier waarop de verbetering van gedetineerden in de praktijk diende te worden gebracht, steeds duidelijker vorm.

Het streven naar zedelijke verbetering van gedetineerden ontwikkelde zich langs de lijn van een religieus getint denken over goed en kwaad en van het beeld van de mens als een afgesloten entiteit die onafhankelijk van de medemens existeert.

In de negentiende geloofde men dat misdadigers het kwaad bedreven vanwege een slecht innerlijk of een ziel die in zedelijk opzicht was bedorven. Bovendien ging men ervan uit dat mensen op grond van hun vrije wil en van rationele overwegingen voor de zonde zwichtten. Verbetering achtte men alleen maar mogelijk voor zover de zondaar in staat was op eigen kracht, in een sociaal vacuüm (Franke, p.100) tot inkeer te komen en zijn innerlijk te zuiveren van het kwaad. De verbetering richtte zich in psychische zin op het innerlijk en het geweten van de dader. Pijniging van het geweten in plaats van pijniging van het lichaam wordt het doel van de straf. Eenmaal verbeterd zou de gedetineerde geen delicten meer willen plegen in plaats van niet meer durven plegen.

Deze denkbeelden omtrent de geestelijke correctie van gedetineerden zijn reeds aan het einde van de achttiende eeuw en het begin van de negentiende eeuw aanwijsbaar in experimenten in Engeland en de Verenigde Staten met gevangenissen of 'penitentiaries' waarin eenzame opsluiting in het teken stond van zedelijke verbetering en het ontwaken van het geweten. In deze eerste experimenten met gevangenissen, gericht op verbetering van gedetineerden ligt de ideologische en pedagogische oorsprong van de negentiende-eeuwse gevangenisstelsels besloten.

De gemeenschappelijke opsluiting in de huizen van correctie in Nederland werd, als gevolg van de nieuwe inzichten omtrent de zedelijke verbetering van delinquenten, steeds meer als een manier van tenuitvoerleggen gezien die uit het oogpunt van zedelijke verbetering juist averechts werkte.

De verbetering van het verdorven innerlijk diende bij voorkeur te geschieden in de strikte eenzaamheid van de cel, zoveel mogelijk afgesloten van de kwade invloeden van medegedetineerden.

De verbeteringsgedachte was in deze periode overigens geen hoofddoel van de vrijheidsbeneming. De rechtvaardiging van de (vrijheids)straf bleef hoofdzakelijk in het teken staan van wraak, vergelding en afschrikking. Door de vrijheidsstraf in de vorm van stricte, eenzame afzondering ten uitvoer te leggen werden tevens de voorwaarden geschapen voor de zedelijke verbetering van de gevangene.

Zedelijke verbetering werd dus als nevendoel aan de straf verbonden. Gevangenen werden op deze manier als het ware in hun eigen belang aan de gevangenisstraf onderworpen.

In Nederland werd in 1851, aanvankelijk op beperkte schaal en in experimentele vorm, de eenzame opsluiting ingevoerd. Men koos voor het Philadelphia- stelsel dat gebaseerd was op de totale afzondering van de gedetineerde gedurende de dag en de nacht als middel ter verbetering van zijn innerlijk. Echter, een dergelijke vorm van opsluiting was slechts toegestaan bij kleinere vergrijpen en voor de duur van hooguit een half jaar.

In 1886 werd het cellulaire stelsel algeheel ingevoerd met het inwerking treden van het Wetboek van Strafrecht. Vastgesteld werd dat de eenzame opsluiting een maximum van vijf jaar niet mocht overschrijden.

In datzelfde jaar traden ook de eerste Beginselenwet van het gevangeniswezen en de Gevangenismaatregel in werking waarin tal van artikelen werden opgenomen die het 
meedogenloos strenge regime van de cellulaire opsluiting waarborgden. De gevangenen hadden op grond van het regime voornamelijk plichten en geen rechten.

In de laatste twee decennia van de negentiende eeuw werden gevangenissen en huizen van bewaring steeds meer op cellulaire wijze ingericht en er werden ook nieuwe cellulaire gevangenissen gebouwd.

In deze gevangenissen werd alles in het werk gesteld om de afzondering van andere gevangenen te waarborgen. Zij mochten alleen contacten onderhouden met cipiers, onderwijzers, geestelijken en leden van het Genootschap tot Zedelijke Verbetering der Gevangenen die hen aanspoorden tot morele verbetering. Die verbetering in de zin van het tot inkeer geraken stond, door het zeer strenge regime en de aansporingen door middel van bijvoorbeeld verplichte godsdienstoefeningen, stichtelijke lectuur en preken van geestelijken en leden van het Genootschap tot Zedelijke Verbetering der Gevangenen, sterk in het teken van de uitoefening van psychisch dwang.

Opmerkelijk is dat sinds 1847 in het kader van de verbeteringsgedachte bij reglementair voorschrift werd aangedrongen op het aanbieden van onderwijs aan gedetineerden die in de grote cellulaire gevangenissen verbleven. Het ging hierbij om vakken als rekenen, lezen, schrijven en specifieke vakkennis. Gevangenen mochten tot op 45-jarige leeftijd deelnemen aan het onderwijs als middel tot 'zedelijke verheffing'. ${ }^{3}$

De eenzame opsluiting op grond van het cellulaire stelsel had ondanks de pretentie van beschaving en vooruitgang van de bestraffers een enorm psychisch leed voor de gevangenen tot gevolg. Naar onze huidige maatstaven lijkt dit cellulaire leed niets met vooruitgang te maken te hebben.

Toch duidt volgens Franke (1990, p.775) de verbinding in de negentiende eeuw van het streven naar zedelijke verbetering met de gevangenisstraf op het ontstaan van een beeld van delinquenten dat complexer en minder statisch is dan het beeld van delinquenten in voorgaande eeuwen. Zowel de cellulaire filosofie als de latere socialisering van de straf duiden op de ontwikkeling van een mensbeeld waarin het besef van de sociale gevormdheid en onderlinge verbondenheid van de mens aan betekenis heeft gewonnen.

\subsection{Resocialisatie in de twintigste eeuw}

\subsubsection{Het ontstaan van het verbeteringstreven als speciaal-preventieve doelstelling van het strafrecht}

"De Nieuwe Richting pleitte voor speciale preventie in plaats van vergelding. Daarmee kreeg het strafrecht een meer instrumenteel karakter. De strafrechtsjuristen zagen zichzelf vanaf dat moment vooral als social engineers, die door speciale preventie en later ook door generale preventie, de maatschappij moesten beschermen tegen criminaliteit." (Denkers, 1976, p.105)

Aan het einde van de negentiende eeuw en het begin van de twintigste eeuw vervulden de criminologie, de strafrechtswetenschap en het opkomend socialisme een vooraanstaande rol

\footnotetext{
'In 1884 trachtte de Minister van Justitie in het kader van het ontwerp voor de eerste Beginselenwet van het Gevangeniswezen het onderwijs aan gevangenen drastisch te beperken uit vrees voor verlies van het 'pijnlijk' karakter van de gevangenisstraf. Deze pogingen leden echter voor een belangrijk deel schipbreuk in de Tweede Kamer.
}

(Franke, p.354-357) 
bij de ontwikkeling van een visie op misdaad en straf die fundamenteel afweek van de gangbare. klassicke denkbeelden uit de negentiende eeuw.

Het verschijnen van de criminologie als nieuwe wetenschap leidde tot cen sterk groeiende aandacht voor de erfelijke, sociale en psychische oorzaken van criminaliteit. Vertegenwoordigers van de antropologische en sociologische stromingen binnen deze nieuwe wetenschap meenden dat het gedrag van delinquenten volledig werd bepaald door oorzaken waarop zij zelf geen enkele invloed hadden (Franke.1990, p.461). Deze deterministische visie werd dermate invloedrijk dat in de strafrechtswetenschap de negentiende-eeuwse klassieke strafrechtelijke begrippen geleidelijk op de achtergrond rakkten. Die begrippen van het klassieke strafrecht waren sterk gebaseerd op godsdienstige dogma's met betrekking tot zonde. schuld en boetedoen. Het bedrijven van kwaad diende altijd vergolden te worden, de straf werd opgelegd ondat was misdreven. Voor verzachtende omstandigheden was weinig ruimte, immers men ging er vanuit dat elke misdaad in principe voortsproot uit een vrij wilsbesluit van de dader.

Deze begrippen van het klassieke strafrecht, waarbij de daad en niet zozeer de dader werd bestraft, verloren binnen het deterministische mensbeeld van de nieuwe stroming in het strafrecht, ook wel de Nieuwe of Moderne Richting genoemd, hun betekenis.

De aanhangers van de Nieuwe Richting vonden dat de dader, als sociaal en psychisch minderbedeelde, in ethisch opzicht niets te verwijten viel. Zij konden het immers niet helpen dat zij door erfelijke aanleg of sociale omstandigheden tot crimineel gedrag waren vervallen. $\mathrm{Bij}$ het straffen zou volgens de Modernen dan ook moeten worden afgezien van begrippen als wraak, vergelding en schuld. De straf diende juist rekening te houden met persoonlijke omstandigheden van sociale en psychische aard en aan de persoon van de dader te worden aangepast.

Niet de misdaad diende de straf te bepalen, maar de vraag wat voor deze delinquent met het oog op zijn of haar toekomst en de maatschappelijke beveiliging een geschikte strafrechtelijke reactie zou zijn.

De straf diende zijn zin te ontlenen aan een te verwachten, nuttig effect in de toekomst (Franke. 1990, p.532). Een van de grondleggers van de Nieuwe Richting, de Duitse strafrechtsgeleerde Von Liszt stelde bij het bereiken van deze nuttige, heilzame effecten in toekomst één doel centraal, namelijk de beveiliging van de samenleving.

Dit speciaal preventieve doel kon volgens Von Liszt op drie manieren worden bereikt: door verbetering, afschrikking en onschadelijkmaking van de individuele dader. Op grond van het toegenomen besef van de sociale gevornudheid van de mens diende volgens de aanhangers van de Nieuwe Richting de verbetering van de dader niet meer te worden gericht op het innerlijk of de bedorven ziel van de gevangene, maar op een verder liggend doel met betrekking tot zijn (toekomstig) sociaal functioneren.

De verbeteringsgedachte in moderne, instrumentele zin, dat wil zeggen verbetering in het kader van een relatieve, speciaal-preventieve doelstelling van de straf die via beïnloeding van sociale relaties, posities en vaardigheden van de dader de maatschappij tracht te beschermen tegen criminaliteit, vindt dus mede zijn oorsprong in de nieuwe denkbeelden over misdaad en straf aan het einde van de negentiende eeuw het begin van de twintigste eeuw.

De strijd die rond de eeuwwisseling gaande was tussen voorstanders van het Klassieke strafrecht en de Nieuwe Richting in het strafrecht betrof overigens niet de verbeteringsgedachte als zodanig. Over de gedachte dat de gevangenisstraf tevens tot verbetering van de gedetineerde strekte, bestond bij de deelnemers aan het debat geen enkele twijfel. De 
verschillen van inzicht hadden vooral betrekking op de manier waarop die verbetering tot stand diende te komen.

De voorstanders van de Nieuwe Richting verwierpen de totale afzondering van het cellulaire stelsel ondat dit stelsel de sociale context van het individu en zijn handelingen ontkende. Niemand, zo meenden zij, wordt in de totale afzondering van de cel, verstoken van vrijwel ieder normal menselijk contact, een beter mens. Eenzame opsluiting maakt de gedetineerde eerder ongeschikt voor een goed sociaal functioneren

Een van de aanhangers van de Nieuwe Richting, de criminoloog Ferri vroeg zich met betrekking tot het onmenselijke karakter van het cellulaire stelsel het volgende af:

"Moeten we dus de misdadigers in cellen sluiten en het laatste restje menselijkheid in hen verstikken? In cellen watar men ze brengt tot krankzinnigheid en zelfmoord, watar ze voor goed tot misdadigers worden?" ( geciteerd door Franke, 1990, p.481)

Dergelijke kritick van de Nieuwe Richting in het strafrecht miste zijn uitwerking op het denken over het cellulaire stelsel in de eerste twee decennia van de twintigste eeuw niet. Het cellulaire stelsel veranderde in het begin van de twintigste eeuw als gevolg van deze nieuwe denkbeclden over het straffen van "paradepaardje tot blok aan het been ", aldus Franke ( ibid., p.481)

Samenvattend kan worden gesteld dat rond de eeuwwisseling de nieuwe denkbeelden over misdaad en straf leidden tot een breuk met de klassieke negentiende eeuwse strafrechtelijke begrippen met betrekking tot zonde, vergelding, schuld en de daad als strafcriterium. Tevens werden het on-sociologische, gesloten mensbeeld en het cellulaire stelsel van eenzame opsluiting ter discussic gesteld.

$\mathrm{Na}$ de Eerste Wereldoorlog kreeg het straffen en verbeteren als gevolg van een toegenomen sociologisch bewustzijn een sterker socialiserend karakter. Na de Eerste Wereldoorlog sprak men ook niet meer over verbetering van misdadigers maar over hun opvoeding. Opvoeding als strafdoel werd in de jaren twintig omschreven als de omvorming van een anti- of asociaal persoon tol iemand die na zijn detentie beter is toegerust voor het leven in de maatschappij. Franke beschrijft de realisering van de opvoedingsgedachte in het gevangeniswezen als volgt:

"Het voorzichtig toclaten van sociale contacten in de cellulaire gevangenissen, individualisering van de straf, classificatic van gevangenen en differentiatic van gevangenissen; het werd allemaal onontbeerlijk geacht voor een strafstelsel dat de opvoedingsgedachte serieus nam. Velen bleken onder opvoeding weinig meer te verstaan dan het aanleren van een vak, het geven van onderwijs. het gewennen aan orde en regelmaat en leren rekening houden met medemensen. Anderen gingen veel verder. Opvoeden was in hun ogen vooral gericht op wilstraining. op het leren beheersen van driften en hartstochten en op het vergroten van 'zelfbestuur' of 'zelftucht'. In tegenstelling tot de cellulairc verbeteraars meenden de nieuwe opvoeders dat juist ruime sociale contacten en een grote mate van vrijheid nodig waren om die zelfdwang in gevangenschap te kunnen aankweken."( ibid., p. 577)

Het leven in de gevangenis tussen de beide wereldoorlogen stond ondanks deze opvoedkundige bedoelingen en de invoering in 1924 van het zogenaamde stelsel van afwijkingen nog sterk in het teken van de eenzame opsluiting. Het stelsel van afwijkingen dat de uniforme en strakke toepassing van het celstelsel beoogde te doorbreken, bleek nauwelijks geschikt om de opvoedingsgedachte te realiseren.

In de praktijk werd het stelsel van afwijkingen al gauw gebruikt als een middel om de rust en orde in het gesticht te handhaven (Franke, 1990, p.585). Op grond van een strafrechtelijk tweesporenbeleid van 'zacht waar het kan en hard waar het moet' werden de verzachtingen 
van de detentieomstandigheden bovendien onthouden aan psychopathische en beroeps-of gewoontemisdadigers. Het zachte pragmatisme van heropvoeden en herintegreren gold alleen de behandeling van gelegenheidsmisdadigers, waartoe men overigens wel het overgrote deel van de veroordeelden rekende. De veranderingen gedurende de periode van het interbellum lijken, vergeleken met de naoorlogse hervormingen van het strafrecht, weinig spectaculair. Ook de strafrechtsdeskundigen die in de jaren dertig pleitten voor een werkelijke opvoedkundige werking van de straf vonden dat de invoering van stelsel van afwijkingen weinig te betekenen had en niet ver genoeg ging (Franke, 1990, p.627). Vanuit het perspectief van de gevangenen was de doorbraak van het celstelsel door middel van het stelsel van afwijkingen echter een belangrijke gebeurtenis. Voor hen betekende het een daadwerkelijke verlichting van het eenzame en depriverende bestaan in een cel en, zoals Franke opmerkt, een heuse breuk met het ellendige bestaan van vroeger.

De periode tussen de beide wereldoorlogen kan men beschouwen als een periode waarin het sociale mensbeeld en de daaruit voortvloeiende (speciaal-preventieve) aandacht voor de persoon van de dader al enigszins terrein had gewonnen in het strafrechtelijke denken. De geesten waren in zekere zin al rijp gemaakt voor de algehele bezinning op vorm en inhoud van vrijheidsbenemende sancties die begin jaren vijftig, na de definitieve afschaffing van het gesloten cellulaire stelsel, plaats zou vinden. De naoorlogse ontwikkeling van het gevangenis-wezen ligt historisch gezien in het verlengde van een tendens tot humanisering en socialisering die zich dus al veel eerder in het twintigste-eeuwse denken over misdaad en straf aftekende.

\subsubsection{Ontwikkelingen na 1945: de resocialisatie-opdracht van artikel 26 van de Beginselenwet}

De twijfels die reeds voor de oorlog werden geuit ten aanzien van het cellulaire stelsel en de hervormingsgedachten waarin aan de sociale aard van de gedetineerde medemens een belangrijke rol werd toegekend, raakten na de Tweede Wereldoorlog in een stroomversnelling. De hervormingsgezindheid was groot, onder meer als gevolg van de detentie-ervaringen van vele burgers tijdens de bezettingsperiode. Ex-politieke gevangenen riepen op tot reorganisatie van het gevangeniswezen, waarbij zij weldra steun kregen van leden van de reclassering, advocatuur en magistratuur.

De commissie Fick presenteerde in 1947 een rapport waarin een fundamentele reorganisatie van het gevangeniswezen werd voorgesteld. Als belangrijke aanbevelingen golden de afschaf-fing van het cellulaire stelsel, een grotere mate van differentiatie van gestichten en een zorgvuldige en nauwgezette selectie van gedetineerden. Het rapport was van grote betekenis voor een nieuwe Beginselenwet gevangeniswezen. In het ontwerp Beginselenwet van 1949 nam de minister de aanbevelingen in grote lijnen over en in 1953 werd een nieuwe Beginselenwet en Gevangenismaatregel ingevoerd.

De belangrijkste karakteristieken van de Beginselenwet vormen de synthese tussen cel en gemeenschap en de voorbereiding op de terugkeer in de samenleving. Na de Tweede Wereldoorlog sprak men ook niet meer over zedelijke verbetering en opvoeding maar over resocialisatie in de betekenis van de voorbereiding van de terugkeer in de samenleving.

$\mathrm{Bij}$ de behandeling in de Tweede Kamer werden de bezwaren tegen het celstelsel als volgt weergegeven:

" Het leven in eenzaamheid is voor de mens een onnatuurlijk leven. Door gebrek aan contact met medemensen ontstaan bij de meeste gedetineerden geestelijke en lichamelijke spanningen, die een 
concentratie op de geestelijke grondslagen van het leven belemmeren". "

In art. 11 wordt nadrukkelijk gebroken met het uniforme celstelsel. De gevangenisstraf dient voortaan al naar gelang de persoonlijkheid van de veroordeelde in algehele of beperkte gemeenschap dan wel in afzondering te worden ondergaan. Voorop gesteld werd de gemeenschap. In een regime van algehele gemeenschap kan men zich, met uitzondering van de nacht, in bepaalde mate vrij bewegen binnen de inrichting.

Van grote betekenis is het artikel 26 van de Beginselenwet waarin resocialisatie formeel als executicve doelstelling werd vastgesteld, hoewel de wet het woord resocialisatie niet gebruikt.

Het artikel luidt:

"Met handhaving van het karakter van straf of maatregel wordt hun tenuitvoerlegging mede dienstbaar gemaakt aan de voorbereiding van de terugkeer in het maatschappelijk leven".

De aanhef van het artikel 'met handhaving van het karakter van straf of maatregel' werd ondanks het feit dat het woord 'mede' toch al betrekking had op de handhaving van het strafkarakter, op verzoek van de Tweede Kamer toegevoegd. Men vreesde dat het hoofddoel van de gevangenisstraf, namelijk de vrijheidsbeneming zonder deze toevoeging wellicht onvoldoende gewaarborgd zou blijven in de praktijk van de tenuitvoerlegging. De minister had er overigens in een Memorie van Antwoord al op gewezen dat het hoofddoel - de opsluiting voorrang heeft boven andere doelen, zoals bij voorbeeld die met een opvoedkundig karakter

Zoals ik eerder in hoofdstuk 1 heb betoogd, dient artikel 26 Beginselenwet tevens te worden geïnterpreteerd als een intrinsieke doelstelling van het strafrecht. De rechtsbescherming van de gedetineerde in de zin van het deel blijven hebben aan de samenleving staat in deze opdracht aan het gevangeniswezen centraal.

Dit uitgangspunt werd, bij de parlementaire behandeling van de wijze waarop de terugkeer in de samenleving gestalte diende te krijgen ook als zodanig verwoord in de Memorie van Toelichting:

"Vooreerst is het doel der gemeenschap in de gestichten om de gedetineerden tijdens hun straftijd te doen voelen, dat zij als individu tot de maatschappij blijven behoren. On dit gevoel van niet* geïsoleerd staan te bevorderen, dient het contact met het maatschappelijk leven voor zover mogelijk te worden gehandhaafd, etc., ."

Kelk (1993,(1)) beschouwt art. 26 Beg.wet met de daarin besloten resocialisatie-opdracht tevens als een streven de autonomie van de gedetineerde te versterken "door de gedetineerde te doen leren werken met zijn rechten, hetgeen tevens impliceert het moeten accepteren van verliezen" (p.33). De betekenis van de resocialisatie-opdracht als intrinsieke doelstelling van het strafrecht blijkt ook duidelijk uit de volgende omschrijving van Kelk (1993, (1), p.34). Het artikel 26 bis Beg.wet ${ }^{6}$ en het artikel 26 Beg.wet tenderen aldus Kelk:

\footnotetext{
${ }^{4}$ Tweede Kamer, zitting 1948-1949, 1189, nr.3, p.2.

"Tweede Kamer, zitting 1948-1949, 1189, nr.3, p.13.

'Dit artikel verwijst naar het beginsel van minimale beperkingen hetgeen impliceert dat onveroordeelden aan geen andere beperkingen worden onderworpen dan die voor het doel van hun opsluiting of in het belang der orde volstrekt noodzakelijk zijn.
} 
"natar de noodzatk van participatic van de gedetineerde in het recht. dus van diens rechtsburgersehap. zij het vanuit verschillende optiek: resp. die van de optimale rechtsgelijkheid van burgers onderling. inhoudende een zo gering mogelijke aantasting van hun integritcil ook als rechtsgenoten (beginsel van minimale beperkingen) en die van de maatschappelijke positie van de burgers, inhoudende het behoud of herstel van matschappelijke functies. dus van hun medeburgerschap (resocialisaticbeginsel)."

Het betrekkelijk tijdloze en universele karakter van art. 26 blijkt bovendien uit het feit dat de concrete invulling grotendeels alan de praktijk van het gevangeniswezen werd overgelaten.

Bij de behandeling in Tweede Kamer van de Beginselenwet werd overigens wel het socialiserende karakter van het resocialisatie-streven in globale termen aangegeven. Er vielen termen als training in maatschappelijk gedrag en de opvoedende werking van het groepsproces. Bovendien wilde men door individualisering van de straf (te bereiken door differentiatie van inrichtingen en regimes en selectic van gedetineerden) een bijdrage leveren aan de realisering van de resocialisatie-opdracht.

Aan het begin van de jaren vijftig begon men in het gevangeniswezen met veel optimisme aan de uitbouw van de voorgenomen vernieuwingen. Voor wat betreft de resocialisaticopdracht werd gepoogd gedetineerden in groepsverband, met hulp en begeleiding van sociaal-cultureel en maatschappelijk werkers, gecstelijk en materieel beter toe te rusten voor het maat-schappelijk bestaan. Men probeerde gedetineerden via sociotherapie en gespreksgroepen om te vormen tot maatschappelijk aangepaste en oppassende burgers. In de volgende paragrataf word deze resocialisatie-praktijk nader onder de loep genomen. Op grond van die praktijk bleck het echter al gauw nodig de hooggespannen verwachtingen omtrent het verbeterings-ideal te temperen.

\subsubsection{Ontwikkelingen in de jaren vijftig en zestig.}

"Nederlandse gevangenissen moeten wel aangename verblijfplaatsen zijn voor gedetineerden, war functionarissen en gedetineerden eendrachtig bezig aijn mot het witbuiten ran de mogelijkheden tot resocialisatie." (Zwezerijnen. 1972. p. 4)

De verwezenlijking van de nieuwe wettelijke uitgangspunten in de jaren vijftig stuitte op een praktijk die vooral in gebouwelijk opzicht grote belemmeringen bleek op te leveren. De commissie 's Jacob (Commissie voor de bouwkundige voorzieningen van het gevangeniswezen) die in 1953 werd geïnstalleerd sprak in de eerste plaats van een onverenigbaarheid tussen artikel 26 Beginselenwet en de bestaande gebouwen. Daarnaast werden ook de differentiatie en selectie door de commissie onder de loep genomen. Resocialisatic kon volgens de commissie vooral worden gerealiseerd door interne differentiatie dat wil zeggen, een indeling in groepen van twintig tot dertig personen. Groepsindeling werd door de deskundigen immers een geschikt middel bevonden ter beïnvloeding van gedetineerden. De commissie constateert echter onduidelijkheid met betrekking tot de selectie-criteria voor de groepsindeling.

De aanbevelingen van de commissie op het gebied van sluiting van bestaande inrichtingen en de bouw van nieuwe inrichtingen werden niet overgenomen.

De problemen met betrekking tot de realiseerbaarheid van het behandelingsideaal blijken vervolgens van een nogal hardnekkige aard. In de Gevangenisnota van 1964 ( p. 9) wordt als een van de vele problemen genoemd het ontbreken van kennis omtrent de juiste selectie- 
methodiek en van voldoende inzicht in de verdere wijze van behandeling van gevangenen. Minister Scholten merkt op dat de institutionele therapie nog in een experimenteel stadium verkeert.

Veringa ( 1964, p.11 en 12 ) merkt op dat socio- en psychotherapeutische activiteiten gefundecrd op wetenschappelijke, theoretische kennis omtrent criminaliteit ontbreken. Voorts constateert hij het ontbreken van een gericht streven naar het verminderen van hernieuwd crimineel gedrag.

Andere deskundigen constateren hetzelfde euvel. Zwezerijnen (1972) meent dat de theorie achter de resocialisatie-gerichte gevangenis in Nederland geen coherent geheel vormt. Zwezerijnen die in 1966 als bewaarder participerend onderzoek verrichtte in een tweetal gevangenissen spreekt in dit verband van "een mengsel van ideeën ontleend aan psychiatrische theorie en de theorie van het maatschappelijk werk, gedachten over humane bejegening en conventionele normen." (ibid., p.8)

Het oordeel van gevangenisdeskundigen over de verwezenlijking van het resocialisatieideaal in het Nederlandse gevangeniswezen van de jaren zestig is nogal somber van aard. Veringa (1966, p.15) concludecrt:

"De alundacht die tot op heden binnen het gegeven kader van selectie en differentiatie aan de wederanpassing werd gegeven, heeft dan ook in feite slechts geleid tot regiems die maatschappelijk perspectief verleenden alan de steeds voortschrijdende humanisering."

Rijksen concludeert dat men niet is toegekomen aan een serieuze bezinning op de vraag hoe de terugkeer in de vrije samenleving op de beste wijze kan worden voorbereid (Rijksen, 1967, p.32).

Aan het einde van de jaren zestig blijkt de behandelingsfilosofie bepaald niet het resultaat te hebben opgeleverd dat door de directeur-generaal van het gevangeniswezen Lamers in 1950 als doel van de voorgestelde hervormingen werd aangewezen namelijk het 'als geregenereerde' terugkeren van de gedetineerde in de maatschappij (Franke, 1990, p.644). Daarvoor was het karakter van de behandeling van gedetineerden in de praktijk veel te perifeer en het belang dat aan recidive-vermindering als een direct, nagestreefd doel van de behandeling werd gehecht te gering (Denkers, 1976, p.235).

Bij Dijksterhuis (1973, p. 74-75) vinden we een illustratief voorbeeld van de weinig intensieve wijze waarop resocialisatie in de jaren zestig in de praktijk werd gebracht. Het betreft een beschrijving van de therapie of behandeling in een speciaal voor de resocialisatie van verkeersdelinquenten bestemde gevangenis (Bankenbos):

"Met betrekking tot de behandeling in therapeutische zin is Bankenbos aanmerkelijk minder speciaal. Het speciale bestaat uit een groepsgesprek met een medewerker van het Consultatiebureau voor Alcoholisme te Assen. Na dit groepsgesprek kan men onder vier ogen met deze functionarissen spreken. maar van deze mogelijkheid wordt weinig gebruik gemaakt. Verder kreeg men één avond verkeersvoorlichting van de verkeerspolitie uit Groningen. De behandeling had dus een perifeer karakter. Op de speciale problemen van de rijders onder invloed werd niet ingehaakt. Het komt er dus op neer dat het verschil tussen Bankenbos en Norgerhaven niet zozeer in een probleemgerichte behandeling zit. maar in de meer humane aanpak van gedetineerden."

\subsubsection{Resocialisatie en humanisering van de detentie}

In de jaren vijftig en zestig van de twintigste eeuw kwam resocialisatie feitelijk vooral neer op het streven naar humanisering van de detentie-situatie

De vruchten die gedetineerden aan het einde van de jaren zestig van het resocialisatie-ideaal 
hadden geplukt, dienen dan ook vooral in termen van een voortschrijdende humanisering en liberalisering van het gevangenisregime te worden gedefinieerd. ${ }^{7}$ Die humanisering werd ook reeds in de gevangenisnota van 1964 nadrukkelijk geformuleerd in het beginsel dat de vrijheid-straf op zich zelf de straf is en dat iedere extra toevoeging van leed zoveel mogelijk moet worden voorkomen.

Doordat men resocialisatie vooral ook trachtte te bereiken door een intensivering van sociale contacten met medegedetineerden en personeel en door verruiming van de indirecte sociale contacten met de vrije maatschappij kreeg de behandeling van gedetineerden in de naoorlogse decennia een meer menswaardig, liberaal karakter. De materiele voorzieningen verbeterden, de bewegingsvrijheid werd groter, de regimes werden minder streng en er werd een begin gemaakt met de verbetering van de rechtspositie van gedetineerden. In concreto leidde dit tot verruimingen op het gebied van bezoek, informatieverstrekking, recreatie, activiteiten-programma's en contacten met professionele hulpverleners. Een belangrijk resultaat van de hervormingen in de jaren vijftig en zestig is voorts de uitbouw van het personeel. Maatschappelijkwerkers, psychologen en andere deskundigen verwierven een belangrijke plaats in de organisatie.

\subsubsection{De Utrechtse School}

In de jaren vijftig en zestig ondervond het streven naar socialisering en humanisering van de behandeling van gedetineerden bovendien ideologische ondersteuning vanuit het gedachtegoed van de Utrechtse school. Wetenschapsbeoefenaren die tot deze school behoorden, zoals de criminoloog Kempe, de strafrechtsgeleerde Pompe, de psychiater Baan en de criminoloog Rijksen, zij allen bepleitten een benadering waarin cen 'ontmoeting met de gevangen mens' centraal stond. Pompe noemde de 'zorg voor de gevangen mens', het zoeken naar de mense-lijke maat in de strafrechtspleging als de voornaamste taak van de overheid bij de toepassing van de gevangenisstraf.

Eerbied voor de medemens, ook voor de misdadiger zou, aldus Pompe, leiden tot eerbied van de misdadiger voor zijn medemens. Kempe stelde zich op het standpunt dat de delinquent een van de onzen is en zijn daad op zich zinvol. Werkelijk recht doen is een levend mens tot zijn recht laten komen (zie hierover Janse de Jonge, 1990, p.91 en 92).

Het bijzondere en kenmerkende van het gedachtegoed van de Utrechtse School ligt vooral in de manier waarop men rekening wilde houden met de persoon van de gedetineerde. Het oorspronkelijke van de naoorlogse hervormingen schuilt volgens Kempe niet zonder meer in de aandacht voor de mens in de strafrechtspleging. De vraag naar de persoon van de dader was immers niet voor het eerst aan de orde in de geschiedenis van de strafrechtspleging (Janse de Jonge, p.90). Die aandacht is er in meerdere of mindere mate geweest, zonder overigens steeds te resulteren in een menselijke strafrechtspleging.

Janse de Jonge (p.90) merkt hierover op:

"Zo nodigde het beeld van de zinneloze en van de rebel, zoals dat voor de Verlichting bestond ertoe

${ }^{7}$ Blokland (1974, p.148) constateert: " De manier waarop in de Nederlandse penitentiaire inrichtingen getracht wordt het in de Beginselenwet opgenomen doel der resocialisatie te verwezenlijken is voornamelijk die van een meer gehumaniseerd regiem. In de bij het onderzoek betrokken inrichtingen zijn geen specifieke behandelings-of trainingsprogramma's ontwikkeld."

"In deze nota (blz.9) staat: "De gedetineerde behoort niet verder in zijn persoonlijke vrijheid te worden beperkt dan met het oog op het doel van zijn detentie nodig of onvermijdelijk is." 
uit, de dader als wild dier, respectievelijk als vijand te behandelen. Dat van de bourgeois uit de 19de eeuw kon het offer van de dader op het altaar van de generale preventie legitimeren, terwijl dat van de misdadige krankzinnige begin deze eeuw leidde tot beveiligingsasyls en bovendien medici perverteerde tot spionnen van het sociaal verweer. Als persona miserabilis kon de dader in de rol van sukkel worden geduwd, dankbaar dat hij door de meneer van de reclassering aan de gevangenis was ontsmapt. Nee, aandacht voor de mens alleen resulteert niet noodzakelijk in beter strafrecht, dat had de geschiedenis Kempe wel geleerd."

Kempe en de overige leden van de Utrechtse School wilden een stap verder gaan door ook de authenticiteit en uniciteit van de dader te erkennen. De straf mag de dader niet tot een object reduceren maar moet hem serieus nemen als mens die bovendien verantwoordelijk is voor zijn eigen daden.

Vanuit deze gedachtegang vindt Pompe de vergeldingsgedachte aanvaardbaar mits zij humaan is en rekening houdt met de persoon van de dader. Een straf die voorbij gaat aan het heden, verleden en mogelijke toekomst van de dader is onrechtvaardig. Zij laat cen levend mens niet daadwerkclijk tot zijn recht komen. Binnen het gedachtegoed van de Utrechtse School heeft men dan ook, mijns inziens zeer terecht, grote bezwaren tegen categorisering van daders in termen van gevaar en onverbeterlijkheid. Een dergelijke door utilitaire overwegingen ingegeven hokjesgeest doet geweld aan de menselijke maat in de strafrechtspleging.

Volgens De Haan (1990, p.69 en 70) is de invloed van de Utrechtse School op een strafrechtelijk klimaat, gekenmerkt door cen sterk humaniserende tendens, vanaf het begin van de jaren vijftig tot aan de jaren tachtig groot geweest. De Utrechtse School zette, aldus de Haan de toon voor een klimat waarin sprake is van fundamentele, humanitaire bezwaren tegen de tocpassing van (lange) gevangenisstraffen. Het was een klimaat waarin bovendien een beroep werd gedaan op het (slechte) geweten van de bestraffers.

In de praktijk van het gevangeniswezen gedurende de jaren vijftig en zestig komt de invloed van de Utrechtse school op zijn minst op verbaal niveau tot uiting (Franke, 1990, p.661-663). Bewaarders werd nog aan het eind van de jaren zestig tijdens hun opleiding voorgehouden dat zij moesten proberen de gedetineerde 'als mens te helpen', 'als een der onzen', aldus Franke (ibid., p.662). Ook het begrip bejegenen had oorspronkelijk een betekenis die was ontleend aan het gedachtegoed van de Utrechtse School namelijk die van een 'menswaardig tegemoet treden'.

\subsubsection{Verklaringen voor het humaniserende karakter van het resocialisatie-streven}

Boin (1998) betoogt in zijn proefschrift over de organisatie van het naoorlogse gevangeniswezen dat de beleidsmakers op centraal niveau er feitelijk nooit in geslaagd zijn cen penitentiaire missie te ontwikkelen. Met betrekking tot de resocialisatie-opdracht stelt Boin (ibid., p.248):

"Het belangrijkste probleem bij het formuleren van een penitentiaire missie was de wettelijke opdracht on de resocialisatie van gedetineerden na te streven. Het vooroorlogs systeem van eenzame opsluiting moest plaats maken voor 'moderne' penitentiaire uitgangspunten en werkwijzen. De beleidsmakers wisten echter niet hoe een dergelijke doelstelling in de praktijk moest worden geinterpreteerd en uitgevoerd. Hoe de moderne inrichting in concreto gestalte kreeg. werd daarom min of meer aan het veld gelaten."

En, zo voegt Boin hieraan toe, directeuren en bewaarders wisten eigenlijk ook niet precies hoe de resocialisatie-opdracht diende vorm diende te krijgen. Op grond van Boins visie zou 
men het feit dat in het penitentiaire veld resocialisatie niet emstig werd nagestreefd kunnen interpreteren als een gevolg van een gebrek aan visie en expertise zowel op het niveau van de beleidsmakers als op het niveau van uitvocring in het veld.

Echter, deze verklaring werpt slechts licht op een enkel aspect van de naoorlogse ontwikkelingen in de stratrechtspleging.

Bij Denkers (1976, p.230-244) vinden we een ander type verklaring dat rekening houdt met de fundamentele en vrij complexe dilemma's warvoor de strafrechtspleging zich tot op de dag van vandaag ziet gesteld.

Ook Denkers concludeerde na een analyse van de inhoudelijke kenmerken van twee inrichtingen die in de jaren zestig bij uitstek bestemd waren voor resocialisatic, dat er van cen serieus streven naar resocialisatie eigenlijk geen sprake was.

Volgens Denkers visie is hier sprake van cen duidelijke discrepantic "tussen de opgegeven of officiële doelstellingen enerzijds en een aantal werkelijke of impliciete doelstellingen ander-zijds. Dit onderscheid in expliciete en impliciete organisatic-doelstellingen is ontleend aan de organisatiesociologie.

Officieel lijkt het voomamelijk on speciale preventie of de verbetering van delinquenten te gaan, maar in werkelijkheid wordt humanisering nagestreefd, hetgeen inhoudelijk toch op iets anders neerkomt dan resocialisatic. Humanisering van de detentiesituatic had als uiteindelijke doel het beperken van vergelding. voorkomen van detentieschade, de indruk bij het publiek wekken dat men een humaan en verlicht strafstelsel hanteert en, op het decentrale niveau van de gevangenis, het handhaven van orde en rust. Voor zover resocialisatie sericus werd nagestreefd, fungeerde humanisering als middel of voorwaarde daartoe (ibid., p.236240). Voorts wijst Denkers (p.234) in dit verband op de gevolgen van het handhaven van het vergeldende karakter van de straf voor de realisering van de resocialisatie-doelstelling. Het handhaven van het vergeldende, leedtoevoegende karakter van de tenuitvoerlegging frustreer-de wel degelijk een effectieve resocialisatie (in de vorm van contacten in en met de vrije samenteving) ook al werd dat in de periode waarin de behandelingsideologie in zwang was, van officiële zijde liever verzwegen.

Vanuit het perspectief van het strafrechtelijk systeem in zijn totaliteit beschouwt Denkers de discrepantie tussen de officiële en werkelijke doeleinden als een gevolg van een meervoudigheid van conflicterende doelstellingen. Het strafrecht is er niet alleen om te straffen of voor de speciale preventie en generale preventie. Het is er ook om te vergelden, om delinquenten onschadelijk te maken, om reeds bestaande criminaliteit te redresseren en om de waarheid omtrent een vermoedelijk crimineel feit vast te stellen (instrumentele doelstellingen). Het mag daarbij de rechten en belangen van justitiabelen niet uit het oog verliezen (intrinsieke doelstellingen) en het kan er niet ombeen oplossingen te zoeken voor

\footnotetext{
"Denkers (ibid., p.169 e.v.) laat zien dat het strafrecht een aantal kenmerken bezit die maken dat de discrepantie tussen wat officieel en feitelijk wordt nagestreefd in het strafrechtelijk apparaat veel groter is dan in welke andere organisatie dan ook.

Denkers noemt hier een vijftal oorzaken:

1. Het 'kwalijke' karakter van het strafrecht;

2. Strafrechtelijke functionarissen kunnen en mogen de werkelijke doelstellingen niet noemen;

3. Strafrechtelijke functionarissen willen de werkelijke doeleinden niet noemen;

4. Het strafrecht werkt met juridische ficties;

5. Het strafrecht staat bloot aan een intensieve en pluriforme 'surveillance' van de buitenwacht.
} 
een groot aantal organisationele problemen (organisationele doelstellingen). Een van de belangrijkste externe organisationele doeleinden betreft het rekening houden met een kritische buitenwacht. Volgens Denkers is dit. naast de rechtsbescherming van het individu, de belangrijkste bron van conflicten tussen doelstellingen van het strafrecht.

De doelstellingen conflicteren met elkaar. daardoor kan het strafrechtelijk apparaat meestal slechts half werk doen. Het is onmogelijk doclstellingen en taken af te stoten als oplossing woor een meer effectieve wijze van realisering van slechts enkele doelstellingen. De taken zijn wettelijk opgedragen, worden opgedrongen door de buitenwacht of zijn om praktisch organisatorische redenen onvermijdelijk.

Niet alleen op het macroniveau van het strafrechtelijk apparaat is er sprake van discrepanties. Ook op het decentrale niveau van de inrichting kan volgens Denkers sprake zijn van een discrepantie doordat gevangenisdirecties activiteiten die officieel bedoeld zijn om de recidive te verminderen een humaniserende functie geven om onvrede weg te nemen en/of te voorkomen. Het cigenlijke doel is hier de handhaving van orde en rust. En dit werkelijke doel hanteert men niet alleen maar om uitvoering te geven aan de eis van een ongestoorde tenuitvoerlegging van de gevangenisstraf, maar ook uit eigen belang. ${ }^{10}$

Denkers (p.238) merkt in dit verband op:

"Zolang directies vrezen dat op hun hoofd de schuld wordt afgewenteld van de onrust die uit sericuze pogingen tot resocialisatie, democratisering, en dergelijke zou kunnen voortvloeien, zijn zij vaak meer geïnteresseerd in 'rust in de tent' dan in resocialisatie".

Denkers concludeert dat resocialisatie op wettelijke. wetshistorische en empirische gronden niet in die mate wordt nagestreefd (en niet kan worden nagestreefd) als onderzoekers en beleidsfunctionarissen ons willen doen geloven. Andere doelstellingen, zoals vergelding en humanisering blijven een aanzienlijke rol spelen.

Overzien we de ontwikkeling van het resocialisatie-streven in de eerste drie decennia na de tweede wereldoorlog, dan blijkt die ontwikkeling in belangrijke mate samen te hangen met bepaalde fundamentele dilemma's in de strafrechtelijke besluitvorming, tijdsgebonden ideolo-gische stellingnamen in de strafrechtspleging en met een zeker gebrek aan expertise. Die ideologische invloeden in de naoorlogse ontwikkeling van het strafrecht stonden sterk in het teken van het streven naar een milde en humane strafrechtelijke cultuur die, volgens de Haan (1990, p.66), is geworteld in een traditie van tempering van vergelding, tolerantie en begrip voor mensen in een nederige (minderheids) positie. Deze cultuur waarin sprake is van een zeker respecteren van de persoonlijke integriteit van de dader of gedetineerde leent zich minder voor vormen van resocialisatie waarbij gedragsveranderingen op een zeer doelgerichte en stelselmatige wijze worden afgedwongen. Een dergelijke praktijk van 'correction' in de vorm van specifieke trainings-en behandelingsprogramma zoals men die in de Verenigde Staten kent, was min of meer wezensvreemd aan het penitentiaire kilmaat in de jaren vijftig en zestig. En de ideologische invloed van de Utrechtse School op dit klimaat

\footnotetext{
1" Voor zover gevangenisdirecties zijn geinteresseerd in speciale preventie in de zin van recidiveuitkomsten betreft dit. aldus Denkers, hooguit het voorkomen van recidive-vermeerdering. Men hoopt dat gedetineerden niet slechter de inrichting verlaten dan zij er zijn ingekomen.

Deze veronderstelling dat gevangenisdirecties feitelijk niet geïnteresseerd zijn in recidivevermindering als doel van resocialisatie-programma's maar veeler in beheersmatige en humane doeleinden treft men ook bij andere onderzoekers aan (Logan en Gaes, 1993. Conrad.1981. Melk. 1985. 1993).
} 
dient daarbij zeker niet te worden onderschat. Het perifere karakter van de behandeling bij het resocialisatie-streven en de sterke nadruk op humanisering als voorwaarde voor resocialisatie zijn mijns inziens niet alleen maar te herleiden tot een niet kumnen (Boin,1998), maar vooral ook tot een niet willen op grond van de vigerende denkbeelden omtrent een humane bejegening waarbij respect voor de autonomie van de dader een voorname plaats inneemt.

\subsubsection{De teloorgang van het resocialisatie-ideaal in de jaren zeventig en tachtig}

De twijfels over de zin van de behandelingsfilosofie groeien aan het eind van de jaren zestig en begin van de jaren zeventig toe (Vegter,1984, p.58) en die twijfels worden in de loop van de jaren zeventig als maar groter.

Aan het begin van de jaren zeventig werd op grond van binnen- en buitenlands evaluatieonderzoek steeds duidelijker dat de vrijheidsstraf als middel tot resocialisatie faalde. De recidive-cijfers bleven hoog en in de gevangenisnota uit 1976 is het vertrouwen van de staatssecretaris Zeevalking in de resocialiserende werking van de gevangenisstraf niet bijster groot meer. Op grond van de onderzoeksliteratuur uit die periode bleek ook steeds meer dat een verblijf in de gevangenis juist averechtse effecten had op de integratie van gedetineerden in de samenleving. Toch mochten op grond van de Gevangenisnota uit 1976 de banden met de samenleving niet worden verbroken en zij dienden waar mogelijk te worden aangehaald. Het handhaven en intensiveren van de banden met de maatschappij werd in plaats van een middel tot resocialisatie een zelfstandige doel van de detentie (Franke, 1990, p.646).

In de jaren tachtig wordt deze scepsis ten aanzien van het resocialisatie-ideaal in expliciete en formele zin in het beleid vertaald.

\subsubsection{De minder ambitieuze invulling van de resocialisatie-opdracht: de nota Taak en Toekomst}

"For the first time in the post-War period, Dutch prison policymakers formulated a rather specific correctional philosopy." (Boin, 1998, p.127)

In de nota Taak en Toekomst van 1982 concludeerde staatssecretaris Scheltema met verwijzing naar wetenschappelijk onderzoek dat het streven om van gedetineerden betere mensen te maken niet erg realistisch is. De staatssecretaris koos dan ook voor een beleid waarin aan de resocialisatie-opdracht een minder ambitieuze invulling wordt gegeven. Deze opdracht werd geformuleerd als:

"de voorbereiding van de terugkeer in de samenleving door het scheppen van kansen en mogelijkheden voor gedetineerden om te werken aan hun persoonlijke ontwikkeling en het oplossen van eventueel aanwezige psychosociale problemen." (p.22)

De voorbereiding van de terugkeer in de samenleving bleef volgens de staatssecretaris echter het nastreven waard. De detentie kan worden benut om de terugkeer in de samenleving beter voor te bereiden, zodat de gedetineerde ook eerder in die samenleving wordt geaccepteerd en - wellicht - zichzelf daarin beter weet te handhaven dan voordien het geval was.

Ook al zijn de verwachtingen over blijvende gedragsveranderingen niet hooggespannen, toch blijft volgens de staatssecretaris de resocialisatie-opdracht van art. 26 Beginselenwet een belangrijke opdracht waaraan het gevangeniswezen zich niet mag onttrekken (nota Taak en Toekomst, p.25). 
In de nota wordt voorts het streven genoemd om via regimesactiviteiten op het gebied van educatie en hulpverlening en via het regime in zijn algemeenheid, gedetineerden "iets mee te geven, waarvan zij na afloop profijt kunnen hebben". Als andere middelen ter realisering van de resocialisatie-opdracht worden in de nota genoemd: het voorkomen van vervreemding van de samenleving middels handhaven en intensiveren van de contactmogelijkheden, detentie-fasering en detentieregionalisering. Detentiefasering betekent dat de gedetineerde zodra dit verantwoord is, wordt overgeplaatst naar een open of half-open inrichting. Detentieregionalisering impliceert het ondergaan van een straf in een inrichting dichtbij de woonplaats van de gedetineerde.

De voorbereiding van de terugkeer in de samenleving ligt als detentiedoelstelling in het verlengde van de twee overige doelstellingen van het beleid namelijk, humanisering van de detentie en het voorkomen en beperken van de schadelijke gevolgen van de detentie.

Een beschrijving van deze twee overige doelstellingen is noodzakelijk om te begrijpen hoezeer de pretenties over de tenuitvoerlegging van de gevangenisstraf in het penitentiaire beleid van de jaren tachtig verminderden. Voorts kan het voorkomen of beperken van detentieschade worden gezien als een negatieve invulling van de resocialisatie-opdracht (Vegter, 1989, p.61).

\subsubsection{Humanisering van de detentie}

De humanisering van de detentie wordt in de Nota Taak en Toekomst gerelateerd aan maatschappelijke ontwikkelingen waarmee in de detentie rekening moet worden gehouden: de scherper wordende tegenstelling tussen het leven in vrijheid en de toegenomen mondigheid van de gedetineerden die meer invloed willen uitoefenen op de wijze waarop de straf wordt ondergaan. Door accentuering van de gelijkwaardigheid van de gedetineerde als medemens die respect verdient, het zelf verantwoordelijkheid dragen en het maken van keuzes tracht men aan te sluiten bij deze maatschappelijke ontwikkelingen. Humanisering betekent meer dan het scheppen van verzachtende omstandigheden en het bevorderen van een humane omgang met gedetineerden. Humanisering houdt vooral een erkenning in van de individuele geaardheid en zelfverantwoordelijkheid van de gedetineerde.

Dit uitgangspunt heeft belangrijke consequenties voor de wijze waarop de terugkeer in de samenleving wordt voorbereid. Het is geen streven meer dat wordt opgelegd of, zoals Kommer (1991, p.12) het formuleert, volgens een medisch model wordt 'toegediend', maar een doel dat door de gedetineerde zelf moet worden bereikt. In plaats van object van behandeling wordt de gedetineerde nu gezien als een autonoom subject met eigen rechten en plichten die aan zijn vorming en psychosociale problemen of 'zelfherstel' (Tulkens, 1988, p.16) werkt.

Doeleinden zoals het tot inkeer brengen of het verbeteren van de gedetineerde worden niet meer gezien als een cruciaal onderdeel van de tenuitvoerlegging van de gevangenisstraf .

Het strafdoel op het niveau van de tenuitvoerlegging behelst niet meer dan de vrijheidsbeneming zelf.

Het beginsel van minimale restricties betekent dat punitieve of extra leedtoevoegende elementen die voor de ongestoorde tenuitvoerlegging van de gevangenisstraf niet noodzakelijk zijn, worden vermeden. Dit beginsel werd in de jaren tachtig min of meer zelfstandig uitgangspunt van het beleid. Omdat een dergelijk beginsel berust op de erkenning van de gedetineerde als autonoom subject spreekt men hier ook wel over het autonome stelsel (Vegter, 1984, p. 29-43). 


\subsubsection{Voorkomen of beperken van detentieschade}

Het voorkomen of beperken van detenticschade verwijst natr de zorg dat de gevangene door de detentie niet verder verslechtert. Die verslechtering kan volgens staatssecretaris Scheltema het gevolg zijn van hospitalisering en van criminele besmetting. Het gevalar van hospitalisering doet zich voor als (langgestrafte) gedetineerden hun zelfstandigheid en initiatief als gevolg van een langdurig verblijf in detentic dreigen te verliezen. Het gevaar van criminele besmetting is anwezig als gedetineerden cen subcultur met eigen. oppositionele waarden en normen gaan vormen. hetgeen fnuikend kan zijn voor de motivatie van gedetineerden. Ook wordt de schade genoemd die het gevolg is van het niet of moeilijk kunnen verwerken van het gemis of verlies van relaties die voor gedetineerden belangrijk zijn en schade die ontstaat doordat gedetineer-den die voor hun detentie geen drugs gebruiken, tijdens de detentie alsnog druggebruiker worden (Taak en Toekomst, p.24).

Denkers concludeerde reeds in de jaren zeventig dat resocialisatie in de praktijk neerkwam op humanisering onder meer om de schadelijke gevolgen van de detentie te beperken of te voorkomen.

In de nota Taak en Toekomst wordt het beperken of voorkomen van detentieschade als werkelijke. impliciete doelstelling van resocialisatie verheven tot een formele zelfstandige doelstelling van het gevangeniswezen. De relatic tussen enerzijds het voorkomen of beperken van detentieschade en anderzijds de resocialisatie-doelstelling en de humanisering van de detentie wordt in de nota Taak en Toekomst nadrukkelijk genoemd. Voorkomen of beperken van detentieschade wordt mede gezien als een voorwaarde voor resocialisatie op grond waarvan vooraleerst de negatieve factoren in de gevangenisomgeving worden weggenomen die een effectieve of goede terugkeer in de samenleving kunnen belemmeren.

De grondslagen van het streven de toestand van de gevangene niet verder te laten verslechteren zijn bovendien aanwijsbaar in beginselen die reeds in de jaren zestig werden geformuleerd zoals de optimale beveiliging is de minimale, en de gedetineerde dient niet verder in zijn persoonlijke vrijheid te worden beperkt dan met het oog op het doel van zijn detentie nodig of onvermijdelijk is (Vegter, 1989, p.60).

Volgens Vegter is bij het voorkomen of beperken van detentieschade vooral sprake van een negatieve invulling van de wettelijke opdracht van artikel 26 Beginselenwet (ibid., p.61).

Die werd, volgens Vegter, in Taak en Toekomst formeel in de plaats gesteld van de positieve: voorbereiden op de terugkeer in de samenleving betekent het beperken van de schade die de detentie uit zijn aard reeds meebrengt. Op grond van deze interpretatie van een negatieve invulling van de resocialisatie-opdracht beschouwt Vegter de gelegenheid voor gedetineerden zich met behulp van educatieve- en hulpverleningsactiviteiten als autonoom belanghebbende te (blijven) ontplooien voornamelijk nog als een middel tot beperking van detentieschade."

Het verlaten van het verbeteringsideaal in het penitentiaire beleid van de jaren tachtig en de voorrang die wordt gegeven aan humanisering en het voorkomen van detentieschade

"De vraag is hoe die interpretatie zich verhoudt tot de wijze waarop gedetineerden zelf. als autonome belanghebbenden de educatieve -en hulpverleningsactiviteiten feitelijk invullen en beleven. In hoeverre staat de deelname van gedetineerden aan bijvoorbeeld het penitentiaire onderwijs, vanuit hun beleving gezien, in het teken van het vermijden of verminderen van de negatieve effecten van de detentie(situatie) of van een reële behoefte an positieve op verbetering en persoonljke groei gerichte idealen? Na een aanwezigheid van meer dan 150 jaar penitentiair onderwijs in Nederlandse gevangenissen weten we dit eigenlijk nog steeds niet. 
betekenen dat het doel van de straf in de sfeer van de tenuitvoerlegging met steeds minder pretenties wordt omgeven.

Franke vat deze ontwikkeling als volgt samen: "Na bijna anderhalve eeuw van optimisme en idealisme werd van de gevangenisstraf alleen nog verwacht dat zij tegenging wat ze zelf aanrichtte" (Franke, 1990, p.647).

In dit opzicht is de nota Taak en Toekomst voor de geschiedenis van het resocialisatiestreven een belangrijke nota.

Beleidsmatig markeert deze nota het eindpunt van een lange ontwikkeling die sterk in het teken staat van verwachtingen omtrent de verbeteringsgedachte als mogelijk speciaal preventief doel van de vrijheidsstraf. In die jaren wordt in het beleid erkend dat er nog weinig redenen zijn om hooggespannen verwachtingen over het verbeteringsideaal in de context van de gevangenisstraf te koesteren.

De nota is voorts een mijlpaal in de ontwikkeling van het resocialisatie-streven door het verdwijnen van het min of meer opgelegde en geforceerde karakter van dit streven. Resocialisatie werd een streven waarbij de gedetineerde zich als een autonoom subject op basis van eigen initiatief en verantwoordelijkheid ontplooit. In dit opzicht levert de nota een coherent antwoord op het probleem van de geringe speciaal preventieve effectiviteit in termen van recidive-vermindering. Men schaft resocialisatie niet af, maar met verwijzing naar de wettelijke resocialisatie-opdracht als intrinsieke doelstelling van het strafrecht blijft men gedetineerden als autonoom belanghebbenden kansen en mogelijkheden bieden om zich voor te bereiden op een betere toekomst na detentie. In de nota Taak en Toekomst giet men de resocialisatie-gedachte beleidsmatig gezien in een acceptabele vorm. Men erkent nadrukkelijk de humane strekking van de resocialisatiegedachte. Bovendien beschouwt men resocialisatie niet meer als een opgelegd streven dat de gedetineerde reduceert tot een ik-loos, niet aansprakelijk object dat behandeld dient te worden. In de nota Taak en Toekomst wordt dit allopathische model waarbij analoog aan de medische wetenschap een bepaald tekort moet worden weggenomen min of meer verlaten. De nota Taak en Toekomst benadrukt cerder de gedachte dat resocialisatie tevens iets is dat van binnenuit moet komen en niet alleen maar van buitenaf. In Taak en Toekomst wordt resocialisatie kortom gedefinieerd als cen streven dat de autonome, verantwoordelijke individualiteit van de gedetineerde in essentie respecteert en waar mogelijk versterkt. Als de gedetineerde geen gebruik wil maken van voorzieningen van humaniserende of resocialiserende aard dan wordt deze keuze in principe gerespecteerd.

In het beleid van de jaren tachtig ligt het initiatief bij de gedetineerde, hetgeen van groot belang is als men zich realiseert dat ook als gevolg van humanisering de relatieve deprivatie en daarmee het leed in de beleving van gedetineerden vaak eerder toeneemt dan afneemt (Denkers, 1976, p.261). ${ }^{12}$

Tenslotte werd in de nota Taak en Toekomst in organisatorisch opzicht de basis gelegd voor

\footnotetext{
12 Tijdens mijn werkzaamheden in de gevangenis geven sommige gedetineerden wel eens te kennen dat zij de psychische druk van het tamelijk milde, humane Nederlandse gevangenisklimaat als bijzonder groot ervaren. Het beroep op de eigen verantwoordelijkheid en zelfdwang (Franke, p. 656660 ) ten behoeve van een ordelijke gang van zaken, de informatie over en beelden van (denk aan TV op cel) de geneugten van het leven in de vrije samenleving, maken het leven in de gehumaniseerde gevangenis er niet lichter op. Sommige gedetineerden merken op dat een dergelijk regime aanzet tot te veel nadenken en piekeren en dat je de straftijd wellicht makkelijker doorkomt in een regime waarin gewoon wordt getucht en het verstand op nul wordt gezet.
} 
de wijze waarop tot op heden de voorzieningen op het gebied van de voorbereiding van de terugkeer in de samenleving worden aangeboden. Kenmerken van de huidige organisatie zoals het aanbod van activiteiten in het kader van een regiemsactiviteiten-programna, de uitbreiding van de begeleidende en bejegenende taken van de penitentiair inrichtingswerker ( PIW-er) op grond van de gestandaardiseerde inrichtingsstructuur en de verhouding tussen het centraal penitentiaire bestuur en de inrichtingsdirecties vinden hun oorsprong in het penitentiaire beleid van de jaren tachtig.

\subsubsection{De ontwikkeling van het strafrechtelijk klimaat in de loop van de jaren tachtig: verharding en verzakelijking.}

Kort na het verschijnen van het de nota Taak en Toekomst viel het kabinet dat de nota had aangeboden. Het volgende kabinet kondigt bij zijn aantreden echter drastische bezuinigingsoperaties aan die ook het gevangeniswezen niet ongemoeid laten.

Uitvoering van het beleid van Taak en Toekomst wordt ernstig belemmerd door de bezuinigingen. Moerings constateert in 1984 dat de bezuinigingen een verslechtering van de positie van gedetineerden tot gevolg hebben. Inkrimping van het personeel leidt tot een inkrimping van de bewegingsvrijheid van gedetineerden, zij verblijven langer op cel, aldus Moerings.

Moerings (1984) laat zich over de nota Taak en Toekomst overigens in harde bewoordingen uit. Hij spreekt over dure termen die veel suggereren, de beloftes echter niet waarmaken en in feite de onmacht van het gevangeniswezen moeten verbloemen (ibid., p.222). Bovendien zal, aldus Moerings, als gevolg van de toegenomen druk op het gevangeniswezen de executie van de gevangenisstraf hoe langer hoe meer worden 'uitgekleed' (ibid., p.235).

In de jaren tachtig is er op strafrechtelijk gebied bovendien veel meer aan de hand dan een gebrek aan financiële middelen. Er is inmiddels een snel oplopend cellentekort ontstaan en het strafrechtelijke klimaat verliest ook geleidelijk aan zijn betrekkelijk milde karakter. Franke (1990) merkt over deze periode op:

"Ideologische vragen, maatschappijkritiek en strafrechtelijke ethiek maken plaats voor een zeer instrumentalistische en technocratische visie op misdaadbestrijding, waarbij het drukken van de kosten, efficiency en automatisering centraal stonden." (Franke, p.716).

Binnen deze visies benadrukt men het vergeldende en punitieve karakter van de straf als gevolg waarvan het aantal langdurige straffen toeneemt.

Deze ontwikkeling van een toenemende verzakelijking en verharding van het strafrechtelijk beleid zet zich voort in de jaren negentig.

De neerslag van deze ontwikkeling is te vinden in de nota Werkzame Detentie (1994). In deze nota is de resocialisatie-doelstelling zoals geformuleerd in de nota Taak en Toekomst (1982) niet meer terug te vinden. Men spreekt in de nota ook niet meer over resocialisatie maar over maatschappelijke integratie.

$\mathrm{Bij}$ het penitentiaire beleid van de jaren negentig wordt vrij uitgebreid stil gestaan omdat het hier een type beleid betreft waarin wordt gebroken met de hiervoor beschreven ontwikkeling van humanisering en individualisering van de detentie, een ontwikkeling waarin men geleidelijk aan steeds meer oog kreeg voor de persoon van de gedetineerde. Aan die ontwikkeling komt op een tamelijk abrupte manier een einde in het penitentiaire beleid van de jaren negentig van de vorige eeuw. Amper tien jaar daarvoor was het beleid van de nota Taak en Toekomst nog gericht op de ondersteuning en aanmoediging van gedetineerden waar het hun toekomst betrof, in de jaren negentig is van een dergelijke ruimhartige mentaliteit 
Resocialisatie en het beleid van het Nederlandse gevangeniswezen

geen sprake meer. Het beleid van de nota Taak en Toekomst, volgens Boin (1998, p.127) de enige beleidsnota in het naoorlogse gevangeniswezen die getuigt van een echte coherente filosofie op de vormgeving van de detentie, werd in de kiem gesmoord. Ervoor in de plaats komt een verschraalde visie waarin van een coherente penitentiaire filosofie met betrekking tot bij voorbeeld de resocialisatie-gedachte, eigenlijk geen sprake meer is.

\subsubsection{Het penitentiaire beleid in de jaren negentig: maatschappelijke integratie en de veiligheid op lange termijn.}

"In de nota Werkzame Detentie worden de 'ongemotiveerde' gedetineerden in het standaardregime in zekere zin afgeschreven. Marar in de persoonlijke gesprekken en groepsbijeenkomsten van pastores en andere hulpverleners blijkt menigmaal dat onder de haat en het cynisme wel degelijk oprechte wanhoop schuil kan gaan en dat er bij velen een intens verlangen is naar een leven dat vervalling biedt." (Knol, 1997, p.278)

\subsubsection{Uitgangspunten van Werkzame Detentie}

Behalve met het probleem van een nijpend cellentekort wordt het gevangeniswezen in het begin van de jaren negentig in toenemende mate geconfronteerd met gedetineerden die behoren tot wat men noemt de probleemcategorieën (zeer lang gestraften, vluchtgevaarlijke en agressieve gedetineerden, psychisch gestoorden, drugsverslaafden). In deze periode bleek bovendien bij een aantal ontsnappingsincidenten dat vluchtgevaarlijke gedetineerden zich vrij gemakkelijk aan de detentie konden onttrekken.

Het beleid van Taak en Toekomst paste ook steeds minder bij het inmiddels geformuleerde integrale criminaliteitsbeleid waarbij criminaliteitsbestrijding voorop werd gesteld en de verschillende schakels van de strafrechtelijke handhavingsketen beter op elkaar dienden te worden afgestemd. De filosofie van Taak en Toekomst had ook geleidelijk aan plaats gemaakt voor een management-filosofie met een sterke nadruk op de 'efficiency' van de organisatie.

Het beleid van het gevangeniswezen werd met het oog op de bovengenoemde ontwikkelingen bijgesteld. Het antwoord van het gevangeniswezen op deze veranderde omstandigheden vinden we in de Nota Werkzame Detentie (1994). De drie kernbegrippen die richtinggevend zijn voor het beleid van de jaren negentig zijn veilig, menswaardig en doelmatig.

De tenuitvoerlegging van vrijheidsbenemende straffen en maatregelen wordt gezien als het sluitstuk van een strafrechtelijke handhavingsketen die gericht is op een effectieve bestrijding van de criminaliteit. Het gevangeniswezen zal dus moeten bijdragen aan de veiligheid van de samenleving. In de eerste plaats door gedetineerden op te sluiten en opgesloten te houden. In de tweede plaats door een bijdrage te leveren aan de veiligheid op de lange termijn. Deze laatste bijdrage bestaat uit het opzetten van effectieve reintegratieprogramma's die de recidive van gedetineerden in neerwaartse zin beïnvloeden.

De tenuitvoerlegging dient op menswaardige plaats te vinden door gedetineerden slechts aan die beperkingen te onderwerpen die noodzakelijk zijn voor het doel van de vrijheidsbeneming (dit verwijst naar het stelsel van minimale beperkingen dat is vastgelegd in artikel 15, vierde lid, van de Grondwet en art. 2 lid 4 van de Penitentiaire Beginselenwet). De menswaardigheid van de tenuitvoerlegging wordt in summiere zin omschreven, de invulling ervan wordt min of meer opengelaten. Men noemt twee voorwaarden voor een menswaardige tenuitvoerlegging van de detentie: de kwaliteit van de regelgeving, die moet voldoen aan de internationale normen ter zake en de alertheid van het personeel. De internationale normen betreffen de Standard Minimum Rules for the Treatment of Prisoners 
van de Verenigde Naties en de European Prison Rules van de Raad van Europa.

Het voorkomen van criminele besmetting en het risico van de fysieke en psychische verslechtering wordt geheel afhankelijk gesteld van deze actieve en alerte houding van het personeel.

Gelet op de uitbreiding van de capaciteit van het gevangeniswezen en de beperkte middelen van het gevangeniswezen dient de uitvoering van het beleid doelmatig te geschieden. Doelmatigheid betekent het intensiveren van inspanningen war de te verwachten effectiviteit in termen van de primaire doelstelling van maatschappelijke veiligheid groot is en beperking van inspanningen waar het te verwachten rendement laag is. De extra inspanningen betreffen (personele) voorzieningen voor gedetineerden die een vlucht/ en of beheersrisico vormen en bijzondere activiteiten gericht op maatschappelijke integratie.

Tot zover een korte samenvatting van de belangrijkste uitgangspunten van de nota Werkzame Detentie.

In het volgend gedeelte van deze paragraaf wordt ingegaan op de nadere uitwerking van deze beleidsvoornemens in de nota Werkzame Detentie. In een aparte paragraaf wordt tenslotte ingegaan op de praktische uitvoering van het beleid.

\subsubsection{De nadruk op het punitieve en vergeldende karakter van de straf}

In de nota Werkzame Detentie wordt onomwonden vastgesteld dat een strafrechtelijke interventie een bewuste leedtoevoeging inhoudt ter compensatie van het leed dat de dader met zijn delict heeft teweeggebracht. Het vergeldende karakter van de straf wordt voorop gesteld. Tevens dient de straf tot beveiliging van de maatschappij door het voorkomen van (verdere) criminaliteit. De uitgangspunten van het beleid zijn daarmee volgens de staatssecretaris in belangrijke mate bepaald. Het punitieve karakter van de gevangenisstraf dient te worden gewaarborgd. Het strafkarakter van de gevangenisstraf ligt primair in de vrijheidsbeneming als zodanig. Maar in de nota verbindt men hieraan de conclusie dat dit niet betekent dat binnen de vrijheidsbeneming de gedetineerde alle comfort moet kunnen genieten. Men houdt de moge-lijkheid open voor verdere restricties.

Over het vergeldende en punitieve karakter van de gevangenisstraf merkı de toenmalige directeur Delinquentenzorg en Jeugdinrichtingen Elting (1994, p.89) op:

" De vrijheidsstraf draagt een punitief karakter. Het woord zegt het al. Zij dient mede ter vergelding van het door de delinquent aangerichte onrecht. Vergelding is een gevoelig begrip, bijna een taboe. Toch is het inherent aan de vrijheidsbeneming en moet het als zodanig onder ogen worden gezien, en niet als een nieuw verschijnsel dat de tegenwoordige hardheid in het denken over straffen zou typeren. De herkenbaarheid van de vrijheidsstraf voor de buitenwacht, die voor een groot deel ligt in die vergelding, is de laatste tijd duidelijk minder geworden."

Volgens Elting heeft die verminderde herkenbaarheid in samenhang met de vergaande differentiatie vooral ook te maken met een te breed en te vrijblijvend aanbod van activiteiten. De herwaardering van de vergeldinggedachte berust blijkens dit citaat mede op een, in wezen organisationele doelstelling, namelijk het inspelen op een kritische buitenwacht. ${ }^{13}$ Van een verharding van het straffen is mijns inziens wel degelijk sprake als men het beleid van Werkzame Detentie afzet tegen het beleid uit voorgaande decennia waarin voor de humanisering van de detentie veel meer aandacht was. Een van de belangrijke functies van

\footnotetext{
13 Zie ook Denkers over dit organisationele doel van de strafrechtspleging, 1976, p.114 e.v.
} 
humanisering en de daarmee gepaard gaande liberalisering van de regimes was het temperen van vergelding. Of anders geformuleerd, het vorm geven aan de vergelding op een maatschappelijk aanvaardbare en positieve wijze. Van een dergelijk streven is in de nota Werkzame Detentie in mindere mate sprake. Er is op het niveau van de tenuitvoerlegging van de gevangenisstraf eerder sprake van een tegengestelde tendens van benadrukking van punitieve en vergeldende elementen ten koste van voorzieningen ten behoeve van humanisering van de detentic en de voorbereiding van de terugkeer in de samenleving. Feitelijk komt dit neer op een verschraling en zekere verharding van de detentie. En het lijkt onwalarschijnlijk dat dit niet als zodanig door de gedetineerden wordt ervaren.

\subsubsection{Het standaardregime}

Het begrip regime kan men in strikte zin omschrijven als het geheel van voorschriften met betrekking tot de rechten en plichten van gedetineerden in een detentiesituatie

In de nota Werkzame Detentie wordt het penitentiaire regime herijkt met verwijzing naar de veranderde gedetineerdenbevolking. Men veronderstelt dat deze bevolking als gevolg van een groter aandeel van probleemgroepen (vluchtgevaarlijken, psychisch gestoorden, langgestraften verslaafden en gedetineerden met een beheersrisico) aanmerkelijk is verzwaard. Een belangrijk uitgangspunt bij deze herijking is de randvoorwaarde van doelmatigheid. $^{1+4}$ Mede op grond hiervan wordt een breed ongeclausuleerd en te vrijblijvend aanbod van activiteiten op basis van het beleid van Taak en Toekomst niet meer passend geacht voor de huidige gedeti-neerdenpopulatie. Dit brede aanbod werd op grond van het beleid van Taak en Toekomst geschapen met het oog op een detentie die zo min mogelijk negatieve effecten voor gedetineerden met zich meebrengt en zo veel mogelijk kansen schept. Een dergelijk aanbod is volgens de staatssecretaris te vergaand en te vrijblijvend. Het is te kostbalar en het leidt onvoldoende zichtbaar tot recidivevermindering.

Waarom het toenmatals heersende systeem van aanbod van voorzieningen te vrijblijvend zou zijn, wordt overigens niet nader beargumenteerd in de nota Werkzame Detentie. Zoals Wiewel (1994, p.16) terecht opmerkt, bevredigt het beroep op een gewijzigde samenstelling van de inrichtingspopulatie, ter rechtvaardiging van bijvoorbeeld het wegnemen van keuzemogelijk-heden bij activiteiten, allerminst.

Als gevolg van deze gewijzigde regimaire benadering wordt een menswaardig doch sober standaardregime ingevoerd. Het standaardregime is een regime van beperkte gemeenschap. In een beperkt regime verblijven gedetineerden alleen dan buiten hun cel indien er sprake is van een programma met gemeenschappelijke activiteiten. In principe worden alle gedetineerden bij het begin van hun detentie aan het standaardregime onderworpen.

Op grond van praktijkervaringen, zo stelt men in de nota, wordt er vanuit gegaan dat $80 \%$

It de Jonge et al. (1999, p.40) interpreteren de invoering van het standaard regime in strikt doelmatige. economische zin: "Invoering van dit standatardregime (een bejegening zonder 'franje') is een gevolg van de enorme nieuwbouwgolf die de jaren negentig kenmerkt. Het geld is besteed aan gebouwen en het daarvoor benodigde personeel en er is gekort op de bejegening van gedetineerden." Mijns inziens heeft de invoering van het standaardregime echter tevens een oorsprong in veranderde opvattingen over het straffen, in het bijzonder in een grotere nadruk op het vergeldende en punitieve karakter van de straf. Een regime ontdaan van 'franje en 'comfort' (nota Werkzame Detentie) dient de tenuitvoerlegging van de vrijheidsstraf juist in overeenstemming te brengen met dit vergeldende en punitieve karakter van de straf. 
van de gedetineerden aan een standaardregime zullen worden onderworpen. ${ }^{15}$ De voorzieningen in het standaardregime bestaan uit een basispakket van voorzieningen waarop iedere gedeti-neerde in beginsel recht heeft.

Het gaat hier om het recht op lichamelijke oefening en sport (art. 48 tweede lid PBW), recreatie (art. 49 tweede lid PBW) en luchten (art. 49, derde lid PBW).

Een breed aanbod van voorzieningen voor alle gedetineerden op het gebied van recreatie, educatie en psychosociale voorzieningen wordt afgeschaft. Voor basiseducatie is voor daartoe geschikte en gemotiveerde gedetineerden enige ruimte voor zover dit de toeleiding naar arbeid na detentie dient. Er is verder slechts ruimte voor de wettelijk gegarandeerde activiteiten zoals luchten, bezoek, recreatie en sport.

Als variant van het regime van beperkte gemeenschap hanteert men sinds 1996 ook het zogenaamde sober regime dat in een van de volgende paragrafen over de praktische uitvoering van het beleid op grond van Werkzame Detentie zal worden toegelicht.

De opstellers van de nota hanteren bij de tenuitvoerlegging van de straf in een standaardregime het uitgangspunt dat deze moet voldoen aan de internationale normen ter zake, echter, deze gewaarborgde minima vormen geen vertrekpunt voor een uitbouw van een zo volwaardig mogelijke detentie, integendeel men kan veeleer spreken van een afbouw naar het minimum (Wiewel, 1994, p.10).

De minimumvoorziening zoals die in concreto in het standaardregime aan de overgrote meerderheid van de gedetineerden wordt geboden, kan men beschouwen als een maat voor wat maximaal van de overheid verwacht mag worden.

Het accent in het standaardregime ligt op het verrichten van maximale arbeid gedurende 26 uur per week. Arbeid naast structuur zijn de twee peilers van het standaardregime. Over deze structuur merkt de toenmalige directeur Delinquentenzorg en Jeugdinrichtingen Elting (1994, p.89) op:

"Gemeenschappelijk kenmerk van de verschillende problemen van of met de gedetineerden is juist dat een duidelijke structuur nodig is. Een inzichtelijke en geordende vormgeving aan de dag die de gedetineerden duidelijkheid en voorspelbaarheid biedt en de organisatie beheersbaarheid biedt."

Aan de arbeid wordt voor de verdere levensloop van de gedetineerde een gunstige, resocialiserende werking toegeschreven. Men hoopt dit effect te bereiken door het wennen aan een structurering van de dag rond de arbeid en door het bijbrengen van arbeidsdiscipline. Disciplinering van gedetineerden door middel van een bonus malus- systeem waarbij volgens de staatssecretaris lastige gedetineerden op een correctie-afdeling kunnen worden geplaatst en gedetineerden met een constructieve opstelling worden beloond in de vorm van bij voorbeeld extra uren recreatie, is eveneens een belangrijk kenmerk van het standaardregime (Nota Werkzame Detentie, p.14).

Goed gedrag is een belangrijk criterium voor het verdienen van een betere bejegening met ruimere faciliteiten op het gebied van recreatie, educatie en psychosociale hulpverlening,

${ }^{15}$ In de PBW is het wettelijk onderscheid tussen regimes van algehele en beperkte gemeenschap gehandhaafd. In de Memorie van Toelichting (Kamerstukken Il 1994/1995, 24263, nr.3) streeft de Minister ernaar met name tot vrijheidsstraf veroordeelden die gedurende het verloop van hun detentie hiervoor geschikt worden bevonden. onder te brengen in een regime van algehele gemeenschap. Dit betekent in concreto dat deze groep gedetineerden meer bewegingsvrijheid heeft (zie: PBW, hoofdstuk V, par.1) 
bijvoorbeeld in de vorm van deelname aan een penitentiair programma of een maatschappelijk integratic-project. ${ }^{16}$

Van terughoudendheid bij het toepassen van vormen van drang en dwang ten aanzien van het gedrag van gedetineerden is, in tegenstelling tot het beleid uit de jaren tachtig (Taak en Toekomst), in de jaren negentig in veel mindere mate sprake. Aanleren van gewenst gedrag en afleren van ongewenst gedrag is blijkens effectiviteitonderzoek (Bol, 1995) in bepaalde mate mogelijk door respectievelijk positief sanctioneren in de vorm van beloning en negatief sanctioneren in de vorm van straf. Dhondt (1993) merkt echter op dat dergelijke technieken alleen kans van slagen hebben in een persoonlijke therapeutische relatie waarin per persoon het te sanctioneren gedrag vooral word gespecificeerd. Volgens sommige onderzoekers (Gendreau, 1996) dienen de positieve sancties de negatieve in ieder geval te overtreffen wil men succes boeken. Het bonus-malus systeem van Werkzame Detentie mist dergelijke specifieke vereisten en refereert slechts in zeer globale en oppervlakkige zin aan therapeutische interventie- technieken waarin positief en negatief sanctioneren worden toegepast.

Een belangrijk motief voor het invoeren van het standaardregime is tenslotte gelegen in de eis van doelmatigheid. Invoering van het versoberde standaardregime zal de benodigde middelen moeten opleveren voor het aanbod van bijzondere regimaire activiteiten in het kader van de integratie in de samenleving van een kleine minderheid van de gedetineerden (ongeveer $20 \%$ ). Tevens is ook het beheersbaar houden van de inrichtingen een belangrijke doel van het standaardregime.

\subsubsection{Maatschappelijke integratie -}

In de nota Werkzame Detentie gaat men ervan uit dat twee derde van de gedetineerden niet of slechts in geringe mate gemotiveerd is om iets van hun detentie te maken. Een derde is redelijk sterk of zeer sterk gemotiveerd. Deze gegevens zijn echter niet gebaseerd op een rechtstreekse ondervaging van gedetineerden doch op een peiling in drie representatieve inrichtingen onder medewerkers van het BSD, penitentiair inrichtingswerkers en penitentiair consulenten.

Voor gedetineerden die een duidelijke motivatie tonen en daarvoor geschikt zijn, worden bijzondere regimaire voorzieningen in een deel van de arbeidsuren gecreëerd. Deze groep van ongeveer $20 \%$ van de gedetineerden wordt in beginsel niet onderworpen aan het standaard-regime.

Die bijzondere voorzieningen zijn bestemd voor drugsverslaafden, gedetineerden met psychische stoornissen die intensieve begeleiding behoeven en gedetineerden die doormiddel van onderwijs, vakopleidingen en arbeidstrainings-programma's hun kansen in de samenleving willen vergroten.

In de nota Werkzame Detentie schat men dat circa $5 \%$ van de mannelijke gedetineerden voor dergelijke arbeidstrainings-programma's waarin met een traject van scholing en bemiddeling wordt gewerkt, in aanmerking komt. Ten aanzien van de bijzondere regimaire voorzieningen wordt de eis gesteld van een duidelijk rendement in termen van recidive-vermindering

\footnotetext{
"Goed gedrag wordt in de PBW (art.l, letter v ) omschreven als: "een zodanige opstelling van een gedetineerde dat hij, met name door de wijze waarop hij het recht op deelname aan de in de inrichting beschikbare arbeid heeft aangewend of door andere, vergelijkbare activiteiten binnen de inrichting heeft doen blijken van een bijzondere geschiktheid tot terugkeer in de samenleving."
} 


\subsubsection{De terugkeer van recidive-vermindering als succes-criterium voor maatschappelijke integratie}

In de nota wordt recidive-vermindering door middel van effectieve matschappelijke integratieprogramma's onder de noemer gebracht van het kernbegrip veiligheid op lange termijn.

Omdat het gevangeniswezen het sluitstuk vormt van de strafrechtelijke handhavingsketen die gericht is op een effectieve bestrijding van criminaliteit (Nota Werkzame Detentic. 1994, p.4) lijkt dit een consequente keuze. Gelet op de uitgangspumten van het beleid uit de jaren tachtig en op de resultaten van het effectiviteitonderzoek van resocialisatie is deze vrij plotselinge herwatrdering van recidive-vermindering als succescriterium van resocialisalie-programmas echter merkwatardig.

In de eerste plaats ondat in het voorgaande beleid gebaseerd op de nota Taak en Toekomst ten aanzien van de verbetering van gedetineerden opgevat als vermindering van recidive voor een realistische en minder ambitieuze benadering werd gekozen. In de tweede plaats staat de nadruk op recidive-vermindering nogal in tegenstelling to de zeer marginale positie die de resocialisatie-doelstelling in het beleid van de nota inneemt.

Nergens wijst de staatssecretaris, zoals zijn voorganger dat in de jaren tachtig (Taak en Toekonst) deed, expliciet op het belang van de wettelijke resocialistie-opdracht.

Nadruk op recidive-vermindering als uiteindelijk na te streven doel van resocialisatieprogramma's veronderstelt toch op zijn minst een behoorlijk groot vertrouwen in de zin en haalbaarheid van de resocialisatie-opdracht. In de derde plats is het vertrouwen in recidivevermindering als mat voor de effectiviteit van resocialisatie-programma's niet zonder meer vanzelfsprekend. De huidige stand van het penologisch onderzoek en de experimentele status van lopende integratie-projecten waarbij gedetineerden via traject-begeieiding naar een betaalde baan worden toegeleid, geven nog geen reden voor optimisme omtrent de effectiviteit van deze projecten. Recente evaluatics (zie hoofdstuk 1, p.10 en 11) laten zien dat er weliswaar bij sommige interventiemethoden successen worden geboekt wat betreft recidive-reductie, maar over het algemeen zijn de resultaten nog steeds heel wisselend. Het onderzoek dat vanuit het perspectief van de 'differential-treatment- benadering wordt verricht, verkeert nog volop in ontwikkeling.

Gelet op het begrip veiligheid op de lange termijn waaronder men immers de maatschappelijke integratieprojecten plaatst. lijkt men dergelijke projecten tevens als cen instrument van criminele politiek te beschouwen. Martinson (1974) toonde in de jaren zeventig in zijn grootschalige programma- evaluatic reeds aan dat het gebruik van resocialisatie-programma's als instrument van criminele-politiek, dat wil zeggen als een instrument gericht op het terugdringen van criminaliteitscijfers van de daderpopulatie in zijn totaliteit, buitengewoon problematisch is (zie ook Palmer, 1975, p.158).

Vanuit het oogpunt van doelmatigheid en het streven van de opstellers van de nota slechts daar te investeren waar rendement in termen van recidive-vermindering is te verwachten, is er eveneens sprake van een bepaalde mate van inconsequentie. Aan effectieve resocialisatieprogramma's dienen volgens de nota gemotiveerde gedetineerden deel te nemen. Uit de onderzoeksliteratuur is evenwel bekend dat het aanbod van resocialisatie-programma's juist aan de veelal minder gemotiveerde gedetineerden met een hoog recidive-risico uit het oogpunt van recidive-vermindering zeer de moeite waard kan zijn (Andrcws et al., (2), 1990; Antonowicz \& Ross, 1994; Gendreau, 1996).

Andrews et al. (p.20) hebben met betrekking tot dit risico-principe vastgesteld dat een hoger niveau van voorzieningen of een intensiever behandeling het meest geschikt is voor gedetineer-den met een hoog recidive-risico. Zij reageren daarop beter dan op een laag 
voorzieningen-niveau. Voor gedetineerden met een laag recidive-risico maakt het niveau van de voor-zieningen weinig of niets uit. Of men deze groep nu een laag of een hoog niveau van voorzieningen aanbiedt, voor de recidive doet het er weinig toe. Vermoedelijk geldt voor gedetineerden met een laag recidive-risico dat $\mathrm{zij}$, op grond van een sterke, positieve motivatie erin slagen om, voornamelijk op eigen kracht, hun leven na detentie weer in goede banen te leiden.

In het licht van dergelijke penologische informatie lijkt het streven om extra faciliteiten op het gebied van maatschappelijke integratic slechts an te bieden aan gemotiveerde gedetineerden nogal aanvechtbaar en vanuit het oogpunt van doelmatigheid, een van de kernbegrippen uit de nota, contraproductief.

Dit soort tegenstrijdigheden duidt er op dat in het beleid van Werkzame Detentic nauwelijks sprake lijkt te zijn van een serieus streven naar een effectieve recidive-vermindering door middel van maatschappelijke integratie. De koppeling van recidive-vermindering aan maatschappelijke integratie dient vooral te worden geinterpreteerd in het kader van het weer herkenbaar maken van de tenuitvoerlegging voor de buitenwacht. Het is een vorm van 'window-dressing'. De reeds eerder genoemde discrepantie tussen de opgegeven en werkelijke doeleinden van het strafrechtelijk apparaat speelt waarschijnlijk ook hier een hee] belangrijke rol.

Zoals wij zagen is deze discrepantie in het strafrechtelijk apparaat veel groter dan in welke andere organisatie dan ook. Een van de oorzaken hiervoor is het gegeven dat het strafrecht bloot staat aan cen intensieve en pluriforme 'surveillance' van de buitenwacht. Volgens Denkers is het inspelen op de buitenwacht een van de organisationele doelstellingen van het strafrecht. Als een van de mogelijke reacties op pressie van de buitenwereld noemt Denkers, afweren en overtuigen, toegeven en de suggestie wekken dat wordt toegegeven. Discrepantie tussen de opgegeven en werkelijke doeleinden ontstaat onder meer als gevolg van het inspelen op de pressie van de buitenwacht. De visie van Boin $(1995,1998)$ op de gebeurtenissen rondom het verschijnen van de nota Werkzame Detentie in 1994 ondersteunen deze inter-pretatie. De nota kwam volgens Boin in nogal hectische omstandigheden tot stand. Het gevangeniswezen had in deze periode schade opgelopen in termen van politieke en publieke steun, mede als gevolg van een aantal verontrustende incidenten en capaciteitsproblemen. Het stereotiepe beeld van de gevangenis als viersterren hotel met eenvoudige uitcheck-service leek in het begin van de jaren negentig keer op keer bevestigd te worden, aldus BGin.

Er was, althans in de perceptie van de politiek verantwoordelijke minister en staatssecretaris en de centrale leiding van het gevangeniswezen in het begin van de jaren negentig sprake van een verkleining van het maatschappelijk en politiek draagvlak voor het tot dan toe gevoerde detentiebeleid. De politieke leiding van het departement poogde door middel van de nota Werkzame Detentie weer greep op de concrete uitvoering van het beleid en op het imago van het gevangeniswezen te krijgen.

De vrij plotselinge terugkeer van het recidive-criterium lijkt niet zozeer te berusten op een groter vertrouwen in de speciaal- preventieve effecten van interventies, maar hangt vermoedelijk meer samen met het motief om de tenuitvoerlegging van de gevangenisstraf weer herkenbaar te maken voor een kritische buitenwacht. Dit motief wordt, zoals wij zagen, ook expliciet door Elting (1994, p.88) genoemd in verband met de versobering van het regime. ${ }^{17}$

${ }^{17}$ Elting (1994, p.88): "De herkenbaarheid van de vrijheidsstraf voor de buitenwacht, die voor een groot deel ligt in die vergelding, is de laatste tijd duidelijk minder geworden. En dat heeft in samen 


\subsubsection{Werkzame Detentie: pragmatisch detentiebeleid?}

Van Stokkom (1999) laat zien dat het hedendaags sanctiebeleid nog steeds in bepaalde mate wordt gekenmerkt door een pragmatisme in de geest van de Nieuwe Richting. Dit pragmatisme bezit een morele oriëntatie die blijkt uit een zekere zorg om de persoon van de dader, die -zowel in het belang van de dader als de samenleving- dwingt te zoeken naar een individueel passende sanctie. Die pragmatische signatuur komt onder meer tot uiting bij de alternatieve sancties. Volgens van Stokkom is hier sprake van een verzachtende tendens in het sanctie-beleid. De tendens tot verharding die tot uiting komt in langere vrijheidstraffen heeft volgens van Stokkom weinig te maken met een harde vorm van pragmatisme omdat er geen sprake is van onschadelijkmaken of beveiligen van de samenleving op basis van de uniciteit ran de zaak en de individuele delinquent.

Eerder gaat het hier om de strafmat vooral te baseren op vergelding, punitiviteit en uniformiteit in de toepassing van sancties (zie ook Janse de Jonge, 1990, p.9). De nota Werkzame Detentie is bijzonder illustratief voor deze nieuwe punitieve en vergeldende gezind-heid. Uniformiteit in de zin van toepassing van ecn zelfde standaardregime voor vrijwel alle gedetineerden en de-differentiatie (Wiewel, 1994, p.19) zijn belangrijke consequenties van het beleid van de jaren negentig. Een veelvormige praktijk in de tenuitvoerlegging van de sanctie wordt verworpen. Een ruim aanbod van activiteiten dat is toegespitst op de persoon van de gedetineerde wordt als te vrijblijvend en niet meer passend geacht onder de huidige omstan-digheden. Zowel deze nadruk op vergelding en punitiviteit en in samenhang daarmee, een verminderde aandacht voor de persoon van de dader of gedetineerde en het denken in termen van efficiency zetten, aldus van Stokkom, het oorspronkelijk, moreel geladen pragmatisme onder druk. Het nieuwe managementdenken in termen van doelmatigheid en beheersbaarheid mist de oriëntatie op de persoon van de dader, het is in feite een amoreel pragmatisme.

Overzien we deze recente ontwikkeling van het penitentiaire beleid dan blijkt de voorspelling die Moerings halverwege de jaren tachtig (1984, p.235) deed, te zijn uitgekomen. De executie van de gevangenisstraf blijkt in de jaren negentig beleidsmatig steeds verder te zijn 'uitge-kleed' voor het merendeel van de gedetineerden. Zij worden op grond van een beveiligings- en management-ideologie gereduceerd tot een enkele categorie van niet of nauwelijks te motiveren gedetineerden die voor wat betreft de aanpak van hun individuele problematiek slechts aanspraak makt op het beperkte aanbod van voorzieningen binnen een standaard-regime.

Bij deze gang van zaken, met name bij het uitsluiten van een grote groep gedetineerden die niet gemotiveerd zou zijn, kan men bovendien nog de volgende kanttekeningen plaatsen.

In de eerste plaats is er voor deze veronderstelling van geringe en ontbrekende motivatie in de nota in ieder geval geen stevige empirische basis te vinden. In de tweede plaats behoren ondersteuning en aanmoediging van minder gemotiveerde gedetineerden juist tot de grote uitdaging van het inrichtingswerk en is op grond van de European Prison Rules bovendien geboden (Wiewel, 1994, p.20). In de derde plaats dient men rekening te houden met onzuiverheden bij de toepassing van de criteria voor gebleken motivatie. Motivatie is een

hang met de vergaande differentiatie vooral te maken met het programma-aanbod dat over de hele linie aan gedetineerden wordt gedaan. Dit programma -aanbod is te vrijblijvend en te ongeclausuleerd". 
moeilijk te meten begrip en het gevaar is niet denkbeeldig dat de beoordeling wordt gekenmerkt door een verstrengeling van hulpverlenings-en beheersingsdoeleinden (Knol, 1997, p.282). Bijgevolg kan selectie voor bijzondere regimes een onderdeel worden van de beheersing van de inrichting en wellicht rekruteert men de kandidaten voor deze regimes niet uit de populatie die deze het hardst nodig heeft, maar uit de populatie die zich het best weet aan te passen. De vrij strenge selectie-criteria voor maatschappelijke integratieprojecten lijken een dergelijke ontwikkeling juist in de hand te werken.

\subsubsection{De praktische uitvoering van Werkzame Detentie}

Vrijwel meteen na het verschijnen van de nota Werkzame Detentie begon het gevangeniswezen met de invoering van het nieuwe beleid in pilot-vorm. Het penitentiaire veld, dat wil zeggen de gevangenisdirecteuren stonden allerminst te springen om met het nieuwe beleid aan de slag te gaan.

Sterker nog, zij beschouwden Werkzame Detentie als een, in wezen opgelegd 'politiek verhaal' dat de greep van het centrale beleid op de gebeurtenissen in het veld probeerde te herstellen ten koste van hun autonomie en hun eigen visies op het detentiebeleid. Boin (1998, p.147 e.v.) stelt dat het verzet van het veld niet alleen op de inhoud van de plannen van Werkzame Detentie betrekking had maar tevens op de dwingende manier waarop het beleid werd opgedrongen.

In 1997 is deze experimentele fase afgesloten met een rapportage van de verschillende projectgroepen van de Dienst Justitiële Inrichtingen die waren belast met de uitwerking van het beleid op onderdelen.

Uit deze rapportages (Rapport van de projectgroep standaardregime 2e fase) blijkt dat de oorspronkelijke uitgangspunten van de nota Werkzame Detentie in de praktijk op een aanzienlijk aantal knelpunten stuitten. Slechts een klein aantal inrichtingen werkt min of meer volgens het oorspronkelijke model van Werkzame Detentie.

In de departementale evaluatie constateert men dat het bonus-malus systeem dat berust op het toekennen van beloning of het opleggen van beperkingen aan gedetineerden al naar gelang het vertoonde gedrag, te weinig effect sorteert in termen van sturing van gedrag en motivatie. (Rapport projectgroep standaardregime 2e fase, p.14). Bovendien blijkt dat gedetineerden meer tijd in hun cel verblijven dan oorspronkelijk was beoogd in Werkzame Detentie. Het oorspronkelijke 'ideaalmodel' van vier hele dagen arbeid levert in het standaardregime grote problemen op voor de bereikbaarheid van de geestelijke verzorging en hulpverlening (ibid., p.17). Voorts zijn de contactmogelijkheden tussen PIW-er en gedetineerden sterk afgenomen en de begeleidende aspecten van de PIW-ers functie zijn grotendeels verdwenen, zo concluderen de opstellers van het rapport (ibid., p. 13).

Een belangrijke conclusie uit het rapport is dat het niet haalbaar en bovendien niet wenselijk is de oorspronkelijke opzet van het standaard-regime strikt voor te schrijven. Men laat ruimte open voor variaties in de manier waarop inrichtingen het standaardregime vorm gaan geven, men erkent daarmee impliciet dat men er niet in geslaagd is het restrictieve beleid zoals dat oorspronkelijk in Werkzame Detentie werd geformuleerd aan het veld op te leggen.

Sinds 1999 schrijft het wettelijk kader van de nieuwe Penitentiaire Beginselenwet en Penitentiaire Maatregel ten aanzien van het regime van beperkte gemeenschap en algehele gemeenschap de minimumduur van het dagprogramma en het minimum aantal uren aan activiteiten en bezoek in dat programma voor.

18 Voor het standaardregime als variant van het regime van beperkte gemeenschap dient het 
Voor de voorzieningen warop elke gedetineerde in beginsel recht heeft (lichamelijke oefening en sport, recreatic en luchten) is de minimumduur wettelijk vastgelegd.

Inrichtingen dienen bij de invulling van het regime in ieder geval te voldoen aan de wettelijke minimumnormen. Sommige inrichtingen doen meer dan datgene wartoe zij wettelijk zijn gehouden. Zo geven sommige inrichtingen voorlopig gehechte gedetineerden in cen standaard-regime nog een enkel uurtje kunstzinnige vorming of onderwijs in de week. Niettemin is ook in dergelijke inrichtingen sprake van een achteruitgang in de beschikbare tijd voor activiteiten.

Andere inrichtingen beperken de activiteiten gericht op de voorbereiding van de terugkeer in de samenleving zoveel mogelijk tot zogenaamde activiteiten-afdelingen waarvoor men slechts in aanmerking komt bij gebleken motivatie. We zullen elders in deze studie zien dat ten tijde van de uitvoering van het onderzoek in 1996 in cen van de onderzochte inrichtingen de invoering van het standatardregime feitelijk resulteerde in een ontbreken van hulpverlening door de reclassering en onderwijs voor bepaalde categorieën gedetineerden, in casu kortgestrafte gedetineerden. In de Memorie van Toelichting op de $\mathrm{PBW}^{19}$ geeft de Minister slechts globale richtlijnen voor de invulling van activiteiten op het gebied van educatie en sport. De invulling van de activiteiten wordt qua aard en omvang athankelijk gesteld van de aard van de inrichting, afdeling of populatie. Natamate de inrichting geslotener is en de gedetineerden er langer verblijven dient het aanbod van activiteiten en zorg toe te nemen. Het aanvangsniveau wordt eveneens van belang geacht. Het recht op onderwijs, andere educatieve activiteiten en hulpverlening kan met het oog hierop worden beperkt. Inrichtingen kunnen de richtlijnen naar eigen inzicht vorm geven. Veroordeelde (langgestrafte) gedetineerden kunnen in het algemeen gebruik blijven maken van educatie en voorzieningen op het gebied van hulpverlening, zij het dat ook hier de beschikbare tijd door de invoering van Werkzame Detentie aanmerkelijk is ingekrompen.

dagprogramma minimaal 83 uur per week te bedragen en daarvan moet minimaal 43 uur aan activiteiten worden geboden. Voor het regime van algehele gemeenschap is de duur van het dagprogramma 88 uur en het voorgeschreven aantal uren aan activiteiten bedraagt 48 uur per week Het ligt aldus de Memorie van Toelichting in de bedoeling om tot vrijheidsstraf veroordeelden die daartoe geschikt bevonden worden in een regime van algehele gemeenschap onder te brengen.

Sinds 1996 kent men bovendien als variant van het regime van beperkte gemeenschap het sober regime dat is bestemd voor:

-arrestanten die in het kader van een 'lopend vonnis' zijn aangehouden om een onherroepelijke vrijheidsstraf als nog uit te zitten. Het betreft hier:

-'zelfmelders' die zich niet aan hun verplichtingen hebben gehouden.

- subsidiair gehechten die hun boete niet hebben betaald en in plaats daarvan een vervangende hechtenis uitzitten

-onveroordeelden uit de overlastcategorie (verslaafden), onveroordeelden die voor kleine vergrijpen zijn aangehouden en op korte termijn worden vervolgd en die naar verwachting tot cen korte vrijheidsstraf worden veroordeeld.

De wettelijk voorgeschreven minima zijn voor het sober regime aanmerkelijk minder dan in het standaardregime. Bovendien kent dit regime geen bijzondere activiteiten die gericht zijn op maatschappelijke integratie, hetgeen strijdig is met de wettelijk gegeven resocialisatie-opdracht in art.2 lid 2 PBW en internationale normen (artikel 10, derde lid van het Verdrag van NewYork, inzake Burgerrechten en Politieke rechten.)

${ }^{19}$ Kamerstukken II 1994/1995, 24 263, nr.3. 
Sommige inrichtingen hebben inmiddels weer het oude bloktijdensysteem ingevoerd waarbij het door de nota Werkzame Detentic voorgeschreven aantal arbeidsuren in vijf halve dagen wordt gercalisecrd. Roostertechnisch gezien leidt dit tot meer ruimte voor de overige voorgeschreven activiteiten. In de oorspronkelijke opzet dienden deze activiteiten op één dag plaats te vinden hetgeen in de praktijk resulteerde in een zeer krap en overbeladen programma walarin de gelegenheid voor bejegenings- en hulpverleningscontacten tussen het personecl en gedetineerden in hel gedrang kwam.

Steds meer inrichtingen ontwikkelen projecten op het gebied van maatschappelijke integratic bijvoorbeeld op hel gebied van arbeidstoeleiding.

Daarnaast beoogt Werkzame Detentie ook de verdere uitbouw van projecten voor verslavingszorg en extra begeleiding voor kwetsbare gedetineerden met psychische problematiek, echter deze voorzieningen zijn nict steeds gericht op reintegratic. Bijzondere zorg voor kwetsbare gedetineerden blijkt in de praktijk veelal gericht op het beheersbaar houden van de problematick. Knol (1997, p.281) schat dat on deze reden niet $20 \%$ mar slechts $13 \%$ van de gedetineerden een resocialisatie-programma kan volgen gericht op hetzij arbeidstoeleiding, hetzij verslavingszorg.

De invocring van de PBW voegt met betrekking tot de terugkeer in de samenleving een nieuwe mogelijkheid toe in de vorm van het penitentiair programma (zie hierover het volgende gedeelte van dit hooldstuk).

Na de invoering van Werkzame Detentic is het aanbod van activiteiten in de inrichtingen als gevolg van een grote autonomic op lokaal niveau, een nogal onoverzichtelijk geheel van allerlei varianten op de uitgangspunten van het centrale belcid geworden. Ondanks deze verscheidenheid is het alanbod van voorzieningen op grond van Werkzame Detentie in essentie selectief en inconsistent.

Encrzijds is er cen grote groep gedetineerden die gebruik maakt van voorzieningen op het gebied van educatic en hulpverlening op grond van (internationale) minimum normen, de PBW en de vrije beleidsruimte van de inrichtingsdirectie bij de invulling van het activiteitenprogramma. Anderzijds is er een kleine groep van uitverkorenen die op basis van bijzondere projecten in het kader van matschappelijke integratie met ruimere middelen op het gebied van educatie en hulpverlening doelgericht aan zijn toekomst werkt uit hoofde van veiligheid op lange termijn. Alleen voor deze laatste groep wordt in expliciete zin de eis gesteld dat hun inspanningen doelgericht en effectief zijn in termen van recidive-vermindering.

Deze inconsistentic in het beleid duidt op het ontbreken van een coherente penitentiaire filosofie waarin in samenspraak met het penitentiaire veld de resocialisatie-gedachte als intrinsieke en instrumentele doelstelling een zelfstandige positie krijgt toebedeeld naast overige doelstellingen (beveiliging en vergelding) van de detentie. In het huidige beleid is men er helaas niet in geslaagd de wettelijke resocialisatie-opdracht die tevens cen humane, rechtsbeschermende functie heeft en op de situatie van alle gedetineerden van toepassing is. binnen een overkoepelende visie te integreren met het volledige aanbod van voorzieningen in de huidige resocialisatiepraktijk.

$V$ an het verbeteringsstreven of wat men later ging noemen resocialisatie of maatschappelijke doelstelling is aan het begin van de eenentwintigste eeuw in ideologische en beleidsmatige zin niet veel meer over. Resocialisatie als toekomstgericht streven dat volgens Tulkens (1991) uiteindelijk de dynamiek van de detentie vormt, is geen zelfstandige doelstelling meer. Vanuit een ideologische desoriëntatie omtrent de inhoud en richting van de detentie is resocialisatie ondergeschikt gemaakt aan het streven naar maatschappelijke beveiliging en doelmatigheid. Resocialisatie als een fundamenteel beginsel met een humane en 
rechtsbeschermende strekking is in de jaren negentig van de twintigste eeuw niet meer richtinggevend voor het penitentiaire beleid. ${ }^{20}$

\subsection{De voorzieningen ten behoeve van resocialisatie: overzicht en inhoud}

\subsubsection{De voorzieningen ten behoeve van resocialisatie: een overzicht}

In het Nederlandse gevangeniswezen voert men, zoals wij in de vorige paragraal zagen, een bepaald beleid met betrekking tot de terugkeer van de gedetineerde in de samenleving. Al naar gelang de eisen van de tijd kunnen de accenten in de wijze waarop dit beleid wordt verwezenlijkt, verschillen vertonen. Het verschil in accent kan betrekking hebben op de doeleinden die men met het resocialisaticbeleid nastreeft en op het gehanteerde beleidsinstrumentarium, d.w.z. de middelen of voorzieningen die men aanwendt. Hoewel de voorzieningen zich in de afgelopen decennia in zekere zin hebben gevormd naar de omstandigheden waarin het gevangeniswezen verkeerde, zijn er in het beleidsinstrumentarium een aantal peilers aan te wijzen die tot op heden van belang zijn voor de concrete uitvoering van het beleid met betrekking tot de voorbereiding van de terugkeer in de samenleving

Als belangrijkste peilers gelden individualisering en differentiatie, detentiefasering en regiona-lisering, het regimesactiviteiten-programma, het penitentiair programma en maatschappelijke integratie-projecten. In deze paragraaf wordt een overzicht gegeven van deze verschillende aspecten van het beleidsinstrumentarium. Dit overzicht is onontbeerlijk voor een goed begrip van het functioneren van de resocialisatie-doelstelling in het Nederlandse gevangeniswezen. Ondat het regiensactiviteitenprogramma van direct belang is voor de probleemstelling van het onderzoek wordt dit aspect van het beleidsinstrumentarium in meer uitgebreide zin beschre-ven.

\subsubsection{Individualisering en differentiatie}

Detentie-doelstellingen van het Nederlandse gevangeniswezen zoals humanisering, beperking van detentieschade en het streven naar resocialisatie veronderstellen, aldus Tulkens (1991, p.90), dat individualisering van de straf ruime aandacht krijgt.

Individualisering van de detentie, waarbij men tracht aan te sluiten op de behoeften van de gedetineerden is alleen mogelijk bij een bepaalde mate van differentiatie qua inrichting en regime.

In het rapport van de commissie Fick (1947) werd reeds de basis gelegd voor het streven naar differentiatie bij de tenuitvoerlegging van de gevangenisstraf. De commissie geeft in zijn rapport heel duidelijk de essentie van het differentiatiebeginsel weer (p.39):

"Indien het gevangeniswezen geen verschillen in uitrusting en regime vertoonde en gekenmerkt werd door een grijze eenvormigheid,dan zou de strafexecutie in stede van gelijk juist geheel ongelijk zijn,

\footnotetext{
${ }^{20}$ Veringa (1990, pp. 204-210) constateert dat met een herijking van het beleid de bakens lijken te worden verzet, maar zo vraagt hij zich af: "Waarheen? Wat willen wij thans in de tenuitvoerlegging van straffen en maatregelen bereiken naast en voorbij de loutere normbevestiging en beveiliging van de samenleving?" Het gevangeniswezen verkeert aldus Veringa in een ideologische desoriëntatie waarbij duidelijke noties over inhoud en richting van de detentie ontbreken.
} 
omdat een uniform regime, gezien de verscheidenheid der gedetineerden de een veel harder treft dan de ander. De eis on te komen tot een gedifferentieerd gevangeniswezen is dan ook een eis van rechtvaardigheid. Slechts de eis van een gedifferenticerd gevangeniswezen is in staat met oordeel des onderscheids de onderling zo sterk uiteenlopende gevangenisbevolking op te nemen, de verschillende gevangenen individueel te behandelen en op die wijze de straf in al haar facetten zo goed mogelijk tot hatar recht te doen komen."

In de Beginselenwet en de Gevangenismaatregel werd de differentiatie van gevangenissen en regimes wettelijk geregeld. De voornaamste criteria die bij de differentiatie van inrichtingen werden gehanteerd waren geslacht, leeftijd, strafduur en juridische status. In de nieuwe Penitentiaire Beginselenwet en de Penitentiaire matregel wordt het differentiatiestelsel aan de hand van het onderscheid in externe (artikelen 8 tot en met 14 PBW) en interne criteria (artikelen 16 lid 3 en 4 PBW) uitgewerkt. Tot de regels van externe differentiatie behoort de bepaling dat inrichtingen of afdelingen door de minister kunnen worden bestend voor de onderbrenging van gedetineerden die bijzondere opvang behoeven. Daarnaast bestaat de mogelijkheid van interne differentiatie waarbij de directeur van de inrichting rekening kan houden met de behoefte aan bijzondere opvangmodaliteiten in de zin van art.14 PBW (art.16 lid 3 PBW).

In de PBW heeft men het onderscheid in jeugdige en volwassen mannelijke gedetineerden opgeheven. Voorts is een onderscheid in kort- en langgestrafte gedetineerden komen te vervallen. De PBW bepaalt voor elke inrichting of afdeling daarvan of zij is bestemd als huis van bewaring of als gevangenis, voor mannelijke of vrouwelijke gedetineerden, voor gedetineerden met een bepaald strafrestant en/of voor bijzondere opvang. Daarnaast geldt de mate van beveiliging van de inrichting of afdeling als criterium (open, half open, gesloten en bijzonder beveiligd). Uitgangspunt van het huidige differentiatiestelsel is een terughoudend gebruik van de mogelijkheden van externe differentiatie.

\subsubsection{Fasering en regionalisering van de detentie}

De basis voor de detentiefasering is te vinden in de nota Beleidsvraagstukken Gevangeniswezen uit 1976, waarin de toenmalige staatssecretaris Zeevalking wees op het belang van het scheppen van omstandigheden in de inrichtingen die het contact met de samenleving bevorderen. In het kader van dit streven wordt tevens gesproken van maatregelen die noodzakelijk kunnen zijn voor de fasering van de detentie. In de nota Taak en Toekomst (1982) krijgen regionalisering en detentiefasering een nadere uitwerking (p.2824).

Regionalisering houdt in dat gedetineerden zoveel mogelijk worden geplaatst in een regio waar zij vandaan komen. Detentiefasering behelst het beginsel dat met name langgestraften niet of zokort mogelijk in een gesloten gevangenis worden geplaatst en zodra dit verantwoord is doorstromen naar een half-open of open inrichting. Uiteindelijk doel is het contact met de eigen omgeving en met eventuele hulpverlening te bestendigen en in een zo vroeg mogelijk stadium van de detentie de gelegenheid te bieden deze contacten te intensiveren. Ons penitentiair stelsel kent met het oog op deze doelstelling een onderscheid in gesloten, half open en open inrichtingen. Bij het naderen van het moment van ontslag kunnen gedetineerden onder bepaalde voorwaarden worden overgeplaatst naar een open inrichting. In deze inrichtingen kent men in vergelijking met de andere executiemodaliteiten ruimere mogelijk-heden om zich voor te bereiden op werk na detentie en eventuele gezinshereniging. In (half) open en gesloten inrichtingen gebruikt men met het oog op het behoud en intensivering van de contacten met de samenleving de mogelijkheid van verlof. Kelk (1993, 
(3), p.73) wijst ten aanzien van het beginsel van detentielasering niet alleen op het belang van zo vroeg mogelijke contacten met de samenleving. maar ook op het belang van hulpverlening en begeleiding naarmate de gradaties van vrijheidsbeweging meer het (definitieve) maatschappelijke leven naderen. Kelk houdt met het oog op resocialisatie een pleidooi voor een intensieve detentiefasering die toegepast wordt per individuele langgestrafte en die verloopt volgens een standaardpatroon van opeenvolgende fasen met bepaalde variatiemogelijkheden. Een individueel detentieplan zou voor de betrokkenen het verloop van de detentie in grote lijnen in beeld dienen te brengen. Een detenticplan brengt enig houvast en enig perspectief (ibid., p.80).

\subsubsection{Het penitentiair programma en maatschappelijke integratie programma's}

De invoering van het penitentiair programma in de nicuwe PBW (art.4 lid 1) houdt voor de invulling van de laatste fase van de detentie een belangrijke verandering in. Onder het penitentiair programma wordt blijkens art.4 lid 1 (PBW) het volgende verstaan: "Een penitentiair programma is een samenstel van activiteiten waaraan word deelgenomen door personen ter verdere tenuitvoerlegging van de aan hen opgelegde vrijheidsstraf of vrijheidsbenemende maatregel in aansluiting op hun verblijf in een inrichting en dat als zodanig door Onze Minister is erkend". Alleen gedetineerden die veroordeeld zijn tot ecn vrijheidsstraf, waarvan het onvoorwaardelijk ten uitvoer te leggen gedeelte minimaal één jaar is, komen voor deelname aan een dergelijk programma in aanmerking (art.4 lid 2 onder a PBW).

Om de terugkeer in de samenleving op een meer succesvolle wijze te laten verlopen introduceert de wet dit type programma waarbij de gedetineerde langzaam weer leert omgaan met zijn vrijheid, maar waarbij nog wel de mogelijkheid bestaat om in te grijpen als hij een misstap begaat. Dergelijke mogelijkheden om het einde van de detentic op een andere wijze in te vullen bestonden ook onder de oude regelgeving al in de vorm van dagdetentie (gedetineerden volgen overdag onder toezicht en begeleiding een bepaald programma, maar verblijven voor het overige deel van de dag gewoon thuis), elektronisch toezicht en plaatsing in een atkickkliniek. Deze zogenaamde extramurale executiemodaliteiten worden onder de nieuwe PBW als penitentiair programma aangeboden. $\mathrm{Zij}$ dienen echter wel te worden aangepast aan de eisen die de PBW aan het penitentiaire programma stelt. Deze extramurale varianten in de tenuitvoerlegging van de vrijheidsstraf krijgen met de invoering van het penitentiair programma een juridische basis.

Naast de bestaande extramurale varianten zullen er bovendien nieuwe varianten van het penitentiair programma worden ontwikkeld. De eisen dic de PBW aan het penitentiair programma stelt en die verder worden uitgewerkt in de Penitentiaire maatregel (Pm) zijn duidelijk geënt op het uitgangspunt dat het hier gaat om het einde van een vrijheidsstraf die de zwaarste straf binnen ons sanctie-arsenaal vormt. Het punitieve karakter komt tot uiting in het verplichte karakter van het dagprogramma met een minimum van 26 uur aan activiteiten (zoals arbeidstoeleiding, educatie en hulpverlening) controle op het gedrag en de aanwezigheid van de deelnemer. Deelname aan het penitentiair programma is geen recht maar een gunst die hij door zijn gedrag kan verdienen dan wel hem op grond van een bijzondere zorgbehoefte geboden wordt (art. 5, Pm).

De invoering van het penitentiair programma is te beschouwen als een belangrijke aanwinst op het gebied van de voorbereiding van de terugkeer in de samenleving en in het bijzonder van de detentiefasering.

Tijdens het verrichten van het veldonderzoek voor deze studie in 1996 verkeerde in één van de onderzochte inrichtingen de ontwikkeling van bijzondere regimaire activiteiten in de vorm 
van cen maatschappelijk integratie-project nog in een aanloopfase. Dergelijke projecten worden in dit onderzock derhalve niet in specifieke zin geëvalueerd.

Maatschappelijke integratie-programma's richten zich op gemotiveerde gedetineerden die een deel van de voor de arbeid bestemde tijd kunnen gebruiken om aan hun verslavingsproblematiek, hun psychische problemen en aan onderwijs en (vak)opleiding te werken. In de nota Werkzame Detentie (1994) worden deze programma's onder de noemer gebracht van bijzondere regimaire voorzieningen die een duidelijk rendement in termen van recidivevermindering dienen op te leveren.

Bij dergelijke voorzieningen begeleidt men de gedetineerden, na een zorgvuldige selectieprocedure in meer intensieve zin. Tevens streeft men naar continuïteit in de begeleiding door tijdens de detentie arbeidstocleidings- of zorgtrajecten uit te zetten die ook na detentie worden voortgezet. Kenmerkend is een multidisciplinaire, planmatige aanpak van de problemen of behoeften van de gedetineerden waarbij zowel de inrichting als instanties daarbuiten zijn betrokken. Bij de externe instanties dient men te denken aan de Reclassering, de Arbeidsvoorziening, verslavingsklinieken en opleidingscentra.

Koppeling van toeleidingstrajecten aan het penitentiair programma behoort in de toekomst eveneens tot de mogelijkheden. De belangstelling van gedetineerden voor deze bijzondere voorzieningen is groot. Jammer genoeg komt slechts een klein deel van de gedetineerdenpopulatie in aanmerking voor deze voorzieningen die mijns inziens een belangrijke belofte voor de resocialisatie-praktijk kunnen inhouden. Voor een meer uitgebreid overzicht van de mogelijkheden en werkwijzen van maatschappelijke integratie wordt verwezen naar het departementale rapport van de verschillende projectgroepen Werkzame Detentie (1997).

\subsubsection{Het regimesactiviteiten-programma}

Ondanks de versobering van het beleid op grond van Werkzame Detentie is het regimesactiviteitenprogramma als instrument van het beleid gehandhaafd. Werkzame Detentie betreft vooral een minder ruime invulling van de activiteiten dan voorheen het geval, in formele zin wordt het voortbestaan van het regimesactiviteitenprogramma echter niet aangetast door de uitgangspunten van de nota.

De basis voor het huidige aanbod van voorzieningen door middel van een regimesactiviteitenprogramma is in beleidsmatige zin gelegd door de nota Taak en Toekomst (1982, pp. 39-41). In de nota acht men het van belang reeds bestaande initiatieven in inrichtingen op het gebied van (vormings)activiteiten, beter te structureren. Het regimesactiviteitenprogramma dient hierin te voorzien: "de bedoeling is een programma te bieden van weloverwogen, op elkaar afgestemde activiteiten waarmee in het dagrooster rekening is gehouden". De activi-teiten worden in drie sectoren onderverdeeld: de arbeidssector, de ontwikkelingssector en de leefsector.

Arbeids- en ontwikkelingsactiviteiten (dat wil zeggen vorming, onderwijs, technische basiskennis, kunstzinnige vorming, gespreksgroepen e.d.) vallen onder de eerste twee sectoren. Alle andere activiteiten, zoals individuele hulpverlening, recreatie e.d. worden ondergebracht in de leefsector. In de geest van de nota Taak en Toekomst wenst men de gedetineerden door middel van het regimesactiviteitenprogramma meer mogelijkheden te geven om de detentie af te stemmen op de eigen behoeften en interessen. Er dient een duidelijke plaats te worden ingeruimd voor ontwikkelings-activiteiten om met name de kansen van gedetineerden te vergroten op een beter persoonlijk en sociaal functioneren in de vrije maatschappij.

In de Nota inzake de ontwikkeling van een regiemsactiviteitenprogramma (RAP-nota, juni 1983) worden de inhoudelijke consequenties van de overkoepelende uitgangspunten van Taak en Toekomst voor het regime verder uitgewerkt. In de RAP-nota brengt men een aantal 
activiteiten onder de noemer van ontwikkelingsactiviteiten, zoals onderwijs, kunstzinnige vorming, sport, technische activiteiten, maatschappij gerichte activiteiten en bibliotheekvoorzieningen. Er wordt geen principieel onderscheid gemaakt tussen ontspanning en ontwikkeling, omdat ontwikkeling mede bijdraagt aan ontspanning en ongekeerd.

In de RAP-nota (p.12-35) vinden we bij de uitwerking van de centrale doelstellingen ten aanzien van de activiteiten de volgende (sub)doelstellingen geformuleerd:

- verminderen van de in- en aanpassingsproblemen bij de terugkeer in de samenleving;

- aansluiten bij de behoefte aan sociaal contact en de situatie buiten de inrichting;

- bestrijding van ledigheid en verveling;

- bevorderen van de zelfstandigheid van gedetineerden;

- het bieden van keuzemogelijkheden naast de inrichtingsarbeid;

- verminderen van antagonisme tussen personeel en gedetineerden;

- overdragen van informatie en het leren van bepaalde vaardigheden (vakinhoudelijke doeleinden);

- het fungeren als 'eye-opener' voor gedetineerden (het ontdekken van bepaalde vaardigheden of interessen door aan te sluiten bij de eigen behoeften van de gedetineerden);

Binnen het kader van deze overkoepelende en afgeleide doelstellingen is er binnen de inrichtingen sinds het verschijnen van Taak en Toekomst een verscheidenheid aan regimesactiviteiten-programma's waarin de accenten kunnen verschillen al naar gelang de aard van de bestemming van de inrichtingen. Een dergelijke verscheidenheid werd wenselijk geacht met het oog het streven naar individualisering en daarmee samenhangend, het streven naar voldoende differentiatie.

In organisatorische zin zijn met name de ontwikkelingsactiviteiten ondergebracht bij de afdeling. Sociaal Kultureel Werk (SKW), die tegenwoordig ook wel Maatschappelijke Integratieafdeling of de afdeling Scholing en Vorming wordt genoemd. De leiding van deze afdeling berust bij het hoofd Scholing en Vorming. Oorspronkelijk had deze functionaris tot voornaam-ste taak de verschillende activiteiten uit het programma te coördineren en voorwaarden-scheppend op te treden ten aanzien van de ontwikkelingsactiviteiten. Eind jaren tachtig was men in bijna alle inrichtingen zover dat een dergelijk functionaris was aangesteld. $\mathrm{Na}$ het verschijnen van de nota Werkzame Detentie enkele jaren later, werd deze functie in een aantal inrichtingen vrij plotseling opgeheven. Men ging er klaarblijkelijk vanuit dat bij de uitvoering van het nieuwe beleid van Werkzame Detentie een dergelijke functie overbodig zou worden. In één van de inrichtingen waar ik zelf werkzaam ben, stelde men korte tijd later, zij het in deeltijd, toch weer een hoofd Scholing en Vorming aan.

Om vanuit centraal, departementaal niveau invloed te kunnen uitoefenen op de kwaliteit van de uitvoering van de activiteiten is er jarenlang gewerkt met zgn. landelijke adviseurs op het gebied van lichamelijke oefening, onderwijs, bibliotheek en kunstzinnige vorming. In 1997 zijn deze functies bij het Ministerie opgeheven, omdat inrichtingsdirecties blijkens een enquête van de DJI geen behoefte meer hadden aan ondersteuning en kwaliteitsbewaking vanuit een centraal niveau. Als gevolg van het beleid van verzelfstandiging van de inrichtingen (ook wel de deconcentratie-operatie genoemd), had men in het penitentiaire veld blijkbaar steeds minder behoefte aan bemoeienis van bovenaf waar het de invulling van het regimesactiviteiten-programma betrof. Inrichtingsdirecties beschikken inmiddels over een behoorlijke mate van bestuurlijke autonomie die in belangrijke mate bepalend is voor het niveau en de inhoud van het activiteitenaanbod. Het zicht op de kwaliteit van dit aanbod is met het verdwijnen van de landelijke adviseurs aanmerkelijk minder geworden. 


\subsubsection{Regimesactiviteiten en deconcentratie}

Nog tot aan het begin van de jaren zeventig heerste er in het Nederlandse gevangeniswezen een zeer hiërarchische organisatie-cultuur waarin bewaarders zich, zoals Boin (1998) beschrijft, voor een paar reserveknopen van hun uniform tot het departement in Den Haag moesten wenden (ibid., p.124). In de decennia erna evolueert het gevangeniswezen steeds meer in de richting van een organisatie waarin de effectiviteit en efficiëntie van de bedrijfsvoering worden aangepast aan de moderne inzichten van de organisatiekunde.

In zowel de Gevangenisnota van 1976 als in de nota Taak en Toekomst (1982) worden gedachten en voornemens geuit over de reorganisatie van de verhouding tussen het centraal penitentiair bestuur en de inrichtingsdirecteur. De uitvoering van dit voornemen heeft in het afgelopen decennium geresulteerd in een reorganisatie die ook wel wordt aangeduid als deconcentratie. Deze reorganisatie impliceert een bepaalde mate van verzelfstandiging van de inrichtingen die uiteindelijk moet uitmonden in een stelsel waarbij de beslissingen zo dicht mogelijk bij het niveau van uitvoering worden genomen. Binnen dit stelsel krijgen de directies het beheer over een vast budget, dat zij tot op zekere hoogte naar eigen inzicht kunnen besteden. De uiteindelijke doelstelling is meer effectieve en efficiënte besteding van de middelen. De ingeslagen koers heeft ook consequenties voor de verhouding tussen inrichtings-directies en inrichtingspersoneel. In principe worden beslissingen over de interne gang van zaken zo veel mogelijk overgelaten aan de hoofden van dienst en aldus naar een lager niveau verschoven. De taak van de inrichtingsdirecties is dan vooral sturing van het globale inrichtingsbeleid en het onderhouden van externe contacten met het centrale, departementale niveau.

De voordelen van deze deconcentratie-operatie die vooral betrekking hebben op het beheer van de organisatie zijn evident. Beslissingen door de directie komen sneller tot stand en de bureaucratische wegen naar Den Haag hoeven niet steeds meer te worden bewandeld. Inrichtingsdirecties bepalen binnen de ruime grenzen van de wet de dagelijkse gang van zaken en daarmee tevens de kwaliteit van de detentie in de inrichtingen.

$V$ an verschillende zijden is gewezen op een aantal gevaren die deconcentratie met zich mee kan brengen (Vegter,1990; Kommer,1991; Moerings ,1993). Directies gaan zich wellicht te veel fixeren op een financiële beheersmatige optiek en minder op de regimaire, beleidsmatige optiek, die veel moeilijker te verantwoorden is dan het beheer (Kommer, 1991, p.287). Voorts ligt het gevaar op de loer dat het beleid op lokaal niveau in strijd is met centrale regelingen. En, zoals Moerings (1993, p.113) laat zien, resulteert een afwijzing van het beleid van de directie door de beklagcommissie en beroepscommissie niet steeds in veranderingen in het regime. De verschillen tussen de regimes in inrichtingen met een zelfde bestemming kunnen, aldus Moerings, bijzonder groot worden.

Vegter (1990, p.190) constateert in dit verband dat de aan de directies toegekende beleidsvrijheid zal moeten worden beperkt door een globaal kader om te voorkomen dat bijvoorbeeld de directeur van een huis van bewaring te A dubbel zo veel bezoek toelaat als zijn collega van het huis van bewaring te $\mathrm{B}$.

In de praktijk doen zich dergelijke verschillen in regimevoering tussen inrichtingen met een vergelijkbare bestemming ook daadwerkelijk voor. Zo komt het voor, geheel in overeenstemming met Vegters voorbeeld, dat in het huis van bewaring te A gedetineerden geen kunst-zinnige vorming krijgen, maar de gedetineerden in het huis van bewaring te $\mathrm{B}$ twintig kilometer verderop wel, omdat de directeur aldaar het belang van die activiteiten hoger aanslaat. Er zijn legio voorbeelden van dergelijke verschillen die voornamelijk berusten op de vrije beleidsruimte van de directie. Men kan hier denken aan kleinere budgetten, het opheffen van de functie van hoofd SKW, het bekorten van de duur van de activiteiten en een 
uiteenlopende toepassing van huisregels.

Vertoonde de praktijk de afgelopen decennia op grond van een reeds grote autonomie van de directeuren een gedifferentieerd beeld van unieke, regimatire kenmerken, sinds hel verschijnen van Werkzame Detentie is dit beeld als gevolg van de eigen varianten van gevangenisdirecties op Werkzame detentie, nog veel minder overzichtelijk geworden. In de ene inrichting geeft men creatieve, innovatieve resocialisatieprogramma's een kans, in de andere inrichting moet men van dergelijke initiatieven niets weten en voert men een nononsense beleid.

De grote mate van autonomie van inrichtingsdirecties bij de invulling van het activiteitenprogramma is te vergelijken is met een mes dat naar twee kanten snijdt. Naarmate men meer getixeerd is op de beheersmatige, bedrijfseconomische optiek en minder op de regimaire problematiek van de kwaliteit van de detentie, des te groter is de kaalslag in tijden van bezuiniging. Oog houden voor de (humane) kwaliteit van de detentie betekent in het gunstigste geval het behoud van activiteiten en van verworvenheden in het algemeen.

Deconcentratie heeft als onmiskenbaar voordeel dat inrichtingsdirecties met hun beleid beter kunnen inspelen op de concrete omstandigheden van plaats en tijd. In dit opzicht kan deconcentratie een belangrijke stimulans voor de handhaving en verbetering van de kwaliteit van de gedetineerdenzorg. De praktijk van het werkveld kan hier een creatieve rol vervullen. Anderzijds dient de beleidsruimte die men in het werkveld heeft gekregen op basis van deconcentratie vanuit centraal niveau in enigerlei mate te worden geclausuleerd vooral om kwaliteit en samenhang te garanderen en om te voorkomen dat situaties naar willekeur neigen (Veringa, 1990, p.209).

Boin (1999) is van mening dat met name op het gebied van de detentiekwaliteit de centrale sturing en clausulering van de vrije beleidsruimte van inrichtingsdirecties te wensen overlaat. $^{21}$ Ook de nieuwe PBW laat de inrichtingsdirecties grote vrijheid bij het invullen van regimes, men dient slechts te voldoen aan de minimumvereisten.

Het naoorlogse gevangeniswezen heeft zich, aldus Boin (1998, p.152) steeds meer ontwikkeld in de richting van een gefragmenteerde organisatie, waarin de inrichtingsdirecties een machtige positie innemen: hij omschrijft gevangenisdirecteuren als "kings within their kingdoms" die ondanks pogingen van departementswege hen in het gareel te krijgen, baas in eigen huis blijven.

$\mathrm{Na}$ deze beschouwing over de beleidsmatige en organisatorische achtergronden van de middelen van resocialisatie wordt in de volgende paragraaf onderzocht welke onderdelen uit het regimesactiviteitenprogramma relevant zijn voor de probleemstelling voor dit onderzoek. Vervolgens worden de relevante activiteiten nader beschreven.

\subsubsection{De regimesactiviteiten en hun relevantie voor het onderzoek}

Bezoekt men een penitentiaire inrichting in Nederland dan zal het de bezoeker niet ontgaan

\footnotetext{
2 Boin, 1999 (p.29 en 30): "Gevangenisdirecteuren worden geacht met het beschikbare budget de kwaliteit van hun inrichting te handhaven. Het oog van de Haagse beleidsmakers is dan ook vooral gericht op de kwaliteit van de bedrijfsvoering. De kengetallen die op het hoofdkantoor binnenstromen zeggen niets over detentiekwaliteit. Er is nauwelijks controle op detentiekwaliteit zoals die geleverd wordt door de afzonderlijke inrichtingen. Sinds de inspecties ter plekke zijn afgeschaft, zijn de beleidsmakers in Den Haag grotendeels afhankelijk van 'softe' informatie: klachten van gedetineerden; berichten in de krant; de geruchten uit het circuit."
} 
dat gedetineerden een belangrijk gedeelte van de dag bezig zijn met activiteiten. Vaak is het voor de buitenstaander niet meteen duidelijk welke doeleinden men nu precies nastreeft met al deze bezigheden. Is er bij een gedetineerde dic in het kader van de gestichtarbeid doosjes vouwt sprake van een bezigheid zonder meer of zijn er misschien ook nog andere doeleinden? In welke opzicht is een kleiende gedetineerde nog bezig met de voorbereiding van de terugkeer in de samenleving? Aan de hand van de globale doelstellingen zijn dergelijke vragen moeilijk te beantwoorden. Zij zijn veelal breed geformuleerd en, als men naar de systematiek van de nota Taak en Toekomst kijkt, lijkt alles met elkaar samen te hangen. Alle activiteiten zijn direct of indirect van betekenis voor de realisering van de detentiedoelstellingen. Die doelstellingen liggen immers volgens de nota Taak en Toekomst in elkaars verlengde.

Voor de probleemstelling van dit onderzoek is het echter zaak die activiteiten te selecteren walarvan kan worden gezegd dat zij bij uitstek geschikt zijn om de terugkeer in de samenleving voor te bereiden.

Bij Tulkens (1991, p.93-96) vinden we een bruikbaar ordeningsprincipe gebaseerd op de belangen van gedetineerden.

Volgens Tulkens hebben de belangen in de eerste plaats betrekking op de 'maatschappelijke inzetbaarheid', waaraan een technisch en psychologisch aspect te onderscheiden is. Vecl gedetineerden, aldus Tulkens, hebben niet alleen een gebrekkige of geen opleiding, maar missen ondanks alle bravoure vaak een noodzakelijk gevoel van eigenwaarde en zelfvertrouwen.

Programma's om in deze leemten te voorzien kunnen bestaan uit arbeid, waarbij werkelijk jets moet worden gepresteerd en uit onderwijs variërend van algemeen vormende en clementaire aard tot beroepsgerichte educatie.

Een tweede belang heeft betrekking op sociale vaardigheden. Contactarmoede, onvermogen tot het opbouwen van relaties, onvoldoende aanvoelingsvermogen van behoeften van anderen en daarmee kunnen rekening houden, het zijn allemaal tekortkomingen die het verwerven van een, voor hen zelf bevredigende plaats in de samenleving bemoeilijken. Hulpverleningsprogramma's op het gebied van psychosociale vaardigheden kunnen hier uitkomst bieden.

Het derde terrein waarop gedetineerden vaak blijk geven van onvermogen betreft het vinden van een zinvolle, bevredigende vrijetijdsbesteding. Met name bij werkloosheid kan dit onvermogen tot criminaliteit leiden, aldus Tulkens.

Programma's dic hieraan tegemoet komen, kunnen bestaan uit het aanleren van creatieve, kunstzinnige vaardigheden, activiteiten in de doe het zelf-sfeer, sportbeoefening en lezen. Dit soort activiteiten kan als 'eye-opener' fungeren.

Als vierde gebied moet tenslotte worden genoemd de psychosociale problematiek die betrekking kan hebben op gezins- huisvestings, werkgelegenheid, inkomensbesteding, verslavingsproblematick. Voorlichting en hulpverlening in sociale, juridische, psychologische, psychiatrische en ook medische zin dienen hier soelaas te bieden.

In de inrichtingen worden voorzieningen op het terrein van de maatschappelijke inzetbaarheid geboden in de vorm van arbeid en penitentiair onderwijs, vrije tijdsbesteding (kunstzinnige vorming, sport, bibliotheekbezoek) en psychosociale hulpverlening door het penitentiair reclasseringswerk, het bureau sociale dienstverlening en de psycholoog/ psychiater.

Gerichte sociale vaardigheidstrainingen zijn overigens een tamelijk zeldzaam fenomeen in de inrichtingen.

In dit onderzoek komen activiteiten aan de orde als arbeid, onderwijs, kunstzinnige vorming, sport, bibliotheek en hulpverlening; echter aan een drietal activiteiten wordt in meer 
diepgaande en uitgebreide zin aandacht besteed. Onderwijs, kunstzinnige vorming en hulpverlening staan in deze studie centraal ondat bij deze activiteiten de thematiek van de maatschappelijke inzetbaarheid, de zinvolle vrije tijdsbesteding en de psychosociale problematiek zich bij uitstek manifesteren.

\subsubsection{Het penitentiair onderwijs}

\subsubsection{Historische ontwikkeling}

Het penitentiaire onderwijs werd, zoals eerder in dit hoofdstuk bleek, in 1847 reeds verplicht gesteld voor gedetineerden. Sindsdien is onderwijs voor gedetineerden steeds voorwerp van een wettelijke regeling geweest. Ook het verplichte karakter kent een lange geschiedenis. Pas in de jaren vijftig wordt in de Gevangenismaatregel (art.76 lid 1) het verplichte onderwijs aan gevangenen beneden de 40 jaar losgelaten: "De gedetineerden die dit wensen, worden in de gelegenheid gesteld gebruik te maken van de in het gesticht aanwezige mogelijkheden tot onderwijs, vorming en recreatie".

Van Zutphen (1986) merkt op dat rond 1949 de fulltime onderwijzer een normale verschijning was in de inrichtingen. Hij vervulde een veel ruimere taak dan nu het geval was. $\mathrm{Hij}$ beheerde de bibliotheek, de informatievoorziening in het algemeen (kranten, tijdschriften) en de ontspanningskas.

Het onderwijs had in de eerste plaats betrekking op basiseducatie, dat wil zeggen lezen, schrijven, rekenen en zo mogelijk aardrijkskunde en geschiedenis. Het percentage gedetineerden dat qua ontwikkeling zeer ver beneden het peil van de zesde klas lagere school bleef, werd op 15\% van de totale inrichtingsbevolking geschat (van Zutphen, p.131).

Uit hoofde van art.43 Beginselenwet werd nog eens benadrukt dat het aanvullend lager schoolonderricht zoveel mogelijk moet worden gegeven an gedetineerden voor wie zulks wenselijk wordt geacht. Dit is, zo merkt (Kelk, 1993, (1), p.243) op, "eenvoudig en primair recht van de gedetineerde, zelfs wanneer de directeur geheel buiten zijn schuld hieraan geen gevolg kan geven" (BC, 28 juli, PI 1981, nr.51).

Allengs breidde men het leerprogramma ook uit tot andere vormen van voortgezet (lager)onderwijs en vakonderwijs. In de jaren vijftig bestond aldus van Zutphen de meeste belangstelling voor de Middenstandscursus (tegenwoordig de cursus Algemene Ondernemers Vaardigheden), terwijl ook onderwijs in boekhouden, handelsrekenen, landbouwvakken en vreemde talen werd gegeven.

Onderwijs en arbeid werden in de jaren vijftig en zestig als belangrijke middelen beschouwd voor het realiseren van het resocialisatiebeginsel. In de Gevangenismaatregel (laatstelijk bijgesteld in 1977) wordt in artikel 76 lid twee bepaald dat onderwijs ook tijdens de arbeidsuren kan plaatsvinden met behoud van loon. Voorts vinden we in de artikelen 77,78 , 79 en 81 bepalingen omtrent het type onderwijs, de bevoegdheden van de directeur bij het aanbod van onderwijs, onderwijs door niet aan het gesticht verbonden personen en instellingen en het bevorderen van zelfstudie.

Ondanks een lange traditie in het Nederlands gevangeniswezen, een wettelijke basis en tal van voornemens en aanbevelingen is de positie van het onderwijs binnen de praktijk van de inrichtingsorganisatie steeds betrekkelijk marginaal geweest (zie van Zutphen, 1986). Vanaf het begin van de jaren tachtig zien we een moeizaam verlopend proces van professionalisering en uitbouw van de mogelijkheden.

In 1987 constateert men in het Raamleerplan Penitentiair Onderwijs (p.24):

"ondanks het feit dat onderwijs als 'belangrijk' en 'nuttig' wordt ervaren door een groot deel van het 
personeel, blijkt het voor de onderwijzers in het veld niet gemakkelijk zich een plaats in het dagprogramma te veroveren."

\subsubsection{Penitentiair onderwijs: doelgroepen, leergebieden en randvoorwaarden}

Onderwijs aan gedetineerden dient men in de eerste plaats te beschouwen als een fenomeen waarbij sprake is van het 'leren' van volwassenen. Het 'leren' van volwassen onderscheidt zich van het onderwijs aan kinderen onder meer door een grotere mate van zelfstandigheid, meer nadruk op de leervragen van de volwassenen, een vrijwillig karakter en meer open leerdoelen versus gesloten leerdoelen.

Tussen volwassenen onderling die weer gaan leren bestaan er grote verschillen in opleiding, cultuur en leeftijd. Daarnaast zijn de motieven om weer te gaan leren nogal divers. Zo noemt men in het Raamleerplan Penitentiair Onderwijs motieven als: sociale contacten, de wens of druk om enkele schoolvakken af te maken, een betere kans op de arbeidsmarkt, persoonlijke groei of algemene ontwikkeling ( p.27).

Het penitentiaire onderwijs kan men in een aantal leergebieden opsplitsen. Volgens de Adviesgroep Volwassenen-educatie (rapport Binnen en buiten de muren, 1985) dient het penitentiaire onderwijs de volgende onderdelen te omvatten: basiseducatie, beroepsgerichte educatie en overige educatie.

Basiseducatie heeft betrekking op het leren lezen, schrijven, rekenen, het ontwikkelen van sociale vaardigheden, met inbegrip van de kunstzinnige vorming, in het bijzonder creatieve expressie gericht op het vergroten van communicatieve vaardigheden.

Als algemeen doel van de basiseducatie geeft het Raamleerplan Penitentiair Onderwijs (p.33) de volgende omschrijving waarbij het belang van de 'maatschappelijke inzetbaarheid' duidelijk tot uiting komt:

'De basiseducatie stelt de deelnemers in staat door middel van activiteiten, die componenten van onderwijs en vorming in zich verenigen, de volgende doelen te bereiken: vergroten van kennis en vaardigheden die strikt noodzakelijk zijn on zich in het dagelijks leven te redden, en in samenhang daarmee- verbreden en verdiepen van de oriëntatie op de samenleving, zowel gericht op persoonlijke ontplooiing als op maatschappelijke weerbaarheid."

Basiseducatie is blijkens deze omschrijving duidelijk gericht op mensen (zowel van autochtone als allochtone oorsprong) in een achterstandssituatie en het streven is gericht op persoonlijke ontplooiing en in samenhang daarmee op een volwaardig participeren in de samenleving.

Beroepsgerichte educatie omvat allerlei vormen van onderwijs waarbij het behalen van een beroepskwalificatie voorop staat. Het belangrijkste doel van beroepsgerichte educatie voor gedetineerden is dat het niveau van de opleiding via het verwerven van een erkend vakdiploma of certificaat voldoende kansen schept voor aansluiting op de arbeidsmarkt. Het betreft hier bij voorbeeld vakopleidingen in de bouw, metaal, horeca, chauffeursopleiding en schoonmak sector. Het verschijnsel vakopleiding in penitentiaire inrichtingen is op zichzelf niets nieuws. De commissie Fick (1948) meldt in zijn rapport dat "vakopleiding eenmaal de trots was van het Nederlandse gevangeniswezen" en beveelt de vakopleiding vooral aan voor jeugdige gevangenen. Sindsdien wordt een vakopleiding in een aantal inrichtingen aangeboden. Toch constateert men in 1987 in het rapport 'Uit de bak, aan de bak' dat een beroepsgericht educatief aanbod slechts in beperkte mate wordt uitgevoerd (p.21). In het 
Raamleerplan constateert men dat de vraag ermal van de zijde van gedetineerden groot is, maar dat om redenen van praktische, financiële en organisatorische aard deze vorm van educatie moeizaam van de grond komt in de inrichtingen (p.34).

Het rapport 'Uit de bak, aan de bak' gaat nader in op de knelpunten dic inherent zijn aan het detentie-systeem zoals de beperkte mogelijkheden voor het opdoen van praktijkervaring en het samenstellen van groepen die gezamenlijk een bepiald programma doorlopen (p.27-31).

Andere belangrijke knelpunten zijn het gebrek aan uren. gebrek aan material, de mocizame samenwerking tussen de arbeidsafdeling en het onderwijs (de arbeid verzorgt immers valk het praktisch gedeelte van de opleiding), interne afstemming lussen inrichtingen onderling en een gebrek aan mogelijkheden om het aanbod af te stemmen op de programma s en de eisen van de educatieve instellingen buiten de inrichting (Centra voor Vakopleiding voor Volwassenen). Eind jaren tachtig speelt bovendien het probleem dat de beroepsgerichte educatie buiten de inrichtingen nog niet goed is afgestemd op volwassenen. Het afgelopen decennium is een en ander verbeterd. Een toenemend aantal inrichtingen introduceert toeleiding in trajectvorm naar een betaalde bakn. Dit is cen belangrijke impuls voor de verbetering van de positie van de beroepsgerichte educatie in het penitentiair onderwijs. De bijdrage van het onderwijs aan een leer/werk traject bestaat in het algemeen uit het leveren van de benodigde scholingsmogelijkheden op het gebied van basiseducatic. beroepsoriënterende activiteiten en schakelcursussen.

Tenslotte onderscheidt men in het Ralamleerplan Penitentiair onderwijs nog de educatie op afstand (bij voorbeeld verzorgd door de Open Universiteit Nederland) en overige vormen van educatie die betrekking kunnen hebben op de algemene ontwikkeling, zinvolle vrije tijdsbeste-ding, vooropleiding voortgezette studie, beroepsvoorbereiding en voorbereiding voor cen beroepsgerichte opleiding (p.35).

\section{Kenmerken van de doelgroep}

Educatie binnen de inrichtingen dient in de eerste plaats rekening te houden met de aard van de gedetineerdenbevolking.

Wat betreft de sociaal economische achtergrond en onderwijs- en werkervaring vertoont de doelgroep het volgende beeld dat wij aan recente gegevens uit de brochure Gedetineerden weer aan het werk" van Crossroads/ Europees Partnerschap (1998) ontlenen.

De meerderheid van de gedetineerdenpopulatie komt uit achtergestelde stadsgebieden, heeft gebrekkig onderwijs genoten en heeft, terwijl men nog leerplichtig was, de school voortijdig verlaten.(p.8) In het rapport vermeldt men verder nog dat 66\% van de Nederlands gedetineerden vóór hun vonnis geen werk had of geen onderwijs volgde. Van de Nederlandse gedetineerden heeft $67 \%$ het secundair (voortgezet) onderwijs niet voltooid (p.3). Andere problemen die men veelvuldig tegenkomt zijn het ontbreken van een vast inkomen, financiële problemen, onstabiele woonomstandigheden en een problematische gezinsachtergrond.

Deelname aan het onderwijs is in Nederlandse gevangenissen niet verplicht. Naar schatting neemt ongeveer $40 \%$ van de gedetineerdenpopulatie op een of andere manier aan het onderwijs in de inrichtingen deel (Yearbook of Correctional Education, 1993, p.156).

Al naar gelang de bestemming en inrichtingscultuur wordt het onderwijsaanbod met verschillende accenten ingevuld. De inhoud van het onderwijs in de inrichtingen wordt voor een belangrijk deel ook bepaald door factoren zoals de visie van de directic op onderwijs, de visie van de leerkrachten en van het hoofd scholing en vorming

Onderwijzen van gedetineerden stelt speciale eisen aan de onderwijsgevende. Het feit dat men te maken heeft met een vorm van volwassenen-educatic en met een steeds wisselende, 
naar achtergrond en motivatie zeer heterogene groep gedetineerden, betekent dat men zich als onderwijsgevende flexibel dient op te stellen. Men dient in de eerste plaats in te spelen op de situatie walarin gedetineerden verkeren. Bovendien dient men bestand te zijn tegen allerlei organisatorische beperkingen die een gevangenis nu eenmal met zich meebrengt voor het onderwijs. Men dient een plaats te veroveren in het dagprogramma, waarin veel andere activiteiten als bezoek, arbeid, sport e.d. zijn opgenomen. Naast didactische en inhoudelijke kennis dient men als onderwijsgevende in een gevangenis vooral te beschikken over uithoudingsvermogen en over communicatieve- en onderhandelingsvaardigheden, teneinde optimale randvoorwaarden te scheppen voor het onderwijs.

De randvoorwaarden uit het Raamleerplan Penitentiair Onderwijs die men nodig acht voor het goed functioneren van het onderwijsaanbod en de onderwijsgevende zijn tien jaar later nog onverminderd actueel (p. 49-53). De randvoorwaarden hebben betrekking op:

- gunstige plaats in het dagprogramma (met zo weinig mogelijk concurrentie van andere activiteiten);

- voldoende onderwijsuren;

- adequate aansluiting van het onderwijsalanbod tussen inrichtingen onderling;

adequate aansluiting op het onderwijsaanbod buiten de muren;

accommodatie;

budget;

leermiddelen;

- deskundigheidsbevordering;

- overleg en samenwerking met andere disciplines.

\subsubsection{Recente ontwikkelingen}

Met de recente prioriteit van de arbeid in het standaard-regime zijn de omstandigheden voor het aanbod van onderwijs ongunstiger geworden. In de meeste inrichtingen geldt dat er in beginsel geen onderwijs meer gevolgd kan worden tijdens arbeidsuren, behalve voor deelnemers aan speciale maatschappelijke integratie-projecten. In de nieuwe Penitentiaire Beginselenwet wordt het recht op onderwijs gehandhaafd. In art. 48 lid 1 wordt bepaald dat de gedetineerde het recht heeft op: " het volgen van onderwijs en het deelnemen aan andere educatieve activiteiten voor zover deze zich
verdragen met de aard en de duur van de detentie en de persoon van de gedetineerde".

Artikel 48 lidl geeft geen omschrijving van de inhoud en omvang van het onderwijsaanbod. Voor activiteiten waarop iedere gedetineerde in beginsel recht heeft namelijk lichamelijke oefening en sport, recreatie en luchten is de minimumduur wettelijk vastgelegd. Voor educatie is zulks achterwege gebleven. In de Memorie van Toelichting wordt opgemerkt dat: "de omvang van deze activiteiten zich op wettelijke niveau nauwelijks laat normeren. Op welke wijze en met welke frequentie aan gedetineerden een aanbod van onderwijs moet worden gedaan wordt sterk bepaald door de aard van de inrichting of afdeling en hun populatie." (Kamerstukken II 1994/1995, 24263, nr.3)

Grofweg gezegd gaat het om het volgen van onderwijsvormen die door de inrichting zelf worden aangeboden en vormen van voortgezet (beroeps)onderwijs van externe onderwijsinstellingen (bij voorbeeld de cursussen van de Open Universiteit)

Naarmate de inrichtingen geslotener zijn en de gedetineerden aldaar langer verblijven zal het aanbod groter moeten zijn. Voorts is het aanvangsniveau van de gedetineerden van belang. 
Met het oog hierop is het recht van de gedetineerde in het cerste lid geclausuleerd. De invulling van de onderwijsactiviteiten wordt grotendeels aan het inzicht van de inrichtingsdirectie overgelaten.

Het onderwijsaanbod kan bovendien variëren al naar gelang de fase van de detentic. Naarmate de detentie langer duurt krijgt de zorg of inspanningsplicht van de overheid met het oog op het beperken van de detentieschade meer inhoud. Of men als voorlopig gehechte gedetineerde of veroordeelde gedetineerde nog op een redelijk adequate manier onderwijs kan volgen, is athankelijk van de inzichten en de budgettaire ruimte van de inrichtingsdirectie. Afgestrafte gedetineerden die niet deelnemen aan een special maatschappelijk integratie-project zullen, mits zij op een afdeling voor reeds veroordeelde gedetineerden verblijven, in het algemeen nog wel onderwijs kunnen blijven volgen. Maar dit impliceert in de praktijk toch een veelal beperkt aanbod.

In het Yearbook of Correctional Education (1993, p.247-257) constateert men naar aanleiding van een internationaal congres dat de situatie van het penitentiair onderwijs in veel landen vergelijkbaar is. De strafrechtspleging staat in veel landen onder druk en in deze moeilijke tijden is er een tendens bespeurbaar om onderwijsvoorzieningen voor gedetineerden op een lager pitje te zetten. Nog meer dan voorheen vindt derhalve het penitentiaire onderwijs in de jaren negentig plaats in een context van 'day-to-day survival'. Het bevechten van een bestaansgrond van het penitentiaire onderwijs op locaal niveau is volgens de opstellers van het rapport op de lange termijn wellicht niet genoeg om het hoofd boven water te houden. Men concludeert:

"Älthough it is appropriate to focus attention on daily classroom needs, more of us must expand our interests to include professional development and intellectual pursuits." (p.247)

\subsubsection{Kunstzinnige vorming}

\subsubsection{Historische ontwikkeling}

Van huisvlijtachtige, creatieve activiteiten was reeds op beperkte schaal sprake in het vooroorlogse gevangeniswezen. In sommige gevangenissen konden gedetineerden knutselen op cel met bij voorbeeld afgebrande lucifers. In een enkel geval was het toegestaan op cel te tekenen.

In de naoorlogse periode kregen gedetineerden al wat meer gelegenheid om zich bezig te houden met huisvlijt (Verhoeven, 1986). Creatieve activiteiten kregen reeds in de jaren vijftig meer aandacht binnen de inrichtingen. Welfare-werksters van het Rode Kruis begonnen in die periode in de psychiatrische observatie-kliniek te Utrecht in het kader van bezigheidstherapie met het begeleiden van creatieve activiteiten. In sommige inrichtingen mochten getalenteerde gedetineerden kunstwerken maken ten behoeve van de aankleding van het gebouw. Volgens Verhoeven (1986) kwam er rond 1970 pas echt iets op gang. In een aantal inrichtingen kwamen, min of meer onafhankelijk van elkaar, initiatieven op beeldend gebied op gang. Idealistische bewaarders organiseerden teken- en boetseeravonden voor gedetineerden. Er werden op een gegeven moment, bij wijze van experiment, ook kunstenaars uitgenodigd om beeldende activiteiten in de inrichtingen te ondersteunen en op te zetten.

Docenten van de Nutsschool te Amsterdam vervulden een pioniersrol bij de introductie van kunstzinnige activiteiten in de inrichting. De initiatieven werden soms mede gesubsidieerd door het toenmalige ministerie van Cultuur Recreatie en Maatschappelijk werk. Begin jaren tachtig was het aantal samenwerkingsprojecten tussen centra voor kunstzinnige vorming en 
inrichtingen inmiddels toegenomen. In 1980 werd in Roermond een eerste proefproject gestart waarbij 'detentiebegeleiders' (de voorlopers van de latere PIW-er) werden bijgeschoold in de creatieve vakken. Dit project kreeg, gesubsidieerd door het CRM navolging in andere inrichtingen. De opzet van bijscholingen of kadertrainingen voor bewaarders viel samen met het verschijnen van een nota inzake de Herziene Gestandaardiseerde Inrichtings Structuur (1981). Aan het begin van de jaren tachtig doet de functic van penitentiair inrichtingswerker als gevolg van deze nota zijn intrede. Op grond van een taakverbreding en verdieping van zijn functie krijgt de PIW-er een belangrijke rol bij de begeleiding van de regimesactiviteiten. Beleidsmatig (Taak en Toekomst, 1982) krijgen de creatieve activiteiten naast de andere activiteiten uit het regimesactiviteiten-programma een duidelijker betckenis voor de persoonlijke ontwikkeling van de gedetineerde. Sindsdien spreekt men ook niet meer over huisvlijt, maar over (kunstzinnige) vorming. PIW-ers krijgen vanaf het einde van de jaren tachtig in de meeste inrichtingen een crea-opleiding. De kortdurende opleiding werd verzorgd door het Centraal Wervings- en Opleidings Instituut (CWOI) en het Landelijk Ondersteu-ningsinstituut voor Kunstzinnige Vorming (LOKV). Tegelijkertijd doet ook de consulent kunstzinnige vorming zijn intrede in de inrichtingen. Oorspronkelijk is de taak van de consulent vooral gericht op de scholing en ondersteuning van de PIW-ers. De laatste jaren ziet men echter in de inrichtingen steeds meer consulenten die de gedetineerden rechtstreeks begeleiden. Organisatorisch werden de activiteiten ondergebracht bij de afdeling SKW (tegenwoordig: Scholing en Vorming). Kunstzinnige activiteiten behelzen zowel twee- als drie-dimensionale technieken (schilderen, tekenen, houtbewerking en keramiek)

\subsubsection{Doelstellingen van de kunstzinnige vorming}

Als doelstellingen van de kunstzinnige vorming binnen de inrichtingen gelden naast de reeds eerder aangehaalde afgeleide doelstellingen uit de RAP-nota (1983), de doelstelling van de beeldende vorming in het algemeen. In de notitie 'Kunstzinnige vorming aan gedetineerden in perspectief '(1993, p.5) formuleert de landelijk adviseur kunstzinnige vorming de volgende doelstelling:

"De beeldende vorming levert, indien deskundig begeleid in agogisch en didactisch opzicht, een wezenlijke bijdrage aan de ontwikkeling van de individuele persoonlijkheid, zijn relatie tot de medemens en zijn bewustwording van de cultureel -maatschappelijke omgeving, dit middels specifieke aandacht voor affectieve, cognitieve en psychomotorische gebieden."

In het algemeen is een belangrijk doel van de beeldende vorming de ontwikkeling van het vermogen tot het doen ontstaan van beelden en vormen die uitdrukking geven aan de leefwereld van het individu.

Volgens de landelijk adviseur kunnen dergelijke algemene doelstellingen van de kunstzinnige of beeldende vorming in de inrichtingen alleen worden bereikt als er sprake is van een samenspel tussen PIW-er en de consulent/docent in de inrichting.

De belangrijkste aandachtspunten in randvoorwaardelijke zin die uit de jaarverslagen van de consulenten en de notitie van de landelijk adviseur (p.9) naar voren komen betreffen:

1. de plaats van de activiteiten in het dagprogramma;

2. de bijscholing en ondersteuning van de PIW-ers;

3. de continuiteit van inzet van PIW-ers;

4. het aantal uren dat beschikbaar is voor het consulentenwerk;

5 . budget en accommodatie. 
Opmerkelijk is dat de problemen zich vooral concentreren rondom de randvoorwatarden in de organisatie. Van problemen bij de begeleiding van gedetineerden lijkt nauwelijks sprake te zijn. Uit de verslagen die consulenten tot aan 1997 jaarlijks uitbrachten aan de landelijk adviseur van de Dienst Justitiële Intichtingen blijkt dat gedetineerden over het algemeen goed gemoti-veerd zijn. Zij blijven, mits sprake is van gunstige randvoorwarden in de organisatie en van een goede begeleiding, onverminderd in grote getale declnemen. ${ }^{22}$

Het begeleiden van kunstzinnige vorming voor gedetineerden, veronderstelt als vorm van volwassen-educatic een aantal specificke vaardigheden. De crea-docent of consulent dient evenals het onderwijzend personeel zeer flexibel te zijn en over het vermogen te beschikken om het programma qua inhoud aan te passen aan de aard van de vaak zeer gemêleerde doelgroep en aan de eisen van de inrichtingsorganisatie.

\subsubsection{Kunstzinnige vorming in de jaren negentig}

In 1993 constateert de landelijk adviseur in haar notitie 'Kunstzinnige vorming aan gedetineer-den in perspectief' dat de kunstzinnige vorming zich ecn structurele plaats in het SKW-veld heeft verworven. In vrijwel alle inrichtingen $(95 \%)$ wordt op dat moment kunstzinnige vorming als activiteit aangeboden, begeleid door vakkrachten en /of PIW-ers.

Over het directe effect van de kunstzinnige vorming krijgen we op basis van informatie uit de inrichtingen uit de notitic van de landelijk adviseur de volgende indruk. De kunstzinnige vorming heeft vooral een positief effect op het verbeteren van de relatie tussen bewaarders en gedetineerden, op het functioneren van gedetineerden onderling in groepsverband en op het gevoel van eigenwarde van gedetineerden

In de meeste inrichtingen worden momenteel nog steeds kunstzinnige activiteiten aangeboden, zij het, als gevolg van de regimesversobering op grond van Werkzame Detentie, in afgeslankte vorm. In sommige inrichtingen wordt de kunstzinnige vorming alleen nog aangeboden op afdelingen met een speciale bestemming (activiteiten-afdelingen met gemotiveerde gedetineerden, verslavings-begeleidingsafdelingen en afdelingen voor gedetineerden met een psychische problematiek). In die inrichtingen is kunstzinnige vorming voor het merendeel van de gedetineerden als activiteit komen te vervallen. Toch kan men op basis van de evaluaties van het Pilot Project Werkzame Detentie (1997) concluderen dat de aanbeveling tot versobering van het regime geen ingrijpende of desastreuze gevolgen heeft gehad voor het aanbod van de kunstzinnige vorming. Ondanks de beperkte invulling van het regime handhaaft $70 \%$ van de onderzochte inrichtingen de kunstzinnige vorming. Men concludeert in het evaluatie-rapport dat de voorgeschreven activiteiten in de sociaal-culturele sector vooral als gevolg van de handhaving van de kunstzinnige vorming minder sterk zijn gedaald dan volgens de nota Werkzame Detentie werd beoogd ( Rapport van de projectgroep standaardregime, p.12).

De invoering van de PBW impliceert dat kunstzinnige vorming een wettelijke basis heeft gekregen. In de Memorie van Toelichting merkt men immers op:

" Naar huidige. internationale opvattingen vallen onder het overkoepelende begrip educatie: onderwijs, scholing en overige vormen van educatie. In de penitentiaire inrichtingen kunnen

\footnotetext{
22 In de meeste inrichtingen is het aantal deelnemers aan cursussen kunstzinnige vorming aan een maximum van om en nabij de 8 deelnemers per bijeenkomst gebonden. In een van de inrichtingen waarin ikzelf werkzaam ben, leidt dit voor sommige afdelingen tot een vraag die het aanbod verre overtreft. Er wordt derhalve gewerkt met wachtlijsten.
} 
onderwijsactiviteiten, het lezen van kranten en tijdschriften, bibliotheckvoorziening, de lichamelijke acfening en sport alsmede veel van de huidige sociaal culturcle activiteiten onder het begrip educatie worden begrepen." (Kamerstukken II 1994/95,24 263,nr.3)

De wettelijke grondslag voor deze activiteiten is zoals uit de vorige paragraal over het penitentiair onderwijs bleck, gelegd in de artikelen 48 cerste en tweede lid. Kunstzinnige vorming die blijkens het Ralamleerplan Penitentiair Onderwijs (p.33) bovendien kan worden beschouwd als een vorm van basiseducatic, valt sinds de invoering van de PBW derhalve ook onder deze wettelijke bepalingen. Maar ook hier geldt dat de invulling van deze activiteit voor een belangrijk deel aan de inzichten van de directie wordt overgelaten

Uit de jaarverslagen vanaf 1990 krijgt men een wisselend beeld van de positie van de kunstzinnige vorming in de verschillende inrichtingen. Kunstzinnige vorming is in een aantal inrichtingen qua randvoorwatarden cen marginale aangelegenheid, in andere inrichtingen is het een bloeiende activiteit die ruime ondersteuning geniet van het management-team en het uitvoerend personeel.

De kunstzinnige vorming blijft mijnsinziens een activiteit die zich binnen de, alsmaar veranderende organisatie, telkens weer opnieuw moet bewijzen. De jaarverslagen van de Dienst Justitiële Inrichtingen laten met name wat de invulling van goede randvoorwaarden betreft, een tamelijk wisselend beeld zien. De invulling van de randvoorwaarden is sterk afhankelijk van de houding van de inrichtingsdirectie.

Uit eigen ervaring weet ik hoe enkel door de komst van een nieuwe directeur met andere opvattingen dan zijn voorganger, een goedlopende en bloeiende crea-afdeling binnen korte tijd weer kan worden gedwongen tot het leiden van een zieltogend bestaan binnen het programma van de inrichting.

Met de nieuwe beleidskaders van Werkzame Detentie en de steeds terugkerende bezuinigingsronden zijn de omstandigheden er niet beter op geworden. Het beeld dat wij van de kunstzinnige vorming in de penitentiaire inrichtingen krijgen is wat dit betreft vergelijkbaar met dat van het penitentiaire onderwijs.

Ondanks deze blijvende perikelen met betrekking tot de randvoorwaarden van de kunstzinnige vorming, kan men vaststellen dat kunstzinnige vorming als 'jonge loot aan de oude stam van het gevangeniswezen' (Verhoeven, 1986) vrij snel is gegroeid. De grootste winst dic de afgelopen tien jaar is geboekt, bestaat vooral uit de ontwikkeling van een 'vreende eend in de bijt' van het gevangeniswezen tol een bekende en door velen gewaardeerde verschijning. In dit verband kan bij voorbeeld worden gewezen op een initiatief van DJI voor de grote overzichtstentoonstelling in 1997 in slot Zeist van kunstwerken gemaakt door gedetineerden. Dergelijke initiatieven laten zien hoe een, aanvankelijk kleinschalig, in de wereld uniek experiment met kunstzinnige vorming in de gevangenis, kan uitgroeien tot een activiteit die in het afgelopen decennium vanuit kunstzinnig en agogisch oogpunt en vanuit het perspectief van de bejegening van gedetineerden zijn waarde duidelijk heeft bewezen. Die waarde ligt mijns inziens vooral besloten in het bieden van gelegenheid tot positieve ervaringen in de overwegend negatieve context van een detentie.

\subsubsection{Het penitentiair reclasseringswerk}

\subsubsection{Psychosociale hulpverlening in de inrichting}

De hulpverleningsactiviteiten binnen de inrichting worden verzorgd door verschillende interne en externe hulpverleners. Interne hulpverleners zoals die van het bureau sociale 
dienstverlening (BSD), psycholoog / psychiater en geestelijk verzorgers, staan in beheersmatige zin onder leiding van de Dienst Justitiële Inrichtingen. De bejegeningsfunctionarissen die bij het BSD werken, behartigen vooral zaken die gedetineerden tijdens hun detentie moeilijk zelt kunnen regelen: contacten met uitkerings- en huisvestingsinstantie, advocaat, verlofaanvragen, infor-matie voor de selectie-adviescommissie en overplaatsing.

Geestelijk verzorgers zijn belast met het verlenen van zorg vanuit een bepaalde levensbeschouwelijke traditie. De ondersteuning van de justitie-pastors richt zich vooral op varagen van existentiële aard, ook wel de problematiek van de zingeving van het bestaan. Van hulpverlening in de zin van een doelgerichte (therapeutische) aanpak van een bepaalde problematiek is bij de geestelijke verzorging eigenlijk geen sprake. Knol (1997, p.270 en 271) formuleert de taak van de pastors vooral als het bevorderen van een comnunicatie in interne en externe zin, dat wil zeggen het bevorderen van het gesprek van de gedetineerde met zichzelf, zijn eigen geschiedenis, waarden en existentiële beelden te midden van andere mensen, andere tradities en andere referentiekaders. De psycholoog en psychiater houden zich bezig met het psychisch welzijn van gedetineerden en uit hoofde hiervan zijn zij belast met individuele hulpverlening en met adviserende taken.

Naast deze groep hulpverleners zijn er maatschappelijk werkers of penitentiair reclasseringswerkers.

Een belangrijk aspect van de taakuitoefening van met name de geestelijk verzorgers en de penitentiair reclasseringswerkers is het opbouwen van een vertrouwensrelatie met gedetineerden. Een dergelijke vertrouwensrelatie betekent dat hulpverleners in beginsel niet verplicht zijn hun informatie over gedetineerden aan andere instanties, zoals bij voorbeeld de inrichtings-directie, ter beschikking te stellen. Een en ander is bedoeld om gedetineerden de mogelijkheid te bieden in hulpverleningscontacten vrijuit te kunnen spreken over hun problemen, zonder de vrees dat deze informatie bij de inrichtingsdirectie terechtkomt.

Een beschrijving in uitgebreide zin van alle vormen van zorg of hulpverlening die door bovengenoemde functionarissen worden verleend is binnen het kader van deze studie wenselijk noch noodzakelijk. Ik beperk mij dan ook tot het penitentiair reclasseringswerk dat in gevangenissen al een lange staat van dienst heeft en dat van oudsher een centrale plats inneemt bij de hulpverlening aan gedetineerden.

\subsubsection{Het penitentiair reclasseringswerk: historische ontwikkeling}

Reclassering is gericht op het zoveel mogelijk betrokken houden of het wederom- met sociaal perspectief-betrekken van de delinquent bij de samenleving (Kelk, 1998, p.421).

Hulpverlening aan gevangenen in charitatieve sfeer vormde het begin van de activiteiten van de reclassering in de eerste helft van de vorige eeuw. In 1823 werd het Nederlandsch Genootschap tot Zeedelijke Verbetering der Gevangenen in het leven geroepen en deze gebeurtenis geldt als de oprichting van de reclassering. Het was een particulier initiatief van burgers die gedetineerden in de gevangenis bezochten om het peil van hun zedelijke beschaving te verhogen. In de loop van de negentiende en twintigste eeuw ontstonden er nog tal van andere reclasseringsinstellingen zoals het Leger des Heils en reclasseringsverenigingen van katholieke en protestantse signatuur. In de negentiende eeuw was het reclasseringwerk een voornamelijk particuliere aangelegenheid. In het begin van de twintigste eeuw is er echter al sprake van subsidiering door de overheid en van een Reclasseringsregeling (1910) waarin de taken van de reclassering werden vastgelegd. Naarmate de strafrechtspleging zich van een daadstrafrecht in de richtingen van een daderstrafrecht ontwikkelt en er meer aandacht ontstaat voor de persoon van de dader wordt 
de ondersteuning breder in de vorm van hulp na ontslag uit detentie en begeleiding en bemiddeling tijdens de fase van het justitiële proces. Hulpverlening tijdens het justitiële proces en tijdens de detentie vat men in het reclasserings-werk ook wel samen onder de noemer van justitiële hulpverlening.

In de ontwikkeling van het reclasseringswerk in deze ecuw kan men een aantal belangrijke aspecten onderscheiden.

In de eerste plaats het aspect van de inhoud van het werk in het bijzonder de voortschrijdende professionalisering. In de jaren zestig verdwijnen vrijwilligers van het toneel en maken plaats voor geschoolde beroepskrachten die te werk gingen volgens een eigen methodiek. Reclassering wordt een vorm van maatschappelijk werk en wordt vervolgens ook ontdekt door wetenschapsbeoefenaren, aanvankelijk door strafrechtsjuristen, later ook door sociologen en psychologen. Die sociaal-wetenschappelijke belangstelling ontstaat met name in de jaren zeventig naar aanleiding van een herbezinning op de taken en op de effectiviteit van het reclasseringswerk. Het tanend geloof in de maakbaarheid van de samenleving en twijfel aan de effectiviteit van de, tot dan toe beproefde methoden van hulpverlening leiden tot onderzoek van het functioneren van de hulpverlening. In dit onderzoek benadert men dit functioneren vanuit het perspectief van de cliënten, hulpverleners, de contacten tussen beiden, de materiële en immateriële hulpverlening en justitiële hulpverlening.

Een tweede aspect van de ontwikkeling van het reclasseringswerk betreft de verhouding met de overheid. De verhouding van de reclasseringsinstellingen met de overheid in casu de strafrechtspleging is niet altijd harmonieus geweest. ${ }^{23}$ De oorsprong van de reclassering als charitatieve particuliere beweging die zich, los van de overheid, zo veel mogelijk aan de zijde van de delinquent opstelt, is hieraan in belangrijke mate debet geweest.

Als een van de belangrijkste bevindingen van een reeks onderzoeken uit de jaren tachtig noemt Brand-Koolen (1997, p.111) dat de justitiële hulpverlening het moeilijkst wordt gevonden door de reclasseringsmedewerkers:

"Men was bang, aldus Brand-Koolen, in de klem te raken tussen enerzijds hun solidariteit met de cliënt en anderzijds hun geloofwaardigheid naar justitie. Toch was het nu juist deze justitiële hulpverlening die vrijwel unaniem door de verschillende onderzoekers als de toekomst voor de reclassering werd aangewezen".

Aanvankelijk lag zeker tot in de jaren tachtig het accent in de taakopvatting van de reclasseringsmedewerkers op de psychosociale hulpverlening of wel het "werken aan de cliënt zelf" en niet zozeer op de justitiële hulpverlening.

In de periode erna kan men spreken van transformatie van het reclasseringswerk van een particulier initiatief met een sterke nadruk op de psychosociale hulpverlening tot een, nagenoeg geheel door de overheid gesubsidieerde organisatie met een belangrijke (publiek-

${ }^{23}$ Zo vermeldt Brand -Koolen et al. (1985, p.6) een periode in de geschiedenis van de reclassering waarin men van mening was dat de band met justitie zou moeten worden doorgesneden en dat het reclasseringswerk als een speciale vorm van maatschappelijk werk zou worden voortgezet onder het (toenmalige) CRM. En in 1973 benadrukt reclasseringsvoorman H. Kuijper bij het honderdvijftig jarig bestaan nog eens dat de reclassering geen onderdeel vormt van criminele politiek (Kuitenbrouwer, NRC-Handelsblad, 18-9-1993). In 1990, zo vermeld Brand-Koolen (1997, p.112), barst er een discussie los over aangekondigde bezuinigingen en ook hier weer is een belangrijk gezichtspunt dat de reclassering als particuliere organisatie 'de eigen broek moet ophouden '. 
rechtelijke) taak die steeds meer in de sfeer van de tenuitvoerlegging van straffen en maatregelen is komen te liggen (Brand-Koolen, 1997, p.112 en 113).

\subsubsection{Recente ontwikkelingen in het penitentiair reclasseringswerk}

Het afgelopen decennium wordt gekenmerkt door een toenadering tot de overheid of tot het netwerk van de strafrechtspleging op grond van een uitbreiding van de laken bij de tenuitvoerlegging van (taak)straffen en maatregelen.

In beleidsmatige zin komt deze toenadering tot de overheid tot uiting in het bijstellen van de reclasseringsdoelen en de afbakening van de doelgroep. In het Strategisch meerjarenplan 1996-1999 met als titel 'Gemotiveerd kiezen' wordt het leveren van een bijdrage aan de bestrijding en vermindering van overlast door justitiabelen als een neveneffect van de reclasseringsinspanningen genoemd. De reclassering formuleert haar doelstelling nadrukkelijk in het verlengde van de overheidstaken op het gebied van criminaliteitsbestrijding. De inspanningen dienen ook een duidelijk resultaat op te leveren in de zin van vermindering van recidive van cliënten. De cliënten worden daarom vooral gezocht in een specifieke doelgroep die een duidelijke motivatie voor gedragsverandering toont en die voor wat betreft de te verwachten effecten in termen van recidive-vermindering het meest te bieden heeft. Behalve op deze groep gemotiveerde verdachte of veroordeelde personen worden de inspanningen ook gericht op justitiabelen die ernstige matatschappelijke overlast veroorzaken.

Tevens is men in de loop van de jaren negentig meer in de richting van de overheid opgeschoven door de werkwijze en organisatie meer te oriënteren op recente ontwikkelingen in het overheidsbeleid waarbij accountancy en accoumtability voorop staan. Ook de reclasseringscultuur beleeft in de jaren negentig een omslag die in het teken staat van verzakelijking. Deze omslag is onder meer een reactie op de bezuinigingen in het kader van Tussenbalans van de staatssecretaris van Justitic (1991).

De Beer en Ploeg (1994, p.13) schetsen in een beschouwing over het rapport 'De reclassering in breder perspectief '(1993) het recente, verzakelijkte klimaat voor het reclasseringswerk als volgt:

"De jaren negentig doen ons een andere overheid kennen: goede intenties en mooic woorden zijn niet meer voldoende. zij wil walar voor haar geld, bovendien wil zij bepalen waarvoor zij betaalt. Een professional geeft vorm aan het hoe, maar dat een product geleverd wordt behoeft instemming van de financier. Deze boodschap zit in het reorganisatietraject verpakt en oefent niet alleen bepalende invloed op de organisatie van het werk uit, maar ook op de inhoud -denk alan de discussie over het aanzienlijk verminderen van het reclasseringsaanbod in penitentiaire inrichtingen."

Voor de inhoud van het reclasseringswerk betekent de recente koersverlegging dat het aanbod op een planmatige en resultaatgerichte wijze plaats vindt. In het nieuwe beleid van de Stichting Reclassering Nederland zijn sinds halverwege de jaren negentig de volgende drie speerpunten te onderscheiden:

-Trajectmatig werken. De SRN hanteert als uitgangspunt dat de begeleiding van iedere cliënt is uitgestippeld in trajectvorm, waarin de middelen en activiteiten staan omschreven die tot bepaalde resultaten moeten leiden.

-Een geïntegreerd aanbod. De SRN streeft naar een efficiënte en effectieve aanpak bij de begeleiding van haar klanten. Na een diagnose dient een plan van aanpak met verschillende, op elkaar afgestemde programmadoelen te worden geformuleerd. 
-Arbeidstoeleiding en arbeidsbemiddeling. $\mathrm{Bij}$ de nieuwe reclassering maken arbeidstoeleiding en arbeidsbemiddeling in toenemende mate onderdeel uit van de begeleiding van de justitiabelen.

Men richt zich bij deze werkwijze bij voorkeur op gemotiveerde justitiabelen aan wie eisen worden gesteld. Bovendien beperkt men zich tot personen die van een strafbaar feit worden verdacht of reeds zijn veroordeeld. Voor begeleiding na ontslag is in beginsel geen ruimte (Fiselier, 1998, (1)). Men richt zich nog wel op de categorie van 17- tot 25-jarigen, gedetineerden in de begin- en eindfase van de detentic, justitiabelen van allochtone oorsprong, verslaafden en dak- en thuislozen.

Van verschillende zijden worden bezwaren geuit tegen deze ontwikkeling van het reclasseringswerk (Kuitenbrouwer, 1993; Otte, 1997; Kelk, 1998; Fiselier, 1998 (2)). Hoewel de nieuwe aanpak in bepaalde opzichten winstpunten oplevert, wordt gewezen op het gevaar dat de reclassering haar eigenlijke en oorspronkelijke doelstelling uit het oog verliest. "De harde werkelijkheid van calculatie en selectiviteit, aldus Kelk (1998), staat veraf van de goedertieren, medemenselijke koopmansgeest waarin de reclassering haar wortels heeft". De hopeloze gevallen dreigen van hulp verstoken te blijven vanwege een te eenzijdige fixatie op het door de overheid gestelde doel slechts daar te investeren waar succes verwacht mag worden. Als gevolg van deze selectiviteit zal aldus Kelk, "een fors gedeelte van de gedetineerden verstoken blijven van sociale perspectieven die voorkomen dat zij blijvend uit de boot vallen. Eens sociaal zwakkere, altijd sociaal zwakkere (als straf na de straf), indien niet aan de primaire normen van motivatie en coöperatie wordt voldaan" (p.425).

\subsubsection{Doelstellingen en kenmerken van het penitentiair reclasseringswerk}

Bij de uitvoering van hun hoofdtaak namelijk de psychosociale hulpverlening aan gedetineerden vallen de penitentiaire reclasseringswerkers in beheersmatige zin onder de Stichting Reclassering Nederland.

In de Reclasseringsregeling van 1995 wordt in art.8, naast de uitvoering van taakstraffen (sindskort ook penitentiaire programma) en het doen van onderzoek en voorlichting, het verlenen van hulp en steun aan gedetineerden in het kader van hun toekomstig functioneren in de samenleving als kerntaak genoemd.

Een belangrijk onderscheid in de problematiek die in de hulpverleningscontacten aan de orde komt is dat tussen materiële en immateriële problemen en de problemen die te herleiden zijn tot het justitiële proces of detentie. In concreto gaat het hier om hulpverlening op het gebied van werk/werkloosheid, financiën, huisvesting, scholing (materiële hulpverlening), relaties met familie, gezondheid, vrijetijdsbesteding, verslaving, problemen die een direct gevolg zijn van de detentie (immateriële hulpverlening) en hulpverleningsactiviteiten die gericht zijn op het begeleiden van de cliënt door het justitiële systeem. Reclasseringshulp bij verslavingsproblemen wordt tegenwoordig ook gegeven op zogenaamde Verslavingsbegeleidingsafdelingen (VBA). De reclassering heeft verder ook een taak bij arbeidstoeleidingsprogramma's of andere bijzondere, intramurale programma's gericht op de terugkeer in de samenleving.

Belangrijke aspecten van het hulpverleningsproces (Spickenheuer, 1984) zijn:

- De aansluiting van de hulpvraag op het hulpaanbod;

- het verschil in visie van cliënt en hulpverlener op de oorzaken van problemen;

- verwachtingen die cliënten hebben ten aanzien van reclasseringshulp;

- de houding van de cliënt tijdens het hulpverleningsproces;

- het organiseren van adequate nazorg; 
In de Beginselenwet werd de sociale verzorging geregeld door artikel 41 dat bepaalt dat het tot de taak van de directie behoort "gedetineerden te helpen bij het zoeken naar een oplossing van de maatschappelijke moeilijkheden, welke met het feit hunner detentie of omstandigheden, die tot het plegen van het stafbare feit hebben geleid, in verband staan." In de Penitentiaire Beginselenwet (art.43 eerste lid) wordt kort en krachtig bepaald dat: "de gedetineerde recht heeft op sociale verzorging en hulpverlening". Het tweede lid van artikel 43 PBW bepaalt dat de directeur zorg draagt dat reclasseringswerkers en andere daarvoor in aanmerking komende gedragskundigen (bij voorbeeld de an de inrichting verbonden psycholoog) de in het eerste lid omschreven zorg en hulp in de inrichting kunnen verlenen.

In de Memorie van Toelichting (Kamerstukken II,1994/1995, 24263, nr.3) wordt opgemerkt dat de positie van de penitentiaire reclasseringswerker thans in beweging is. Het reclasserings-werk in de inrichtingen is in de afgelopen jaren immers minder intensief geworden. Naarmate de aanwezigheid van de reclasseringswerker in de inrichting wordt beperkt is het, volgens de Memorie van Toelichting, in het kader van de reïntegratie-opdracht van belang dat mede-werkers van de bureaus sociale dienstverlening een intensieve werkrelatie gaan onderhouden met de reclassering. Als richtlijn stelt de Memorie van Toelichting dat de zorgplicht van de overheid ten aanzien van gedetineerden meer inhoud krijgt naarmate de inrichting geslotener is en de detentie langer duurt.

Speldenbrink (1994, p.65) omschrijft de cliënt van de reclassering als volgt:

- ongeacht leeftijd, geslacht, ras heeft meer dan $80 \%$ te maken met een probleem dat in de relationele sfeer ligt;

- er is sprake van een gering ontwikkeld gevoel van eigenwaarde;

- het gaat veelal om jonge mensen met een gebrekkige opleiding;

- vaak komen ze uit gebroken gezinnen;

- ze hebben veel moeite met autoriteit in het algemeen;

- ze lopen met een grote boog om het woord 'moeten' heen;

- hun kreet is 'dat maken wij zelf wel uit'.

De problemen van gedetineerden zijn blijkens een overzicht dat Kelk (1998, p.423 en 424) in een beschouwing over de reclassering geeft zijn bepaald niet gering. Een overgrote meerderheid behoort tot de groep van kansarme en afhankelijke gedetineerden met weinig of geen scholing, met schulden, geen vooruitzicht op werk en huisvesting (57\% kan niet terugkeren naar de oude woonsituatie voor detentie) en een verleden van druggebruik. De kansrijke gedetineerde is overwegend een autochtone Nederlander met een tamelijk gunstige achtergrond qua opleiding, sociale contacten en woon-en werksituatie. Deze categorie gedetineerden is echter zeer klein. De kansarme gedetineerden hebben juist vanwege hun geringe (sociale) vaardigheid en vrij passieve houding weinig kansen op verbetering van hun situatie.

Juist deze groep vraagt om een actieve opstelling van de hulpverlenende instanties. Kelk constateert echter een, over het algemeen afwachtende houding bij deze instanties. Men wacht op een hulpverzoek maar de prikkel daartoe ontbreekt bij de kansarme, minder gemotiveerde en minder 'redzame' groep gedetineerden, die als gevolg daarvan in een vicieuze cirkel dreigt te geraken. 


\subsubsection{De gestichtsarbeid}

\subsubsection{Historische ontwikkeling}

Het verband in Nederland tussen de vrijheidsbenemende straf en de verplichte arbeid dateert reeds vanaf het einde van de zestiende eeuw met de oprichting van de werk- annex tuchthuizen ook wel de rasp- en spinhuizen genoemd. Met de invoering van deze tuchthuizen beschikte men behalve over lijf- en doodstraffen nu ook over een nieuwe sanctie in de vorm van de vrijheidsstraf. In deze inrichtingen werd voor het eerst de gedwongen arbeid op systematische wijze toegepast.

De doeleinden die men met de dwangarbeid in de rasp-en spinhuizen nastreeft, lijken al erg veel op de doeleinden die men in de eeuwen erna aan de gedwongen arbeid toekent. Naast economische motieven zoals het bestrijden van de kosten van de detentie, speelden doeleinden gericht op de correctie en bestraffing van gedetineerden en het handhaven van de orde binnen de inrichting een belangrijke rol.

Dergelijke economische, punitieve, beheersmatige en reclasserende functies zijn tot op de dag van vandaag van betekenis voor de rechtvaardiging van de penitentiaire arbeid.

Wat deze rechtvaardiging van de gevangenisarbeid betreft, in strikt juridische zin heeft geen enkele overheid ooit moeite gedaan de arbeidsdwang voor gedetineerden te voorzien van een bijzondere rechtsgrond. Arbeidsdwang, aldus de Jonge (1995), had en heeft nog steeds een axiomatisch karakter, dat wil zeggen stilzwijgend acht men de verplichte arbeid inherent aan de tenuitvoerlegging van de gevangenisstraf.

Als men de gevangenisarbeid in historisch perspectief beschouwt dan valt in de eerste plaats op hoe vaak de geschiedenis zich herhaalt. Of anders gezegd: door de eeuwen heen zijn de problemen die de autoriteiten ontmoeten bij het toepassen van de dwangarbeid in essentie steeds dezelfde.

De economische doelen die men heeft gesteld en die in de loop der tijd konden variëren van zich zelf als inrichting kunnen bedruipen tot een volwaardige economische en winstgevende bedrijfsvoering blijken moeilijk realiseerbaar. Reeds de rasp-spinhuizen konden zichzelf in economische zin niet bedruipen en ook latere vormen van rendementsdenken bij de penitentiaire arbeid bleken vaak te hoog gegrepen.

Ook als men de gedwongen arbeid ten dienste wilde stellen aan de verheffing van de individuele gedetineerde bleek een dergelijke reclasserende of resocialiserende bedoeling maar weinig effect te hebben op de wederaanpassing van de gedetineerden.

De oorzaken voor deze geringe effectiviteit blijken op het niveau van de inrichtingsorganisatie door de eeuwen heen steeds dezelfde. Gedetineerden zijn moeilijk vooruit te branden met een arbeidsaanbod in de gedwongen, restrictieve sfeer van de detentie. Bovendien kenmerkt het aanbod zich door weinig uitdagend werk en een karige beloning. Een voortdurend wisselende gedetineerdenpopulatie, een onderbreking van de arbeid door andere regimesactiviteiten en economische recessies of crises belemmeren de bedrijfseconomische doelstellingen. En als men in deze eeuw aandacht gaat besteden aan de instructie en opleiding van gedetineerden in het kader van de arbeid, blijkt de gemiddelde detentieduur te kort te zijn en de ervaring van gedetineerden met geregelde en geschoolde arbeid te gering om de voorgenomen resultaten te realiseren.

Het beleid van het Nederlandse gevangeniswezen zoals dat in de afgelopen twee eeuwen is gevoerd met betrekking tot de gevangenisarbeid laat op zeer illustratieve wijze zien hoe de officiële, economische en reclasserende bedoelingen elkaar, overigens zonder veel resultaat, veelvuldig afwisselen. Het beeld dat men vervolgens van de gevangenisarbeid krijgt, toont 
hoe verplichte arbeid in gevangenissen zijn hardnekkige aanwezigheid en werkelijke bestaansreden vooral ontleent aan beheersmatige overwegingen en aan een vermeende disciplinerende werking.

In de 19e eeuw, aldus de Jonge (1994), wordt de verplichte arbeid niet als een straf gezien, maar vooral als een middel om de orde in de gestichten te bewaren, bestrijding van de kosten van levensonderhoud en verbetering van de veroordeelden. In 1886 krijgt de gevangenisarbeid een wettelijke basis in de Beginselenwet Gevangeniswezen

Onder invloed van een veranderend denken over het strafrecht (de zgn. Nieuwe Richting) wordt aan het begin van deze eeuw aan de arbeid een resocialiserende functie toegedacht.

Deze ontwikkeling vindt vele jaren later pas zijn neerslag in de Gevangenismaatregel van 1932. De economische neergang van de dertiger jaren belet echter dat de reclasserende functie van de arbeid verder gestalte krijgt.

$\mathrm{Na}$ de tweede wereldoorlog kiest de Commissie Fick voor gevangenisarbeid die, naar het model van het bedrijfsleven, vooral het economisch motief nastreeft. Een gebrekkige outillage had tot gevolg dat deze voornemens slechts in zeer beperkte mate gerealiseerd konden worden. In de jaren zestig grijpt men weer terug op het resocialisatie-ideaal als leidend beginsel bij de gevangenisarbeid (Nota Scholten). Eind jaren zeventig neemt men weer min of meer afstand van het beleid van de Nota Scholten en wordt arbeid vervolgens gezien als een van de vele regimesactiviteiten. Dit beleid wordt in de jaren tachtig voortgezet en vastgelegd in de nota Taak en Toekomst (1982). In deze nota noemt men een aantal factoren die ik reeds eerder in deze paragraaf als oorzaak aanwees voor het falen van de gestichtsarbeid als zinvolle, reclasserende en productieve activiteit. Men legt zich min of meer bij dit falen neer en men ziet arbeid hoofdzakelijk als een middel om de gedetineerden zinvol bezig te houden. Andere inrichtingsactiviteiten zijn even belangrijk, zo niet belangrijker in de visie van de Staatssecretaris.

\subsubsection{De rol van de arbeid in de nota Werkzame Detentie}

Met het verschijnen van de nota Werkzame Detentie (1994) krijgt de arbeid vrij plotseling weer een centrale plaats in het regime van de inrichtingen. Het tot dusver geldende activiteitenaanbod wordt te vrijblijvend en te ongeclausuleerd bevonden voor de huidige gedetineerdenpopulatie. Gedetineerden zullen volgens de nota maximale arbeid moeten gaan verrichten. Hierbij wordt de kwaliteit van de individuele detentie-omstandigheden rechtstreeks afhankelijk gesteld van de inzet bij de arbeid. Wie niet werken wil, zit het grootste deel van de tijd op cel. Men tracht de aanpassing van de gedetineerde aan het regime vooral ook via de inzet tijdens de arbeid tc beïnvloeden. Arbeid fungeert als een instrument ter beïnvloeding van het gedrag tijdens detentie. Het is tevens een beheersmatig instrument gericht op disciplinering van gedetineerden.

Een tweede voornemen met betrekking tot de organisatie van de arbeid is de bedrijfsmatige en meer commercieel gerichte opzet van de arbeid. De opbrengsten van de arbeid, de bedrijfsresultaten, moeten worden verbeterd. Men streeft op zijn minst naar een kostendekkende arbeid.

De arbeid als beheersmatig instrument gericht op disciplinering van de gevangene komt duidelijk tot uiting in de nota. In de bewoordingen van de nota zijn ledigheid en verveling uit den boze en het dagelijks verrichten van werk om in het levensonderhoud te voorzien kan een gunstig effect hebben op de verdere levensloop, in het bijzonder op de integratie van de (ex)gedetineerde in de samenleving. Het wennen aan de structurering van de dag rond de arbeid en het bijbrengen van arbeidsdiscipline zijn de voorwaarden daartoe en waaraan met de invoering van het standaardregime wordt voldaan. Aan het standaardregime en aan het 
verwerven van arbeidsdiscipline wordt dus tevens een resocialiserende werking toegekend. $\mathrm{Bij}$ de resocialiserende bedoelingen van de arbeid volgens de opzet van Werkzame Detentie lijkt het beslist niet te gaan om een arbeidsprogramma dat expliciet gericht is op training van arbeidsvaardigheden. Het lijkt voornamelijk te gaan om een vermeend resocialiserend effect van het verrichten van reguliere en betrekkelijk eenvoudige vormen van arbeid. Uit evaluatie-studies (Palmer, 1994) blijkt dat het netto-effect van een training arbeidsvaardigheden gemengde resultaten oplevert. De effectiviteit van dergelijke programma's neemt overigens toe als er sprake is van een brede coherente aanpak waarin arbeidstraining wordt gecombineerd met aspecten als arbeidstoeleiding, training interpersoonlijke vaardigheden en scholing.

De departementale evaluatics (1997) van Werkzame Detentie zoals ingevoerd in een aantal Pilot-inrichtingen tonen aan dat de plannen waar het de arbeid betreft toch wel erg hoog gegrepen en zijn en op het eerste gezicht van een enige naïviteit getuigen. Met enige kennis van of gevoel voor de historie van de gevangenisarbeid in de penitentiaire inrichtingen had men zich deze teleurstellingen en evaluaties wellicht kunnen besparen. Wat dat betreft was de visie van Taak en Toekomst realistischer en veel meer geënt op de structurele beperkingen van de gevangenisarbeid die blijkens de geschiedenis inherent aan het systeem zijn. Maar bij nader inzien gaat het in de nota Werkzame Detentie ondanks de grote nadruk op de gestichtsarbeid als peiler van het beleid, helemaal niet om een goede theoretische onderbouwing. Arbeid lijkt vooral te zijn beoordeeld op zijn geschiktheid om een groeiende, heterogene gestichtsbevolking tegen lagere kosten hanteerbaar te houden (de Jonge, 1995, p.71). Bovendien is arbeid als 'no-nonsense' middel in deze tijden ideologisch en politiek veel beter te verkopen als de klei-cursus of het kostbare maatschappelijke integratieprogramma, waarvan de opbrengsten niet direct aantoonbaar zijn.

In de PBW wordt de arbeid geregeld in artikel 47 (lid 1 ), dat bepaalt dat de gedetineerde recht heeft op deelname aan de in de inrichting beschikbare arbeid. In het derde lid van dat artikel staat verder dat gedetineerde die tot een vrijheidsstraf zijn veroordeeld verplicht zijn de aan hen door de directeur opgedragen arbeid, zowel binnen als buiten de inrichting of afdeling, te verrichten. Onveroordeelden in een Huis van Bewaring zijn niet verplicht tot deelname aan de arbeid.

\subsection{Samenvatting en discussie}

In dit hoofdstuk werd om te beginnen de betekenis van het begrip resocialisatie nader onderzocht en in operationele zin gedefinieerd. Vervolgens werd het streven naar verbetering van gedetineerden in het Nederlandse gevangeniswezen vanuit een historisch perspectief belicht. De onderzoeksvraag die daarbij als uitgangspunt fungeert, werd in hoofdstuk 1 als volgt geformuleerd: op welke wijze heeft men in het Nederlandse gevangeniswezen tot op heden gestalte gegeven aan het streven naar verbetering of resocialisatie?

Er werd beschreven hoe de verbinding tussen de gevangenisstraf en het streven naar verbetering van gedetineerden aan het begin van de negentiende eeuw geleidelijk aan gestalte kreeg vanuit een religieus getinte visie op de gedetineerde als een wezen met een verdorven innerlijk. Hierbij werd tevens gewezen op de invloed van cultureel bepaalde, humanitaire drijfveren die tot uiting kwamen in een groeiende sensibiliteit voor het leed van delinquenten. Het opsluiten van delinquenten stond in de negentiende eeuw primair in het teken van vereffening van het door hen aangerichte kwaad, het was een vorm van retributie 
of boete doen. Het strikt eenzame karakter waarmee die opsluiting gepaard ging, werd als middel gehanteerd om zijn verdorven innerlijk te zuiveren van kwade krachten. In de tweede helft van de negentiende eeuw wordt het Nederlandse gevangeniswezen in praktische en juridische zin steeds meer op de leest geschoeid van dit streven naar zedelijke verbetering door middel van eenzame opsluiting. In diezelfde periode nemen de twijfels over deze cellulaire filosofie toe als gevolg van veranderende wetenschappelijke denkbeelden over de oorzaken van crimineel gedrag.

Aan het begin van de twintigste eeuw kristalliseren deze nieuwe, overwegend deterministische denkbeelden over criminaliteit zich uit in een nieuwe stroming in het strafrechtelijk denken, de Moderne of Nieuwe Richting. Als gevolg van de invloed van de Nieuwe Richting makt het a-sociologische, gesloten mensbeeld en het cellulaire stelsel van eenzame opsluiting plaats voor een visie op straffen en verbeteren die veel meer in het teken staat van de persoonlijke, sociale en psychische omstandigheden van de dader. De straf diende zijn zin niet meer te ontlenen aan wrak en vergelding maar aan een toekomstig, heilzaam en nuttig effect op dader en samen-leving. Het rekening houden met en beinvloeden van die persoonlijke omstandigheden van de dader dienden het karakter van de straf te bepalen. Deze denkbeelden vormden de basis voor de resocialisatie-gedachte in moderne zin. Immers verbetering of, in de terminologie van de Nieuwe Richting, opvoeding, wordt aan het begin van deze eeuw reeds gedefinieerd als een specialal preventief doel van de straf dat betrekking heeft op een beter toekomstig sociaal functioneren van de dader. In beleidsmatige en wettelijke zin krijgt het streven naar een beter toekomstig sociaal-functioneren van de (ex)- gedetineerde pas serieus gestalte na 1945. Socialisering van de gevangenisstraf en een daarmee gepaard gaande liberalisering en humanisering van het gevangenisregime werden als belangrijke voorwaarden voor het realiseren van de resocialisatie-gedachte gezien. De verwezenlijking van de resocialisatie-opdracht kwam in de naoorlogse periode vooral neer op humanisering van de detentie-omstandigheden en niet zozeer op het stelselmatig nastreven van blijvende gedrags-veranderingen in de zin van minder recidive na detentie. Van een stelselmatig en ernstig nastreven van recidive- vermindering als doel van resocialisatie is feitelijk geen sprake. Het uitblijven van substantiële recidive-vermindering wordt in de jaren zeventig en tachtig een belangrijke reden om de resocialisatie-gedachte in beleidsmatige zin minder aandacht te geven. In de jaren tachtig en negentig verliest de resocialisatie-gedachte steeds verder terrein in het beleid van het gevangeniswezen. In de jaren negentig zijn veiligheid, doelmatigheid en menswaardigheid de belangrijkste doelen van het gevangeniswezen. Resocialisatie of maatschappelijke integratie is een doel dat wordt geformuleerd als het streven naar veiligheid op lange termijn. In het beleid van de jaren negentig wordt niet meer gerept over het belang van de wettelijk gegeven resocialisatieopdracht. In de nieuwe Penitentiaire Beginselenwet van 1999 wordt de resocialisatieopdracht overigens wel gehandhaafd.

De praktijk van het resocialisatie-streven in de jaren negentig wordt gekenmerkt door selectiviteit en een bepaalde mate van inconsistentie. Enerzijds is er een zeer kleine groep veelbelovende of kansrijke gedetineerden die aanspraak kunnen maken op ruimere aandacht voor hun toekomstperspectieven in de vorm van speciale terugkeerprogramma's. Die programma's dienen te resulteren in een duidelijk rendement in termen van recidivevermindering en een bijdrage te leveren aan de veiligheid op lange termijn. Anderzijds is er een overgrote meerderheid van gedetineerden die als minder gemotiveerd word beschouwd. Deze groep kan slechts in beperkte mate gebruik maken van ontwikkelingsactiviteiten. Voor 
zover deze groep gedetineerden aan deze activiteiten kan deelnemen, gebeurt dit voornamelijk uit hoofde van de wettelijk gegeven resocialisatie-opdracht en de wettelijke bepalingen omtrent het recht op educatie en hulpverlening. Het streven van deze minder bevoorrechte groep gedetineerden naar betere toekomstperspectieven berust voornamelijk op de humanitaire grondslag van de wettelijke gegeven resocialisatie-opdracht en de visie van de gevangenis-directie op de invulling van deze opdracht. De beleidsmatige eis van een duidelijk rendement in recidive-vermindering van de nota Werkzame Detentie heeft op de inspanningen van deze groep geen betrekking.

Overzien we de ontwikkeling van de verbeterings- opvoedings of resocialisatie-gedachte in het Nederlandse gevangeniswezen, dan kan men concluderen dat van het oorspronkelijke ideaal om gedetineerden tijdens en door middel van een detentie te veranderen in betere mensen zonder criminele tendenties weinig terecht is gekomen. Na detentie neemt de meerderheid van de gedetineerden tot op de dag van vandaag zijn criminele levensstijl weer op. De vraag dringt zich onvermijdelijk op hoe dit komt. Een belangrijke oorzaak werd reeds in hoofdstuk 1 aangestipt: de psycho-sociale problematiek van gedetineerden is niet van dien aard dat zij zich leent voor snelle en gemakkelijke oplossingen tijdens een detentie. Bovendien is de gevangenis op zichzelf al een weinig uitnodigende omgeving voor een bevredigende oplossing van de vele problemen waarmee gedetineerden kampen.

Zonder overigens de pretentie van een volledige beantwoording van deze vraag geeft de beschrijving van de geschiedenis van de resocialisatie-gedachte in de Nederlandse strafrechts-pleging nog een aantal andere oorzaken aan.

De problemen waarop men in de afgelopen decennia bij de uitvoering van de resocialisatieopdracht in de praktijk stuitte, blijken voor een deel inherent aan de besluitvorming van het strafrechtelijk apparaat als zodanig. Behalve aan speciale preventie, in casu resocialisatie dient het strafrecht tegelijkertijd recht te doen aan tal van andere doelstellingen. Resocialisatie dient het, in de context van de uitvoering van het beleid steeds op te nemen tegen andere, concurrerende doelstellingen zoals vergelding, beveiliging en afschrikking. $\mathrm{Er}$ is kortom sprake van een meervoudigheid van conflicterende doelstellingen die maken dat het strafrecht noodgedwongen half werk aflevert. ${ }^{24}$ Het bewerkstelligen van recidivevermindering lijkt eerder thuis te horen in organisatie die een dergelijke doelstelling in officiële en werkelijke zin ten volle nastreeft, zoals bij voorbeeld de reclassering.

Tevens bleken bepaalde ideologische factoren een rol te spelen. Het streven in de jaren vijftig en zestig van de twintigste eeuw naar een humaan strafrechtelijk klimaat waarin respect is voor de dader als medemens leende zich niet voor een behandelingsfilosofie met specifieke en stelselmatig afgedwongen gedragsveranderingen. Op ideologische en voor een deel ook cultuurgebonden gronden koos men bij de verwezenlijking van de resocialisatie-opdracht bewust voor behandelings-vormen met een perifeer, voornamelijk humaan karakter waarbij toepassing van dwang zo veel mogelijk werd geschuwd.

Tenslotte werd ook gewezen op het ontbreken van (wetenschappelijke) kennis en expertise met betrekking tot de uitvoering van adequate penitentiaire interventies.

it Denkers,(1976, p.122 en 123): "In het strafrecht is de marge waarbinnen twee of meer doelstellingen kunnen samengaan zonder dat zij elkaars realisering in ernstige mate frustreren, veel kleiner. Winst voor de ene doelstelling betekent al heel gauw verlies voor de andere. Toch moet aan alle doelstellingen worden rechtgedaan. Het gevolg is dat het strafrecht eigenlijk nooit iets goed kan doen." 
Samenvattend kan worden gesteld dat het resocialisatie-ideaal in speciaal preventief" opzicht niet die vruchten heeft afgeworpen waarop men alanvankelijk had gehoopt.

De vruchten die Nederlandse gedetineerden in de afgelopen decennia wèl konden plukken van het resocialisatie-streven hebben vooral betrekking op een gehumaniseerde bejegening tijdens de detentie en niet zozeer op een leven zonder criminaliteit na afloop van detentie. Resocialisatie probeerde men vooral te bereiken door handhaven en intensiveren van sociale contacten hetgeen indirect resulteerde in reële verbeteringen in hun behandeling. Niet alleen de gekozen middelen mar ook het achterwege blijven van het uiteindelijke doel, namelijk recidive-vermindering droeg vervolgens bij tot een verdere problematisering en beperking van leed-toevoegende elementen van de vrijheidsstraf (Franke, 1990, p.784). Humaniscring of het betrachten van menselijkheid werd in de jaren tachtig zelfs de hoofddoelstelling van het gevangeniswezen. Volgens Franke $(1990.0 .12) \mathrm{kwam}$ het wegvallen van de resocialisatie-doelstelling als legitimering van de vrijheidsstraf ten gocde alan de machtspositic en indirect datrmee ook aan het emancipatieproces van gevangenen als achtergestelde en onderdrukte groepering (Franke. p.12). Niet het succes, matar juist het falen van resocialisatic bij het voorkomen van recidive heeft dus onbedoeld en indirect in het voordeel van gedetineerden en in het bijzonder van hun bejegening gewerkt.

Als laatste, maar zeker niet de minste verworvenheid dient de erkenning van de resocialisatie-gedachte als wettelijk beginsel te worden genoemd.

De wettelijke resocialisatie-opdracht als doelstelling in intrinsieke, nomatieve zin die de uitshiting van gedetineerden van de samenleving beoogt te voorkomen en juist de nadruk legt op "het leit dat zij daarvan deel uit blijven maken" bleef decemnia lang een rol spelen in het formele beleid, los van de gehanteerde instrumenten en de (uitblijvende) effecten. In de jaren negentig tenslotte zien we dat de nadrukkelijke verwijzing naar deze humane en ethisch- normatieve strekking van het resocialisatie-beginsel in het beleid achterwege blijft.

Beleidsmatig gezien lijkt resocialisatie alan het begin van deze nieuwe eeuw geen rol van betekenis meer te spelen. Resocialisatie is noch in instrumentele, noch in intrinsicke, normatieve zin een belangrijke doelstelling van het recente penitentiaite beleid. Het is een vrij kwetsbare doelstelling geworden.

De effectiviteit van het resocialisatie-streven in termen van recidivevermindering is nog steeds niet indrukwekkend en de overtuiging dat wij, in beginsel op humane gronden aan alle gedeti-neerden perspectief moeten bieden, lijkt niet zo stevig verankerd in het bewustzijn van beleidsmakers, publiek en politiek. Volgens Garland (p.236) is de humanitaire kant van strafrechtelijke hervorming altijd nogal kwetsbaar gebleken:

"Of all the 'civilizing'changes in punishment, however. the enhancement of sympathy for the offender and the amelioration of penal conditions is perhaps the least well developed.. Despite 200 years of penal reform and demands for more humane methods many prisons continue to be squalid, brutal places relative to general standards of life in the world outside. The average length of prison sentences is in many places increasing: thousands of offenders are still sent to prison for minor crimes: and capital punishments are still carried out in several states of the USA."

Garland constateert evenals Denkers (1976) dat humanisering (en als aspect hiervan het resocialisatiebeginsel) het steeds moet opnemen tegen concurrerende doeleinden zoals vergel-ding. beveiliging, afschrikking en een wijdverbreide punitieve vijandigheid van de samenleving tegen delinquenten.

Toch kan een humane strafrechtspleging het niet stellen zonder een resocialisatie-beginsel. Een tenuitvoerlegging van de gevangenisstraf die geen perspectieven meer biedt en zich 
voornamelijk beperkt tot werken, op cel zitten en luchten (denk aan het sober regime!) glijdt af naar een bedenkelijk niveau. Ook al leidt resocialisatie niet steeds tot een substantiële recidive-vermindering, aandacht voor het maatschappelijk herstel van gedetineerden blijft om humane redenen geboden. Dit streven houdt overigens meer in dan het vrijblijvend verschaffen van luxe en comfort op grond van charitatieve overwegingen. Intramurale voorzieningen die men op grond van humane, niet- rationele overwegingen aanbiedt kunnen tevens een muttige functie vervullen voor de persoonlijke en sociale ontwikkeling van de gedetineerde, voor zijn voorbereiding in trajectvorm op extramurale vervolgvoorzieningen en voor het scheppen van een humaan klimaat dat constructief is en de schade van de detentie beperkt. Vanuit dit perspectief richt het onderhavige onderzoek zich op datgene wat er met het oog op de voorbereiding van de terugkeer in de samenleving binnen de muren van de gevangenis in humaan, utilitair en organisationeel opzicht gebeurt en eventueel kan worden verbeterd.

In dit hoofdstuk werd niet alleen de betekenis van de resocialisatiegedachte voor het Nederlandse gevangeniswezen onderzocht. Tevens werd het beleidsinstrumentarium beschreven waarmee men in het Nederlandse gevangeniswezen de resocialisatie-opdracht heeft trachten te realiseren.

In het bijzonder werd aandacht besteed aan het regimesactiviteiten-programma. Activiteiten als onderwijs, kunstzinnige vorming, hulpverlening en arbeid die worden geacht een bijdrage te leveren aan de voorbereiding van de terugkeer in de samenleving, werden zowel naar hun inhoud als naar hun organisatorische en juridische context beschreven.

Eerder in dit hoofdstuk bleek dat onderzoekers in de jaren zeventig concludeerden dat de wijze waarop uitvoering werd gegeven aan de resocialisatie-opdracht een weinig specifiek en doelgericht karakter droeg.

Een belangrijke vraag is of deze conclusie ruim twintig jaar later nog actueel is.

Bekijkt men de wijze waarop de verschillende, als resocialiserend bedoelde activiteiten thans worden aangeboden dan blijkt die conclusie uit de jaren zeventig nog weinig aan actualiteit te hebben ingeboet.

Men biedt volgens een bepaalde vakinhoudelijke methodiek en vanuit bepaalde, nogal breed en vaag geformuleerde einddoelstellingen de activiteiten aan. Echter, de bijdrage van de activiteiten aan de voorbereiding van de terugkeer in de samenleving blijft veelal onuitgesproken. De impliciete basisfilosofie is nog steeds dat een aanbod van activiteiten zonder meer, een gunstig effect heeft op een proces van zelfherstel.

In proces-evaluatieve termen zou men hier kunnen spreken van het ontbreken van een expliciet geformuleerde conceptuele of theoretische basis. Een visie op en selectie van criminogeen geachte factoren en een vertaling hiervan (via operationele richtlijnen) in een detentieplan met concrete interventies, blijkt niet aanwezig. Een uitzondering geldt hier voor de recente initiatieven in de vorm van speciale maatschappelijke integratie-projecten bestemd voor een kleine groep gemotiveerde gedetineerden. Bij deze projecten is wel sprake van een zekere planmatigheid en een afstemming van de activiteiten binnen het kader van een detentieplan en een bepaald traject.

Voor de gedetineerden die buiten deze bijzondere programma's vallen geldt dat zij op een weinig doelgerichte wijze deelnemen aan de activiteiten. Een expliciet geformuleerde relatie tussen deze activiteiten en het toekomstig leven buiten de muren ontbreekt veelal. Hun positieve betekenis en waarde ligt vooral in andere, directe (humaniserende) effecten die tijdens de detentie optreden. 
- 


\section{HOUDINGEN TEN AANZIEN VAN RESOCIALISATIE: LITERATUUROVERZICHT}

"For most inmates, incarceration interrupts some sort of pro-social career, although the latter may be sporadic and evanescent." (Toch, 1977, p.70)

\subsection{Inleiding}

Dit hoofdstuk begint met een verheldering van het begrip houding in gedragswetenschappelijke zin. Het begrip houding of attitude is immers een betrekkelijk ruim en vaag begrip, dat om uitleg vraagt.

Op grond van de onderzoeksliteratuur wordt in dit hoofdstuk vervolgens een beeld geschetst van de houding van het publiek en strafrechtsfunctionarissen ten aanzien van resocialisatie. Het resocialisatic-streven is immers geen geïsoleerd verschijnsel dat niet verder reikt dan de muren van de gevangenis. De meningen van publiek en politiek leggen, zoals in het vorige hoofdstuk bleek, een behoorlijk gewicht in de schaal bij de justitiële besluitvorming op centraal niveau. De tenuitvoerlegging van de gevangenisstraf moet immers voor het publiek herkenbaar blijven. De publieke opinie over misdaad, straffen en resocialiseren is derhalve een factor van belang.

Aansluitend wordt in dit hoofdstuk op basis van de onderzoeksliteratuur een beeld geschetst van de houdingen van gedetineerden.

In de onderzoeksliteratuur geven onderzoekers, veelal op basis van impressies, een nogal somber beeld van de houdingen van gedetineerden ten aanzien van resocialisatie. Naar zij veronderstellen zijn die houdingen als gevolg van de belastende en depriverende omstandigheden van de detentie overwegend negatief, onverschillig en opportunistisch van aard.

Er zijn echter enkele, meer recente studies die laten zien dat de houding van gedetineerden ten aanzien van resocialisatie toch minder eenzijdig negatief of opportunistisch is dan veelal wordt verondersteld.

Dit hoofdstuk besluit met een overzicht van de aspecten die als aanknopingspunt kunnen dienen voor een verder empirisch onderzoek van de houdingen van gedetineerden.

\subsection{Het begrip houding}

In de Engelstalige onderzoeksliteratuur wordt het begrip houding aangeduid met het woord 'attitude'. Deze Engelse term heeft tevens in bepaalde mate ingang gevonden in de 
Nederlandstalige onderzoeksliteratuur. Toch wordt in dit onderzoek de voorkeur gegeven ain de Nederlandstalige term 'houding'. Immers het woord houding geeft, in tegenstelling tot het woord attitude, de strekking van het voorliggende onderzock op directe wijze weer. Het woord houding is qua betekenis toegankelijker en vermijdt bovendien de taalvertrocbeling door Engels onderzoeksjargon.

Ajzen (1993, p.41) omschrijft een houding als een dispositic van het individu op grond waarvan hij of zij in gunstige of ongunstige zin reageert op warneembare aspecten van de omringende wereld. Die aspecten kunnen betrekking hebben op dingen, mensen, gedrag, insti-tuties en gebeurtenissen. In de onderzoekstiteratuur treft men tal van definities van het begrip houding. Volgens Ajzen hebben zij één ding gemeen, zij benadrukken steeds een evaluatieve dimensie. Het gaat on een bepaalde mate van 'voor of tegen' zijn en om positieve of negatie-ve betekenissen. Deze evaluatieve dimensie blijkt ook duidelijk uit de manier waarop men houdingen in de gedragswetenschappen meet. Men gebruikt steeds schalen die resulteren in een score op een evaluatief continuim dat betrekking heeft op een bepaald object van de houding.

Houdingen van mensen ten aanzien van bepaalde zaken zijn niet direct waarneembaar. Men moet ze afleiden uit meetbare reacties van het individu op het houdingsobject. Het begrip houding duidt men daarom ook wel aan als een hypothetisch construct (Ajzen, 1993, p.42).

Die reacties kunnen, behoudens een, in het algemeen gunstig, ongunstig of neutraal karakter, van velerlei aard zijn. In de onderzoeksliteratuur heeft men de reacties daarom grofweg geclassificeerd in een drietal categorieën. Het classificatie-schema hanteert een onderscheid dat reeds in de oudheid bij Plato is te vinden, namelijk: cognitief, affectief en conaticf. Het schema wordt verder verfijnd door een onderscheid te maken in verbale en non-verbale reacties op een bepaald houdingsobject. In deze studie hebben we te maken met verbale en non-verbale reacties of expressies van respondenten. Die expressies kan men beschouwen als indicatoren of aanwijzingen voor een bepaalde houding. Verbale expressies van cognitieve aard betreffen de opvattingen (ook wel 'beliefs': zie Ajzen, 1993, p.42). De affectieve, verbale reacties hebben betrekking op emoties. Conatieve reacties verwijzen naar wilsbetrokken aspecten die zich op verbaal niveau uiten in bepaalde gedragsmatige tendenties. intenties, voomemens en betrokkenheid. Op non-verbaal niveau hebben conatieve reacties de vorm van motorische reacties, bijvoorbecld in de zin van concrete handelingen ten aanzien van het object van de houding.

Als deze verschillende reacties als manifeste indicatoren van een bepaalde houding kunnen worden beschouwd, dan geldt die houding als een latente variabele.

Rosenberg en Hovland (1960) hebben op grond van deze aanname een hierarchisch dric componenten-model opgesteld dat tot op heden als een bruikbaar uitgangspunt voor onderzoek van houdingen geldt. 


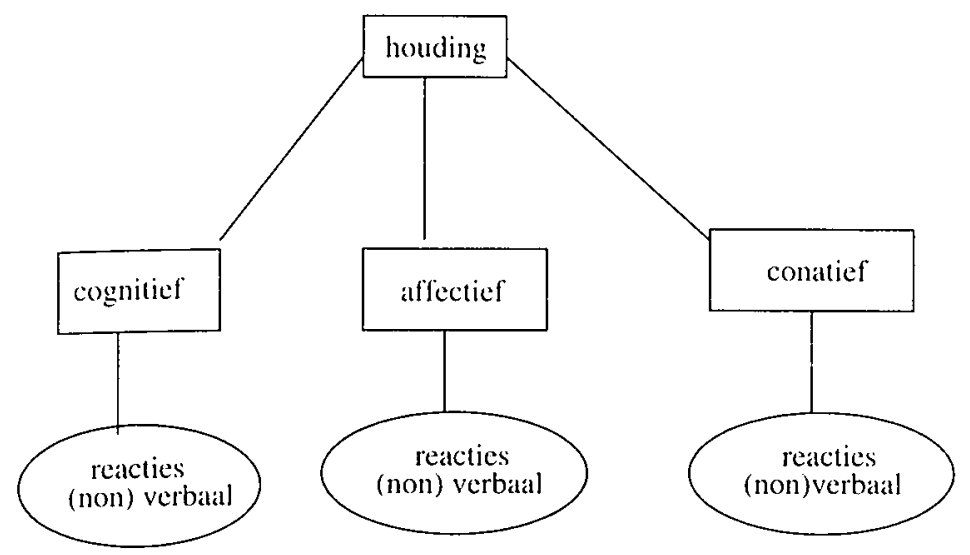

Figuur 1: Rosenberg en Hovland (1960): Hicrarchical Model of Attitude in: Krebs en Schmidt, (1993, p.49)

Ajzen (1993, p.44) merkt op dat de resultaten van het onderzoek van houdingen over het algemeen een structuur vertonen die overeenkomt met het hiërarchisch model van Rosenberg en Hovland. De drie componenten vertonen een samenhang als gevolg van het feit dat zij door cen achterliggende houding of latente variabele worden beïnvloed.

Het hiërarchisch model is voor deze studie vooral van belang vanwege de verheldering van het begrip houding.

Zowel cognitieve, affectieve als conatieve reacties zullen in het empirisch gedeelte van deze studie als indicatoren voor de houdingen ten aanzien van resocialisatie worden gebruikt.

De houdingen zullen worden onderzocht ten aanzien van een drietal terreinen namelijk de resocialisatie-doelstelling, de concrete voorzieningen of activiteiten en de organisationele context van de voorzieningen.

Bij de houdingen ten aamzien van de resocialisatie-doelstelling gaat het vooral on cognitieve reacties in de zin van opvattingen. Bij de houding ten aanzien van de activiteiten gaat het om de declname en beleving waarbij respectievelijk conatieve en affectieve responsen als indicatoren worden gebruikt. Deelname aan resocialiserende voorzieningen kan men beschou-wen als een non-verbale indicator voor de houding ten aanzien van resocialisatic. De relatic tussen bepaalde verbale indicatoren (opvattingen en beleving) en deelname als nonverbale indicator kan men op grond van de theoretische literatuur aanduiden als een relatic tussen houding en gedrag ( Ajzen, ibid., p.47).

Ajzen (ibid.. pp.48-54) heeft met betrekking tot de relatie tussen houding en gedrag een theoretisch model ontwikkeld, de 'theory of planned behavior'. Het begrippenkader van dit theoretische model lijkt ook geschikt om het onderzoek naar de houdingen ten aanzien van resocialisatie richting te geven.

\subsubsection{Ajzens 'theory of planned behavior'}

In Ajzen's theorie is de intentie van het individu om een bepaalde vorm van gedrag aan de dag te leggen een centraal begrip. Intenties omvatten de motivationele factoren die van invloed zijn op gedrag. Ajzen: "they are indications of how hard people are willing to try, of how much of an effort they are planning to exert, in order to perform the behavior "(ibid., 
p.48). Intentie is volgens Ajzen's theorie een van de onmiddellijke antecedenten van gedrag.

De theorie kent een drietal conceptueel onalhankelijke determinanten van intenties:

- de houding ten aanzien van het gedrag;

de subjectieve norm;

- de waargenomen mate van controle over het voorgenomen gedrag

De houdingscomponent verwijst naar de mate waarin het individu in ongunstige of gunstige zin over een bepaalde vorm van gedrag of activiteit denkt. De subjectieve norm heeft betrekking op de waargenomen sociale druk on al dan niet tot een bepaalde vorm van gedrag over te gaan. De controlecomponent verwijst naar de waargenomen mate van realiseerbaarheid van het voorgenomen gedrag. Het gaat hier om de mate waarin men bepaalde hindernissen waarneemt. Vooral eerdere ervaringen beinvloeden deze gepercipicerde mate van 'behavior control'. Ajzen wijst in dit verband tevens op het belang van factoren van nietmotivationele aard zoals de werkelijk aanwezige mogelijkheden om het gedrag te realiseren. Tussen de waargenomen en werkelijke mogelijkheden om het gedrag te realiseren kan een discrepantie bestaan.

Past men het begrippenkader van Ajzen's theorie toe op de houdingen van gedetineerden ten aanzien van resocialisatie dan betekent dit dat positieve opvattingen over het resocialisatiedoel als zodanig, niet steeds tot een daadwerkelijke deelname aan bepaalde integratieactiviteiten hoeven te leiden. Afhankelijk van de perceptie van bepaalde sociale factoren (de sociale druk) en van de waargenomen en feitelijke mogelijkheden ontwikkelt het individu een intentie on aan zijn toekomst te werken. De gevangenis als totale institutie lijkt haaks te staan op het ontwikkelen van intenties tot het daadwerkelijk voorbereiden van de terugkeer in de samenleving. De veronderstelde, negatieve sociale druk vanuit een oppositionele gedetineer-dencultuur, de institutionele nadruk op beveiliging, bedrijfsmatigheid en voorspelbaarheid, de schadelijke effecten van het verblijf voor het persoonlijk welzijn en het betrekkelijk abstracte en ververwijderde doel van maatschappelijk herstel, het zijn kortom allemaal factoren die de bereidheid tot een daadwerkelijke voorbereiding van de terugkeer in de samenleving in de weg kunnen staan. Een onderzoek naar de houdingen van gedetineerden ten aanzien van resocia-lisatie, in het bijzonder naar de opvattingen van gedetineerden dient zich dus niet alleen te beperken tot de opvattingen over de resocialisatie-gedachte als zodanig. Een dergelijk onderzoek dient ook opvattingen in de zin van de waargenomen mogelijkheden voor zelfherstel binnen de context van de gevangenis in ogenschouw te nemen. Intenties tot en voorbereiden van de terugkeer in de samenleving door daadwerkelijk deelname aan de verschillende activiteiten zijn waarschijnlijk tevens afhankelijk van de waargenomen mogelijk-heden voor resocialisatie tijdens een detentie.

In het onderhavige onderzoek naar de opvattingen van gedetineerden ten aanzien van resocialisatie worden derhalve een tweetal aspecten onderscheiden waarop die opvattingen betrekking kunnen hebben. In de eerste plaats is er het aspect van de zinvolheid of het belang van de resocialisatie-doelstelling als zodanig. Het gaat hier om de resocialisatie-opdracht in meer algemene zin.

Het tweede aspect heeft betrekking op de opvattingen over resocialisatie in de context van de gevangenis, in het bijzonder over de waargenomen mogelijkheden voor het daadwerkelijk voorbereiden van de terugkeer in de samenleving tijdens een detentie.

De houdingen van gedetineerden zullen niet alleen in de zin van de opvattingen ten aanzien van resocialisatie worden onderzocht. $\mathrm{Zij}$ zullen tevens worden onderzocht in de zin van de deelname aan en de concrete beleving van de activiteiten die zijn bedoeld om de terugkeer in 
de samenleving voor te bereiden. In dit hoofdstuk zal de literatuur worden onderzocht op relevante informatie over de houdingen in bovengenoemde zin. De resultaten van dit literatuuronderzoek dienen verder als aanknopingspunt voor de opzet en uitvoering van het empirisch onderzoek.

\subsection{Resocialisatie: het denkklimaat in de jaren negentig}

De beschrijving in hoofdstuk 2 van het penitentiaire beleid met betrekking tot de resocialisatie-doelstelling toont een verzakelijking en verharding in het strafrechtelijk klimaat van de jaren tachtig en negentig. De rechtvaardiging van het straffen wordt meer gezocht in punitieve en vergeldende motieven. Bovendien is er in de strafrechtspleging sprake van meer nadruk op instrumentele en organisationele doelstellingen. Het is een ontwikkeling die wordt gekenmerkt door minder aandacht voor bepaalde ethisch-normatieve aspecten (rechtsbescherming) en minder belangstelling voor de persoon van de dader.

Zoals in het vorige hoofdstuk bleek, is de aandacht voor het resocialisatie-ideaal in ideologisch en beleidsmatig opzicht in de jaren negentig van de twintigste eeuw afgenomen. Straf-rechtelijke functionarissen geven in het begin van de jaren negentig ook duidelijk blijk van hun scepsis ten aanzien van resocialisatie van gedetineerden.

't Hart (NRC-Handelsblad, 6-11-93) constateert in deze periode dat het stereotype van de onverbeterlijke gedetineerde als strafrechtelijk relevant stereotype steeds meer populariteit geniet onder justitiële beleidsfunctionarissen.

Dit stereotype bezit volgens 't Hart totalitaire trekken:

"het claimt de hele werkelijkheid van de gedetineerden weer te geven: die gedetineerden vormen een categorie die IS zoals de beleidsfunctionaris zegt dat zij IS: zij zijn -allemaal- niet te resocialiseren."

En de forensisch psychiater de Smit schetst in zijn afscheidsrede een buitengewoon somber beeld van het resocialisatie-streven in de gevangenis. Hij meent dat in gevangenissen

" een uitzichtloze, normloze gemeenschap is ontstaan waarin elk perspectief dat een aanzet zou kunnen inhouden tot een resocialisatie-proces ontbreekt. Omdat de reclasseringsgedachte ideologisch teloor is gegaan, is de gevangenis gereduceerd tot een opbergplaats die er op gericht is de gedetineerde als object slechts te bewaken. Hierdoor dreigt een uitzichtloze situatie"

(bron: NRC-Handelsblad, 5-11-93).

Ook bij het publiek lijkt het geloof in de resocialisatie-doelstelling in de afgelopen decennia te zijn verminderd. De Konink en Schepers (1998) concluderen op grond van gegevens van opinie-onderzoek dat de weerstand van het publiek tegen een resocialiserende behandeling van delinquenten lijkt te zijn toegenomen. Die toename lijkt, aldus de onderzoekers, vooral samen te hangen met ontwikkelingen in de criminaliteit en niet zozeer met veranderde ideologische opvattingen. Fiselier (1998, (2)) constateert dat die weerstand tegen resocialisatie in de jaren negentig in ieder geval aanzienlijk hoger ligt dan in de jaren zeventig.

Uit een onderzoek van Berghuis en Essers (1986) komt naar voren dat in de jaren tachtig $70 \%$ van de bevolking voorstander is van een gematigd punitief beleid. Het publiek kan het gebruik van (strengere) straffen goedkeuren, maar tegelijkertijd acht men, zij het in iets minder sterke mate, het aanbieden van verschillende vormen van hulp en steun aan daders 
eveneens een geschikt middel in de strijd tegen de misdaad.

Fiselier, (1998, (2)) stelt dat recente opinie-peilingen geen reden geven voor de veronderstelling dat het oordecl van de bevolking over misdaad en straf zich de laatste jaren nog verder heeft verhard. Er lijkt sprake van een zekere stabilisatie. Over de resultaten van recent opinie-onderzoek merkt Fiselier op: "Ik meen dat men eruit kan afleiden dat de bevolking in meerderheid het meer punitieve strafrechtelijke klimat steunt, maar tegelijkertijd niet anadringt op een verdere verharding"(ibid., p.51).

Rood-Pijpers (1989) meent dat de waarde van conclusies van het gangbare publicke opinieonderzoek nogal beperkt is juist vanwege de sterk vereenvoudigde wijze waarop men doorgaans bij de bestudering complex verschijnsel als de publicke opinie te werk gaat. Het oordeel van de bevolking over misdaad en straf vertoont mogelijke nuances die onvoldoende aan het licht komen.

Zo baseren de Konink en Schepers (ibid.) hun conclusie op een analyse van gegevens van het Sociaal Cultureel Planbureau. Bij de ondervraging van de bevolking gebruikt het SCP ten aanzien van de resocialisatie-doelstelling een enkel item dat nogal ongelukkig is geformuleerd. Het item is geformuleerd als:

"men moet misdadigers niet in de eerste plaats straffen, maar men moet vooral proberen ze te veranderen." ( De Konink en Schepers, p.262)

Deze uitspraak dwingt de respondent tot een keuze tussen straffen of resocialiseren. Die twee alternatieven hoeven elkaar niet uit te sluiten. Bij voorkeur blijven zij in de strafrechtspleging juist met elkaar verbonden. De strekking van de Penitentiaire Beginselenwet (art.2 lid 2) is dan ook dat de tenuitvoerlegging van de vrijheidsbenemende sanctie recht doet aan zowel het punitieve, vergeldende element van het straffen als aan het rechtsbeschermende, humaan ethische aspect van maatschappelijk herstel. Deze nuance van het geldende penitentiaire recht komt in de bovengenoemde uitspraak onvoldoende tot uiting. Bovendien negeert de uitspraak het feit dat sinds de jaren tachtig van de twintigste eeuw het 'proberen te veranderen' van daders, in de zin van het opleggen en afdwingen van gedragsveranderingen, in het beleid van het gevangeniswezen geen rol van betekenis meer speelt. Men kan zich afvragen of met het voorleggen van een dergelijke. nogal gedateerde uitspraak over straffen en resocialiseren de mogelijke nuances in de publieke opinie voldoende tot hun recht komen.

Over deze mogelijke nuances in het denken van het publiek over de resocialisatie-doelstelling geeft met name de buitenlandse onderzoeksliteratuur interessante informatie.

Innes (1993) constateert in een overzicht van het opinieonderzoek in de Verenigde Staten dat het in de eerste plaats verschil maakt of men het publiek vragen voorlegt over 'criminelen'cq- 'misdadigers' of over gedetineerden. Het publiek is geneigd milder te denken over gedetineerden omdat zij, eenmaal opgesloten in een penitentiaire inrichting, geen directe bedreiging meer vormen voor zijn veiligheid. Het denken van het publiek over misdaad en misdaadbestrijding is, volgens Innes, vooral praktisch getint. Het belang van maatschappelijke veiligheid voert de boventoon. Maar, zo stelt Innes, er zijn in het onderzoek van de afgelopen decennia geen aanwijzingen te vinden voor de veronderstelling dat voorzieningen in gevangenissen op het gebied van educatie en hulpverlening zonder meer door het publiek worden verworpen. Die acht het publiek over het algemeen wel verenigbaar met het (strenger) straffen of het handhaven van maatschappelijke veiligheid. Indien men in de voorgelegde uitspraken termen vermijdt als resocialisatie, behandeling, criminelen en misdadigers en deze vervangt door de term 'gedetineerden' en door een verwijzing naar onderwijs- en hulpver-leningsprogramma's die op veilige afstand van de burger binnen de 
muren van een gevangenis worden aangeboden, dan blijkt het publiek in meerderheid een humaan, constructief regime dat gedetineerden bepaalde perspectieven biedt, te ondersteunen. Of het Nederlandse publiek er ook zo over denkt is onduidelijk. Onderzoek van bepaalde nuances in het denken van de bevolking over resocialisatie ontbreekt. Dergelijk onderzoek is echter van belang voor het beleid van het gevangeniswezen. Zoals in het vorige hoofdstuk bleek, bcsloten functionarissen van het gevangeniswezen in de jaren negentig tot een versobering van de voorzieningen gericht op resocialisatie onder meer om de herkenbaarheid van de tenuitvoerlegging van de gevangenisstraf voor het publiek en de politiek te vergroten. Bij de beleidsfunctionarissen van justitie bestond halverwege de jaren negentig de indruk dat het toenmaals geldende voor-zieningenaanbod geen ondersteuning meer ondervond in de Nederlandse samenleving. Het imago van de gevangenis als Hiltonhotel diende volgens de leiding van het departement te worden bijgesteld (Boin, 1998). Maar de vraag in welke mate dat negatieve Hilton-imago bepalend is voor de opvattingen van de Nederlandse bevolking is tot op heden niet op bevredigende wijze is beantwoord.

Niet alleen heeft men tot op heden weinig pogingen ondernomen om de meningen van het publiek over resocialisatie in meer uitgebreide zin te peilen.

Ook de houding van Nederlandse gedetineerden ten aanzien van de resocialisatiegedachte en meer in het algemeen hun visie op de detentie, is slechts in beperkte mate voorwerp van wetenschappelijk onderzoek geweest.

\subsection{Meningen van Nederlandse gedetineerden over de detentie}

De afgelopen twee eeuwen vertonen een ontwikkeling in de behandeling van gedetineerden die men, volgens Franke (1990), kan omschrijven als een emancipatie-proces. Een belangrijk aspect van dit proces is een groeiende belangstelling voor de situatie van gevangenen. Deze toegenomen aandacht bracht met zich mee dat de mening van gedetineerden over hun leven in gevangenschap publiekelijk bekend werd en gehoor vond. Aanvankelijk gebeurde dit slechts in zeer beperkte mate en zeker niet steeds in een wetenschappelijke vorm. Een van de eerste omvangrijke Nederlandse publicaties waarin gedetineerden hun mening geven over hun detentie is Rijksen's Meningen van Gedetineerden (1958), een boek dat, aldus Franke, een storm van verontwaardiging over het gevangenisleed teweegbracht (ibid., p.692). Franke constateert dat de meningen van gedetineerden sindsdien steeds belangrijker werden voor de evaluatic of voorbereiding van nieuwe hervormingen in het gevangeniswezen. De groeiende aandacht voor de visie van gedetineerden op de detentie leidde uiteindelijk ook tot een verbetering van hun situatie.

In evaluatie-studies die in de afgelopen drie decennia in Nederland zowel door universitaire als justitiële onderzoekers zijn verricht, werd gedetineerden dan ook regelmatig gevraagd hun mening te geven over een aantal aspecten van de detentie. Men dient hier echter een onderscheid te maken.

In de meeste studies is het doel niet zozeer de beleving van de verschillende aspecten van de detentie op zich. In een aantal studies met name die uit de jaren zeventig gaat het vooral om het vaststellen van veranderingen in houding en gedrag (recidive) als resultaat van bepaalde, op humanisering en resocialisatie gerichte bejegeningvormen. Wij kunnen hier denken aan studies van Fiselier (1969), Steenhuis (1972), Dijksterhuis (1973), Caminada (1973), Berghuis (1981) en Van der Linden (1981).

In deze studies onderzoekt men het effect van de strafmodus (open versus gesloten regime bij voorbeeld) of meer in het algemeen, het gedrags- of houdingsveranderend (recidive-ver- 
minderend) effect van verschillende regimes.

Studies met als voornaamste doel te peilen wat gedetineerden nu precies vinden van hun detentie en in het bijzonder van resocialisatie, zijn echter niet zo talrijk. Een belangrijke studie uit de jaren zeventig is die van Moerings (1978), waarin wordt onderzocht wat de detentie nu werkelijk betekent voor de gedetineerde en zijn sociale relaties. Een aantal studies uit de jaren tachtig betreft de beleving van de detentie van mannelijke gedetineerden in het Huis van Bewaring te Rotterdam (Grapendaal et al., 1985) en van vrouwelijke gedetineerden (Brouwers en Sampiemon 1988; Zwering, 1989).

In de jaren negentig kunnen we een aantal studies noemen van de Afdeling Beleidsinformatie van de DJI, waarin het detentieklimaat in met name een aantal nieuwe inrichtingen aan een onderzoek wordt onderworpen (zie onder meer Herbschleb en Zorge, 1992).

Verder dienen we hier nog te noemen een peiling in het kader van de nota Werkzame Detentie (p.51) onder executief personeel in een drietal inrichtingen. Het personeel werd in deze peiling gevraagd gedetineerden in te delen in categorieën met betrekking tot de mate waarin zij gemotiveerd zijn iets van hun detentie te maken.

Naspeuringen in de Nederlandse onderzoeksliteratuur naar studies waarin de houdingen van gedetineerden ten aanzien van resocialisatie het voornaamste doel van het onderzoek zijn, leverden buitengewoon weinig op.

We zullen het voor wat het Nederlandse onderzoek betreft voornamelijk moeten doen met studies waarin de beleving van de activiteiten als een aspect van de beleving van het regime in zijn totaliteit aan de orde komt. In de buitenlands literatuur treffen we echter wat meer onderzoek aan van de opvattingen en beleving van gedetineerden met betrekking tot het resocialisatie-streven.

\subsection{Het onderzoek van de opvattingen van gedetineerden over resocialisatie}

Begin jaren veertig van de twintigste eeuw ontstaat in de sociologie belangstelling voor de manier waarop gedetineerden zich aanpassen aan de pijnlijke onstandigheden van de gevangenis. Clemmer (1940) geldt als grondlegger van deze sociologische studies van de gevangenis. Hij beschreef voor het eerst het proces van 'prisonization' of wel de reacties die gedetineerden vertonen op een belastend en depriverend leven in gevangenschap. Een belangrijke reactie van gedetineerden op het verlies van hun autonomie en op de aantasting van hun persoonlijkheid door het gevangenissysteem is het vormen van een eigen tegen-of subcultuur. Het ontstaan van een dergelijke bewonerssubcultuur is ook later beschreven door onderzoekers als Sykes, (1958), Goffman (1961), Irwin en Cressey, (1962). Voor gedetineerden is een tegen-cultuur met eigen normen en sociale structuur een belangrijk middel om de deprivatie en vernederingen van het gevangenisleven te weerstaan. Kenmerkend voor de tegen-cultuur is een bepaalde mate van oppositie. Gedetineerden ontwikkelen immers als gevolg van het vernederende karakter van de detentie een gevoel van verbittering en haat. En de haat is, veelal in de vorm van een subcultuur met deviante normen en waarden, gericht tegen de officiële doelen van het gevangenissysteem. Het klassieke onderzoek van prisonisatie-processen laat zien dat de deviante subcultuur van gedetineerden inderdaad leidt tot bepaalde vormen van verzet tegen het gevangenissysteem. Het ligt voor de hand te veronderstellen dat het verzet van de gedetineerdensubcultuur zich ook richt tegen de pogingen van officiële zijde om gedetineerden te resocialiseren. Gedetineerden zullen wellicht tevens negatieve opvat-tingen hebben over de resocialisatie-doelstelling als zodanig. 
De opvattingen van gedetineerden over resocialisatie zijn echter zelden in het kader van een oppositionele gedetineerdencultuur onderzocht. Men heeft het effect van een oppositionele gedetineerdencultuur voornamelijk onderzocht in de zin van regel- of normschendend gedrag. Terwijl het onderzoek van prisonisatie-processen juist werd geïnitieerd met het oog op het vaststellen van de negatieve effecten van de gedetineerdencultuur op pogingen gedetineerden te resocialiseren. Zingraff (1975, p.367) merkt hierover op:

"Researchers have simply abandoned this pursuit, and what was originally a means to an end became an end in and of itself."

Voor zover de houdingen van gedetineerden ten aanzien van resocialisatie in de onderzoeksliteratuur in verband worden gebracht met een oppositionele gedetineerdencultuur is er veelal sprake van een veronderstelling op basis van extrapolatie of van impressies.

Cloward (1969) gaat er overigens van uit dat een deviante gedetineerdencultuur en hoge recidive-cijfers niet het gevolg zijn van het verwerpen van sociaal wenselijke doelen door gedetineerden. Integendeel, hij stelt:

" (...) the reverse is generally true, most prisoners seek passage from their degraded status to a socially accepted one." (p.89).

Evenals Cloward meent Irwin (1980) dat een substantieel deel van de gedetineerdenpopulatie positief staat tegenover resocialisatie.

Irwin noemt in zijn typologie van gedetineerden de 'gleaners'. Het werkwoord 'to glean' betekent letterlijk: oogsten, rapen en verwijst naar gedetineerden die hun detentie vooral beschouwen als een gelegenheid om aan hun zelfherstel te werken. Naast deze categorie is er een groep gedetineerden die de detentie beschouwt als een kwestie van 'doing time' of 'jailing', hetgeen zoveel betekent als het streven de gevangenisstraf zo rustig en gemakkelijk mogelijk uit te zitten.

Ook in de meer recente literatuur beperkt men zich voor wat betreft de houdingen van gedetineerden ten aanzien van de penitentiaire beleidsdoelstellingen nog steeds tot de veronderstelling dat deze als gevolg van een deviante subcultuur over het algemeen op verzet of onverschilligheid van de kant van gedetineerden stuiten (Patterson, 1988).

Hamm en Schrink (1989) veronderstellen dat de bereidheid van vooral recidivisten of 'career criminals' om aan hun toekomst te werken de afgelopen decennia geringer is geworden vanwege ontbrekende kansen en mogelijkheden voor zelfherstel in de post-detentiefase. Zij concluderen eigenlijk dat gedetineerden telkens weer 'blij worden gemaakt met een dode mus'. Gedetineerden krijgen tijdens de detentie resocialisatie-programma's aangeboden, verlaten dan vol goede hoop op een betere toekomst de gevangenis, maar lopen vervolgens, vanwege onvoldoende begeleiding buiten de muren, telkens weer tegen dezelfde problemen aan. Bij terugkeer in de gevangenis valt een resocialisatie-programma aan deze groep gedetineerden steeds moeilijker te verkopen.

Empirisch onderzoek waarin gedetineerden naar hun opvattingen over resocialisatie wordt gevraagd is uiterst schaars. Een gang door de onderzoeksliteratuur leverde slechts een drietal studies op waarin deze opvattingen werden onderzocht, zij het, als een aspect van een breder onderzoek over resp. het prisonisatie-proces, coping -gedrag van gedetineerden en detentiebeleving ( Zingraff, 1975; Zamble en Porporino, 1988; Kolstad, 1996).

Zingraff onderzocht de invloed van een oppositionele gedetineerdencultuur op de houdingen ten aanzien van resocialisatie in meer indirecte en algemene zin. Hij concludeert dat het 
verzet van gedetineerden tegen het instituut gevangenis en tegen de wet ('the legal system') erop wijst dat gedetineerden zich in feite de positieve, sociaal wenselijke normen en waarden van de resocialisatie-doelstelling niet hebben eigen gemaakt. Zingraff vroeg gedetineerden echter niet in rechtstreeks zin naar hun opvattingen over de resocialisatie-doelstelling.

Uit de studie van Kolstad onder Noorse gedetineerden komt nat voren dat de meerderheid van de gedetineerden de opgelegde vrijheidsstraf als verdiend beschouwt, echter, de meesten maken bezwaar tegen de lengte. De meeste gedetineerden zien de gevangenis als een ongeschikte omgeving om hun terugkeer in de samenleving op een adequate wijze voor te bereiden. Men onderschrijft in meerderheid het beeld van de gevangenis als criminele leerschool, die een averechts effect heeft op het resocialisatie-streven. Slechts een vijfde van de gedetineerden meent dat de detentie althans voor het eigen criminele gedrag een duidelijke atschrikkende werking heeft. Een belangrijk deel van de gedetineerden (44\%) zegt door de detentie een meer vijandige en kritische houding tegenover de samenleving en het strafrechtelijk systeem te hebben gekregen.

Tegenover de resocialisatie-doelstelling op zich staat men positief. Het hebben van werk, het volgen van onderwijs en het opbouwen van meer bevredigende, positieve sociale relaties ziet men voor zichzelf als de belangrijkste voorwaarden voor zelfherstel. Bijna de helft van de ondervraagden vindt dat de maatschappij hun kansen en mogelijkheden zou moeten bieden om voortaan een leven zonder criminaliteit te leiden.

Het onderzoek van Zamble en Porporino over coping-vaardigheden van Canadese gedetineerden laat zien dat zij met name aan de beginfase van de detentie positief staan tegenover de resocialisatie-doelstelling. Een substantieel gedeelte van de gedetineerden is sterk gemotiveerd on het zelfherstel in de vorm van deelname aan resocialisatie-programma's aan te pakken.

Zamble en Porporino toetsten de motivatie van gedetineerden nog eens aan de hand van de begrippen van Irwin (1980). Het blijkt dat $51 \%$ van de gedetineerden zichzelf categoriseerde als 'gleaner', dat wil zeggen als iemand die in positieve zin de detentie wil benutten om zijn levenssituatie te verbeteren. De overige gedetineerden rekenen zichzelf voornamelijk tot de categorie die de detentieperiode zonder al te veel moeilijkheden en zonder al te veel inspanningen probeert door te komen.

Zamble een Porporino komen tot de conclusie dat hun onderzoekspopulatie grofweg in drie groepen kan worden ingedeeld. Ongeveer 20 tot $25 \%$ kan worden gerekend tot de categorie 'doing time', een groep kortom die de detentie accepteert en weinig negatieve gevoelens heeft over het gevangenissysteem. Tussen de 10 en $15 \%$ behoort tot een categorie die uitgesproken positief is over de detentie en zelfs dankbaar is voor het feit dat hun problematisch, crimineel gedrag uiteindelijk heeft geleid tot een interventie in de vorm van detentie. $\mathrm{Zij}$ beschouwen de detentie als een goede gelegenheid om hun leven drastisch te gaan veranderen. De grootste groep, een middencategorie van rond de $60 \%$ is weliswaar kritisch en negatief ten opzichte van het gevangenissysteem, maar is tegelijkertijd optimistisch over hun kansen op een beter toekomstig leven zonder criminaliteit.

De onderzoekers noemen het opvallend dat veel gedetineerden beweren niet te zijn zoals 'de rest' van de gedetineerden. Zij onderschrijven het, in de publieke opinie populaire beeld van gedetineerden als tamelijk onverbeterlijk, echter zij vinden dat zij zelf niet in dit beeld passen. Zij zien hun delict toch vooral als een incidentele misstap (terwijl hun dossier veelal een indrukwekkend crimineel verleden te zien geeft) en hebben goede hoop dat zij in hun gedrag verandering kunnen brengen.

Verder blijkt dat een meerderheid plannen makkt met betrekking tot de detentietijd en de 
periode erna, echter die plannen bleken in veel gevallen nogal onrealistisch en vaag.

Driekwart van de gedetineerden heeft een doel voor zichzelf gesteld op het gebied van educatie en $13 \%$ stelt zichzelf tot doel zijn gedrag te veranderen. Tevens blijkt bij vier van de tien gedetineerden op cognitief niveau sprake van reflectie op het delict, de detentie en de levenssituatic. Een meerderheid echter probeert zo weinig mogelijk over de dingen na te denken en laat de gedachtenstroom de vrije loop.

In het volgende hoofdstuk wordt bij de bespreking van het onderzoek naar het proces van aanpassing aan de detentic nader ingegaan op de bevinding van Zamble en Porporino dat de motivatic voor gedragsverandering het sterkst is aan het begin van de detentie.

Opmerkelijk is dat de hiervoor besproken studies van buitenlandse origine zijn. Studies van de opvattingen over de resocialisatie-doelstelling van Nederlandse gedetineerden blijken niet voor handen tc zijn.

Er is weliswaar een onderzoek van de afdeling Beleidsinformatie van het gevangeniswezen naar de houding van gedetineerden ten aanzien van het resocialisatie-streven, maar hierin werden gedetineerden niet ondervraagd.

Het gaat hier om een peiling in het kader van de nota Werkzame Detentie (p.53) onder medewerkers van het Bureau Sociale Dienstverlening, penitentiair inrichtingwerkers en penitentiair consulenten in een drietal penitentiaire inrichtingen. Deze medewerkers werd gevraagd een schatting te maken van het percentage gedetineerden dat is gemotiveerd om iets van hun detentie te maken. Tweederde blijkt volgens de schattingen niet of in geringe mate gemotiveerd en nog geen derde $(27 \%)$ is redelijk sterk gemotiveerd. Een zeer kleine minderheid van $10 \%$ kan op basis van deze schattingen als zeer sterk gemotiveerd worden beschouwd. Aangezien het bij deze gegevens van het Gevangeniswezen niet om een rechtstreekse peiling onder gedetineerden gaat is er alle reden om de houdingen van gedetineerden aan een nader onderzoek te onderwerpen.

Uit het voorgaande overzicht van de literatuur blijkt dat de opvattingen van gedetineerden over de resocialisatie-doelstelling nauwelijks in empirische zin zijn onderzocht. In de literatuur treft men veelal extrapolaties aan op basis van onderzoek naar de aanpassing van gedetineerden aan de depriverende detentie-omstandigheden. Daarbij wijzen sommige onderzoekers op een verzet van gedetineerden tegen de officiële resocialisatie-doelstelling. Dit verzet brengen $\mathrm{zij}$ in verband met de aanwezigheid van een deviante gedetineerdensubcultuur. Andere onderzoekers veronderstellen dat de opvattingen van gedetineerden over resocialisatie een positiever of gevarieerder karakter vertonen.

Het schaarse empirische onderzoek toont dat een meerderheid van de gedetineerden, met name in de beginfase van de detentie, een positieve houding heeft ten aanzien van de resocialisatie-doelstelling als zodanig. Voor wat betreft de opvattingen over resocialisatie in de zin van de mogelijkheden die men voor zichzelf ziet om tijdens de detentie iets aan zelfverbetering te doen, is het onderzoek niet eenduidig. Het onderzoek van Kolstad laat nogal negatieve opvattingen van gedetineerden zien ten aanzien van de gevangenis als resocialiserend instituut. Bij Zamble en Porporino vinden we een meerderheid die weliswaar ook negatief en kritisch denkt over het gevangenissysteem, maar hieraan geen negatieve consequenties verbindt voor pogingen tot zelfverbetering. Afgaande op de plannen die men maakt, beschouwt een meerder-heid van de gedetineerden het streven naar zelfverbetering blijkbaar niet geheel onmogelijk of zinloos. Een kleine minderheid, zo blijkt uit de studie van Zamble en Porporino is zeer positief gestemd over de gevangenis en ziet de detentie als een goede gelegenheid om zijn leven te veranderen.

Empirisch onderzoek naar de opvattingen van Nederlandse gedetineerden over de 
resocialisatie-doelstelling is niet voor handen. Er is alleen empirisch materiaal uit de jaren negentig van de Dienst Justitiële Inrichtingen waarin het personeel aangeeft dat een meerderheid van de gedetineerden niet of nauwelijks gemotiveerd is voor een serieus streven naar resocialisatie.

\subsection{Gedetineerden en hun beleving van de activiteiten: een overzicht van het onderzoek}

Activiteiten in het kader van de resocialisatie van gedetineerden zijn in de afgelopen decennia regelmatig voorwerp van evaluaties geweest. Zoals wij in het eerste hoofdstuk reeds opmerkten, gebeurde dit zowel in Nederland als daarbuiten voornamelijk vanuit het perspectief van een product-evaluatieve benadering. Het uiteindelijk doel is vast te stellen of de deelname van gedetineerden aan bepaalde therapeutische en educatieve programma's al dan niet binnen het kader van een bepaald regime een indirect effect oplevert in de zin van recidive-vermindering.

Voor wat betreft de verschillende vormen van educatie en hulpverlening en hun effect op recidive-cijfers zijn de resultaten heel wisselend. Uit sommige studies blijkt een significant effect in de vorm van verminderde recidive, in andere studies daarentegen worden geen belangrijke verschillen gevonden (Ryan, 1991).

Uit effectiviteitonderzoek blijkt dat een weinig doelgericht en niet-directief aanbod dat beperkt blijft tot louter educatie of hulpverlening bepaald geen garantie biedt voor recidivevermindering (Andrews et al., (1),1990). Een bredere aanpak waarin scholing of vorming wordt gecombineerd met andere interventie-vormen zoals bij voorbeeld training in cognitieve en sociale vaardigheden is overwegend effectiever (Palmer, 1991;1994). Een studie van Adams et.al (1994) laat zien dat penitentiair onderwijs aan de allerlaagst opgeleide gedetineerden in termen van recidive-vermindering het meest effectief is. Het optreden van een substantiële recidive-vermindering is echter afhankelijk van de duur van het onderwijsaanbod. Minimale onderwijsvoorzieningen sorteren geen effect. De omstandigheden waaronder en intensiteit waarmee interventies in de vorm van scholing worden uitgevoerd, zijn eveneens van belang.

Onderzoek waarbij de activiteiten ten behoeve van resocialisatie vanuit het feitelijk functioneren en de beleving van de participanten op een meer systematische en diepgaande wijze worden onderzocht, is vrij schaars.

Studies vanuit een dergelijke proces-evaluatieve benadering waarin de verschillende belevings-aspecten van de activiteiten in meer uitgebreide zin naar hun aard en oorsprong worden onderzocht zijn voornamelijk van buitenlandse herkomst.

Binnen dit type onderzoek kan men de belevingsaspecten grofweg verdelen in aspecten die samenhangen met een als depriverend ervaren detentie-omgeving en aspecten die daarvan min of meer los lijken te staan en die betrekking hebben op de persoonlijke ontwikkeling en toekomstige levenssituatie.

\subsubsection{De beleving van de activiteiten in de context van de detentiesituatie}

In de literatuur wordt niet alleen bij de opvattingen van gedetineerden ten aanzien van resocialisatie een belangrijke rol toegekend aan de depriverende omstandigheden van een detentie. Ook in het onderzoek van de beleving van resocialiserende voorzieningen spelen ver-onderstellingen over de invloed van de depriverende detentie-omstandigheden een belangrijke rol.

Onderzoekers veronderstellen dat als gevolg van de (relatieve) deprivatie waarmee voor veel 
gedetineerden de detentic gepaard gaat, de activiteiten hun oorspronkelijk bedoelde bijdrage aan de voorbereiding van de terugkeer in de samenleving verliezen. De beleving van de activiteiten staat als gevolg van de depriverende omstandigheden van de detentie sterk in het het teken van de poging van gedetineerden te overleven in een lege, uitzichtloze situatie en niet zozeer door een daadwerkelijke voorbereiding van de terugkeer in de samenleving.

In de Nederlandse onderzoeksliteratuur treffen we deze veronderstelling bij een aantal auteurs aan.

Moerings (1984) constateert in 1984 dat de nota Taak en Toekomst weliswaar een grote realiteitszin vertoont ten aanzien van de haalbaarheid van de resocialisatie-doelstelling, maar tegelijkertijd constateert hij 'dure' termen die veel suggereren, de beloftes echter niet waarmaken en in feite de onmacht van het gevangeniswezen moeten verbloemen. Voorts stelt hij dat de resocialisatie-pretentie dan wel wat is afgezwakt, feit blijft dat ook humanisering alsmede de beperking van de detentieschade haaks staan op beveiliging en vrijheidsberoving. Dit dilemma wordt door wijziging van terminologie en aanpassingen binnen de organisatie niet opgelost: het wezenlijke karakter daarvan blijft onveranderd. Moerings verwacht dan ook niet dat de terugkeer in de samenleving een gunstiger verloop zal hebben voor degenen die de 'heilzame' werking van de GIS- en RAP-nota hebben mogen ondervinden.

Verder merkt hij op dat activiteiten die officieel vanuit hogere waarden (resocialisatie) worden verdedigd, in feite fungeren als een belangrijk mechanisme om gedetineerden koest te houden. Voorts meent Moerings dat, bijvoorbeeld bij de geestelijke verzorging, de motivatie van gedetineerden voor deelname voornamelijk wordt ingegeven door praktische overwegingen (niet op cel hoeven zitten, gezelligheid) en niet door een oriëntatic op hogere waarden.

In een andere, meer recente publicatie stelt Moerings (1992) dat totale instituties, waaronder de gevangenis, vaak de pretentie hebben de bewoners te rehabiliteren en voor te bereiden op de terugkeer in de samenleving. De afhankelijk makende en mortificerende processen, inherent aan een totale institutie, belemmeren de verwezenlijking van de officiële doelstellingen. Moerings spreekt van een tegenstrijdige realiteit waarin humane maatstaven zoals resocialisatie niet tot hun recht komen als gevolg een grote nadruk op institutionele efficiency en op de handhaving van orde en rust.

Melk (1985 en 1993) constateert eveneens een dominantie van het orde en rust-principe. Zijn belangrijkste stelling is dat het orde- en rustprincipe in plaats van een middel tot iets, in feite is geworden tot het algehele doel van de inrichting. Van hoog tot laag is het personeel voornamelijk bezig met de detentiesituatie en het lenigen van nood en verminderen van spanning die het gevolg zijn van deze situatie. Groei en ontwikkeling in de levenssituatie, dat wil zeggen, het leren van gemaakte fouten, het opheffen van beperkingen en het tegengaan van over-accentueringen, nemen een ondergeschikte plaats in. Deelname aan activiteiten en de beleving daarvan staan niet of te weinig in het teken van persoonlijke groei, maar dragen noodzakelijkerwijs het karakter van wat Melk aanduidt als 'het vergeten in bezig zijn' en het verlichten van spanningen. Hun voornaamste functie is gedetineerden rustig te houden. Melk constateert dat er binnen de gevangenisstructuur een soort geloof is gegroeid in de onverbeterlijkheid van gedetineerden en in de onmacht van het gevangeniswezen.

Kelk (1993, (1), p.56) meent het volgende:

“ de samenleving binnen een inrichting wordt traditioneel primair bepaald door het postulaat van een geordende continuering van die inrichting (dat betekent: verstarring), het ideële doel (resocialisatie etc.) is er eigenlijk ondergeschikt." 
Neemt het verminderen van de spanningen als gevolg van de detentie en in het verlengde daarvan. het rustig houden van gedetineerden inderdaad zo'n prominente plats in binnen de gevangenisorganisatie, dan mag men verwachten dat de beleving van de activiteiten door gedetineerden vooral wordt gekleurd door hun behoefte de onangename aspecten en spamingen van het verblijf in een gevangenis te verminderen. Wat de Nederlandse wetenschappelijke bronnen betreft is van een toetsing in empirische zin geen sprake. De eerder genoemde auteurs baseren hun veronderstellingen voomamelijk op impressics.

Buitenlands onderzoek verschaft in dit opzicht meer empirische informatic.

In sommige Amerikaanse studies waarin de motieven van gedetineerden voor deelname aan de activiteiten in empirische zijn onderzocht, vat men moticven die gericht zijn op het verminderen van de ongemakken en spanningen van de detentie samen onder het begrip 'self -assertion' (Boshier, 1983) of 'avoidance posture' (Parsons en Langenbach, 1993; Winters, 1993). Het begrip duidt op motieven die specifiek zijn voor deelnemers aan educatieve en vor-mende activiteiten in een penitentiaire setting. In concreto kunnen deze motieven betrekking hebben op het zoeken van afwisseling, ontspanning en gezelschap en op het afreageren van spanningen, kortom op de 'kunst' van het uitzitten van een straf (in de Anglo-Amerikaanse literatuur kort en krachtig aangeduid als 'doing time').

Zo onderzocht Boshier (1983) motieven voor deelname aan educatic. Boshier operationaliseerde de motieven die gerelateerd zijn aan de detentie-situatic als het doorbreken van de dagelijkse routine van het gevangenisleven, frustraties van zich afzetten, een positicve sfeer opzoeken en mentaal gezond blijven.

Deelname van gedetineerden aan activiteiten voorzover men die tracht te begrijpen als een reactie op een, als depriverend ervaren gevangenisomgeving, kan men op basis van empirisch onderzoek van Toch (1977) onder de noemer brengen van een tweetal functies:

\section{Activiteit als reactie op een stimulus-arme omgeving.}

Verveling is een gevoel dat een ieder in mindere of meerdere mate bijna dagelijks ervaart. Verveling ontstaat vaak in situaties waarin men gedwongen passief en afwachtend moet blijven of waarin sprake is van voorspelbare routine. In gevangenissen is in een tamelijk permanente vorm sprake van een dergelijke situatie. Het leven in een gevangenis verloopt volgens een strikte, zich als maar herhalende dagindeling die resulteert in een nogal prikkclarme omgeving die gevoelens van verveling, overbodigheid en zinloosheid kan oproepen. Ook als fysieke omgeving levert de gevangenis voor de bewoners weinig stimuli op. Gedetineerden kijken jaar in jaar uit tegen dezelfde muur, de alledaagse visuele rijkdom van de wereld buiten de muren gaat tijdens de detentie aan hen voorbij. Voor gedetineerden kan een dergelijke omgeving belas-tend zijn en het bezig zijn met activiteiten kan in die situatic een belangrijk middel vormen om de spanningen die men als gevolg van de verveling ervaart te reduceren.

Activiteiten vervullen niet voor alle gedetineerden een even cruciale rol bij het uitzitten van hun detentietijd. Voor sommige gedetineerden is bezig zijn of bezig gehouden worden minder belangrijk. Gedetineerden voor wie activiteiten wel een belangrijke rol spelen bij de aanpassing aan de detentie, beoordelen hun gevangenisomgeving vooral op de geboden gelegenheid voor een actieve tijdsbesteding. Actief bezig zijn is voor hen de meest aangewezen manier om te overleven in een verarmde omgeving die bij deze groep in versterkte mate gevoelens van leegte, doelloosheid en verveling oproept. De stimulusarmoede van de omgeving wordt opgeheven door zelf actief, nieuwe en rijkere 
stimuli te creëren.

Volgens Toch bestrijden activiteiten niet alleen bepaalde vormen van externe stimulusdeprivatie. Er is ook sprake van een functic voor wat betreft de interne stimuli. Interne stimuli zijn onbewuste en onderdrukte gedachten en gevoelens die in een omgeving waarin weinig gebeurt en waarin alleiding ontbreekt plotseling het bewustzijn kunnen overweldigen. Door bezig te zijn met activiteiten kan men deze onbewuste gedachten afweren en de aandacht op de directe omgeving en gebeurtenissen richten.

\section{Activiteit als uitlacuklep}

Niet alleen het monotone karakter van het gevangenisleven kan een bron van spanningen zijn. Er zijn tijdens de detentie tal van spanningsbronnen. Te denken valt hier aan de beginperiode van de detentie. Men moet zich enerzijds aanpassen aan het leven in een gevangenis-gemeenschap, anderzijds heeft men te maken met de problemen die de detentie voor het thuisfront teweegbrengt, het verlies van werk en uitkering, de schuld- en schaamtegevoelens en de onzekerheid die inherent is aan de fase van de voorlopige hechtenis. Het verblijf in detentie gaat voor gedetineerden gepaard met spanningen die vanuit tal van bronnen afkomstig kunnen zijn. Zowel in fysiek en mentaal opzicht is het dan van belang dat in dergelijke situaties spanningen, frustraties en angsten een uitlaatklep kunnen vinden in activiteiten. Activiteiten hebben in dit opzicht een regulerende en stabiliserende werking. In een normale alledaagse situatie gebeurt dit op vrij natuurlijke wijze. De talrijke beslommeringen van gezin, werk en vrije tijdsbesteding maken dat de aandacht van een bepaald probleem word afgeleid en de bijbehorende spanningen minder worden. In de tamelijk kunstmatige omgeving van een gevangenis ontbreken dit soort natuurlijke, alledaagse vormen van afleiding. Regimes-activiteiten zorgen vervolgens voor een uitlaatklep. Hierbij malakt het eigenlijk niet uit om wat voor soort activiteiten het gaat, als zij maar voor ontlading, ontspanning en afleiding zorgen.

Zowel bij het verminderen van spanningen in het algemeen als bij het tegengaan van spanningen als gevolg van stimulus-deprivatie kan de deelname van gedetineerden aan activiteiten worden beschouwd als een vorm van hantering van stress. Daarmee vervullen de activiteiten in de eerste plaats een belangrijke functie voor de basale behoeften van gedetineerden.

In zoverre bevestigen de onderzoeksresultaten van Toch de veronderstellingen van Moerings, Melk en Kelk over de functie van de activiteiten voor gedetineerden. Het verlichten van spanningen blijkt inderdaad een belangrijk motief te zijn bij de deelname van gedetineerden aan activiteiten.

Echter het verlichten van spanningen van de detentie is, zo blijkt verder uit het onderzoek van Toch en een aantal recente studies, lang niet het enige motief voor gedetineerden om aan de verschillende regiemsactiviteiten deel te nemen. Behoeften die verder reiken dan het basale niveau van stresshantering blijken minstens zo belangrijk, zo niet belangrijker te zijn voor gedetineerden. Het gaat hier om aspecten met betrekking tot de deelname en beleving van gedetineerden die verband houden met de persoonlijke ontwikkeling en (toekomstige) levens-situatie.

\subsubsection{De beleving van de activiteiten in de context van de persoonlijke ontwikkeling en (toekomstige) levenssituatie}

Activiteiten kunnen niet alleen een belangrijke functie vervullen voor meer basale behoeften zoals het beter hanteren van stresssituaties maar ook voor behoeften van een hogere orde zoals de behoeften aan persoonlijke groei, zelfverwerkelijking en zelf-expressie. 
In deze zin kunnen activiteiten het zelfbeeld in positieve zin beïnvloeden, het leven van de gedetineerde voorzien van een doel en een proces van zelfontdekking en zelfverwezenlijking bevorderen.

Een en ander kan men onder de noemer brengen van de begrippen taakbetrokkenheid, egobetrokkenheid en zelfverwerkelijking (Toch,1977).

Activiteiten die gericht zijn op de persoonlijke ontwikkeling van gedetineerden, op groei kortom, vervullen binnen de overwegend negatieve context van de gevangenisomgeving de unieke functie van, wat Toch noemt, 'oases of psychological murturance' (ibid., p.25). Zij scheppen juist door hun gerichtheid op persoonlijke groei de voorwaarden voor positieve ervaringen tijdens de detentie. Zij voorkomen daarmee tevens dat de detentie louter wordt gedomineerd door negatieve ervaringen.

Toch maakt in dit verband gebruik van het begrip 'support' of ondersteuning. De gevangenisomgeving dient ook ondersteuning te bieden aan gedetineerden die blijk geven van een sterke behoefte aan persoonlijke groei en vooruitgang. Toch (ibid., p.70) beschouwt dit als een belangrijk doel van de detentie:

"Prisons are environments designed for those who pursue the wrong goals, or the right goals in the wrong way. Prisons are self-consciously intended (1) to remind inmates of the wages of sin by being uncomfortable (to serve as punishment and deterrence), (2) to help inmates to "shape up" by providing opportunities for self- examination (to rehabilitate), and (3) to increase an inmate's chances for negotiating future life opportunities by supplying him with marketable skills (reintegration)".

De detentieomgeving dient zodanig te zijn ingericht dat er een bepaalde mate van congruentie is tussen deze omgeving en de behoeften van gedetineerden aan persoonlijke groei. Toch noemt dit de "opportunity structure" die dient aan te sluiten op de capaciteiten en het niveau van de gedetineerden.

Niet alle gedetineerden grijpen de geboden mogelijkheden om te werken aan de persoonlijke ontwikkeling en (toekomstige) levenssituatie even gretig aan. Met name gedetineerden die 'vooruit willen' en die voor zichzelf een toekomstbeeld hebben waarin men de zaken toch anders en beter aanpakt dan in het verleden, maken gebruik van de geboden kansen. Hun houding is doelgericht. Men gebruikt de faciliteiten op het gebied van resocialisatie om de stap te maken van een 'verleden zonder doel' naar 'een toekomst met een doel'. Volgens Toch hoort bij deze houding ook een specifieke kijk op het eigen verleden. De fouten die men in het verleden heeft gemaakt, durft men te erkennen en onder ogen te zien. Tegelijkertijd interpreteert men de oorzaken voor het eigen falen in termen van gemiste, niet gekregen kansen op het gebied van scholing en algemene ontwikkeling en gemiste kansen in meer opvoedkundige zin.

Gedetineerden met een sterke behoefte aan groei en vooruitgang kunnen blijkens het onderzoek van Toch (1977) uiterst positief zijn over hun detentie als aan hun specifieke behoeften tegemoet wordt gekomen. Een passage uit de door Toch gehouden interviews is in dit verband illustratief:

"The highest on my mind is education, because, once you have that, everything else is going to come right on top of it. When I have an education, when I get to learn more about society and the way the world is made around me, l'll be able to see where I fit in my world and try to work out my problems that are going to come along... I got to get down on the books, you know, and find myself while I'm in here, you because, you know, in my mind, you know, I try not to look at it as just, you know, doing time..." (ibid., p. 72 en 73) 
Programma's gericht op persoonlijke ontwikkeling worden niet alleen bezocht door gedetineerden met een oprechte, intrinsieke motivatie. Er zijn ook gedetineerden die voornamelijk om pragmatische redenen deelnemen. Dit type deelnemer is niet echt geïnteresseerd, maar ziet van resocialiserende activiteiten vooral de voordelen op korte termijn. Men veinst als het ware een oprechte motivatie om zijn voordeel te doen op het gebied van verlof, vrijstelling van arbeid, en overplaatsing naar een milder regime (Toch, 1977, p.74).

Ongemotiveerde gedetineerden, kunnen tot grote ergernis van de gemotiveerde deelnemers de integriteit van het programma danig aantasten:

"It is a plus that they bring the college programs in here, and they give the inmates an opportunity to get in. But it's a negative to the extent that no one really is interested in education as a means of trying to rectify the past, trying to modify behavior patterns. It's just some program that you get into in order to try and get paroled..."(ibid., p.74)

\subsubsection{Beleving van ontwikkelingsactiviteiten: resultaten van recent onderzoek}

Toch's studie dateert van het einde van de jaren zeventig. In een aantal latere studies wordt het door Toch geschetste beeld van de betekenis van regimesactiviteiten voor gedetineerden in grote lijnen bevestigd. In deze studies onderzoekt men regimesactiviteiten, in het bijzonder op het gebied van het penitentiair onderwijs, vanuit de motieven en beleving van gedetineerden.

Gedetineerden die deelnemen aan het penitentiair onderwijs onderscheiden zich van studenten buiten de muren door hun leerstijl. Winters (1993) omschrijft deze leerstijl als weinig effectief ('maladaptive').

De visie van gedetineerden op educatie wordt ook in verband gebracht met de aanwezigheid van een externe 'locus of control' (Love,1991). Een externe locus of control duidt op de neiging van het individu on de mate van persoonlijk succes of falen op bepaalde terreinen (gezondheid, maatschappelijke status, materiele welvaart) voornamelijk te zien als een gevolg van andere, 'machtige' personen, instanties of krachten. Een interne locus of control duidt op de neiging om zichzelf vooral verantwoordelijk te stellen voor het persoonlijk slagen of falen.

Op basis van een sterke externe locus of control zou men, aldus Winters (1995), mogen verwachten dat gedetineerden hun crimineel gedrag vooral toeschrijven aan een gebrek aan kansen in het onderwijs. Die veronderstelling kon door Winters echter niet worden bevestigd. Het onderzoek is op dit punt overigens nog volop in ontwikkeling en zeker niet eenduidig. Onderzoek naar de samenhang tussen locus of control en de houding van gedetineerden ten aanzien van het onderwijs laat bij voorbeeld ook zien dat gedetineerden met een interne locus of control vaker aan het onderwijs deelnemen en over een groter probleem-oplossend vermogen beschikken (Pugh, 1993).

Gedetineerden in het penitentiair onderwijs onderscheiden zich van deelnemers aan het reguliere onderwijs door achterstanden in cognitief opzicht (Ross, Fabiano, Ewles, 1988). Deze achterstand komt bij voorbeeld tot uiting in een verminderd vermogen om de gevolgen van het eigen handelen met name voor anderen te overzien. Ten grondslag hieraan ligt onder meer een gebrekkig vermogen om te redeneren in termen van middelen en doelen.

Over de motieven van gedetineerden om deel te nemen aan het penitentiair onderwijs is weinig empirisch onderzoek voor handen. Uit een tweetal studies blijkt dat de motieven voor een deel parallelen vertonen met de motieven van de deelnemers aan de volwasseneneducatie buiten de muren (Boshier, 1983; Parsons en Langenbach, 1993; Winters, 1995). 
Evenals de deelnemers aan de volwassenen-educatic is een belangrijk motief voor deelname het streven om de eigen maatschappelijke positie en levensstijl te verbeteren. Men streeft naar persoonlijke groei en vooruitgang (goal orientation). Daarnaast speclt de behoefte om bezig te zijn (activity-oriented) en cognitieve belangstelling in de zin van het zoeken naar kennis, leren om het plezier van het leren zelf (learning oriented) een rol. Gedetineerden onderscheiden zich echter van de deelnemers aan de reguliere volwassenen-eduactie buiten de muren door motieven die te maken hebben met het verminderen van de ongemakken en de stress van de detentie-situatie.

Deze factoren met betrekking tot 'avoidance posture' blijken ook bij deelname aan penitentiaire educatie een rol te spelen. Het recente onderzock lat evenwel zien dat dit niet de belangrijkste factor is. Gedetineerden nemen vooral deel vanwege bepaalde (toekomstige) doelen die men voor ogen heeft zoals een betere maatschappelijke positie, betere kansen op werk en een andere, niet criminele levensstijl (Tootoonchi, 1993; Whittington, 1994; Winters, 1995). Regimesactiviteiten gericht op de persoonlijke ontwikkeling vertegenwoordigen in de beleving van gedetineerden vooral een positief element in een overwegend negatief ervaren detentie-situatie (Toch, 1977; Tootoonchi, 1993).

Gedetineerden geven in meerderheid aan dat zonder onderwijs de gevangenis niets positiefs aan hun leven zou toevoegen.

Gedetineerden denken bovendien door onderwijs meer grip te krijgen op de problemen waarmee men in de eigen levenssituatie te maken heeft. Door onderwijs te volgen achten gedetineerden bovendien de kans groter dat men later een criminele levensstijl zal kunnen afzweren (Tootoonchi, 1993).

Sommige gedetineerden plaatsen echter kanttekeningen bij dit laatste, zonder overigens de waarde van educatie voor gedetineerden verder in twijfel te trekken. Een gedetineerde uit de studie van Tootoonchi (p.39) merkt in dit verband op:

"Some people believe that education alone will reduce the rate of recidivism. I don't! Even though you are educated, society still will place roadblocks on your path because of your conviction record. However, getting an education in prison will allow you to confront these roadblocks more rationally and construct more feasible alternatives. Without education in prison. a released inmate would probably resort to destroying the roadblock and returning to his/her old methods of operating, and ultimately return to prison."

In een aantal van deze recente studies worden niet alleen de motieven voor deelname aan activiteiten onderzocht, men onderzoekt de beleving ook in de zin van een aantal directe effecten van de onderwijsactiviteiten. Onderwijsactiviteiten kunnen een positief effect hebben op het beeld dat men van zichzelf heeft en versterken het zelfvertrouwen van de deelnemers (Parker, 1990; Whittington, 1994; Ryan, 1991).

Self-efficacy of de overtuiging dat men bekwaam en in staat is bepaalde doelen te bereiken wordt niet beïnvloed door het volgen van onderwijs. De effecten van penitentiair onderwijs op de zelfwaardering en sociale vaardigheden zijn wel aanwijsbaar (Parker, 1990).

$\mathrm{Zij}$ waren zelfs sterker dan de effecten van achtergrondvariabelen als ras, leeftijd en verblijfsduur.

Uit verschillende studies blijkt een positief effect van met name alfabetisering op het zelfbeeld van gedetineerden (Ryan,1991). Vanuit een holistische benadering beschouwd, kunnen leren lezen, schrijven en rekenen de totale persoonlijkheid van de gedetineerden beïnvloeden. Ryan noemt in dit verband de koppeling van alfabetiseringsonderwijs aan een aantal andere doelen op het gebied van verantwoordelijkheidsgevoel, zelfstandigheid, 
zelfkennis, sociale en cognitieve vaardigheden en maatschappelijke waarden.

Onderwijsactiviteiten zijn van bijzondere betekenis voor langgestraften (Whittington, 1994). Een aantal aspecten van de detentic houden, blijkens hun reacties, de langgestraften bijzonder bezig: nl. het handhaven van de persoonlijke identiteit, individualiteit en de eigen wil of autonomie, het omgaan met de tijd die men nog moet uitzitten en de contacten met de buitenwereld. Onderwijsactiviteiten vormen voor deze groep een belangrijk middel om mentaal gezond en alert te blijven en om een positief zelfbecld te handhaven en te versterken. De langgestraften bleken zich vooral zorgen te maken om hun toekomst en een doel in het leven te missen. Onderwijsactiviteiten hadden ook in dit opzicht een belangrijke functie. Het verschafte gedetineerden de mogelijkheid zich op een constructieve manier met de toekomst bezig te houden.

Nederlands onderzoek waarin de beleving van vormende activiteiten werd onderzocht dateren uit de jaren tachtig. Een onderzoek van van der Linden (1981) laat zien dat gedetineerden het vormingsprogramma een aantrekkelijke invulling van hun detentie vinden met als uitschieters sport, creatieve activiteiten en buitenprojecten (70\%). De helft van de gedetineerden vindt het programma nuttig omdat men denkt er later nog iets aan te hebben.

De mate waarin gedetineerden aan het onderwijs deelnemen en de relatie met bepaalde achtergrondvariabelen is een facet van het onderzoek van het penitentiaire onderwijs dat niet onvermeld mag blijven. Voor wat betreft de situatie in het Nederlandse gevangeniswezen zijn er een aantal gegevens uit de jaren tachtig (Grapendaal et al., 1985) over gedetineerden in een Huis van Bewaring

Een derde van de gedetineerden nam aan een of andere vorm van onderwijs deel. Gedetineerden met een middelbaar opleidingsniveau (MBO, MAVO) zijn ondervertegenwoordigd en die met een laag en hoog opleidingsniveau zijn sterk oververtegenwoordigd. In de jaren negentig wordt, zo bleek in het vorige hoofdstuk, het deelname-percentage hoger geschat door de landelijk adviseur, namelijk op $40 \%$.

Ryan (1991) stelt op basis van een vergelijking van statistieken over verschillende landen dat drie kwart van de gedetineerden niet deelneemt aan onderwijsprogramma's.

Ondanks de toegankelijkheid van onderwijsfaciliteiten voor alle gedetineerden kan er dus sprake zijn van relatief beperkte deelname en een ondervertegenwoordiging van bepaalde groepen. De kenmerken van die ondervertegenwoordigde groepen beperken zich niet alleen tot het opleidingsniveau, er zijn ook verbanden gevonden met leeftijd, burgerlijke staat, strafduur en intensiteit van de contacten met familie. Oudere, ongehuwde en langgestrafte gedetineerden die relatief meer steun ontvingen van familie, vrienden en kennissen bleken in een studie van Glover en Lotze (1989) sterker vertegenwoordigd te zijn onder de onderwijsdeelnemers dan jongere, ongehuwde gedetineerden met weinig intensieve contacten met de buitenwereld. Dit type onderzoek levert, al naar gelang de verschillende locale en culturele omstandigheden, nogal wisselende resultaten op.

De beleving van andere activiteiten zoals kunstzinnige vorming, sportbeoefening, bibliotheekbezoek en arbeid is nauwelijks onderzocht. Over de beleving van kunstzinnige vorming bleek zowel in binnen-en buitenlands onderzoeksliteratuur vrijwel geen recent empirisch wetenschappelijk onderzoek aanwezig.

Er zijn slechts de eerder genoemde studies van Grapendaal et al. (1985) en die van van der Linden (1981). Uit de studie van Grapendaal et al. blijkt het volgende.

De sport is een activiteit waarvoor buiten de arbeid de meeste belangstelling bestaat, $45 \%$ neemt eraan deel en de waardering is hoog, $91 \%$ van de deelnemers verklaarde er met plezier aan deel te nemen.

Een belangrijk verband bleek met de variabele drug-gebruik. Sport, naast andere doe- 
activiteiten heeft voor druggebruikers in de ontwenningsfase een bijzondere betekenis.

Twee kunstzinnige activiteiten, muzische vorming en kunstzinnige vorming (Krea), werden respectievelijk door $10 \%$ en $18 \%$ van de respondenten bezocht en door het merendeel als nuttig beoordeeld.

De deelname-frequentie aan activiteiten werd ook gerelateerd aan bepaalde categoricën gedetineerden. Surinaamse gedetineerden participeerden relatief weinig frequent, drugsverslaafden daarentegen relatief vaak.

Het onderzoek van van der Linden meldt verder over het nut van de vormingsactiviteiten dat eenderde van de ex-gedetineerden meende na ontslag nog iets te hebben gehad aan de activiteiten, vooral creatieve vorming werd hierbij vaak genoend.

Als pleister op de wonde voor de betrekkelijke schaarste aan onderzoeksmateriaal over de beleving van de kunstzinnige vorming geef ik hier een illustratief commentaar over creatieve activiteiten van een gedetineerde:

"By creative grappling with the experience of prison you can maintain a strong sense of self. We are outcasts but art enables people to look at you as a human being. Outside they saly we are having fun in prison. But this is the only thing that has a significant rehabilitational effect. 1 have become more the person I should have been." (Financial Times, 7-11-1993)

Gedetineerden zien de arbeid vooral als een manier om de tijd om te krijgen en niet als een activiteit die een meerwarde heeft voor de persoonlijke ontwikkeling en voor de voorbereiding van de terugkeer in de samenleving (van der Linden, 1981; Burns, 1998). Echter, zinvolle vormen van arbeid die aansluiten bij de interesses van gedetineerden kunnen, zo laten de interviews van Toch (1977) zien, wel degelijk een belangrijke functie hebben voor de behoefte van gedetineerden aan ontwikkeling en zelfverwerkelijking (zie hierover ook Burns, 1998, p.177). Gevangenisarbeid waarbij gedetineerden in vakinhoudelijke zin iets leren en die, in combinatie met een redelijke beloning, voldoende uitdaging biedt, kan in meer algemene zin dienstig zijn aan het leven na ontslag uit detentic. Burns (ibid., p.178) constateert dat in West-Europa in de meeste gevangenissen van een dergelijk streven nauwelijks sprake is:

"The inevitable differences between work and training inside and outside prisons may lead to the view that prison workshops and courses can, at best, form a broad -based preparation for life on release, but the organisation of work and training in many prison regimes fails even this test, both in an objective sense and-critically- in the opinion of prisoners."

Over de beleving van de hulpverleningsactiviteiten is in Nederland in de jaren tachtig in meer uitgebreide zin in wetenschappelijk onderzoek verricht. In een volgende, aparte paragraaf zullen de belangrijkste resultaten hiervan worden besproken.

\subsubsection{Beleving van hulpverleningsactiviteiten}

De behoefte van reclasseringscliënten aan hulp, begeleiding en ondersteuning door de maatschappelijke werker is tijdens de verschillende fasen van het justitiële proces waaronder de detentie-fase, relatief sterk (Spickenheuer, 1984). Gedetineerde cliënten ervaren de bezoek-frequentie van de maatschappelijke werker in meerderheid als voldoende en bijna driekwart ervaart de contacten als zinvol, voornamelijk vanwege de gelegenheid om eens tegen iemand aan te kunnen praten, ontvangen van emotionele steun en het bespreken van het toekomstige leven na ontslag (Spickenheuer, 1984; Rood -Pijpers en Combrink-Kuiters, 1991). De functie van 'praatpaal' van de reclasseringsmedewerker voor de cliënt in detentie is 
belangrijk (Brand-Koolen, 1985).

Cliënten die weinig heil zien in een contact met de reclassering voeren als belangrijkste reden hiervoor aan dat de maatschappelijk werker weinig alert regeert op bepaalde verzoeken of helemaal niets doet voor de cliënt. Men vindt dat daadwerkelijke hulpverlening ontbreekt. Over de hulp bij de voorbereiding op de vrijlating zijn gedetineerden over het algemeen ontevreden (Rood-Pijpers en Combrink-Kuiters, 1991).

Cliënten hebben geen extreem hoge verwachtingen ten aanzien van reclasseringshulp. Als cliënten bepaalde problemen ervaren, heeft nooit meer dan de helft van hen de verwachting dat de reclassering iets zou kunnen bijdragen aan de oplossing. Cliënten gaan er veelal vanuit dat de reclassering voor bepaalde problemen niet de aangewezen instantie is of dat de reclasseringshulp toch te beperkt is om daadwerkelijk iets tot stand te brengen.

Er blijken opmerkelijke verschillen te zijn tussen cliënt en hulpverlener als het gaat om het aangeven van de oorzaken van een probleem. Cliënten zijn weinig geneigd zichzelf daarbij te betrekken, de vinger is gericht op anderen of op bepaalde omstandigheden terwijl de maatschappelijk werker eerder geneigd is, zonder aan de argumenten van de cliënt voorbij te gaan, de oorzaak van de problemen bij het (dis)functioneren van de cliënt zelf te leggen (Spickenheuer, 1984).

Bovendien lijkt er in de jaren tachtig nog steeds een kloof te bestaan tussen de reclasseringswerkers en cliënten als het om de perceptie van de problematiek gaat (Brand-Koolen,1985). Cliënten zouden meer zijn geïnteresseerd in praktische, materiële hulpverlening en reclasseringsambtenaren in psychosociale hulpverlening. Spickenheuer stelt echter dat zowel cliënten als hulpverleners materiële problemen benadrukken, maar dat partijen die problemen verschillend benoemen. Voor de cliënt is een materieel probleem een concrete zaak die meestal door andere problemen veroorzaakt is en waarvoor men een concrete oplossing wil. Voor de reclasseringsambtenaar is een materieel probleem vaak een symptoom van persoonlijk disfunctioneren. Dit materiële probleem moet volgens de reclasseringsmedewerkers wel worden opgelost, maar dat dient te gebeuren door tevens aan de cliënt zelf te werken.

\subsection{Samenvatting en conclusies}

In dit hoofdstuk werden de houdingen van gedetineerden ten aanzien van resocialisatie beschreven vanuit verschillende, voornamelijk wetenschappelijke bronnen. Om te beginnen werd een beeld gegeven van het huidige denkklimaat met betrekking tot de zorg op het gebied van resocialisatie. Geconstateerd werd dat de opvattingen van het Nederlandse publiek over misdaadbestrijding in de jaren tachtig van gematigd punitieve aard lijken te zijn. Naar de mening van de meeste Nederlanders mag er best strenger worden gestraft, maar dit betekent niet dat men het bieden van hulp en steun aan gedetineerden volledig verwerpt. Gedetineerden de mogelijkheid bieden om hun leven te beteren wordt door het publiek tevens als een geschikt instrument in de strijd tegen de misdaad beschouwd. Echter op grond van recent onderzoek (de Konink en Schepers, 1998) bestaat het vermoeden dat in de jaren negentig de steun onder het publiek voor resocialisatie als middel in de strijd tegen de misdaad is verminderd. Gewezen werd op de beperkingen van het publieke opinieonderzoek. Het belangrijke onderscheid met betrekking tot de resocialisatie-doelstelling in intrinsieke en instrumentele zin wordt veelal niet gemaakt. In het penitentiaire beleid van de jaren negentig is de resocialisatie-doelstelling naar de achtergrond verdrongen, hetgeen ook duidelijk wordt uit de manier van denken van (sommige) beleidsfunctionarissen. Hun 
percepties van de ontvankelijkheid van gedetineerden voor de resocialisatie-gedachte en van het imago van de gevangenis bij het publiek zijn veelal gebaseerd op impressies en zelden op empirisch wetenschappelijk onderzoek.

Een tamelijk smalle empirische en theoretische basis bleck ook kenmerkend voor veel binnen- en buitenlandse bronnen van wetenschappelijk onderzoek waarin aandacht wordt besteed aan de houdingen van gedetineerden ten aanzien van resocialisatic. In dit wetenschappelijk onderzoek wordt een overwegend negatief beeld van de houdingen van gedetineerden ten aanzien van resocialisatic gegeven. Men gatat hierbij steeds uit van de pijnlijke en vernederende ervaring van gevangenschap (de 'pains of imprisonment') die vervolgens leidt tot het ontstaan van een negatieve, oppositionele gedetineerdencultuur. De negatieve gedetineerdencultuur leidt tot verzet tegen conventionele normen en walarden en, naar men veronderstelt ook, tot een zich afzetten tegen de resocialisatie-doelstelling. Voorts veronderstellen onderzoekers dat zowel de dominantie van het orde- en rustpatroon als de spanningen van de detentie ertoe leiden dat de activiteiten die oorspronkelijk zijn gericht op persoonlijke groei voornamelijk nog worden gebruikt om te overleven in een vernederende en depriverende detentic-situatie. Opvallend hierbij is dat de doelgroep zelf, de gedetineerden en hun opvattingen of hun ervaringen, in empirische zin de grote alwezige vormt. Onderzoek waarbij men gedetineerden in meer uitgebreide en systematische zin vraagt naar hun houdingen ten aanzien van het resocialisatie-streven is schaars.

Opmerkelijk is dat zodra de houdingen van gedetineerden ten aanzien van resocialisatie in wat meer dicpgaande en uitgebreide zin worden onderzocht, het gangbare beeld van overwegend negatieve houdingen wordt gerelativeerd. Op zijn minst een substanticel gedeelte van de gedetineerden blijkt positief te denken over pogingen tot zelfverbetering. Men gebruikt de activiteiten niet alleen maar op een opportunistische wijze om te overleven in een lege, uitzichtloze en vernederende detentiesituatie. Behoeften van cen hogere orde dic gericht zijn op persoonlijke groei en de toekomstige levenssituatie blijken even belangrijk, zo niet belangrijker te zijn dan het weerstaan van de lasten van de detentic.

Het blijkt in sommige studies dat de feitelijk aangetroffen situatic een veel complexer en meer gedifferentieerd beeld vertoont dan veelal wordt verondersteld.

De indruk die men na deze gang door de literatuur overhoudt, is die van cen betrekkelijk onontgonnen terrein. Zo is er nagenoeg geen systematisch onderzoek aanwezig van de wijze waarop gedetineerden het aanbod van een activiteit als kunstzinnige vorming beleven. Naar de beleving van de educatieve activiteiten en van de hulpverlening in een penitentiaire omgeving heeft men wat meer onderzoek verricht maar ook hier kan men hooguit spreken van een aanzet tot een meer systematische en empirische onderbouwing. Van pogingen om de persoonlijke ontwikkeling van gedetineerden in te passen in een theoretisch kader waarbij zowel de theorievorming met betrekking tot het aanpassingsproces aan de detentie als de theorievorming met betrekking tot bijvoorbeeld het leren van volwassenen wordt betrokken, is geen sprake.

Op basis van het literatuuronderzoek kan over de kenmerken van de houdingen ten aanzien van resocialisatie voorlopig het volgende worden geconcludeerd.

Een operationalisering van de houding ten aanzien van resocialisatie dient voor wat betreft de opvattingen ten aanzien van resocialisatie uit te gaan van:

- opvattingen ten aanzien van de resocialisatie-doelstelling als zodanig ;

- opvattingen ten aanzien van resocialisatie in de context van de detentiesituatie.

De resocialisatie-doelstelling als zodanig kan met behulp van de vergaarde kennis uit de 
voorgaande hoofdstukken worden geoperationaliseerd als een intrinsieke doelstelling of een beginsel, wartoe men los van de eventuele effecten, om humane redenen is gehouden. Verder kan men het resocialisatiedoel operationaliseren in instrumentele zin, dat wil zeggen als een doel met een nuttig effect. Dit effect kan op zijn beurt weer in enge zin (louter recidive-vermindering) of in ruime zin (andere doelen dan recidive-vermindering) worden geoperationaliseerd.

Voor wat betreft de beleving van de activiteiten dient men bij de conceptualisering rekening te houden met:

-aspecten van de beleving die gerelateerd zijn aan de detentiesituatie;

-belevingsaspecten die gerelateerd zijn aan de persoonlijke ontwikkeling en de (toekomstige) levenssituatie. 


\section{THEORETISCHE ACHTERGROND VAN HET ONDERZOEK}

"The clarification of the mission for the correctional system must begin with a valid and verifiable appreciation of how imprisonment impinges on human beings" (Zamble en Porporino, 1988, p.2)

\subsection{Inleiding}

In het vorige hoofdstuk werd de aard van de houdingen van gedetineerden ten aanzien van resocialisatie nader bepaald door middel van een verkenning van de literatuur. De aard van de houdingen werd onderzocht in het kader van een aantal vragen die in hoofdstuk 1 werden afgeleid uit de algemene probleemstelling.

Deze probleemstelling bevat niet alleen een beschrijvende component, maar tevens een verklarende component die ten aanzien van de houdingen van gedetineerden als volgt werd gepreciseerd:

"Welke persoons-en omgevingsgebonden factoren zijn, eventueel in onderlinge samenhang, van invloed op de houdingen van gedetineerden ten aanzien van resocialisatie?"

In dit hoofdstuk wordt uitgaande van deze verklarende probleemstelling gezocht naar bepaalde omgevingskenmerken of individuele, persoonsgebonden kenmerken die mogelijk van invloed zijn op de houding van gedetineerden ten opzichte van pogingen tot zelfherstel.

Ten behoeve van deze selectie van factoren die mogelijk van invloed zijn op de houding ten aanzien van resocialisatie, wordt een conceptueel model geconstrueerd. Kant en klare modellen waarin bepaalde relaties tussen houdingen en gedrag van gedetineerden en bepaalde achtergrondfactoren op een overzichtelijke wijze worden gepresenteerd, zijn in de literatuur niet aanwezig.

Dit hoofdstuk begint met een reeks paragrafen waarin de belangrijkste theoretische begrippen worden geïntroduceerd. Deze begrippen dienen vervolgens als de ruwe bouwstenen van een conceptueel model. Dit model fungeert als leidraad bij de selectie van de variabelen die in verband kunnen worden gebracht met de houdingen van gedetineerden ten aanzien van resocialisatie. Deze selectie van relevante variabelen wordt afgesloten met een variabelenschema en met een aantal onderzoeksvragen. 


\subsection{Naar een interactionistisch conceptueel model: uitgangspunten}

\subsubsection{Verklaringsmodellen}

Zoals wij reeds in het vorige hoofdstuk vaststelden, richtten onderzoekers in de vrocge sociologische en psychologische beschrijvingen van de gevangenis zich vooral op de schadelijke effecten van een langdurig verblijf van gedetineerden in een gevangenis (Clemmer, 1940; Goffman, 1961).

Het psychologisch onderzoek heeft zich de laatste decennia vooral gericht op het schadelijke effect van detentie op de persoonlijkheid in de zin van bij voorbeeld het functioneren in motorische, cognitieve en emotionele zin.

Het sociologisch onderzoek van de gevangenis als samenleving heeft zich vooral toegelegd op de gevolgen van de 'pains of imprisonment' voor het sociale gedrag van gedetineerden.

Zo beschreef Clemmer de groepsprocessen onder gedetineerden die ontstaan als gevolg van de depriverende detentie-omstandigheden. Als belangrijkste reactie beschreef Clemmer het ontstaan van een gedetineerden-subcultuur met cen eigensoortig geheel van normen, waarden en sociale structuur.

Een belangrijk kenmerk van deze subcultuur is het oppositionele karakter op grond waarvan gedetineerden zich afzetten tegen conventionele waarden zoals die worden uitgedragen door het gevangenispersoneel en de omringende samenleving. Clemmer valte dit assimilaticproces samen onder het begrip prisonisatie. Prisonisatie werd bovendien als een proces beschouwd dat haaks staat op pogingen om gedetineerden te resocialiseren (Wheeler, 1961). Zoals ik in het vorige hoofdstuk liet zien is dat een veronderstelling die in de decennia erna, in beschouwingen over houdingen van gedetineerden ten aanzien van resocialisatie, tamelijk dominant blijft.

In de afgelopen decennia hebben onderzoekers, uitgaande van Clemmers begrip prisonisatie, getracht een verklaring te vinden voor het ontstaan en voortbestaan van subculturen in penitentiaire inrichtingen.

In de literatuur treft men een drietal verklaringsmodellen aan: het deprivatie-model, het import-model en het integratie-model.

Het deprivatie-model legt bij de verklaring voor het assimilatie-proces van gedetineerden de nadruk op het depriverende karakter van de detentie. Ervaringen voorafgaand aan de detentie vormen de basis van het importmodel. Houding en gedrag van gedetineerden tijdens de detentie is volgens dit model steeds het product van persoonsgebonden factoren die zij, als het ware, van buitenaf in de inrichting meebrengen. Zowel het deprivatie- als importmodel ondervonden kritiek vanwege een eenzijdige benadering. Sinds het einde van de jaren zeventig en het begin van de jaren tachtig zijn onderzoekers het erover eens dat een verklaring voor de aanpassing van gedetineerden aan de detentie dient te worden gezocht in een model waarin elementen van het import-en deprivatiemodel worden geïntegreerd (Thomas, Peterson en Zingraff, 1978; Rook, 1983; Grapendaal, 1987).

Binnen een dergelijk integratie-model gebruikt men drie groepen variabelen namelijk achtergrondkenmerken van gedetineerden ook wel de pre-detentie factoren genoemd, de factoren die met de depriverende detentie-omgeving samenhangen en verwachtingen van gedetineerden met betrekking tot de periode na ontslag uit detentie (Thomas en Foster, 1972; Thomas en Petersen, 1977; Thomas, Petersen en Zingraff, 1978).

Waarom een meer integratieve verklaring van gedragingen en houdingen van gedetineerden tijdens detentie de voorkeur verdient is een vraag waarop het antwoord zich in cerste instantie reeds aandient door pure observatie in een gevangenis. 
Een ieder die wat langere tijd in een gevangenis verblijft, hetzij als werknemer of als bewoner weet dat gedetineerden, ondanks het uniforme restrictieve karakter van de gevangenisomgeving, toch heel verschillende reacties op die omgeving kunnen vertonen.

Sommige gedetinecrden reageren op hun detentic met apathie, vrijwillig isolement en weer anderen reageren met subversief gedrag of een constructieve, coöperatieve houding. De restrictieve omstandigheden van de detentie zijn blijkbaar nict zo dominant en determinerend dat zij uniforme effecten, bijvoorbeeld in de vorm van oppositionele houdingen, op het gedrag teweegbrengen. Evenmin zijn individuele kenmerken of disposities dermate dominant dat zij het gedrag van gedetineerden, ongeacht de kenmerken van de omgeving, bepalen. Klaarblijkelijk kunnen het gedrag of de houdingen van gedetineerden derhalve het meest adequaat verklaard worden vanuit een beschouwing van zowel de objectieve eigenschappen van de omgeving of de situatie, als de verschillende wijzen waarop gedetineerden op die situatic reageren.

Verklaring van gedrag of houdingen van gedetineerden vanuit dit interactionistische perspectief is lange tijd betrekkelijk onderbelicht gebleven in het onderzoek van het socialisatieproces in de gevangenis ( Zamble en Porporino, 1990; Wright, 1991)

\subsubsection{Het begrip interactie}

In de psychologische en sociologische theorievorming gebruikt men theoriëen waarbij het begrip interactie een centrale rol speclt. Het begrip interactie wordt in de context van deze theorievorming gebruikt om een verklaring te geven voor het handelen van de mens.

Voor het handelen van de mens bestaan verschillende verklaringsmodellen. Ten eerste kunnen verschillen in handelen worden herleid tot louter individuele kenmerken zoals eigenschappen, gewoonten, motieven en persoonlijkheid. In de tweede plaats kunnen oorzaken voor het handelen uitsluitend worden gezocht in de omgeving of situatie. Een derde mogelijkheid is dat het handelen zowel met individuele (persoonsgebonden) factoren als met omgevingsfactoren in verband wordt gebracht. Bij een dergelijke benadering van het menselijk handelen is sprake van complexe relaties tussen een reeks onafhankelijke variabelen en de te verklaren afhankelijke variabelen. Hierbij gaat het uiteindelijk om de vraag welke effecten zijn toe te schrijven aan de persoon, aan de situatie (of omgeving) of aan een interactic tussen persoon en situatie (of omgeving). Deze benadering die men aanduidt als de interactionistische benadering kan in een aantal punten worden samengevat.

-gedrag wordt bepaald door een continu proces van interactie tussen het individu en de situatie;

-het individu is een actieve, intentionele actor; -cognitieve factoren zijn belangrijk;

-de psychologische betekenis van de situatie of omgeving is een essentiële determinant van het gedrag.

Ook de interacties tussen het individu en de detentie-omgeving, in het bijzonder in de zin van zijn of haar aanpassing aan die ongeving kan men vervolgens vanuit dit interactionistische perspectief bestuderen.

\subsubsection{De aanpassing aan de detentie als interactie tussen individu en omgeving}

Over gevangenissen bestaan in de maatschappij verschillende beelden. Omschrijvingen van een zeer stereotiepe aard zijn bijvoorbeeld die van de gevangenis als luxe hotel, criminele leerschool, instellingen ter onderdrukking van minderbedeelden en broedplaatsen van geweld en verderf. 
Wetenschappelijk onderbouwde beschrijvingen leggen veelal de nadruk op de 'pains of imprisonment' of de depriverende omstandigheden van de detentic, zoals het verlies van vrijheid, autonomie, privacy, status en bepaalde materiele zaken.

Aan de gevangenisomgeving worden vaak eigenschappen toegeschreven waarvan men het plausibel acht dat zij schadelijk zijn voor het welzijn van gedetineerden. Malar, zoals Toch (1977, p.7) stelt, plausibiliteit is niet genoeg. Het blijft veelal onduidelijk of de eigenschappen die schadelijk worden geacht door de onderzoeker ook als zodanig door de meeste gedetineerden worden ervaren.

Om hierover opheldering te verkrijgen, verdient een fenomenologische benadering van de (gevangenis)omgeving de voorkeur. Binnen een dergelijke benaderingswijze word de sociale en fysieke omgeving vooral bekeken vanuit de percepties en wijzen van aanpassing van het individu aan de omgeving. Men kan hier ook spreken van interacties of transacties tussen het individu en de omgeving.

Een veronderstelling die hierbij veelal stilzwijgend een rol speelt, is dat de perceptie van de omgeving niet louter het product is van de objectieve eigenschappen van de omringende wereld. Er is sprake van een bepaalde transformatie van de objectieve omgeving in een psychologische omgeving door een waarnemend en interpreterend wezen.

Een belangrijk uitgangspunt is bovendien dat mensen de omgeving op verschillende wijzen interpreteren al naar gelang bepaalde behoeften of eisen die men ten aanzien van die omgeving stelt.

Aanpassing aan de omgeving verloopt doorgaans voorspoedig als de omgeving eigenschappen vertoont die congruent zijn met de persoonlijke behoeften ten aanzien van de omgeving.

Vanuit dit perspectief kan men ook naar de gevangenisomgeving kijken en onderzoeken welke aspecten of dimensies van de omgeving over het algemeen belangrijk worden gevonden door gedetineerden. Het aanpassingsproces van gedetineerden aan het leven in een gevangenis kan men vervolgens bestuderen vanuit deze interactie tussen het individu en bepaalde aspecten van de detentie-omgeving.

De aspecten of dimensies van de gevangenisomgeving die in dit verband relevant zijn en op empirische gronden zijn vastgesteld door Toch (1977), hebben betrekking op: activiteit, privacy, autonomie, veiligheid, structuur, ondersteuning bij pogingen tot zelfherstel en emotionele feedback

Gedetineerden kunnen verschillen vertonen in hun waardering van deze dimensies van de omgeving. Er kan bovendien sprake zijn van een incongruentie tussen enerzijds de omgeving en anderzijds de persoonlijke behoeften van de gedetineerden. Sterker nog, de gevangenisomgeving lijkt bij uitstek een omgeving te zijn waarin bepaalde behoeften van gedetineerden in het gedrang kunnen komen. Het verlies aan bewegingsvrijheid en privacy, het isolement van de naasten, het niet kunnen beschikken over bepaalde materiële goederen en degradatie van de maatschappelijke status, zijn kortom factoren die ertoe kunnen leiden dat het verblijf in een gevangenis voor de bewoners in meerdere of mindere mate gepaard gaat met spanningen of stress.

Stress is een verschijnsel waarmee mensen in het dagelijkse leven buiten de muren, evenzeer te maken krijgen. Meestal beschikt het individu in alledaagse situaties over allerlei strategieên om deze stress te reduceren (bijvoorbeeld emotionele ondersteuning door de naasten, ontspanning via allerlei activiteiten).

Dergelijke mogelijkheden van stress-reductie zijn onder de restrictieve omstandigheden van een detentie uiteraard in veel mindere mate aanwezig. 
Bovendien is het in gevangenissen welhalast een ongeschreven wet dat men als gedetineerde nooit te koop loopt met zijn kwetsbaarheid en opeengehoopte spanningen en vervolgens openlijk hulp en emotionele ondersteuning zoekt bij mede-gedetineerden of het personeel. Een gedetineerde die dat wel doet loopt het risico de rest van zijn detentie te worden aangezien voor een 'jankerd'. Men geeft als gedetineerde hooguit wat signalen af dat men 'moeilijk zit'.

Als gedetineerde zal men, ondanks deze moeilijke omstandigheden, toch een aantal jaren in een dergelijke omgeving moeten overleven. Volgens Toch (1977) komt dit overleven neer op het streven naar een congruentie tussen de omgeving en de persoonlijke behoeften. Dit streven kan men samenvatten als het zoeken naar cen niche. Het gaat hier bij om een exploratief proces waarbij gedetineerden een setting of ruimte trachten te scheppen waarin men de stress binnen acceptabele grenzen weet te houden en waarin uiteindelijk sprake is van een zekere aanpassing. Niches worden ook bewust ingebouwd in de organisatie van bepaalde instellingen waarin mensen voor een bepaalde tijd onder dwang verblijven. In gevangenissen hebben speciale afdelingen voor meer intensieve begeleiding of bescherming van kwetsbare gedetineerden, de functie van een niche. Maar ook op een meer informele manier vinden gedetineerden een bepaalde modus om te overleven. Hierbij maakt men gebruik van allerlei middelen die kunnen variëren van bepaalde baantjes, programma's, een bepaald type activiteiten, steun van gelijkgezinden. De niche die men vervolgens voor zichzelf inricht, bevat veelal een combinatie van elementen die te herleiden zijn tot de bovengenoemde dimensies.

Het proces van survival of aanpassing waarbij dus het begrip niche een belangrijke rol speelt, verloopt volgens bepaalde fasen die uiteindelijk resulteren in een zeker evenwicht op grond waarvan gedetineerden ieder voor zich een manier vinden om de tijd uit te zitten.

Over de beginperiode van het aanpassingsproces merkt Toch (p.185) het volgende op:

"During that period, when an inmate's free-floating anxiety is heavy, the inmate must negotiate the immediate physical and social environment that confronts him. Coping with the disequilibrium involves a long slow proces of controlling, eliminating, and reducing noxious stimuli, and of gathering and harvesting resources that facilitates "doing time'".

Toch duidt deze interactie tussen de gedetineerde en de gevangenisomgeving aan als een transactioneel proces om het aspect van de wederzijdse beïnvloeding van persoon en omgeving te benadrukken. Dit transactionele proces van aanpassing aan de detentie kan men onderverdelen in vijf fasen (Ittelson et al., 1974, p.97):

- een affectieve fase waarin emoties in de vorm van onzekerheid en angst de boventoon voeren;

- een oriënterende fase waarin men na een periode van hevige emoties weer enigszins in balans raakt en vervolgens zijn plaats binnen het systeem probeert te bepalen;

een fase van catalogiseren, waarin men de fysieke en sociale omgeving onderzoekt op aspecten die relevant zijn voor de persoonlijke behoeften. Men ontdekt bij voorbeeld situaties, plaatsen en personen die men beter kan mijden;

- een fase waarin men een soort modus of systeem voor zichzelf schept om te overleven in de gevangenisomgeving. In deze fase ervaart men een zekere controle over de omgeving, men vindt bij voorbeeld personen waarmee men kan praten. Het individu ontdekt hoe men bepaalde zaken voor zichzelf moet regelen;

- een manipulerende fase waarin men bepaalde doeleinden weet te bereiken door aspecten van de (sociale) omgeving te controleren en te beheersen. 


\subsubsection{Een interactionistische benadering van houdingen ten aanzien van resocialisatie}

In de vorige paragraaf werd de aanpassing van het individu aan de detenticomgeving onderzocht vanuit een interactionistisch perspectief. De vralag is hoe de houdingen van gedetineerden ten aanzien van resocialisatie binnen deze interaclionistische benadering kunnen worden gekarakteriseerd.

De wijze warop gedetineerden zich opstellen ten atmzien van het resocialisatiedoel en de bijbehorende voorzieningen is, gelet op de keuze voor een integratic-model, het product van factoren die aan de detentie-omgeving zijn gerelateerd en van persoonsgebonden factoren die los staan van de omgeving. De wijze walarop men zich vervolgens opstelt ten alanzien van de omgeving is voor een deel afhankelijk van de objectieve kenmerken van de omgeving. Bij de wijze waarop men deze ongeving vervolgens interpreteent. oefenen ook persoonsgebonden kenmerken een invloed uit. De interpretatic van de omgeving vertoont bepaalde individuele verschillen. Er is, juist omdat er werd gekozen voor een interactionistische benadering, geen sprake van unidirectionele, deterministische verbanden tussen het individu en de omgeving.

Het interactionistische perspectief veronderstelt immers een aanpassingsreactie aan een, mogelijk als depriverend ervaren omgeving.

Gedetineerden leggen bij hun aanpassing aan de detentie-omgeving het accent op bepaalde dimensies van de omgeving, zoals privacy, activiteiten, autonomie, structuur en emotionele feedback. De dagelijkse gevangenisomgeving laat deze verschillende accenten in het aanpassingsproces duidelijk zien. Zo is er op elke afdeling steevast een groep gedetineerden die een sterke behoefte aan privacy vertoont en op grond darvan activiteiten in groeps-verband mijdt. Deze groep die zich min of meer alfijdigheid houdt van het sociale leven op een afdeling vormt de tegenhanger van de gedetineerden die zich veelal in groepsverband op activiteiten oriënteren. Terwijl deze laatste groep juist de stimulus- armoede of de sleur van het gevangenisleven tracht te doorbreken door het ondernemen van allerlei activiteiten, heeft de op privacy gerichte groep juist last van de externe stimuli in de vorm van de drukte van het leven op een afdeling watar veel mensen in een beperkte ruimte moeten samenleven. Men trekt zich terug om de aanpassing aan het leven in detentie te vergemakkelijken.

De gedetineerden die zich op de activiteiten oriënteren gebruiken deze activiteiten voor verschillende doeleinden zoals afreageren van spanningen, mentaal in beweging blijven, de behoefte een doel in het leven te vinden en iets te bereiken. Men vindt via de activiteiten een niche waarbij sprake is van een congruentie tussen de persoonlijke behoeften en de omgeving. Men heeft de activiteiten ontdekt als een manier of een van de manieren om te overleven in de detentie-situatie. De houdingen zijn, voorzover zij met de omgeving te maken hebben vanuit deze interactionistische (transactionele) optiek te beschouwen als cen reactie die de aanpassing vergemakkelijkt.

Naast deze, vanuit een interactionistisch perspectief verklaarde invloed van de omgeving dient men, op basis van een keuze voor een integratie-model, er tevens van uit te gaan dat persoons-gebonden (import) variabelen een mogelijk onafhankelijk effect op de houdingen kunnen blijven uitoefenen, los van de omgevingsfactoren

\subsubsection{Detentie, stress en coping}

De gevangenisomgeving is een omgeving waarin de participanten te maken krijgen met allerlei potentiële stressoren en de daaruit voorvloeiende spanningen of stress. De spanningen kunnen dermate hoog oplopen dat bepaalde stressreacties zoals angsten en depressies het gevolg zijn. De gevolgen kunnen zelfs nog extremer vormen aannemen zoals psychoses, zelfverminking en suïcide.

Dhondt (1989) wijst op het belang van de begrippen 'coping' en 'crisis' voor de verklaring van de effecten van het verblijf in detentie op de psychische gesteldheid van gedetineerden. Een 
verblijf in een gevangenis kan, aldus Dhondt, het karakter krijgen van een permanente crisisperiode, die voortdurend coping-gedrag vereist en in bepalde gevallen kan leiden tot acute vormen van crisisgedrag zoals zelfmoord en zelfverminking.

In empirische zin zijn de negatieve effecten van de detentie op de psyche van gedetineerden in de afgelopen jaren vastgesteld, zij het dat de resultaten niet eenduidig zijn. De effecten die men heeft onderzocht betreffen de persoonlijkheid, cognitieve en motorische functies en psychopathologische verschijnselen. Zamble en Porporino (1988) concluderen na een evaluatic van de vele onderzoeken dat psychische schade voor gedetineerden als gevolg van de detentie in ernst varieert. Bovendien is er in veel studies niet gecontroleerd voor de invloed van eventuele andere achtergrondvariabelen. Opvallend is echter de aanwijzing dat angsten en depressies met name aan het begin van de detentie het hevigst zijn. Na verloop van tijd ziet men echter deze verschijnselen verminderen. Ook bij andere effecten constateren onderzoekers een vermindering van de stressreacties naarmate de verblijfsduur toeneemt. Uit het onderzoek van Zamble en Porporino blijkt dat het niveau van angst, depressie en wanhoop in het begin van de detentie vele malen hoger is dan het niveau dat men normaal aantreft onder niet-gedetineerde burgers. Zij beschouwen de psychische conditie van de meeste gedetineerden aan het begin van de detentie als ronduit slecht en in veel gevallen is volgens de onderzoekers extra aandacht en begeleiding dringend geboden. Na verloop van tijd zien ook Zamble en Porporino verbeteringen optreden echter, de psychische gezondheid van gedetineerden blijft toch onder de maat in vergelijking met die van niet-gedetineerde burgers.

Deze psychologische studies naar de schadelijke effecten van de detentie leveren in ieder geval ondersteuning op voor de veronderstelling dat de detentie in meerdere of mindere mate stress met zich meebrengt voor de meeste gedetineerden. Verder vormt de geconstateerde invloed van de verblijfsduur een aanwijzing voor het feit dat gedetineerden zich op een of andere manier trachten aan te passen aan de stressvolle omstandigheden. Er lijkt kortom sprake te zijn van hanteringgedrag of coping.

Het begrip coping refereert aan gedragsvormen die de mens aanwendt in een toestand van bedreiging, angst en onzekerheid. Het gaat hier om cognitieve, affectieve en gedragsmatige pogingen die erop gericht zijn een bepaald probleem, dan wel de negatieve emoties die ermee samenhangen terug te brengen.

Lazarus en Launier (1978) benadrukken bij het begrip coping de transactie tussen het individu en zijn omgeving waarbij het individu de omgeving kan beïnvloeden via allerlei hanteringgedrag.

Dit hanteringgedrag verdeelt men in de onderzoeksliteratuur onder in een drietal vormen, namelijk handelend optreden (het probleem direct aanpakken), heroriëntatie op of herbeoordeling van de situatie en vluchtgedrag, waarbij men de bedreigende situatie probeert te ontvluchten. Dergelijke vormen van hanteringgedrag zijn in de context van de detentie in meer uitgebreide zin onderzocht door Zamble en Porporino (1988).

Voor dit onderzoek is het begrip coping van belang in het kader van de functie die activiteiten voor gedetineerden hebben bij de hantering van een (stressvolle) detentie-situatie. Een belangrijke veronderstelling is dat de mate waarin gedetineerden de detentie als stressvol ervaren mogelijk voor een belangrijk deel afhankelijk is van verschillen in de wijze waarop zij de problemen van de detentiesituatie trachten te hanteren.

\subsubsection{Het begrip programma-integriteit}

In de voorgaande paragrafen werd de betekenis van omgevingskenmerken en persoonsgebonden kenmerken voor de houdingen van gedetineerden ten aanzien van resocialisatie 
vanuit een interactionistisch perspectief toegelicht. De kenmerken van de (detentie)ongeving en van de persoonsgebonden kenmerken werden daarbij niet nader omschreven. Bij omgevingskenmerken of de context waarin men met resocialisatie bezig is kan men een belangrijk onderscheid maken. In de eerste plaats kan men naar de omgeving of context in meer algemene zin kijken. Het gaat hier dan bijvoorbeeld om het regime, de gebouwelijke omstandigheden of het inrichtingsklimaat. Daarnaast kan men in meer specifieke zin kijken naar de context of situatie waarin de resocialiserende activiteiten plaats vinden. De aandacht gaat dan uit naar de wijze van uitvoering van de activiteiten. Een belangrijke vraag in dit verband is of de activiteiten op adequate en voorgeschreven wijze worden uitgevoerd. Het gaat hier om de kwaliteit van de implementatie van een resocialisatie- of activiteitenprogramma, die blijkens de onderzoeksliteratuur, van invloed kan zijn op de beleving van de activiteiten door gedetineerden. Dit randvoorwaardelijke aspect van resocialisatie-programma's wordt in de literatuur ook wel aangeduid met het begrip program-integrity of programma-integriteit. Ook dit aspect zal deel uit dienen te maken van een conceptueel model met factoren die mogelijkerwijs van invloed zijn op de houdingen ten aanzien van resocialisatie.

Met deze korte omschrijving van het begrip programma-integriteit zijn de belangrijkste bouwstenen voor een conceptueel model gegeven. In de volgende paragraaf zullen deze bouwstenen en hun onderlinge relaties in een model worden weergegeven.

\subsection{Een interactionistisch conceptueel model}

Hoewel de literatuur met betrekking tot socialisatie-processen in de gevangenis vrij omvangrijk is, zijn er totnogtoe nauwelijks pogingen ondernomen om deze processen in modelvorm weer te geven. Een model van Ohlin (1986, weergegeven bij Hamm \& Schrink, 1989, p.171) op basis van de systeem-theorie, beschrijft het implementatie-proces van resocialisatie-programma's in de penitentiaire organisatie en is in het kader van de probleemstelling van deze studie slechts zijdelings van belang. Wright (1991) hanteert cen model met drie componenten namelijk individuele effecten, interactie-effecten en omgevingseffecten. Ook dit model is te weinig specifiek voor wat betreft de houdingen ten aanzien van resocialisatie als afhankelijke, te verklaren variabele en de relaties met mogelijk relevante onafhankelijke en interveniërende variabelen. Een relatiemodel van Grapendaal (1987), hoewel illustratief voor de inbedding van prisonisatie-variabelen in de organisatie van de inrichting, vertoont te weinig detail voor wat betreft de rol van activiteitenprogramma's bij het socialisatie-proces.

In geen van de drie genoemde modellen zijn bovendien de concepten stress en coping opgenomen.

Gezien het feit er nauwelijks modellen voor handen zijn in de penologische literatuur ligt het voor de hand aanknopingspunten te zoeken in andere onderzoeksgebieden.

Een belangrijk uitgangspunt hierbij zijn de begrippen stress en coping waarvan, blijkens het hiervoor geschetste theoretisch kader, wordt verondersteld dat zij relevant zijn voor de aanpassing aan de detentiesituatie. In de gezondheidswetenschappen kent men al geruime tijd een vrij omvangrijke onderzoekstraditie op het gebied van de aanpassing van het individu aan een stressvolle omgeving. Hier beschikt men over meer gedetailleerde modellen.

Een bruikbare structurering van begrippen lijkt mogelijk op grond van het zgn. Michigan organisatie-stressmodel. Dit model is opgesteld door een onderzoekersgroep op het gebied 
van werkstress, ook wel de Michigan-groep genoemd (Kleber, 1982, p.57). In dit model (fig. 1) wordt onderscheid gemaakt tussen:

a. een objectieve omgeving

b. de subjectieve beleving

c. spanningen of stressreacties en

d. strains.

Persoonskenmerken en sociale ondersteuning en begeleiding worden verondersteld een modererend, mediërend of direct effect te hebben.

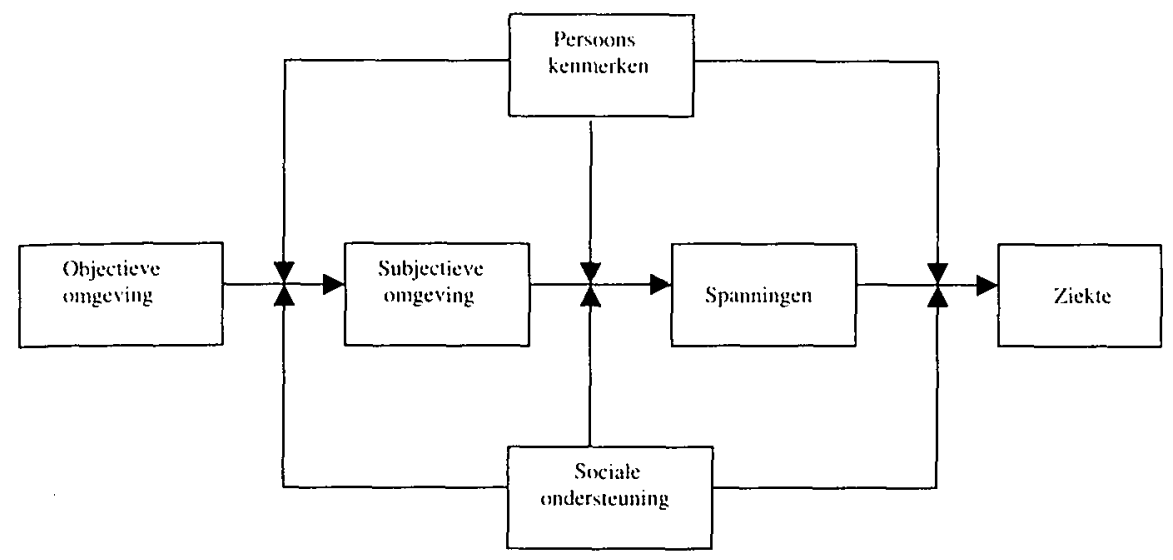

Figuur 1: Michigan Organisatie-Stressmodel (Kleber,1982)

Centraal uitgangspunt binnen het Michigan-model is de subjectieve beleving. Er wordt een objectieve omgeving verondersteld die los staat van het individu. De objectieve omgeving wordt waargenomen door het individu en geeft aanleiding tot een subjectieve beleving van de omgeving. Deze subjectieve beleving van de omgeving kan vervolgens weer van invloed zijn op individuele stressreacties en ziekteverschijnselen.

Belangrijk is in dit verband te wijzen op de aanvullingen die dit oorspronkelijke Michiganmodel heeft gekregen in de vorm van het begrip hantering van stressvolle situaties.

Het ontbreken van nader gespecificeerde vormen van hanteringgedrag wordt in de literatuur gezien als een tekortkoming van dit model. Kritiek op dit aspect berust vooral op de gedachte dat het individu binnen het Michigan-model te zeer een passieve rol krijgt toebedeeld. Uitgaande van de gedachte dat er een voortdurende transactie bestaat tussen het individu en de omgeving, waarbij het individu de omgeving kan beïnvloeden via allerlei hanteringgedrag, heeft men het Michigan-model in dit opzicht bijgesteld. In het onderzoek van werkstress gebruikt men veelal een uitgebreider model waarin de manieren om stress het hoofd te bieden (hanteringgedrag) zijn geïntegreerd (Lazarus en Launier,1978).

Het Michigan-model is overigens geen echt theoretisch model, het is veeleer een model dat gebruikt wordt om de verschillende variabelen te ordenen. 
Hoewel deze studie niet over stress en strains als athankelijke variabelen gatat, lijkt dit model bruikbaar om andere reacties op een, eveneens, potentiecl belastende omgeving als de gevangenis in modelvorm inzichtelijker te maken.

Met name de nadruk in dit model op de subjectieve beleving van de omgeving en de rol van overige modererende of interveniërende achtergrondvariabelen bieden een bruikbare structuur on de relevant geachte variabelen te ordenen.

Vertaald naar de probleemstelling van dit onderzoek kan men op basis van het Michiganmodel het volgende model construeren (ïg.2)

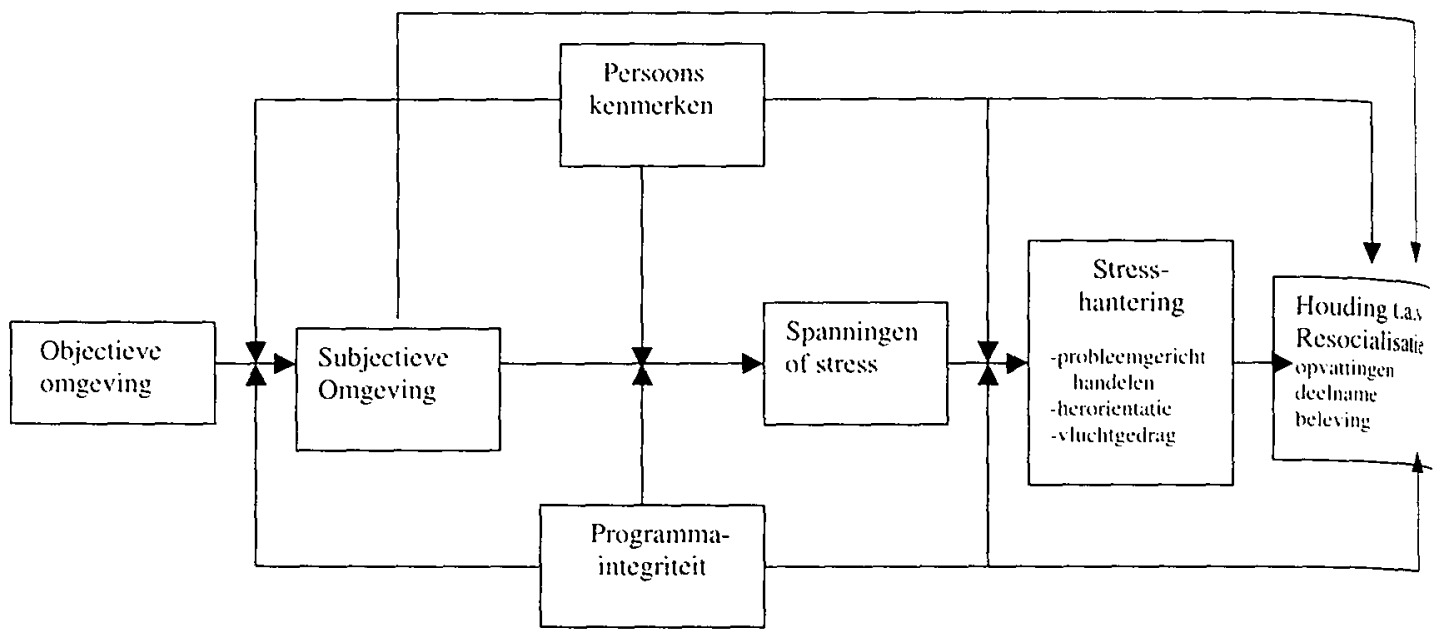

Fig.2 interactionistisch conceptueel model van houdingen en gedrag van gedetineerden inzake resocialisatic

In dit aangepaste model (fig.2) is cen belangrijk uitgangspunt dat de gevangenis-omgeving bij gedetineerden in meerdere of mindere mate spanningen teweegbrengt. Vervolgens is, uitgaande van het bijgestelde Michigan-model, ook het hanteringgedrag of coping-stijl opgenomen.

In onderzoek van de houdingen van gedetineerden ten aanzien van resocialisatie is overigens de rol van dit begrip 'coping' als mogelijke relevante variabele nooit eerder onderzocht.

Het bovenstaande model in figuur 2, deels afgeleid van het Michigan-model en verder toegespitst op de vraagstelling van deze studie, waarbij de rol van 'coping' naast de overige variabelen inzichtelijk wordt gemaakt, omvat de volgende samenhangende factoren:

-de objectieve omgeving (bijvoorbeeld gebouwelijke omstandigheden, inrichtingsideologie, beleid en regime);

-de subjectieve omgeving (ervaren inrichtingsklimaat bij voorbeeld in relatie tot het regime); -de (ervaren) kwaliteit van de implementatie van de activiteiten (de zgn. programmaintegriteit); 
-persoonskenmerken (recidive, leeftijd, tockomstverwachtingen, opleiding, burgerlijke staat arbeidsverleden, etnische achtergrond);

-penitentiaire gegevens (verblijfsduur, strafduur, strafrestant, detenticfase);

-manieren om spanningen als gevolg van detentic het hoofd te bieden: het hanteringgedrag of de coping-stijl. Dit kan resulteren in verschillende reacties zoals vluchtgedrag, apathic, verzet en meer constructieve, positieve en problecmgerichte strategieën. Actieve participatie in activiteiten en positieve houdingen ten aanzien van resocialisatie en kansen voor zelf-verbetering behoren naar ik veronderstel tot de meer probleemgerichte en 'hogere' coping-stijlen. Deelname aan de activiteiten met als voornatamste motief de directe ongemakken en spanningen van de detentie te reduceren zou men kunnen beschouwen als een vorm van vlucht- of vermijdingsgedrag.

-opvattingen over resocialisatie, declname aan en beleving van de activiteiten.

Het proces van aanpassing en de rol dic daarin gespeeld wordt door omgeving, persoonskenmerken, en de houdingen ten aanzien van de resocialisatie-doelstelling en de bijbehorende activiteiten zou men stapsgewijs als volgt kunnen samenvatten.

Gedetincerden nemen de (objectieve) detentie- omgeving waar, zij beleven die omgeving op een bepaalde manier. Die individuele waarneming of perceptie van de omgeving kan men aanduiden als de subjectieve omgeving. Die subjectieve omgeving zoals beleefd door het individu, is in de eerste plaats het product van bepaalde objectieve kenmerken van de omgeving zoals de inrichtingsideologie, bestemming, beleid, regime, gebouwelijke omstandigheden en in meer specifieke zin ook van de wijze waarop de randvoorwaarden met betrekking tot de verschillende voorzieningen voor gedetineerden worden ingevuld.

In de tweede plaats wordt die subjectief beleefde omgeving beïnvloed door persoonskenmerken. Op grond van persoonskenmerken interpreteren gedetineerden de objectieve eigenschappen van de omgeving niet steeds op dezelfde manier. Een voorbeeld: allochtone gedetinecrden met detentie-ervaring in het land van herkomst ondergaan het regime in een Nederlandse inrichting wellicht anders dan Nederlandse gedetineerden.

Op grond van deze subjectief beleefde omgeving kunnen er bij gedetineerden in meerdere of mindere mate spanningen ontstaan. Deze spanningen zijn niet alleen het product van de (subjecticl) beleefde omgeving maar kunnen, onafhankelijk van de subjectieve omgeving, ook voortvloeien uit factoren met betrekking tot de persoon.

Zowel omgevingsfactoren als factoren van persoonlijke aard kunnen het optreden van spanningen (stressoren) en de reacties daarop (stressreacties) beïnloeden (directe effecten), en/of de kans vergroten of verkleinen dat deze stressoren optreden en vervolgens gepaard gaan met stressreacties (modererende of bufferende effecten).

Zo zal een iemand die weinig steun ontvangt van familie wellicht meer last van eenzaamheid en spanningen hebben dan iemand die zich wel ondersteund weet door naasten. Vervolgens probeert men de spanningen te reduceren. De wijze waarop men omgaat met de stress als gevolg van de detentie kan men beschouwen als een vorm van hanteringsgedrag of coping.

Hierbij kunnen gedetineerden verschillende strategieën of stijlen hanteren. Zij kunnen zich richten op activiteiten als middel om de spanningen te reduceren, of op andere mogelijkheden zoals het zoeken van emotionele ondersteuning, structuur, veiligheid en privacy. Tenslotte kan men hier ook denken aan het zich wenden tot de normen en waarden van de (deviante) gedetineerdencultuur als reactie op de depriverende omstandigheden van de detentie. Het ontwikkelen van dit eigensoortig complex van waarden en normen, waarbij de nadruk ligt op het verwerven van een nieuwe, andere waardering van zichzelf, zou men kunnen beschouwen als een vorm van hanteringgedrag, in casu heroriëntatie. 
Uit het model blijkt verder dat de drie clusters van achtergrondfactoren (ongevings- en persoonsgebonden factoren en de programma-integriteit) zowel een indirecte als directe invloed kunnen uitoefenen op de houdingen ten aanzien van resocialisatie. Een indirect effect verloopt wellicht via de spanningen als gevolg van de detentie en de wijze waarop men deze spanningen hanteert.

Aan de hand van dit model en de relevante literatuur zullen de bovengenoende concepten en hun relatie tot de deelname en de houdingen met betrekking tot de regimesactiviteiten nader worden uitgewerkt.

Hierbij wordt gekozen voor de volgende opzet.

De begrippen objectieve en subjectieve omgeving worden als eerste toegelicht aan de hand van de onderzoeksliteratuur. Daarbij wordt in het kader van de effecten van die omgeving op houdingen en gedrag van gedetineerden tevens het begrip prisonisatie toegelicht. Daarna volgt een bespreking van het onderzoek waarin men verbanden heeft gevonden tussen enerzijds de houdingen ten aanzien van resocialisatie en bepaalde aspecten van die omgeving.

De studies die verricht zijn vanuit het perspectief van het importmodel vormen de basis voor de bespreking van de persoonsgebonden factoren die van belang worden geacht voor de verklaring van de houdingen ten aanzien resocialisatic.

Verder zullen de begrippen stress en coping en hun betekenis voor de verklaring van de aard en oorsprong van de houdingen ten aanzien van resocialisatie worden toegelicht.

Het volgende begrip uit het onderzoeksmodel dat zal worden toegelicht aan de hand van de literatuur is het begrip 'program integrity' of wel het vraagstuk van de programma-integriteit. Dit vraagstuk behandelt het proces van implementatie van de voorzieningen gericht op de voorbereiding van de terugkeer in de samenleving. Onderzocht wordt welke (organisatorische) aspecten of randvoorwaarden van betekenis zijn voor een adequate implementatie. Tevens zal worden onderzocht welke aanwijzingen er in de literatuur zijn te vinden voor bepaalde effecten van het implementatie-proces op de houdingen van gedetineerden ten aanzien van resocialisatie.

Dit hoofdstuk besluit met een reeks onderzoeksvragen die het verklarend deel van de probleemstelling verder toespitsen.

\subsection{De objectieve omgeving: de 'people changing'-organisatie, inrichtingsideologie en inrichtingsbeleid}

\subsubsection{De gevangenis als people-changing organisatie}

Een belangrijk begrip in de organisatie-sociologische benadering van de penitentiaire inrichting is het begrip 'people-changing organisation'. Met dit begrip wordt het verschil aangegeven tussen organisaties waarin men op een of andere manier het gedrag van mensen tracht te beïnvloeden en andere organisaties in de samenleving die zich voornamelijk toeleggen op het produceren van goederen en diensten.

Beide typen organisaties maken gebruik van mensen om hun taak te vervullen, echter de 'people changing' organisatie werkt niet alleen met of doormiddel van mensen. In de 'people changing' organisatie is het eindresultaat van een deel van de inspanningen eveneens gericht op de mens. In het geval van de gevangenis bijvoorbeeld op het (toekomstig) functioneren van de gedetineerde in psychosociale zin. De 'people-changing' organisatie is overigens niet alleen te vinden binnen de categorie van de penitentiaire inrichting. Psychiatrische inrichtingen, militaire academies, religieuze organisaties, bepaalde onderwijsinstellingen stellen zich eveneens tot doel het gedrag van mensen in een bepaald opzicht te beïnvloeden. 
Street, Vinter en Perrow (1966) noemen een aantal typische kenmerken van 'people-changing' organisatie die ook van toepassing zijn op gevangenissen:

1. ondat het om de beïnvloeding van mensen gaat, zijn bepaalde vormen van psychosociale of medische technologie uit humane en mensenrechtelijke overwegingen bij voorbaat uitgesloten;

2. de reactie van de leden van de doelgroep is onvoorspelbaar en medewerking aan het gedrags- of houdingsveranderend proces is niet steeds gegarandeerd;

Street et al., (p.4):

" there is a constant danger of unanticipated response, as evidenced by prison riots or collective disturbances in mental hospitals, wards or classrooms."

Vooral in de gesloten 'people changing' organisatie is er een sterke nadruk op controle, immers gedetineerden of patiënten verblijven er op onvrijwillige basis. Een en ander gaat tevens gepaard met een omvangrijke regulering van gedrag in de vorm van voorschriften. Voorts behoren zij tot de klasse van totale institutie;

3. er is een voortdurende spanning tussen de neiging tot bureaucratisering en de tendens rekening te houden met de bijzondere omstandigheden of eigenschappen van de leden van de doelgroep.

Anders geformuleerd: er is een zekere noodzaak de mens en zijn of haar gedrag te beschouwen als een niet-uniform, divers of individueel verschijnsel. Tegelijkertijd ontkomt men niet aan de noodzaak tot een zekere categorisering van groepen gedetineerden en hun gedrag;

4. men stelt zich bij voorbeeld met resocialisatie een betrekkelijk abstract doel, waarvan het bovendien onduidelijk is met welke technologie of middelen dit doel het beste verwezenlijkt kan worden. In penitentiaire inrichtingen treft men een breed scala van gedragsbeinvloedende strategieën aan, variërend van 'military' bootcamps tot meer 'zachte' therapeutische benaderingen, waarvan de effectiviteit niet bij voorbaat vast staat;

5. 'people-changing' organisaties opereren in een zeer kritische omgeving, men dient steeds rekening te houden met de reacties van publiek en politiek;

6. De ideologische basis van de organisatie speelt een belangrijke rol bij het ontwikkelen van gedragbeïnvloedende strategieën en het opzetten van concrete activiteiten. Denkbeelden over het ontstaan van deviantie, het veranderen van deviante gedragspatronen en het doel van de vrijheidsbeneming als sanctie, zijn in belangrijke mate van invloed op de richting waarin de organisatie zich ontwikkelt.

Een vraag die hier zeker niet onbeantwoord mag blijven, is hoe het begrip 'people changing'organisatie zich bij voorbeeld verhoudt tot het autonome gevangenisstelsel dat in de jaren tachtig uitgangspunt werd voor het Nederlandse penitentiaire bestel.

Het autonome stelsel gaat ervan uit dat de gedetineerde in essentie een autonoom subject is, hetgeen als belangrijk gevolg heeft dat de gedetineerde niet langer meer als het object van resocialiserende inspanningen wordt gezien, maar als subject dat zelf een initiatief neent op het gebeid van zijn of haar zelfherstel. De gedetineerde vormt in wezen zichzelf en lost zijn eigen problemen op, uiteraard met de nodige ondersteuning vanuit de professionele staf en 
het uitvoerend personeel (in casu, de bewalarders). Kommer (1991) spreckt in dit verband van een verschuiving van een medisch model naar een zelfhulpmodel.

Ondanks deze verschuiving van opgelegde, geforcecte resocialisatie natr een zelfhulpmodel behouden Nederlands penitentiaire inrichtingen mijns inziens toch het karakter van een 'people-changing' organisatic. Alle bovengenoemde eigenschappen blijven, zelfs met het formeel afzweren van een afgedwongen en opgelegde resocialisatie, onverminderd gelden voor het Nederlandse gevangeniswezen. Essentieel voor het begrip 'people-changing' organisatie is dat de organisatiestructuur op één of andere manier gericht is op veranderingen qua gedrag en houding bij gedetineerden.

Bovendien kan men zich afvragen of ondanks de keuze voor een autonoom stelsel het dwangaspect van het streven naar verbetering in impliciete vorm aanwezig blijft. Tulkens (1991, p.86) doelt hierop als hij zegt:

"de zorg en aandacht van specialisten en hulpverleners in een iurichting getuigen niet zelden. hoezeer ook onbedoeld. van een houding van 'weten wat goed voor je is' en van de verwachting, zelfs eis, dat de gedetineerde zich daaraan overgeeft. hetgeen dan motivatie heet".

Street et al. (1966) maken in dit verband een verhelderend onderscheid tussen socialiserende en resocialiserende 'people changing' organisaties. 'People changing' organisaties bevinden zich voor wat deze doeleinden betreft op een continuüm.

In de organisaties waarin men socialisatie benadrukt, zoals scholen bij voorbeeld, gaat men ervan uit dat de, te beïnvloeden persoon hiertoe reeds cen zekere intrinsieke motivatie heeft en er vrijwillig voor kiest. Bijgevolg kunnen hier intensieve, geforceerde gedragsveranderingen achterwege blijven. Organisaties die resocialisatie benadrukken, hanteren, althans in de Verenigde Staten, binnen de context van de totale institutie veelal ingrijpender en intensieve methoden om ongewenst gedrag tegen te gaan en conformerend gedrag ervoor in de plaats te stellen.

Met het invoeren van het autonome stelsel in de jaren tachtig is in Nederland de penitentiaire inrichting als 'people-changing' organisatie veel meer opgeschoven in de richting van socialisatie. Niet de opgelegde systematische behandeling of verandering van de persoonlijkheid is bepalend voor de bejegening, mar het scheppen van cen gehumaniseerd en genormaliseerd detentieklimaat waarin (re)socialisatieprocessen vooral op basis van vrijwilligheid plaatsvinden.

De nota Werkzame Detentie (1994) betekent met name waar het de veronderstelde resocialiserende effecten van de activiteiten betreft, een verschuiving op het continuium in de richting van een min of meer opgelegde resocialisatie. Over de arbeid lezen we immers in de nota Werkzame Detentie (p.9) het volgende:

"Het beschreven standaardregime kent twee peilers: arbeid en structuur. Dit regime leidt niet alleen tot een meer adequate invulling van de detentietijd zelf- verveling en ledigheid maken plats voor zinvolle tijdsbesteding- maar beoogt bovendien bij te dragen aan de integratie van de ex -gedetineerde in de samenleving. Het dagelijks verrichten van werk om in het levensonderhoud te voorzien kan een gunstig effect hebben op de verdere levensloop. Het wennen aan de structurering van de dag rond de arbeid en het bijbrengen van arbeidsdiscipline zijn daartoe voorwaarden waaraan met de invoering van het standaardregime wordt voldaan."

De lezer zij eraan herinnerd dat reeds bij de invoering van de spin-, rasp en tuchthuizen rond 1600 de gevangenisarbeid vrijwel dezelfde functie kreeg, zij het dat indertijd, naast het bestrijden van ledigheid, de bestrijding van de kosten van detentie een belangrijk doel was (Besier, 1986). 
In de Nota Werkzame Detentie treft men bij het aanbod van de overige activiteiten eveneens een grotere nadruk op sturing van het gedrag van gedetineerden. Voor de faciliteiten die nodig zijn voor een adequate voorbereiding van de terugkeer in de samenleving komt men niet zomaar in aanmerking. Men moet blijk geven van voldoende motivatie. In regimes met een bonus malus-systeem kent men, al naar gelang het vertoonde gedrag, bepaalde beloningen toe in de vorm van extra faciliteiten voor gedetineerden. Resocialisatie is niet meer een aangelegenheid waarop iedereen zonder meer aanspraak kan maken, men moet resocialisatie met andere woorden 'verdienen'.

\subsubsection{Inrichtingsideologie}

Street, Vinter en Perrow (1966) noemen de ideologische basis van de organisatie een belangrijk kenmerk dat gevangenissen als 'people changing' organisatie onderscheidt van andere organisaties. In deze paragraaf wordt dit begrip nader toegelicht.

In het Nederlandse gevangeniswezen wordt van departementswege het overkoepelend beleid geformuleerd voor de inrichtingen. Sinds de reorganisatie aan het eind van de jaren tachtig, ook wel aangeduid als deconcentratie, wordt een beleid gevoerd waarbij de beslissingen zo dicht mogelijk bij het niveau van uitvoering worden genomen (zie ook hoofdstuk 2). Het overkoepelend beleid bepaalt het globale kader waarbinnen het inrichtingsbeleid gestalte krijgt.

Inrichtingsdirecties beschikken dus over speelruimte bij de invulling van het overkoepelend beleid. Dit heeft als consequentie dat er tussen inrichtingen verschillen bestaan in de wijze waarop men gedetineerden bejegent, dat wil zeggen in de regelgeving, conflicthantering en orde- versus gedetineerden-gerichtheid van het regime, kortom in detentie- en werkklimaat.

De verschillen in inrichtingsklimaat zijn voor een deel terug te voeren op een aantal bewuste beleidskeuzen. De inrichtingsideologie als samenstel van een aantal waarden, normen, mensbeelden, denkbeelden over criminaliteit, bestraffing en vrijheidsbeneming wordt vertaald in een inrichtingsbeleid dat zijn neerslag vindt in handelingsvoorschriften en regimesactiviteiten-programma's (Grapendaal, 1987). Uiteraard zijn er een aantal aspecten van de ideologie die niet expliciet kunnen worden vastgelegd in beleid. Niet iedereen huldigt dezelfde ideologie, accenten kunnen door leden van het personeel op een andere manier worden gelegd, kortom een deel van de inrichtingsideologie blijft min of meer impliciet van aard.

In hoofdstuk 2 bleek dat die verschillen in het inrichtingsbeleid niet alleen maar zijn te herleiden tot de uiteenlopende bestemming van inrichtingen. Die verschillen zijn voor een belangrijk deel ook te herleiden tot de vrije beleidsruimte van inrichtingsdirecties (Boin, 1998).

Kommer (1991) hanteert een begrippenschema waarin het voorgaande op een meer systematische manier wordt weergegeven.

De inrichtingsideologie of ideële basis is uitgewerkt in een formele inrichtingsstructuur, die overigens slechts op papier bestaat. Vervolgens wordt deze structuur geactualiseerd in een gebouw met personeelsformatie en een regime, hetgeen men de geactualiseerde structuur kan noemen. In de volgende fase nemen concrete personen hun posities binnen de organisatie in en dan is de actuele organisatiestructuur operationeel.

Deze actuele of werkelijk bestaande structuur ontleent haar vorm en karakter aan de interpretaties van de ideologische basis, de formele en geactualiseerde structuur door concrete personen.

Kommer stelt dat een drietal ideologische bases ten grondslag liggen aan het proces van formalisering, actualisering en concretisering in de penitentiaire inrichting, namelijk de 
officiële ideologie, de individuele en collectieve ideologie van de ontwerpers van de geactualiseerde structuur en de collectieve en individuele ideologie van degenen die het uiteindelijke resultaat op de 'werkvloer' tot stand brengen.

Onder de individuele en collectieve ideologie verstat Kommer de privé-opvattingen van personen en de gezamenlijke doelstellingen die in de loop der tijd ontstaan ("dit is een goedlopende tent, het is hier altijd een puinhoop geweest en dat zal voorlopig wel zo blijven"). Men kan dit ook wel de officieuze ideële basis noemen. De officiële en officieuze ideologie, voor een deel vertaald in bewuste beleidskeuzen bepalen in belangrijke mate het klimaat of algemene karakter van een inrichting.

De invloed van de doelen of ideologie op het functioneren van de organisatie van de penitentiaire inrichting is in de jaren vijftig en zestig vrij uitgebreid onderzocht door Cressey (1959; 1960), Ohlin (1958), Zald (1962), Street et al. (1966), en Gruskey (1959). Om de aard van de inrichtingsideologie te operationaliseren gebruikt men in deze studies het onderscheid tussen zgn., 'treatment-oriented' of behandelingsgerichte inrichtingen en 'custody-oriented' of beveiligingsgerichte inrichtingen.

Inrichtingen bevinden zich in organisatorische zin op een continuüm met als extremen beveiliging en behandeling. Inrichtingen wier organisatie relatief beveiligingsgericht is, kenmerken zich door een nadruk op beheersbaarheids- en ordemotieven. De omgang van het personeel met gedetineerden staat vooral in het teken van gehoorzaamheid, discipline, een grote onderlinge sociale afstand tussen partijen, training van het personeel op beveiligingsaspecten, beperkte beslissingsbevoegdheid van het personeel, geringe vrijheid van gedetineerden en het gebruik van negatieve sancties. De wijze van benadering van gedetineerden kan men omschrijven als ongedifferentieerd, "gelijke monniken, gelijke kappen". Het is een misverstand dat deze organisaties puur op bewaring of onschadelijkmaking en niet op gedragsverandering zijn gericht. Gedragsbeïnvloeding kan zeer wel een doel zijn, de (schijn)aanpassing van gedetineerden verloopt echter via repressie en deprivatie, men probeert in extreme gevallen het verblijf in de inrichting zo onaangenaam mogelijk te maken, conditionering en onderwerping van gedetineerden aan het gehoorzaamheidsmodel, desnoods met negatieve sancties, behoren tot de mogelijkheden.

De behandelingsgerichte organisatie is gebaseerd op de gedachte dat de detentie vooral gericht moet zijn op het herstel van de gedetineerde in psychosociale zin. Een en ander impliceert het bevorderen van een zo klein mogelijke afstand tussen personeel en gedetineerden, ontvankelijkheid voor en afstemming van de behandeling op de individuele behoeften en mogelijkheden, positieve motivatie van gedetineerden, tolerant inrichtingsklimaat, sancties als uiterste middel en een agogische scholing en vrij grote mate van autonomie van het personeel.

In het algemeen geldt dat de ideologie van penitentiaire organisaties varieert van zeer eenvoudige veronderstellingen tot zeer complexe veronderstellingen ten aanzien van gedragsbeïnvloeding.

Street et al. (1966) onderscheiden hierbij een aantal in complexiteit toenemende dimensies: -incarceration/deprivation;

-authority/ obedience;

-learning;

-socialization;

-therapy;

Vervolgens leiden zij hieruit een aantal organisatie-modellen af waarvan het 'obedience/conformity'- en het 'treatment'-model overeenkomen met respectievelijk de begrippen 
beveiligings- of orde gericht en behandelingsgericht. Voorts noemen zij nog het 're-education /development' model' waarbij onderwijs en training voorop staan. Tenslotte onderscheiden zij het 'mixed-goal' type.

Nederlandse gevangenissen behoren in het algemeen tot het laatste type. Men treft er enerzijds elementen van orde- en beveiligingsgerichte aard en anderzijds elementen uit de behandelingsgerichte organisatie aan. De begrippen beveiligings- en behandelingsgericht zijn ideaaltypen die men in de praktijk niet in zuivere vorm aantreft. De officiële en officieuze inrichtingsideologic zijn doorgaans een mengsel van (soms) conflicterende doelstellingen hetgeen uiteindelijk kan resulteren in een organisatie- of detentieklimaat dat naar, hetzij de beveiligings- hetzij de behandelingspool neigt.

In feite gaat het om de vraag in welke richting men in de praktijk de accenten legt. Het gedetineerden-gerichte of beveiligingsgerichte karakter van de Nederlandse inrichtingen is primair afhankelijk van het differentiatie-stelsel. In half-open en open inrichtingen neemt de terugkeer in de samenleving in vergelijking met gesloten inrichtingen een belangrijker plaats in en dit heeft consequenties voor de mate waarin het regime is gericht op orde-en beveiligingsgerichte aspecten of behandelingsgerichte aspecten. Ook binnen een inrichting kunnen er grote verschillen bestaan in de mate waarin regimes in het teken staan van deze aspecten. Men kan hier denken aan bijvoorbeeld de verregaande mate van beveiliging in de EBI-afdeling in de inrichting te Vught en aan de restrictieve regimes in speciale afdelingen voor beperkt gemeenschapsgeschikte, veroordeelde gedetineerden.

Voor wat de Nederlandse situatie betreft is het eigenlijk niet juist te spreken van behandelingsgerichte regimes. Systematische, veelal gedwongen behandeling van gedetineerden volgens bepaalde therapeutische methoden is een typisch fenomeen uit de Anglo-Amerikaanse wereld van 'corrections' van enkele decennia geleden. De huidige situatie in Nederlandse gevangenissen kan men het best omschrijven met behulp van het begrip gedetineerden-gericht (Grapendaal, 1987).

Het begrip gedetineerden-gericht strookt het best met de Nederlandse resocialisatiepraktijk zoals die tot halverwege de jaren negentig in de inrichtingen werd gevoerd. Immers het beleid werd sinds de nota Taak en Toekomst decennium niet meer gericht op het stelselmatig en geforceerd nastreven van houdings- en gedragsveranderingen, maar veeleer op het scheppen van een detentieklimaat waarin de gedetineerde wordt aangemoedigd tot een constructieve opstelling en met de nodige ondersteuning initiatieven neemt ten aanzien van zijn problemen en toekomstige maatschappelijke positie (RAP-nota,1983).

Een dergelijke doelstelling veronderstelt een inrichtingsideologie waarin het personeel open staat voor de behoeften en individuele mogelijkheden van gedetineerden. Een en ander impliceert een minder grote afstand tussen personeel en gedetineerden, een beroep op een gedeelde, dat wil zeggen gemeenschappelijke verantwoordelijkheid van gedetineerden en personeel voor een humane en leefbare inrichting.

Grapendaal (1987) spreekt hier van een zgn. systeemgerichte ideologie die berust op de gedachte dat de verschillende groepen in de inrichting meer overeenkomsten dan verschillen hebben en bereid zijn gedeeld belang te laten prevaleren boven eigen belang.

Samenvattend kan worden gesteld dat de Nederlandse inrichtingen overwegend tot het zgn. 'mixed-goal'- type behoren, het ordegerichte doel van de ongestoorde tenuitvoerlegging van de gevangenisstraf en de overige doelstellingen gericht op humanisering, voorkomen van detentieschade en resocialisatie worden gelijktijdig nagestreefd. Ondanks deze gemeenschappelijke, formele basis van het beleid kunnen inrichtingen verschillen vertonen in de wijze waarop de officiële ideologie wordt geconcretiseerd. De ideologie van de inrichtingen zal, naar men mag veronderstellen, verschillen vertonen qua orde-gerichtheid en 
gedetineerdengerichtheid. De accenten in het beleid zullen niet steeds op dezelfde manier worden gelegd. Hun positic op het continuün zal verschillen vertonen, zij het waarschijnlijk niet in opzienbarende zin. Liberalisering van de regimes in de jaren tachtig heeft ertoe geleid dat tot aan het verschijnen van de Nota Werkzame Detentie een overwegend gedetineerdengericht regime werd gevoerd. De invoering van het beleid van Werkzame Detentie (1994), in het bijzonder de invoering van het standaardregime, impliceert een accentverschuiving in meer restrictieve, disciplinerende zin. Thans zijn deze restricties in het regime van de inrichtingen in vrij algemene zin doorgevoerd, zij het dat als gevolg van de betrekkelijk grote autonomie van de inrichtingsdirecties regimaire verschillen aanwijsbaar blijven. Invoering van het beleid van Werkzame Detentie betekent voor het merendeel van de gedetineerden dat zij hun detentie doorbrengen in een regime dat, in vergelijking met de situatic in de jaren tachtig, een duidelijk minder gedetineerdengericht karakter draagt.

\subsection{De subjectieve omgeving en het prisonisatie-proces}

In sociologisch en (sociaal)-psychologisch onderzoek van de gevangenis is, met name in de Verenigde Staten gedurende de afgelopen decennia betrekkelijk veel aandacht geschonken aan prisonisatie-verschijnselen en hun verschillende effecten op houdingen en gedrag van gedetineerden.

De basis voor dit type onderzoek werd gelegd door (Clemmer, 1940). In zijn studie 'The Prison Community' onderzocht hij het proces van aanpassing van gedetineerden aan het leven in een gevangenisgemeenschap. Dit aanpassings-of assimilatie-proces staat volgens Clemmer sterk in het teken van de beleving door gedetineerden van de detentie-omgeving als depriverend en belastend. De detentie behelst een reeks van pijnlijke consequenties voor gedetineerden, zoals het verlies aan bewegingsvrijheid, de degradatie van maatschappelijke status, het niet kunnen beschikken over bepaalde materiële goederen en diensten, het isolement ten opzichte van de naasten, het verlies van de werkkring. Deze gevolgen worden door gedetineerden vrijwel eenstemmig ervaren als zeer pijnlijk (Sykes, 1958). De individuele gedetineerde staat met deze pijnlijke gevolgen van zijn detentie niet alleen, het is een gemeenschappelijk lot dat ook zijn of haar mede-gedetineerden treft. Deze lotsverbondenheid vormt volgens Clemmer (1940), Sykes (1958) en Goffman (1961) de basis voor het ontstaan van een gedetineerdencultuur met een eigensoortig geheel van normen, waarden en sociale structuur. Men duidt deze cultuur doorgaans aan met het begrip subcultuur of tegencultuur, waarbij in de penologische literatuur het oppositionele karakter van deze cultuur wordt benadrukt. Betrokkenheid bij de gedetineerden-cultuur is een manier om de deprivatie van de detentie het hoofd te bieden en binnen acceptabele grenzen te houden

Het proces van betrokken raken bij de gedetineerden (sub)cultuur duidt Clemmer aan met het begrip prisonisatie. Volgens Clemmer blijft vrijwel geen enkele gedetineerde gevrijwaard van prisonisatie-effecten die gepaard gaan met een afwijkend (oppositioneel) of crimineel normen- en waardenpatroon.

De basis van deze verklaring van assimilatie-processen in gevangenissen ligt uiteindelijk in een (subjectieve) beleving van de gevangenisomgeving als depriverend en belastend. Vandaar dat een verheldering van het begrip subjectieve omgeving uit het conceptueel model in eerste instantie dient aan te sluiten bij de verklaringen op grond van een deprivatiemodel. Het begrip subcultuur speelt in het onderzoek van het assimilatie-proces een centrale rol. De vraag is echter of men in de Nederlandse gevangenissen wel kan spreken van subculturen of prisonisatie-processen zoals die bij voorbeeld in Amerikaanse studies zijn aangetroffen. 


\subsubsection{Subculturen in Nederlandse inrichtingen}

Veel onderzock over de alanwezigheid van subculturen in penitentiaire inrichtingen is afkomstig uit de Verenigde Staten. De omstandigheden in de Amerikaanse gevangenissen verschillen in een aantal opzichten van die in Nederlandse gevangenissen. Een van de kenmerken waardoor het Nederlandse gevangeniswezen zich onderscheidt van gevangenissen in het buitenland is de betrekkelijk geringe mate van antagonisme tussen personeel en gedetineerden en een rustig en betrekkelijk mild detentieklimaat. Een belangrijke vraag is dan ook of en in welke mate men in Nederlandse gevangenissen kan spreken van een aanwezige subcultuur.

In de jaren tachtig is deze vraag in het kader van een grotere nadruk op het functioneren van gedetineerden tijdens detentie in de nota Taak en Toekomst (1982) in de programmering van het Wetenschappelijk Onderzoeks-en Documentatie Centrum van het Ministerie van Justitie als onderzocksvraag opgenomen (Grapendaal, 1987). Grapendaal concludeert dat er weliswaar sprake is van een subcultuur in de zin van een contra-cultuur in twee van de drie onderzochte inrichtingen, maar van een gemeenschappelijk gevoelde oppositie tegen de inrichting is geen sprake. Er is veeleer sprake van isolationisme en exploitatie. Deze bevinding staat, aldus Grapendaal, in schrille tegenstelling tot de uitkomsten van Amerikaans onderzoek, waarin oppositie en onderlinge solidariteit als toonaangevende componenten van de gedetineerden (sub)-cultuur worden aangetroffen. Oppositie kenmerkt slechts een relatief kleine groep. Grapendaal verklaart de afwezigheid van bij voorbeeld cen sterke onderlinge solidariteit uit een hoger voorzieningenniveau in Nederlandse gevangenissen, waardoor gedetineerden voor bepaalde behoeften minder sterk op medegedetineerden zijn aangewezen. Dit verschil werd tijdens mijn werkzaamheden eens heel duidelijk onder woorden gebracht door een Belgische gedetineerde, dic opmerkte dat het Nederlandse gevangenissysteem in zijn ogen in feite neerkomt op een doortrapt 'verdeel en heers'-systeem. Deze gedetineerde omschreef het als een systeem waarin gedetineerden niet meer solidair met elkaar zijn, maar alleen maar, via allerlei voorzieningen, bezig zijn hun zaken voor zichzelf zo goed mogelijk te regelen. Betrokken gedetineerde zat liever in België, waar de verhoudingen in de gevangenissen naar zijn gevoel veel duidelijker waren.

Opvallend, aldus Grapendaal, is de relatieve rust in de inrichtingen. In één inrichting hing dit vooral samen met de perceptie van zowel personeel als gedetineerden van complementaire en gedeelde belangen met betrekking tot een rustige en voorspelbare gang.

Grapendaal (ibid., p.79) merkt hierover het volgende op:

"Vastgesteld kan worden dat er weliswaar sprake is van een dichotome gevangenisgemeenschap, met aan de ene kant de gedetineerden en aan de andere kant de bewaarders en het overig personeel, maar dat een 'superordinate goal'- vanuit de gedetineerden gedefinieerd als eigenbelang-een balans in stand houdt. die het leven in de inrichting voorspelbaar makt."

Cloward (1969) kwam overigens tot soortgelijke bevindingen ten aanzien van een stabiele en rustige gang van zaken in gevangenissen en ook hij concludeerde dat de interactie tussen personeel en gedetineerden mede wordt gekenmerkt door een regulerend sociaal mechanisme ('structural accomodation') waarbij gedeelde belangen een rol spelen.

\subsubsection{Effecten van subculturen op houdingen en gedrag van gedetineerden.}

In de literatuur worden naar aanleiding van de vraag naar de invloed van subculturen in penitentiaire inrichtingen een tweetal effecten onderscheiden.

In de eerste plaats worden de effecten op korte termijn onderscheiden. Dit zijn de effecten die zich manifesteren tijdens detentie. Daarnaast worden effecten onderscheiden die na 
beëindiging van detentie optreden, dat wil zeggen de lange termijn effecten (Thomas en Petersen, 1977). Bij deze laatste effecten dient men te denken aan hernieuwd crimineel gedrag. Voor deze studie zijn vooral de korte termijn effecten van belang.

Deze effecten hebben in sociologische analyses betrekking op de relaties tussen gedetineerden onderling (Clemmer, 1940; Sykes en Messinger, 1960; Wheeler, 1961; Garabedian, 1964; Schrag, 1961), de relaties tussen gedetineerden en personeel (Street et al., 1966), het zelfbeeld van gedetineerden (Tittle,1972, Faine,1973), houding tegenover de gevangenisorganisatie als zodanig en de houding tegenover de doelstellingen van het penitentiair beleid (Street et al., 1966; Berk, 1966; Akers et al., 1977; Thomas en Zingraff, 1975)

Een belangrijk aspect van de gedetineerdencultuur is de aanwezigheid van bepaalde waarden en normenpatronen of gedragscodes die volgens Sykes en Messinger (1960) betrekking hebben op twee thema's namelijk oppositie tegenover de organisatie en onderlinge solidariteit.

In dit verband hebben onderzoekers tevens aandacht besteed aan de rollen die gedetineerden in de inrichting vervullen. Volgens Sykes en Messinger (1960) zijn de verschillende rollen uiteindelijk weer te herleiden tot oppositie en onderlinge solidariteit.

Andere onderzoekers gaan ervan uit dat er binnen de inrichting meerdere subculturen kunnen bestaan ( Irwin en Cressey, 1962; Irwin, 1970). Binnen deze subculturen kan het accent liggen op solidariteit, exploitatie van medegedetineerden en zich conformeren aan de officiële waarden en normen.

Samenvattend kan worden gesteld dat in het onderzoek van de korte termijn effecten van subculturen in penitentiaire inrichtingen de aandacht vooral is uitgegaan naar effecten als onderlinge solidariteit, oppositioneel gedrag van gedetineerden jegens de penitentiaire organisatie en het personeel en tevens naar onderling geweld tussen gedetineerden, collectieve geweldsuitbarstingen en druggebruik (Rook, 1983).

De gedetineerdencultuur hoeft zich niet steeds op een uniforme wijze te manifesteren. De inhoud van de gedetineerdencultuur kan per inrichting verschillen en heeft in de percepties van gedetineerden niet steeds dezelfde inhoud. In de literatuur worden verschillende wijzen van aanpassing genoemd die tot gevolg hebben dat er binnen de inrichting verschillende groepen of culturen zijn te onderscheiden.

Zo onderscheidt Goffman (1961) als reacties onder meer radicale regressie (isolationisme), intransigentie (oppositie) en opportunisme. Grapendaal (1987) stelt dat er in de inrichting grofweg drie groepen gedetineerden zijn te onderscheiden namelijk, een groep die loyaal is aan de heersende waarden en normen, een groep die zich afzijdig houdt en groep die het doelwit is van spotternijen. Er zijn kortom verschillende aanpassingsreacties en verschijningsvormen van de subcultuur.

De afgelopen decennia hebben onderzoekers vervolgens getracht een verklaring te vinden voor het ontstaan en voortbestaan van subculturen. Zoals reeds eerder in dit hoofdstuk bleek, treft men een drietal verklaringsmodellen aan, namelijk het deprivatie-model, het importmodel en het integratiemodel.

Het deprivatie-model berust op de veronderstelling dat prisonisatie of de aanpassing aan subculturele normen en waarden het gevolg is van de depriverende omstandigheden in de gevangenis (Sykes, 1958). Intra-institutionele of omgevingsfactoren staan bij deze benadering, waarbij de gevangenis als een gesloten systeem wordt beschouwd, voorop. De mate van prisonisatie heeft men binnen dit verklaringsmodel trachten vast te stellen via de verblijfsduur en of detentiefase, (Clemmer, 1940; Wheeler, 1961; Garabedian, 1963; Wellford, 1967; Akers et al., 1970), interpersoonlijke relaties, (Schrag, 1960), rolgedrag, het 
type organisatie (Street et al., 1966) en de mate van vervreemding. Een drietal factoren van intra-institutionele aard zijn voor dit onderzoek van belang. In de volgende paragrafen zullen deze worden besproken in het bijzonder in samenhang met de verklaring van de houdingen van gedetineerden ten aanzien van resocialisatie.

\subsubsection{Orde- en gedetineerdengerichte regimes, prisonisatie en de effecten op de houdingen van gedetineerden}

Een van de eerste studies waarin de samenhang tussen organisatie-kenmerken van de penitentiaire inrichting en houdingen van gedetineerden werd onderzocht is die van Street, Vinter en Perrow (1966). Zij vergeleken een zestal inrichtingen waarin al naargelang de heersende inrichtingsideologie een verschillend accent werd gelegd op orde-gerichte en gedetineerdengerichte aspecten van de detentie. Street et al. onderscheiden binnen deze inrichtingen een drietal institutionele modellen: het obedience/conformity-, treatment- en het re-education/development-model.

In elke inrichting treft men naast het doel van de ongestoorde tenuitvoerlegging van de gevangenisstraf in meerdere of mindere mate voorzieningen voor gedetineerden aan die gericht zijn op de voorbereiding van de terugkeer in de samenleving (beroepsgerichte- en basiseducatie al dan niet in combinatie met therapeutische bejegeningsvormen)

Vervolgens onderzochten Street et al. de houding van gedetineerden ten aanzien van het personeel en de algehele gang van zaken in de inrichting, hun wijze van aanpassing aan het inrichtingsregime en hun zelfbeeld.

De gedetineerden in de meer orde-gerichte inrichtingen beoordeelden de kwaliteit van de zorg op het gebied van recreatieve faciliteiten en de ondersteuning ten aanzien van de voorbereiding van de terugkeer in de samenleving veel negatiever dan de gedetineerden in de overige, meer gedetineerde-gerichte inrichtingen.

Voorts bleek het beeld dat gedetineerden van zichzelf hebben in de orde-gerichte inrichtingen veel minder positief dan dat van hun lotgenoten in de inrichtingen met een meer gedetineerdengericht regiem. Gedetineerden in de orde-gerichte inrichtingen hadden veel minder vaak het gevoel tijdens detentie iets geleerd te hebben over zichzelf en hun levenssituatie. Hun toekomstbeeld was bovendien veel pessimistischer.

Naarmate het verblijf in de inrichting langer duurde beleefden gedetineerden in de ordegerichte inrichtingen het regime en het optreden van het personeel steeds negatiever. Ook na controle van een eventuele invloed van achtergrondvariabelen met betrekking tot de gedetineerdenpopulatie bleven deze verschillen in beleving tussen de verschillende institutionele typen aanwezig.

Ook Feld (1981) constateert na controle op achtergrondkenmerken en interactie-effecten tussen kenmerken van gedetineerden en verschillende bejegeningsvormen, dat positieve houdingen van gedetineerden ten aanzien van de staf, een grotere mate van leefbaarheid, en een minder gewelddadige sociale structuur van de subcultuur van de gedetineerden samenhangen met een gedetineerden-gericht detentieklimaat. Op grond van deze studies mag men concluderen dat er een verband bestaat tussen de organisatie-kenmerken van de inrichting en de houding en het gedrag van gedetineerden.

Soortgelijk onderzoek werd verricht in Nederland door van der Linden (1981) en Berghuis (1981)

In deze studies werden inrichtingen met een verschillend regime onder meer vergeleken met betrekking tot detentiebeleving. De beleving van de detentie bleek in de inrichtingen met een ordegericht regime veel minder positief dan in de inrichtingen met een meer behandelings- of gedetineerdengericht regime. Echter de mogelijke verschillen in de houding ten aanzien van resocialisatie tussen gedetineerden van de verschillende typen inrichting werden in deze 
studies niet onderzocht. Zo blijkt uit de studie van van der Linden dat in de ordegerichte gevangenis (de Boschpoort) destijds slechts in beperkte mate aandacht werd besteed aan resocialisatie. In de gedetinecrde-gerichte inrichting werd in ruimere mate een aanbod van vormingsactiviteiten gedaan. De beleving van deze vormingsactiviteiten werd echter niet vergeleken met opvatting en beleving van resocialisatic van gedetineerden uit de inrichting met een meer ordegericht regime. In deze studie vergeleek men wel de beleving van de recreatieve activiteiten die veel negatiever werden beoordeeld in de orde-gerichte gevangenis. voomamelijk vanwege de beperkte faciliteiten.

Ook de reeds eerder genoemde WODC-studie van Grapendaal (1987) waarin bestan. aard en inhoud van de gedetineerdencultuur in een drietal inrichtingen werd onderzocht, toont de invloed van de inrichtingsideologie. De inrichtingsideologie bleek immers een belangrijke verklarende factor voor de gevonden verschillen in de gedetineerden-cultuur te zijn. Deze factor heefi, volgens Grapendaal belangrijke gevolgen voor de manier waarop gedetineerden hun detentie-situatie beoordelen. (zie ook Rook, 1983)

De recente onderzoeksliteratuur blijkt in binnen- en buitenland verder geen specifieke empirische studies op te leveren over de relatie tussen enerzijds de aard van de inrichtingsideologic (en het daarop gebaseerde beleid en regime) en anderzijds houdingen ten aanzien van middelen en doeleinden van resocialisatic.

Wel is er recent onderzoek waarin de invloed van meer restrictieve en liberale regimes wordt onderzocht vanuit het perspectief van de beheersbarheid van de inrichting en de aanpassing van gedetineerden aan hun detentie.

Wright (1991) onderzocht het effect van de gevangenisomgeving (geoperationaliseerd volgens een achttal omgevingsdimensies met betrekking tot regelgeving, veiligheid en de aanwezigheid van activiteiten) op de detentiebeleving en het regelschendend gedrag van gedetineerden. Ook hier zien we een positieve invloed van een meer gedetineerdengericht regime op de aanpassing van gedetineerden aan de detentie en in het bijzonder op het verminderen van stress.

Wright ( ibid., p.238) concludeert :

"Modifications in the environment of prisons will have some positive effects. First, results of the study conform the long-held view that productive and future-oriented inmates cause fewer problems. Specifically, increased activity and more support for self-improvement should lead to reductions in disruptive behavior."

De studie van Wright is tevens voor deze paragraaf van belang vanwege het onderscheid dat hij maakt tussen een inrichtingsklimaat op het niveau van de organisatie en op individueel niveau.

Wright stelt dat gedeelde ervaringen van de leden van een organisatie de basis vormen voor het klimaat of het algemene karakter van een organisatie.

Wright (ibid., p.225):

"Individuals, as they live and work in an organization. form impressions about the characteristics of the setting. These perceptions form the basis for what the individual expects from the environment. More global, organizational climates arise from members shared experiences. These contextual conditions tend to be enduring, distinguish the organization in question from other organizations, and affect the members' behavior. Organizational climate typically is reflected in the members common perceptions and is measured by averaged aggregate scores." 
Kommer (1991) noemt dit de actuele structuur als resultaat van interpretaties van de leden van de organisatie. Die interpretaties berusten op een individuele (persoonsgebonden) en collectieve ideologie. In Wright's onderzoek is het organisatieklimaat vooral het resultaat van een collectieve ideologie.

Het klimaat van de instelling zoals dat op het niveau van het individu wordt ervaren, betreft het geheel van eerdere ervaringen, privé-opvattingen, verwachtingen en individuele doelstellingen van personen in de organisatic. Wright (ibid., p.226) spreekt hier van de "unique but relative perception" door het individu van bepaalde kenmerken of dimensies van de organisatie. Zowel het gepercipieerde klimaat op het macroniveau van de organisatie als op het micro -niveau van het individu beinvloeden houdingen en gedrag. Het orde-gerichteversus gedetineerde gerichte karakter van de inrichtingsorganisatie zal in deze studie op de twee bovengenoemde niveaus aan de orde komen.

Gaat het om het instellingsklimaat op macro niveau dan zijn de observatie-eenheden afdelingen binnen een inrichting of inrichtingen zelf. Op het microniveau zijn de 'cases' de individuele respondenten.

Kenmerkend voor een dergelijke conceptualisering van het karakter van de organisationele context is het belang dat wordt gehecht wordt aan de interpretaties van de participanten of anders geformuleerd, het interactionistische perspectief. Vanuit deze visie is er dus geen sprake van een unidirectionele, deterministische relatie tussen het individu en zijn omgeving, deterministisch in de zin van omgevingsprikkels op basis waarvan de mens als een soort automaat altijd hetzelfde gedrag vertoont. Het gaat veeleer om het beeld van de mens als autonoom individu die de wereld interpreteert en op basis van die interpretaties iets doet of laat.

Beschouwt men op het niveau van het individu de beleving van ordegerichte of gedetineerde gerichte aspecten van het regime vanuit dit interactionistische perspectief, dan is het aannemelijk dat de percepties van deze aspecten verschillen zullen vertonen. Deprivatie is relatief en niet absoluut. Zo kan een Nederlandse gedetineerde die een detentie heeft uitgezeten in een inrichting voor langgestraften met een meer liberaal regime (Norgerhaven bij voorbeeld) zijn huidige detentie in een andere inrichting voor langgestraften met een meer restrictief regime, als meer ordegericht ervaren dan een mede-gedetineerde van buitenlandse komaf die tijdens een eerdere detentie in een buitenlandse gevangenis heeft doorgebracht onder voor Nederlandse begrippen, erbarmelijke omstandigheden.

Dat de perceptie of beleving van het regime aanmerkelijke verschillen kan vertonen blijkt ook uit de studie van Toch (1977).

De tevredenheid met het regime bleek in drie verschillende niveaus te kunnen worden onderverdeeld, namelijk in een lage, gemiddelde en hoge mate van tevredenheid.

Naarmate gedetineerden meer tevreden zijn leggen zij bovendien meer de nadruk op intensieve interpersoonlijke contacten en zelfherstel: zij tonen meer interesse in onderwijsprogramma's en leggen een grotere behoefte aan 'bezig zijn' aan de dag. Tenslotte hebben gedetineerden die tevreden zijn met het regime een minder sterke behoefte zich af te zetten tegen het gezag. Gedetineerden die weinig tevreden zijn met het regime hebben een ander behoeftepatroon dat veel sterker in het teken staat van de dimensie 'freedom', dwz. van autonomie.

Wright (1991) laat zien dat voor sommige gedetineerden een regime met een strakke en duidelijke regelgeving niet per definitie tot ontevredenheid en oppositie hoeft te leiden.

Volgens Wright kunnen gedetineerden met bepaalde psychische stoornissen heel goed gedijen en betrekkelijk weinig problemen veroorzaken in een regime met een duidelijke structuur en regelgeving. Een ordegericht regime hoeft niet per definitie steeds in negatieve 
zin ervaren te worden. Het gaat hier om wat Wright noemt "congruence as a measure of fit between person and environment".

Samenvattend kan worden geconcludeerd dat op grond van bestaand onderzoek het voor de hand ligt de mogelijke verklaring van houdingen van gedetineerden ten aanzien van resocialisatie voor een deel te zoeken in de beleving van de detentieomgeving, in het bijzonder van het regime. In het onderzoek wordt een negatief effect gevonden van een restrictieve (orde-gerichte) detentie-omgeving op houdingen en gedrag van gedetineerden. In het bijzonder zijn ook effecten van de omgeving gevonden op het ontstaan van een (oppositionele) gedetineerdencultuur. De vraag of die, als restrictief of depriverend ervaren detentie-omgeving ook de houdingen van gedetineerden ten aanzien van resocialisatie in negatieve zin beinvloedt, is nooit in expliciete en meer uitgebreide zin onderzocht. Op grond van het totnogtoe verrichte onderzoek lijkt het overigens wel plausibel dat depriverende en restrictieve factoren in de gevangenisomgeving, mogelijk via een oppositionele gedetineerdencultuur, negatieve houdingen ten aanzien van resocialisatie in de hand werken.

De onderzoeksliteratuur geeft bovendien geen eenduidig antwoord op de vraag hoe de invloed van een depriverende detentie-omgeving precies verloopt. Een nadere bepaling van de aard van de effecten van de detentieomgeving op de houdingen van gedetineerden blijft veelal achterwege. Of er sprake is van directe, indirecte of modererende effecten wordt niet duidelijk. Globaal gezien lijkt er op grond van het onderzoek dat zich bij de verklaring van houdingen en gedrag van gedetineerden baseert op een deprivatiemodel, vooral sprake te zijn van een indirect effect. Naarmate de omgeving als meer depriverend wordt ervaren, richten gedetineerden zich eerder tot een deviante, oppositionele gedetineerdencultuur. De sterkere betrokkenheid van gedetineerden bij deze subcultuur draagt er vervolgens toe bij dat gedrag en houdingen en mogelijk ook de houdingen ten aanzien van de resocialisatiegedachte een negatiever karakter krijgen.

In het gepostuleerde onderzoeksmodel verloopt de relatie tussen de detentieomgeving enerzijds en houdingen en gedrag anderzijds via de subjectieve beleving van de situatie.

De subjectieve beleving van de omgeving, in casu de beleving van het regime wordt in het onderzoeksmodel voorlopig beschouwd als een factor die mogelijk een indirect of een direct effect kan uitoefenen op de houding ten aanzien van resocialisatie.

Onderzocht zal worden of de beleving van het regime als meer orde- of gedetineerdengericht een bepaald direct of indirect effect oplevert voor de houdingen ten aanzien van resocialisatie. De aanwezigheid van een (oppositionele) gedetineerdencultuur wordt in dit onderzoek niet expliciet gemeten. Wel wordt in meer exploratieve zin, op grond van de gevonden resultaten gekeken of er indicaties zijn voor een bepaalde rol van de gedetineerdencultuur bij de invloed van omgevingsgebonden factoren op de houdingen ten aanzien van resocialisatie.

\subsubsection{De effecten van verblijfsduur en detentiefase}

Een belangrijke veronderstelling van Clemmer (1940) is dat met het voortschrijden van de detentie, de houdingen van gedetineerden ten aanzien van conventionele normen en waarden, voor een deel belichaamd in de officiële inrichtingscultuur, door de invloed van een oppositionele gedetineerdencultuur steeds negatiever zullen gaan worden. Aan de invloed van de gedetineerdencultuur ontsnapt, volgens Clemmer, vrijwel niet één gedetineerde. Gedetineerden vertonen, naar Clemmer veronderstelde, echter wel verschillen in de mate en snelheid waarmee men de werking van het prisonisatie-proces ondergaat.

Gedetineerden die het meest gevrijwaard blijven van het prisonisatie-proces kenmerken zich door positieve en meer hechte sociale relaties voorafgaand aan en tijdens de detentie, een korte opgelegde straftijd of een minder intensieve omgang met mede-gedetineerden. 
Clemmer trachtte de aanpassing van gedetineerden aan een gedetineerdensubcultuur vervolgens zichtbaar te maken door het 'process of induction' in de inrichtingscultuur te relateren aan de hoeveelheid tijd die men in een inrichting doorbrengt.

Uit onderzoek van Wheeler (1961) en Garabedian (1963) blijkt dat naarmate deze verblijfsduur toeneemt, gedetineerden zich inderdaad steeds meer negatief gaan opstellen ten aanzien van verwachtingen die het personeel heeft omtrent hun gedrag, houding en motivatie. De hypothese van Clemmer dat het tempo en de mate waarin gedetineerden het prisonisatieproces ondergaan mede afhankelijk is van de intensiteit van de contacten met medegedetineerden, werd eveneens bevestigd. Hoe meer zij contact zoeken met medegedetineerden des te minder sterk conformeren gedetineerden zich aan de verwachtingen van het gevangenispersoneel en des te meer is men geïnvolveerd in de gedetineerdencultuur. Wheeler constateert dat naar mate de verblijfsduur toeneemt er een zekere onverenigbaarheid optreedt tussen een conformistische houding enerzijds en het hebben van sterke banden met medegedetineerden anderzijds. Er is sprake van een polarisatie van enerzijds conformisten die zich nauwelijks inlaten met de rest van de gedetineerden en anderzijds non-conformisten die zich in hun contacten sterk richten op medegedetineerden. Bijgevolg ontstaat er een tweedeling van enerzijds gedetineerden die in toenemende mate geprisoniseerd raken en anderzijds gedetineerden die het isolement zoeken. Echter de tendens tot non-conformisme of tot oppositie is over het algemeen dominanter.

Wheeler betrok tevens de detentiefase in zijn onderzoek. Wheeler acht dit op het eerste gezicht een belangrijke factor omdat gedetineerden eigenlijk nooit meteen kunnen aangeven hoe lang zij al zitten, maar des te exacter weten hoe lang zij nog moeten. De tijdsperiode die men nog moet uitzitten is in de beleving van de gedetineerden belangrijker. Wheeler relateerde scores op een conformisme-schaal aan drie categorieën gedetineerden die in een begin-midden-en eindfase van hun detentie verkeerden. Het percentage lage scores op de conformisme-schaal nam per fase geleidelijk toe. Het percentage hoge-scores op deze schaal vertoonde echter een $U$-vormig patroon: begin- en eindfase van de detentie worden gekenmerkt door een overwegend sterke gerichtheid op conventionele waarden en normen. Wheeler concludeert dat gedetineerden zich het minst conformeren aan de officiële normen en waarden gedurende de middenfase van de detentie. Het prisonisatie-proces doet zich in deze fase het sterkst gelden. Er is tevens sprake van een proces waarbij de binding met de maatschappij in sterkte varieert. Deze binding is het sterkst in de begin- en eindfase van de detentie en het zwakst gedurende de middenfase. De prisonisatie-theorie wordt dus in zijn meest scherpe vorm zichtbaar als men naar de variable verblijfsduur kijkt. Bij de variabele detentie-fase wordt een meer genuanceerd, complex proces zichtbaar dat slechts ten dele is te interpreteren in termen van een prisonisatie-proces. Wheeler neemt tenslotte ook nog de mogelijkheid in ogenschouw dat het cyclische karakter van de aanpassing wellicht verdwijnt als men controleert op sociale-wenselijkheid, echter op grond van de data blijkt er toch geen sprake te zijn van een schijneffect.

Hoewel een uitgebreid overzicht van de verschillende interpretaties van dit cyclische aanpassingsproces buiten het bestek van deze paragraaf valt, is het wellicht verhelderend de interpretatie van Sykes en Messinger (1960) in het kort weer te geven.

Hun verklaring komt op het volgende neer: het leven in een gevangenis heeft als belangrijke consequentie voor gedetineerden dat hun zelfwaardering negatief wordt beïnvloed. Men zoekt zijn toevlucht tot een gedetineerden(sub)cultuur waarin men een bepaalde status en een positief zelfbeeld ontleent aan criminele, subculturele waarden en normen. De rol van de 
gedetineerdencultuur is in dit opzicht functioneel en probleemoplossend van aard. Naarmate het einde van de detentie in zicht komt, zo veronderstellen Sykes en Messinger en Wheeler, ervaart men de problemen van het gevangenisleven als minder acuut en pijnlijk. Men richt zijn blik weer meer op de buitenwereld en wendt zich af van de gedetineerdencultuur die men niet meer zo dringend nodig heeft. De statusdefinities van de gedetineerdencultuur verliezen hun waarde. Volgens Wheeler blijven ook na ontslag status-degradatie en (maatschappelijke) uitsluiting kenmerkend voor de situatie van de (ex)-gedetineerde.

Voor de meeste gedetineerden breekt bij de terugkeer in de samenleving cen periode aan waarin status-degradatie in cen andere vorm wordt gecontinueerd, de gedetineerdencultuur heeft dan ook niet zo zeer een probleemoplossende functie, veeleer stelt zij de confrontatie met problemen als gevolg van status-degradatie en stigmatisering uit.

Het prisonisatie-onderzoek waarin men detentiefase en verblijfsduur relateerde aan houdingen van gedetineerden vertoont overigens geen consistent beeld wat de uitkomsten betreft. Meer recente studies (Atchley and Mccabe, 1968; Bukstel and Kilmann, 1980; Thomas, Petersen and Zingraff, 1978; Troyer and Frease, 1975) vertonen wisselende resultaten. Bovendien dient men zich te realiseren dat een grotere mate van betrokkenheid bij een gedetineerdensubcultuur en negatieve houdingen ten aanzien van de officiële inrichtingscultuur niet per definitie leiden tot een grotere kans op terugval na detentic. Het tegendeel kan het geval te zijn. De terugval bij minder geprisoniseerde gedetineerden bleek in ene studie van Miller and Dinitz (1973) veel hoger te zijn.

Een belangrijke studie die hier niet onvermeld mag blijven, is die van Zamble en Porporino (1988, 1990). Zamble en Porporino onderzochten het coping gedrag van gedetineerden dat wil zeggen, de manier waarop zij omgaan met de stressvolle omstandigheden van een detentie. Zij onderzochten tevens de vraag in welke fase van de detentie gedetineerden nu het meest gemotiveerd zijn voor programma's gericht op gedragsverandering. De begin- en eindfase blijken de meest geschikte momenten te zijn om resocialisatie-programma's aan te bieden. Echter, alleen de conclusies ten aanzien van de geschiktheid van de beginperiode berusten op empirische gegevens. De meeste gedetineerden zijn bij aanvang van de detentie gemotiveerd voor programma's die hun psycho-sociaal welzijn en hun maatschappelijke positie kunnen versterken. Enkele maanden later echter bleek uit de 'drop-out' cijfers dat de motivatie en ontvankelijkheid van deze groep gedetineerden voor bepaalde interventies was verminderd.

Zamble en Porporino (1990, p.64):

" Inmates dropped out of self-improvement programs and and took routine institutional jobs, and they switched their concern from the outside to the daily grind of existence within prison."

Zamble en Porporino's studie laat tevens zien dat gedetineerden wier motivatie voor zelfherstel reeds in de eerste maanden van de detentie afneemt, tevens een grotere kans op recidive vertonen.

De onderzoekers veronderstellen verder dat voor bepaalde vormen van gedrag, een interventie in de eindfase van de detentie het meest effectief is. Hierbij dient men zich vooral te richten op vaardigheden die van pas komen bij het omgaan met levenssituaties in de vrije maatschappij. Zamble en Porporino:

"(...) ideale, one should lay down the basis of behavioral change at the very beginning of a term and then reinforce and build on the foundation before and just after the time of release". (p.67) 
Pogingen om het coping-gedrag ten aanzien van de specifieke problemen van de detentiesituatie, bij voorbeeld gedurende de midden-fase van detentie te verbeteren zullen weinig of geen invloed hebben op coping-vaardigheden in normale levenssituaties buiten de gevangenis vanwege de grote verschillen tussen de gesloten gevangenisgemeenschap en het leven in de vrije maatschappij, aldus Zamble en Porporino.

Tenslotte, Zamble en Porporino lijken de grotere mate van gemotiveerdheid van gedetineerden voor programma's gericht op zelfverbetering aan het begin van de detentie vooral toe te schrijven aan de 'shock of incarceration' en niet zozeer aan de, aanvankelijk nog sterke binding met de maatschappij buiten de muren.

De studie van Zamble en Porporino is naast die van Street et al. (1966) een van de weinige studies waarin houdingen van gedetineerden ten aanzien van resocialisatie in verband worden gebracht met de variabelen verblijfsduur en detentie-fase.

Uit de studie van Whittington (1994) die wij in het vorige hoofdstuk bespraken, blijkt tenslotte ook dat bepaalde activiteiten zoals onderwijs voor langgestraften in de middenfase van de detentie tevens een belangrijke functie vervullen voor het hanteren van de problemen van een langdurige detentic.

Samenvattend kan worden gesteld dat onderzoekers in het kader van het prisonisatieonderzock de werking van een gedetineerdencultuur tevens hebben proberen aan te tonen via factoren als strafduur, verblijfsduur en detentic-fase. Door middel van deze tijdsvariabelen wordt in sommige studies de negatieve werking van een gedetineerdencultuur inderdaad manifest. Echter het effect in dit verband op houdingen van gedetineerden ten aanzien van resocialisatic is tot op heden niet in uitgebreide zin onderzocht.

In deze studie zullen houdingen ten aanzien van resocialisatie worden gerelateerd aan tijdsvariabelen als opgelegde strafduur, verblijfsduur en detentiefase. Tevens zal de mate van contact met medegedetineerden worden gerelateerd aan de houdingen ten aanzien van resocialisatic

Eventucel gevonden verschillen kunnen wellicht worden toegeschreven aan het effect van mogelijk aanwezige prisonisatie-processen. Deze aanwezigheid wordt in deze studie, zoals wij reeds in de vorige paragraaf stelden, op zichzelf niet verder onderzocht, eenvoudigweg om de reden dat dit het onderzoek tot een veel te omvangrijke onderneming zou maken. In dit opzicht kan men het karakter van deze studie eerder als exploratief beschouwen en niet zozeer als toetsend.

\subsection{De invloed van persoonsgebonden factoren}

Bezwaren die tegen de verklaring van de houdingen van gedetineerden op grond van het deprivatie-model zijn aangevoerd hebben betrekking op het statische karakter van het model: verschillen in subculturen en in de mate van prisonisatie van gedetineerden kunnen niet afdoende worden verklaard door dit model.

Deze kritiek heeft geleid tot de ontwikkeling van een aangepast deprivatie-model en het import- model. In het aangepaste deprivatie-model wordt de mate van deprivatie afhankelijk gesteld van organisatie-kenmerken, in het bijzonder het orde- of behandelings gerichte karakter van het regime (zie bijvoorbeeld Street et al., 1966). Niettemin blijft zelfs in dit aangepaste deprivatie-model een opvatting aanwezig waarbij de inrichtingsorganisatie en de gedetineerdencultuur als gesloten systemen worden beschouwd, dwz als onafhankelijk van pre-detentie ervaringen van gedetineerden. 
Deze laatste factor nl. pre-detentie ervaring vormt de basis van het alternatieve model voor de verklaring van het aanpassingsproces $\mathrm{nl}$. het importmodel (Irwin en Cressey, 1962; Thomas and Peterson, 1977). In het onderzoek op basis van het importmodel kan zowel het sociaal systeem van gedetineerden de analyse-eenheid zijn als de individuele gedetineerde.

In dit laatste type studie wordt gezocht naar directe verbanden tussen gedragingen en de houdingen van gedetineerden ten opzichte van het personeel en medegedetineerden enerzijds en achtergrondkenmerken dat wil zeggen pre-detentiefactoren anderzijds.

Pre-detentie factoren die men overigens niet op consistente wijze in verband heeft kunnen brengen met prisonisatie zijn:

-algemene sociaal-economische en demografische factoren als leeftijd, etnische achtergrond, ras, opleidingsniveau, sociaal economische status en arbeidssituatie (Alpert,1979; Jensen en Jones, 1976; Schwartz,1971; Thomas, 1977);

-druggebruik. Een recente studie van Winfree et al. (1994) toont aan dat druggebruik geen voorspellende waarde heeft voor wat betreft de mate van aanpassing aan een deviante, oppositionele subcultuur, maar wel voor de mate waarin men zich negatief opstelde ten aanzien van hulpverleners;

-strafrechtelijk en penitentiair verleden (Alpert, 1979; Wellford, 1967; Zingraff, 1980; Flanagan, 1983);

-participatie in een criminele subcultuur voorafgaand aan de detentie (Thomas en Poole,1975; Zingraff, 1980);

-het zelfbeeld van het individu (Faine,1973; Hepburn en Stratton, 1977, Tittle, 1972);

-identificatie met politieke, sociale raciale en religieuze ideologieën (Irwin,1980; Jacobs, 1976).

Door Thomas et al (1978) is kritiek geleverd op deze benadering als zijnde een simplificatie omdat men te veel de nadruk legt op factoren die reeds bij aanvang van de detentie aanwezig zijn.

Er zijn tal van andere belangrijke factoren die los staan van de detentie-situatie en in het onderzoek op basis van het import-model toch over het hoofd worden gezien. Zij noemen bij voorbeeld de mate waarin gedetineerden de mogelijkheid hebben om contact te onderhouden met de buitenwereld en de verwachtingen die zij hebben ten aanzien van het leven na detentie als het gaat om steun van familie en het vinden van werk. Het verband tussen deze factoren in het bijzonder met toekomstverwachtingen is door Thomas et al. vastgesteld (Thomas en Foster, 1972; Thomas, 1973; Thomas, 1977; Thomas Petersen en Zingraff, 1978). In een studie van Zingraff (1975) werd gevonden dat de aard van toekomstverwachtingen van invloed is op de mate van prisonisatie en op de effecten van prisonisatie. Ongunstige toekomstverwachtingen leiden eerder tot prisonisatie en tot oppositionele houdingen ten aanzien van de inrichtingsorganisatie en conventionele normen en waarden. Hoe (on)gunstiger gedetineerden de toekomst zien des te (meer) of minder is men verwikkeld in de gedetineerdencultuur en des te meer (of minder) ontvankelijk zij zijn voor pogingen tot zelfverbetering. Toekomstverwachtingen hebben vooral een modererend effect (Zingraff, 1975). De aard van de toekomstverwachtingen wordt vooral gezien als een factor die de mate van prisonisatie kan versterken of afzwakken.

De persoonskenmerken die voor dit onderzoek werden geselecteerd zijn opleiding, burgerlijke staat, arbeidssituatie voorafgaand aan detentie, drugsgebruik, leeftijd, etnische achtergrond, recidive en toekomstverwachtingen. Qua theoretische origine en qua wijze van operationalisatie heeft de variabele toekomstverwachtingen in de onderzoeksliteratuur steeds het karakter van importvariabele (Grapendaal,1987), dat wil zeggen een variabele die onafhankelijk is van de detentiesituatie. In het hiervoor beschreven onderzoeksmodel dient de variabele toekomstverwachtingen eveneens als een importvariabele te worden beschouwd. 
De relatie tussen de pre-detentie factoren en houdingen ten aanzien van resocialisatie kan men vanuit het conceptuele model op gelijksoortige wijze omschrijven als de veronderstelde relaties op basis van een deprivatie-model. Enerzijds kan men de aard van de houdingen mogelijk voor een deel verklaren op grond van een direct effect van de pre-detentiefactoren. Zoals wij in het vorige hoofdstuk zagen, lijken factoren als leeftijd, burgerlijke staat, etnische achtergrond een direct effect te hebben op bij voorbeeld de deelname aan de activiteiten en daarnaast wellicht ook op de beleving en opvattingen inzake resocialisatie.

Maar ook bij de pre-detentiefactoren kan wellicht sprake zijn van indirecte effecten op de houdingen ten aanzien van resocialisatie, bijvoorbeeld via het proces van prisonisatie. Predetentie-ervaringen leiden tot een gedeelde achtergrond in termen van houdingen, (subculturele) normen en waarden. Deze gedeelde achtergrond leidt tot het ontstaan van een deviante gedetineerdencultuur die vervolgens tot negatieve houdingen ten aanzien van resocialisatie leidt.

Uitgaande van het conceptuele model dat in essentie een integratie-model is, zou men de rol van de pre-detentie factoren voor zover het prisonisatie-verschijnselen betreft als volgt kunnen preciseren.

Een oppositionele subcultuur van gedetineerden is een reactie op de depriverende detentiesituatie, maar de mate waarin gedetineerden zich de normen en waarden van die tegencultuur eigen maken is mede afhankelijk van persoonlijke, van de detentie onafhankelijke, kenmerken van gedetineerden.

De invloed van de pre-detentiefactoren op de mate van betrokkenheid bij de gedetineerdencultuur, ook wel de mate van prisonisatie genoemd, is wellicht van een modererende aard. Bepaalde factoren van persoonlijke aard zoals de aard van de toekomstverwachtingen kunnen spanningen als gevolg van de depriverende detentie- situatie afzwakken of juist versterken en aldus het proces van het zich eigen maken van de normen en waarden van de tegencultuur in positieve of negatieve zin beïnvloeden.

Ook bij de persoonsgebonden, detentiesituatie-onafhankelijke variabelen zullen dergelijke indirecte effecten via de manifestatie van een (oppositionele) gedetineerdencultuur niet in expliciete zin worden vastgesteld. Er wordt hooguit in exploratieve zin gekeken naar een indicatie van de invloed van een mogelijk aanwezige gedetineerdencultuur.

\subsection{Recente kritiek op het prisonisatie-onderzoek.}

Zowel het deprivatie-model als het importmodel werden bekritiseerd om een eenzijdige benadering van het aanpassingsproces en sindsdien zijn er pogingen ondernomen om tot een integratie van beide modellen te komen, het zogenaamde integratie-model. Binnen dit model wordt het aanpassingsproces van gedetineerden aan het leven in detentie verklaard met drie groepen variabelen, nl. achtergrondkenmerken, de met de (depriverende) detentie samenhangende factoren en de verwachtingen van gedetineerden met betrekking tot de periode na ontslag (Thomas en Foster,1972; Thomas en Petersen,1977; Thomas Petersen en Zingraff, 1978).

Sinds het begin van de jaren tachtig kan men spreken van een zekere consensus ten aanzien van de gedachte dat beide modellen elkaar niet hoeven uit te sluiten.

Het is opvallend dat na deze hausse aan prisonisatie-onderzoek aan het eind van de jaren zeventig deze vorm van onderzoek min of meer een terugval heeft beleefd.

Dit heeft wellicht te maken met veranderende opvattingen ten aanzien van de haalbaarheid van de resocialisatie-doelstelling en de opkomst van meer punitieve en meer pragmatische visies op detentie. Wellicht is een oorzaak ook te vinden in de resultaten van het prisonisatie- 
onderzoek. Zamble en Porporino (1988) bestempelen de resultaten van het prisonisatieonderzoek als teleurstellend met name in theoretisch opzicht.

En inderdaad, de onderzoeksresultaten wijzen geenszins uitsluitend in de richting van een van de drie genoemde modellen. In bepaalde studies lijken de resultaten het ene model te bevestigen in weer andere studies vindt men weer ondersteuning voor het andere model. Ook binnen het onderzoek van een bepaald model zijn de gevonden samenhangen allesbehalve consistent en bovendien vaak zwak. (Bowker, 1977; Hawkins, 1976; Thomas, 1977; Thomas en Peterson, 1977; Zingraff, 1980). Een factor die zeer belangrijk wordt geacht voor de aanwezigheid van prisonisatie-processen $\mathrm{nl}$. verblijfsduur is evenmin op een eenduidige en consistente manier aangetoond. (Atchley en Mc Cabe, 1968; Bukstel en Kilmann, 1980; Thomas, Petersen en Zingraff, 1978; Troyer en Frease, 1975; Wheeler, 1961).

Een zeltde conclusie kan men trekken ten aanzien van studies wararin de invloed van de gevangenis op de persoonlijkheid vanuit (klinisch) psychologisch en psychiatrisch perspectief wordt onderzocht. Ook hier zijn de resultaten allesbehalve consistent en weerleggen in leite de opvatting dat gevangenschap in gelijke mate schadelijk is voor gedelineerden (zie voor een overzicht van de relevante literatuur Zamble en Porporino, 1988).

Er zijn verschillende redenen aan te wijzen voor het gebrek aan vooruitgang in het onderzoek waarbij aanpassingsprocessen vanuit het begrip prisonisatie worden benaderd.

Allereerst zijn er een aantal methodologische problemen met betrekking tot de indicatoren voor het concept prisonisatie. Deze vertonen grote onderlinge verschillen qua inhoud (regelschendend gedrag, mate van onderlinge solidariteit, conformeren aan subculturele normen, enz), qua betrouwbaarheid en validiteit (Poole. Regoli en Thomas, 1980).

Verder zijn de meeste studies cross-sectioneel en niet longitudinaal.

Het tweede bezwair is meer van theoretische aard en heeft betrekking op de grote nadruk in de verklaring van het prisonisatie-proces op uniformiteit in de reactics van gedetineerden. Men heeft met andere woorden het onderzoek eenzijdig gericht op het verklaren van datgene wat gedetineerden gemeenschappelijk hebben in hun reactie op hun detentie. Zamble en Porporino (1988, p.9) constateren dat:

"It has directed criminological research to the explanation of uniformity in behavior, rather than individual behavior".

En ook Wright (1991, p.218) stelt dat: "Unfortunately, scholars have tended to direct their attention toward the mechanisms that promote anti-social behavior and attitudes among prisoners rather than striving for more global views of the determinates of behavioral reponses".

Grapendaal (1987) lijkt eveneens een dergelijke eenzijdigheid te constateren als hij opmerkt dat een contextueel kader waarin resultaten geplaatst kunnen worden in de literatuur veelal ontbreekt.

Zamble en Porporino (1988) bepleiten een gewijzigde benadering van het begrip prisonisatie voor in het onderzoek van aanpassingsprocessen in gevangenissen.

$\mathrm{Zij}$ gaan ervanuit dat de gevangenisomgeving het gedrag van het individu op vele manieren kan beinvloeden en het is heel goed mogelijk dat individuen die in gelijke mate 'geprisoniseerd' zijn, op bepaalde andere dimensies verschillen vertonen die op hun beurt weer van invloed kunnen zijn op de wijze waarop men zich aanpast.

Zij bepleiten dan ook een soort analyse van het aanpassingsproces die minder grof is dan de totnogtoe beproefde analyse-methoden. Hun onderzoeksstrategie komt er vervolgens op neer dat prisonisatie niet meer wordt gezien als de voornaamste, te voorspellen aanpassingsvorm, 
maar prisonisatie definiëren zij als 'attitudinal factor' die in combinatie met andere variabelen de aanpassing beïnvloedt.

Kern van hun aanpak is een verklaring zien te vinden voor de verschillen in het functioneren van gedetineerden tijdens de detentie, korton voor de verschillen in het aanpassingsproces van gedetineerden.

Cruciaal bij deze betrekkelijk nieuwe benadering van aanpassingsprocessen is de interactie tussen het individu en zijn omgeving. Zamble en Porporino (1988, p.9) merken hierover op:

"(...) studies that have related offender background differences and institutional practices or structural factors with more specific aspects of behavior in prison have been much more succesful in explaining differences in reaction to imprisonment".

Een van de studies die zij in dit verband noemen is die van Toch (1977).

De opzet van de onderhavige studie vertoont gelijkenis met de hierboven door Zamble en Porporino voorgestelde onderzoekstrategie. Deze gelijkenis is overigens niet rechtstreeks aan Zamble en Porporino ontleend. Pas zeer recentelijk, na afronding van het veldonderzoek en na raadpleging van nieuwe relevante literatuur stuitte ik op deze bron van overeenkomst.

In de voorliggende studie gaat het niet om het verklaren van aanpassingsprocessen. Aanpassing aan een gedetineerdencultuur of prisonisatie figureert in deze studie als een variabele die mogelijk een samenhang vertoont met de afhankelijke variabelen, namelijk opvattingen, beleving van en deelname aan resocialiserende activiteiten.

\subsection{Coping en houdingen ten aanzien van resocialisatie}

Een voor deze studie belangrijke, aan de literatuur ontleende veronderstelling is dat een beschrijving en verklaring van gedrag en houdingen van gedetineerden tijdens detentie in jeder geval rekening zou moeten houden met het gegeven van de depriverende en belastende aard van de detentie. Een belangrijke veronderstelling voor deze studie is tevens dat het gedetineerd worden en vervolgens het gedurende kortere of langere tijd gedetineerd zijn voor vrijwel alle gedetineerden spanningen oproept. De verschillende bronnen van spanning zijn in de afgelopen jaren uitgebreid beschreven.

Als belangrijkste kunnen we hier noemen het verlies van bewegingsvrijheid en daarmee van autonomie, privacy, degradatie van de maatschappelijke status, het gemis van bepaalde materiële goederen en diensten, en het isolement van en mogelijk verstoorde relaties met de naasten.

Zoals in het begin van dit hoofdstuk bleek kunnen reacties van gedetineerden op deze 'pains of imprisonment' verschillen vertonen. Een belangrijk uitgangspunt voor dit onderzoek is dat de invloed van de gevangenisomgeving op het individuele gedrag niet deterministisch van aard is. Het beeld van gedetineerden als passieve objecten die gelijkelijk en universeel slachtoffer worden van de schadelijke werking van de gevangenisomgeving lijkt, als men als onderzoeker of werknemer wat langere tijd in een gevangenis verblijft, weinig plausibel. Bovendien is deze veronderstelling, op basis van resultaten van onderzoek naar de effecten van detentie, moeilijk houdbaar.

Of en in welke mate detentie leidt tot destructieve effecten lijkt veeleer afhankelijk te zijn van een samenstel van factoren van persoonlijke, situationele en organisatorische aard.

Een interactionistische benadering waarbij wordt gekeken naar zowel de eigenschappen van de omgeving of situatie als naar de verschillende wijzen waarop het individu kan omgaan met die situatie lijkt derhalve een meer voor de hand liggende benadering. 
Een interactionistische benadering kan indien aangevuld met de leerstukken van de copingtheory zoals geformuleerd door Lazarus en Launier (1978), cen vruchtbaar conceptueel kader bieden voor deze studie.

In het conceptueel model dat wij aan het begin van het hoofdstuk opstelden wordt het gedrag dat men aanwendt om bepaalde spanningen van de detentie te hanteren als element opgevoerd. Dit hanteren van spanningen of coping heeft een plaats in het model gekregen ondat de houdingen ten aanzien van resocialiserende voorzieningen voor een deel kunnen worden begrepen als een reactie op de spanningen van een depriverende detentieomgeving. Een belangrijke vraag die vervolgens rijst is in welk opzicht opvattingen, beleving en deelname inzake resocialisatie nu zijn te beschouwen als een vorm van coping.

Alvorens nader in te gaan op de relatie tussen het begrip coping en de houdingen ten aanzien van resocialisatie is het wellicht verhelderend een voorbeeld te geven van de wijze waarop de interactie tussen de individuele gedetineerde en zijn omgeving beschreven kan worden in termen van coping-gedrag. Dit voorbeeld waarin twee gedetineerden A en B voorkomen is geïnspireerd op de observaties die $i k$ in de loop der jaren deed gedurende mijn werkzaamheden in de gevangenis.

Veronderstel twee gedetineerden A en B die in gelijke mate te maken hebben met de restrictieve leefomstandigheden van een regime waarin zij zijn geplaatst. Gedetineerde A heeft vanwege zijn karakter en eerdere ervaringen, kortom op grond van zijn persoonlijke individuele kenmerken sterk de neiging om de buitenwereld, bijvoorbeeld justitie en de maatschappij, de schuld te geven van de depriverende situatie waarin hij nu verkeert. Hij reageert op de spanningen van zijn detentie door te klagen en de confrontatie of het gevecht aan te gaan met het personeel. Niets of niemand deugt in zijn interactie met het bewarend personeel of met de crea-begeleider en er ontstaan als gevolg daarvan steeds discussies. De geringste aanleiding bij de crea-activiteiten, zoals een ontbrekend schroefje gebruikt hij om los te barsten in een scheldtirade over de slechte voorzieningen, slecht personeel enz. Gedetineerde B heeft de neiging om de oorzaak voor de situatie waarin hij zich nu bevindt vooral te zien als een kwestie van persoonlijk falen. Hij is in staat na een langdurig proces van geestelijk zelfonderzoek de oorzaak ook daadwerkelijk bij zichzelf te leggen. Hij heeft vastgesteld dat als er iemand is die iets kan verbeteren aan zijn situatie, hijzelf de meest aangewezen persoon is. Hij klaagt nooit. Hij toont zich serieus bij activiteiten als onderwijs en kunstzinnige vorming. Hij wordt geaccepteerd door zijn medegedetineerden hoewel hij niet duidelijk tot de gedetineerdensubcultuur behoort. Gedetineerde A heeft zich intussen wel goed ingewerkt in de gedetineerdensubcultuur, heeft alle gedachten aan de toekomst uitgebannen en besteed zijn tijd nu voornamelijk alleen nog maar aan klagen, medestanders zien te vinden en subversief gedrag. Bij de crea lijkt hij alleen nog maar langs te komen als hij in is voor een weer een nieuw conflict met het personeel. Hij doet dit bij voorbeeld door naar een materiaal te vragen waarvan het reeds van tevoren vast staat dat het nooit direct voor handen is. Het ontbrekend materiaal is vervolgens een aanleiding om helemaal uit zijn dak te gaan. Na verloop van tijd blijkt gedetineerde A te zijn overgeplaatst naar een andere afdeling met een restrictiever regime dat meer structuur biedt. Gedetineerde A kon, zoals dat heet, niet overweg met de vrijheden en verantwoordelijkheden die hem in het eerdere regime werden gegund. Gedetineerde B echter die ook nog vele jaren moet, behaalt bij onderwijs een diploma en bij crea ontpopt hij zich tot een talentvol schilder. Het personeel krijgt een steeds meer positief beeld van deze gedetineerde, geeft hem een fel begeerd baantje als reiniger en kweekt zoveel goodwill door zijn gedrag en constructieve opstelling dat hij en nog een aantal andere gedetineerden voor kunstzinnige activiteiten extra tijd en faciliteiten 
krijgen. Bij het slagen voor zijn middenstandsdiploma kreeg hij zelfs een geschenk van het afdelingshoofd.

Beide gedetineerden die nog vele jaren hebben te gaan blijken op grond van de verschillende wijze waarop zij op de detentieomstandigheden reageren ook anders behandeld te worden door personeel en medegedetineerden. Deze ervaringen zijn op hun beurt weer van invloed op de emotionele respons en op de wijze waarop deze gedetineerden hun gevangenisomgeving zullen beoordelen. Gedetineerde A keert vermoedelijk op een andere wijze terug in de samenleving dan gedetineerde $B$.

De manier waarop gedetineerden reageren op een potentieel stressvolle detentie-situatie en de effectiviteit van deze inspanningen zou men kunnen omschrijven als een voortdurende transactie tussen individu en omgeving waarbij het individu ook de omgeving kan beïnvloeden via allerlei hanteringgedrag. Dit hanteringgedrag brengt men in de Anglosaksische literatuur onder de noemer van het begrip 'coping'. Lazarus en Launier (1978, p.311) omschrijven coping als:

"efforts both action oriented and intrapsychic to manage (i.e. master, tolerate, reduce) environmental and internal demands and conflicts which tax or exceed a person's resources."

Men kan coping derhalve beschouwen als alle cognitieve, affectieve en pogingen (inclusief de inefficiënte pogingen) die erop gericht zijn het probleem, dan wel de negatieve emoties die ermee samenhangen terug te brengen. Het kan daarbij gaan om reacties die bewust of onbewust zijn of om inspanningen op de korte of lange termijn en om actieve of passieve reacties. Uitgaande van de bovengenoemde omschrijvingen kan men er vanuit gaan dat zeer veel gedrag dat samenhangt met spanningen of stress onder de noemer van het begrip coping vallen. Het feit dat naar de opvatting van sommige onderzoekers een verblijf in de gevangenis kan worden beschouwd als een permanente crisisperiode waarvoor de bekende of geijkte oplossingsmechanismen ontoereikend zijn en dus voortdurend coping-gedrag vereist, maakt de relevantie van het begrip coping voor de penologie alleen maar groter.

Coping-gedrag of hanteringgedrag heeft men getracht te structureren via een aantal taxonomieën. Een van de meest geaccepteerde indelingen (Rijsman, 1981) is de volgende driedeling in:

1. Probleemgericht handelen, hetgeen neerkomt op een consistente, doordachte en systematische benadering van een problematische situatie waarbij gedragsverandering als een belangrijke optie wordt gezien.

2. Herbeoordeling van de situatie: hetgeen neerkomt op het handhaven van een positief zelfbeeld middels diverse cognitieve strategieën, zoals relativeren, het kiezen van andere vergelijkingspersonen of dimensies bij wie men er wel goed afkomt en het vergroten van de afstand tot bestaande vergelijkingspersonen of dimensies

3. Vluchtgedrag of emotie gerichte coping via welke men negatieve gevoelens reduceert. In zekere zin betekent deze laatste strategie het opgeven van het streven naar een positief zelfbeeld.

Vertaalt men deze drie hanteringstrategieën naar de detentiestuatie dan worden een aantal reactiepatronen van gedetineerden inzichtelijker. Gedetineerden die de situatie waarin zij verkeren op een meer probleemgerichte wijze willen benaderen zullen waarschijnlijk eerder hun toevlucht nemen tot deelname aan programma's waarbij het zelfherstel voorop staat. Gedetineerde B uit het boven beschreven voorbeeld is typisch een gedetineerde die kiest voor een meer probleemgerichte aanpak. 
Zo lijkt herbeoordeling of heroriëntatie door het vergroten van de afstand tot bestaande vergelijkingspersonen of dimensies heel goed toepasbaar op het zich wenden tot de gedetineerden-subcultuur'. Men keert zich af van vergelijkingspersonen of dimensies die conventionele waarden belichamen en men richt zich vervolgens op een wereld met subculturele waarden en normen waarbij men makkelijker een positief zelfbeeld kan handhaven. $\mathrm{Bij}$ Wheeler, (1961, p.172) vinden we een treffende omschrijving van de belangrijkste functie van de gedetineerdencultuur voor gedetineerden.

Het handhaven van een positief zelfbeeld van de gedetineerde door middel van de gedetineerdencultuur wordt bij Wheeler omschreven als "to reject his rejectors, rather than himself". Deze interpretatie geeft duidelijk aan dat er sprake is van heroriëntatie. Gedetineerde A uit het voorbeeld is dan ook typisch iemand die kiest voor heroriëntatie Vluchtgedrag is een welbekend verschijnsel in gevangenissen. Dhondt (1989) noemt reactievormen als terugtrekking in de fantasie en realiteitsvervreemding die worden aangewend als middel om ondraaglijke leefomstandigheden draagbaar te maken. Drugsgebruik in gevangenissen zou men ook onder deze categorie kunnen scharen.

Coping-vaardigheden van gedetineerden voorafgaand aan de detentie en tijdens de detentic werden onderzocht door Zamble en Porporino (1988). Hun conclusie was weinig verrassend: gedetineerden proberen hun problemen wel op te lossen, echter de gekozen hanteringstrategieën zijn slechts bij een kleine minderheid van een probleemgericht en redelijk adequaat karakter. De meerderheid maakte gebruik van minder effectieve (of wel: "lowerlevel coping behaviors") of zelfs contra-productieve hanteringstrategieèn die voornamelijk neerkomen op reductie van negatieve emoties via vluchtgedrag. Tijdens de detentie zetten gedetineerden hun weinig effectieve copingstijl voort. Echter, Zamble en Porporino vonden wel een duidelijke toename van een type reactie op de detentiesituatie dat zij omschrijven als cognitief /herinterpreterend, dat wil zeggen een reactie van meer reflectieve aard.

In het bijzonder aan het begin van de detentie leidt de "shock of incarceration" tijdelijk bij een meerderheid van de gedetineerden tot een zekere breuk met de gebruikelijke, weinig effectieve copingstrategieën en tot een grotere bereidheid tot verandering van de levenssituatie. Zamble en Porporino (1988, p.89):

"Misery is one of the best motivators, and the evidence indicates that emotional distress was strikingly high at the beginning of the prison term. The conditions we surveyed at the beginning of a prison term are sufficient to break up many old patterns, at least temporarely, to allow room for new ways of acting. Thus we see the shock of incarceration opening a window of opportunity."

Een belangrijke bevinding van de onderzoekers is tevens dat met het voortschrijden van de detentie er één type probleem, temidden van de vele andere typen problemen die gedetineerden ervaren, voor hen steeds belangrijker wordt, namelijk problemen die gerelateerd zijn aan de toekonst.

Een veronderstelling van deze studie is dat positieve houdingen ten aanzien van de resocialisatie-doelstelling en ten aanzien van resocialiserende voorzieningen voor zover $z \mathrm{ij}$ dienen te worden begrepen als een reactie op de detentiesituatie, samenhangen met het (tijdelijk) gebruik van meer probleemgerichte 'hogere' copingstijlen of hantering-strategieën. Met name bij het bevredigen van hogere behoeften zoals persoonlijke groei en zelfverwerkelijking en het benutten van, wat Toch (1977) noemt, 'opportunity for achievement' kunnen houdingen en gedrag ten aanzien van activiteiten worden beschouwd als het resultaat van meer probleemgerichte hanteringstrategieën. 
Toch (1977) maakt, wat de verschillende functies van activiteiten betreft, een duidelijk onderscheid. In de eerste plaats kunnen activiteiten een functie hebben voor het puur overleven of zich staande houden: "It can be a release for feelings, it can distract attention from pain or anesthesize, and can keep the mind from being concerned with unpleasant thoughts or memories" (p.22). Daarnaast kunnen activiteiten hogere functies vervullen: "Transcending survival needs, activity can provide goals, fulfillment, or scope for creativity" (p.22).

Het lijkt plausibel dat als bij activiteiten hogere behoeften in het spel zijn, probleemgerichte hanteringstrategieën een belangrijke rol spelen. Als het om het reduceren van of tegengaan van negatieve emoties en het vinden van een uitlaatklep gaat, lijkt de hanteringstrategie meer in de zin van vluchtgedrag te moeten worden geïterpreteerd.

Resumerend kunnen we derhalve stellen dat voor zover gedrag en houdingen met betrekking tot resocialiserende voorzieningen een reactie vormen op een, als problematisch ervaren detentie-situatie zij kunnen worden beschouwd als vormen van coping.

Een belangrijk vraagstuk dat hier zeker niet onbesproken mag blijven betreft de vraag naar de effectiviteit van bepaalde hantering-strategieën. Uit de onderzoeksliteratuur (Folkman et al., 1986) blijkt dat vluchtreacties bij problemen in de werkomgeving een negatieve invloed hebben op de lichamelijke en psychische gezondheid. Daarentegen kunnen andere strategieën zoals probleemgericht handelen een duidelijk stressremmend effect hebben. Een verklaring voor de veronderstelde gunstige relatie tussen probleemgericht handelen en stressreductie is dat probleemgericht handelen een constructief bezig zijn met de oplossing veronderstelt en dat men meer mogelijkheden ziet om het probleem aan te pakken. Beide aspecten leiden ertoe dat het individu een sterker gevoel van controle over de situatic ervaart waardoor hij of zij deze vervolgens als minder bedreigend beschouwt. Bovendien blijkt uit de literatuur (Folkman et al., 1986) dat los van het feit of het probleem daadwerkelijk wordt opgelost, probleemgericht handelen gepaard gaat met minder stress en een positiever zelfbeeld. Vluchtgedrag kan men beschouwen als de tegenpool van probleemgericht handelen. Het is een gedragsstijl die samenhangt met een negatieve beleving van de omgeving of situatie, controleverlies en meer negatieve gevoelens.

De vraag naar de effectiviteit van coping is naar men aanneemt niet zonder meer te beantwoorden. Men gaat er weliswaar vanuit dat probleemgericht handelen een 'betere' strategie is, echter het is ook afhankelijk van de situatie. Vanwege het restrictieve karakter van de gevangenisomgeving waarin men bepaalde problemen niet direct kan aanpakken ligt het meer voor de hand om in deze omgeving andere, minder effectieve copingstrategieën te kiezen. Duidelijk is dat er geenszins een unidirectionele relatie is tussen coping enerzijds en stress of stressoren anderzijds. De relatie tussen individu en omgeving of tussen stress en coping is veel complexer dan wel eens wordt gesuggereerd. De keuze voor één of meerdere hantering-strategieën zal voor een belangrijk deel worden bepaald door de mate waarin de situatie als bedreigend wordt ervaren, door eerdere ervaringen en door de perceptie van concrete hanteringsmogelijkheden.

Voor wat het onderzoek naar de stressreducerende werking van activiteiten in gevangenissen betreft, zijn er duidelijke aanwijzingen dat activiteiten een effectief middel kunnen zijn in het reduceren van stressreacties (Wright, 1991).

In deze studie wordt de begrippen stress en coping vooral geïntroduceerd in het kader van de interpretatie van de gegevens. Spanningen bij gedetineerden die weliswaar als begrip in het conceptuele model zijn opgenomen worden niet gemeten. De belangrijkste reden hiervoor is gelegen in de omvang van het onderzoek. De functie van een dergelijke variabele in dit onderzoek is vooral van exploratieve, en verkennende aard. 
Het begrip coping of hantering van spanningen wordt in indirecte zin gemeten en wel via de operationalisering van de opvattingen ten aanzien van resocialisatie. De items die in deze schaal worden gebruikt zijn weliswaar niet expliciet geformuleerd om de variabele coping of hanteringstrategie te meten. Echter, de items op deze schaal zijn zodanig geformuleerd dat zij kunnen worden beschouwd als een indicatie voor de aan of afwezigheid van meer probleemgerichte hanteringstrategieën.

\subsection{Het activiteitenprogramma en de kwaliteit van de implementatie: programma-integriteit}

Een conditionerende onafhankelijke variabele die voor dit onderzoek van belang is, betreft de kwaliteit van de implementatie van de doelen die men heeft geformuleerd ten aanzien van ontwikkelings- en hulpverleningsactiviteiten. In het conceptuele model wordt dit aspect onder de noemer gebracht van de 'ervaren ondersteuning en begeleiding' met betrekking tot activiteiten die voor resocialisatie relevant zijn. In de Anglo-Amerikaanse literatuur duidt men dit aspect wel aan met het begrip 'program integrity' dat de overeenkomst behandelt tussen het programma zoals in theorie opgesteld en de feitelijke uitvoering of implementatie. In de meeste evaluaties van resocialisatie-programma's uit de jaren zestig en zeventig beperkt men zich hoofdzakelijk tot de kwaliteit van de (experimentele) onderzoeksopzet, de dataanalyse en de resultatat- of effectmeting. Deze criteria vormen uiteraard een noodzakelijke doch geen voldoende voorwaarde voor een adequate evaluatie. Een goede evaluatie impliceert immers dat men niet alleen het resultaat van beïnvloeding vaststelt maar dat men ook zicht heeft op het proces van beïnvloeding. Bepaling van de waarde van de onderzoeksresultaten is alleen goed mogelijk als men het proces dat tot de resultaten heeft geleid in zijn feitelijk verloop evenzeer aan een analyse onderwerpt (Quay, 1977).

In de meeste evaluatiestudies uit de jaren zeventig die in de Verenigde Staten werden verricht en op grond waarvan men tot de conclusie kwam dat resocialisatie niet werkt, werd dit proces niet aan een analyse onderworpen. Een adequate beschrijving van de inhoud en het verloop van het activiteiten-programma ontbreekt in veel onderzoeksrapporten. Men blijft door deze tekortkoming in het ongewisse over de factoren die hebben geleid tot het slagen of falen van het programma.

Sechrest et.al $(1979$, p.37) betwijfelen of de kwaliteit van het proces van beïnvloeding bij de meeste resocialisatie-programma's optimaal is geweest:

"What has been done in planning interventions appears to have been based on intuition and practicality rather than on a rationale stemming from concern to make the treatment as powerful as possible. In fact, many rehabilitative attempts may merely seek to make prison life more tolerable by giving offenders something to do. In this sense 'rehabiliation'may be viewed as nothing more than a tool for prison management. Whether any treatment has been tested in its optimum form is questionable."

Een welhaast klassiek en zeer illustratief onderzoek met betrekking tot 'program integrity' werd verricht door Quay (1977). Hij onderwierp een evaluatie-studie, die bij wijze van uitzondering wel voldoende gegevens opleverde ten aanzien van de 'program integrity' aan een nader onderzoek. Het betrof een studie die in de jaren zeventig veelvuldig werd aangehaald als een bewijs dat groepstherapie geen gunstig resocialiserend effect heeft. Martinson (1974) merkt in zijn bekende evaluatiestudie 'What Works?' over dit programma op dat men bij de uitvoering erin was geslaagd de institutionele omgeving op een uitgebreide 
en rigoureuze manier af te stemmen op de inhoud van het programma. Quay komt na zijn analyse tot geheel andere bevindingen omtrent de opzet en uitvoering van het programma:

-een duidelijke conceptuele basis en operationele richtlijnen ontbraken;

-slechts eenderde van de behandelaars geloofde dat groepstherapie een gunstig effect op recidive zou hebben;

-de meeste behandelaars hadden geen professionele opleiding;

-instructies omtrent therapeutische technieken waren ontoereikend;

-de trainingsbijeenkomsten voor de behandelaars werden slecht bezocht;

-er was geen continuiteit in de trainingen en de counseling-coordinator werd zelden geraadpleegd;

-deelname aan het programma door gedetineerden was onvrijwillig, de groepen deelnemers waren zeer heterogeen en de wijze van samenstelling was niet systematisch. Gedetineerden beoordeelden de inhoud en opzet van het programma negatief;

Het feit dat dit programma en de evaluatie ervan doorging voor zeer degelijk geeft te denken over de integriteit van de talloze pogramma's die bekend staan als minder degelijk en minder goed gedocumenteerd.

Quay noemt een aantal voorwaarden waaraan bij de toetsing van de integriteit van een bepaalde interventie dient te zijn voldaan

-cen daadwerkelijke uitvoering van de voorgeschreven activiteiten zowel qua inhoud, duur en intensiteit. Vooral de vraag of de activiteiten daadwerkelijk plaatsvonden en of datgene wat er tijdens de bijeenkomsten gebeurt in overeenstemming is met de gestelde doelen is volgens Quay uiterst belangrijk;

-de aanwezigheid van voldoende getraind en gemotiveerd personeel met een adequate supervisie;

- een voldoende mate van afstemming van het programma op de behoeften, interessen en kenmerken van de doelgroep;

Wat dit laatste betreft vinden we ook in Toch's studie (1977, p.79) fraaie voorbeelden, zoals deze:

"Prepare you to go back into society? Well. how can they do that when nothing in the institution has anything to do with society? Like, none of the educational programs fit into the society... not what they 're teaching you in here anyway. You know? The jobs that they teach you in here, you can't get none of them in the streets."

Over de noodzaak van proces-evaluatief onderzoek dat zich richt op de implementatieaspecten van interventies bestaat sinds de publicatie van Quay geen twijfel meer. Ook recentelijk wordt er aan dit vraagstuk in het onderzoek van resocialisatie steeds meer aandacht besteed (Palmer, 1994 ; Lösel, 1996).

Voor wat betreft de relevantie van het integriteitsvraagstuk voor de onderhavige studie is er geen twijfel mogelijk. Het is een belangrijk aspect dat zeker bij een attitude-survey over resocialisatie in de gevangenis aan de orde moet komen. In het bijzonder de beleving van en deelname aan de activiteiten kunnen in negatieve zin worden beïnloed door een gebrekkige implementatie. Bij de vormende activiteiten zoals onderwijs en kunstzinnige vorming, zo bleek in Hoofdstuk 2, is de invulling van belangrijke randvoorwaarden een permanent probleem bij de uitvoering van activiteitenprogramma's. Een en ander kan op de motivatie van betrokkenen een negatieve invloed hebben. In dit onderzoek zullen in relatie tot onderwijs en kunstzinnige vorming ook de meningen van gedetineerden worden gepeild over aspecten als afstemming van de activiteiten op de behoeften van de deelnemers, informatie, plaats in het regimes-activiteitenprogramma, materiaal en middelen, ondersteuning en bege- 
leiding. In het conceptuele model kunnen de variabelen met betrekking tot de implementatie van de activiteiten zowel indirect als direct van invloed zijn op de houdingen van gedetineerden. In indirecte zin vervullen zij wellicht een gelijksoortige modererende rol als de persoons-kenmerken. De kwaliteit van de implementatie immers kan de spanningen als gevolg van de detentie in positieve of negatieve zin beïnloeden. Indirect beinvloeden zij daarmee het aanpassingsproces aan de detentie en wellicht ook de kijk van de gedetineerden op resocialisatie.

\subsection{Een overzicht van de geselecteerde variabelen}

Het ruwe model zoals dat in het begin van dit hooldstuk werd geschetst onvat een reeks clusters van factoren die mogelijk van invloed zijn op de houdingen van gedetineerden ten aanzien van resocialisatic.

Vervolgens werden aan de hand van de theoretische en empirische literatuur voor een alutal van deze clusters de relevant geachte variabelen geselecteerd en tocgelicht.

In het kader van de invloed van een (depriverende) detenticomgeving werd in de eerste plaats de perceptie van het regime als belangrijke variabele geselecteerd. In het verlengde van deze invloed van een depriverende detentieomgeving werd op basis van de literatuur de rol geschetst van de gedetineerdencultuur en het proces van prisonisatie. Als indicatie voor de mogelijke aanwezigheid en invloed van een gedetineerdencultuur, kortom van een prisonisatieproces, werden achtereenvolgens verblijfsduur, strafduur, detentiefase en contacten met medegedetineerden als variabelen geselecteerd. Deze variabelen kan men vanwege hun expliciete relatie met het prisonisatie-proces anduiden met de term 'prisonisatievariabelen'.

Voor de omgevingskenmerken, in het conceptuele model weergegeven als de subjectieve omgeving, worden derhalve de volgende variabelen geselecteerd.

- het regime (en de perceptie ervan);

- prisonisatievariabelen (verblijfsduur, strafduur, detentiefase en contacten met medegedetineerden).

Met betrekking tot de persoonskenmerken (of individuele kenmerken) werden op basis van de literatuur de volgende variabelen geselecteerd:

-leeftijd;

-burgerlijke staat;

-culturele achtergrond;

-opleiding;

-arbeidsverleden;

-druggebruik;

-recidive

Voor de kenmerken van de programma-integriteit werden de volgende variabelen geselecteerd:

-informatieverstrekking;

-mate van afstemming van de activiteiten op de behoeften van deelnemers;

-plaats in het dagprogramma;

-mate van ondersteuning en begeleiding;

-materiaal en middelen. 
Met betrekking tot de aanwezigheid van stress en het verband tussen verschillende vormen van stresshantering en de houdingen ten aanzien van resocialisatie bleek elders in dit hoofdstuk dat deze componenten niet expliciet worden onderzocht. De invloed van stress en stress-hantering speelt in dit onderzoek in meer exploratieve zin een rol. Bij de interpretatie van de onderzoeksresultaten zal worden gekeken of er bepaalde aanwijzingen zijn voor een mogelijk effect van deze factoren.

\subsection{Vraagstellingen naar aanleiding van het verklarende deel van de probleemstelling}

In hoofdstuk 1 werd een algemene probleemstelling geformuleerd. De algemene probleemstelling van dit onderzoek werd geformuleerd als:

Wat houdt het resocialisatie-streven in het Nederlandse gevangeniswezen precies in, hoe beoordelen gedetineerden en personeel dit streven en door welke factoren wordt hun oordeel beïnloed?

Ten aanzien van het laatste, verklarende deel van de probleemstelling kan men de volgende deelvragen formuleren voor de relaties tussen omgevingskenmerken, persoonskenmerken en kenmerken van programma-integriteit:

Relaties tussen omgevingskenmerken en houdingen ten aanzien van resocialisatie Betoogd werd dat prisonisatie-processen wellicht van invloed zijn op houdingen ten aanzien van resocialisatie. Op grond van deze veronderstelling mag men verwachten dat de (depriverende) kenmerken van het regime, verblijfsduur, strafduur, detentiefase en de contacten met medegedetineerden een bepaalde samenhang vertonen met de houdingen ten aanzien van resocialisatie.

De onderzoeksvraag is of gedetineerden die het regime als meer ordegericht beleven negatiever denken over resocialisatie dan gedetineerden die het regime op een meer gedetineerden-gerichte wijze beleven.

De volgende onderzoeksvraag in dit verband is of verblijfsduur, strafduur en detentiefase op een gunstige dan wel ongunstige manier samenhangen met houdingen ten aanzien van resocialisatie

Tenslotte is een onderzoeksvraag in dit verband of de mate van intensiteit van de contacten met medegedetineerden op een gunstige dan wel ongunstige wijze samenhangt met houdingen ten aanzien van resocialisatie

Relaties tussen persoonskenmerken en houdingen ten aanzien van resocialisatie Betoogd werd dat pre-detentiefactoren of persoonskenmerken een directe, dan wel indirecte invloed kunnen uitoefenen op de houdingen ten aanzien van resocialisatie

Onderzocht wordt of bepaalde persoonlijke factoren een relatie vertonen met houdingen ten aanzien van resocialisatie.

Relaties tussen de kwaliteit van de implementatie van programma's en houdingen ten aanzien van resocialisatie 
Er zijn aanwijzingen dat de kwaliteit van de implementatie van regimesactiviteitenprogramma's zowel een directe als indirecte invloed kan hebben op de houdingen ten aanzien van resocialisatie.

De vraag is of de kwaliteit van de implementatie direct dan wel indirect verband houd met houdingen ten aanzien van resocialisatie.

Relaties tussen omgevingskenmerken, persoonskenmerken, kenmerken van het implementatie-proces enerzijds en houdingen ten aanzien van resocialisatie anderzijds. Betoogd werd dat de bovengenoemde factoren mogelijk van invloed zijn op de aard van de houdingen.

De onderzoeksvraag is welke soort factoren de houdingen ten anzien van resocialisatie het sterkst beïnloeden.

Relaties tussen stress, hanteringgedrag en houdingen ten aanzien van resocialisatie Beargumenteerd werd dat resocialiserende activiteiten voor gedetineerden voor een deel kunnen worden gezien als een manier on de spanningen van de detentie beter te hanteren.

Om exploratieve redenen wordt daarom onderzocht of houdingen ten aanzien van resocialisatie tevens kumnen worden beschouwd als een bepaalde vorm van hanteringsgedrag.

\subsection{Samenvatting en conclusies}

In dit hoofdstuk is vanuit een theoretisch perspectief gezocht naar factoren die mogelijk van invloed zijn op de houdingen van gedetineerden ten aanzien van resocialisatie. In het algemeen verdient het de voorkeur een dergelijke zoektocht op een gestructureerde manicr te laten verlopen. In dit hoofdstuk werd dan ook als eerste stap een conceptueel model geformuleerd dat richtinggevend zou moeten zijn voor de sclectie van relevante factoren.

$\mathrm{Bij}$ de constructie van dit model werd op grond van de theoretische en empirische literatuur het volgende voorop gesteld.

1. In het conceptuele model dienen zowel persoonsgebonden (of individuele) kenmerken als omgevingskenmerken te worden opgenomen.

2. Het model zou rekening moeten houden met een interactie tussen individu en omgeving. Als een belangrijk uitgangspunt geldt hierbij dat de kenmerken van de detentie-ongeving door gedetineerden niet objectief op eenzelfde wijze worden waargenomen. De invloed van de omgeving op houdingen en gedrag van gedetineerden is niet van een unidirectionele of deterministische aard, maar verloopt via subjectieve perceptie door een waarnemend of betekenisgevend individu.

3. In het model zou op een of andere manier het verschijnsel van stress en stresshantering in een detentie-omgeving dienen te worden verdisconteerd.

4. Het vraagstuk van de programma-integriteit of wel de wijze van implementatie van resocialisatie-programma's zou in het model tot uiting dienen te komen.

Vervolgens werden de, in het model gepostuleerde relaties tussen omgevings-en individuele kenmerken enerzijds en de houdingen ten aanzien van resocialisatie anderzijds, aan de hand van de literatuur onderzocht.

Op grond van deze literatuur werden een reeks mogelijk relevante kenmerken geselecteerd. Behalve deze selectie leverde deze gang door de literatuur in theoretisch en empirisch opzicht tevens het volgende inzicht op: 
1. van integratie van individuele-en omgevingskenmerken door middel van theoretische onderbouwing is nauwelijks sprake;

2. theoretische onderbouwing vanuit een interactionistisch perspectief is uitzonderlijk. In slechts twee studies namelijk die van Toch (1977) en die van Wright (1989) is sprake van een expliciete aanzet hicrtoe;

3. concepten als stress en stresshantering die voor de verklaring van het proces van aanpassing aan de detentie toch van enige importantie lijken te zijn, komen slechts incidenteel aan bod in de penologische literatuur;

4. er zijn in de literatuur weliswaar bepaalde clusters van kenmerken te onderscheiden, maar zowel binnen de clusters als tussen de clusters onderling blijft het onduidelijk hoe de verschillende kenmerken zich tot elkaar verhouden;

5. de samenhang tussen houdingen van gedetineerden ten aanzien van resocialisatie en bepaalde omgevings- en individuele kenmerken is in empirische zin nauwelijks onderzocht. Selectie van de kenmerken die mogelijk van invloed zijn op houdingen ten aanzien van resocialisatie vond derhalve voornamelijk plaats op basis van empirisch onderzoek waarin men anderssoortige houdingen of vormen van gedrag (bijvoorbeeld regelschendend gedrag of oppositionele houdingen) heeft trachten te verklaren. Op grond van de bevindingen van deze studies werd een mogelijk direct of indirect effect van bepaalde omgevingskenmerken en persoonsgebonden kenmerken op houdingen ten aanzien van resocialisatie als plausibel verondersteld.

Gelet op de bovengenoemde theoretische en empirische leemten kan men de inhoud van dit hoofdstuk tevens beschouwen als een aanzet tot een theoretisch onderbouwde integratie van factoren die mogelijk van invloed zijn op de houdingen van gedetineerden ten aanzien van resocialisatie. En daarmee levert dit hoofdstuk in zekere zin tevens een bijdrage aan een theoretische onderbouwing van de kennis over het proces van aanpassing aan de detentie in het algemeen. 


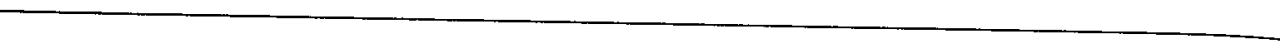




\section{OPZET EN UITVOERING VAN HET ONDERZOEK ONDER GEDETINEERDEN}

\subsection{Inleiding}

In dit hoofdstuk zal worden beschreven hoe het onderzoek onder gedetineerden in de praktijk werd uitgevoerd. Hierbij komen onderwerpen aan de orde als de methode van dataverzameling, procedure, respons, representativiteit en de gehanteerde meetinstrumenten. Bovendien wordt een beschrijving gegeven van de inrichtingen waarin het onderzoek werd uitgevoerd.

\subsection{Dataverzameling, procedure en respons}

\subsubsection{De onderzoeksgroep en de inrichtingen}

De ondervraagde groep gedetineerden bestaat uit mannen die krachtens een voorlopige of vervangende hechtenis dan wel een veroordeling van hun vrijheid zijn beroofd en derhalve verblijven in een Huis van Bewaring of gevangenis. Het onderzoek werd uitgevoerd in een drietal penitentiaire inrichtingen.

Bij de keuze van het aantal en soort inrichtingen speelden de volgende overwegingen een rol. Zeer belangrijk was uiteraard de beheers- en uitvoerbaarheid van het onderzoek. Voor één onderzoeker zonder assistentie is een aantal van drie inrichtingen het absolute maximum.

Bij de vraag welke drie inrichtingen zouden worden benaderd was in de eerste plaats een belangrijk criterium de aanwezigheid van een breed activiteitenprogramma waarin alle activiteiten in het kader van de voorbereiding van de terugkeer in de samenleving waren vertegenwoordigd. Als gevolg van de toegenomen autonomie van de inrichtingen en de recente beleidsontwikkelingen in het kader van Werkzame Detentie was een breed activiteitenprogramma ten tijde van de voorbereiding van het onderzoek niet meer vanzelfsprekend. In sommige inrichtingen bleek als gevolg van deze ontwik-kelingen bijvoorbeeld een activiteit als kunstzinnige vorming te zijn afgeschaft. Daamaast werd ook gelet op de ligging en de bestemming van de inrichting. De inrichtingen dienden om redenen van bereikbaarheid in het zuidoosten van het land te liggen. Bovendien was, gelet op het verklarende deel van de probleemstelling van het onderzoek, een belangrijke voorwaarde dat gedetineerden bepaalde verschillen zouden vertonen qua verblijfsduur en strafduur. Het lag derhalve voor de hand inrichtingen te kiezen met een verschillende bestemming, dat wil zeggen zowel inrichtingen met een bestemming van Huis van Bewaring als inrichtingen met de bestemming van gevangenis. De dichtstbijzijnde inrichting te Maastricht huisvest zowel voorlopig gehechte gedetineerden als langgestraften, echter deze inrichting viel af vanwege het ontbreken van de kunstzinnige vorming in het regimesactiviteiten-programma.. De keus viel vervolgens op een andere, gesloten inrichting te Sittard waarin in de periode van het veldonderzoek zowel langgestraften, 
kortgestraften en voorlopige gehechte gedetineerden werden ondergebracht. In deze inrichting werden alle relevante activiteiten aangeboden, bovendien is de auteur als consulent beeldende vorming verbonden aan deze inrichting en derhalve goed bekend met de gang van zaken aldaar. De overige twee inrichtingen in Roermond en Grave waarin het veldonderzoek werd uitgevoerd, hebben de bestemming van Huis van Bewaring.

\subsubsection{Methode van dataverzameling}

Bij de dati-verzameling werd gekozen voor een combinatie van kwalitatieve en kwantitatieve methoden om de probleemstelling van het onderzoek zo adequaat mogelijk te beantwoorden. Qua probleemstelling en methode kan men dit onderzoek als een proces-evaluatie omschrijven (Grizzle en Witte, 1981). In de eerste plaats door de beschrijving van de beleidsmatige, ideologische en organisatorische context waarbinnen het aanbod valn activiteiten op het gebied van resocialisatie plaatsvindt. Daarnaast wordt het proces-evaluatieve karakter van dit onderzoek vooral bepaald door het accent op het feitelijk functioneren van het resocialisatie-streven. Naar het feitelijk functioneren wordt gekeken vanuit de beleving van de activiteiten door gedetineerden en personeel. Die beleving heeft betrekking op zowel de inhoud van de regimesactiviteiten als de organisatorische randvoorwaarden van het activiteitenaanbod. Ook het verklarend deel van de probleemstelling van dit onderzoek kan men rekenen tot het domein van de proces-evaluatie. De verklarende probleemstelling behelst een poging te achterhalen tot welke factoren de beschreven aard van de deelname en beleving van gedetineerden te herleiden is. In proces-evaluaties van resocialisatie-programma's is een dergelijke verklarende component uiterst belangrijk, zij werpt licht op de vraag waarom bepaalde programma's succesvol of minder succesvol zijn.

De technieken van dataverzameling van een proces-evaluatic beperken zich blijkens de methodologische literatuur veelal niet tot een bepaalde techniek. Meestal hanteert men, al dan niet in combinatie, meerdere technieken zoals interviews, observatie, schriftelijke enquêtes, tests en analyse van documenten.

Als methode van dataverzameling werd in het kader van dit onderzoek in de eerste plaats gebruik gemaakt van vragenlijsten die schriftelijk werden afgenomen. Gelet op de randvoorwaarden met betrekking tot tijd en geld is dit de meest aangewezen methode om een grote hoeveelheid goed vergelijkbare informatie bij een omvangrijke groep respondenten te vergaren.

Bovendien vloeit de voorkeur voor vragenlijsten voort uit de probleemstelling van het onderzoek. Doel van het onderzoek is niet alleen maar het vastleggen van specifieke individuele ervaringen. Het verkrijgen van een algemeen beeld van de houdingen van gedetineerden (en personeel) ten aanzien van een aantal aspecten van de resocialisatie-doelstelling, is eveneens cen belangrijke doelstelling. Immers individuele specifieke ervaringen kunnen weliswaar heel informatief zijn, het nadeel is echter dat specifieke ervaringen geen inzicht geven in de vraag in welke mate bepaalde opvattingen of ervaringen vòòrkomen bij een grotere groep mensen.

Specifieke individuele ervaringen van de participanten zijn met name in de meer exploratieve fase van het onderzoek middels observatie en een aantal oriënterende gesprekken vastgelegd. Zo werd bijvoorbeeld in het kader van een onderzoeksstage op het onderdeel kunstzinnige vorming door een student van het $\mathrm{HBO}$ een reeks interviews gehouden met gedetineerden en personeel met betrekking tot het functioneren van deze activiteit in de inrichting te Sittard.

Belangrijk voor de oriënterende fase van het onderzoek zijn uiteraard ook de observaties die ik zelf tijdens mijn werkzaamheden in deze inrichting in de loop der jaren heb kunnen verrichten. Deze observaties dient men niet op te vatten als observatie in strikt systematische zin, veeleer gaat het hier om een participerende rol als begeleider van gedetineerden en bewarend personeel 
bij de kunstzinnige vorming. Een dergelijke positie als onderzoeker levert uiteraard een schat aan achtergrondinformatie op over het feitelijk verloop van de activiteiten, de verschillende intenties van gedetineerden en personeel die erbij betrokken zijn en de plaats van deze activiteit binnen de actuele organisatie.

Het feit dat ik als onderzoeker tevens werkzaam was in een van de onderzochte inrichtingen, zou van invloed kunnen zijn op de betrouwbaarheid van het onderzoek. Er zou, bij voorbeeld omdat ik een aantal respondenten via mijn werkzaamheden al kende, sprake kunnen zijn van een sterkere instemmingstendens onder deze respondenten. Dit verschijnsel duidt op een sterkere neiging om op elke uitspraak of bewering positief te antwoorden omdat men denkt dat de onderzoeker dat graag hoort.

Of en in welke mate mogelijk sprake is van een dergelijke vertekening is moeilijk te beoordelen.

Deze 'bias' werd in ieder geval zoveel mogelijk ondervangen door het 'spiegelen' van de voorgelegde uitspraken, dat wil zeggen door het onderwerp van de voorgelegde items ook nog eens in tegengestelde richting te formuleren. Via betrouwbaarheids- en factoranalyse kan men bovendien achteraf achterhalen of deze tendens is opgetreden.

Naast deze vorm van vertekening is een andere 'response bias' de neiging tot het geven van sociaal wenselijke antwoorden. Voor het onderhavige onderzoek betekent deze tendens dat gedetineerden positieve antwoorden geven omdat zij weten dat werken aan je toekomst een sociaal wenselijk streven is. Aan één van de remedies hiertegen, namelijk een zorgvuldige formulering van de voorgelegde uitspraken werd uiteraard aandacht besteed.

Tenslotte dient men rekening te houden met de consistentie-neiging. Dit verschijnsel duidt op de neiging van respondenten om uitspraken over een bepaald onderwerp steeds in dezelfde geest te beantwoorden. Om vertekening als gevolg hiervan te voorkomen, werden clusters met uitspraken in de vragenlijst gemengd tot één, ogenschijnlijk heterogene reeks van items. Verder werd aan de respondenten gevraagd zo eerlijk mogelijk te antwoorden. In de voorbereidende fase van het onderzoek werden proefvragenlijsten afgenomen onder een aantal gedetineerden om eventuele onduidelijkheden in de vragenlijst op te sporen.

\subsubsection{Procedure}

Voorafgaande aan de enquête die in 1996 werd gehouden, kregen gedetineerden en personeel een schriftelijk verzoek om aan het onderzoek mee te werken. In deze schriftelijke benadering werd een korte uitleg gegeven van het doel van het onderzoek. De waarborgen betreffende anonimiteit en vertrouwelijke behandeling van de gegevens werden tevens omschreven. Van zowel de brief waarin om medewerking werd verzocht als van de vragenlijst werd naast de Nederlandstalige versie ook een Franstalige versie gebruikt. Van het gebruik van een Engelstalige- of Duitstalige versie werd afgezien, omdat, zo bleek op de verschillende afdelingen, betrekkelijk veel buitenlanders die nauwelijks of geen Nederlands beheersten, zich wel in de Franse taal in woord en geschrift konden uitdrukken. Uit een WODC studie van Grapendaal et al. (1985) bleek overigens dat van de buitenlandse gedetineerden $64 \%$ Nederlands kan spreken. De onderzoekers stellen dat het zich verstaanbaar kunnen maken in het Nederlands een belangrijke voorwaarde is voor deelname aan een aantal activiteiten. Afgaande op dit percentage van $64 \%$ dat Grapendaal et al. noemen, zou men mogen verwachten dat vanwege dit taalprobleem een substantieel gedeelte van de buitenlandse gedetineerden niet deelneemt aan bepaalde activiteiten en evenmin aan een enquête over die activiteiten.

In dezelfde week werden vervolgens de vragenlijsten uitgedeeld, waarbij ik zoveel mogelijk zelf aanwezig was om te assisteren en eventuele vragen van gedetineerden te beantwoorden. Dit bleek met name voor de respons een belangrijke factor te zijn. $\mathrm{Na}$ nog eens benadrukt te hebben 
dat dit onderzoek een persoonlijk initiatief was onder supervisie van de Universiteit van Maastricht, en het Ministerie van Justitie slechts indirect betrokken was, bleken weifelende gedetineerden alsnog bereid de vragenlijsten te beantwoorden.

De vragenlijsten werden rond de middag-of avondpauze uitgedeeld en een uur later weer opgehaald. Dit is in gevangenissen in het algemeen de beste methode om een goede respons te krijgen. Gedetineerden krijgen, terwijl zij zijn ingesloten. de gelegenheid om het vragenformulier in alle rust in te vullen. Het moment tussen het uitreiken van de formulieren en het ophalen wordt zo kort mogelijk gehouden, teneinde uitstel en mogelijk afstel voor wat betreft het beantwoorden van het vragenformulier te beperken.

Eveneens is het zaak dat de onderzoeker zoveel mogelijk zelf bij het uitreiken en ophalen van de enquête-formulieren aanwezig is, vooral om het doel en het belang van het onderzoek bij de respondenten zo goed mogelijk kenbaar te maken. Zeer lage respons-percentages van schriftelijke enquêtes zijn niet zelden een gevolg van het feit dat men de wijze van introductie, uitreiken en inzamelen van de vragenformulieren onvoldoende heeft afgestemd op de specifieke kenmerken van de omgeving en van de doelgroep.

Tenslotte mag hier niet onvemeld blijven dat de omvang van het enquêteformulier voor veldonderzoek in gevangenissen uitzonderlijk groot was. Gedetineerden kregen een formulier van 13 pagina s met meer dan 200 vragen en uitspraken voorgelegd.

\subsubsection{Respons in de inrichting te Sittard}

Deze inrichting had op het moment van afname van de enquête in april 1996 een formele capaciteit van 262 gedetineerden. Het aantal bezette cellen bedroeg 260 . Van deze groep gedetineerden vielen 12 gedetineerden van de E-unit af vanwege het afwijkende regime van deze afdeling. Voorts werd een tweetal subsidiair gehechten van de HVB -unit, vanwege de zeer korte duur van hun verblijf niet voor medewerking benaderd. In eerste instantie zouden dus 246 gedetineerden worden benaderd. Tijdens de afname bleek een aantal gedetineerden (25) on verschillende redenen evenwel niet mee te kunnen doen. Het betrof hier omstandigheden zoals transport, overwerk, plaatsing in een isoleercel. opgelegde beperking, taalproblemen, analfabetisme en psychische instabiliteit. Taalproblemen vormden de meest frequente reden voor deze uitval (12). Het ging hier om gedetineerden die alleen hun moedertaal (Spaans of Afrikaans) beheersten en verder geen enkele andere West-Europese taal konden lezen.

Dit probleem met de taal bleek niet alleen vooraf, maar ook tijdens het ophalen van de enquêteformulieren. Sommige allochtonen hadden het formulier niet of zeer onvolledig ingevuld vanwege problemen met de taal. Deze gevallen zijn om praktische redenen niet steeds systematisch geregistreerd. Non-respons vanwege taalproblemen zal in werkelijkheid dan ook wel wat hoger liggen dan in het hierboven aangegeven cijfermateriaal tot uiting komt.

Bij de overige twee inrichtingen deed zich dit taalprobleem eveneens voor.

Derhalve konden in de inrichting te Sittard 221 gedetineerden worden benaderd voor medewerking aan de enquête. Van deze groep retoumeerden 114 gedetineerden een bruikbaar ingevuld formu-lier, hetgeen voor deze inrichting een respons oplevert van $51,1 \%$.

\subsubsection{Respons in de inrichting te Grave}

In deze inrichting werden in september 1996 in eerste instantie 120 gedetineerden op vier afdelingen benaderd voor medewerking aan het onderzoek. Slechts een beperkt aantal afdelingen in deze inrichting hebben een regimesactiviteiten-programma waarin alle, voor dit onderzoek rele-vante activiteiten waren vertegenwoordigd

Van deze afdelingen werden er drie geselecteerd op basis van dit ruimere activiteiten-aanbod. Een afdeling waarvoor een standaard-regime met slechts zeer beperkte mogelijkheden voor 
activiteiten gold, werd eveneens geselecteerd om na te gaan in welke opzichten en in welke mate de meer gemotiveerde gedetineerden verschillen van gedetineerden die op grond van een gebrekkige motivatie in een meer sober regime worden geplaatst

Ook in deze inrichting bleck een aantal gedetineerden (14) niet mee te kunnen doen vanwege talalproblemen, transport en ziekte. Van de totale groep konden derhalve 106 gedetineerden daadwerkelijk worden benaderd. Het aantal respondenten dat een bruikbaar vragenformulier inleverde bedroeg 57 , hetgeen een respons oplevert van $55,5 \%$.

\subsubsection{Respons in de inrichting te Roermond}

Van de totale populatic (116 gedetineerden) werden in december 1996 in eerste instantie 107 gedetineerden benaderd. Om redenen die te maken hebben met onbereikbaarheid en taalproblemen ontvingen uitcindelijk 94 gedetineerden een vragenformulier en van deze groep retourneerden 55 gedetineerden een bruikbaar formulier. Het responspercentage voor deze inrichting bedraagt $58,5 \%$.

In totaal werden 226 enquête -formulieren ontvangen die op een bruikbare manier waren ingevuld.

De respons van gedetineerden over alle drie de inrichtingen bedraagt $54 \%$. Dit is, vergeleken met soortgelijke enquêtes in penitentiaire inrichtingen een alleszins redelijk niveau. Een studie van Herbschleb en Zorge (1992) naar de kwaliteit van de detentie in de inrichting te Sittard leverde vrijwel hetzelfde percentage op (54\%). Ter vergelijking noemen Herbschleb en Zorge nog een aantal percentages van andere inrichtingen waar zij soortgelijk onderzoek verrichtten en deze vielen in twee gevallen aanmerkelijk lager uit ( $18 \%$ en $27 \%$ ).

Het respons-percentage is tenslotte ook heel redelijk te noemen als men de onvang van het enquête-formulier en de beperkte tijd die men voor het beantwoorden kreeg, in ogenschouw neemt.

\subsection{Een beschrijving van de onderzoeksinstrumenten}

Het voornaamste doel van deze studie is het vergaren van meer kennis over opvattingen en beleving van gedetineerden en personeel inzake resocialisatie. Via literatuurstudie werd onderzocht welke factoren hierbij mogelijk een rol zouden kunnen spelen. Vervolgens werd een onderzoeksmodel gerepresenteerd met relevant geachte variabelen.

Bij de meting van bepaalde variabelen werd gebruik gemaakt van bestaande meetinstrumenten. Voor het merendeel van de relevant geachte variabelen ontbraken reeds beproefde meetinstrumenten, zodat hier nieuwe meetinstrumenten moesten worden ontwikkeld.

Hierbij spelen een tweetal criteria een rol namelijk face-validity en interne consistentie.

Op basis van 'face-validity', dat wil zeggen op basis van de inhoudelijke betekenis van de items, werden clusters van items geselecteerd. De geselecteerde items werden onderworpen aan een reliability-analyse, waarbij de betrouwbaarheid van de schaal wordt vastgesteld. Een belangrijk begrip hierbij is de interne consistentie, of anders geformuleerd, de onderlinge samenhang van de individuele items. De interne consistentie wordt uitgedrukt in Cronbach's alpha, hoe hoger de alpha-waarde des te lager de error variantie van de verschillende items uit de vragenlijst. Als stelregel werd gehanteerd dat de resulterende schaal een alfa moest hebben van tenminste .50 . Over de waarde die de Cronbach's alpha dient te bezitten om te kunnen spreken van een acceptabele interne consistentie wordt verschillend gedacht. In sommige studies wordt als vuistregel een waarde van ongeveer .70 gehanteerd. In weer 
andere studies zijn lagere waarden van $.50 \mathrm{en} .60$ niet ongebruikelijk. Een waarde lager dan .50 wordt in het algemeen als niet acceptabel beschouwd.

$\mathrm{Bij}$ sommige grote clusters is factor-analyse uitgevoerd, in het bijzonder de principale componenten analyse, om te onderzoeken of er subschalen zijn te onderscheiden. De criteria die hierbij werden gehanteerd zijn: een eigen waarde groter dan I en toewijzing van een item aan een factor vindt plaats indien een factorlading van het item groter is dan .40 en hoger dan op enige andere factor.

Bij de presentatie van de gehanteerde meetinstrumenten zal zoveel mogelijk de structuur worden overgenomen van de voorgaande hoofdstukken waarin de probleemstelling en het onderzoeksmodel werden geformuleerd.

\subsubsection{Opvattingen over resocialisatie}

Aan de hand van de literatuur werden veertien items geselecteerd die verschillende aspecten met betrekking tot het denken over resocialisatie weergeven.

In hoofdstuk drie werd een aantal studies (Kolstad, 1996; Zamble en Porporino, 1988) besproken waarin bij de opvattingen van gedetineerden over resocialisatie een onderscheid werd gemaakt tussen de zinvolheid of het belang van de resocialisatiedoelstelling als zodanig en de gepercipieerde zinvolheid van de resocialisatie-opdracht in de comtext van de detentie die men ondergaat.

Principale componenten-analyse met varimaxrotatie resulteerde in een clustering van 14 items rondom twee factoren (zie bijlage 1). De items die hoog laden op de eerste factor hebben allen betrekking op het belang dat men toekent aan resocialisatie en de items die hoog laden op de tweede factor hebben betrekking op de mogelijkheden die men ziet on tijdens de detentie aan de toekomst te werken. Op basis hiervan werden twee (sub)schalen geconstrueerd: belang van resocialisatie en scepsis.

De interne consistentie van de eerste schaal Belang van Resocialisatie bestaande uit 5 items is, uitgedrukt in Cronbach's alpha, .51. Hoe hoger men scoort op deze schaal des te meer waarde hecht men aan het scheppen van kansen en mogelijkheden voor gedetineerden om de terugkeer in de samenleving voor te bereiden.

Voor de tweede schaal Scepsis, bestaande uit 9 items, is Cronbach's alpha .70.

Hoe lager men scoort op de schaal Scepsis des te minder mogelijkheden neemt men voor zichzelf waar om tijdens de detentieperiode de terugkeer in de samenleving voor te bereiden.

De antwoordcategorieën bij deze schalen variëren van 1 tot en met 5 (mee eens, enigszins mee eens, niet mee eens /niet mee oneens, enigszins mee oneens, mee oneens).

\subsubsection{Belang van resocialisatie}

$\mathrm{Bij}$ het belang dat men toekent aan de resocialisatie-doelstelling als zodanig werden items geformuleerd die betrekking hebben op resocialisatie als een beginsel van humaniteit en als een detentiedoel met een nuttig effect. Tevens werden twee items geformuleerd die betrekking hebben op de mate waarin het streven zich te verbeteren van belang is in het persoonlijk leven van de betrokkene. 
Schaal Belang van resocialisatie

- Als gedetineerde moet je de kans krijgen om je voor te bereiden op de toekomst.

- Met de meeste gedetineerden gatat het, als ze vrij zijn, toch weer fout omdat ze te weinig worden geholpen.

Hoe meer hulp en steun gedetineerden krijgen des te beter zij zich later zullen redden.

Ik gebruik mijn straftijd vooral om mijn leven weer op orde te brengen.

Je moet tijdens je straftijd al het mogelijke doen voor een betere toekomst.

\subsubsection{Scepsis ten aanzien van de gevangenis als resocialiserend instituut.}

Gedetineerden kunnen in een bepaalde mate een belang aan de resocialisatie-doelstelling toekennen afgezien van de omstandigheden waaronder een en ander dient te geschieden. Die omstandigheden of context waarin men werkt aan de toekomst vormen, blijkens de onderzoeksliteratuur eveneens een belangrijk aspect van het denken over resocialisatie. Men kan positief denken over resocialisatie als zodanig en bezig zijn met de toekomst maar tegelijkertijd veel minder positief of zelfs negatief zijn over de gevangenis als instituut of als omgeving waarin men de terugkeer in de samenleving voorbereidt.

In de opvattingen over de gevangenis als context voor de realisering van de resocialisatiedoelstelling kan men met name op grond van de eerder besproken literatuur een aantal visies onderscheiden:

- Een negatieve visie waarin de gevangenis wordt gezien als een instituut dat niet resocialiserend werkt maar ten opzichte van zelfverbetering juist averechts werkt. Pogingen tot resocialisatie in de context van de gevangenis worden in essentie als zinloos of onder de huidige omstandigheden als onmogelijk beschouwd.

- Een positieve visie waarin het verblijf in de gevangenis als een goede gelegenheid wordt beschouwd om veranderingen in de levenssituatie aan te brengen (vergelijk in dit opzicht het begrip 'gleaners' van Irwin, 1980 en Toch, 1977).

- Een visie waarin sprake is van een discrepantie tussen de officiële resocialisatie-doelstelling en de waargenomen doelstelling. In officiële zin zijn de activiteiten bedoeld zijn om de terugkeer in de samenleving (beter) voor te bereiden maar in de perceptie van gedetineerden komen de activiteiten als gevolg van de depriverende omstandigheden van de detentie feitelijk neer op het louter bezig houden van gedetineerden (Melk, 1985; 1993).

- Een visie die het midden houdt tussen uitgesproken negatief of zeer optimistisch. Men zou hier kunnen spreken van een gematigd negatieve visie. Zo bleek uit de studie van Zamble en Porporino (1988) dat ondanks een kritische houding naar het gevangenissysteem, voor een meerderheid van de gedetineerden de toekomst wel degelijk een onderwerp van belang was. Zelfverbetering of het veranderen van en nadenken over de (toekomstige) levenssituatie zijn doeleinden die men tijdens de detentie niet bij voorbaat als zinloos verwerpt. Echter, men acht de omstandigheden waaronder men dit moet doen niet gunstig. Een en ander kan onder meer gepaard gaan met een zeker gevoel van machteloosheid ten aanzien van de toekomstige levenssituatie.

In de items van de schaal scepsis zijn de vier bovengenoemd visies op de gevangenis als resocialiserend instituut terug te vinden. 
Schaal Scepsis

- Werken aan een betere toekomst tijdens je straftijd is zinloos.

- Het zitten in een gevangenis ontneemt je alle zin om je met je toekomst berig te houden.

- Ik vind mijn verblijf hier een goed moment om mijn leven een betere wending te geven.

- Activiteiten zijn er in de gevangenis alleen maar om gedetineerden een beetje bezig te houden.

- Hoe mijn leven $n a$ de bajes eruit gatat zien houdt mij nu weinig bezig.

- Je goed voorbereiden op je toekomst, daar kom je in de bajes nauwelijks aan toe.

- Op je toekomst heb je als gedetineerde weinig invloed.

- Door gevangenisstraf gaat het eerder slechter dan beter met je.

- Hoe langer ik hier zit des te somberder zie ik mijn toekomst.

\subsubsection{Beleving van de activiteiten}

De bespreking van de beleving van de activiteiten in Hooldstuk 3 in het kader van de onderzoeksliteratuur geeft aanleiding te veronderstellen dat de beleving zich kenmerkt door verschillende aspecten.

De aspecten die in de literatuur het meest frequent worden genoemd hebben betrekking op de depriverende detentie-situatie. Men gebruikt de activiteiten als uitlaatklep voor de spanningen als gevolg van de detentie, als middel on de verveling te verdrijven en afwisseling en gezelligheid te zoeken, om niet op cel op of op de afdeling te hoeven verblijven. Het gaat hier in belangrijke mate om vermijdingsgedrag of 'avoidance posture'.

Daarnaast kan men op grond van de literatuur een aantal aspecten onderscheiden die te maken hebben met de behoefte aan actief bezig zijn, zelfexpressie, persoonlijke groei en (maatschappelijke) vooruitgang en met het zelfbeeld en zelfvertrouwen van gedetineerden. Het gaat hier kortom om aspecten die samenhangen met het scheppen van de voorwaarden voor verandering in de (toekomstige) levenssituatie.

De verschillende aspecten van de beleving worden in dit onderzoek bij een vijftal activiteiten in meer diepgaande zin onderzocht, namelijk het penitentiaire onderwijs, kunstzinnige vorming, hulpverlening en de gestichtarbeid en vrije tijdsbesteding.

Voor elk van deze activiteiten zijn meetinstrumenten ontwikkeld.

\subsubsection{Beleving van de onderwijsactiviteiten}

Bij de beleving van de onderwijsactiviteiten werden de volgende aspecten geselecteerd die te maken hebben met de ongemakken en depriverende omstandigheden van de detentie:

1) vermijdingsgedrag, 2) ontspanning, 3) het verlichten van de depriverende detenticomstandigheden in het algemeen.

De aspecten die gericht zijn op de persoonlijke groei en zelfverbetering betreffen het volgende;

1) onderwijs is in het algemeen een zinvolle, positieve manier van tijdsbesteding, 2) zelfvertrouwen, 3) zelfbeeld, 4) cognitieve doelen, of anders gezegd 'leren on het plezier van het leren zelf', 5) toekomstige werk- en levenssituatie.

Er werd een schaal Onderwijs geconstrueerd bestaande uit 10 items met een alpha van .86 .

Hoe hoger de score des te zinvoller acht men het onderwijs voor de persoonlijke ontwikkeling en toekomstig functioneren.

De antwoordcategorieën variëren van 1 "mee eens" tot en met "mee oneens" 5. 
Schaal Onderwijs

- Bij het onderwijs heb ik het gevoel dat ik mijn tijd op een positieve manier doorbreng.

Ik heb iets nieuws geleerd bij het onderwijs.

lk ben trots op mijn prestaties bij het onderwijs.

Aan een cursus bij het onderwijs heb je altijd wel iets.

Bij het onderwijs heb ik plezier gekregen in het studeren.

Door onderwijs denk ik straks, na vrijlating eerder werk te vinden.

Door onderwijs te volgen ben ik positiever over mijn toekomst gaan denken.

Door onderwijs weet ik nu beter wat voor werk of opleiding ik kan gaan doen als ik weer vrij ben.

Na mijn vrijlating wil ik doorgaan met het volgen van onderwijs.

Wat ik bij onderwijs leer. is denk ik nuttig voor mijn toekomst.

\subsubsection{Beleving van de kunstzinnige vorming}

Bij de beleving van de kunstzinnige activiteiten, ook wel 'crea' in het gevangenisjargon, werd eveneens een onderscheid gemaakt in aspecten die verwijzen naar de detentie-situatie en aspecten die betrekking hebben op de persoonlijke ontwikkeling en (toekomstige) levenssituatie. De uitspraken in relatie tot de detentic-situatie hebben betrekking op: vermijdingsgedrag, het doden van de tijd en gerichtheid op gezelligheid en ontspanning.

De belevingsaspecten die betrekking hebben op de persoonlijke ontwikkeling en de (toekonstige) levenssituatic werden als volgt gerepresenteerd: crea als zinvolle tijdsbesteding, verhogen van zelfvertrouwen en zelfbeeld, cognitieve doelen, zelfexpressie, het vinden van een zinvolle, toekomstige vrije tijdsbesteding en sociale ontwikkeling.

Voor de crea-activiteiten konden na principale componenten-analyse twee factoren worden onderscheiden namelijk een factor voor de belevingsaspecten die gerelateerd zijn aan de detentie-situatie en een factor die betrekking heeft op de beleving van crea in termen van persoonlijke groei: Crea Kort, gericht op korte termijn-aspecten en Crea Lang, gericht op het persoonlijk functioneren en op de toekomst gerichte effecten (bijlage 2).

De schaal Crea Kort bestaat uit 7 items en heeft een Cronbach's alpha van .75. De schaal Crea Lang bestaat uit 11 items en heeft een Cronbach's alpha van .84. De antwoordcategorieën variëren van 1 "mee eens tot en met 5 "mee oneens".

Schaal Crea kort

- De belangrijkste reden voor mij om naar crea te gaan is om van de afdeling of cel af te zijn.

Ik vind het niet zo belangrijk wat ik bij de crea doe, als ik de tijd maar on krijg.

Ik ga naar de crea als ik mij verveel.

Iets nieuws leren bij de crea vind ik niet zo belangrijk.

Als ik naar de crea ga weet ik van tevoren nooit wat ik wil gaan doen.

Ik ga vooral naar de crea voor de gezelligheid.

Ik ga alleen naar de crea als ik nog iets nodig heb voor op cel. 
Schaal Crea lang

- Bij de crea heb je het gevoel dat je je tijd nuttig besteedt

- Bij de crea krijg je steeds meer plezier in het maken van dingen

- Bij de crea ben ik een stuk handiger geworden in het hanteren van materialen en technieken

- $\quad l k$ ben trots op de dingen die $i k$ bij de crea heb gemaakt

- Bij de crea heb ik ontdekt meer te kunnen dan ik eigenlijk dacht

- Ik vind het belangrijk iets nieuws te leren bij de crea

- Als ik naar de crea ga. weet ik van tevoren al wat ik wil gaan maken

- Na mijn vrijlating wil ik in een cursus verder gaan met creatieve activiteiten

- Door de crea denk ik na vrijlating minder problemen te hebben met vrije tijdsbesteding

- Door de crea kan ik prettiger ongatan met mede-gedetineerden

- Door de crea heb ik een beter contact gekregen met bewarend personeel

\subsubsection{Beleving van de hulpverleningsactiviteiten}

Ten aanzien van de beleving van de gesprekken die men heeft gevoerd met hulpverleners van het penitentiair reclasseringswerk, de psycholoog en geestelijke verzorgers werden eveneens aspecten geselecteerd die met de directe problemen, spanningen en ongemakken van de detentie verband houden en aspecten met betrekking tot persoonlijke groei en toekomstige levenssituatie. In de onderzoeksliteratuur werd immers een verschil in visie op de problemen geconstateerd tussen cliënt en hulpverlener. De cliënt is sterker geïnteresseerd in praktische en materiële hulpverlening en de hulpverleners van de reclassering bij voorbeeld leggen veel meer de nadruk op psycho-sociale hulpverlening.

Belevingsaspecten met betrekking tot de detentiesituatie zijn als volgt geoperationaliseerd: het ontladen, afreageren van spanningen en de 'praatpaalfunctie van de hulpverlener en het verminderen van de directe praktische problemen als gevolg van de detentie.

De belevingsaspecten die samenhangen met de persoonlijke ontwikkeling en (toekomstige) levens-situatie hebben betrekking op zelfvertrouwen, zelfbeeld of zelfinzicht en de toekomstige levens-situatie.

Op basis van inhoudelijke verschillen tussen de items zijn twee schalen hulpverlening kort en hulpverlening lang geconstrueerd.

Schaal Hulpverlening kort

- Door een gesprek met de hulpverleners voel ik me minder gespannen.

- Door mijn gesprekken met hulpverleners vind ik het uitzitten van mijn straf minder zwaar.

- Door mijn gesprekken met hulpverleners vind ik emotionele steun.

- Het belangrijkste vind ik dat hulpverleners naar mij luisteren.

- Door gesprekken met hulpverleners kan ik de problemen die hier op mij afkomen beter aan.

Schaal Hulpverlening lang

- Na een gesprek met de hulpverleners krijg ik weer meer vertrouwen in mezelf.

- Door mijn gesprekken met hulpverleners begrijp ik nu beter waarom ik in de problemen ben geraakt.

- Contacten met hulpverleners vind ik belangrijk voor mijn toekomst.

- Door de ondersteuning van de hulpverleners weet ik beter hoe ik straks na vrijlating verder moet.

- De hulpverleners heb ik nodig om voortaan uit de bajes te blijven. 
Hulpverlening kort bestaat uit 5 items met betrekking tot de belevingaspecten van hulpverlening die gerelateerd zijn aan de directe omstandigheden van de detentie. Deze schaal heeft een Cronbach's alpha van .78. Hulpverlening lang heeft betrekking op de belevingsaspecten die gerelateerd zijn aan de persoonlijke ontwikkeling en toekomstige levenssituatie. Deze schaal omvat vijf items; Cronbach's alpha is .85 .

Hoe hoger de score des te meer waardeert men de hulpverlening voor hetzij het effect op de korte termijn, hetzij op de lange termijn. De antwoordcategorieën variëren van 1 "mee eens" tot en met 5 "mee oneens".

\subsubsection{Arbeidssatisfactie}

In het beleid dat voortvloeit uit de Nota Werkzame Detentie neemt de arbeid een cruciale rol in binnen het regimesactiviteitenprogramma. Arbeid dient meer structuur te geven aan het dagelijkse leven van de gedetineerden. Bovendien zullen hierdoor, naar men hoopt ook de kansen van de gedetineerden op de arbeidsmarkt verbeteren. De betere toekomstige positie op de arbeidsmarkt als verwacht effect van de arbeid is een van de vijf onderwerpen die gedetineerden kregen voorgelegd. De overige aspecten hebben betrekking op het nut in het algemeen, op de persoonlijke ontwikkeling,

De schaal Tevredenheid Arbeid bestaat uit 5 items; Cronbach's alpha is .76. De antwoordcategorieën variëren van 1 "mee eens" tot en met 5 "mee oneens".

Schaal tevredenheid arbeid

- Door met arbeid bezig te zijn denk ik later gemakkelijker werk te vinden.

- Ik leer hier bij de arbeid nuttige dingen.

- Bij de arbeid leer je iets nieuws.

Ik heb plezier in de arbeid die ik hier moet doen.

I $\mathrm{k}$ vind de arbeid hier eentonig.

\subsubsection{Vrije tijdsbesteding}

Uit een studie van de afdeling Beleidsinformatie van de Dienst Justitiële Inrichtingen ( Herbschleb en Zorge, 1992) naar de kwaliteit van de detentie in een van de inrichtingen bleek dat verveling een belangrijk probleem vormt voor gedetineerden. Een van de doeleinden van het regimes-activiteitenprogramma is het tegengaan van verveling. In de voorliggende studie werd eveneens onderzocht in welke mate gedetineerden vinden dat zij hun vrije tijd op een zinvolle en prettige manier kunnen doorbrengen. Het betreft hier de tijd die men doorbrengt buiten het reguliere programma van activiteiten zoals arbeid, onderwijs, sport, crea, bibliotheekbezoek en hulpverleningscontacten. Tevens werd de wijze onderzocht waarop men de vrije tijd doorbrengt, dat wil zeggen met andere gedetineerden of voornamelijk alleen op cel.

De antwoordcategorieën variëren van 1 "heel vaak" tot en met 5 "nooit".

De schaal Tevredenheid Vrijetijdsbesteding bestaat uit 4 items; Cronbach's alpha is .62. De scores op de twee eerste items werden gespiegeld. Een hoge score op deze schaal betekent dat men tevreden is over de wijze waarop men de vrije tijd kan doorbrengen.

Schaal Tevredenheid vrijetijdsbesteding

- Vindt u dat u hier de vrije tijd op een prettige manier kunt doorbrengen?

- Als u 's avonds, in het weekend of in uw vrije dagdeel op de afdeling verblijft, hoe vaak brengt $u$ dan uw tijd door in de groep?

- Blijft $\mathrm{u}$ in uw vrije tijd ook wel eens op cel?

- Hoe vaak komt het voor dat u zich verveelt? 
Tenslotte wordt een item met betrekking tot het doorbrengen van de vrije tijd met de groep medegedetineerden als een aparte variabele Contacten met Medegedetineerden in het onderzoek betrokken. Deze variabele wordt daatoe slechts op item-niveau gemeten. Het betrefi hier een analyse waarbij. in het kader van de veronderstelde werking van het prisonisatic-proces, de relatie van deze variabele met de houdingen ten anzien resocialisatie wordt onderzocht.

\subsubsection{Deelname aan de activiteiten}

De dechame atan de activiteiten onderwijs, crea, hulpverlening, bibliotheckbezoek en sport werd op item- niveau gemeten. Bchalve bij de hulpverleningsactiviteiten variëren de antwoordcategoricën van I "heel vaak" tot en met 5 "nooit". Ook hier werd de richting van de scores veranderd zodat een hoge score van 5 betekent dat men heel valak deelneemt en een lage score van 1 dat men nooit deelneemt.

Bij de hulpverleningsactiviteiten werd gedetineerden gevaangd of men gedurende het afgelopen half jaar een of meerdere contacten had met medewerkers van het BSD. Penitentiair Reclasseringswerk, Geestelijke Verzorging en met de psycholoog/ psychiater. De antwoordcategorieën variëren hier van l "Ja" lot 2 "Nee".

Om een indruk te krijgen van de aard van de contacten met deze instanties kon men voor het BSD onderwerpen aankruisen als verblijfsvergunning, overplaatsing, uitkering, onderdak. algemeen verlof, algemene informatie, informatie over het CAD en overige redenen.

Voor de overige instanties waren de mogelijke onderwerpen van gesprek huisvesting. uitkering, scholing/ opleiding, werk, relaties met familie/ partner, drugsverslaving, psychische problemen. gezondheid, problemen met vrije tijdsbesteding, problemen op de afdeling en overige onderwerpen.

Bij het penitentiaire onderwijs werd een soongelijke inventarisatie gemaakt van het lype onderwijs of cursus die men volgt. Respondenten konden de volgende onderwerpen atankruisen: Algemene Ondernemers Vaardigheden (AOV), computeronderwijs, Nederlands als tweede taal, leren lezen en schrijven, optriscursus Nederlands, Engels, verkeerstheorie, vakopleiding houtbewerking, technische test-en oriëntatiecursus en en Maatschappelijk Integratie-project. Wat dit laatste onderdeel betreft, in de inrichting te Sittard konden gedetineerden ten tijde van de uitvoering van het veldonderzoek zich opgeven voor het M.I.-project dat kont daarvoor van start was gegaan. De selectie van deze onderwerpen berust op een inventarisatie van het onderwijsaanbod in de drie inrichtingen. Tevens werd gevraagd of men bij het onderwijs van de inrichting waarin men verblijft reeds een diploma of certificat heeft gehaald. Deze vraag is niet onbelangrijk, men krijgt immers op grond hiervan in enigerlei mate een indruk van de doelgerichtheid van de onderwijsactiviteiten.

Bij onderwijs, hulpverlening en crea konden respondenten tevens de redenen aangeven waarom men geen gebruik maakt van deze activiteiten. Een reden kan zijn dat de activiteiten qua inhoud niet aanspreken, men andere dingen belangrijker vindt, men liever de tijd rustig op cel of op de afdeling wil doorbrengen of omdat men het vervelend vindt om in een groep aan cen activiteit te doen. Voor zover men andere dan de bovengenoemde redenen had kon men die eveneens aangeven.

Tenslotte werden de deelname-categorieën bij de hulpverlening nog verder verfijnd door ze op te splitsen in een vijftal categorieën die variëren van 'geen contact met een van de genoemde instanties, contact met een of meerdere (oplopend tot vier) van de genoemde instanties.

\subsubsection{De subjectieve omgeving: regimesevaluatie}

In het conceptuele model uit hoofdstuk 4 werd een onderscheid gemaakt in een objectieve en subjectieve omgeving. De subjectieve omgeving weerspiegelt de gevangenisomgeving zoals 
deze door gedetineerden wordt beleefd. In de onderzoeksliteratuur meet men de subjectieve ongeving veelal via de beleving van het regime. In het regime immers worden objectieve eigenschappen zoals de inrichtingsideologie en het hicrmee samenhangende beleid geconcretisecrd. In het Nederlandse onderzoek uit de jaren tachtig naar de detentiebeleving (van der Linden, 1981, Grapendaal,1987) operationaliseert men de beleving van het regime door middel van de contacten tussen gedetineerden en bewarend personeel. Ten grondslag aan deze keuze ligt de bevinding dat de aard van deze contacten in belangrijke mate bepalend is voor de wijze waarop gedetineerden het regime in zijn totaliteit beoordelen. Bij de operationalisering van de beleving van het regime hanteert men doorgaans het uit de onderzoeksliteratuur bekende onderscheid in gedetineerden-cq-ordegerichte aspecten. De orde-gerichte aspecten betreffen onderwerpen als regelgeving, handhaving van de regels, duidelijkheid ten aanzien van de regels, een ongedifferentiecrde benadering (gelijke monniken, gelijke kappen) grote onderlinge, sociale afstand. Gedetineerdengerichte aspecten van het regime hebben betrekking op onderling vertrouwen, alandacht voor de individuele behoeften van gedetineerden, ondersteuning, aanmoedigen tot een zinvolle invulling van de detentie en het toepassen van sancties als uiterste middel. Het verschil tussen de orde- en gedetineerden gerichte aspecten komt in het kort gezegd neer op een nadruk op enerzijds gehoorzaamheid en discipline en anderzijds aandacht voor de bejegening en het herstel van gedetineerden in psycho-sociale zin.

De formulering van de items met betrekking tot de twee aspecten van het regime werden voor een deel ontleend aan de studies van van der Linden (1981) en Grapendaal (1987).

De schaal Regimesevaluatie omvat 11 items; Cronbach's alpha is .84. Hoe lager de score des te meer ervalart men het regime als orde-gericht. Een hoge score duidt op een meer als gedetineerden-gericht ervaren regime

De antwoordcategorieën van deze schaal variëren van 1 "mee eens" tot en met 5 "oneens".

\section{Schaal Regimesevaluatic}

Bewaarders behandelen gedetineerden hier als een nummer.

Bewaarders treden hier streng op tegen het overtreden van de regels.

Het lijkt wel of bewaarders er alleen maar op uit zijn je het leven zo zuur mogelijk te maken.

Bewaarders en gedetineerden zijn tegenover elkaar staande partijen.

Hier moet je zonder tegensputteren doen wat je gezegd wordt.

Bewatarders zijn niet te vertrouwen.

Bewaarders moedigen je aan ook nog iets positiefs van je detentie te maken.

Bewaarders zien hier veel door de vingers.

Bewaarders hebben hier echte belangstelling voor je.

Als je problemen hebt, proberen bewaarders je zo veel mogelijk te helpen.

\subsubsection{Achtergrondkenmerken van persoonlijke, strafrechtelijke en penitentiaire aard}

Bij de beschrijving van de achtergrondkenmerken van persoonlijke, strafechtelijke en penitentiaire aard van de onderzochte populatie werd uitsluitend gebruik gemaakt van gegevens die door gedetineerden zelf werden verstrekt.

\subsubsection{Persoonskenmerken}

Gevraagd werd naar de volgende persoonskenmerken:

1. Leeftijd ("hoe oud bent u?);

2. Werkervaring (had $u$ werk toen u gedetineerd werd?);

Hiermee werd aangegeven of men al dan niet over werk beschikte voorafgaand aan de detentie.

3. Druggebruik voorafgaand aan de detentie en het soort druggebruik (harddrugs en/ of 
softdrugs);

4. Opleidingsniveau van de onderzochte populatie werd gemeten via een zevental antwoordmogelijkheden namelijk lager onderwijs, lager beroepsonderwijs, MAVO of middelbaar beroepsonderwijs, HAVO of VWO, HBO of Universitaire opleiding, andere opleiding en "geen opleiding afgemaakt";

5. Burgerlijke staat omvat een vijftal antwoordmogelijkheden namelijk gehuwd, ongehuwd, gescheiden, samenwonend, vaste relatie maar niet samenwonend;

6. De culturele of etnische achtergrond werd gemeten via een zestal categorieën, namelijk Nederlands, Surinaams, Antilliaans, Turks, Marrokaans en een categorie overige alkomst;

7. Toekomstverwachtingen;

De verwachtingen ten aanzien van de toekomst, een variabele dic van invloed kan zijn op aanpassingsprocessen en indirect ook op houdingen ten aanzien van de voorbereiding van de terugkeer in de samenleving werd gemeten door een zevental items, ontleend aan Zingraff et al. (1975). Deze items weerspiegelen de vooruitzichten die men voor zichzelf ziet na terugkeer in de samenleving bij voorbeeld in de vorm van ondersteuning door familie, vrienden en bekenden, de mate waarin men zijn (toekomstig) leven geschaad acht door de detentie en de mate van optimisme omtrent het leven na ontslag.

De schaal Toekomstverwachtingen bestaat uit 7 items; Cronbach's alpha is .75 . Hoe hoger de score des te positiever is men over de toekomst. De antwoordcategorieën van deze schalal variëren van 1 tot en met 5 .

Schaal Toekomstverwachting

- Op familie en vrienden hoef ik verder niet meer te rekenen.

- Ik denk dat mijn vroegere vrienden en bekenden mij straks, als ik weer vrij ben, nog steeds zullen respecteren.

- Het lijkt mij erg vervelend om straks als ik vrij ben allerlei bekenden tegen te komen.

- Het feit dat ik in de gevangenis zit heeft mijn hele leven gerü̈neerd.

- In mijn leven is totnogtoe zoveel fout gegaan, datarom zie ik mijn leven na de bajes weinig rooskleurig in.

- Ik heb goede hoop dat als ik weer eenmaal vrij ben het allemaal wat beter met me zal gaan.

- Ik denk dat de mensen mij straks als ik weer vrij ben en mij goed gedraag een eerlijke kans zullen geven.

\subsubsection{Strafrechtelijke en penitentiaire kenmerken}

In dit onderzoek wordt ten aanzien van de strafrechtelijke en penitentiaire kenmerken aandacht besteed aan een zestal kenmerken. Achter elk kenmerk wordt tussen haakjes de operationalisering middels de aan de respondenten voorgelegde vraag weergegeven

1. Recidive ("is dit de eerste keer dat u een straf uitzit?");

2. Verblijfstitel. Het begrip verblijfstitel of status behelst een administratieve typologie van gedetineerden naar de aard van de detentie. De fase in het strafproces (voorlopige hechtenis) en de aard van de opgelegde vrijheidsstraf (kortgestraft en langgestraft) gelden in dit onderzoek als criteria;

3. Duur van het verblijf in een penitentiaire inrichting in het algemeen ("hoe lang zit u al?") uitgedrukt in maanden;

4. Duur van het verblijf in de inrichting waar men op het moment van de afname van de enquête gedetineerd is ("hoe lang zit $\mathrm{u}$ al in deze inrichting?") uitgedrukt in maanden;

5. Strafrestant ("hoe lang moet u nog?") uitgedrukt in maanden;

6. Strafduur. De strafduur wordt in dit onderzoek opgevat als de totale tijd die men inclusief het 
ondergane voorarrest en de toepassing van de regeling van de vervroegde invrijheidstelling krachtens een veroordeling tot cen vrijheidsstraf in detentie moet verblijven. De strafduur wordt uitgedrukt in maanden en wordt berekend door de verblijfsduur en het strafrestant te sommeren. Bij de beschrijving van de variabelen verblijfsduur, strafduur en strafrestant worden de volgende vier catcgorieën gebruikt: korter dan 6 maanden; zes maanden tot een jaar; een jaar tot twee jaar; langer dan twee jaar;

7. Detenticfase: in dit onderzoek worden drie categorieën voor de detentiefase gehanteerd namelijk een beginfase, een middenfase en een cindfase. In navolging van Wheeler (1961) worden de drie fases als volgt gedefinieerd:

- de beginfase: respondenten die minder dan 6 maanden in detentie verblijven;

- de middenfase: respondenten die al meer dan 6 maanden in detentie verblijven en nog langer dan 6 maanden in detentie moeten verblijven;

- de eindfase: respondenten die minder dan 6 maanden in detentie moeten verblijven.

Voor wat betreft de detentiefase wordt volstaan met een globale vergelijking van de respondenten in een HVB regiem, de kortgestrafte en langgestrafte respondenten. Het merendeel (66\%) van de HVB-respondenten bevindt zich immers minder dan zes maanden in detentie en de gemiddelde verblijfsduur is niet exorbitant veel hoger dan zes maanden (namelijk 9 maanden). Van de langgestraften dient een merendeel (75\%) nog langer dan 6 maanden in detentie te verblijven en slechts één langgestrafte gedetineerde verbleef minder dan 6 maanden in detentie. De overige langgestrafte gedetineerden verbleven allemaal reeds langer dan zes maanden in detentie. Alle kortgestrafte gedetineerden hadden een strafrestant van minder dan zes maanden. Van de kortgestraften had 58\% reeds 6 maanden tot twee jaar detentie achter de rug.

Op basis van deze cijfers wordt voor wat betreft de detentiefase volstaan met een ruwe vergelijking aan de hand van de verblijfstitel. De HVB-respondenten worden beschouwd als gedetineerden die overwegend in de beginfase van de detentie verkeren. De langgestrafte gedetineerden worden aangemerkt als een groep die overwegend in de middenfase van de detentie verkeert en de kortgestraften worden beschouwd als een groep die als geheel in de eindfase van de detentie zit.

\subsubsection{De kwaliteit van de implementatie: informatie, ondersteuning en begeleiding, materiaal en middelen}

Een van de doelen van het onderzoek is het nagaan in welke mate de kwaliteit van de implementatie van de activiteiten van invloed is op de houdingen van gedetineerden. Bij de onderwijsactiviteiten, kunstzinnige vorming en de hulpverlening werd dan ook een aantal items in de vragenlijst opgenomen die verwijzen naar informatie- verstrekking over de activiteiten, de plaats in het dagprogramma, ondersteuning en begeleiding, afstemming en materiaal en middelen.

\subsubsection{Informatie}

Belangrijk voor gedetineerden is dat zij bij binnenkomst in de inrichting voldoende geinformeerd worden over de gang van zaken in de inrichting. Een belangrijke rol speelt hier het personeel van de afdeling waarop men geplaatst wordt, zij dienen gedetineerden in dit opzicht wegwijs te maken. Voor wat betreft activiteiten als onderwijs, crea en hulpverlening is er vaak ook sprake van een extra inspanning van degenen die deze activiteiten verzorgen, in de vorm van voorlichtingsmateriaal op de afdeling. Een gebrekkige informatjevoorziening heeft uiteraard gevolgen voor de bereikbaarheid van de activiteiten voor gedetineerden.

Om een indruk te krijgen van de kwaliteit van de informatievoorziening zowel wat betreft de tijden als de inhoud van de activiteiten werden voor het onderwijs en de kunstzinnige vorming 
een aantal items geformuleerd.

De schaal Informatie bestaat uit 7 items, met een Cronbach's alpha van .71. De antwoordcategorieën variëren van 1 tot en met 5 .

Schaal Informatie

- Bij binnenkomst in deze inrichting krijg je voldoende informatie over onderwijs.

- Bij binnenkomst in deze inrichting krijg je voldoende informatic over crea.

- Bij bimnenkomst in deze inrichting krijg je voldoende informatic over hulpverlening door BSD.

- De tijden walarop je hier naar onderwijs kunt gaan zijn duidelijk.

- De tijden waarop je hier naar crea kunt gaan zijn duidelijk.

- Het is hier lastig om te weten te komen wat je zoal kunt gatan doen bij de crea.

- Je weet wat je kunt gaan doen bij het onderwijs.

\subsubsection{Ervaren ondersteuning en begeleiding}

De kwaliteit van de begeleiding en ondersteuning werd gemeten m.b.v. items die betrekking hebben op de mate van bereikbaarheid en aanwezigheid van de hulpverleners, onderwijzers en crea-consulent; de mate waarin men wordt geholpen als men problemen heeft met de lesstof (onderwijs) of met bepaalde technieken (crea) en als men bepaalde (acute) psycho-sociale problemen heeft (hulpverlening). De antwoordcategorieën van deze schaal variëren van 1 tot en met 5

De schaal Ondersteuning bestaat uit 7 items, met een Cronbach's alpha van .74 .

Schaal Ondersteuning

- Mijn ervaringen met het onderwijzend personeel zijn goed.

- Als je de leerstot moeilijk vindt, leggen onderwijzers het goed uit.

- Een gesprek met de onderwijzers is hier snel geregeld.

- Met vragen kan ik altijd bij het onderwijs terecht.

- Als je een bepaald idee bij de creat wilt uitwerken. word je daarbij goed geholpen.

- De bewaarders moedigen je aan naar de crea te gaan.

- Als ik crea heb, is de crea-consulent meestal wel anowezig

\subsubsection{Materiaal en middelen}

Bij de kunstzinnige vorming staat of valt de kwaliteit van deze activiteit niet alleen met de aanwezigheid van een professionele begeleider, ook zaken als voldoende aanwezig materiaal en een goed lokaal dat regelmatig wordt onderhouden zijn zeer belangrijk. Uit de jaarverslagen van de crea-consulenten blijkt dat gebrekkige middelen en onvoldoende faciliteiten een adequate begeleiding van de activiteiten kunnen belemmeren. Om de kwaliteit in dit opzicht te meten werden items geformuleerd met betrekking tot de aanwezige materialen en de conditie van de lesruimte.

Deze schaal Materiaal en Middelen bestaat uit 3 items en heeft een Cronbach's alpha van .80 . Evenals de bovengenoende schalen met betrekking tot de kwaliteit van de implementatie van de activiteiten heeft de schaal antwoordcategorieën die variëren van l"mee eens" tot en met 5 "mee oneens". 
Schaal Materiaal en Middelen

- Als je iets wilt maken bij de crea zijn de materialen aanwezig.

- De creitruimte is een prettige ruimte om in te werken

- De gereedschappen zijn in orde.

\subsection{Beschrijving van de onderzoekspopulatie en representativiteit}

Bij dit onderzoek werd gekozen voor een onderzoeksstrategie waarbij alle potentiële respondenten in eerste instantie worden benaderd. Er werd afgezien van het trekken van een representatieve steckproef in de inrichtingen. In de eerste plaats omdat, gelet op de randvoorwaarden aangaande tijd en geld, dit een veel te omvangrijke onderneming zou worden. In de tweede plaats kan een steekproefsgewijze aanpak in een gevangenisomgeving tot allerlei vervelende complicaties Iciden. Een onderzoek van Grapendaal (1987) laat zien hoe benadering van slechts een deel van de bevolking (de steekproef) nog voor de feitelijke afname van een vragenlijst kan leiden tot een hinderlijke geruchtenstroom met discussies over de vertrouwclijkheid en zin van het onderzoek. Er werd derhalve gekozen voor een strategie waarbij de kans op complicaties zo klein mogelijk werd gehouden.

In de derde plaats geldt hier tevens een methodologisch argument, namelijk dat een steekproef uit de tolale populatie van de drie inrichtingen ( 485 gedetineerden) bij een te verwachten respons van ongeveer $50 \%$ tot te kleine aantallen respondenten leidt, hetgeen weer nadelige gevolgen kan hebben voor het vinden van significante verschillen en samenhangen tussen variabelen.

Om te bepalen of de respondenten representatief zijn voor de totale populatie uit de drie inrichtingen zou cen vergelijking gemaakt kunnen worden tussen response en non-response op een aantal achtergrondkenmerken. Echter, van deze werkwijze moest worden afgezien omdat werd gekozen voor een enquête waarbij anonimiteit werd gewaarborgd. Vergelijking tussen nonresponse en respons op achtergrond-variabelen impliceert immers tevens het opgeven van een naam door de respondent en vervolgens het raadplegen van vertrouwelijke informatie uit de administratie van de inrichting en of de registers van de Justitiële Documentatie.

Een en ander was bovendien te bewerkelijk gelet op de omstandigheden waaronder dit onderzoek moest plaats vinden. Voorts bleek bij navraag in een van de inrichtingen naar het eventueel vergaren van achtergrondinformatie over de inrichtingsbevolking, dat men in cerste instantic hieraan niet wilde meewerken. Ook bleek men niet direct over een bestand te beschikken warin de bevolking op een overzichtelijke wijze naar een aantal achtergrondkenmerken wordt beschreven.

Hoe gevoelig de vertrouwelijke behandeling van gegevens bij gedetineerden ligt, bleek tijdens de afname van de enquête. Niet alleen wilden respondenten weten wat er met de gegevens gebeurde, sommigen weigerden mee te doen aan de enquête op grond van een, blijkbaar diepgeworteld wantrouwen ten aanzien van alles wat met het verstrekken van persoonlijke informatie aan derden te maken heeft.

De meest voor de hand liggende methode is derhalve de respondenten qua achtergrondgegevens te vergelijken met de gegevens over 1995 van het CBS en met gegevens uit 1993 van de afdeling Beleidsinformatie van de Dienst Justitiële Inrichtingen ten aanzien van de kenmerken van de gehele gedetineerdenbevolking. De vergelijking betreft kenmerken als leeftijd, burgerlijke staat, culturele achtergrond, opleidingsniveau, arbeidsverleden, recidive, verblijfstitel, verblijfsduur en strafduur. Het CBS hanteert ten aanzien van de gegevens over de gehele gedetineerdenbevolking een peildatum (30 september). Gebleken is dat gegevens verzameld op deze datum over het algemeen een representatief beeld geven van de gedetineerdenbevolking op een willekeurige 
dag in het jaar. Ten aanzien van kenmerken van de gedetineerden ontleent het CBS de informatie aan een geautomatiseerd verblijfsregistratiesysteem van het Ministeric van Justitie. Het beeld van de gedetineerden bevolking zoals dit uit de overzichten van het CBS naar voren kont kan beschouwd worden als representatief voor de samenstelling van de gedetineerdenbevolking in Nederland op een willekeurige dag in 1995.

Een vergelijking van de kenmerken van de onderzochte gedetineerdenbevolking in deze studie met de gegevens van het CBS en de afdeling Beleidsinformatie van DJI heeft een belangrijke voordeel. Beschrijving van houdingen van gedetineerden ten aanzien van resocialisatie worden, blijkens de onderzoeksliteratuur, nogal eens gekenmerkt door een beperkte generaliseerbaarheid van de conclusies, met name als men de conclusies baseert op impressies en steekproeven waarbij de representativeit niet eens aan de orde wordt gesteld (Kolstad, 1996). Het blijft niet zelden onduidelijk inhoeverre de beschreven houdingen representaticf zijn voor de gedetineerdenbevolking in zijn totaliteit. Inzicht in de kenmerken van de onderzochte populatic en een vergelijking van deze kenmerken met de kenmerken van de algehele gedetineerdenbevolking makt het (tot op zekere hoogte) mogelijk de geldigheid van de conclusies voor een grotere groep gedetineerden te generaliseren. Een dergelijke vergelijking maakt het tenslotte ook mogelijk vast te stellen of de aard van de houdingen al dan niet samenhangt met de onder- cq -oververtegenwoordiging van respondenten met eigenschappen (opleidingsniveau, leeftijd, burgerlijke staat, etnische achtergrond) die blijkens de literatuur de houdingen ten aanzien van resocialisatie kunnen beïnvloeden.

\subsubsection{Leeftijd}

Vergelijken we de percentages van het CBS uit 1995 over de verschillende leeftijdscategorieen van mannelijke gedetineerden met de gegevens over leeftijd van de respondenten uit de enquête dan zien we een verdeling die grotendeels parallel loopt.

Tabel 1: Leeftijdsopbouw van de onderzoekspopulatie in percentages, vergeleken met CBS-gegevens

\begin{tabular}{ccc}
\hline Leeftijd & CBS & Steekproef $N=208$ \\
\hline$<25$ jaar & $26 \%$ & $21 \%$ \\
$25-30$ jaar & $24 \%$ & $28 \%$ \\
$30-40$ jaar & $34 \%$ & $36 \%$ \\
$>40$ jaar & $16 \%$ & $16 \%$ \\
Totaal & $100 \%$ & $100 \%$ \\
\hline
\end{tabular}

De leeftijdscategorie 25-30 jaar is in dit onderzoek vergeleken met het landelijk niveau iets sterker vertegenwoordigd, maar deze afwijking tast de overeenkomst qua leeftijdsopbouw tussen respondenten en de CBS-gegevens niet wezenlijk aan.

De CBS-cijfers laten verder zien dat $84 \%$ van de gedetineerden jonger is dan 40 jaar; deze enquête bleek exact hetzelfde percentage op te leveren. De gemiddelde leeftijd van de respondenten in deze studie is 31 jaar.

\subsubsection{Burgerlijke staat}

De burgerlijke staat van de respondenten werd door middel van vijf categorieën gemeten. In de CBS cijfers komt de categorie vaste relatie maar niet samenwonend niet voor. Deze personen worden in de CBS statistiek waarschijnlijk gerekend tot de categorie ongehuwden. Als we de categorie vaste relatie maar niet samenwonend bij de ongehuwden optellen dan komen we in 
deze studie op een percentage dat het CBS percentage van $58 \%$ enigszins overschrijdt $(61 \%)$. Opvallend is verder dat het percentage gescheiden gedetineerden in deze studie hoger ligt. Verder zijn de percentages vrijwel gelijk.

Tabel 2: Burgerlijke staat van de onderzoekspopulatie in percentages, vergleken met CBS-gegevens

\begin{tabular}{lcc}
\hline Burgerlijke staat & CBS & Stcekproef N N 206 \\
\hline Gehuwd & $14 \%$ & $17 \%$ \\
Ongehuwd & $58 \%$ & $47 \%$ \\
Gescheiden & $7 \%$ & $13 \%$ \\
Samenwonend & $7 \%$ & $9 \%$ \\
Vast, niet samenwonend & - & $14 \%$ \\
Onbekend & $13 \%$ & - \\
Totaal & $100 \%$ & $100 \%$ \\
\hline
\end{tabular}

\subsubsection{Culturele achtergrond}

In deze studie werd gedetineerden gevraagd naar hun culturele achtergrond en niet zoals bij het CBS gebruikelijk is naar de nationaliteit. De reden voor deze keuze is gelegen in het feit dat bij het begrip nationaliteit de eventueel niet-Nederlandse culturele achtergrond van gedetineerden die toch de Nederlandse nationaliteit hebben, onvoldoende tot uiting komt.

Van de 226 respondenten waren 145 gedetineerden van Nederlandse komaf, 11 van Turkse, 9 van Antilliaanse, 14 van Marokkaanse en 13 van Surinaamse afkomst. De categorie 'overige culturele achtergronden' werd ingevuld door 19 gedetineerden. Van 15 gedetineerden is de culturele afkomst onbekend.

Volgens het CBS heeft 50\% van de gedetineerden de Nederlandse nationaliteit en is de andere helft allochtoon. Onder de groep gedetineerden met een Nederlandse nationaliteit kan zich niettemin een gedeelte bevinden met een niet-Nederlandse culturele achtergrond. In werkelijkheid is in de CBS-statistieken het percentage gedetineerden met een buitenlandse culturele achtergrond wellicht nog hoger dan $50 \%$.

In deze studje is het percentage gedetineerden met een Nederlandse culturele achtergrond $64 \%$ procent. De overige gedetineerden (30\%) zijn van buitenlandse komaf. Van $6 \%$ was de achtergrond onbekend.

Een verklaring voor dit resultaat dat nogal afwijkt van de CBS-gegevens is wellicht dat in de regio zuidoost de gedetineerden van buitenlandse komaf wat minder sterk zijn vertegenwoordigd dan bij voorbeeld in de inrichtingen in het westen van het land.

In één inrichting (Roermond) stelde men een overzicht ter beschikking van het aantal gedetineerden met een buitenlandse nationaliteit. Het betrof hier slechts een percentage van $20 \%$ van de totale inrichtingspopulatie.

Gedetineerden met een buitenlandse culturele achtergrond zijn waarschijnlijk ook minder sterk vertegenwoordigd onder de respondenten vanwege de uitval door taalproblemen.

In onderstaande tabel wordt een en ander nog eens samengevat. 
Tabel 3: Culturele achtergrond van de onderzockspopulatie in percentages

\begin{tabular}{lr} 
Culturele achtergrond & $\mathrm{N}=226$ \\
Nederlands & $64 \%$ \\
Surinatams & $6 \%$ \\
Antiliaans & $4 \%$ \\
Turks & $5 \%$ \\
Marrokaans & $6 \%$ \\
Overig & $9 \%$ \\
Onbekend & $6 \%$ \\
Totaal & $100 \%$ \\
\hline
\end{tabular}

\subsubsection{Recidive}

Recidive in dit onderzoek werd geoperationaliseerd door middel van de volgende vraag "Is dit de eerste keer dat u een straf uitzit?". Recidive dient men hier op te valten in de zin van het reeds eerder onvoorwaardelijk veroordeeld zijn tot een gevangenisstraf.

Het percentage first-offenders onder de respondenten bedraigt $40 \%$. De overige gedetineerden $60 \%$ behoorden tot de categorie recidivisten. Een gelijksoortige verdeling treffen we eveneens aan in de algehele gedetineerdenpopulatie, wat het percentage recidivisten, naar cen gangbare schatting tussen de 60 en $70 \%$ ligt. Bij navraag bleken exacte gegevens ontrent recidivisme voor de gehele gedetineerdenpopulatic over het jaar 1995 noch bij het Ministerie van Justitic noch bij het CBS voor handen.

Tabel 4: Recidive voor de onderzoekspopulatie in percentages

\begin{tabular}{lc}
\hline Recidive/ first offender & $\mathrm{N}=206$ \\
Eerste keer in detentie & $40 \%$ \\
Reeds eerder in detentie & $60 \%$ \\
Totaal & $100 \%$ \\
\hline
\end{tabular}

\subsubsection{Opleiding}

In dit onderzoek werd gedetineerden gevraagd naar hun schoolopleiding. Het bleek dat $18 \%$ alleen het lager onderwijs had afgerond, $29 \%$ had een opleiding in het lager beroepsonderwijs en $18 \%$ had een (beroeps) opleiding op middelbaar niveau. Over een HAVO of VWO -opleiding beschikte $8 \%$. Slechts $4 \%$ van de respondenten beschikte over een $\mathrm{HBO}$ of universitaire opleiding. In de categorie andere dan voornoemde opleidingen noemde $4 \%$ een opleiding die bij nadere inventarisatie veelal op middelbaar niveau lag. Tenslotte bleek dat $19 \%$ geen enkele opleiding had afgerond. Deze categorie werd uiteindelijk ingedeeld bij de groep op het laagste niveau, namelijk lager onderwijs.

Resumerend blijkt dat van alle respondenten $66 \%$ qua vooropleiding valt in de categorie lager onderwijs/ lager beroepsonderwijs, hetgeen heel goed overeenkomt met gegevens uit 1993 van de afdeling Beleidsinformatie van de Dienst Justitiële Inrichtingen (DJI). Uit die gegevens blijkt dat $65 \%$ van de gedetineerden die werken, een vorm van arbeid verrichten die op het niveau ligt van ongeschoolde en geschoolde handarbeid. We mogen ervan uitgaan dat het soort werk dat men verricht tegelijkertijd een vrij getrouwe afspiegeling geeft van de genoten vooropleiding. Een vergelijking met de gegevens van het Ministerie is om die reden derhalve legitiem. Uit diezelfde gegevens van de afdeling BI/DJI blijkt dat $26 \%$ werkzaam is op middelbaar niveau. In 
deze enquête komen we tot een percentage van $18 \%$. Als we dit percentage vermeerderen met de $4 \%$ van de categorie 'andere opleiding dan voornoemd' dan komen we uit op een percentage van $22 \%$. Volgens de gegevens van het DJI is $9 \%$ werkzaam op hoger niveau en in deze enquete is $12 \%$ van de gedetineerden hoger opgeleid.

Samenvattend kunnen we ook voor wat betreft de vooropleiding van de respondenten stellen dat de frequenties overeenkomen met het gangbare beeld dat de totale gedetineerdenpopulatie qua opleiding doorgaans te zien geeft.

Tabel 5: Opleidingsniveau van de onderzoekspopulatic in percentages

\begin{tabular}{lr}
\hline Opleiding & $N=154$ \\
\hline Lagere school & $37 \%$ \\
LBO & $29 \%$ \\
MAVO/MBO & $22 \%$ \\
HAVO/VWO & $8 \%$ \\
HBO/Universiteit & $4 \%$ \\
Totaal & $100 \%$ \\
\hline
\end{tabular}

\subsubsection{Werkervaring}

Gegevens van het DJI uit 1993 laten zien dat $44 \%$ van de gedetineerden hetzij in de vorm van een eigen bedrijf, hetzij in de vorm van een betaalde baan (29\%) over werk beschikte. Bijna de helft was werkloos en aangewezen op een uitkering (46\%). Gedetineerden die wel een eigen inkomen hadden maar dat inkomen noch uit een betaalde baan noch uit een eigen bedrijf haalden, vertegenwoordigden 10\% van het totaal. Deze beschikten dus eigenlijk niet over werk in de reguliere zin en kunnen derhalve bij de categorie werkloos worden gevoegd. De DJI gegevens laten dus een werkloosheidpercentage zien van 56\%. Van de respondenten uit deze enquête bleek $57 \%$ werkloos te zijn en $34 \%$ beschikte wel over werk voordat men gedetineerd werd. Van de respondenten beantwoordde $9 \%$ deze vraag niet en valt onder de categorie onbekend. Vergeleken met de DJI gegevens is in deze studie het aantal werkenden lichtelijk ondervertegenwoordigd.

In tabel 7 worden de gegevens over het arbeidsverleden van de onderzoekspopulatie gepresenteerd.

In deze tabellen wordt het percentage 'onbekend' buiten beschouwing gelaten en ligt het percentage respondenten over de hele populatie dat werk had voordat men gedetineerd werd op $38 \%$ en het percentage dat geen werk had is $62 \%$.

Tabel 6: Werkervaring van de onderzoekspopulatie in percentages

\begin{tabular}{lc}
\hline Werkervaring & $\mathrm{N}=205$ \\
\hline Wel werk & $38 \%$ \\
Geen werk & $62 \%$ \\
Totaal & $100 \%$ \\
\hline
\end{tabular}




\subsubsection{Drugs}

Van de respondenten gebruikte $56 \%$ drugs voordat men werd gedetineerd en $44 \%$ gebruikte geen drugs. Het betreft hier drugsgebruik naar eigen opgave. Zoals bekend uit eerder onderzoek (Grapendaal et al.,1985) moet rekening worden gehouden met een 'dark number' van rond de $20 \%$. Dit percentage berust op onderzoek uit de jaren tachtig, wellicht ligt het 'dark number' nu nog aanmerkelijk hoger.

Evenals in de studie van Grapendaal verschilt het gebruik van alleen soft drugs voor detentie weinig van het gebruik van alleen hard drugs. De percentages die in het onderhavige onderzoek werden gevonden zijn identiek (29\%).

Zowel hard drugs als soft drugs werden door $42 \%$ van de respondenten gebruikt voorafgaande aan de detentie.

Meer dan de helft van de respondenten die aan dit onderzoek meewerkten, gebruikten voorafgaand aan de detentie, naar eigen zeggen, drugs. Dit is een aanzienlijk percentage. Ook hier zijn geen exacte gegevens over het jaar 1995 voor handen. Men mag echter op grond van datgene wat algemeen bekend is over de mate van druggebruik van gedetineerden ervan uitgaan dat de percentages die in dit onderzoek werden gevonden met dit beeld in overeenstemming zijn.

Tabel 7: Druggebruik van de onderzoekspopulatic in percentages

\begin{tabular}{lc}
\hline Druggebruik & $\mathrm{N}=209$ \\
\hline Wel druggebruik & $56 \%$ \\
Geen druggebruik & $44 \%$ \\
Totaal & $100 \%$ \\
\hline
\end{tabular}

\subsubsection{Verblijfstitel}

Van de 226 respondenten bevonden 134 personen zich tijdens de afname van de enquête in een Huis van Bewaring, 48 personen verbleven op een afdeling voor kortgestraften en 44 personen verbleven op een tweetal afdelingen voor langgestraften. Op grond hiervan kan men vaststellen dat het percentage gedetineerden dat tot een gevangenisstraf is veroordeeld en daadwerkelijk in een gevangenis verblijft $40 \%$ is.

Niet al de 134 respondenten in een HVB-regime waren in afwachting van de behandeling van hun zaak ter terechtzitting. Op de vraag "hoe lang moet u nog"? konden immers 73 respondenten die in een HVB verblijven een antwoord geven, derhalve waren deze respondenten blijkbaar al veroordeeld. De vraag tot welke soort vrijheidsstraf men veroordeeld is, namelijk een principale dan wel vervangende hechtenis of een gevangenisstraf is niet aan de respondenten voorgelegd. De helft van de reeds veroordeelde gedetineerden in een HVB -regime had een strafrestant van minder dan zes maanden en zat dit restant uit in aansluiting op de voorlopige hechtenis. De precieze samenstelling van het overige deel van de afgestraften in een HVB regime is echter niet vastgesteld. Onder deze groep bevinden zich in de regel ook respondenten die qua verblijfstitel tot de categorie gevangenisstraf dienen te worden gerekend, omdat men reeds veroordeeld is tot een gevangenis-straf en in afwachting is van een definitieve plaatsing in een gevangenis.

In tabel 10 wordt een overzicht gegeven van de verblijfstitel van de onderzoekspopulatie. Van deze populatie heeft $40 \%$ als verblijfstitel gevangenisstraf. De resterende $60 \%$ bestaat uit respondenten die in een Huis van Bewaring verblijven. Van deze groep zit bijna de helft in voorlopige hechtenis en de overige helft bestaat dus uit respondenten die hun vrijheidsstraf in een Huis van Bewaring uitzitten of in afwachting zijn van plaatsing in een gevangenis cq TBS- 
kliniek of van uitlevering en of uitzetting.

Een vergelijking van de verblijfstitel van de respondenten met CBS gegevens over de algehele gedetineerdenpopulatie laat het volgende zien. Landelijk is de verblijfstitel voor $33 \%$ van de gedetineerden voorlopige hechtenis. Voorts blijkt uit de gegevens van het CBS dat $32 \%$ van de algehele populatic van Huizen van Bewaring is veroordeeld tot een vrijheidsstraf. Van de gedetineerdenbevolking is $56 \%$ veroordeeld tot een gevangenisstraf.

Tabel 8: verblijfstitel van de onderzoekspopulatie vergeleken met CBS gegevens

\begin{tabular}{lrr}
\hline Verblijfstitel & $\mathrm{N}=226$ & $\mathrm{CBS}$ \\
\hline HVB-voorlopig gehecht & $28 \%$ & $33 \%$ \\
HVB-overig & $32 \%$ & \\
Kortgestraft & $21 \%$ & \\
Langgestraft & $19 \%$ & $56 \%$ \\
Overig & & $11 \%$ \\
Totaal & $100 \%$ & $100 \%$ \\
\hline
\end{tabular}

De onderzoekspopulatie vertoont, als het gaat om het verblijf in een Huis van Bewaring krachtens voorlopige hechtenis of een veroordeling tot een vrijheidsstraf, een verdeling die vergelijkbaar is met de verdeling in de algehele gedetineerden bevolking. Gaat het echter om het aandeel van gedetineerden die tot een gevangenisstraf zijn veroordeeld en ook daadwerkelijk in een gevangenis verblijven, dan wijkt de onderzoekspopulatie aanmerkelijk af van het percentage dat in de algehele gedetineerdenbevolking door het CBS werd gevonden. Met name het aantal langgestrafte gedeti-neerden is in vergelijking met de landelijke gegevens aan de lage kant.

Men kan dus hier spreken van een ondervertegenwoordiging van de gedetineerden in de onderzoekspopulatie die tot een gevangenisstraf zijn veroordeeld als men een vergelijking treft met de verdeling qua verblijfstitel in de algehele gedetineerdenbevolking.

\subsubsection{Verblijfsduur ten tijde van het onderzoek}

Van de respondenten verbleef ten tijde van de enquête $42 \%$ minder dan zes maanden in detentie en $24 \%$ verbleef een half jaar tot een jaar in detentie. Van een tot twee jaar verbleef $17 \%$ in detentie en langer dan twee jaar verbleef eveneens $17 \%$ in detentie. De gemiddelde verblijfsduur over alle respondenten is 12 maanden terwijl de gemiddelde verblijfsduur landelijk 108 dagen of ruim drie maanden is.

Niet alle respondenten hebben de tijd dat zij in detentie verblijven steeds in dezelfde inrichting doorgebracht. Men kan om allerlei redenen worden overgeplaatst van de ene naar de andere inrichting. Men dient dus een onderscheid te maken tussen de duur van het verblijf in detentie in het algemeen en de duur van het verblijf in de inrichting waarin de respondent op het moment van de enquête is ondergebracht.

Het verblijf in de inrichting waarin men zich op het moment van de afname van de enquête bevindt, is voor $70 \%$ van de respondenten minder dan zes maanden en voor $19 \%$ zes maanden tot een jaar. Van een jaar tot twee jaar verbleef $10 \%$ in de inrichting en langer dan twee jaar $1 \%$. Het gemiddelde verblijf in de onderzochte inrichtingen is een half jaar. 
Tabel 9: Verblijfsduur van de onderzockspopulatic in percentages

\begin{tabular}{lc}
\hline Verblijfsduur & $\mathrm{N}=200$ \\
$<6$ maanden & $42 \%$ \\
6 maanden tot 1 jaar & $24 \%$ \\
1 tot 2 jaar & $17 \%$ \\
$>2$ jaar & $17 \%$ \\
Totaal & $100 \%$ \\
\hline
\end{tabular}

\subsubsection{Strafduur}

Gedetineerden moeten, zoals Wheeler (1961) terecht constateerde, altijd even rekenen bij de vraag hoe lang men al vastzit of tot welke onvoorwalardelijke strafduur zonder aftrek van vervroegde invrijheidstelling men veroordecld is. Echter op de vraag naar het strafrestant hoe lang moet u nog' weet men doorgaans meteen het antwoord in weken maanden of jaren te geven. Voor wat betreft de strafduur in de zin van het onvoorwaardelijk deel van de opgelegde gevangenisstrat, ongeacht de duur van het ondergane voorarrest of de toepassing van de regeling van vervroegde invrij-heidstelling (VI) werd de respondenten geen afzonderlijke vraag voorgelegd. Gekozen werd voor een beperking van het aantal vragen met betrekking tot penitentiaire gegevens en voor een duidelijke en zo simpel mogelijke formulering in termen van "hoe lang zit u al?" en "hoe lang moet u nog?" De strafduur werd vastgesteld door het aanal maanden of jaren van de verblijfsduur in het algemeen en het aantal maanden of jaren van het strafrestant te sommeren. Gemiddeld moesten de respondenten nog ruim 11 maanden van hun straf uitzitten.

De gemiddelde strafduur van respondenten veroordeeld tot een gevangenisstraf bedraagt ruim 25 maanden. Het landelijk percentage op basis van de CBS gegevens is 30 maanden. Hierbij dient te worden aangetekend dat de strafduur zoals gemeten door het CBS de duur van het onvoorwaardelijk opgelegde deel van de gevangenisstraf betreft ongeacht de duur van het voorarrest en toepassing van de vervroegde invrijheidsstelling. De manier waasop de strafduur van de respondenten in dit onderzoek is gemeten wijkt af van de methode van het CBS. Respondenten gaan naar ik veronderstel, bij de vraag "hoe lang moet u nog" immers uit van de tijd die men feitelijk nog te gaan heeft met aftrek van de vervroegde invrijheidsstelling, die eenderde van de totale onvoorwaardelijk opgelegde gevangenisstraf bedraagt bij straffen van meer dan één jaar.

Tabel 10: Strafduur van de onderzoekspopulatie in percentages, vergeleken met CBS-gegevens

\begin{tabular}{lcc}
\hline Strafduur & CBS & Steekproef $\mathrm{N}=156$ \\
\hline$<$ 6maanden & $26 \%$ & $4 \%$ \\
6 maanden tot 1 jaar & $13 \%$ & $30 \%$ \\
1 tot 2 jaar & $17 \%$ & $29 \%$ \\
$>2$ jaar & $44 \%$ & $37 \%$ \\
Totaal & $100 \%$ & $100 \%$ \\
\hline
\end{tabular}

Vergeleken met de CBS-cijfers zijn de respondenten met een strafduur minder dan 6 maanden sterk ondervertegenwoordigd, het percentage bedraagt $4,5 \%$ terwijl het landelijk percentage $26 \%$ is van het totaal. Bij $30 \%$ betreft het straffen van zes maanden tot een jaar (CBS: $13 \%$ ) en $29 \%$ van de respondenten heeft een opgelegde straf van een jaar tot twee jaar (CBS:17\%). 
Langer dan twee is jaar is de straldur bij $37 \%$ van de respondenten. Uit de CBS statistieken blijkt dat dit percentage onder de Nederlandse gedetineerdenbevolking hoger ligt namelijk $44 \%$.

\subsubsection{Strafrestant}

In tabel 11 wordt tenslotte nog een overzicht gegeven van het strafrestant van de onderzochte populatie Het blijkt dat voor meer dan de helft van de respondenten het einde van de detentie binnen een periode van zes maanden in zicht is.

Tabel 11: Strafrestant van de onderzoekspopulatie in percentages

\begin{tabular}{lr}
\hline Strafrestant & $N=159$ \\
\hline$<6$ maanden & $55 \%$ \\
6 maanden tot 1 jaar & $18 \%$ \\
1 jaar tot 2 jalar & $14 \%$ \\
$>2$ jaar & $13 \%$ \\
Totaal & $100 \%$ \\
\hline
\end{tabular}

Resumerend kan worden gesteld dat de respondenten uit deze enquête qua persoonskenmerken over het algemeen geen sterke afwijkingen vertonen ten opzichte van de kenmerken van de algehele gedetineerdenpopulatie. Een uitzondering geldt hier voor de culturele achtergrond van de respondenten. De gedetineerden met een Nederlandse culturele achtergrond zijn in deze studie sterker vertegenwoordigd dan in de algehele populatie. Het overheersende beeld van de onder-zochte populatie is dat van cen groep mensen die laag is opgeleid, veelal over geen werk bcschikt, ongehuwd is en kampt met een verslavingsproblematiek.

Gaat het om penitentiaire en strafrechtelijke gegevens dan is er een duidelijke overeenkomst met de algehele gedetineerdenpopulatie qua recidive en verblijfstitel als het gaat om gedetineerden die in een Huis van Bewaring verblijven. De onderzochte populatie vertoont vrijwel dezelfde verdeling. De overeenkomst is veel minder groot bij het percentage gedetineerden dat tot een gevangenisstraf is veroordeeld.

De gemiddelde verblijfsduur van de onderzochte populatie is veel hoger dan het landelijk gemiddelde.

Bij de strafduur wijkt de onderzochte populatie als het on de gemiddelde strafduur gaat niet sterk af van de algehele populatie, echter als de strafduur wordt opgesplitst in verschillende perioden dan blijkt de verdeling onder de onderzoekspopulatie in sterke mate af te wijken van de verdeling onder de algehele populatie. Ondanks deze verschillen kan men op grond van het voorgaande conciuderen dat de kenmerken van onderzoekspopulatie in redelijke mate overeenkomsten vertoont met de kenmerken van de algehele gedetineerdenbevolking. 


\subsection{De inrichtingen}

In deze paragraaf zal een korte beschrijving worden gegeven van de inrichtingen waarin het onderzoek werd gehouden.

\subsubsection{Inrichting te Sittard ten tijde van het onderzoek}

\section{Gebouwelijke omstandigheden en bestemming}

Deze gesloten inrichting werd in 1990 in gebruik genomen en kende ten tijde van de uitvoering van het veldonderzoek een Huis van Bewaring (HVB), een tweetal atdelingen voor langgestraften en een afdeling voor kortgestrafte gedetineerden.

Het is een in lichte tinten uitgevoerd complex dat ruim is opgezet. Het voorgebouw is bestemd voor directie-ruimtes en administratie. Vervolgens komt men via een lange gang op cen zogenaand kruispunt centraal dat toegang verschaft tot vier vleugels. Hier zijn de gedetineerden ondergebracht op vleugels die uit twee of drie ringen bestaun.

De activiteiten zijn ondergebracht in een apart gebouw. Hierin bevinden zich de sportfaciliteiten, onderwijs-en crea-ruimtes en de bibliotheek. Tussen de verschillende gebouwen bevinden zich de luchtplaatsen en de sportvelden.

Komt men voor het eerst in deze gevangenis en is men de wat oudere gevangenissen gewend, dan moet men toch wel even wennen aan het nieuwe, steriele karakter van het gebouw, dat voornamelijk in wit is uitgevoerd.

Deze inrichting bezit een formele capaciteit van 262 gedetineerden. Ten tijde van deze enquête werden de vleugels verbouwd om nog meer gedetineerden te huisvesten.

De verdeling van de bewoners over de verschillende afdelingen is als volgt:

A-vleugel: Huis van Bewaring; 50 plaatsen bestend voor mannelijke gedetineerden die in preventieve of vervangende hechtenis zijn genomen, gedetineerden die tot gevangenisstraf zijn veroordeeld en wier werkelijke straftijd niet meer bedraagt dan zes maanden en gedetineerden die zijn veroordeeld tot gevangenisstraf of een TBS hebben gekregen en die in afwachting zijn van een definitieve plaatsing in een gevangenis of TBS-inrichting.

B-vleugel; 74 plaatsen voor kortgestrafte mannelijke gedetineerden, die een straf uitzitten van minder dan zes maanden met een beperkt regime.

C-en D -vleugel: 124 plaatsen voor langgestrafte volwassen mannelijke gedetineerden met een regime van algehele gemeenschap.

E-vleugel; 12 plaatsen voor langgestraften gedetineerden die om verschillende redenen (bv.groepsgeschiktheid) niet geplaatst kunnen worden op de C-en D-vleugel.

Ten tijde van de afname van de enquête in april 1996 was deze inrichting sinds een half jaar Pilot-Werkzame Detentie. Een en ander betekende dat gedetineerden binnen een standaardregime meer gingen werken en dat de ruimte voor de verschillende activiteiten in het regimesactiviteiten-programma kleiner werd. Per week beschikten gedetineerden over een vrije dag waarop vrijwel alle activiteiten op het gebied van onderwijs, kunstzinnige vorming, hulpverlening en geestelijke verzorging dienden plaats te vinden.

Sinds de in gebruikname van de inrichting zien we met name voor de activiteiten die onder de afdeling Sociaal Cultureel Werk vallen, zoals onderwijs, crea, sport en bibliotheek een 
geleidelijke teruggang van het aantal beschikbare uren. Konden bij voorbeeld bij de crea gedetineerden in 1990 en 1991 nog zo'n zes uur per week naar deze activiteit, in 1996 was dit aantal uren geslonken tot anderhalf uur.

Deze ontwikkeling halverwege de jaren negentig hangt samen met bezuinigingen en veranderingen in het beleid.

De status van Pilot Werkzame Detentie en de invoering van een standaard-regime heeft in sommige inrichtingen geleid tot verminderde prioriteit voor activiteiten in de SKW-sector. Zo zijn in een aantal inrichtingen de hoofden SKW van het toneel verdwenen en is de kunstzinnige vorming afgeschaft. In deze inrichting echter handhaafde men de functie van hoofd SKW. De activiteiten in de SKW-sector werden, zij het in afgeslankte vorm, zoveel mogelijk gehandhaafd. De consequenties van deze koersveranderingen in het beleid bleven ook voor deze inrichting niet alleen beperkt tot een vermindering van het aantal beschikbare uren. Met name de plaats van de activiteiten in het dagprogramma werd voor de meeste activiteiten ongunstiger. Een activiteit kon vanwege de krapte in het programma samen vallen met een andere activiteit als bezoek. Crea werd bij voorbeeld voor de B-afdeling voor kortgestraften ingeroosterd op een moment waarop begelei-ding door een consulent niet mogelijk was. De begeleiding bij deze activiteit vond als gevolg hiervan op onregelmatige en minder adequate wijze plaats.

De randvoorwatarden voor een adequate uitvoering van de activiteiten die onder de afdeling SKW vallen, werden als gevolg van een versoberd beleid, ongunstiger.

Buiten het standaardregime vallen gedetineerden die deelnemen aan het zgn. Maatschappelijke Integratie-project. Deze kleine groep gedetineerden die op de $\mathrm{C}$-afdeling voor langgestraften verblijven, krijgen tot op heden ruimere mogelijkheden op het gebied van scholing en vorming. Ten tijde van het onderzoek verkeerde het project Maatschappelijke Integratie in een beginfase. Ook de hulpverleningsactiviteiten in deze inrichting ondervonden de gevolgen van een regimesversobering halverwege de jaren negentig.

Door Werkzame Detentie bleken de cliënten voor het PRW moeilijker bereikbaar. Kon men vroeger gedetineerden ook tijdens arbeid oproepen, in 1996 waren zij alleen op het vrije dagdeel, waarin reeds zoveel andere activiteiten plaatsvonden, bereikbaar. Het zwaartepunt van de psychosociale begeleiding lag in deze inrichting in eerste instantie bij de afdelingen zelf. Integrale penitentiaire zorg (veiligheid, begeleiding en detentieplanning) kreeg vooral gestalte via een beleid onder verantwoordelijkheid van de afdelingsleiding. Problemen dienden in de cerste platats zo veel mogelijk door de PIW-ers/mentoren te worden opgevangen. Bovendien zorgde het dienstvak PIW voor de verblijfsrapportages ten behoeve van begeleidings- en detentieplannen. Voor de kortgestraften op de B-vleugel was ten tijde van de enquête geen mogelijkheid gebruik te maken van de dienstverlening door het PRW.

Door de status van Pilot-inrichting Werkzame Detentie werd in deze inrichting het accent in het Penitentiaire Inrichtingswerk verschoven van de verblijfsafdeling en ontwikkelingsactiviteiten naar de arbeid. Een aantal PIW-ers veranderden van functie en ging als medewerker bij de arbeid aan de slag.

Samenvattend kan worden gesteld dat de beleidswijzigingen in het kader van Werkzame Detentie in deze inrichting ingrijpende consequenties had voor het activiteitenaanbod. De ruime mogelijkheden die voorheen aanwezig waren voor de verschillende activiteiten werden aanmerkelijk verminderd.

\section{Het regimesactiviteitenprogramma}

De volgende beschrijving van het regimesactiviteiten-programma is gebaseerd op de situatie in 1996. Deze situatie is op een aantal gebieden, met name op het gebied van het Penitentiair Reclasseringswerk inmiddels alweer aanmerkelijk gewijzigd. 
Het onderwijs is voor alle afdelingen in principe toegankelijk. zij het dat de afdeling voor kortgestraften veel minder mogelijkheden heeft dan de afdelingen voor langgestraften. Zo volgen kortgestraften en gedetineerden op de addeling met als bestemming een Huis van Bewaring, voomamelijk een cursus verkecrstheoric en een computcrcursus. Voor de HVBgedetineerden en de kortgestratten geldt overigens een regime van beperkte gemeenschap: indien gedetineerden niet deelnemen alan de arbeid of andere activiteiten dan verblijven ze in principe op cel. De langgestraften. met name diegenen die zijn toegelaten tot een MI-traject, krijgen wat ruimere mogelijkheden op het gebied van onderwijs en volgen bij voorbeeld een cursus AOV, of een vakopleiding hout of metaal. De langgestraften verblijven in een regime van algehele gemeenschap met meer bewegingsvrijheid.

Verder kunnen gedetineerden cursussen volgen als Nederlands, leren lezen en schrijven, Engels en een technische test- en orientatiecursus. De onderwijsaldeling is actiel betrokken bij het MIproject. waarbij vooral de langgestrafte gedetineerden die daarvoor in aanmerking komen via de Individuele Traject Begeleidings-methode worden toegeleid naar een betaalde baan of een (vak)opleiding. In deze inrichting was het ten tijde van de enquête voor cen kleine groep gedetineerden mogelijk om tijdens arbeid naar onderwijs te gaan. Er werken vier onderwijzers in deeltijd bij deze afdeling.

De crea-activiteiten zijn in principe toegankelijk voor alle gedetineerden. Bij de start van de inrichting volgden vrijwel alle PIW-ers een crea-opleiding. Bedoeling was aanvankelijk dat de PIW-ers crea in de eerste lijn zouden gaan geven en door de consulent zouden worden begeleid en geschoold. Dit is sinds de opening van de inrichting in 1990 nooit gebeurd vanwege budgettaire en roostertechnische problemen. De rollen zijn nu feitelijk omgedraaid, de consulent geeft crea en de PIW-ers houden toezicht.

Per crea-bijeenkomst kunnen maximaal 8 gedetineerden deelnemen. De feitelijke bezetting is hierdoor hoog. op sommige afdelingen kunnen niet alle belangstellenden worden geplaatst. Men werkt met wachtlijsten. Voor elke afdeling geldt dat men een malal per week anderhalf uur natar de crea-activiteiten kan gaan. Gedetineerden kunnen er houtbewerken, schilderen, tekenen, keramiek beofenen. Bovendien worden er regelmatig speciale projecten, bijvoorbeeld voor tentoonstellingen buiten de inrichting, georganiseerd. Voor kortgestraften en voorlopig gehechten geldt dat indien men niet deelneemt, men achter de deur zit.

Probleem bij deze activiteit is de krapte in de uren van de consulent en van de gedetineerden. Het is hier woekeren met de tijd. Veel gelegenheid om projecten voor te bereiden, aan werving te doen is er niet. Als consulent is men voornamelijk bezig met het begeleiden van groepen. Bij deze begeleiding is een belangrijk uitgangspunt dat gedetineerden de vrijheid krijgen on te maken wat men wil. Weliswaar bestaat het activiteitenprogramma ook uit cursorische onderdelen waarbij de deelnemers gerichte opdrachten uitvoeren om bepaalde technieken onder de knie te krijgen, maar zodra er sprake is van een zekere technische valardigheid worden de deelnemers zoveel mogelijk vrij gelaten om hun eigen ideeën uit te werken. Binnen de dagelijkse gang van zaken in een gevangenis, waarbij het leven volgens een programma verloopt dat heel weinig ruimte overlaat voor eigen initiatief, ontstaan er bij de kunstzinnige vorming aldus waardevolle momenten waarop gedetineerden wel keuzes kunnen maken en eigen initiatieven ontplooien.

Een gedetineerde merkt hierover op: "Er zijn al zoveel regeltjes waar ik me aan moet houden. Ik vind het fijn bij de crea zelf te bepalen wat ik ga doen".

Aan een verslag van een stage-onderzoek uit 1996 naar de rol van kunstzinnige vorning in gevangenissen ontlenen we de volgende opmerkingen van het hoofd SKW van deze inrichting: 
"Crea is en blijft een activiteit die niet per se hoeft te worden aangeboden, hier in deze inrichting noemt men dit wel "overschep". Door deze facultatieve uitgangspositie komt crea slecht uit de bus. Eigenlijk zou de crea-consulent de PIW-ers moeten begeleiden in het begeleiden van gedetineerden. Er zou een pool moeten komen van PIW-ers die graag crea willen begeleiden, maar dergelijke voorstellen zijn tot op heden niet acceptabel bevonden door de dienstcommissie. Momenteel is het gevangenisbeleid aan het versoberen. Binnen dat beleid is geen plaats (meer) voor kunstzinnige vorming. De publieke opinie speelt hierbij een grote rol. Het is immers moeilijk te verkopen aan het publiek en de politiek dat moordenaars en dieven in de gevangenis vrolijk zitten te kleien."

Sport is een belangrijk onderdeel binnen de SKW-afdeling, er werken drie sportinstructeurs die belast zijn met de begeleiding van de PIW-ers. De PIW-ers begeleiden in de eerste lijn de sportactiviteiten. Gedetineerden kunnen meerdere malen per week naar de sport -en fitnessafdeling. Eenmaal per week kunnen gedetineerden een bezoek brengen aan de bibliotheek. Voorheen waren de mogelijkheden voor bibliotheekbezoek ruimer. De bibliotheek kent in het algemeen een hoog bezockersaantal. Ook hier geldt dat de kortgestrafte en voorlopig gehechte gedetineerden die niet naar de bibliotheek gaan op cel verblijven.

Voor een gesprek met een van de hulpverleners van het PRW, Geestelijke Verzorging, BSD en met de psycholoog of psychiater dienen gedetineerden een zgn. loopbriefje in te vullen. Vervolgens worden zij dan opgeroepen voor een gesprek. De hulpverleners van het PRW werken in de begin- en eindfase van de detentie in de ecrste lijn, maar in de tussenfase werken zij in de tweede lijn. Gedetineerden komen in de tussenfase slechts na doorverwijzing bij het PRW terecht. Er werken drie part-time medewerkers, één van hen is belast met verslavingsproblemen. Uit de oriënterende gesprekken met twee van de drie hulpverleners van het PRW blijkt dat de huidige wijze van werken in de tweede lijn grote problemen met zich meebrengt waar het de bereikbaarheid van het PRW betreft. Gedetineerden zijn bovendien weinig bereid hun problemen in eerste instantie voor te leggen aan bewaarders.

De geestelijke verzorgers houden individuele -en groepsgesprekken. Alle denominaties zijn in deze inrichting vertegenwoordigd.

\subsubsection{De inrichting te Grave ten tijde van het onderzoek}

\section{Gebouwelijke omstandigheden en bestemming}

Deze gesloten inrichting die het Huis van Bewaring Grave huisvest, is eind jaren tachtig in gebruik genomen en heeft een formele capaciteit van 348 plaatsen. De indeling van het gebouw is voor de bezoeker die er de eerste keer binnenkomt niet direct overzichtelijk. De cellengebouwen liggen niet bij elkaar en zijn verbonden via een reeks gangen waar men als buitenstaander al gauw de weg kwijt raakt. Een zeer opvallend aspect van het gebouw is de grote hoeveelheid kunst van gedetineerden die er permanent wordt tentoongesteld. Dit is een element dat de sfeer zeer ten goede komt.

Het Huis van Bewaring kent drie verblijfsunits, namelijk de A-,B-, en de E-unit. Elke unit bestaat uit vier afdelingen. De A-en B- unit hebben hetzelfde regime. De E-unit huisvest de bijzondere zorg afdelingen.

ledere gedetineerde komt binnen op een afdeling waar een standaardregime heerst, in deze inrichting ook wel een nul-regime genoemd. Dit regime werd in 1993 door toenmalig directeur Helgers ingevoerd als voorloper op het standaardregime van Werkzame Detentie.

De regimes zijn gebaseerd op de bonus-malus gedachte. Selectie naar een ruimer regime is 
afhankelijk van de gedragsrapportages door personeel van de afdeling en de arbeid. Deelname aan de arbeid is een noodzakelijke voorwaarde voor overplaatsing naar een meer socpel regime. Uit gesprekken met een lid van het management-team bleek gedurende de afname van de enquête dat het bonus-malus systeem toch niet helemaal aan de verwachtingen beantwoordde. In dit verband wil ik verwijzen naar wat Dhondt (1993) heeft opgemerkt naar aanleiding van de invoering van de bonus-malus gedachte. Dhondt beschouwt de invoering van het bonusmalussysteem als een verkapte invoering van dwang. Dwang fungeert als een sturend middel om gedetineerde het 'goede' te laten doen en het 'kwade' achterwege te laten. Dhondt constateert bij de legitimering van de bonus-malusgedachte een onterecht beroep op gedragstherapeutische technieken. Dergelijke technieken hebben slechts kans van slagen in een persoonlijke relatie én als voorat, per persoon, het te veranderen gedrag wordt gespecificeerd, aldus Dhondt.

Er zijn vier afdelingen met een standaardregime. namelijk de Al en A2 en de B1 en B2 als inkomstenafdeling en de $\mathrm{AO}$ en de $\mathrm{B} 0$ als arbeidsafdelingen. De $\mathrm{B} 0$-afdeling kent 15 studieplaatsen voor gedetineerden die in plats van arbeid een studie willen volgen. Studie op deze afdeling heeft een verplicht karakter en men ontvangt een normale arbeidsbeloning. Ten tijde van de afname van de enquête in 1996 was deze studieafdeling (tijdelijk) opgeheven.

De A3 en B3 zijn activiteiten-afdelingen, waarbij de ene helft van de afdeling als aanvulling op het basisprogramma een onderwijsprogramma heeft, en de andere helit een sportprogramma.

De E-unit is bestemd voor een Individuele Begeleidingsafdeling, een drugsvrije afdeling (DVA), thans aangeduid als Verslavings Begeleidingsafdeling, een Detentie inpassingsaldeling en een Baantjesafdeling. Aan deze enquête werkten gedetineerden van de Verslaving Begeleidings Afdeling mee. Op deze afdeling worden gedetineerden geplaatst met een duidelijke verslavingsproblematiek waaraan men wil werken. Men kent hier een uitgebreid activiteiten-programma met een verplicht karakter zoals arbeid, sport, huisdienst, gespreksgrocpen, crea, urinecontrole en celreinigen.

Voor deze enquête werden de volgende afdelingen benaderd: de A3, B3, BO en VBA. Reden voor deze selectie heeft onder meer te maken met de mogelijkheid vergelijkingen te treffen tussen de houdingen van gedetineerden die helemaal niet of weinig motivatie tonen voor activiteiten (B0) met gedetineerden die op grond van een betere motivatie doorstromen naar een afdeling met meer activiteiten (A3, B3 en DVA).

Een gedetineerde van de DVA schreef:

"mijn antwoorden zijn gebaseerd op het feit dat ik op een drugsvrije afdeling zit. Als dit niet zo zou zijn zou ik sommige vragen zeker negatiever hebben beantwoord. Je bent hicr positief bezig, in tegenstelling tot andere afdelingen, waar je je tijd uitzit (Nutteloos en Doelloos). Hier zijn de meeste activiteiten verplicht."

\section{Het regimesactiviteitenprogramma}

Kijken we naar het regimesactiviteitenprogramma van deze inrichting zoals dat in 1996 was samengesteld, dan zien we dat van de veertien afdelingen er slechts vijf afdelingen zijn die onderwijs en crea hebben. Sport en bibliotheekbezoek is echter wel toegankelijk voor alle gedetineerden.

Ondanks het feit dat onderwijs en crea in brede zin niet toegankelijk zijn voor gedetineerden, leidt de SKW-afdeling van deze inrichting toch geen zieltogend bestaan. De inrichting hangt vol met kunstwerken van gedetineerden. Het SKW laat zijn gezicht in deze inrichting duidelijk zien. Ook als we vervolgens kijken naar de personeelsbezetting en andere faciliteiten voor crea en onderwijs dan kunnen we spreken van een redelijk stevige positie in de organisatie. Zowel crea als onderwijs zijn activiteiten die in deze inrichting redelijk goed functioneren. 
Onderwijs krijgen gedetineerden van de A3 en B3 afdelingen en VBA en IBA-afdeling. Voor sommige afdelingen bestaat een wachtlijst. Gedetineerden kunnen vier maal per week naar het onderwijs. Het onderwijsprogramma komt in grote lijnen overeen met het programma in de inrichting te Siltard. Ook hier werkt men met vier onderwijzers met een deeltijdaanstelling. In deze inrichting worden de crea-activiteiten voor de IBA en VBA in de eerste lijn verzorgd door een crea-consulent, gedurende twee dagen per week. Dit is een ruime aanstelling vergeleken met sommige andere inrichtingen waar een consulent voor een zelfde aantal gedetineerden het vaak met twee uur per week moet doen. De crea-activiteiten voor de A3 en B3 worden door PIW-ers verzorgd. Ook de tijdsduur van een crea-blok is ruim bemeten voor sommige afdelingen. Gedetineerden van de IBA hebben in totaal vier uur crea per week.

Uit gesprekken met het hoofd SKW bleek dat een stevige positie van het SKW, met name in de afgelopen jaren waarin het beleid werd versoberd, bevochten moest worden. De mate waarin een afdeling SKW zich weet te handhaven is niet alleen afhankelijk van de 'goodwill' van de directie, cruciaal is blijkbaar tevens een hoofd SKW dat het belang van zijn afdeling ook in moeilijke tijden weet hard te maken tegenover de leiding van de inrichting.

In deze inrichting kunnen gedetineerden voor hun materiële hulpvragen (uitkering, huisvesting naast verlofaanvragen) terecht bij het Bureau Sociale Dienstverlening. Voor de meer immateriële hulpverlening is het PRW de aangewezen instantie. Vanuit de inkomstenafdeling krijgen gedetineerden een intake door een maatschappelijk werker van het PRW.

Uit een gesprek met een van de medewerkers van het PRW bleek dat de hulpverlening die men kan bieden ter voorbereiding van de terugkeer in de samenleving toch in veel gevallen ontoereikend is. Terugval in de criminaliteit is, aldus een van de hulpverleners, mede hierdoor vaak het gevolg.

Bij psychische problemen kunnen gedetineerden zich wenden tot de PIW-ers, het afdelingshoofd en het maatschappelijk werk, geestelijke verzorging, en de psycholoog. Maar zulks is alleen maar mogelijk na een gesprek met het afdelingshoofd, dat vervolgens een verzoek aan de psycholoog voorlegt.

\subsubsection{De inrichting te Roermond ten tijde van het onderzoek}

\section{Gebouwelijke omstandigheden en bestemming}

Deze inrichting met als bestemming Huis van Bewaring behoort tot een van de oudste van het land. $\mathrm{Zij}$ dateert uit de vorige eeuw, hetgeen tot een sfeer leidt die onvergelijkbaar is met de twee andere moderne inrichtingen. De cellengebouwen tellen drie verdiepingen die smal en hoog zijn en versterken daardoor de indruk dat alles en iedereen op elkaar gepakt zit. Onder gedetineerden heeft deze inrichting de naam gezellig te zijn, volgens sommige gedetineerden vele malen gezelliger dan de inrichtingen in Sittard, Grave of Maastricht. De formele capaciteit voor het huis van bewaring is 116 plaatsen.

De gedetineerden uit het Huis van Bewaring zijn ondergebracht in twee vleugels, de A-en B vleugel. De inrichting kent geen interne differentiatie, hetgeen impliceert dat er geen speciale inkomstenafdeling is en derhalve ook geen speciaal inkomstenprogramma.

In tegenstelling tot de twee andere inrichtingen is ten tijde van het veldonderzoek in 1996 van de invoering van een standaardregime in deze inrichting nog geen sprake. Om redenen van gebouwelijke beperkingen en de beperkte orderportefeuille van de arbeid wordt hiervan voorlopig afgezien.

Toch wordt in deze inrichting al in toenemende mate de nadruk gelegd op de rendementsgedachte, men stelt: "regimair-inhoudelijk zal de deelname aan overige niet recreatieve activiteiten 
nadrukkelijk worden gekoppeld aan het te verwachten rendement." Declname aan deze activiteiten zal bovendien nooit vrijblijvend zijn. Inkomsten gesprekken met individuele gedetineerden spelen een belangrijke rol wanneer het gaat om het al dan niet deelnemen aan regimesactiviteiten. Het hootd detentieplanning en selectic beschikt over deze intakegegevens en hij beslist over deelname aan onderwijsprogramma's. Men streeft nalar een regimesactiviteitenprogramma dat de beheersbaarheid dient en vrijblijvende tijdsinvulling beperkt.

Bij de declname van gedetineerden aan het regimes-activiteitenprogramma staan de eigen keuze en eigen verantwoordelijkheid centrail. Hierbij zullen voor zover mogelijk de haalbare uitgangspunten van de nota "Werkzame Detentie" worden uitgevoerd.

Ook in deze inrichting kiest men voor een centrale rol van de PIW-er bij de beveiliging. begeleidingstrajecten en activiteitenbegeleiding.

\section{Het regimesactiviteitenprogramma}

Het regimesactiviteitenprogramma uit 1996 levert het volgende beeld op.

In deze inrichting is een onderwijzer alangesteld die wat het onderwijs betreft vooral een aanbod van basiseducatie verzorgt, zoals taalonderwijs en verkeerseducatic. De rol van de onderwijzer is tevens initiërend en ondersteunend op het gebied van beroepsoriënterend onderwijs, korte cursussen en voorlichtingsprojecten in het kader van trajecten van matschappelijke integratie.

Ook in deze inrichting is het streven het traditionele socialal-cultureel werk steeds meer het karakter te geven van maatschappelijke integratie en het onderwijsprogramma te baseren op de nota "Werkzame Detentie". Men stelt nadrukkelijk dat penitentiair inrichtingswerkers nauw bij de uitvoering van maatschappelijke integratieprogramma's worden betrokken.

De crea-activiteiten in deze inrichting worden door de PIW-ers gegeven in een tweetal tot crealokaal omgebouwde cellen. In deze inrichting houdt men vast aan de oorspronkelijke opzet van crea-activiteiten die in de eerste lijn worden gegeven door PIW-ers. De consulent werkt gedurende twee uur per week in de tweede lijn en is belast met de begeleiding van de PIW-ers. Helaas zo blijkt ook uit de jakrverslagen van de consulent vallen dit soort bijscholingsbijeenkomsten om roostertechnische redenen nogal cens uit.

De sport en bibliotheek worden ook in deze inrichting druk bezocht. Ook het bibliotheekwerk, zo is het streven zal in de toekomst meer moeten gaan aanbieden op het terrein van maatschappelijke integratie.

Hulpverlening in de zin van penitentiair reclasseringsaanbod onderging in 1995 een inkrimping en in werkelijkheid was er in dat jaar een aanbod van 1,26 tte. Daarnaast levert het CAD 22 uur. Er was sprake van een achteruitgang in formatie van 14 uur. In 1996 ligt het in de bedoeling dat de Stichting Reclassering qua formatie een nieuw aanbod doet en dal naast individuele hulpverlening wordt begonnen met individuele- en groepstrainingen zoals bij voorbeeld Goldstein-trainingen.

Naast het PRW hebben ook de geestelijk verzorgers een belangrijke rol in de individuele begeleiding van gedetimeerden. Voorts signaleert men een stijgend beroep op de districtspsychiater om te adviseren en te bemiddelen in problemen van individuele gedetineerden. 


\subsection{Samenvatting en conclusie}

In dit hoofdstuk werd een beschrijving gegeven van de wijze waarop het onderzoek heeft plaatsgevonden. Met betrekking tot de opzet van het onderzoek werd ingegaan op de methode van dalaverzameling, de procedure, respons, meetinstrumenten en representativiteit. De aard van het uitgevoerde onderzock laat zich, gelet op de probleemstelling in de eerste plats omschrijuen als proces-evaluaticf van aard. Bij de dataverzameling werden zowel kwantitatieve als kwalitatieve methoden gebruikt. Het zwaartepunt bij de data-verzameling vormde een attitude-survey met een omvangrijke vragenlijst voor gedetineerden. Ruim de helft van de gedetineerden die voor medewerking aan het onderzoek werden benaderd, vulden het vragenformulier op een bruikbare manier in. Men kan spreken van een acceptabel responspercentage.

Nagegaan werd of de respondenten in een bepaalde mate als representatief konden worden beschouwd voor de gedetineerdenpopulatic in Nederland. Kenmerken van de respondenten werden daartoe vergeleken met de kenmerken van de Nederlandse gedetineerdenpopulatie zoals deze ( jaarlijks, i.c. 1995 ) worden vastgelegd door het Centraal Bureau voor de Statistick en door de Dienst Justitiële Inrichtingen.

Het beeld dat in dit hoofdstuk van de ondervraagde gedetineerden werd gegeven, strookt grotendeels met het algemene beeld van de gedetineerdenpopulatic zoals dat uit de statistieken naar voren komt. Ook de ondervraagde populatie is over het algemeen ongeschoold of laag opgeleid, ongehuwd, werkloos, druggebruiker, recidivist en gemiddeld rond de dertig jaar.

Op één kenmerk blijkt de onderzochte populatie aanmerkelijk af te wijken van de algehele gedetineerdenpopulatie, namelijk culturele achtergrond. Het percentage respondenten met een buitenlandse culturele achtergrond vormt binnen de onderzochte populatic cen minderheid, terwijl op landelijk niveau in dit opzichı sprake is van een meerderheid. Een aantal mogelijke oorzaken voor deze ondervertegenwoordiging werd besproken .

Vergeleken met de algchele gedetineerdenpopulatie wijkt de onderzoekspopulatic bovendien af qua penitentiaire kenmerken als verblijfstitel en verblijfsduur.

Ondanks deze verschillen kan men vaststellen dat de kenmerken van de onderzochte populatic globaal overeenkomen met de kenmerken van de algehele gedetineerdenbevolking.

Tenslotte werd een beschrijving gegeven van de drie inrichtingen waarin het onderzoek werd uitgevoerd.

Ontwikkelingen die in hoofdstuk 2 in het beleid van het gevangeniswezen op basis van de literatuur werden gesignaleerd, blijken ook in concreto hun neerslag te vinden in de dric onderzochte inrichtingen.

De gevolgen van de versobering en verzakelijking van het beleid in de jaren negentig tekenen zich, op het moment van de uitvoering van het veldonderzoek in 1996 in de inrichtingen, reeds af. Men is of al bezig uitvoering te geven aan het beleid van Werkzame Detentic of men begint zich in de organisatie voor te bereiden op de invoering ervan.

Bij de uitvoering van de activiteiten die van belang zijn voor de voorbereiding van de terugkeer in de samenleving kampt men als gevolg van het beleid van Werkzame Detentie in toenemende mate met problemen in randvoorwaardelijke sfeer. 



\section{HOUDINGEN VAN GEDETINEERDEN Een beschrijving van de onderzoeksresultaten}

"Er wordt te weinig gedaan als je los komt. Je wordt als een hond de straat opgeschopt, dus veel gedetineerden komen ook vaak terug. Ze hebben het hier beter als buiten. Ho langer je zit hoe gekker je wordl. Je wordt van kwaad naar erger gestuurd. Een baan is belangrijk. Maar nu loop ik bajes in bajes uit, alsof het de normaalste zaak van de wereld is." (uitspraak van gedetineerde)

\subsection{Inleiding}

Dit hoofdstuk beschrijft de houdingen van gedetineerden met behulp van de resultaten van het vragenlijst-onderzoek zoals dat werd uitgevoerd in de drie inrichtingen. Als uitgangspunt gelden hierbij de volgende vraagstellingen die in hoofdstuk 1 werden geformuleerd naar aanleiding van opvattingen, deelname aan en beleving van resocialisatie.

De opvattingen: hoe denken gedetineerden over de resocialisatie-doelstelling?

De deelname : op welke wijze en in welke mate zijn gedetineerden betrokken bij de activiteiten gericht op de voorbereiding van de terugkeer in de samenleving?

De beleving: op welke wijze beleven gedetineerden de verschillende activiteiten gericht op de voorbereiding van de terugkeer in de samenleving?

Vanuit het in hoofdstuk 4 beschreven onderzoeksmodel gaat het in dit hoofdstuk om een beschrijving van de kenmerken van de afhankelijke, te verklaren variabelen

Bij de beschrijving van de opvattingen, deelname en beleving van gedetineerden wordt gebruik gemaakt van de gevonden frequenties en van kwalitatief materiaal.

De frequenties hebben betrekking op de items uit de schalen zoals die in het vorige hoofdstuk werden gepresenteerd.

Het kwalitatieve materiaal is enerzijds verzameld op grond van het geschreven commentaar van gedetineerden bij de vragen van de schriftelijke enquête. Anderzijds is het kwalitatieve materiaal afkomstig uit interviews die onder meer in het kader van een HBO-stageonderzoek naar het functioneren van de kunstzinnige vorming in een van de inrichtingen werden gehouden.

Dit hoofdstuk beschrijft de houdingen van gedetineerden ten aanzien van resocialisatie niet alleen voor de totale onderzoekspopulatie. Er wordt tevens voor elke inrichting afzonderlijk en, waar mogelijk, ook voor afdelingen binnen een inrichting een beschrijving gegeven van de houdingen van gedetineerden. 


\subsection{Opvattingen over resocialisatie}

\subsubsection{Belang van resocialisatie}

Opvattingen ten aanzien van resocialisatic werden door middel van cen tweetal instrumenten gemeten. Deze instrumenten werden in hoofdstuk 5 beschreven. Het denken van gedetineerden over de resocialisatie-doelstelling als zodang werd gemeten met de schaal Belong van Resocialisatie. Hierbij werd een drietal aspecten onderscheiden namelijk de visic op resocialisatic als beginsel van humaniteit, als een detentiedoel met een nuttig effect en het belang van het resocialisatie-streven voor het persoonlijk leven van de gedetineerde.

Uit de frequentie-verdeling blijkt dat de visie op resocialisatic als beginsel van humaniteit de meeste ondersteuning van de respondenten krijgt: $95 \%$ is het eens met de uitspraak dat gedetineerden de kans moeten krijgen om zich voor te bereiden op de toekomst. De visie op resocialisatie als een detentiedoel met een nuttig effect wordt blijkens de reacties op de items die dit aspect meten, eveneens door een ruime meerderheid onderschreven (resp. 80\% en 75\%). Men legt een duidelijk verband tussen het niveau van de voorzieningen op het gebied van resocialisatie en het prolijt ervan voor de toekomstige positic in de samenleving. Recidive of het zich beter weten te redden in de samenleving is in de ogen van een meerderheid athankelijk van de mate van hulp en steun die men gedetineerden biedt.

Een vergelijkbare meerderheid van de gedetinecrden onderschrijft het belang van inspanningen tijdens de detentic die gericht zijn op een betere toekomst $(80 \%)$. Relatcert men het belang van resocialisatie voor het persoonlijk leven expliciet aan het daadwerkelijk benutten van de straftijd voor het persoonlijk zeltherstel dan vinden we een pereentage dat in benedenwaartse richting eruit springt.

Iets meer dan de helft van de gedetineerden zegt zijn straftijd vooral te gebruiken om zijn leven weer op orde te brengen.

Blijkbaar impliceert het onderschrijven van het belang van het werken aan een betere toekomst niet steeds het daadwerkelijk ondernemen van acties ten behoeve van een (toekomstig) leven waarin men de zaken anders en beter gatat anpakken

Op grond van deze gegevens kan men vaststellen dat de resocialisatie-doelstelling als zodanig bij het overgrote deel van de gedetineerden ruime ondersteuning vindt.

Gedetineerden lijken resocialisatic in de eerste plaats te beschouwen als een streven dat hen in humaan ethisch, emancipatoir opzicht min of meer toekomt. Gedetineerden vinden immers dat zij tijdens een detentie een nieuwe kans moeten krijgen en dat deze detentie meer dient in te houden dan het alleen mar uitzitten van hun straf. In de tweede plaats wordt het verlenen van zo veel mogelijk hulp en steun in beginsel beschouwd als een belangrijke voorwaarde voor een beter leven na detentie. Elke vorm van hulp en steun wordt als welkom gezien. Sterker nog, zij schrijven het feit dat zij na hun detentie veelal weer in de oude fouten vervallen juist toe aan een gebrek aan hulp en steun.

De houding van de gedetineerden ten aanzien van de resocialisatie-gedachte wijkt dus aanmerkelijk af van de gangbare visie op resocialisatie buiten de gevangenis. Het geloof in de resocialisatie als een waardevol humaan ethisch beginsel en als instrumentele doelstelling van het strafrecht is in het afgelopen decennium afgenomen. De 'Nothings Works' ideologie heeft, zoals $i k$ in een van de vorige hoofdstukken liet zien, zijn sporen nagelaten in de vorm van een groeiende scepsis ten aanzien van resocialisatie. Die scepsis treffen we echter niet aan bij gedetineerden. De houding van gedetineerden ten aanzien van de resocialisalie-gedachte zou men eerder in tegengestelde zin kunnen omschrijven namelijk als 'Anything Works'. Zij zien resocialisatie vooral als een doel dat hun (toekomstige) belangen dient. Deze reactie zegt tegelijkertijd ook iets over de wijze waarop zij hun eigen positie beoordelen. Het beeld dat zij 
van hun eigen (huidige) positic hebben is vermoedelijk dat van een nadelige, achtergestelde of hulpbehoevende positie. De houding van gedetineerden ten aanzien van de resocialisatiedoelstelling als zodanig lijkt nogal sterk in het teken te staan van deze negatieve perceptie van hun eigen positic. In hoofdstuk 3 bij de bespreking van de onderzoeksliteratuur bleek dat gedetineerden uit Kolstads onderzock (1996) een vergelijkbare reactie vertoonden. Ook in Kolstads studie komt een negatief zelfbeeld van gedetineerden tevoor-schijn, in het bijzonder het idee dat men reeds voor de detentic min of meer buiten het conventionele maatschappelijke leven stond. Dit negatieve zelfbeeld wordt, volgens Kolstad, door een detentie alleen nog maar versterkt, gedetineerden beschouwen zich in essentic als uitgestoten en vervolgd door de rest van de maatschappij. Ongeveer de helft van de gedetineerden in Kolstads studie ziet als belangrijkste oplossing voor zijn problematische situatie dat de samenleving hen, door het bieden van hulp en steun, weer opneemt in haar gelederen. Deze groep gedetineerden stelt zich erg afhankelijk op en legt, aldus Kolstad, de verantwoordelijkheid voor een leven zonder criminaliteit nauwelijks bij zichzelf.

\subsubsection{De mate van scepsis over de gevangenis als resocialiserend instituut.}

Gedetineerden kunnen zoals we zojuist zagen in een bepaalde mate het belang van resocialisatie onderschrijven afgezien van de omstandigheden waaronder men de doelstelling tracht te realiseren

De omstandigheden of context waarin men aan de toekomst werkt, vormen blijkens de onderzoeksliteratuur eveneens een belangrijk aspect van het denken over resocialisatie. Men kan positief denken over het resocialisatie-doel als zodanig, maar tegelijkertijd veel minder positief of zelfs negatief zijn over de gevangenis als omgeving waarin men de terugkeer in de samenleving voorbereidt.

Op basis van de literatuur is een viertal visies met betrekking tot deze dimensie te onderscheiden, namelijk een negatieve, positieve, gematigd negatieve visie en een visie waarbij het beheersmatige karakter van de activiteiten wordt benadrukt.

De frequentieverdelingen op de verschillende items die deze visies weerspiegelen en de schaal Scepsis vormen, laten het volgende zien.

Bijna de helft van de gedetineerden vindt het verblijf in de gevangenis geen goed moment om aan de toekomst te werken. Van de tien gedetineerden vinden vier gedetineerden dat echter wel. Eenmaal in de gevangenis, zo vindt $61 \%$ van de gedetineerde, dan heb je weinig invloed meer op je toekomst. Toch is een derde van de respondenten die mening niet toegedaan.

Meer dan twee derde van de gedetineerden $(68 \%)$ vindt dat je aan een goede voorbereiding van de toekomst nauwelijks toekomt. Een minderheid (23\%) is het hiermee niet eens.

Meer dan driekwart onderschrijft het bekende gegeven dat het door gevangenisstraf eerder slechter dan beter met je gaat. Meer dan 10\% van de respondenten is het hiermee echter niet eens. Deze bevinding behoeft een kanttekening. Het is een bekend gegeven dat een relatief klein aantal gedetineerden tijdens hun gevangenisstraf zienderogen opknapt. Deze kleine minderheid, hoe vreemd het ook klinkt, profiteert in mentaal en fysiek opzicht, althans tijdelijk van de detentie. Deze groep komt veelal mentaal verward door overmatig druggebruik binnen. Fysiek zijn zij er slecht aan toe, en vervolgens ziet men door de regelmaat en structuur van het gevangenisleven en vooral ook door een goede medicatie en extra aandacht, dat deze gedetineerden weer redelijk goed kunnen functioneren. Sommige sterk vereenzaande gedetineerden vinden in het gevangenisleven vaak ook nog een stabiele, sociale omgeving waarin zij vergeleken met 'buiten' ook in de omgang met anderen weer beter gaan functioneren. Het volgend commentaar van een van de respondenten illustreert dit gegeven enigszins:

"Er wordt te weinig gedaan als je los komt. Je wordt als een hond de straat opgeschopt, dus veel 
gedetineerden komen ook valak terug. Ze hebben het hier beter als buiten. Hoe langer je zit hoe gekker je wordt. Je wordt van kwaad naar erger gestuurd. Een baan is belangrijk. Maar nu loop ik bajes in bajes uit, alsof het de normalalste zalak van de wereld is."

Hoewel gedetineerden in ruime meerderheid vinden dat de gevangenisomgeving geen geschikte omgeving is om aan een beter leven te werken, is het leven na de bajes een onderwerp dat twee derde van de gedetineerden toch bezig houdt.

Een substanticel deel van de gedetineerde is ook niet van plan de moed te laten zakken. Vier op de tien gedetineerden is het niet eens met de uitspraak dat het verblijf in een gevangenis je alle zin ontneemt om nog iets aan een betere toekomst te doen. Een zelfde deel van de respondenten is het echter wel eens met deze uitspraak.

Twee derde overigens ziet naarmate men langer zit de toekomst wel steeds somberder in. Maar een derde zegt hiervan geen last te hebben.

Eerder in deze studie werd het verschijnsel besproken dat activiteiten die oorspronkelijk zijn bedoeld om gedetineerden beter voor te bereiden op de toekomst dit doel verliezen en in de praktijk vooral neerkomen op een middel om orde en rust in de inrichting te brengen.

Een zeer grote meerderheid $(80 \%)$ vindt dat de activiteiten in de gevangenis er eigenlijk alleen maar zijn on de gedetineerden bezig te houden. Blijkbaar heeft men het gevoel dat de activiteiten voor zover zij de voorbereiding van de terugkeer in de samenleving dienen te bevorderen, te weinig doelgericht zijn.

Tenslotte is opvallend dat ondanks de toch overwegend hoge mate van scepsis ten aanzien van de gevangenis als resocialiserend instituut, een grote meerderheid $(67 \%)$ het werken aan een betere toekomst tijdens de straftijd op zichzelf niet verwerpt, men vindt het toch zinvol. Bijna een kwart vindt het echter wel zinloos.

Op basis van deze resultaten kan men de visie van de meerderheid van de gedetineerden op de gevangenis als resocialiserend instituut omschrijven als gematigd negatief. Bovendien vindt een meerderheid dat de activiteiten eerder in het teken staan van 'bezig houden' dan van een doelgericht streven naar resocialisatie.

Een uitgesproken negatieve visie treffen we aan onder een minderheid van de respondenten die inspanningen op het gebied van resocialisatie als zinloos beschouwen. Eveneens tot een minderheid behoren de gedetineerden met een uitgesproken positieve visie op de mogelijkheden om tijdens detentie een proces van zelfherstel gestalte te geven.

Voegen we deze uitkomsten met betrekking tot de dimensie scepsis bij de uitkomsten van de dimensie belang van resocialisatie dan kan men voor wat betreft de opvattingen van gedetineerden het volgende beeld schetsen. Het belang van inspanningen op het gebied van resocialisatie wordt in meerderheid door gedetineerden onderkend, echter ten aanzien van de mogelijkheden om tijdens detentie aan resocialisatie of zelfverbetering te werken is men gematigd negatief. In termen van Ajzen's 'theory of planned behavior' (Hoofdstuk 3, p. 81) is de waargenomen mate van 'behavior control' ten aanzien van het streven naar zelfverbetering aan de lage kant. Zowel de frequentieverdelingen op de schaal Belang van Resocialisatie als op de schaal Scepsis laten een kleine minderheid zien die, als het gaat om het nut van de doelstelling en de feitelijke mogelijkheden om de doelstelling te realiseren, uitgesproken negatief is. Deze groep lijkt resocialisatie hooguit te erkennen als een humaan beginsel waarop gedetineerden recht hebben. Tenslotte laten de frequentieverdelingen op, met name de schaal Scepsis zien dat een substantiële minderheid van de gedetineerden een visie heeft waarin positieve opvattingen aangaande het belang van resocialisatie gepaard gaan met een uitgesproken optimisme over de mogelijkheden om een en ander daadwerkelijk te realiseren.

De response van de ondervraagde gedetineerden op de schaal Scepsis wijkt, ondanks een 
gematigd negatieve visie op resocialisatie in de context van de gevangenis, in een bepaald opzicht af van de gangbare visie op de gevangenis en het resocialisatiestreven.. Volgens deze visie is de gevangenis in de context van het verbeteringsstreven een mislukking omdat het ondergaan van een detentie de meeste gedetineerden niet verandert in conformerende burgers. Eerder ondergaat hun maat-schappelijke positie een verslechtering als gevolg van de detentie (Janssen, 1999). Desondanks vindt een meerderheid van de gedetineerden het werken aan betere toekomst tijdens een detentie niet zinloos. Men vindt het werken aan de toekomst in een gevangenis overigens wel moejlijk. Hoe valt deze uitkomst nu te rijmen met de gangbare negatieve visie op de gevangenis als resocialiserend instituut? Mij dunkt dat ook hier weer de perceptie van de eigen positie als hulpbehoevend en achtergesteld resulteert in een houding dat elke stap in de richting van zelfherstel op zichzelf waardevol is. Voor gedetineerden is werken aan de toekomst tijdens een detentie niet zozeer het streven om, wat Conrad (1981) noemt, later 'non-recidivist' te worden, maar een streven dat gericht is op het in gang zetten van een proces van persoonlijke groei en voonitgang. Hun houding ten aanzien van resocialisatie in de context van de gevangenisomgeving is in essentie die van 'alle beetjes helpen' en veel minder een houding in termen van "alles of niets".

\subsection{Deelname aan de activiteiten}

In de enquete werd gedetineerden gevraagd met welke frequentie (heel vaak/ vaak/ af en toe/ zelden / nooit) zij gebruik maken van voorzieningen als onderwijs, hulpverlening, crea, sport en bibliotheek.

In elke inrichting kunnen gedetineerden als zij willen, deelnemen aan deze activiteiten. In geen enkele inrichting is deelname verplicht.

Onder deelname dient bij onderwijs en crea te worden verstaan het daadwerkelijk meedoen aan de activiteiten in de vorm van een cursus of creatieve bezigheid.

Bij hulpverlening dient deelname te worden opgevat als het raadplegen van de hulpverlener. Indien respondenten aangeven nooit van een activiteit gebruik te maken, werd hun vervolgens gevraagd een aantal redenen hiervoor aan te kruisen.

Ook deze resultaten van dit onderdeel van de enquête zullen worden besproken.

\subsubsection{Deelname aan het onderwijs}

Uit de enquête blijkt dat van de respondenten die de vraag naar de deelname aan het onderwijs beantwoordden $(\mathrm{N}=205) 28 \%$ heel vaak of vaak naar onderwijs gaat. Af en toe of zelden gaat $19 \%$ van de gedetineerden. In totaal maakt dus $47 \%$ in meerdere of mindere mate gebruik van de onderwijsfaciliteiten en $53 \%$ van de gedetineerden gaat nooit naar onderwijs.

Hierbij moet worden opgemerkt dat in één inrichting (Grave) vanwege het regime van een tweetal afdelingen waarop men verbleef, gedetineerden geen of slechts in zeer beperkte mate gebruik konden maken van de onderwijsfaciliteiten. Op de B0 -afdeling was ten tijde van de enquête de studieafdeling ter ziele gegaan en was alleen zelfstudie op cel mogelijk en de A3 vleugel was opgesplitst in een sport en onderwijsgedeelte. Diegenen die voor sport kozen, werden uitgesloten van deelname aan onderwijs.

Zonder dergelijke regimaire beperkingen zouden de deelname-cijfers wellicht hoger uitvallen.

Gedetineerden werd tevens gevraagd naar de redenen waarom zij geen gebruik maakten van het onderwijs. Als redenen worden genoemd het ontbreken van informatie, problemen met concentratie, de afwezigheid van een beroepsgerichte opleiding, ongunstig tijdstip tijdens bezoek-uren, en de geringe mogelijkheden die men ziet om in de maatschappij als ex- 
gedetineerde ondanks de behaalde diploma s aan de slag te kunnen. Zo schreef een gedetineerde op zijn vragentormulier dat hij gedurende een vorige detentic al diploma's had behaald bij onderwijs. maar dat hij nu niet meer ging ondat je er in de maatschappij als ex-gedetineerde toch weinig aan hebt.

Een oudere gedetineerde had het volgende te melden:

"Mijn leeftijel is 50+. Dit doet de mening van de Directie ontstaan dat je enkel nog geschikt bent on vloeren te schrobben. Vragen naar zelfstudie komt overeen met roepen in de woestijn. MI-projecten komen hierdoor vanzelfsprekend ook nict in alammerking. Verder mis ik nog een paar specilieke eisen voor zo'n plaatsing b.v. geen drugsverleden. De gedetineerden in deze inrichting worden zeer verschillend behandeld. De 50+-ers worden enkel nog als werkdieren gezien. De zgn. 'hulpverleners' hebben ons leven tot een ware bel gemaakt tijdens mijn detentie. Jullic vragen zijn op niets gebouwd."

Een buitenlandse gedetineerde schreef het volgende commentaar over discriminatic waar het de deelname aan bepaalde activiteiten of het gebruik maken van bepaalde regelingen betreft:

\footnotetext{
"Waarom worden er geen vragen gesteld aangaande 'discriminatie' tegenover buitenlanders? Wij hebben nergens recht op. Te denken valt hier alan verlof. TVI-dagen, plaatsing in een half-open of open inrichting en deelname aan een MI-project. Wij vreemdelingen zitten 70 dagen meer dan Nederlanders. Waarom? Moeten wij ons dan niet opnieuw aanpassen (integreren) aan de matschappij? Dank U Nederlanders".
}

Naast de bovengenoemde redenen geven gedetineerden ook aan dat zij niet deelnemen ondạt men eenvoudigweg geen interesse heeft in het onderwijs, zij andere dingen belangrijker vinden en omdat zij het vervelend vinden om met medegedetincerden deel te nemen aan een groepsactiviteit.

Gedetineerden werd ook gevraagd aan te geven welke cursus of cursussen zij bij het onderwijs volgden. Computercursussen zijn het meest populair, zij worden door ruim de helft $(n=55)$ van de 97 respondenten die deelnemen aan het onderwijs bezocht. Aan verkecrstheoric neemt bijna cen derde van de respondenten $(n=27)$ deel en aan de cursus Algemene Ondernemersvaardigheden neent ruim $16 \%(n=16)$ deel. Voor de overige reeks cursussen zoals Nederlands, leren lezen en schrijven, Engels, vakopleiding hout, technische test en orientatiecursus liggen de percentages lager. Van de 97 gedetineerden die gebruik maken van het onderwijs zegt $19 \%(n=18)$ een diploma of certificaat bij het onderwijs in de inrichting te hebben behaald.

\subsubsection{Hulpverleningscontacten}

Het bezoek aan instanties voor individuele hulp zoals het Bureau Sociale Dienstverlening (BSD), Penitentiair Reclasseringswerk (PRW), Geestelijke Verzorging en de psycholoog/psychiater vertoont het volgende beeld: ongeveer twee derde van de respondenten zegt gedurende het laatste half jaar met BSD (66\%, $\mathrm{N}=183)$, PRW $(64 \%, \mathrm{~N}=184)$, en geestelijk verzorgers $(61 \%, \mathrm{~N}=176)$ contact te hebben gehad. Een derde van de respondenten (30\%, $\mathrm{N}=161$ ) heeft een gesprek gehad met de psycholoog of psychiater. In de onderstaande tabel 1 wordt een overzicht gegeven van het aantal instanties waarmee men het afgelopen half jaar contact heeft gehad. 
Tabel 1: Hulpverleningscontacten van de onderzoekspopulatic in percentages

\begin{tabular}{lc}
\hline Aantal geconsultec de instantics & $\mathrm{N}=226$ \\
Geen instantic & $23 \%$ \\
Een instantic & $22 \%$ \\
Twee instanties & $24 \%$ \\
Dric instanties & $24 \%$ \\
Vier instantics & $8 \%$ \\
Totaal & $100 \%$ \\
\hline
\end{tabular}

Ruim de helf $(56 \%)$ van de respondenten heeft met meer dan een hulpverleningsinstantie contact gehad gedurende het afgelopen half jaar.

De hulpvragen die men voor een bezoek aan het BSD had, betreffen in volgorde van belangrijkheid achtereenvolgens: algemeen verlof, overplaatsing en algemene informatie.

De gesprekken met het PRW, Geestelijke Verzorging en psycholoog / psychiater gingen met name over relaties met familie of partner, drugsverslaving en psychische problemen

Als gedetineerden commentaar schreven bij de vragen over de hulpverleningscontacten dan betrof dit bijvoorbeeld de moeilijke bereikbaarheid van de hulpverlening en het onvermogen om daad-werkelijk iets te doen. Zo schreef een gedetineerde die de hulpverlening had geraadpleegd over opleidingsmogelijkheden:

"Praten, praten en niets doen, geen opleiding, valse hoop geven dat doet men, ik ben het zat!"

Voorts blijkt uit het geschreven commentaar dat sommige gedetineerden behoefte hebben aan meer contacten dan op grond van het regimesactiviteitenprogramma mogelijk is.

\subsubsection{De deelname aan de kunstzinnige vorming}

Van het totaal aantal respondenten $(\mathrm{N}=196)$ zegt $52 \%$ nooit naar de kunstzinnige vorming te gaan. Heel vaak of vaak gaat $27 \%$, af en toe of zelden gaat $21 \%$. Men kan dus stellen dat bijna de helft van de respondenten in meerdere of mindere mate gebruik maakt van deze voorziening.

Ruim een kwart van de respondenten die zelden of nooit naar de crea gaat zegt liever op cel te tekenen of te schilderen. De meest frequent genoemde reden om niet naar de crea te gaan, is dat de crea-activiteiten de respondenten niet aanspreekt. De reden die daarna het meest wordt opgegeven, is dat men andere zaken belangrijker vindt.

Het minst frequent wordt als reden opgegeven dat men het vervelend vindt om in een groep aan een activiteit deel te nemen. Een reden die tevens een rol bleek te spelen bij een geringe of afwezige deelname aan crea-activiteiten was organisatorisch van aard. Zo konden 72 kortgestrafte gedeti-neerden in een van de inrichtingen ten tijde van de afname van het interview nauwelijks optimaal gebruik maken van de crea-activiteiten en faciliteiten vanwege ontbrekende begeleiding door de crea-consulent en door een zeer onregelmatige inzet van bewarend personeel. Crea stond wel op het programma, maar gedetineerden werden er zelden voor opgeroepen.

Een gedetineerde merkte in dit verband op:

"Als ik zie hoeveel moeite het de PIW-ers kost om te bepalen wie (van het bewarend personeel) meegaat naar de crea, dan heb ik al geen zin meer. Op die manier hoeft het voor mij niet".

\subsubsection{Bibliotheekbezoek}

Van de bibliotheek wordt door gedetineerden druk gebruik gemaakt. Slechts 3\% zegt nooit gebruik te maken van de bibliotheek. De overige respondenten $(97 \%)$ maakt in meerdere $(59 \%)$ of mindere mate $(38 \%)$ gebruik van deze faciliteit. $(\mathrm{N}=208)$ 


\subsubsection{Sportbeoefening}

Ook de sport-activiteiten worden intensief bezocht, heel vaak of vaak gaat $62 \%$ van de gedetineerden. Af en toe of zelden gaat $23 \%$, hetgeen betekent dat $85 \%$ van de gedetineerden in meerdere of mindere mate van de sport gebruik gemaakt. $(\mathrm{N}=190)$

Overzien we het voorgaande met betrekking tot de deelname aan de activiteiten dan blijken sommige activiteiten, zoals sportbeoefening en bibliotheekbezoek bij gedetineerden bijzonder in trek te zijn. Activiteiten zoals onderwijs en crea vertonen wat lagere deelnamepercentages, hetgeen wellicht toe te schrijven is aan het relatief hoogdrempelige karakter van deze activiteiten.

Opvallend is dat de deelname-percentages in dit survey niet opzienbarend afwijken van bijvoorbeeld het deelname-patroon dat in de jaren tachtig werd gevonden in de studie van Grapendaal, Rook en Van der Linden (1985). Dit geldt in het bijzonder als men kijkt naar de deelname-categorieën heel vaak of vaak. Alleen bij de deelname aan de kunstzinnige vorming liggen de deelname-percentages in deze antwoord-categorieën aanmerkelijk hoger dan de percentages die in de studie van Grapendaal et al. werden gevonden. Breiden we het deelname criterium uit met de categorieën af en toe en zelden dan ligt over alle activiteiten het declname percentage in deze studie zelfs aanmerkelijk hoger.

Indien het daadwerkelijk deelnemen aan activiteiten zoals onderwijs, crea en hulpverlening kan worden beschouwd als een indicatie voor de motivatie van gedetineerden om iets van hun detentie te maken, dan kan men deze resultaten beschouwen als een weerlegging van de veronderstelling als zou de huidige inrichtingspopulatie steeds minder gemotiveerd zijn voor deelname aan activiteiten, in het bijzonder voor de activiteiten die gericht zijn op de voorbereiding van de terugkeer in de samenleving. Vergelijking van de deelname -frequentie in dit onderzoek met gegevens uit de jaren tachtig geven geen trend tot verminderde deelname aan de activiteiten in de jaren negentig te zien. Integendeel, de deelname aan de activiteiten blijkt in dit onderzoek zelfs hoger te liggen dan de deelname-frequenties die werden gevonden in onderzoek uit de jaren tachtig.

\subsection{Beleving van de activiteiten}

In deze enquête werd bij een drietal activiteiten dieper ingegaan op de vraag naar de beleving door gedetineerden. Het gaat hier on het penitentiaire onderwijs, hulpverlening en crea. De beleving van overige activiteiten zoals arbeid en vrije tijdsbesteding werden minder uitgebreid onderzocht.

Totnogtoe werd in onderzoek naar de beleving van dergelijke activiteiten door gedetineerden veelal volstaan met een enkele vraag over het ervaren nut van of tevredenheid met de activiteiten.

Bovendien, zo veronderstelt men, wordt de beleving van de activiteiten sterk gekleurd door de detentie-situatie. Gedetineerden, zo gaat men er vanuit, waarderen deze activiteiten vooral als een middel om de depriverende omstandigheden van de detentie en de spanningen die deze omstandig-heden oproepen te verlichten.

Zoals elders in Hoofdstuk 3 bleek, zijn er aanwijzingen in de onderzoeksliteratuur dat de beleving van de activiteiten door gedetineerden niet louter wordt gekleurd door de behoefte om de spanningen of stress als gevolg van de detentie te reduceren. Niet alleen basale behoeften als stress-reductie maar ook behoeften van een hogere orde zoals die aan persoonlijke groei, zelfexpressie en ego-involvement (Toch, 1977) kunnen de beleving van de activiteiten 
beïnvloeden.

Dat de motieven voor deelname aan kunstzinnige vorming bij voorbeeld verder kunnen reiken dan het louter van 'de cel af te zijn', blijkt ook uit een HBO-stageonderzoek in een van de onderzochte inrichtingen. Gedetineerden noemen motieven zoals 'nieuwe dingen willen doen met het oog op de toekomst', 'het nuttig willen besteden van de vrije tijd', 'iets willen maken zodat je voor jezelf het idee hebt dan je iets kunt'.

Ter illustratie van het meer complexe en veelzijdige karakter van de motieven voor deelname volgt hier, bij wijze van introductie, een passage uit het kwalitatieve materiaal van deze studie. Dit interviewfragment laat zien dat de beleving van de activiteiten allesbehalve statisch is en dat, al naar gelang de detentiefase waarin men verkeert, het karakter van de beleving verandert.

"In het begin van mijn gevangenisstraf kon ik het vooruitzicht dat ik waarschijnlijk nog vele jaren zou moeten 'zitten', nauwelijks verdragen. Ik werd er bijna gek van. Op dat moment zag ik nog maar één oplossing. namelijk uitbreken, ik moest en zou die gevangenis uit. Mijn ontsnappingspoging mislukte en ik heb het idee van een ontsnapping uit mijn hoofd gezet. Tegelijkertijd zag ik geen andere oplossingen voor mijn situatie en ik raakte weer in zo'n toestand van absolute wanhoop. Maar op een gegeven moment vroeg een andere gedetineerde aan mij of ik mee ging naar de crea. Ik ging naar de crea en dat beviel mij goed, ik begon te schilderen en ik ben ermee doorgegaan.. Vanaf dat moment voelde ik me veel rustiger en het leek wel alsof ik langzaam maar zeker de dingen weer in hun juiste proporties kon zien. Al schilderend, zo leek het wel, kreeg ik weer een gevoel van controle over mijn leven terug. Op het schildersdoek kon $\mathrm{ik}$ mijn eigen wereld scheppen, het was een ruimte waarin ik een bepaald soort vrijheid terug kreeg. Als ik nu terugkijk is dat voor mij een belangrijke periode geweest, omdat ik begon na te denken over mijn leven en de oorzaken van alle ellende waarin ik mij had gestort. Jk werd eigenlijk nieuwsgierig naar mijzelf en wilde mij zelf kennen, maar dan wel op een eerlijke manier. Ik heb me sindsdien wel honderd keer veranderd en ik denk dat ik nu alle twijfels en angsten die ik heb op een directe en eerlijke manier onder ogen durf te zien. Ik heb geen zin meer om erom heen te draaien en ik heb ook geen zin om anderen of het systeem de schuld te geven van de toestand waarin ik nu zit. Ik wil niet wegzinken in frustratie en als maar klagen of hier wegzakken in een toestand waarin mijn geest volkomen dood is. Ik ben gaan studeren en ik schilder nog steeds en zo blijf ik actief en dat is voor mij eigenlijk de manier om tegen de muren te vechten. Ik denk wel dat ik mijn draai in deze gevangenis gevonden heb, ik heb het gevoel dat ik weer grip op mijn leven heb. Ik vind het eigenlijk nog steeds heel wonderlijk dat vooral via zulke activiteiten als schilderen of onderwijs je kijk op jezelf en op de wereld kunnen veranderen."

Uit dit verslag blijkt dat cen activiteit als kunstzinnige vorming in de beginfase van de detentie een belangrijke rol kan spelen bij het reduceren van stress in een situatie van acute crisis (Ittelson et al., 1974). Vervolgens zien we dat kunstzinnige vorming geleidelijk aan meer de functie krijgt van het vinden van een zinvolle tijdsbesteding die, vooral bij een langdurige gevangenisstraf, wordt gebruikt om mentaal actief te blijven. Een activiteit voorziet binnen het gesloten, kunstmatige karakter van de gevangenisgemeenschap aldus in een behoefte aan persoonlijke groei, aan het vinden van een bepaald doel en aan positieve ervaringen.

De onderzoeksresultaten van de schriftelijke enquête waarin de beleving werd gemeten met afzonderlijke schalen op basis van een onderscheid in een ervaren zinvolheid van de activiteiten op korte en lange termijn laten het volgende beeld zien.

\subsubsection{Beleving van het onderwijs}

In het vorige hoofdstuk bleek bij de uiteenzetting over de meetinstrumenten dat bij de beleving van de onderwijsactiviteiten een schaal Onderwijs kon worden geconstrueerd met betrekking tot aspecten die gerelateerd zijn aan persoonlijke groei en zelfverbetering.

Van de respondenten heeft $82 \%$ het gevoel de tijd bij het onderwijs op een positieve manier door 
te brengen ( $\mathrm{N}=127)$ en $70 \%$ is van mening iets nieuws te hebben geleerd.

Onderwijs volgen heeft voor een meerderheid van de respondenten een positiel elfect op het zelfvertrouwen $(62 \%)$ en zelfbeeld $(57 \%)$. Cognitieve doeleinden worden evenzeer gewatardeerd door een meerderheid. Van de respondenten denkt $88 \%$ er altijd wel wijzer van te worden en heeft plezier gekregen in het studeren $(54 \%)$.

Over het nut van onderwijs voor de toekomstige leef-en werksituatie is er sprake van een zekere verdecldheid onder de respondenten. Het beeld dat de frequentieverdelingen bij deze belevingsaspecten opleveren is minder eenduidig positief dan het beeld van de overige belevingsaspecten. Bijna de helft van de respondenten $(46 \%)$ denkt door het volgen van onderwijs zijn kansen op de arbeidsmarkt te vergroten. Voor $42 \%$ van de respondenten geldt dat men door deelname aan het onderwijs zijn kansen op de arbeidsmarkt nict hoger inschat. Op de uitspraak "ik volg wel onderwijs, maar na vrijlating heb ik er weinig aan" werd een nagenoeg gelijke frequentieverdeling gevonden. Hiermee was $46 \%$ het niet eens en $40 \%$ was het er wel mee eens.

Het volgen van onderwijs betekent voor $46 \%$ van de respondenten dat men hierdoor positiever is gaan denken over de toekomst. Voor $42 \%$ is dat niet het geval.

Bijna $40 \%$ weet door het volgen van onderwijs beter wat voor soort werk of opleiding men wil gaan doen na vrijlating. Bovendien wil $58 \%$ na vrijlating doorgaan met cen of andere vorm van onderwijs. Voor een kwart van de respondenten is dat niet het geval.

En tenslotte, $65 \%$ meent dat het volgen van onderwijs nuttig is voor zijn tockomst.

In de beleving van de meeste gedetineerden is het onderwijs in het algemeen van belang voor de toekomst Het is een activiteit waarvan men meent dat deze op een of andere manier ten goede komt aan het toekomstige leven, echter de manier waarop en in welke vorm blijft voor de meeste respondenten een vrij diffuse aangelcgenheid.

Ongeveer vier op de tien respondenten heeft voor wat betreft de tockomstige effecten van onderwijs op de toekomstige leef-en werksituatic voor zichzelf wel cen wat duidelijker beeld.

Hoewel de aspecten van de beleving van het onderwijs die gerelateerd zijn aan de (depriverende) detentiesituatie geen schaal bleken te vormen is het toch de mocite waard de frequenties hiervan te presenteren.

Een vijfde van de respondenten zegt dat het niet zoveel uitmaakt wat zij bij het onderwijs doen als ze maar niet op de cel of de afdeling hoeven te verblijven. Bijna 70\% van de respondenten is het met deze uitspraak niet eens. Op vrijwel dezelfde wijze werd de uitspraak "ik zit mij vaak te vervelen bij onderwijs" beantwoord. Voor $19 \%$ is zulks het geval. Voor $70 \%$ is dat niet het geval. Ruim de helft van de respondenten beschouwt onderwijs tevens als een vorm van ontspanning. Voor ruim $30 \%$ gold dit niet.

Voor $44 \%$ van de respondenten betekent het volgen van onderwijs dat de detentie er minder zwaar door wordt. Voor ruim $40 \%$ makt het voor de zwaarte van de detentie niets uit of men nu onderwijs volgt of niet.

Een ruime meerderheid lijkt dus serieus met onderwijs bezig zijn, ondanks het feit dat men onderwijs ook als een vorm van ontspanning beschouwt. De activiteit wordt niet louter als excuus gebruikt om van achter de deur te zijn of om niet naar de arbeid te hoeven.

\subsubsection{Beleving van de hulpverleningscontacten}

Ook bij hulpverlening werd de ervaren zinvolheid vertaald in itemss die betrekking hebben op de detentiesituatie (de schaal Hulpverlening kort) en op de persoonlijke ontwikkeling en toekomstige levenssituatie (de schaal Hulpverlening lang)

Uit gesprekken met gedetineerden en met medewerkers van het PRW en BSD blijkt dat als het om hulpverlening gaat de toekomst voor veel gedetineerden erg ver weg ligt. Met name aan het begin van de detentie zijn er veel spanningen bij gedetineerden die te maken met de directe 
noden van het gedetineerd zijn. Men is heel erg bezig met de consequenties voor de relatie met familic of partner, de te verwachten uitspraak, het wennen aan het gevangenisleven. Volgens de medewerkers van het PRW is het al heel wat als je als hulpverlener in een dergelijke situatie een beetje orde in het leven van de gedetinecrde kunt brengen en bepaalde spanningen of angsten kunt verminderen. Naar hun mening heeft de toekomst, althans in de gesprekken die zij voerden met gedetineerden, weinig prioriteit.

In de beleving van de contacten met hulpverleners blijkt dat $36 \%$ van de gedetineerden door deze gesprekken verlichting ondervindt. Men ervatart de detentie als minder zwaar door deze gesprek-ken. Voor de helft van de gedetineerden geldt dit echter niet, het zitten blijft in hun ogen even zwalar ondanks deze gesprekken.

Ongeveer de helft ondervindt in deze gesprekken emotionele steun en voelt zich minder gespannen, matr voor vier van de tien respondenten is dit niet het geval.

lets meer dan de helft van de respondenten zegt door de gesprekken met de hulpverleners de directe problemen als gevolg van de detentic beter aan te kunnen. Voor $35 \%$ geldt dit niet.

Een bewijs voor de gedachte dat hulpverleners voor gedetineerden vooral een klankbord zijn, bij wie men zijn hart kan luchten is zeker aanwezig: bijna $80 \%$ van de respondenten vindt het belangrijk bij hulpverleningscontacten dat de hulpverlener luistert.

Het belang van de hulpverleningsgesprekken voor de persoonlijke ontwikkeling zoals bij voorbeeld het beter begrijpen waarom men in de problemen is geraakt, vormt slechts voor een derde van de respondenten een belangrijk aspect van de beleving. Voor meer dan de helft van de respondenten speelt dit aspect bij de contacten geen rol. Hulpverleningsgesprekken betekenen voor $40 \%$ van de respondenten wel dat men weer wat meer vertrouwen heeft gekregen in zichzelf.

Een substantieel deel (44\%) van de respondenten vindt vervolgens wel dat men als gevolg van de ondersteuning door de hulpverleners een betere kijk heeft gekregen op de vraag hoe men na detentic verder moet.

Ruim de helft van de respondenten meent de hulpverleners niet nodig te hebben om voortaan uit de bajes te blijven. Een derde meent om die reden wel een beroep te moeten doen op de hulpverleners.

Echter als het meer in algemene termen om de toekomst gaat ('Contact met hulpverleners vind ik belangrijk voor mijn toekomst') dan blijkt toch weer een ruime meerderheid (63\%) het hiermee eens te zijn. Een kwart van de respondenten vindt de hulpverleningscontacten niet belangrijk voor de toekomst.

Een verklaring voor dit verschil ligt misschien in het gegeven dat veel gedetineerden beseffen dat men bij naderend ontslag uit de detentie de hulpverleners toch nodig heeft om een aantal praktische zaken zoals huisvesting, financiën en werk te regelen.

Overigens is de bevinding dat meer dan de helft van de respondenten aangeeft dat zij de hulpverleners niet nodig hebben om voortaan uit de bajes te blijven tamelijk opzienbarend. Het kan enerzijds een indicatie zijn van een tamelijk kritische visie op de mogelijkheden van de hulpverlening als het gaat om de voorbereiding van de terugkeer in de samenleving. Anderzijds duidt deze bevinding wellicht op een onderschatting van de ernst van de problemen die men heeft of van een overschatting van de eigen zelfredzaamheid.

Overzien we resultaten met betrekking tot de beleving van de hulpverleningscontacten door gedetineerden dan kan men vaststellen dat deze over het algemeen sterk wordt gekleurd door de detentiesituatie. Het denken op lange termijn en in het bijzonder het voornemen om een leven zonder criminaliteit te leiden heeft geen hoge prioriteit in de contacten van de meeste respondenten. Wel geeft $40 \%$ van de respondenten aan door de ondersteuning van de hulpverleners nu beter te weten hoe men na ontslag verder moet. Bovendien vindt twee derde 
van de respondenten hulpverleningscontacten belangrijk voor de toekomst, maar dit belang lijkt niet te zijn gekoppeld aan een expliciet voornemen om een leven zonder criminaliteit te leiden. Het ligt meer voor de hand te veronderstellen dat bij de meeste respondenten het belang van de hulpverlening voor de toekomst vooral gerelateerd is an vormen van ondersteuning in praktische zaken. Hulpverlening in de zin van een bewuste poging van zowel hulpverlener als hulpvrager om een crimineel waardenpatroon te doorbreken en om te buigen in een goede richting ('Voortaan uit de bajes blijven') speelt slechts voor $30 \%$ een rol.

De functie van klankbord in de hulpverleningsgesprekken is heel duidelijk alanwezig. Een overgrote meerderheid van de gedetineerden met hulpverleningscontacten waardeert deze contacten het meest ondat zij een gelegenheid bieden om cens goed zijn hart te luchten. Verder waardeert de helft van de respondenten de gesprekken vooral als middel om de problemen verbonden aan de detentie beter het hoofd te bieden en als middel on weer wat meer zelfvertrouwen te krijgen.

\subsubsection{Beleving van de kunstzinnige vorming}

Voor de beleving van de crea-activiteiten konden twee schalen worden geconstrueerd. Het betreft hier een schaal met items die verwijzen naar detentie-situatie gebonden effecten (de schaal Crea kort) en een schaal met op de persoonlijke ontwikkeling en (toekomstige) levenssituatie gerichte effecten (de schaal Crea lang).

Vermijdingsgedrag dat samenhangt met de ongemakken en onaangename kanten van de detentiesituatie speelt bij de kunstzinnige vorming een duidelijke rol.

Voor bijna de helft van de respondenten is het van de cel of afdeling af zijn de belangrijkste reden om naar de crea te gaan. Voor ruim een derde van de respondenten is dit niet het geval.

Voor 38\% makt het niet uit wat men bij de crea doet, als je de tijd maar omkrijgt. Bijna de helft van de gedetineerden vindt dat het wel iets uitmaakt en beschouwt crea niet als louter een middel om de tijd kapot te krijgen. Ruim $48 \%$ van de respondenten weet vooraf wat men wil gaan doen bij de crea. Maar $41 \%$ weet van tevoren nooit wat men wil gaan doen. Alleen naar de crea gaan uit verveling is voor $31 \%$ een belangrijke reden, voor $53 \%$ is dit geen reden om naar de crea te gaan.

Het lijkt op grond van deze gegevens aannemelijk dat voor veel gedetineerden het niet op cel te hoeven zitten een reden van belang is, maar dit betekent geenszins dat het voor hen verder niet uitmaakt wat men bij de crea doet. Blijkbaar wil men het aangename wel met het nuttige of leerzame verenigen.

Crea heeft ook een sociale functie, gezelligheid en een goede sfeer wordt door veel deelnemers op prijs gesteld (52\%). Voor bijna een derde echter is gezelligheid geen doorslaggevende reden om naar de crea te gaan.

Het sociale aspect van de kunstzinnige vorming lijkt zich vooral te beperken tot gezelligheid als een prettige bijkomstigheid. Een sociaal aspect in de zin van het beter omgaan met medegedetineerden of het personeel speelt een veel minder gewichtige rol.

Beter omgaan met mede-gedetineerden is voor $27 \%$ een effect dat belangrijk is, voor meer dan de helft van de gedetineerden is dit onbelangrijk.

Een functie die in de RAP-nota (1983) wordt genoemd is een betere omgang met het bewarend personeel. Een kwart zegt via de crea-activiteiten een beter contact te hebben gekregen met het bewarend personeel. Voor $56 \%$ is een dergelijk effect niet van belang.

Ontspanning is eveneens voor een overgrote meerderheid (70\%) een belangrijk aspect van de crea-activiteiten.

Het komt bij voorbeeld bij langgestraften wel eens voor dat zij alleen naar de crea gaan als men iets nodig heeft voor op cel, bijvoorbeeld een tafeltje, een rek, e.d. Alleen om deze zeer 
praktische reden gaat slechts $10 \%$ en voor $73 \%$ speelt deze reden geen rol.

Aspecten die met de persoonlijke ontwikkeling en (toekomstige) levenssituatie samenhangen (zelfvertrouwen, zelfexpressie, zelfbeeld, iets willen leren ) krijgen over het algemeen duidelijke waardering van de respondenten.

Van de deelnemende respondenten heeft $65 \%$ het gevoel dat men bij de creatieve activiteiten de tijd op een nuttige manicr doorbrengt. Het creatief bezig zijn en ontdekken dat je meer kunt dan je aanvankelijk dacht, is voor $43 \%$ een belangrijk effect. Voor $41 \%$ speelt een dergelijk effect geen belangrijke rol. Trots op de dingen die men bij de crea gemaakt heeft is $70 \%$.

Een gedetineerde zegt in dit verband: " Als ik klaar ben met mijn schilderwerk en tevreden ben, kan ik soms uren naar dat schilderij kijken en mij afvragen: heb ik dat gemaakt?"

En $45 \%$ meent een stuk handiger te zijn geworden in het hanteren van materialen en technieken. Het steeds meer plezier krijgen in het maken van dingen is een effect dat door $66 \%$ van de respondenten wordt onderkend.

lets nieuws leren bij de crea is voor $64 \%$ belangrijk. Voor eenvijfde van de respondenten geldt dit niet.

Bijna de helft van de respondenten denkt niet door crea minder problemen te hebben met vrije tijdsbesteding. Voor $40 \%$ van de respondenten is crea een activiteit waar men later misschien nog wel iets aan heeft.

Het beeld dat we van de beleving van de crea-activiteiten krijgen is overwegend gunstig. Een ruime meerderheid van de deelnemende respondenten heeft het gevoel dat men de tijd nuttig besteedt. Detentie-situatie gebonden overwegingen spelen een belangrijke rol. Het niet op cel hoeven zitten, gezelligheid en ontspanning zijn voor de meerderheid van de respondenten belangrijke aspecten.

Tegelijkertijd zien we dat de functies die de crea- activiteiten hebben voor de persoonlijke ontwik-keling en de toekomstige levenssituatie evenzeer gewaardeerd worden.

Ook gedetineerden die door een HBO- stagiaire werden ondervraagd in het kader van een stageonderzock over kunstzinnige vorming geven als reden op dat ze "nieuwe dingen willen met het oog op de toekomst"; dat ze "hun vrije tijd nuttig willen besteden"; dat ze "iets willen maken zodat ze voor zichzelf het idee hebben dat ze toch nog iets kunnen"

Crea is voor de grootste groep respondenten geen vrijblijvende activiteit die men louter en alleen gebruikt om de ongemakken van het gedetineerd zijn tegen te gaan. Men wil graag iets nieuws leren, men heeft vooraf ook ideeën die men wil gaan uitvoeren, men constateert bij zichzelf bepaalde leereffecten en het vertrouwen in eigen kunnen wordt versterkt. Bovendien denkt een substantieel deel van de deelnemers er later ook nog iets aan te hebben.

Sinds jaar en dag kan men in gevangenissen de welhaast tot cliché geworden opvatting beluisteren dat gedetineerden alleen maar deelnemen aan crea om "vanachter de deur" te zijn. Deze onder-zoeksresultaten laten zien dat de motivatie van gedetineerden om deel te nemen aan crea een meer veelzijdig karakter heeft dan doorgaans wordt verondersteld.

\subsubsection{Tevredenheid met de vrijetijdsbesteding}

Om en indruk te krijgen van de mate waarin gedetineerden hun vrije tijd op een zinvolle en prettige wijze kunnen doorbrengen werden vier vragen opgenomen. Ook deze vragen bleken een schaal Vrije Tijd te vormen. Het betreft hier de tijd die men doorbrengt buiten het reguliere programma van activiteiten zoals arbeid, onderwijs, crea, sport, bibliotheekbezoek en hulpverleningscontacten.

De grootste groep respondenten vindt slechts dat men de vrije tijd af en toe op een prettige manier kan doorbrengen. Een kwart vindt dat dit heel vaak of vaak mogelijk is en $37 \%$ vindt dat dit zelden of nooit het geval is. 
Ruim $45 \%$ zegt de vrije tijd heel vaak of vaak in de groep door te brengen en een kwart doet dit zelden of nooit, terwijl een derde af en toe de vrije tijd in de groep doorbrengt.

Op cel verblijft in de vrije tijd $21 \%$ heel vaak of valak, voor een kwart is dat slechts af en toc en meer dan de helft verblijft zelden of nooit op cel in de vrije tijd.

Heel vaak of valak verveelt zich $64 \%$ van de respondenten. Af en toe verveelt zich $22 \%$ en $15 \%$ verveelt zich zelden of nooit.

Men kan dus concluderen dat het doorbrengen van de vrije tijd in detentie voor de grootste groep gedetineerden nog steeds een probleem vormt, verveling is een belangrijk aspect van het verblijf in een inrichting. Ook uit een klimaatschaal-studie die in een van de inrichtingen uit dit onderzoek in 1992 werd gehouden (Herbschleb en Zorge, 1992) bleek dat verveling (evenals in een aantal andere inrichtingen) een groot probleem vormt, met name voor de langgestraften.

\subsubsection{Tevredenheid met de arbeid}

Sinds de invoering van De Nota Werkzame detentie is arbeid een belangrijk aandachtspunt geworden in het penitentiaire beleid. Gedetineerden moesten meer gaan werken onder meer met het oog op het aanbieden van meer structuur in de detentie. Bovendien verwacht men dat gedetineerden door de arbeid beter toegerust worden voor een arbeidzaam leven na detentie. Aan de arbeid wordt in zekere zin een resocialiserende werking toegekend.

In deze studie werd gedetineerden dan ook gevraagd wat zij vonden van de arbeid. Via een vijftal items werd de tevredenheid over de arbeid gemeten. Deze items vormen de schaal Tevredenheid Arbeid.

De tevredenheid van gedetineerden over de arbeid vertoont een nogal negatief beeld. Een vijfde van de gedetineerden vindt dat men iets nieuws leert bij de arbeid en $60 \%$ is die mening niet toegedaan. Een zeer grote groep $76 \%$ denkt niet door de arbeid makkelijker werk te vinden. Plezier in de arbeid heeft $35 \%$ van de respondenten. De helft geeft aan geen plezier te hebben in de arbeid. Men vindt de arbeid eentonig $(80 \%)$ maar men vindt toch ook wel dat men nuttige dingen leert $(46 \%)$. Een bijna even grote groep vindt dat men bij de arbeid geen nuttige dingen leert.

Een substantieel deel van de gedetineerden heeft een ronduit negatieve houding ten aanzien van de arbeid. Dit gegeven is, gelet op het beleid van de nota Werkzame Detentie, niet bepaald bemoe-digend te noemen. Het beleid van deze nota is erop gericht de meerderheid van de gedetineerden te plaatsen in een standaardregime met veel arbeid, een dienstvak dat bovendien tot betere bedrijfsresultaten dient te komen. Men kan zich echter afvragen hoe een en ander dient te worden gerealiseerd met gedetineerden die weinig uitdaging en plezier aan de arbeid beleven. Een gedetineerde merkte hierover op:

"Ik ben echt niet te belazerd om te werken. buiten heb ik ook altijd gewerkt bij een baas, maar om hier nou de hele dag die doosjes te moeten vouwen, daardoor krijgen de meeste hier alleen nog maar een grotere hekel aan werken."

Over de beloning van gedetineerden voor de verrichtte arbeid werden in de enquête geen itenıs opgenomen. Dit leek mij immers een item waarop bij voorbaat het antwoord al bekend is, gedetineerden in Nederlandse inrichtingen zijn hierover sinds jaar en dag zeer ontevreden. De geringe beloning (ongeveer vijftig gulden) voor 26 uur arbeid vormt bepaald geen stimulans om de handen nu eens flink uit de mouwen te gaan steken. 


\subsection{De houdingen ten aanzien van resocialisatie: een vergelijking tussen inrichtingen en afdelingen}

Informatic, verkregen op basis van vergelijkingen tussen inrichtingen of afdelingen, kan worden gebruikt onder meer om een indruk te krijgen van de rol van het inrichtings-of afdelingsklimaat. Op grond van de onderzoeksliteratuur kunnen inrichtingen, zo bleck, ondanks een zelfde bestemming en een gemeenschappelijke, formele basis van het beleid, verschillen vertonen in de wijze waarop het beleid wordt geconcretisecrd. Ondanks een zelfde bestemming kunnen inrichtingen kortom verschillen vertonen in klimaat. Deze verschillen kunnen bij voorbeeld het gevolg zijn van factoren als gebouwelijke omstandigheden (nieuwbouw versus oudbouw), inrichtingsideologie, ervaren versus onervaren personeel, en een gevestigde inrichtingscultuur versus een cultuur in wording. Voor deze studie is het van belang te vermelden dat in twee van de onderzochte inrichtingen ter uitvoering van het nieuwe beleid van Werkzame Detentie recentelijk een regimesversobering had plaatsgevonden. In een inrichting was van een regimesversobering ten tijde van de enquête nog geen sprake. Twee inrichtingen hebben een

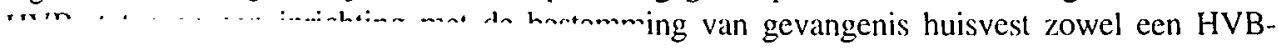
n.

vorden getoetst door middel van een variantie:ken of de verschillen in gemiddelde scores op

ergeleken voor drie inrichtingen

ingschalen die resp. het belang dat men toekent iclang van Resocialisatie) en de gepercipieerde

I de drie inrichtingen, in gemiddelde scores

\begin{tabular}{lll}
\hline snd & Grave & Totaal \\
& $\mathrm{N}=52$ & $\mathrm{~N}=206$ \\
\hline$=7)$ & $4.2(\mathrm{sd}=.6)$ & $4.2(\mathrm{sd}=.7)$ \\
$=.7)$ & $2.9(\mathrm{sd}=.8)$ & $2.7(\mathrm{sd}=.8)$ \\
\hline
\end{tabular}

hoge gemiddelde score op de schaal die het ling als zodanig meet. De hoogste score is hier les te meer belang of waarde men toekent aan de richting zijn niet significant. Opvallend is echter le laagste score heeft. De inrichtingen verschillen 1 Scepsis $(\mathrm{p}=<.005)$. De gemiddelde score over an de lage kant is als men zich realiseert dat een mogelijkheden voor zelfherstel tijdens detentic 
impliceert. Ook hier scoort de inrichting met de status van gevangenis als laagste. In deze inrichting zien gedetineerden dus gemiddeld minder mogelijkheden om tijdens de detentie het zeltherstel ter hand te nemen dan in de beide andere inrichtingen. Een verklaring hiervoor lijkt in eerste instantie wellicht de alanwezigheid van langgestrafte gedetineerden in de inrichting te Sittard. Een nadere analyse in deze paragraaf van de verschillen tussen de afdelingen voor resp. HVB gedetineerden en kort-en langgestrafte gedetineerden zal hierover meer opheldering verschaffen. De hoogste score van de inrichting Grave met een HVB bevolking op de variabele Scepsis lijkt in de eerste plaats te worden veroorzaakt door het feit dat de geïnterviewde gedetineerden in deze inrichting voor het merendeel bestonden uit gedetineerden op een, zogenaamde activiteitenafdeling. Bij plaatsing op deze afdelingen wordt geselecteerd op motivatie voor ontwikkelingsactiviteiten als onderwijs en crea. Voor deze groep respondenten moest worden gekozen omdat gedetineerden op andere afdelingen geen of nauwelijks gelegenheid kregen om deel te nemen aan ontwikkelingsactiviteiten. Daarnaast zouden de verschillen voor een deel ook kunnen worden verklaard door verschillen in inrichtingsklimaat. In de imrichting Grave bijvoorbeeld werkt men weliswaar reeds met een soort standaardregime, echter dit neemt niet weg dat de SKW-afdeling naar mijn indrukken op grond van observatie en interviews in deze inrichting een redelijk sterke positie in de organisatie leek in te nemen en qua randvoorwaarden in vergelijking met de twee andere inrichtingen er iets beter voorstond. De positie van de SKW-afdeling leek mij daarnaast ook sterker in de zin van een zowel door het uitvoerend personeel (PIW-ers en afdelingshoofden) als de directie in ruimere mate ondersteunde en gewaardeerde afdeling, tenminste als men dat vergelijkt met de twee andere inrichtingen.

\subsubsection{Deelname aan de activiteiten}

Aan de respondenten werd gevraagd om voor activiteiten als onderwijs, crea, sport en bibliotheekbezoek op een vijfpuntsschaal aan te geven in welke matc men gebruik maakt van deze activiteiten. Voor de hulpverleningsactiviteiten werd een tweepuntsschalal gebruikt.

In de onderstaande tabellen wordt per activiteit een overzicht gegeven van de deelnamepercentages over de drie inrichtingen.

Uit tabel 3 blijkt dat qua deelname aan het onderwijs de verdelingen in percentages over het merendeel van de deelname categorieën geen grote verschillen laten zien. Het percentage gedetineerden dat nooit aan het onderwijs deelneemt is het hoogst in de inrichting te Sittard. Bijna zes op de tien gedetineerden hebben in deze inrichting geen contact met het onderwijs. Inrichtingen verschilden overigens qua deelname aan het onderwijs niet significant van elkaar.

Tabel 3: Deelname onderwijs in de drie inrichtingen, in percentages

\begin{tabular}{lcccc}
\hline Deelname onderwijs & Sittard & Roermond & Grave & Totaal \\
& $N=109$ & $N=47$ & $N=49$ & $N=205$ \\
\hline Nooit & $57 \%$ & $49 \%$ & $47 \%$ & $53 \%$ \\
Zelden & $4 \%$ & $17 \%$ & $6 \%$ & $7 \%$ \\
Af en toe & $11 \%$ & $13 \%$ & $14 \%$ & $12 \%$ \\
Vaak & $18 \%$ & $17 \%$ & $21 \%$ & $19 \%$ \\
Heel vaak & $10 \%$ & $4 \%$ & $12 \%$ & $9 \%$ \\
Totaal & $100 \%$ & $100 \%$ & $100 \%$ & $100 \%$ \\
\hline
\end{tabular}

Chi-kwadraat $=11.21, \mathrm{df}=8, \mathrm{p}=.19$ 
In tabel 4 zien we dat inrichtingen voor wat betreft de deelname aan de kunstzinnige vorming wel aanmerkelijke verschillen vertonen. Deze verschillen zijn in hoge mate significant. De inrichting te Grave laat op drie deelname categorieën een groot verschil met de overige inrichtingen zien. Het percentage gedetineerden dat in deze inrichting nooit deelneemt aan de kunstzinnige vorming is veel lager dan in de andere twee inrichtingen. En het percentage gedetineerden dat in Grave vaak of heel vaak naar de crea gaat, is aanzienlijk groter dan in de twee andere inrichtingen. Opvallend is voorts dat het HVB te Roermond qua deelname aan deze activiteiten er in benedenwaartse richting uitspringt.

Tabel 4: Deelname kunstzinnige vorming in drie inrichtingen, in percentages

\begin{tabular}{lcccc}
\hline Deelname crea & Sittard & Roermond & Grave & Totaal \\
& $N=96$ & $N=47$ & $N=52$ & $N=195$ \\
\hline Nooit & $51 \%$ & $83 \%$ & $27 \%$ & $52 \%$ \\
Zelden & $12 \%$ & $2 \%$ & $6 \%$ & $8 \%$ \\
Af en toe & $16 \%$ & $2 \%$ & $17 \%$ & $13 \%$ \\
Vaak & $12 \%$ & $9 \%$ & $33 \%$ & $17 \%$ \\
Heel vaak & $9 \%$ & $4 \%$ & $17 \%$ & $10 \%$ \\
Totaal & $100 \%$ & $100 \%$ & $100 \%$ & $100 \%$ \\
\hline
\end{tabular}

Chi-kwadraat $=39.35, \mathrm{df}=8, \mathrm{p}<.001$

Een verklaring hiervoor ligt naar alle waarschijnlijkheid op het gebied van de randvoorwaarden voor de SKW-activiteiten. In het oudere HVB te Roermond waren deze verre van optimaal te noemen. Zo ontbrak in deze inrichting ten tijde van de enquête in 1996 een crea-consulent die de gedetineerden bij de kunstzinnige vorming rechtstreeks begeleidt. Rechtstreekse begeleiding door een vakkracht is echter een noodzakelijke voorwaarde voor een goede kwaliteit van de begeleiding. In de inrichting te Grave is er bij voorbeeld wel sprake van een consulent die, met een ruim aantal uren, een deel van de gedetineerden rechtstreeks begeleidt. Crea in Roermond daarentegen werd gegeven door PIW-ers die in de tweede lijn, onregelmatig door steeds wisselende consulenten werden bijgeschoold. Bovendien had deze consulent slechts een aanstelling van twee uur per week. Van coördinatie van de activiteiten door een hoofd SKW was, na tijdelijke opheffing van deze functie, in deze inrichting slechts zeer recentelijk weer sprake.

De hogere deelname-percentages voor de kunstzinnige vorming van het HVB te Grave worden waarschijnlijk voor een deel ook veroorzaakt door de meer gemotiveerde populatie die op grond van gebleken motivatie geselecteerd werd voor de activiteitenafdelingen. En voor een deel worden de verschillen wellicht dus ook veroorzaakt door de betrekkelijk goed ingevulde randvoorwaarden en een, in het algemeen goed functionerende SKW-afdeling

In tabel 5 zijn voor wat betreft de sportbeoefening de deelnamepercentages weergegeven. De verschillen tussen de inrichtingen zijn significant. Het HVB in Grave springt er in positieve zin uit qua deelname aan de sport-activiteiten. Ook hier wordt dit verschil wellicht veroorzaakt doordat op drie van de vier onderzochte afdelingen in de inrichtingen te Grave werden geselecteerd op motivatie. In het HVB te Roermond lijken gedetineerden vergeleken met de gedetineerden in de overige twee inrichtingen wat minder actief te zijn als het om de sportbeoefening gaat. 
Tabel 5: Deelname sport in de drie inrichtingen, in percentages

\begin{tabular}{lrccc}
\hline Declname sport & Sittard & Rocrmond & Grave & Totaal \\
& $\mathrm{N}=91$ & $\mathrm{~N}=45$ & $\mathrm{~N}=53$ & $\mathrm{~N}=189$ \\
\hline Nooit & $12 \%$ & $22 \%$ & - & $11 \%$ \\
Zelden & $3 \%$ & $7 \%$ & $2 \%$ & $4 \%$ \\
Af en toe & $21 \%$ & $24 \%$ & $15 \%$ & $20 \%$ \\
Vaak & $23 \%$ & $31 \%$ & $30 \%$ & $27 \%$ \\
Heel vaak & $41 \%$ & $16 \%$ & $53 \%$ & $38 \%$ \\
Totaal & $100 \%$ & $100 \%$ & $100 \%$ & $100 \%$ \\
\hline
\end{tabular}

Chi-kwadraat $=23.83 . \mathrm{df}=8 . \mathrm{p}<.01$

De inrichtingen vertonen geen significant verschillen voor wat betreft het bezock aan de bibliotheek. Op basis van tabel $6 \mathrm{kan}$ men concluderen dat in de inrichting te Grave gedetineerden iets actiever zijn dan in de overige twee inrichtingen.

Tabel 6: Bibliotheekbezock in de drie inrichtingen, in percentages

\begin{tabular}{lcccc}
\hline Bezoek bibliotheek & Sittard & Roermond & Grave & Totaal \\
& $N=107$ & $N=47$ & $N=53$ & $N=207$ \\
\hline Nooit & $5 \%$ & $2 \%$ & - & $3 \%$ \\
Zelden & $5 \%$ & $13 \%$ & $4 \%$ & $6 \%$ \\
Af en toe & $32 \%$ & $36 \%$ & $26 \%$ & $31 \%$ \\
Vaak & $31 \%$ & $30 \%$ & $34 \%$ & $32 \%$ \\
Heel vaak & $27 \%$ & $19 \%$ & $36 \%$ & $28 \%$ \\
Totaal & $100 \%$ & $100 \%$ & $100 \%$ & $100 \%$ \\
\hline
\end{tabular}

Chi-kwadrat $=10.35, \mathrm{df}=8, \mathrm{p}=.24$

Uit een analyse van de frequenties van de hulpverleningscontacten uit tabel 7 blijkt dat van de totale groep respondenten $(\mathrm{N}=226) 22 \%$ geen enkel contact heeft gehad gedurende het afgelopen half jaar met een van de vier genoemde hulpverleningsinstanties (BSD, PRW, Geestelijke verzorging, Psychiater/Psycholoog). Contact gehad met een enkele instantic heeft $21 \%$, met twec van de genoemde instanties heeft $24 \%$ contact gehad, met drie van de genoemde instanties heeft $25 \%$ contact en met alle vier de instanties heeft slechts $8 \%$ contact gehad. De meerderheid van de respondenten $(57 \%)$ heeft gedurende het afgelopen half jaar met meer dan een van de genoemde instanties contact gehad. De verschillen tussen inrichtingen op het gebied van hulverlenings-contacten zijn niet significant. 
Tabel 7: Hulpverleningscontaclen in de drie inrichtingen, in percentages

\begin{tabular}{lcccc}
\hline Contacten met instanties & Sittard & Roermond & Grave & Totaal \\
& $\mathrm{N}=114$ & $\mathrm{~N}=57$ & $\mathrm{~N}=55$ & $\mathrm{~N}=226$ \\
\hline 0 instanties & $24 \%$ & $18 \%$ & $24 \%$ & $22 \%$ \\
1 instantic & $22 \%$ & $21 \%$ & $20 \%$ & $21 \%$ \\
2 instanties & $20 \%$ & $28 \%$ & $29 \%$ & $24 \%$ \\
3 instanties & $24 \%$ & $28 \%$ & $22 \%$ & $25 \%$ \\
4 instanties & $10 \%$ & $5 \%$ & $5 \%$ & $8 \%$ \\
Totaal & $100 \%$ & $100 \%$ & $100 \%$ & $100 \%$ \\
\hline
\end{tabular}

Chi- $\mathrm{kwad}$ anat $=4.82, \mathrm{df}=8, \mathrm{p}=.77$

\subsubsection{Beleving van de activiteiten}

De beleving van de activiteiten en de verschillende aspecten die ermee samenhangen werden bij de verschillende activiteiten middels aparte schalen gemeten. In tabel 8 vinden we een overzicht van de gemiddelde score over de totale populatie en voor de inrichtingen afzonderlijk

Voor al deze schalen geldt dat een score van 5 duidt op een hoge mate van waardering van de in de schal genoemde aspecten en een score van 1 duidt op een lage waardering. De schalen die betrekking hebben op de arbeid en de vrije tijdsbesteding meten niet zozeer een waardering van bepaalde belevingsaspecten maar meten veeleer de mate van tevredenheid met deze activiteiten Ook hier geldt dat een score van 5 duidt op een hoge mate van tevredenheid en een score van 1 op een hoge mate van ontevredenheid

Tabel 8: Beleving van activiteiten in de drie inrichtingen, in gemiddelde scores

\begin{tabular}{lllll}
\hline Beleving & Sittard & Roermond & Grave & Totaal \\
& $45<\mathrm{N}_{<} 108$ & $10<\mathrm{N}_{<} 54$ & $32<\mathrm{N}_{<} 53$ & $90<\mathrm{N}_{<} 215$ \\
\hline Onderwijs * & $3.8(\mathrm{sd}=.9)$ & $3.2(\mathrm{sd}=.9)$ & $3.6(\mathrm{sd}=1)$. & $3.6(\mathrm{sd}=.9)$ \\
Crea (lang) & $3.1(\mathrm{sd}=.9)$ & $3.2(\mathrm{sd}=.4)$ & $3.2(\mathrm{sd}=.9)$ & $3.1(\mathrm{sd}=.9)$ \\
Crea (kort) & $2.7(\mathrm{sd}=9)$ & $2.5(\mathrm{sd}=1)$. & $2.8(\mathrm{sd}=.9)$ & $2.7(\mathrm{sd}=.9)$ \\
Hulpverlening (lang) & $2.7(\mathrm{sd}=1)$. & $2.8(\mathrm{sd}=1)$. & $3.1(\mathrm{sd}=1)$. & $2.8(\mathrm{sd}=1)$. \\
Hulpverlening (kort) & $3.0(\mathrm{sd}=1)$. & $3.1(\mathrm{sd}=1)$. & $3.4(\mathrm{sd}=.9)$ & $3.1(\mathrm{sd}=1)$. \\
Arbeid & $1.9(\mathrm{sd}=.9)$ & $2.2(\mathrm{sd}=.9)$ & $1.8(\mathrm{sd}=.7)$ & $2.0(\mathrm{sd}=.9)$ \\
Vrije tijd * & $2.8(\mathrm{sd}=.8)$ & $3.1(\mathrm{sd}=.7)$ & $3.1(\mathrm{sd}=.6)$ & $3.0(\mathrm{sd}=.7)$ \\
\hline
\end{tabular}

*Beleving Onderwijs: $F=3.69, \mathrm{df}=2, \mathrm{p}=<.05$

* Beleving vrije tijd; $F=3.85$, df $=2, p=<.05$

De gemiddelde score van de beleving van de onderwijsactiviteiten toont een positieve waardering van aspecten die samenhangen met persoonlijke groei, en verbetering van de toekomstige levenssituatie. Een zelfde tendens valt waar te nemen bij de waardering van deze lange termijn aspecten bij de crea-activiteiten. Een gemiddelde score van 3.6 bij onderwijs en 3.1 bij crea duidt op enige tot veel waardering voor aspecten die samenhangen met de psychosociale ontwikkeling.

De gemiddelde score voor de totale populatie op de schaal die de korte termijn aspecten bij de crea-activiteiten meet, laat zien dat de waardering van de activiteiten om redenen die te maken 
hebben met de directe ongemakken van de detentie-situatie aan de lage kant is. Men zou de waardering kunnen omschrijven als matig of enigszins positief.

De gemiddelde scores over de totale populatie bij de beleving van de hulpverleningsactiviteiten laten een omgekeerde tendens zien. De aan de directe detentie-situatie gerelateerde belevingsaspecten, ook wel de korte termijn aspecten genoemd, vertonen een tendens tot een hogere waardering. En de lange termijnaspecten vertonen een tendens tot een lage of matige waardering. Het beeld dat de bespreking van de frequenties oplevert wordt hicrmee in grote lijnen bevestigd.

Over de arbeid is men over het algemeen weinig tevreden tot zeer ontevreden, gelet op de geniddelde score over de populatie van 2.0. Over de vrije tijdsbesteding is men matig tevreden.

De verschillen tussen de inrichtingen zijn significant bij de tevredenheid over de vrije tijdsbesteding

$(F=3.85, d f=2, p=.02)$ en de beleving van het onderwijs ( $F=3.69, d f=2, p=.02)$ Gemiddeld gesproken zijn de gedetineerden in de inrichting met de bestemming van gevangenis (Sittard) het meest ontevreden over de vrije tijdsbesteding. De inrichting met de status van gevangenis (Sittard) laat overigens over alle activiteiten behalve het onderwijs een lagere score zien als het gaat om de beleving van of tevredenheid met deze activiteiten. Dit verschil hangt wellicht samen met de kenmerken van de gehuisveste populatie, de aard van het regime, het inrichtingsklimaat en daarmee samenhangend, de wijze waarop de randvoorwaarden van de activiteiten worden ingevuld. Om meer inzicht te krijgen in de factoren die mogelijk een rol spelen zal in de volgende paragraaf de informatie over de verschillen tussen inrichtingen worden aangevuld met informatie over de verschillen tussen afdelingen

\subsubsection{Opvattingen, deelname en beleving vergeleken voor afdelingen}

Om na te gaan of er behalve verschillen tussen inrichtingen ook verschillen in houding aanwezig zijn tussen afdelingen binnen een inrichting, werden in de inrichting met de bestemming van gevangenis en de inrichting Grave met de status van HVB de gemiddelde scores van de verschillende afdelingen onderling vergeleken. De andere inrichting met de bestemming van HVB (Roermond) bleef bij deze vergelijkingen buiten beschouwing omdat tussen de afdelingen geen verschillen in regime aanwezig waren.

\subsubsection{Een vergelijking van opvattingen, deelname en beleving voor afdelingen in de inrichting met de bestemming van gevangenis (Sittard)}

Het feit dat in deze inrichting zowel voorlopig gehechte als kort-en langgestrafte gedetineerden worden gehuisvest vormt op zichzelf een goede gelegenheid om een eerste inzicht te krijgen in de factoren die de houdingen van gedetineerden ten aanzien van resocialisatie mogelijk beïnvloeden. In de onderstaande tabel wordt een overzicht geven van de gemiddelde scores per afdeling. 
Tabel 8: Opvattingen, beleving en declname in Sittard uitgesplitst naar afdeling, in gemiddelde scores

\begin{tabular}{llllll}
\hline Houding & $\begin{array}{l}\text { A.Voorl. } \\
\text { Gehecht } \\
7<\mathrm{N}<22\end{array}$ & $\begin{array}{l}\text { B.Kort } \\
\text { gestraft } \\
15<\mathrm{N}<47\end{array}$ & $\begin{array}{l}\text { C.Lang } \\
\text { gestraft } \\
12<\mathrm{N}<21\end{array}$ & $\begin{array}{l}\text { D.Lang } \\
\text { gestraft } \\
5<\mathrm{N}<22\end{array}$ & Totaal \\
\hline Belang resocialisatic & $4.2(\mathrm{sd}=.6)$ & $4.2(\mathrm{sd}=.7)$ & $3.7(\mathrm{sd}=1)$. & $4.0(\mathrm{sd}=.7)$ & $4.1(\mathrm{sd}=.7)$ \\
Scepsis & $2.6(\mathrm{sd}=.7)$ & $2.5(\mathrm{sd}=.8)$ & $2.3(\mathrm{sd}=.8)$ & $2.4(\mathrm{sd}=.7)$ & $2.5(\mathrm{sd}=.8)$ \\
Beleving onderwijs & $3.7(\mathrm{sd}=.8)$ & $3.7(\mathrm{sd}=.7)$ & $4.1(\mathrm{sd}=.8)$ & $3.7(\mathrm{sd}=1)$. & $3.8(\mathrm{sd}=.8)$ \\
Beleving crea (kort) & $3.0(\mathrm{sd}=.8)$ & $2.9(\mathrm{sd}=.8)$ & $2.3(\mathrm{sd}=1)$. & $2.1(\mathrm{sd}=1)$. & $2.6(\mathrm{sd}=.9)$ \\
Beleving crea (lang) & $2.9(\mathrm{sd}=8)$ & $2.8(\mathrm{sd}=1)$. & $3.5(\mathrm{sd}=.9)$ & $3.1(\mathrm{sd}=.9)$ & $3.1(\mathrm{sd}=.9)$ \\
Beleving hulp (kort) & $3.4(\mathrm{sd}=.9)$ & $3.0(\mathrm{sd}=1)$. & $3.1(\mathrm{sd}=1)$. & $2.6(\mathrm{sd}=1)$. & $3.0(\mathrm{sd}=1)$. \\
Beleving hulp (lang) & $3.4(\mathrm{sd}=.8)$ & $2.7(\mathrm{sd}=1)$. & $2.0(\mathrm{sd}=1)$. & $2.5(\mathrm{sd}=1)$. & $2.7(\mathrm{sd}=1)$. \\
Tevreden arbeid & $2.2(\mathrm{sd}=.9)$ & $1.9(\mathrm{sd}=.9)$ & $1.6(\mathrm{sd}=1)$. & $1.8(\mathrm{sd}=.8)$ & $1.9(\mathrm{sd}=.9)$ \\
Tevreden vrije tijd & $3.1(\mathrm{sd}=1)$. & $3.1(\mathrm{sd}=.6)$ & $2.3(\mathrm{sd}=.6)$ & $2.3(\mathrm{sd}=.6)$ & $2.8(\mathrm{sd}=.8)$ \\
Deelname onderwijs & $2.1(\mathrm{sd}=1)$. & $1.9(\mathrm{sd}=1)$. & $2.9(\mathrm{sd}=1)$. & $2.1(\mathrm{sd}=1)$. & $2.2(\mathrm{sd}=1)$. \\
Deelname crea & $2.6(\mathrm{sd}=1)$. & $1.8(\mathrm{sd}=1)$. & $2.7(\mathrm{sd}=1)$. & $1.9(\mathrm{sd}=1)$. & $2.1(\mathrm{sd}=1)$. \\
Deelname sport & $4.0(\mathrm{sd}=1)$. & $3.7(\mathrm{sd}=1)$. & $3.6(\mathrm{sd}=1)$. & $3.5(\mathrm{sd}=1)$. & $3.7(\mathrm{sd}=1)$. \\
Deelname bibl. & $4.0(\mathrm{sd}=1)$. & $4.0(\mathrm{sd}=.8)$ & $3.3(\mathrm{sd}=.9)$ & $3.0(\mathrm{sd}=1)$. & $3.7(\mathrm{sd}=1)$. \\
\hline
\end{tabular}

Hulpverlening lang: $F=4.62$, $d f=3, p=.005$

Tevredenheid vrije tijdsbesteding: $F=9,81, \mathrm{df}=3, \mathrm{p}=.000$

Bibliotheekbezoek: $F=5.99, \mathrm{df}=3, \mathrm{p}=.001$

Deelname Crea (kunstzinnige vorming): $F=2.68, \mathrm{df}=3, \mathrm{p}=.05$

De A-vleugel in deze inrichting is bestemd voor gedetineerden die in voorlopige hechtenis zitten. Tegelijkertijd bevindt zich hier een klein aantal gedetineerden die reeds zijn veroordeeld tot een gevangenisstraf en het strafrestant hier uitzitten. De B-vleugel is bestemd voor kortgestraften. De meeste kortgestrafte respondenten (58\%) zitten hier het laatste deel van een langdurige gevangenis-straf uit. Het overige deel verblijft op deze afdeling in het kader van een veroordeling tot een kortdurende gevangenisstraf van maximaal zes maanden. Het regime op deze beide afdelingen is een regime van beperkte gemeenschap. Indien men geen gemeenschappelijke activiteiten volgens het dagprogramma heeft, zit men in dit regime achter de deur.

De C- en D-vleugel huisvest langgestrafte gedetineerden. Intern vindt er een selectie plaats, de meer gemotiveerde langgestrafte gedetineerden worden geplaatst op de iets kleinere C-vleugel met een capaciteit van 48 gedetineerden. Bovendien is de strafduur voor de gedetineerden op deze vleugel gemiddeld genomen langer. De D-vleugel staat vooral bekend on de drugsproblematiek op deze vleugel, informeel spreekt men hier over 'Perron 0 ' of de 'vergaarbak' van de inrichting.

Wat de opvattingen over resocialisatie betreft zien we de laagste scores op de beide opvattingsschalen bij de langgestrafte gedetineerden op de C- en D-vleugel. Het meest negatief zijn de langgestraften van de $C$-vleugel waar het de opvattingen over resocialisatie betreft.

Vergeleken met gedetineerden op de HVB afdeling (A) en de kortgestraften-afdeling (B) hebben de langgestraften als groep de meest negatieve opvattingen over resocialisatie.

Voor de deelname aan en beleving van de onderwijsactiviteiten halen de gedetineerden van de $\mathrm{C}$-vleugel de hoogste gemiddelde score niet alleen ten opzichte van de andere afdelingen, maar ook ten opzichte van de respondenten in de twee andere inrichtingen. Voor de deelname en voor 
de beleving van de lange termijn aspecten bij de kunstzinnige vorming geld hetzelfde, de gemiddelde score van de C-vleugel is hier het hoogst.

Deze hoge scores duiden op een positieve houding ten aanzien van ontwikkelingsactiviteiten als onderwijs en crea. Het feit dat men tegelijkertijd nogal negatief denkt over resocialisatic en men zeer sceptisch is ten aanzien van de mogelijkheden voor zelfherstel is een opmerkelijke bevinding. Hoe valt deze discrepantie nu te verklaren?

Verschillende factoren kunnen hier een rol spelen.

In de eerste plaats het feit dat men nog een lange tijd te gaan heeft. het moment van terugkeer in de samenleving ligt nog ver weg, men zit veelal in de middenfase van de detentie en men richt zich meer op de actuele omstandigheden van de detentiesituatic dan op de toekomst.

In de tweede plaats lijkt de C-vleugel meer dan de D-vleugel een groep gedetineerden te huisvesten die men zou kunnen omschrijven met de terminologie van Toch (1977) als 'activityoriented'. Men gebruikt de activiteiten wellicht als een middel om vorm en zin te geven aan de detentie, om geestelijk in beweging te blijven en om niet weg te zakken in apathie, ledigheid en verveling. Het eventuele nut van de activiteiten voor de latere toekomstige levenssituatie verschuift mogelijk naar de achtergrond

In de derde plaats geldt wellicht voor deze groep, die sterker lijkt te zijn gericht op zelfherstel in de zin van persoonlijke groei, dat zij Clowards discrepantie tussen 'aspirations for rehabilitation and expectations of achievement' in sterkere mate ervaren (Cloward, 1969). Op grond hiervan raakt deze groep, naarmate men langer in detentic verblijft, steeds minder overtuigd van de waarachtigheid van op zelfherstel gerichte bedoelingen en steeds meer teleurgesteld over de feitelijke mogelijkheden hiertoe. Opvallend in dit verband is dat de andere groep langgestraften van de Dvleugel die bij onderwijs en crea veel minder actief zijn, weliswaar negatiever denkt over resocialisatie en de mogelijkheden ertoe dan voorlopig gehechten en kortgestraften, maar gemiddeld toch meer positieve opvattingen over resocialisatie heeft dan de gedetineerden van de C-vleugel ( 3.7 versus 4.0). Dit is wellicht een indicatie voor het feit dat de meer gemotiveerde groep langgestraften van de $\mathrm{C}$-vleugel kritischer is en hogere eisen stelt voor wat de persoonlijke ontplooiing betreft, maar dat een zekere teleurstelling over de feitelijke mogelijkheden hiertoe tot meer negatieve opvattingen over resocialisatie leidt.

Een ander opmerkelijk verschil tussen de gemiddelde scores tussen enerzijds de HVB -en kortgestraften-vleugel en anderzijds de langgestraften betreft de beleving van de korte termijnaspecten van de crea-activiteiten. De waardering voor deze aspecten is onder de gedetineerden van de A-en B-vleugels gemiddeld hoger dan onder die van de langgestraften-vleugels $C$ en $D$. Wij zien hier duidelijk de rol van het regime te voorschijn komen. Door de grotere restricties van de regimes op de HVB- en kortgestraftenvleugels komt de beleving van de kunstzinnige vorming meer in het teken te staan van het verminderen van de negatieve aspecten van de detentie-situatie.

De beleving van de hulpverleningsactiviteiten laat qua gemiddelde scores alleen een belangrijk verschil zien bij de lange termijn aspecten. Langgestraften lijken deze aspecten minder te waarderen dan de gedetineerden van de overige vleugels.

Kijken we naar de tevredenheid over de arbeid en de vrije tijdsbesteding dan vallen ook hier in vergelijking met de overige afdelingen en met andere inrichtingen de lage scores op van de groep langgestraften. Dezelfde trend valt tenslotte ook nog op bij de deelname aan de sport en de bibliotheek.

De verschillen in gemiddelde scores zijn significant bij de beleving van de lange termijn aspecten van de hulpverlening $(\mathrm{F}=4.62, \mathrm{df}=3 \mathrm{p}=.005)$, tevredenheid over de vrije tijdsbesteding $(\mathrm{F}=9.81, \mathrm{df}=3, \mathrm{p}=.000)$, bibliotheekbezoek $(\mathrm{F}=5.99$, df $=3, \mathrm{p}=.001)$ en deelname aan de 
kunstzinnige vorming ( $\mathrm{F}=2.68, \mathrm{df}=3, \mathrm{p}=.05)$.

\subsubsection{Een vergelijking van opvattingen, deelname en beleving op afdelingen in een inrichting met de bestemming van HVB (Grave)}

In deze inrichting werden activiteiten niet zomaar aan alle gedetinecrden aangeboden. Activiteiten als onderwijs en crea en extra sport werden aangeboden op activiteitenafdelingen en bijzondere zorgafdelingen. Voor een dergelijke afdeling komen gedetineerden in aanmerking na gebleken motivatie of indicatie op grond van gedragsrapportage.

Voor de schriftelijke enquête in deze inrichting werden gedetineerden van vier afdelingen met elk een capaciteit van 30 gedetineerden benaderd. Drie van deze afdelingen kennen op grond van de speciale bestemming van de afdeling een ruimer aanbod van onderwijs, crea en sport dan andere, zgn. inkomsten- en arbeidsafdelingen. Het betreft hier twee activiteitenafdelingen (A3 en B3) en een Verslavingbegeleidings-afdeling (VBA). Bij de activiteiten-afdelingen heeft de ene helft van de afdeling als aanvulling op het basisprogramma sport en de andere helft heeft onderwijs als extra activiteit. De vierde afdeling was een Arbeidsafdeling (B0) waar gedetineerden worden geplaatst die hun tijd voornamelijk met arbeid doorbrengen en niet deelnemen aan crea en onderwijs. Onderwijs in de vorm van een studieafdeling was ten tijde van de enquête op de B-0 afdeling tijdelijk opgeheven.

Vergelijking van afdelingen voor wat betreft de opvattingen, beleving en deelname aan activiteiten werpt wellicht een interessant licht op het functioneren van het selectiesysteem, dat zoals wij eerder beschreven was gebaseerd op het bonus-malussysteem. Op basis van dit systeem zou men mogen verwachten dat gedetineerden op de afdelingen met een ruimer activiteiten-aanbod (A3, B3 en VBA) hogere gemiddelde scores vertonen qua opvattingen, beleving en deelname ten aanzien van resocialisatie dan bij voorbeeld de gedetineerden op een B-0 afdeling.

De verschillen tussen de afdelingen zijn significant of bijna significant voor wat betreft de beleving van de hulpverlening (korte en lange termijn) en onderwijs, de arbeid, de crea (korte termijn) en de deelname aan onderwijs en crea..

Opvallend zijn de verschillen in gemiddelde scores waar het de opvattingen betreft. Deze zijn weliswaar niet significant, maar zij laten wel zien dat deze op de A3, een activiteiten-afdeling, het laagst zijn. Men zou mogen verwachten dat de gedetineerden van de B-0 hier het laagst zouden scoren.

De selectie op motivatie voor activiteiten wordt overigens wel duidelijk als we kijken naar de gemiddeld hogere scores van de gedetineerden van de VBA-afdeling en de B3 op de beide opvattingsschalen. Dat een significant verschil in opvattingen ontbreekt ondanks het gehanteerde selectiesysteem duidt erop dat het bonus-malussysteem in zijn werking voor wat betreft de gebleken motivatie van gedetineerden weinig specifiek is. Sturing van gedrag in de 'goede richting', middels de drang van een bonus-malussysteem lijkt op basis van de gevonden resultaten niet steeds gepaard te gaan met positieve houdingen ten aanzien van resocialisatie. 
Tabel 9: Opvattingen, beleving en deelname in Grave uitgesplitst naar afdeling, in geniddelde scores

\begin{tabular}{|c|c|c|c|c|c|}
\hline Attitude & $\begin{array}{l}\text { A..Activit. } \\
\text { Afdeling } \\
8 \leq \mathrm{N}<13\end{array}$ & $\begin{array}{l}\text { B.Activit. } \\
\text { Afdeling } \\
8<\mathrm{N}<15\end{array}$ & $\begin{array}{l}\text { C.Drugs-vrije } \\
\text { afd. } \\
12 \leq \mathrm{N}<18\end{array}$ & $\begin{array}{l}\text { D.Arbeids } \\
\text { afdeling } \\
2<\mathrm{N}<8\end{array}$ & $\begin{array}{l}\text { Totaal } \\
32<N_{<} 55\end{array}$ \\
\hline Belang resocialisatie & $3.8(\mathrm{sd}=.7)$ & $4.3(\mathrm{sd}=.4)$ & $4.4(\mathrm{sd}=.6)$ & $4.1(\mathrm{sd}=.7)$ & $4.2(\mathrm{sd}=.6)$ \\
\hline Scepsis & $2.5(\mathrm{sd}=.8)$ & $2.9(\mathrm{sd}=.7)$ & $3.2(\mathrm{sd}=.8)$ & $2.8(\mathrm{sd}=1)$. & $2.9(\mathrm{sd}=.8)$ \\
\hline Beleving onderwijs & $2.8(\mathrm{sd}=.8)$ & $3.6(\mathrm{sd}=1)$. & $3.8(\mathrm{sd}=.9)$ & $4.1(\mathrm{sd}=.6)$ & $3.5(\mathrm{sd}=1)$. \\
\hline Beleving crea (kort) & $3.5(\mathrm{scl}=.9)$ & $2.6(\mathrm{sd}=.8)$ & $2.5(\mathrm{sd}=.8)$ & $2.4(\mathrm{sd}=.2)$ & $2.7(\mathrm{sd}=.9)$ \\
\hline Beleving crea (lang) & $2.7(\mathrm{sd}=.9)$ & $3.0(\mathrm{sd}=1)$. & $3.3(\mathrm{sd}=.6)$ & $3.9(\mathrm{sd}=.7)$ & $3.1(\mathrm{sd}=.9)$ \\
\hline Beleving hulp (kort) & $2.6(\mathrm{sd}=.8)$ & $3.3(\mathrm{sd}=.6)$ & $3.8(\mathrm{sd}=.9)$ & $3.2(\mathrm{sd}=1)$. & $3.3(\mathrm{sd}=.9)$ \\
\hline Beleving hulp (lang) & $2.2(\mathrm{sd}=1)$. & $2.9(\mathrm{sd}=.8)$ & $4.0(\mathrm{sd}=1)$. & $2.7(\mathrm{sd}=1)$. & $3.0(\mathrm{sd}=1)$. \\
\hline Tevreden Arbeid & $1.9(\mathrm{sd}=.6)$ & $2.2(\mathrm{sd}=.8)$ & $1.4(\mathrm{sd}=.5)$ & $1.7(\mathrm{sd}=1)$. & $1.8(\mathrm{sd}=.7)$ \\
\hline Tevreden Vrije tijd & $2.9(\mathrm{sd}=.4)$ & $3.2(\mathrm{sd}=.6)$ & $3.0(\mathrm{sd}=.6)$ & $3.3(\mathrm{sd}=.9)$ & $3.1(\mathrm{sd}=.6)$ \\
\hline Deelname onderwijs & $2.4(\mathrm{sd}=1)$. & $3.0(\mathrm{sd}=1)$. & $2.5(\mathrm{sd}=1)$. & $1.1(\mathrm{sd}=.3)$ & $2.4(\mathrm{sd}=1)$. \\
\hline Deelname crea & $2.6(\mathrm{sd}=1)$. & $2.9(\mathrm{sd}=1)$. & $4.2(\mathrm{sd}=.7)$ & $1.3(\mathrm{sd}=1)$. & $3.0(\mathrm{sd}=1)$. \\
\hline Deelname sport & $4.0(\mathrm{sd}=.9)$ & $4.2(\mathrm{sd}=.9)$ & $4.5(\mathrm{sd}=.6)$ & $4.3(\mathrm{sd}=.7)$ & $4.3(\mathrm{sd}=.8)$ \\
\hline Deelname bibl. & $3.5(\mathrm{sd}=.7)$ & $4.1(\mathrm{sd}=.8)$ & $4.2(\mathrm{sd}=.8)$ & $4.1(\mathrm{sd}=.9)$ & $4.0(\mathrm{sd}=.8)$ \\
\hline
\end{tabular}

Teveredenheid arbeid: $F=2.82, \mathrm{df}=3, \mathrm{p}=.049$

Hulpverl.lang: $\mathrm{F}=4.90, \mathrm{df}=3, \mathrm{p}=.006$

Deelname onderwijs: $F=4.08, \mathrm{~d} f=3, p=.037$

Deelname crea (kunstzinnige vorming): $F=12.53, \mathrm{df}=3, \mathrm{p}=.000$

De A3 blijkt ook als het gaat om de beleving van de activiteiten over het algemeen veel negatiever en minder actief te zijn. De scores zijn bij de beleving van het onderwijs, van de hulpverlenings-activiteiten lager dan die van de B-0 afdeling waar juist gedetineerden worden geplaatst die minder gemotiveerd zijn voor activiteiten of voor het werken aan hun zelfherstel. Tevens zien we de hoogste score op de beleving van de detentie-situatie gebonden of korte termijn aspecten van de crea-activiteiten bij de A3 vleugel. Het feit dat de crea-activiteiten door de VBA-afdeling het drukst werden bezocht, hangt behalve met de selectie van de meer gemotiveerde en actieve gedetineerden vermoedelijk ook samen met de beschikbare tijd en de kwalitatief goede en continue begeleiding door een professionele docent. De crea op de A3 en B3 afdeling werd gegeven door PIW-ers overigens zonder ondersteuning door een consulent. Deze omstandigheid is duidelijk afleesbaar aan de scores op de deelname aan de crea van de A3 en B3

De onvolkomenheid van het bonus-malussysteem komt ook hier tot uiting. De status van activiteiten-afdeling van de A3-afdeling correspondeert eigenlijk niet met de feitelijk aangetroffen houdingen.

De volgende variabelen vertonen een significant verschil in gemiddelde scores: Tevredenheid arbeid $(\mathrm{F}=2.82, \mathrm{df}=3, \mathrm{p}=.049)$, beleving lange termijn aspecten van de hulpverlening $(\mathrm{F}=4.90$, $\mathrm{df}=3, \mathrm{p}=.006)$, deelname onderwijs $(\mathrm{F}=4.08, \mathrm{df}=3, \mathrm{p}=.037)$, deelname kunstzinnige vorming ( $\mathrm{F}=12.53, \mathrm{df}=3, \mathrm{p}=.000$ ). 


\subsection{Samenvatting en conclusies}

In dit hoofdstuk werden de houdingen van gedetineerde ten aanzien van middelen en doelstellingen van resocialisatie beschreven. Deze beschrijving levert ten aanzien van de vraag hoe gedetineerden nu precies aankijken tegen de resocialisatie-doelstelling en de bijbehorende activiteiten een veel genuanceerder en rijker beeld op dan totnogtoe veelal wordt verondersteld. Het beeld dat het merendeel van de gedetineerden weinig of in zeer geringe mate gemotiveerd is voor resocialisatie dient op grond van deze gegevens te worden genuanceerd. De gegevens laten zien dat de werkelijkheid toch minder eenvoudig in elkaar zit dan veelal wordt gesuggereerd.

Een overgrote meerderheid van de gedetineerden denkt positief over de resocialisatiedoelstelling als zodanig. Slechts een kleine minderheid blijkt geen waarde toe te kennen aan deze doelstelling. Deze bevindingen zijn, zoals we zagen, in overeenstemming met de resultaten van het onderzoek van Kolstad (1997) en Zamble en Porporino (1988).

Gedetineerden vinden in meerderheid dat een detentie kansen op een betere toekomst dient te bieden. In tegenstelling tot de heersende opvattingen buiten de muren van de gevangenis geloven gedetineerden nog steeds in resocialisatie als een nuttige doelstelling waarvan zij in beginsel profijt kunnen hebben. Vermoedelijk vanuit de perceptie van hun eigen positie als hulpbehoevend en achtergesteld, beschouwt men hulp en steun in het kader van een betere toekomst in beginsel als belangrijk en waardevol. Hun opvatting ten aanzien van de resocialisatie-doelstelling als zodanig kan men met een parafrase op Martinsons 'Nothing Works' hypothese, samenvatten onder het motto 'Anything Works'.

Overzien we de resultaten met betrekking tot de opvattingen over resocialisatie in de context van de gevangenis, dan valt op dat zij het beeld dat Zamble en Porporino (1988) onder Canadese gedetineerden en Kolstad (1995) onder Noorse gedetineerden aantroffen, grotendeels bevestigen. Een meerderheid is kritisch naar de omstandigheden waaronder men het zelfherstel zou moeten bewerkstelligen. Een meerderheid vindt de detentie eigenlijk geen goed moment om aan de toekomst te werken. Dit betekent echter niet dat de toekomst hen niet meer bezighoudt, voor een meerderheid is dat nog wel een belangrijk onderwerp. Bovendien impliceert die kritische houding naar de detentieomstandigheden, of in het algemeen, de negatieve houding naar de gevangenis als resocialiserend instituut geenszins dat men verdere pogingen om tijdens de detentie aan een betere toekomst te werken als zinloos beschouwt. Een meerderheid vindt het werken aan de toekomst tijdens de detentie moeilijk doch niet volstrekt zinloos. Men zou de houding van de meerderheid van de gedetineerden ten aanzien van de gevangenis als resocialiserend instituut derhalve kunnen omschrijven als gematigd negatief. Een minderheid, ongeveer een vijfde verwerpt resocialisatie in de gevangenis als zinloos. Wellicht behoren deze gedetineerden tot de categorie die Zamble et al. omschrijven als "just doing time". Zij hebben een uitgesproken negatieve houding..

Uit onze gegevens zien we tenslotte nog een substantiële minderheid tevoorschijn komen van tussen de dertig en veertig procent die niet van plan is de moed te laten zakken en die zich in de pogingen tot zelfherstel klaarblijkelijk niet voelt gehinderd door de detentieomstandigheden. Deze optimistische minderheid lijkt minder kritisch te zijn naar de detentieomstandigheden en vertoont gelet op de reacties overeenkomsten met de categorie die in de onderzoeksliteratuur (Irwin, 1980) wordt aangeduid met het begrip "gleaners." ('to glean' is letterlijk vertaald 'oogsten'). Het lijkt erop dat deze groep niet alleen positief denkt over resocialisatie, maar tevens bereid is in actieve zin aan de slag te gaan met het werken aan de toekomst.

De visie van gedetineerden op de gevangenis als resocialiserend instituut verschilt in een bepaald opzicht van de gangbare visie buiten de muren van de gevangenis.

Volgens die visie is resocialisatie in de gevangenis met name uit hoofde van een effectieve 
recidive-mindering een mislukking. Voor gedetineerden lijkt die mislukking in termen van recidive-vermin-dering niet zo belangrijk te zijn. Voor hun geldt dat elke stap die tijdens de detentie in de richting van groei en zelfherstel er blijkbaar één is. Hun houding is er meer een van alle beetjes helpen'en in die zin is hun definitie van resocialisatie als instrumentele doelstelling een andere dan de gangbare, sceptische definitie buiten de muren die men veeler in het teken lijkt te staan van een 'alles of niets'-benadering.

De bevindingen ten alanzien van de opvattingen van gedetineerden ten aanzien van de gevangenis als resocialiserend instituut worden vervolgens weerspiegeld in het declname patroon bij activiteiten die specifiek zijn gericht op de voorbereiding van de terugkeer in de samenleving.

Activiteiten als onderwijs en kunstzinnige vorming worden in meerdere of mindere mate bezocht door bijna de helft van de respondenten en iets meer dan een kwart van de gedetineerden bezoekt deze activiteiten heel vaak of vaak. Bij de hulpverlenings-activiteiten ligt de contact- frequentie ho-ger, omdat met name de dienstverlening door het BSD die veelal praktische zaken als verlof, strafonderbreking e.d. betreft, door veel gedetineerden als belangrijk worden ervaren. Ruim driekwart van de gedetineerden meldt een of meerdere contacten met medewerkers van het PRW, BSD en geestelijke verzorging gedurende het afgelopen jaar.

Aanmerkelijk hogere deelnamepercentages werden gevonden bij de sportactiviteiten en bibliotheek -bezoek.

Hoe kunnen wij nu de vastgestelde mate van participatie van gedetineerden in het activiteitenprogramma beoordelen? Een algemeen oordeel geven over de deelname aan alle onderzochte activiteiten in termen van een hoge, optimale of suboptimale deelname ligt niet voor de hand. Men moet differentiëren ondat de activiteiten in inhoudelijke zin grote verschillen vertonen.

De deelnamegraad aan activiteiten als sport en bibliotheekbezoek kan men zonder meer als zeer hoog bestempelen. Bij activiteiten als onderwijs en kunstzinnige vorming is de declname-graad minder indrukwekkend. De vraag is echter hoe men de regelmatige en actieve deelname van ongeveer een kwart van de gedetineerden aan deze activiteiten dient te beoordelen. Is het een maximaal haalbaar percentage of zou het wel wat beter kunnen? Het beïnloeden of stimuleren van de participatie van gedetineerden in de activiteiten is een aspect dat, naar mijn indruk, in de onderzochte inrichtingen wel de nodige aandacht krijgt. Er is sprake van voorlichting en werving bij het aanbod van betrekkelijk hoogdrempelige ontwikkelings-activiteiten als onderwijs en kunstzinnige vorming.

En, zoals ik op grond van mijn ervaring als docent kunstzinnige vorming in een van de inrichtingen heb kunnen vaststellen, met een intensieve werving, goede voorlichting en begeleiding kan men het aantal deelnemers behoorlijk opvoeren. Maar niet zelden stuit men bij meer intensieve werving op een bovengrens die door de organisatie wordt gesteld aan het aantal deelnemers per bijeenkomst. Het aantal gegadigden overtreft dan het aantal beschikbare plaatsen en dit probleem lost men zelden op door uitbreiding van het aantal crea-momenten en van personeelsformatie. Meestal kiest men in dit geval voor wachtlijsten of het opsplitsen van groepen deelnemers. In het laatste geval betekent dit voor de gedetineerden dat zij bij voorbeeld niet één keer in de week kunstzinnige vorming hebben, doch één keer in de twee weken.

Ook bij maatschappelijke integratieprojecten kan, zo blijkt in één van de onderzochte inrichtingen, de vraag het aanbod, in de vorm van het aantal beschikbare plaatsen en middelen, ruimschoots overtreffen. Via strengere selectie probeert men de grote toeloop vervolgens af te remmen.

Op grond van observatie en interviews met begeleidend personeel blijkt in ieder geval dat, 
indien men het maximum aantal toegestane deelnemers per bijeenkomst als criterium hanteert, de deelname van de gedetinecrden aan het onderwijs en kunstzinnige vorming goed tot zeer goed is.

Relateren we de gegevens over de declname aan eerder verricht onderzoek van de deelname van gedetineerden aan bij voorbeeld onderwijsactiviteiten (Grapendaal et al., 1985), dan zijn er geen opzienbarende verschillen te constateren: zij vonden dat een derde van de gedetineerden aan een of andere vorm van onderwijs deelnam. Rekenen we de categorie af en toe en zelden eveneens tot een vorm van deelname dan valt het percentage deelname aan onderwijs in deze studie aanmerkelijk hoger uit. Het percentage deelnemers in deze studie komt overeen met de schattingen die in de jaren negentig met betrekking tot de deelname aan het onderwijs zijn gedaan.

De deelnamecijfers die in de studie van Grapendaal et al. werden gevonden liggen niet alleen voor het onderwijs maar ook voor de crea, lager dan in deze studie. Een mogelijke verklaring hiervoor is dat de studie van Grapendaal werd verricht halverwege de jaren tachtig gedurende de aanloopfase van de huidige opzet van regimesactiviteitenprogramma's. Zowel crea als onderwijs zijn gedurende het afgelopen decennium als activiteiten steeds meer ingeburgerd geraakt. Gedetineerden weten inmiddels wel de weg te vinden naar deze activiteiten.

Met betrekking tot de beleving van de onderwijsactiviteiten en de kunstzinnige vorming en in mindere mate ook ten aanzien van de beleving van de hulpverleningsactiviteiten kunnen we concluderen dat de hier gevonden resultaten het beeld bevestigen dat in een aantal andere studies zoals die van Toch (1977), Parsons en Langenbach (1993), Winters (1993) en Tootoonchi (1993) werd gevonden. De beleving van de activiteiten blijkt niet louter en alleen een kwestie te zijn van het bevredigen van behoeften op het meer basale niveau van reductie van stress als gevolg van de detentie. Ook behoeften van een hogere orde zoals die aan zelfexpressie, zelfbevestiging, cognitieve interesse en zelfcontrole waarbij men doeleinden als persoonlijke groei en verandering van levenstijl en levenssituatie voorop stelt, spelen voor gedetineerden een belangrijke rol. Van de vermeende vrijblijvendheid van de activiteiten waarvan in de Nota Werkzame Detentie gewag wordt gemaakt blijkt in de beleving van de participerende gedetineerden in ieder geval geen sprake te zijn.

Naar aanleiding van de resultaten met betrekking tot de beleving van de activiteiten lijkt er evenmin sprake te zijn van de door Melk $(1985,1993)$ veronderstelde dominantie van de beleving van de activiteiten door een enkel doel, namelijk het handhaven van orde en rust. Volgens Melk hebben vanuit dit primaat van orde en rust veel activiteiten uitsluitend de functie van het afreageren van spanningen en het 'vergeten- in-bezig- zijn'. Doel is aanpassing in de detentiesituatie te bereiken en niet ontwikkeling en groei in de levenssituatie. De activiteiten reiken niet verder dan het simpele doel van bezighouden. Melk beschrijft deze fixatie op het orde en rust-principe vooral op het niveau van de organisatie, hij beschrijft het orde-en rust principe als een kenmerk van de gevangenis-structuur. Vervolgens extrapoleert hij van het macro-niveau naar het micro-of individuele niveau van de gedetineerde en zijn beleving van de activiteiten, die evenzeer wordt beheerst door het orde-en rustprincipe. Het is heel goed mogelijk dat op het niveau van de organisatie inderdaad een dergelijk tendens tot overheersing van het orde-en rustprincipe aanwezig is, echter de resultaten van dit onderzoek laten zien dat de beleving van de activiteiten op het individuele niveau een veel heterogener karakter draagt. Groei in de levenssituatie en persoonlijke ontwikkeling spelen als motieven wel degelijk een rol in de beleving van de deelnemers en zij blijken, ondanks een mogelijk aanwezige dominantie op een geaggregeerd niveau van het orde- en rust-principe, een belangrijk aspect te zijn van de beleving met name bij ontwikkelingsactiviteiten als onderwijs en kunstzinnige vorming.

De beleving van de hulpverleningsactiviteiten vertoont een karakter dat meer in de richting gaat 
van het, door Melk geschetste beeld van de zgn. 'ritssluitingproblematiek.' De 'ritssluitingproblematiek' houdt in dat het gevangeniswezen de persoon van de gedetineerde als het ware vastzet in de positie en instelling, waarop hij altijd heeft geleefd. Dit vereist, aldus Melk, het minste werk. Als tot doel van de detentie wordt gesteld dat er rust moet zijn, dat alles zo ongestoord mogelijk verloopt, dan moet worden aangesloten bij de persoonlijke eigenschappen van gedeti-neerden. Kwetsbare kanten in de persoon zoals- het niet uiten van je gevoelens, met een masker rondlopen, beperkt en concreet denken- bevorderen een rustige sfeer.

Ook de hulpverleners gaan doen wat het systeem en de gedetineerde verwachten. Ook de hulpverlening is in de 'ritssluiting' van het orde- en rustsysteem opgenomen en is voor resocialisatie krachtenloos gemaakt. De gedetineerde heeft bijgevolg een beperkte hulpvraag waarin voomamelijk concrete en materialistische oplossingen domineren en die voomamelijk betrekking hebben op de detentiesituatie (strafonderbreking, materiele problemen, overplaatsing). Een echte hulpvraag waarin de persoonlijke problematiek op een meer fundamentele wijze aan de orde komt ontbreekt, aldus Melk. Hulpverleners hebben, volgens Melk, de neiging zich eenzijdig bezig te houden met de beperkte hulpvraag en werken hoofdzakelijk in het belang van een ongestoorde tenuitvoerlegging van de detentie. Ook de resultaten van deze studie laten zien dat de hulpvraag van gedetineerden vooral in het teken staat van de directe problemen van de detentie-situatie. Echter het gaat mij te ver om dit, in navolging van Melk, louter te interpreteren als een bewuste of onbewuste strategie van het systeem en van de hulpverleners om aanpassing aan het systeem te bewerkstelligen. Mijns inziens dient het blijven steken van de hulpverleningscontacten in de directe gevolgen van de detentiesituatie tevens te worden beschouwd in het licht van de grote mate van schadelijkheid van een detentie voor het persoonlijke leven van de gedetineerde en zijn omgeving, van de complexiteit van de persoonlijke problematiek en van het moeizame karakter van hulpverleningsprocessen in het algemeen. Om het niet toekomen aan de echte hulpvraag voornamelijk te interpreteren in termen van de inkapseling in het orde- en rust-principe is mijns inziens een te eenzijdige weergave van de werkelijkheid. De betrekkelijk ondergeschikte betekenis van een echte hulpvraag in de hulpverleningscontacten duidt eerder op de prioriteit van een ander detentiedoel, namelijk het beperken of voorkomen van detentieschade. Bij uitstek bij de hulpverleningscontacten lijkt dit doel tot uiting te komen. Bij de beleving van de overige activiteiten zoals onderwijs en kunstzinnige vorming spelen het reduceren van de nadelige gevolgen van de detentie een veel minder saillante rol. Hierbij staat de beleving sterker in het teken van een positieve invulling van de resocialisatie-opdracht. In zoverre relativeren de onderzoeksresultaten de in hoofdstuk 2 behandelde visie uit de jaren waarin de voorzieningen ten behoeve van de terugkeer in de samenleving louter nog een negatieve functie van het beperken van detentieschade krijgen toebedeeld. In de beleving van de gedetineerden is daarvan maar ten dele sprake.

De onderzoeksresultaten waarvan in dit hoofdstuk verslag werd gedaan geven tevens aanleiding tot het nuanceren van uitspraken over gedetineerden die in het kader van het penitentiaire beleid van de jaren negentig in de nota Werkzame detentie (1994) worden gedaan. Het betreft in het bijzonder de veronderstelling dat een meerderheid niet of in geringe mate gemotiveerd zou zijn om iets van de detentie te maken. Dit soort uitspraken wekken al snel de suggestie als zou de meerderheid de resocialisatiegedachte verwerpen. Dit blijkt geenszins het geval, integendeel de toekomst is een onderwerp dat een meerderheid van de gedetineerden bezighoudt en slechts een kleine minderheid verwerpt het werken aan de toekomst tijdens de detentie als zinloos.

De bevinding dat een meerderheid niet negatief staat ten opzichte van de resocialisatiedoelstelling als zodanig, maar de mogelijkheden voor zelfherstel tijdens detentie laag inschat, is een belangrijk gegeven. Dit gegeven vormt indirect een bevestiging van de reeds in de jaren 
zestig door Cloward geopperde veronderstelling van de aanwezigheid van een discrepantie tussen wat hij noemt "aspirations for rehabilitation and expectations of achievement". Cloward kent zoals wij zagen een belangrijke betekenis toe aan deze discrepantie voor het ontstaan van een deviante subcultuur tijdens detentie. De vraag hoe gedetineerden die aspiraties met betrekking tot resocialisatie ontwikkelen wordt door Cloward beantwoord met de veronderstelling dat in de moderne gevangenis "incentives" tot conformerend gedrag en tot acceptatie van sociaal wenselijke doelen in de plaats zijn gekomen van vormen van sociale controle die berusten op fysieke dwang. Ook Tulkens (1988, p.15 en 16) lijkt de discrepantie tussen op 'zelfherstel gerichte bedoelingen' en de feitelijke mogelijkheden om deze te realiseren als een fundamenteel gegeven te beschouwen dat in de natuur van de gevangenis besloten ligt. In zijn inaugurele rede merkt hij hierover op:

"De gevangenisstraf impliceert dat het individu en dus zijn zelfherstel secundair zijn. Niet omdat de rechter dat bedoelt, maar omdat het in de 'natuur' van de gevangenis ligt. Zij maakt het uiterst moeilijk gedetineerden te overtuigen van de waarachtigheid van op zelfherstel gerichte bedoelingen." En over die natuur zegt hij: "Het zijn dwanginstituten. Degenen die er geplaatst worden, worden gedwongen er te blijven. Daartoe is verregaande reglementering, overzichtelijkheid, discipline en controle nodig. Deze twee eigenschappen, bedrijfsmatigheid en beveiliging, versterken elkaar en maken de gevangenis tot een systeem, waarin speciaal preventieve doeleinden van zelfherstel niet of zeer beperkı zijn te realiseren."

De discrepantie tussen op zelfherstel gerichte bedoelingen en de feitelijke mogelijkheden daartoe in een instituut dat tevens retributie en beveiliging tot doel heeft, vloeit uiteindelijk voort uit de tegenstrijdige opdracht van het gevangeniswezen. Kommer (1991, p.57) spreekt in dit verband over een 'absurditeit'. Hij zegt:

"(...) de tegenstrijdige opdracht van de gevangenis komt voort uit de absurditeit dat de maatschappij mensen voor langere tijd buiten de samenleving wil plaatsen (retributie en beveiliging), maar ze tegelijkertijd als mens wil blijven zien die bij terugkomst in de samenleving weer zonder wrok moet kunnen functioneren (beperking van de schade en resocialisatie)."

Hoe absurd en tegenstrijdig deze opdracht ook is en hoe groot de beperkingen van het gevangenis-systeem ook mogen zijn, de beschreven houdingen van gedetineerden ten aanzien van resocialisatie geven blijk van een reële behoefte aan persoonlijke groei en maatschappelijk perspectief. Die behoefte is in empirische zin inherent aan de toepassing van de vrijheidsbenemende sanctie. Met het gebruik van een sanctie die daders buiten de samenleving plaatst, schept men tegelijkertijd bij die daders een behoefte om weer deel te hebben aan de samenleving. In empirische zin ligt in de vrijheidsbeneming dus tevens de behoefte aan maatschappelijk herstel besloten. Straffen en resocialiseren lijken in dit opzicht tot elkaar veroordeeld. In hoeverre die behoefte aan maatschappelijk herstel serieus wordt genomen is in essentie afhankelijk van de mate waarin een samenleving bereid is tot het aanleggen van bepaalde humane maatstaven bij de bestraffing van delinquenten. De bevindingen waarvan in dit hoofdstuk verslag wordt gedaan roepen tenslotte de vraag op waarom ondanks die positieve opvattingen over de resocialisatie-gedachte als zodanig, een deel van de gedetineerden wat de waargenomen mogelijkheden tot zelfherstel tijdens detentie betreft, tamelijk sceptisch en passief blijft en een ander deel zich optimistisch en actief opstelt. Een eerste stap in de richting van een antwoord levert de vergelijking van gemiddelde scores op. De vergelijking tussen inrichtingen en afdelingen toont dat de duur van de straf en de duur van het verblijf vermoedelijk relevante factoren zijn voor de verklaring van de aard van de houdingen. Echter, vergelijking van gemiddelde scores is een te ruw instrument om de samenhang tussen de verschillende factoren 
te verhelderen. De relatic tussen de houdingen en persoons- en ongevings-gebonden variabelen dient daarom in meer gedetailieerde zin aan hand van het onderzoeksmodel en door middel van correlationele analyses en causale modellering te worden onderzocht.

Aan deze analyses gaat in het volgende hoofdstuk echter nog cen typering van de onderzoekspopulatie vooraf op een aantal, nog niet beschreven kenmerken. 


\section{DE ONAFHANKELIJKE VARIABELEN: KENMERKEN VAN OMGEVING, GEDETINEERDEN EN PROGRAMMA- INTEGRITEIT}

\subsection{Inleiding}

In hoofdstuk 4 volgde na onderzoek van de theoretische en empirische literatuur een selectie van onafhankelijke variabelen die mogelijk van invloed zijn op de afhankelijke variabelen, dat wil zeggen de houdingen van gedetineerden ten aanzien van resocialisatic. Ten aanzien van deze onafhankelijke variabelen werd een drietal clusters onderscheiden:

1. variabelen met betrekking tot de (depriverende) detenticomgeving:

-de beleving van het regime (regimesevaluatie);

-prisonisatievariabelen (strafduur, verblijfsduur, strafrestant, detentiefase en contacten met medegedetineerden )

2. variabelen met betrekking tot de persoon van de gedetineerde: leeftijd, burgerlijke staat, culturele achtergrond, opleiding, arbeidsverleden, druggebruik, recidive en toekomstverwachtingen.

3. variabelen met betrekking tot de programma-integriteit: informatie, begeleiding en ondersteuning en materiaal en middelen

In hoofdstuk 5 werden alle persoonskenmerken, behalve de toekomstverwachtingen in het kader van het onderzoek naar de representativiteit van de onderzoekspopulatie beschreven. Het ging hier on de volgende kenmerken: leefiijd, burgerlijke staat, culturele achtergrond, recidive, opleiding, werkervaring, druggebruik.

De gemiddelde leeftijd van de onderzochte populatie is 31 jaar, het merendeel is ongehuwd, laag opgeleid, heeft een Nederlandse culturele achtergrond. was werkloos en gebruikte drugs voordat men werd gedetineerd. De meerderheid heeft reeds eerder in detentie gezeten.

In hoofdstuk 5 werd de onderzoekspopulatie tevens beschreven op kenmerken als verblijfsduur, strafduur, strafrestant en detentiefase. Uit deze beschrijving bleek dat $42 \%$ van de respondenten minder dan 6 maanden in detentie verbleef, $24 \%$ verbleef 6 maanden tot een jaar in detentic en $34 \%$ verbleef reeds langer dan een jaar in detentie. De gemiddelde verblijfsduur bedroeg 12 maanden.

De totale duur van de vrijheidsbeneming, de strafduur bleek maar voor $4 \%$ van de respondenten minder dan 6 maanden te bedragen, de strafduur is voor de meerderheid $(66 \%)$ een jaar of langer. De gemiddelde strafduur bedroeg 25 maanden. Voor meer dan de helft (55\%) bleek het stafrestant minder dan 6 maanden te zijn. Gemiddeld moest men nog 11 maanden straftijd uitzitten.

Het merendeel van de HVB-respondenten (66\%) bevindt zich in de beginfase van de detentie, 
dat wil zeggen men verkeert minder dan 6 maanden in detentie. De langgestraften verkeren overwegend in de middenfase van de detentie, het strafrestant is voor deze groep meer dan zes maanden en de verblijfsduur is langer dan zes maanden. De kortgestraften bevinden zich in hun geheel in de eindfase van een langdurige detentie en het stafrestant van deze detentie is korter dan 6 maanden.

In dit hoofdstuk wordt de onderzoekspopulatie getypeerd op de resterende omgevingskenmerken (regimesevaluatie, contacten met mede-gedetineerden), persoonskenmerken (toekomstverwachtingen) en kenmerken van de programma-integriteit (informatie, ondersteuning en begeleiding en materiaal en middelen).

\subsection{Kenmerken van regimesevaluatie}

De beleving van het regime werd gemeten middels een schaal Regimesevaluatie. De items die bij deze schaal horen werden beschreven in hoofdstuk 5 . Het betreft hier ordegerichte items die betrekking hebben op onderwerpen als regelgeving, onderlinge afstand tussen personeel en gedetineerden, een ongedifferentieerde benadering, duidelijkheid van de regels e.d. en gedetineer-dengerichte items waarbij sprake is van ondersteuning, persoonlijke aandacht, aandacht voor de individuele behoeften van gedetineerden, e.d.

Over de mate waarin het bewarend personeel stimulerend optreedt om iets positiefs van de detentie te maken zijn de respondenten verdeeld. Ruim $40 \%$ vindt dat dit niet het geval is, terwijl eveneens $40 \%$ vindt dat dit wel het geval is. Bijna een derde van de respondenten vindt dat bewaarders veel door de vingers zien, maar de helft is die mening niet toegedaan. Bijna $60 \%$ vindt dat bewaarders geen echte belangstelling hebben voor gedetineerden. Een kwart vindt dat wel. Bijna de helft voelt zich als een nummer behandeld door de bewaarders, en eenderde heeft niet die indruk. Achter de uitspraak "bewaarders behandelen gedetineerden als een nummer" schreven sommige gedeti-neerden: "als groot vuil" of "als een hond ".

Bij persoonlijke problemen heeft $37 \%$ niet het gevoel dat bewaarders zoveel mogelijk proberen te helpen, maar $46 \%$ heeft dat gevoel wel. De meerderheid is van mening dat bewaarders streng optreden tegen het overtreden van regels, je moet zonder tegensputteren doen wat je gezegd wordt.

Bijna een derde van de gedetineerden denkt dat bewaarders er alleen maar op uit zijn je het leven zo zuur mogelijk te maken. Twee derde van de respondenten is het hiermee niet eens.

Een gedetineerde schreef:

"Voor acht van de tien bewaarders is het een sport om gedetineerden te vernederen".

Een meerderheid gaat ervan uit dat gedetineerden en bewaarders tegenover elkaar staande partijen zijn. Als commentaar schreef een gedetineerde bij de uitspraak "bewaarders en gedetineerden zijn tegenover elkaar staande partijen":

"Natuurlijk, je zit hier in de bajes!"

Bijna de helft van de respondenten vindt tenslotte dat bewaarders niet te vertrouwen zijn.

Deze resultaten laten zien dat de onderzochte populatie gedetineerden in de drie inrichtingen het inrichtingsklimaat niet in eenduidige zin beoordeelt als zeer orde-gericht of zeer gedetineerdengericht. Men zou hun reactie het best kunnen omschrijven als gematigd orde-gericht.

In tabellen 1 tot en met 3 is een overzicht gegeven van de gemiddelde scores van de beoordeling 
van het regime voor de drie inrichtingen en voor de afdelingen binnen een tweetal inrichtingen.

Tabel 1: Evaluatie van het regime in de drie inrichtingen, in gemiddelde scores

\begin{tabular}{lllll}
\hline & $\begin{array}{l}\text { Sittard } \\
\mathrm{N}=98\end{array}$ & $\begin{array}{l}\text { Roermond } \\
\mathrm{N}=52\end{array}$ & $\begin{array}{l}\text { Grave } \\
\mathrm{N}=49\end{array}$ & $\begin{array}{l}\text { Totaal } \\
\mathrm{N}=206\end{array}$ \\
\hline Regimesevaluatie & $2.3(\mathrm{sd}=.9)$ & $3.2(\mathrm{sd}=.7)$ & $2.8(\mathrm{sd}=.8)$ & $2.7(\mathrm{sd}=.9)$ \\
\hline
\end{tabular}

Regimesevaluatie $F=16.77, \mathrm{df}=2, \mathrm{p}<.001$

Tabel 2: Evaluatie van het regime in de afdelingen van Sittard, in gemiddelde scores

\begin{tabular}{llllll}
\hline & $\begin{array}{l}\text { A. HVB } \\
\mathrm{N}=17\end{array}$ & $\begin{array}{l}\text { B.kort -gestraft } \\
\mathrm{N}=44\end{array}$ & $\begin{array}{c}\text { C.lang-gestraft } \\
\mathrm{N}=20\end{array}$ & $\begin{array}{l}\text { D.lang-gestraft } \\
\mathrm{N}=17\end{array}$ & $\begin{array}{l}\text { Totaal } \\
\mathrm{N}=98\end{array}$ \\
\hline Reginesevaluatie & $2.7(\mathrm{sd}=.9)$ & $2.3(\mathrm{sd}=.7)$ & $2.3(\mathrm{sd}=8)$ & $2.1(\mathrm{sd}=.8)$ & $2.3(\mathrm{sd}=.9)$ \\
\hline
\end{tabular}

Regimesevaluatie $F=1.44, \mathrm{df}=3, \mathrm{p}=.23$

Tabel 3: Evaluatie van het regime in de afdelingen van Grave, in gemiddelde scores

\begin{tabular}{llllll} 
& $\begin{array}{l}\text { A3.Activit. } \\
\text { Afdeling }\end{array}$ & $\begin{array}{l}\text { B0.Arbeid } \\
\text { Afdeling } \\
\mathrm{N}=11\end{array}$ & $\begin{array}{l}\text { B3 Activit. } \\
\text { Afdeling } \\
\mathrm{N}=7\end{array}$ & $\begin{array}{l}\text { Versl. Beg. } \\
\text { Afdeling }\end{array}$ & Totaal \\
& $\mathrm{N}=14$ & $\mathrm{~N}=17$ & $\mathrm{~N}=49$ \\
\hline Regimes-evaluatie & $2.7(\mathrm{sd}=.9)$ & $2.7(\mathrm{sd}=.7)$ & $2.6(\mathrm{sd}=.8)$ & $3.0(\mathrm{sd}=.8)$ & $2.8(\mathrm{sd}=.9)$ \\
\hline
\end{tabular}

Regimesevaluatie $\mathrm{F}=.57$, df $=3, \mathrm{p}=.63$

Tabel 4: Evaluatie van het regime door respondenten in HVB's en op afdelingen voor kort- en langgestraften

\begin{tabular}{llllll}
\hline & HVB & Kort gestraft & Lang-gestraft & Lang-gestraft & Totaal \\
& Sittard Roermond & Afd.B & Afd.C & Afd.D & \\
& Grave & Sittard & Sittard & Sittard & \\
& $\mathrm{N}=118$ & $\mathrm{~N}=44$ & $\mathrm{~N}=20$ & $\mathrm{~N}=17$ & $\mathrm{~N}=199$ \\
\hline Regimesevaluatie & 3.0 & 2.3 & 2.3 & 2.1 & 2.7 \\
& $(\mathrm{sd}=.8)$ & $(\mathrm{sd}=9)$ & $(\mathrm{sd}=1.0)$ & $(\mathrm{sd}=.7)$ & $(\mathrm{sd}=9)$ \\
\hline
\end{tabular}

Regimesevaluatie $\mathrm{F}=10.22, \mathrm{df}=3, \mathrm{p}=<.001$

Uit tabel 4 blijkt dat de inrichtingen significant verschillen op de variabele regimesevaluatie. De gemiddelde score over de drie inrichtingen van 2.7 geeft aan dat de conclusie van een gematigd ordegerichte beleving van het regime door de totale populatie juist is. Een dergelijke score vertoont immers een tendens tot een meer ordegerichte beleving. In de gevangenis te Sittard met gedeti-neerden die hetzij in een HVB verblijven hetzij afgestraft zijn, vertoont de beleving van het regime vergeleken met de scores van de twee overige inrichtingen, de laagste gemiddelde score. Dit is waarschijnlijk toe te schrijven aan de kenmerken van de populatie, in casu de aanwezigheid van reeds afgestrafte gedetineerden. Deze groep respondenten vertoont aanmerkelijk lagere gemiddelde scores op de schaal regimesevaluatie, zoals in tabel 2 te zien is. Voor een deel spelen hier wellicht ook verschillen in regime een rol, in het bijzonder als men de relatief hoge gemiddelde score van de inrichting te Roermond in ogenschouw neemt. Gedetineerden in deze inrichting met een HVB-regime zijn positiever dan de HVB- 
gedetineerden in de overige twee inrichtingen. Wat de verschillen in regime betreft, het HVB tc Roermond was de enige inrichting watar ten tijde van de afname van de enquête nog geen regimesversobering in het kader van Werkzame Detentie had plaatsgevonden en de beleving van het regime is hier gemiddeld het hoogst (3.2), deze tendeert het meest naar een gedetineerdengerichte beleving. Behalve de afwezigheid van een restrictiever standaardregime is een andere oorzaak voor de gemiddeld meer positieve beleving van het regime in het HVB te Roermond misschien een verschil in leeftijdsopbouw van het personeel. Het personeel in deze inrichting is wat ouder, en daardoor waarschijnlijk ook wat meer ervaren dan het bewarend personeel in de overige twee betrekkelijk nieuwe inrichtingen. Vermoedelijk is in de inrichting te Roermond sprake van een meer gevestigde inrichtingscultuur met meer ervaren personeel. En zo blijkt uit een onderzoek van Kommer (1991), naarmate bewaarders ouder zijn, hechten zij meer belang aan de resocialisatie-opdracht. Deze gegevens bevestigen overigens de reputatie die deze inrichting sinds jaar en dag heeft onder de gedetineerden als een inrichting waar het ondanks het gebrek aan comfort het over het algemeen goed toeven is. Zo legde een gedetineerde in het HVB te Sittard die ook in het HVB te Roermond had gezeten uit dat bewaarders in Roermond vergeleken met de bewaarders in Sittard over het algemeen iets meer bereid zijn wat voor gedetineerden te doen en alerter reageren op bepaalde problemen en vragen van gedetineerden. Samenvattend kan men stellen dat de hogere gemiddelde score op regimesevaluatie van de inrichting te Roermond waarschijnlijk tevens een gevolg is van het ontbreken van een (restrictiever) standaardregime en van een meer gedetineerdengerichte inrichtingscultuur.

Opvallend is verder dat de HVB-afdeling te Sittard qua gemiddelde score op regimesevaluatie niet noemenswaardig afwijkt van de HVB-afdelingen in de inrichting Grave. De beide inrichtingen zijn qua standaard-regime vergelijkbaar, hetgeen erop duidt dat de lage gemiddelde score voor regimesevaluatie voor alle respondenten van de inrichting te Sittard waarschijnlijk wordt veroor-zaakt door de aanwezigheid van een meer negatieve groep langgestraften.

In tabel 4 zien we een vergelijking van gemiddelde scores op de schaal Regimesevaluatie voor respondenten die in een HVB verblijven en veroordeelde respondenten van gevangenisafdelingen voor kort-en langgestraften. De verschillen zijn significant. Gedetineerden die aan het begin van een detentie in een HVB verblijven oordelen significant positiever over het regime dan gedetineerden die in het kader van veroordeling tot een lange of korte vrijheidsstraf reeds langer in detentie verblijven.

Afdelingen in de inrichting te Sittard en Grave verschillen onderling niet significant in de beoordeling van het regime. Wel is er een duidelijke tendens waarneembaar in de inrichting te Sittard van een meer ordegerichte beleving van het regime door kortgestrafte en langgestrafte gedetineerden vergeleken bij gedetineerden in een HVB-regime binnen deze inrichting ( zie: tabel 2 en 3). In een onderzoek naar de werking van de korte vrijheidsstraf komt Janssen (1999, p.94) tot gelijksoortige bevindingen ten aanzien van de aard van de contacten tussen PIW-ers en kortgestrafte gedetineerden. De onderlinge afstand tussen gedetineerden en PIW-ers bleek betrekkelijk groot, gedetineerden interpreteerden de contacten vooral in termen van 'wij' en 'zij'.

\subsection{Kenmerken van de contacten met medegedetineerden}

De mate van aanpassing van gedetineerden aan een gedetineerdencultuur met deviante of oppositionele normen en waarden heeft men blijkens de onderzoeksliteratuur (Wheeler,1961) onder meer gerelateerd aan de intensiteit van de contacten met medegedetineerden. De veronderstelling die hieraan ten grondslag ligt, is dat naarmate men frequenter contact heeft met 
medegedetineerden de betrokkenheid bij de gedetineerdencultuur groter is.

De variabele Contacten met mede-gedefineerden werd gemeten op item-niveau. Qua frequentieverdeling kan men de onderzoekspopulatie $(\mathrm{N}=222)$ als volgt op deze variabele beschrijven. Ruim $45 \%$ zegt de vrije tijd heel vaak of vaak in de groep door te brengen, $32 \%$ brengt slechts af en toe de vrije tijd in de groep door en $24 \%$ brengt zelden of nooit de vrije tijd in de groep door.

Tabel 5: Contacten met medegedetineerden voor respondenten in een HVB-regime en op afdelingen voor kor1-en langgestraften, in gemiddelde scores

\begin{tabular}{llllll}
\hline & HVB. & Kort- & Lang- & Lang - & Totaal \\
& Sittard & Gestraft & Gestraft & Gestraft & \\
& Roermond & Afd.B & Afd.C & Afd.D & \\
& Grave & Sittard & Sittard & Sittard & \\
& $\mathrm{N}=133$ & $\mathrm{~N}=47$ & $\mathrm{~N}=20$ & $\mathrm{~N}=22$ & $\mathrm{~N}=222$ \\
\hline $\begin{array}{l}\text { Contact met } \\
\text { mede-gedetineerden }\end{array}$ & 2.6 & 2.5 & 3.3 & 3.2 & \\
\hline
\end{tabular}

Contact met mede-gedetineerden $F=5.29, \mathrm{df}=3, \mathrm{p}<.01$

In tabel 5 worden de gemiddelde scores van alle respondenten in een HVB-regime vergeleken met de scores van de respondenten die kortgestraft, respectievelijk langgestraft zijn. De verschillen zijn significant. Het zijn met name de langgestraften die intensiever lijken om te gaan met medegedetineerden. Gedetineerden die zich in voorlopige hechtenis bevinden of een korte vrijheidsstraf uitzitten, geven blijk van minder intensieve contacten met medegedetineerden. Wat opvalt is dat de scores van de kortgestrafte gedetineerden veel overeenkomst vertonen met de scores van de HVB-populatie.

Dit verschil tussen langgestrafte gedetineerden en de overige kortgestrafte en voorlopig gehechte gedetineerden zou kunnen samenhangen met een verschil in regime. Immers kortgestrafte en voorlopig gehechte gedetineerden worden onderworpen aan een meer restrictief regime, waarin men minder bewegingsvrijheid op de afdeling heeft en veel meer tijd achter de deur doorbrengt. Recreatie in groepsverband op de afdeling is in een dergelijk regime in beperkter mate mogelijk vergeleken bij een regime voor gemeenschapsgeschikte langgestraften. Het regime lijkt echter geen belangrijke rol te spelen, immers van de HVB gedetineerden en van de kortgestraften blijkt respectievelijk $48 \%$ en $57 \%$ zelden of nooit de vrije tijd op de afdeling met medegedetineerden door te brengen. Blijkbaar hebben HVB-gedetineerden en kortgestraften wat minder behoefte aan contacten met medegedetineerden. Janssen (1999) constateert overigens dat de onderlinge contacten van kortgestraften in het teken lijken te staan van een zeker wantrouwen. Illustratief is voorts dat niemand van de langgestrafte respondenten aangeeft de vrije tijd op de afdeling nooit met andere medegedetineerden door te brengen. Slechts $20 \%$ van de HVB respondenten en $15 \%$ van de kortgestraften zegt vaak of heel vaak de vrije tijd op de afdeling met medegedetineerden door te brengen.

Deze resultaten lijken de bevindingen te bevestigen uit het onderzoek van Wheeler (1961) waar eveneens een duidelijk verschil werd geconstateerd in contacten met medegedetineerden al naar gelang de detentiefase waarin gedetineerden zich bevinden. Wheeler's onderzoek laat zien dat gedetineerden in de middenfase (in dit onderzoek zijn dit de langgestraften), veel sterker zijn 
betrokken op medegedetineerden en daarmee tevens op de gedetineerdencultuur. Voor de gedetineerden aan het begin van de detentie en in de eindfase van de detentie vond Wheeler veel minder intensieve contacten met medegedetineerden, de mate van intensiteit van de contacten van deze groepen was vergelijkbaar. De verklaring van dit U-vormige patroon van de contacten met medegedetineerden en van de betrokkenheid op de gedetineerdencultuur wordt, zo bleek in hoofdstuk 4, voornamelijk gezocht in een sterkere oriëntatie van gedetineerden op de buitenwereld gedurende het begin en einde van de detentie.

\subsection{De kenmerken van toekomstverwachtingen}

Over de toekomst opgevat als het leven dat men na ontslag denkt te gaan leiden, is een derde van de respondenten somber. De helft van de gedetineerden is dat echter niet. Driekwart van de respondenten denkt zelfs dat als men eenmaal in vrijheid is gesteld het allemaal wel weer wat beter zal gaan. Meer dan een kwart denkt echter dat als men eenmaal vrij is men niet meer op steun van vrienden en familie hoeft te rekenen. Een duidelijke meerderheid heeft wel de indruk dat men na de detentie weer een beroep kan doen op familie en vrienden. Over de gevolgen van de detentie voor het persoonlijke leven is meer dan de helft van de gedetineerden duidelijk: men vindt zijn leven door de detentie geruïneerd. Een derde vindt het vervelend als men straks na vrijlating weer vrienden en bekenden tegenkomt en bijna een derde denkt niet na ontslag een eerlijke kans op herstel door de samenleving te krijgen. Overzien we deze resultaten dan blijkı een belangrijk gedeelte van de gedetineerden, $\mathrm{nl}$. een derde negatief over de toekomst te denken. Opvallend is dat een meerderheid van de gedetineerden, ondanks het feit dat men de schade van de detentie voor het eigen leven groot acht, toch met enig optimisme over het toekomstig leven na detentie denkt.

Op basis van de onderstaande twee tabellen van gemiddelde scores op de schaal toekomstverwachtingen blijken er tussen inrichtingen (tabel 6) en tussen gedetineerden in een HVBregime en reeds afgestrafte gedetineerden (tabel 7) geen significante verschillen aanwezig te zijn. Gedetineerden in het HVB Roermond hebben de meest gunstige verwachtingen over de toekomst vergeleken bij de gedetineerden in de twee andere inrichtingen.

Tabel 6: Toekomstverwachtingen van respondenten in de drie inrichtingen, in gemiddelde scores

\begin{tabular}{lllll}
\hline & $\begin{array}{l}\text { Sittard } \\
\mathrm{N}=100\end{array}$ & $\begin{array}{l}\text { Roermond } \\
\mathrm{N}=42\end{array}$ & $\begin{array}{l}\text { Grave } \\
\mathrm{N}=52\end{array}$ & $\begin{array}{l}\text { Totaal } \\
\mathrm{N}=194\end{array}$ \\
\hline Toekonist- & 3.5 & 3.6 & 3.4 & 3.5 \\
Verwachtingen & $(\mathrm{sd}=.9)$ & $(\mathrm{sd}=.8)$ & $(\mathrm{sd}=.9)$ & $(\mathrm{sd}=.8)$ \\
\hline
\end{tabular}

Toekomstverwachtingen: $\mathrm{F}=.44, \mathrm{df}=2, \mathrm{p}=.63$

Reeds afgestrafte gedetineerden zijn afgaande op de resultaten in tabel 6 minder gunstig gestemd over de toekomst dan gedetineerden in een HVB regime. Opvallend is tenslotte dat de gedetineerden in het HVB te Grave een gemiddelde score op de schaal toekomstverwachtingen vertonen die de gemiddelde score van de langgestrafte gedetineerden benadert. 
Tabel 7: Toekomstverwachtingen in een HVB-regime en veroordeelde respondenten, in gemiddelde scores

\begin{tabular}{llllll}
\hline & HVB inr & Kort- & Lang- & Lang & Totaal \\
& Sittard & Gestraft & Gestraft & Gestraft & \\
& Roermond & Afd.B & Afd.C & Afd.D & \\
& Grave & Sittard & Sittard & Sittard & \\
& $\mathrm{N}=112$ & $\mathrm{~N}=44$ & $\mathrm{~N}=20$ & $\mathrm{~N}=17$ & $\mathrm{~N}=199$ \\
\hline Toekomst- & 3.6 & 3.4 & 3.4 & 3.4 & 3.5 \\
Verwachtingen & $(\mathrm{sd}=.8)$ & $(\mathrm{sd}=.9)$ & $(\mathrm{sd}=.9)$ & $(\mathrm{sd}=.9)$ & $(\mathrm{sd}=8)$ \\
\hline
\end{tabular}

Toekomstverwachtingen $\mathrm{F}=.23, \mathrm{df}=3, \mathrm{p}=.87$

\subsection{Kenmerken van programma-integriteit}

\subsubsection{Informatieverstrekking}

Over de informatieverstrekking bij binnenkomst in de inrichting met betrekking tot het onderwijs en de kunstzinnige vorming is het merendeel van de gedetineerden niet tevreden (respectievelijk $64 \%$ en $67 \%$ ). Een kwart vindt de informatie over deze activiteiten wel voldoende. Nog ongunstiger denkt men over de informatieverstrekking vanuit het BSD over de sociale dienstverlening

Met de uitspraak 'je weet wat je kunt gaan doen bij het onderwijs' is $51 \%$ het eens. Van de tijden waarop men naar het onderwijs kan gaan, is bijna twee derde van de respondenten op de hoogte. Het merendeel van de gedetineerden vindt het niet lastig om te weten te komen wat je zoal kunt gaan doen bij de crea en men is ook goed op de hoogte van de tijden.

Verblijven gedetineerden reeds enige tijd in de inrichting dan blijkt dus dat de meeste respondenten goed op de hoogte raken van de tijden en de mogelijkheden van de activiteiten. $\mathrm{Bij}$ binnenkomst is de informatieverstrekking volgens de meeste respondenten echter minder optimaal.

\subsubsection{Ondersteuning en begeleiding}

Een ruime meerderheid is positief over de ondersteuning en begeleiding door het onderwijzend personeel. Over de ondersteuning bij de crea-activiteiten is bijna twee derde van de respondenten goed te spreken, echter bijna $60 \%$ vindt dat bewaarders de deelname niet aanmoedigen.

Over de ondersteuning door hulpverlenende instanties (BSD, PRW, Geestelijke Verzorging en psycholoog/ psychiater) in het bijzonder het gemak waarmee een gesprek te regelen valt, is $48 \%$ tevreden, en ruim een derde van de respondenten ontevreden. Over de ondersteuning bij problemen is vier van de tien respondenten of tevreden of ontevreden.

\subsubsection{Materiaal en middelen}

De schaal Materiaal en middelen heeft betrekking op de materiele voorzieningen en accommodatie die bij de kunstzinnige vorming worden geboden. Een ruime meerderheid is tevreden over de faciliteiten die bij de kunstzinnige vorming worden geboden.

In onderstaande tabellen 8 en 9 wordt een overzicht gegeven van de gemiddelde scores op de programma-integriteitsschalen voor de drie inrichtingen en voor vier afdelingen in de inrichting te Sittard met een HVB regime, en regimes voor kort- en langgestraften. De verschillen op 
inrichtingsniveau en afdelingsniveau zijn niet significant. De verschillen tussen de inrichtingen zijn het meest opmerkelijk bij de schaal Ondersteuning en Begeleiding. Het HVB te Roermond scoort hier gemiddeld het laagst en het HVB te Grave het hoogst. De eerder beschreven positie van de SKW-afdeling (en het PRW) binnen de inrichtingsorganisatie lijkt zich in dezc gemiddelde scores te weerspiegelen.

Op afdelingsniveau in de inrichting te Sittard doet zich eveneens een opmerkelijk verschil voor. De beter gemotiveerde groep langgestraften van de C-vleugel blijkt zeer tevreden te zijn over de ondersteuning en begeleiding. Dit verschil laat zien dat de beoordeling van de kwaliteit van de begeleiding door gedetineerden voor een deel ook samenhangt met de motivatie voor en intensiteit waarmee men gebruik maakt van de activiteiten. Hoe intensiever men gebruik maakt van een bepaalde activiteit des te meer weet men wellicht op het gebied van ondersteuning en begeleiding door het personeel te bewerkstelligen en des te meer tevreden is men waarschijnlijk over de geboden ondersteuning. De interesse en motivatie van gedetineerden voor de activiteiten speelt bij de totstandkoming van het oordeel over de randvoorwaarden op het gebied van informatie, begeleiding en ondersteuning vermoedelijk een belangrijke rol, naast uiteraard de objectieve ken-merken van de invulling van de randvoorwaarden op het niveau van de organisatic. Het minst tevreden, zo blijkt uit tabel 9, zijn de gedetineerden van de B-vleugel. Ten tijde van de afname van de enquête waren de voorzieningen voor deze afdeling op het gebied van crea en onderwijs tamelijk minimaal, zo niet volledig afwezig. Een en ander is duidelijk af te lezen uit de lage score van deze afdeling op de schaal Ondersteuming en Begeleiding.

Tabel 8: Kenmerken van programma-integriteit in de drie inrichtingen, in gemiddelde scores

\begin{tabular}{lllll}
\hline & $\begin{array}{l}\text { Sittard } \\
29<\mathrm{N}<95\end{array}$ & $\begin{array}{l}\text { Roermond } \\
8<\mathrm{N}<40\end{array}$ & $\begin{array}{l}\text { Grave } \\
22<\mathrm{N}<44\end{array}$ & $\begin{array}{l}\text { Totaal } \\
59<\mathrm{N}<179\end{array}$ \\
\hline Informatie & $2.7(\mathrm{sd}=.9)$ & $3.0(\mathrm{sd}=.9)$ & $2.9(\mathrm{sd}=.8)$ & $2.8(\mathrm{sd}=.9)$ \\
Ondersteuning en begeleiding & $3.6(\mathrm{sd}=.8)$ & $3.3(\mathrm{sd}=.9)$ & $3.8(\mathrm{sd}=.8)$ & $3.6(\mathrm{sd}=.8)$ \\
Materiaal en middelen & $3.5(\mathrm{sd}=1)$. & $3.3(\mathrm{sd}=1)$. & $3.4(\mathrm{sd}=1)$. & $3.5(\mathrm{sd}=1)$. \\
\hline
\end{tabular}

Informatie $\mathrm{F}=1.4, \mathrm{df}=2, \mathrm{p}=.24$

Ondersteuning en begeleiding $\mathrm{F}=1.06, \mathrm{df}=2, \mathrm{p}=.35$

Materiaal en middelen $F=.15, \mathrm{df}=2, \mathrm{p}=.86$ 
Tabel 9: Kenmerken van programma-integriteit: gemiddelde scores van respondenten in HVB's en op afdelingen voor kort-en langgestraften

\begin{tabular}{|c|c|c|c|c|c|}
\hline & $\begin{array}{l}\text { HVB.inr } \\
\text { Sittard } \\
\text { Roerm. } \\
\text { Grave }\end{array}$ & $\begin{array}{l}\text { Kort- } \\
\text { Gestraft } \\
\text { Afd.B } \\
\text { Sittard }\end{array}$ & $\begin{array}{l}\text { Lang- } \\
\text { Gestraft } \\
\text { Afd.C } \\
\text { Sittard }\end{array}$ & $\begin{array}{l}\text { Lang - } \\
\text { Gestraft } \\
\text { Afd.D } \\
\text { Sittard }\end{array}$ & Totaal \\
\hline Informatic & $\begin{array}{l}2.9 \\
(\mathrm{sd}=.8) \\
\mathrm{N}=103\end{array}$ & $\begin{array}{l}2.8 \\
(\mathrm{sd}=.7) \\
\mathrm{N}=43\end{array}$ & $\begin{array}{l}2.6 \\
(\mathrm{sd}=.8) \\
\mathrm{N}=18\end{array}$ & $\begin{array}{l}2.4 \\
(\mathrm{sd}=.8) \\
N=15\end{array}$ & $\begin{array}{l}2.8 \\
(\mathrm{sd}=.9) \\
N=179\end{array}$ \\
\hline Ondersteuning en begeleiding & $\begin{array}{l}3.7 \\
(\mathrm{sd}=.8) \\
\mathrm{N}=35\end{array}$ & $\begin{array}{l}3.2 \\
(\mathrm{sd}=.7) \\
\mathrm{N}=11\end{array}$ & $\begin{array}{l}4.1 \\
(\mathrm{sd}=.8) \\
\mathrm{N}=9\end{array}$ & $\begin{array}{l}3.3 \\
(s d=.8) \\
N=4\end{array}$ & $\begin{array}{l}3.6 \\
(\mathrm{sd}=.8) \\
\mathrm{N}=59\end{array}$ \\
\hline Materiaal en middelen & $\begin{array}{l}3.5 \\
(\mathrm{sd}=.8) \\
\mathrm{N}=63\end{array}$ & $\begin{array}{l}3.4 \\
(\mathrm{sd}=.7) \\
\mathrm{N}=16\end{array}$ & $\begin{array}{l}3.7 \\
(\mathrm{sd}=.8) \\
\mathrm{N}=13\end{array}$ & $\begin{array}{l}3.3 \\
(s d=.8) \\
N=7\end{array}$ & $\begin{array}{l}3.5 \\
(\mathrm{sd}=1 .) \\
\mathrm{N}=99\end{array}$ \\
\hline
\end{tabular}

Informatic $\mathrm{F}=1.4, \mathrm{df}=3, \mathrm{p}=.22$

Ondersteuning en begeleiding $F=2.2$, $\mathrm{df}=3, \mathrm{p}=.09$

Materiaal en middelen $F=. .20, d f=3, p=.89$

\subsection{Samenvatting en conclusies}

$\mathrm{Na}$ beschrijving van de onderzoekspopulatie op een aantal achtergrondkenmerken is het beeld van de onafhankelijke variabelen die mogelijk gerelateerd kunnen worden aan de houdingen van gedetineerden ten aanzien van resocialisatie compleet.

Voor wat betreft de typering van de onderzoekspopulatic op de kenmerken die in dit hoofdstuk werden onderzocht, kan men het volgende vaststellen.

De populatie beoordeelt het regime noch in zuiver orde-of gedetineerdengerichte zin.

Men zou de houding van de onderzoekspopulatie in zijn geheel als gematigd orde-gericht kunnen omschrijven. In één inrichting bleek de beoordeling van het regime in vergelijking met de overige twee inrichtingen iets meer te tenderen naar een gedetineerden-gericht karakter. Dit werd verklaard door de aanwezigheid van een minder restrictief regime en door een wat meer gedetineerden-gericht inrichtingsklimaat.

Langgestrafte gedetineerden in de middenfase van de detentie, blijken veel intensiever om te gaan met medegedetineerden dan gedetineerden die in de begin-of eindfase van de detentie. Deze resultaten zijn in overeenstemming met de onderzoeksliteratuur waarin de meer intensieve omgang met medegedetineerden gedurende de middenfase van de detentie wordt toegeschreven aan de invioed van de gedetineerdencultuur.

De onderzochte populatie is over het algemeen niet uitgesproken optimistisch en evenmin erg pessimistisch ten aanzien van de toekomst. Men kijkt met overwegend gemengde gevoelens naar de toekomst. Uit de frequentieverdelingen op de afzonderlijke schaal-items blijkt dat een op de drie respondenten somber gestemd is over de toekomst. In meerderheid is men het eens over de schadelijkheid van de detentie voor het eigen (toekomstig) leven.

Tenslotte werden de houdingen van de gedetineerden onderzocht te aanzien van de wijze waarop activiteiten als onderwijs, hulpverlening en kunstzinnige vorming worden uitgevoerd ( ook wel de programma-integriteit).

Over de informatie bij binnenkomst in de inrichting is men minder tevreden. 
Na verloop van tijd raakt men echter beter op de hoogte van de aard en inhoud van het activiteiten aanbod. Over de geboden begeleiding en ondersteuning door de docenten bij het onderwijs en kunstzinnige vorming is men tevreden. Het oordeel over de geboden ondersteuning bij psycho-sociale problemen laat een zekere verdeeldheid zien onder de respondenten. Vier op de tien gedetineerden is hierover ontevreden en een zelfde deel van de respondenten is hierover echter wel tevreden. Men is in meerderheid tevreden over de faciliteiten in materiële zin die bij de kunstzinnige vorming worden geboden. De verschillen tussen inrichtingen en afdelingen op het gebied van begeleiding en ondersteuning bij de activiteiten weerspiegelen in zekere mate de positie van het SKW en het PRW in de inrichtingsorganisatie. In het volgende hoofdstuk zullen de relaties tussen de houdingen en de variabelen met betrekking tot de omgeving, de persoon en de programma-integriteit verder worden onderzocht. 


\section{DETERMINANTEN VAN DE HOUDING VAN GEDETINEERDEN TEN AANZIEN VAN RESOCIALISATIE}

\subsection{Inleiding}

In dit hoofdstuk worden de onderzoeksresultaten besproken die verband houden met het verklarende deel van de probleemstelling. Deze verklarende probleemstelling werd in Hoofdstuk 1 voor de gedetineerden als volgt geformuleerd:

"Welke omgevings- en persoonsgebonden factoren zijn, eventueel in onderlinge samenhang, van imloed op de houding van gedetineerden ten aanzien van de voorbereiding van de terugkeer in de samenleving?"

In hoofdstuk 4 werd op basis van de onderzoeksliteratuur een interactionistisch onderzoeksmodel geconstrueerd waarin gedrag en houdingen van gedetineerden worden verklaard vanuit de depriverende detentie-omgeving, persoonskenmerken en de kwaliteit van de uitvoering van de activiteiten in en door de inrichtings-organisatie (de 'program-integrity' factoren, ook wel programma-integriteit).

De volgorde waarin de onderzoeksresultaten in dit hoofdstuk worden besproken is analoog aan de volgorde waarin de relevant geachte onafhankelijke variabelen uit het onderzoeksmodel werden gepresenteerd.

Als afhankelijke variabelen gelden opvattingen, deelname en beleving. De onafhankelijke variabelen zijn de reeks persoons- en omgevingsgebonden factoren die worden verondersteld van invloed te zijn op de houdingen. Niet alleen de relaties tussen deze afhankelijke en onafhankelijke variabelen zullen worden besproken, ook zal worden onderzocht welke relaties er bestaan tussen opvattingen, beleving en deelname onderling.

Deze samenhang tussen opvattingen, deelname en beleving onderling wordt als eerste onderdeel in dit hoofdstuk behandeld. Vervolgens wordt de samenhang onderzocht tussen de houdingen en de onafhankelijke variabelen die in het onderzoeksmodel betrekking hebben op de (depriverende) detentie-omgeving, de zogenaamde deprivatievariabelen. Het betreft hier de variabelen regimes-evaluatie, de intensiteit van de omgang met medegedetineerden, verblijfsduur, strafduur en detentie-fase.

Analoog aan de presentatie van het onderzoeksmodel worden dan de houdingen gerelateerd aan een reeks persoonskenmerken. Deze persoonskenmerken zijn ontleend aan de onderzoeksliteratuur waarin prisonisatie-processen worden verklaard op basis van het importmodel. In het onderzoeksmodel werden de volgende onafhankelijke persoonsgebonden variabelen opgenomen: leeftijd, opleiding, recidive, burgerlijke staat, culturele achtergrond, 
druggebruik, arbeidsverleden en toekonstverwachtingen.

Tenslotte volgt een bespreking van de samenhang van de houdingen met de onathankelijke variabelen die te maken hebben met de kwaliteit van de implementatie van de activiteiten, de variabelen met betrekking tot de programma-integriteit, informatie, ondersteuning en begeleiding en materiaal en middelen.

De verbanden tussen de houdingen en de verschillende onafhankelijke variabelen die op basis van de eerste-orde correlaties worden gevonden zullen verder worden onderzocht door middel van de methode van het modelleren van structurele vergelijkingen (structural equations modeling, SEM) en regressie-analyse. De resultaten van deze analyse zullen worden gepresenteerd in een aparte paragraaf 'modellering van de relaties tussen houdingen en achtergrondvariabelen'.

Correlatie-analyse geeft inzicht in het verband tussen twee variabelen. Met de correlatie-analyse is het mogelijk de mate van samenhang en de richting (positief of negatief) van de lineaire samenhang tussen variabelen vast te stellen. Het correlatie-coëfficiënt betreft de bivariate Pearson correlatie-coëfficiënt. De correlatie-analyse is gebaseerd op de veronderstelling dat variabelen ratio of interval zijn geschaald. Een positieve correlatic houdt in dat als de ene variabele stijgt, de andere eveneens stijgt. Een hogere correlatie betekent een sterker verband tussen twee variabelen. Bij het berekenen van de correlatie-analyse worden ontbrekende waarden behandeld volgens de methode 'pairwise' waarbij voor de te berekenen correlaticcoëfficiënt wordt bepaald welke waarnemingen kunnen worden gebruikt, dat wil zeggen geldige waarden hebben voor de betrokken twee variabelen.

\subsection{De relaties tussen opvattingen, beleving en deelname}

In het hoofdstuk over de theoretische achtergronden veronderstelden wij op grond van een geïntegreerd onderzoeksmodel dat houdingen van gedetineerden het meest adequat zouden kunnen worden verklaard vanuit een visie waarin zowel variabelen gerelateerd aan de detenticomgeving als persoonsgebonden variabelen die los staan van de detentic-omgeving, cen rol spelen.

Op grond van dit uitgangspunt ligt het voor de hand dat gedetineerden de inrichting binnenkomen met bepaalde opvattingen over conventionele sociale doeleinden (bereiken van maatschappelijk succes en aanzien) en dat deze opvattingen hun houding ten aanzien van resocialisatie mede beïnvloeden. Vervolgens heeft ook het verblijf in de gevangenisomgeving invloed op de houdingen ten aanzien van resocialisatie.

Een plausibele veronderstelling is dat al naar gelang de instelling waarmee gedetinecrden binnen komen en al naar gelang hun reactie op de detentie-omgeving, er bepaalde patronen in de onderlinge relaties tussen opvattingen, deelname en beleving zijn te ontdekken. Zo zou men kunnen verwachten dat naarmate gedetineerden in meer gunstige zin denken over resocialisatic en over het bereiken van conventionele sociale doeleinden in het algemeen, zij frequenter aan de activiteiten zullen deelnemen en dat hun beleving van de activiteiten zich navenant in positieve zin onder-scheidt. Ook op grond van het eerder beschreven hiërarchische model van de houdingen mag men verwachten dat de verschillende cognitieve, affectieve en conatieve componenten van de houdingen ten aanzien van resocialisatic cen onderlinge samenhang zullen vertonen. Ajzen ( 1993, p.43):

"given that the three components reflect the same underlying attitude, they should correlate to some degree with each other. Yet, to the extent that the distinction between cognitive, affective, and conative 
response categories is of psychological significance, measures of the three components should not be completely redundant. In combination. these expectations imply correlations of moderate magnitude among measures of the three components".

In de volgende paragraten zullen deze verbanden met behulp van correlationele analyse worden onderzocht. Met behulp van deze correlationele analyse worden eerst de interne relaties binnen de opvattingen, deelname en beleving onderzocht.

\subsubsection{Relaties tussen belevingsvariabelen}

Op grond van, bijvoorbeeld de bevindingen van Toch (1977), blijkt dat er onder een bepaalde groep gedetinecrden van een positieve houding ten aanzien van activiteiten in hun algemeenheid sprake is. Het lijkt daarom plausibel te veronderstellen dat de wijze van waardering van een bepaalde activiteit niet op zich zelf staat maar ook terug te vinden is in de beleving van andere activiteiten. Men zou op grond hiervan mogen verwachten dat gedetineerden die bijvoorbeeld bij de kunstzinnige vorming de aspecten van persoonlijke groei weten te waarderen dat evenzeer zullen doen bij andere activiteiten. De correlaties tussen de belevings-variabelen laten inderdaad een dergelijk patroon zien.

Tabel 1: Correlaties tussen belevingsvariabelen $(54<N<210)$

\begin{tabular}{lccccccc}
\hline Beleving & 1 & 2 & 3 & 4 & 5 & 6 & 7 \\
\hline 1. Onderwijs & 1.00 & -.19 & $.62^{* *}$ & $.44^{* *}$ & $.48^{* *}$ & $.22^{*}$ & $.19^{*}$ \\
2. Crea kort & & 1.00 & -.20 & -.02 & -.08 & -.16 & -.06 \\
3. Crea lang & & & 1.00 & $.43^{* *}$ & $.34^{* *}$ & $.37^{* *}$ & .02 \\
4. Hulpverlening kort & & & & 1.00 & $.75^{* *}$ & $.35^{* *}$ & $.26^{* *}$ \\
5. Hulpverlening lang & & & & & 1.00 & $.36^{* *}$ & $.31^{* *}$ \\
6. Arbeid & & & & & 1.00 & $.23^{* *}$ \\
7. Vrije tijd & & & & & & 1.00 \\
\hline
\end{tabular}

$* \mathrm{p}<.05: * * \mathrm{p}<.01$

Zo blijkt uit tabel 1 dat de beleving van de onderwijsactiviteiten een positieve samenhang vertoont met de beleving van de lange termijnaspecten van de kunstzinnige vorming. Hoe meer men de onderwijsactiviteiten waardeert om hun betekenis voor persoonlijke groei en de toekomstige levenssituatie des te meer zal men ook de kunstzinnige vorming waarderen voor een bijdrage aan deze belevingsaspecten. De correlaties in de tabel laten over het algemeen hoog positieve significante relaties zien tussen de beleving van de verschillende activiteiten.

Op basis van een Mc Quitty- analyse, een eenvoudige methode om de clusters te achterhalen die in een correlatie-matrix zijn verborgen, komen er twee clusters te voorschijn met betrekking tot de onderlinge verbanden tussen belevingsvariabelen.

Enerzijds is er een cluster met drie variabelen, namelijk de beleving van de hulpverlening met betrekking tot de korte en lange termijnaspecten en de tevredenheid met de vrije tijdsbesteding. Een tweede cluster bestaat uit vier belevingsvariabelen, namelijk de beleving van het onderwijs, de beleving van de lange en korte termijnsapecten van crea en tevredenheid met arbeid. De beleving van de korte termijn aspecten van de creatieve vorming is negatief gerelateerd aan dit cluster. 
Schematisch ziet dit er als volgt uit:

Clusterl

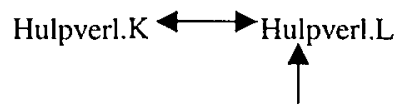

Tevredenheid Vrije tijd
Cluster 2

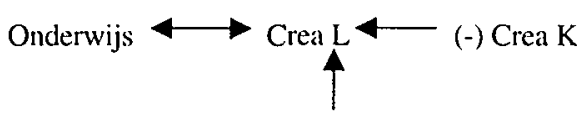

Tevredenheid Arbeid

\subsubsection{Relaties tussen deelnamevariabelen}

Er blijken niet alleen onderlinge correlaties tussen de belevingsvariabelen. In tabel 2 zien we dat er een aantal positieve significante verbanden aanwezig is tussen de verschillende deelnamevariabelen.

Tabel 2: Correlaties tussen deelnamevariabelen $(174<N<208)$

\begin{tabular}{lccccc}
\hline Deelname & 1 & 2 & 3 & 4 & 5 \\
\hline 1. Onderwijs & 1.00 & .13 & .09 & $.18^{*}$ & .13 \\
2. Crea & & 1.00 & .06 & $.38^{* *}$ & $.22^{* *}$ \\
3. Hulpverlening & & & 1.00 & -.10 & -.01 \\
4. Sport & & & 1.00 & $.36^{* *}$ \\
5. Bibliotheek & & & & & 1.00 \\
\hline
\end{tabular}

$* \mathrm{p}<.05 ; * * \mathrm{p}<.01$

Gedetineerden die vaker naar het onderwijs gaan, zijn ook actiever bij de sport. Bij de crea wordt een soortgelijk verband aangetroffen. Naarmate men vaker naar de crea gaat, makkt men ook vaker gebruik van de sport en de bibliotheek. En naarmate men vaker aan sport doet, des te frequenter bezoekt men de bibliotheek. Dit duidt erop dat er waarschijnlijk sprake is van een onderliggende positieve houding van de respondenten ten aanzien van de activiteiten in hun algemeenheid.

Een Mc Quitty analyse met betrekking tot de variabelen in de matrix van tabel 2 wijst uit dat zij een cluster vormen waar de deelname aan de hulpverleningsactiviteiten min of meer buiten valt.

Deze resultaten bevestigen de bevindingen van Toch (1977) die erop wijzen dat onder gedetineer-den een groep aanwezig is met een relatief sterke behoefte aan zinvolle bezigheden en onder-steuning op het gebied van zelfherstel. Als gevolg van een sterkere behoefte aan bezig zijn, maakt men op alle mogelijke fronten gebruik van de activiteiten.

Toch (ibid., p.22) merkt hierover op:

"Inmates differ in their approach to time through the importance they assign to being distracted, entertained, or actively occupied. Some inmates feel that continuous activity is crucial to their survival. Such inmates rate prison environments in terms of the opportunity that is furnished for them to keep busy".

\subsubsection{Relaties tussen opvattingen en deelname}

Het ligt voor de hand te veronderstellen dat de opvattingen van gedetineerden ten aanzien van de voorbereiding van de terugkeer in de samenleving hun deelname aan de activiteiten beïnvloeden. Hoe positiever men over de voorbereiding van de terugkeer in de samenleving denkt, des te frequenter maakt men gebruik van de voorzieningen ten behoeve van de voorbereiding van de terugkeer in de samenleving.

De variabele Belang van resocialisatie blijkt op grond van de correlaties in tabel 3 niet 
significant samen te hangen met de frequentie waarmee men deelneemt aan de activiteiten.

Tabel 3: Correlaties tussen opvattingen en deelnamevariabelen $(173<\mathrm{N}<208)$

\begin{tabular}{lcc}
\hline Deelname & Resocialisatie & Scepsis \\
\hline 1. Onderwijs & .04 & $.30^{* *}$ \\
2. Crea & .07 & $.26^{* *}$ \\
3. Hulpverlening & .07 & $.23^{* *}$ \\
4. Sport & .11 & $.24^{* *}$ \\
5. Bibliotheek & .13 & $.22^{* *}$ \\
\hline
\end{tabular}

$* p<.05 ; * * p<.01$

Kijken we echter naar de samenhang van de variabele Scepsis met deelname over alle activiteiten dan zien we in tabel 3 een verband dat zeer sterk significant is $(\mathrm{P}<.01)$. Dit verband laat zien dat naarmate men negatiever denkt over de mogelijkheden om tijdens de detentie jets aan zelfherstel te doen, men minder gebruik maakt van de activiteiten. Of anders geformuleerd: hoe positiever men is over de mogelijkheden om iets te doen aan zelfherstel tijdens detentie, des te frequenter maakt men gebruik van de activiteiten.

\subsubsection{Relaties tussen opvattingen en beleving}

Het belang dat men toekent aan de resocialisatie-doelstelling blijkt, zoals in tabel 5 te zien is, een significante correlatie te hebben met de beleving van een aantal activiteiten. Hoe groter het belang dat men toekent aan de resocialisatiedoelstelling, des te positiever de beleving van de activiteiten.

Het betreft hier activiteiten als onderwijs, arbeid, crea, hulpverlening, vrije tijdsbesteding en arbeid.

We zien bij onderwijs en crea dat het verband zich alleen voordoet bij de ervaren zinvolheid van de lange termijn-aspecten dat wil zeggen, de aspecten met betrekking tot de persoonlijke ontwikkeling en (toekomstige) levenssituatie.

Tabel 4: Correlaties tussen opvattingen en belevingsvariabelen $(67<N<206)$

\begin{tabular}{lcc}
\hline Beleving & Resocialisatie & Scepsis \\
\hline 1. Onderwijs & $.36^{* *}$ & .17 \\
2. Crea kort & -.09 & $-.46^{* *}$ \\
3. Crea lang & $.24^{*}$ & -.01 \\
4. Hulpverlening kort & $.35^{* *}$ & .15 \\
5. Hulpverlening lang & $.44^{* *}$ & $.20^{*}$ \\
6. Arbeid & $.14^{*}$ & $.15^{*}$ \\
7. Vrije tijd & $23^{* *}$ & $.39 * *$ \\
\hline
\end{tabular}

$* \mathrm{p}<.05 ; * * \mathrm{p}<.01$

$\mathrm{Bij}$ de beleving van de hulpverleningscontacten vertonen zowel de aspecten die betrekking hebben op de hantering van de detentiesituatie als aspecten die betrekking hebben op de persoonlijke ontwikkeling en (toekomstige) levenssituatie een significant verband met de waarde die men hecht aan de resocialisatie-doelstelling.

Opvallend in de correlaties van tabel 4 is dat bij de beleving van de crea-activiteiten de 
waardering van de korte termijn-aspecten die aan de detentie-situatie zijn gerelateerd (ontspanning, gezellig-heid, niet op cel hoeven zitten, de tijd doden, etc.) alleen significant samenhangen met de gepercipieerde mogelijkheden voor zeltherstel tijdens detentie (i.c.de variabele Scepsis). Hoe sceptischer men is over de gevangenis en de mogelijkheden voor maatschappelijke integratie des te meer is men geneigd de crea-activiteiten te beschouwen als een middel om de directe spanningen van het gedetineerd zijn te reduceren.

Bij de beleving van het onderwijs ontbrak een dergelijk verband met de variabele Scepsis. Bij hulpverlening werd een significante positieve samenhang gevonden tussen de variabele Scepsis enerzijds en de beleving van de lange termijn aspecten anderzijds. Hoe minder sceptisch men is ten aanzien van de mogelijkheden voor zelfherstel tijdens detentic, des te meer waardeert men het nut van de hulpverleningscontacten voor de persoonlijke ontwikkeling en de (toekomstige) levenssituatie.

Voorts blijkt men niet alleen meer tevreden te zijn over de arbeid en vrije tijdsbesteding naarmate men een groter belang toekent aan de resocialisatie-doelstelling als zodanig, ook als men gunstiger denkt over de detentie als een moment of gelegenheid om het zelfherstel ter hand te nemen, is men meer tevreden met de arbeid en de vrije tijdsbesteding.

\subsubsection{Relaties tussen deelname en beleving}

Men zou kunnen verwachten dat indien gedetineerden veelvuldig gebruik maken van de activiteiten hun beleving van deze activiteiten positief is, of omgekeerd, dat een positieve beleving gepaard gaat met een meer frequente deelname. Gedetineerden die de activiteiten interessant vinden, zullen wellicht ook vaker gebruik maken van de activiteiten.

In tabel 5 zien wij dat bij de onderwijsactiviteiten een dergelijke samenhang aanwezig is, hoe zinvoller en positiever men het onderwijs beoordeelt, des te frequenter bezockt men deze activiteit. Of, hoe vaker men deelneemt aan het onderwijs, des te positiever de beleving van deze activiteit.

Bij de crea-activiteiten werd een negatieve correlatie gevonden tussen enerzijds de meer detentie-situatie gebonden korte termijn aspecten van de beleving en anderzijds de deelname aan deze activiteit. Hoe meer men deze activiteit beschouwt als een middel om bij voorbeeld niet op cel te hoeven zitten of om de verveling te verdrijven, kortom als een manier om de onaangename kanten van de detentie te verdrijven, des te minder frequent neemt men deel aan de crea.

In tabel 5 zien we tevens een negatieve significante correlatie tussen de beleving van de korte termijn aspecten van kunstzinnige vorming en de deelname aan onderwijs en de sport. Gedetineerden die de crea-activiteiten vooral beleven in termen van reductie van de directe spanningen en onaangename aspecten van de detentie nemen significant minder frequent deel aan onderwijs-en sportactiviteiten. Tenslotte valt op dat gedetineerden die actiever zijn bij het onderwijs en sport en vaker de bibliotheek bezoeken ook meer tevreden zijn over de vrije tijdsbesteding.

Tabel 5: Correlaties tussen deelname en beleving $(174<\mathrm{N}<208)$

\begin{tabular}{lccccccc}
\hline Beleving & Onderwijs & $\begin{array}{c}\text { Crea } \\
\text { Kort }\end{array}$ & $\begin{array}{c}\text { Crea } \\
\text { Lang }\end{array}$ & $\begin{array}{c}\text { Hulpverl } \\
\text { Kort }\end{array}$ & $\begin{array}{c}\text { Hulpverl } \\
\text { Lang }\end{array}$ & Arbeid & $\begin{array}{l}\text { Vrije } \\
\text { ijjd }\end{array}$ \\
\hline 1. Deelname onderwijs & $.28^{* *}$ & $-.29^{* *}$ & -.02 & .05 & -.04 & .02 & $.17^{*}$ \\
2. Deelname crea & .12 & $-.21^{*}$ & .03 & -.00 & .03 & -.11 & .13 \\
3. Deelname sport & $.23^{*}$ & $-.23^{*}$ & .12 & .13 & $.17^{*}$ & .11 & $.31^{* *}$ \\
4. Deelname bibliotheek & .16 & -.06 & .06 & $.18^{*}$ & .12 & .02 & $.17^{*}$ \\
\hline
\end{tabular}

${ }^{*} \mathrm{p}<.05,{ }^{* *} \mathrm{p}<.01$ 


\section{Samenvatting}

Indien de resultaten met betrekking tot de relaties tussen opvattingen, deelname en beleving worden geresumeerd, dan blijkt er sprake te zijn van een aantal duidelijke verbanden.

In de eerste plaats is er sprake van interne verbanden tussen de deelname- en belevingsvariabelen zelf. Er kunnen bij de deelname en beleving een aantal clusters van onderling gerelateerde variabelen worden onderscheiden. Deze verbanden suggereren de aanwezigheid van een sterke, positieve gerichtheid op zinvolle bezigheden in het algemeen. Hoe vaker gedetineerden deelnemen aan een bepaalde activiteit en hoe positiever de beleving hiervan, des te frequenter en positiever is ook de deelname en beleving bij andere activiteiten.

Correlatie-analyses laten verder een aantal verbanden zien tussen opvattingen, deelname en beleving onderling. Uit de analyses blijkt dat de opvattingen geindiceerd als het belang dat men toekent alan de resocialisatie-doelstelling als zodanig, geen rol spelen met betrekking tot de deelname aan de activitciten. Kijkt men echter naar de opvattingen in de zin van de mogelijkheden die men voor zichzelf ziet om tijdens detentie iets te doen aan zelfherstel, dan blijkt een duidelijk verband met deelname. Dit impliceen dat mensen die aangeven meer kansen en mogelijkheden te zien voor zelfherstel tijdens detentie, vaker deelnemen aan de activiteiten dan mensen die negatiever zijn over die mogelijkheden. In dit opzicht vormen de onderzoeksresultaten een bevestiging van Ajzen's 'theory of planned behavior'. Die theorie postuleert dat een positieve houding ten aanzien van een bepaalde gedragsvorm slechts dan in het feitelijk realiseren van dat gedrag resulteert als het individu een bepaalde sociale druk en voldoende mogelijkheden daartoe waarneemt. Volgens Ajzen wordt gedrag bovendien het best voorspeld door houdingen die betrekking hebben op een bepaald handelen. De schaal Scepsis bestaat vooral ook uit items (zie hoofdstuk 5) die betrekking hebben op een handelen in de vorm van het daadwerkelijk toekomen aan een goede voorbereiding van de terugkeer in de samenleving tijdens de detentie. Het is met name deze opvattingsvariabele Scepsis die gecorreleerd is aan de feitelijke deelname.

Het belang dat men toekent aan de resocialisatie-doelstelling als zodanig blijkt wel samen te hangen met de beleving van de activiteiten. Gedetineerden die een groter belang of waarde toekennen aan resocialisatie geven bij de beleving van de activiteiten blijk van een sterkere waardering voor aspecten die verwijzen naar persoonlijke groei en de (toekomstige) levenssituatie. De beleving van activiteiten wordt sterker gekleurd door de behoefte de ongemakken of spanningen van de detentie te reduceren (niet op cel hoeven zitten, verveling verdrijven, ontspanning) naarmate men minder mogelijkheden voor zelfherstel percipieert tijdens detentie.

Tenslotte is er ook een relatie tussen deelname aan en beleving van de activiteiten. Naarmate de beleving sterker in het teken staat van het vermijden of reduceren van de ongemakken van de detentie, des te minder frequent neemt men deel.

De gevonden samenhang tussen de opvattings-, beleving- en deelnamevariabelen leveren in zekere zin een bevestiging op van een belangrijke theorie die met betrekking de relatie tussen non-verbale en verbale houdingen is ontwikkeld, namelijk "the theory of planned behavior" van Ajzen (1993). 


\subsection{Relaties tussen omgevingskenmerken, persoonskenmerken, kenmerken van programma-integriteit en de houdingen van gedetineerden ten aanzien van resocialisatie}

Aan het eind van hoofdstuk 4 werd een aantal onderzoeksvragen geformuleerd met betrekking tot de invloed van omgevingskenmerken, persoonskenmerken en kenmerken van programmaintegriteit. Ter recapitulatie worden deze hieronder vermeld.

Onderzoekvragen met betrekking tot de relatie tussen omgevingskenmerken en de houdingen ten aanzien van resocialisatie:

Is er een samenhang tussen een orde-dan wel gedetineerdengerichte beleving van het regime enerzijds en de houdingen van gedetineerden ten aanzien van resocialisatie anderzijds?

Hangen verblijfsduur, strafduur, detentiefase en contacten met medegedetineerden op een gunstige, dan wel ongunstige manier samen met de houdingen van gedetineerden ten aanzien van resocialisatie?

De onderzoeksvraag met betrekking tot de relaties tussen persoonskenmerken en houdingen ten aanzien van resocialisatie:

Is er een samenhang tussen bepaalde persoonsgebonden kenmerken en houdingen ten aanzien van resocialisatie?

Als persoonsgebonden variabelen worden achtereenvolgens geselecteerd: leeftijd, opleiding, werkervaring, druggebruik, recidive en toekomstverwachtingen. Burgerlijke staat en culturele achtergrond blijven bij de presentatie van de correlationele analyses buiten beschouwing. De verbanden tussen deze twee persoonsgebonden variabelen en de houdingen van gedetineerden zijn overigens wel onderzocht, maar on redenen die te maken hebben met de leesbaarheid en omvang van dit hoofdstuk blijft een presentatic van deze verbanden achterwege. Een verdere, meer gedetailleerde statistische bewerking van het vergaarde onderzoeksmateriaal met betrekking tot de relaties tussen culturele achtergrond en houdingen ten aanzien van resocialisatie zou op zich zelf al onderwerp voor een omvangrijke onderzoekspublicatic kunnen zijn.

De onderzoeksvraag met betrekking tot de relaties tussen kenmerken van programma-integriteit en houdingen ten aanzien van resocialisatie:

Is er een samenhang tussen bepaalde kenmerken van programma-integriteit en de houdingen van gedetineerden ten aanzien van resocialisatie?

In hoofdstuk 4 werd de vraag gesteld naar de invloed van de kwaliteit van de implementatie van het activiteitenprogramma op de houdingen ten aanzien van resocialisatie. In de onderzoeksliteratuur wordt de rol van deze factoren ook wel samengevat onder de noemer van het begrip 'programma integriteit'. De kenmerken van programma-integriteit worden gerepresenteerd door de variabelen informatie, begeleiding en ondersteuning, en materiaal en middelen.

De houdingen van gedetineerden ten aanzien van resocialisatie worden in de volgende paragrafen steeds als volgt in verband gebracht met de drie typen van achtergrondvariabelen. Eerst worden de opvattingen aan de omgevingskenmerken, persoonskenmerken en kenmerken van programma-integriteit gerelateerd en vervolgens komen de relaties tussen de deelname aan en beleving van de activiteiten en deze drie typen van achtergrondkenmerken aan de orde. De 
relaties tussen de houdingen en de drie clusters van achtergrondkenmerken worden in de eerste plaats onderzocht met behulp van correlationele analyse. Vervolgens wordt onderzocht of er causale verbanden bestaan tussen de afhankelijke variabelen en de onafhankelijke variabelen. Hierbij wordt gebruikt gemaakt van regressie-analyse en de methode van Structural Equations Modelling (SEM, Bentler, 1992).

\subsubsection{Relaties tussen omgevingskenmerken en opvattingen ten aanzien van resocialisatie}

Allereerst werd de samenhang onderzocht tussen de opvattingen over resocialisatie en de ongevingskenmerken (zie tabel 6)

Tabel 6: Correlaties tussen omgevingskenmerken en opvattingen $(146<N<206)$

\begin{tabular}{lcc}
\hline Omgevingskenmerken & Resocialisatie & Scepsis \\
\hline 1. Regimesevaluatie & .09 & $.46 * *$ \\
2. Verblijfsduur & .01 & $-.23 * *$ \\
3. Strafduur & -.04 & $-.18^{*}$ \\
4. Contact gedetineerden & $-.23 * *$ & $-.19 *$ \\
\hline
\end{tabular}

$* \mathrm{p}<.05 ; * * \mathrm{p}<.01$

Uit tabel 6 blijkt dat het belang dat men toekent aan de resocialisatie-doelstelling als zodanig geen samenhang vertoont met de waardering van het regime, noch met verblijfsduur en strafduur. De mogelijkheden die men voor zichzelf waarneemt om tijdens de detentie aan de toekomst te werken en het zelfherstel ter hand te nemen (de schaal Scepsis) vertoont een positieve samenhang met regimesevaluatie en een negatieve relatie met de strafduur en de verblijfsduur.

Regimesevaluatie vertoont een positieve correlatie met de variabele Scepsis. Hoe positiever, dat wil zeggen in meer gedetineerdengerichte zin gedetineerden het regime beoordelen, des te meer moge-lijkheden zien zij om tijdens de detentie de terugkeer in de samenleving voor te bereiden. Hoe negatiever, dat wil zeggen, in meer ordegerichte zin gedetineerden het regime beoordelen, des te sceptischer zijn zij ten aanzien van de mogelijkheden voor zelfherstel.

De samenhang met de prisonisatie-variabelen verblijfsduur en strafduur is negatief. Dit betekent dat men meer mogelijkheden ziet om tijdens de detentie aan het zelfherstel te werken naarmate men minder lang in detentie verblijft en naarmate de opgelegde strafduur (met aftrek van de vervroegde invrijheidstelling) lager is. Men neemt minder mogelijkheden voor zelfherstel waar naarmate men langer in detentie verblijft en naarmate de opgelegde strafduur hoger is.

Zowel het belang dat men aan resocialisatie toekent als de mogelijkheden die men voor zichzelf waarneemt om aan de toekomst te werken, correleren negatief met de contacten met medegedetineerden. Hoe minder belang men aan resocialisatie toekent en hoe sceptischer men is ten aanzien van de mogelijkheden voor zelfherstel des te intensiever gaat men om met medegedetineerden

In tabel 7 worden de gemiddelde scores op de opvattingsschalen door middel van variantieanlalyse (ANOVA-analyse) vergeleken voor de detentiefase waarin gedetineerden zich bevinden. De HVB-respondenten die zich in de beginfase van de detentie bevinden en de kortgestraften die overwegend in de eindfase van de detentie verkeren, zijn gemiddeld het meest positief waar het de schaal Belang van resocialisatie betreft. De langgestraften die in de middenfase van de detentie verkeren, denken gemiddeld negatiever over het belang van 
resocialisatie dan de gedetineerden in de beide andere fasen.

De gemiddelde scores op de schaal Scepsis zijn het hoogst bij de HVB-respondenten die in de beginfase van de detentie verkeren. De scores voor de kort- en langgestrafte gedetineerden zijn lager. Hoe hoger de score des te meer mogelijkheden voor zelfherstel neemt men waar.

De verschillen in opvattingen voor de drie fasen van de detentie zijn significant.

Tabel 7: Gemiddelde scores op opvattingsschalen voor de begin- midden- en eindfase van de detentic

\begin{tabular}{|c|c|c|c|c|}
\hline Schaal & $\begin{array}{c}\text { HVB } \\
\text { Inr.Sit/Inr.Roc/Inr.Gra } \\
\text { Beginfase }\end{array}$ & $\begin{array}{l}\text { Kortgestraft } \\
\text { Aft.B. Sitt } \\
\text { Eindfase }\end{array}$ & $\begin{array}{l}\text { Langgestraft } \\
\text { Afd.C. Sitt } \\
\text { Middenfase }\end{array}$ & $\begin{array}{l}\text { Langgestraft } \\
\text { Afd.D.Sitt } \\
\text { Middenfase }\end{array}$ \\
\hline Belang resocialisatie* & 4.2 & 4.2 & 3.7 & 4.0 \\
\hline Scepsis* & 2.8 & 2.6 & 2.3 & 2.6 \\
\hline
\end{tabular}

${ }^{*} \mathrm{p}<.05$

Tussen de onafhankelijke variabelen onderling blijkt ook een aantal correlaties aanwezig te zijn (zie tabel 8). De beoordeling van het regime vertoont een samenhang met de verblijfsduur. Hoe langer men in detentie verblijft des te meer beoordeelt men het regime in een meer negatieve, ordegerichte zin. Hoe langer men zit en hoe hoger de opgelegde strafduur des te intensiever de omgang met medegedetineerden.

Tabel 8: Correlaties tussen omgevingsvariabelen $(140<\mathrm{N}<222)$

\begin{tabular}{lcccc}
\hline Omgevingsvariabelen & 1 & 2 & 3 & 4 \\
\hline 1. Regimesevaluatie & 1.00 & $-.23 * *$ & .02 & -.10 \\
2. Verblijfsduur & & 1.00 & $.75 * *$ & $.15^{*}$ \\
3. Strafduur & & & 1.00 & $.20^{*}$ \\
4. Contact gedetineerden & & & 1.00 \\
\hline
\end{tabular}

$* \mathrm{p}<.05 ; * \mathrm{p}<.01$

\subsubsection{Relaties tussen persoonskenmerken en opvattingen ten aanzien van resocialisatie} Vervolgens werd de samenhang onderzocht tussen persoonskenmerken en opvattingen ten aanzien van resocialisatie (zie tabel 9).

Tabel 9: Correlaties tussen opvattingen en persoonsvariabelen $(145<\mathrm{N}<206)$

\begin{tabular}{lcc}
\hline Persoonsvariabelen & Resocialisatie & Scepsis \\
\hline 1. Leeftijd & -.11 & -.05 \\
2. Opleiding & -.11 & $.23^{*}$ \\
3. Werkervaring & .07 & .11 \\
4. Drugsgebruik & -.09 & -.03 \\
5. Recidive & .00 & -.08 \\
6. Toekomstverwachting & .11 & $.39^{* *}$ \\
\hline
\end{tabular}

$* \mathrm{p}<.05 ;{ }^{* *} \mathrm{p}<.01$

Tabel 9 laat zien dat van de opvattingsschalen slechts één schaal Scepsis een samenhang vertoont met persoonskenmerken als opleiding en toekomstverwachtingen. Hoe hoger men is 
opgeleid en hoe gunstiger men denkt over de toekomst na ontslag, des te meer mogelijkheden ziet men voor zichzelf om tijdens detentie te werken aan zelfherstel.

De persoonskenmerken vertonen onderling een aantal interessante relaties (tabel 10). Zo blijken leeftijd en opleidingsniveau positief samen te hangen met druggebruik. Hoe ouder men is en hoe hoger men is opgeleid, des te groter de kans dat men, naar eigen zeggen, geen drugs gebruikt. De relatie van druggebruik met recidive is eveneens significant, maar dan in negatieve richting. Gedetineerden dic voor het eerst in detentic verblijven, geven vaker aan dat zij geen drugs gebruiken. Bovendien blijkt dat naarmate het opleidingsniveau van gedetineerden hoger is, zij vaker voor het eerst in detentie verblijven. Gedetineerden die voor het eerst in detentie verblijven, hadden ook vaker werk voorafgaand aan de detentie. Een hogere opleiding blijkt onder gedetineerden ook significant vaker gepaard te gaan met een meer optimistische kijk op de toekomst.

Tabel 10: Correlaties tussen persoonsvariabelen $(138<N<208)$

\begin{tabular}{lcccccc}
\hline Persoonsvariabelen & 1 & 2 & 3 & 4 & 5 & 6 \\
\hline 1. Leeftijd & 1.00 & .00 & -.06 & .14 & .12 & -.07 \\
2. Opleiding & & 1.00 & .14 & $.19 *$ & $-.31 * *$ & $.21^{* *}$ \\
3. Werkervaring & & & 1.00 & $.24 * *$ & $-.30^{* *}$ & .13 \\
4. Drugsgebruik & & & & 1.00 & $-.35^{* *}$ & .09 \\
5. Recidive & & & & 1.00 & -.04 \\
6. Toekomstverwachting & & & & & \\
\hline
\end{tabular}

$* \mathrm{p}<.05 ; * * \mathrm{p}<.01$

\subsubsection{Relaties tussen kenmerken van programma-integriteit en opvattingen ten aanzien van resocialisatie}

De relatie tussen de kwaliteit van de implementatie van de activiteiten en de opvattingen van gedetineerden wordt in de onderstaande tabel beschreven.

Tabel 11: Correlaties tussen opvattingen en programma-integriteit $(56<N<206)$

\begin{tabular}{lcc}
\hline Programma-integriteit & Resocialisatie & Scepsis \\
\hline 1. Informatie & $.15 *$ & .14 \\
2. Ondersteuning & .05 & $.33 *$ \\
3. Materiaal & .08 & .10 \\
\hline
\end{tabular}

$* \mathrm{p}<.05 ; * * \mathrm{p}<.01$

Het belang dat men aan resocialisatie toekent vertoont een positieve samenhang met het oordeel over de informatieverstrekking. Hoe beter men te spreken is over de informatie verstrekking des te meer belang hecht men aan de resocialisatie-doelstelling. Enerzijds kan een goede informatieverstrekking gepaard gaan met een positiever denken over resocialisatie. Anderzijds kan een groter belang dat men toekent aan de resocialisatie-doelstelling gepaard gaan met een zich beter informeren over resocialiserende voorzieningen tijdens de detentie.

De mogelijkheden die men voor zichzelf ziet om tijdens detentie aan de toekomst te werken vertonen een positieve relatie met de ervaren mate van ondersteuning en begeleiding bij de creaactiviteiten en het onderwijs. Hoe beter men te spreken is over de geboden ondersteuning en begeleiding, des te positiever is men over de kansen en mogelijkheden voor zelfherstel. Of anders-om geformuleerd: hoe meer mogelijkheden voor zelfherstel men voor zichzelf 
waarneemt, des te intensiever maakt men wellicht gebruik van de activiteiten en des te meer weet men ondersteuning en begeleiding te bewerkstelligen en te waarderen.

Onderling blijkt de evaluatie van de informatieverstrekking, ondersteuning en begeleiding en materiaal en middelen door de respondenten eveneens een samenhang te vertonen (tabel 12). Tevredenheid over de informatieverstrekking is positief gerelateerd aan de ervaren begeleiding en ondersteuning. Ervaren begeleiding en ondersteuning hangen weer positief samen met het oordeel over materiaal en middelen.

Tabel 12: Correlaties tussen programma-integriteit variabelen $(58<N<179)$

\begin{tabular}{lccc}
\hline Programma-integriteit & 1 & 2 & 3 \\
\hline 1. Informatie & 1.00 & $.54^{* *}$ & .20 \\
2. Ondersteuning & & 1.00 & $.41^{* *}$ \\
3. Materiaal & & 1.00 \\
\hline
\end{tabular}

$* \mathrm{p}<.05 ; * * \mathrm{p}<.01$

\section{Samenvattend}

Naar aanleiding van de resultaten van de voorgaande correlationele analyses waarin de relaties werden onderzocht tussen de opvattingen ten aanzien van resocialisatie enerzijds en de kenmerken van de omgeving, persoon en programma-integriteit anderzijds, kan men het volgende vaststellen.

Omgevingsgebonden variabelen als regimesevaluatie, verblijfsduur en strafduur oefenen vooral een invloed uit op de opvattingen in de zin van de waargenomen mogelijkheden voor zelfherstel. Naarmate men minder gunstig denkt over het regime des te minder kansen op zelfherstel neemt men waar. Hoe langer gedetineerden in detentie verblijven en hoe langer zij nog te gaan hebben des te minder gunstig denken zij over de mogelijkheden voor zelfherstel tijdens detentie. Contacten met medegedetineerden vertonen een samenhang met het belang dat men aan resocialisatie toekent en aan de waargenomen mogelijkheden voor zelfherstel.

Hoe intensiever de contacten met medegedetineerden des te minder gunstig denkt men over resocialisatie. Gedetineerden die in een fase van de detentie (de middenfase) verkeren waarin zij nog betrekkelijk ver verwijderd zijn van een terugkeer in de samenleving denken minder gunstig over resocialisatie.

Van de opvattingsvariabelen vertoont vooral de variabele Scepsis een samenhang met persoonsgebonden factoren als opleiding en toekomstverwachtingen. Men ziet meer mogelijkheden voor zelfherstel tijdens detentie naar mate men hoger is opgeleid en gunstiger denkt over de toekomst. Kenmerken van programma-integriteit als informatieverstrekking en ondersteuning en begeleiding vertonen een positieve samenhang met respectievelijk het belang dat men toekent aan resocialisatie en de waargenomen mogelijkheden voor zelfherstel.

\subsubsection{Causale modellering van relaties tussen opvattingen en variabelen met betrekking tot de omgeving, persoon en programma-integriteit}

In de vorige paragrafen is een aantal verbanden besproken tussen enerzijds opvattingen ten aanzien van resocialisatie en anderzijds een aantal achtergrondvariabelen van verschillende origine. Bij deze verbanden die primair werden geanalyseerd met behulp van eerste ordecorrelaties blijft het onduidelijk hoe de bivariate verbanden tot stand zijn gekomen. Achter een set correlaties kunnen een reeks causale verbanden schuil gaan. Causale verbanden kunnen ook ontbreken. Correlaties dienen niet te worden verward met causale relaties. Het gelijktijdig optreden van bepaalde kenmerken impliceert niet steeds een oorzaak-gevolg relatie. 
Een voorbeeld: opleiding blijkt een positieve correlatie op te leveren met de opvattingsvariabele scepsis. De vraag is of hier sprake is van een rechtstreekse invloed. Het zou evenzeer mogelijk kunnen zijn dat de invloed van de opleiding, als er al sprake is van een oorzaak-gevolg relatie, via een andere variabele verloopt zoals bij voorbeeld toekomstverwachtingen. Opleiding leidt tot gunstiger toekomstverwachtingen, die op hun beurt weer resulteren in een meer positieve kijk op de mogelijkheden voor zelfherstel tijdens de detentie.

Om dergelijke causale verbanden zichtbaar te maken kan de methode van het modelleren van structurele vergelijkingen (Structural Equations Modeling, SEM) worden toegepast. SEM is een methode met behulp waarvan de onderzoeker een model kan formuleren in een databestand en dit theoretische model wordt vervolgens aan die data getoetst. De vergelijkingen die worden gehanteerd zijn multipele regressies. In het bovengenoemde voorbeeld zouden de vergelijkingen als volgt kunnen worden weergegeven:

Scepsis $=$ Toekomstverwachtingen + Error

Toekomstverwachtingen $=$ Opleiding + Error

In modelvorm ziet de eerste mogelijkheid waarbij zowel toekomstverwachtingen als opleiding een onafhankelijke invloed uitoefenen op de opvattingsvariabele scepsis er als volgt uit:

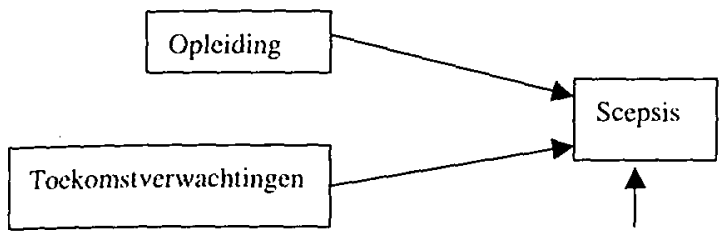

Error

Het alternatieve model namelijk Opleiding oefent een indirecte invloed uit op Scepsis via Toekomstverwachtingen ziet er als volgt uit:

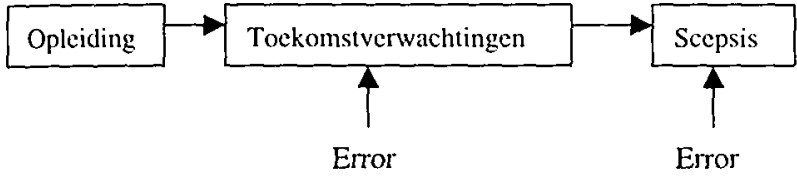

In deze twee voorbeelden zijn slechts enkele variabelen betrokken. Bij het modelleren van structurele vergelijkingen is het uiteraard mogelijk het aantal variabelen uit te breiden. Het toetsen van een gepostuleerd model aan de data stelt de onderzoeker in staat te beslissen of het theoretisch model niet door de data wordt tegengesproken. Het model kan, met andere woorden, passen of niet passen.

\subsubsection{Resultaten van de causale modellering bij de opvattingsvariabelen}

De opvattingen gemeten via de schalen Belang van resocialisatie en Scepsis werden in de vorige paragrafen gecorreleerd met de drie clusters van achtergrondvariabelen. Toepassing van de methode van structural equations veronderstelt het vooraf postuleren van een model door middel van vergelijkingen waarin de relatie tussen de onafhankelijke en afhankelijke variabelen wordt weergegeven. Om een eerste inzicht te verkrijgen in de mogelijk aanwezige verbanden tussen de opvattingen en de onafhankelijke variabelen met betrekking tot de omgeving, persoon en 
programma-integriteit werd een regressie-analyse uitgevoerd volgens de methode 'forward'. Regressie-analyse is evenals de correlatie-analyse een techniek die kan worden gebruikt als een lineair verband wordt verondersteld tussen twee (of meer) interval of ratio geschaalde variabelen. Correlatie-analyse heeft betrekking op de samenhang tussen telkens twee variabelen. Regressie-analyse wordt gebruikt om een numerieke verklaring te geven van de afhankelijke variabele door een of meer onafhankelijke variabelen. Door middel van regressie-analyse is het mogelijk een bepaalde afhankelijke variabele te voorspellen op basis van een of meer onafhankelijke variabelen. In tegenstelling tot correlatie-analyse veronderstelt regressie-analyse een causaal verband. Uitgangspunt van de regressie-analyse vormt een vergelijking, de regressievergelijking. Het opnemen van de te verklaren afhankelijke variabele en de verklarende onafhankelijke variabelen in de regressievergelijking kan volgens verschillende methoden gebeuren. Bij de methode 'enter'wordt de regressie-analyse berekend door alle opgegeven variabelen in één keer in de vergelijking op te nemen.. Bij een groot aantal op te nemen variabelen die van invloed zouden kunnen zijn verkrijgt men valak een hoge $\mathrm{R} 2$ waarde die de mate van verklaring aangeeft. Het aantal verklarende onafhankelijke variabelen kan zo groot zijn dat interpretatie wordt bemoeilijkt. Men moet een afweging maken tussen de mate van verklaring en de bruikbaarheid van de resultaten. Om die afweging te maken neemt men uiteindelijk die variabelen in het model op waarvan de regressiecoëfficiënten significant van nul verschillen. Deze regressiecoëfficiënten die men ook wel Bêta-waarden noemt, geven een indicatie van het relatieve belang van de variabelen.

Een variant op deze werkwijze volgens de methode 'enter is de methode 'forward'. De variabelen worden één voor één in de vergelijking opgenomen indien zij voldoen aan een bepaald opname-criterium. De analyse begint dan met de variabele die de hoogste absolute correlatie heeft met de afhankelijke variabele. Voldoet deze variabele aan het opname-criterium, dan volgt een regressie-analyse met alléén deze variabele. Vervolgens wordt de variabele geselecteerd met de op één na hoogste correlatie en deze variabele ondergaat een zelfde bewerking als de eerste variabele. Deze procedure gaat door tot een variabele niet meer aan het opname-criterium voldoet of tot alle onafhankelijke variabelen zijn opgenomen in de vergelijking. Ontbrekende waarden worden behandeld volgens de methode list-wise, waarbij alleen die waarnemingen worden gebruikt die geldige waarden hebben voor zowel de afhankelijke als onafhankelijke variabelen.

Bij de opvattingsvariabele Belang van resocialisatie resulteerde regressie-analyse bij het cluster van persoonsgebonden variabelen in de aanwijzing van twee variabelen met een significante voorspel-lende waarde, namelijk toekomstverwachtingen en opleidingsniveau. Het belang dat men toekent aan de resocialisatie-doelstelling is hoger naarmate men lager is opgeleid en gunstiger toekomst-verwachtingen heeft.

Omgevings-gebonden variabelen, dat wil zeggen variabelen uit het deprivatiemodel zoals bij voorbeeld regimesevaluatie blijken geen enkele voorspellende rol te vervullen voor betreft de waarde die men toekent aan de resocialisatie-doelstelling. Derhalve wordt het belang dat men toekent aan resocialisatie vermoedelijk bepaald door predetentie-factoren die verankerd liggen in de sfeer van de sociale omgeving en van de persoonlijkheid.

Vervolgens werd de opvattingsvariabele scepsis eveneens aan een regressie-analyse volgens de methode 'forward'onderworpen en dit resulteerde in de aanwijzing van een drietal variabelen met een significante voorspellende bêta-waarde, namelijk regimesevaluatie, toekomstverwachtingen en strafduur.

Hoe positiever men het regime beoordeelt en hoe gunstiger de toekomstverwachtingen des te meer mogelijkheden voor zelfherstel neemt men waar. Hoe korter de duur van de opgelegde 
straf des te positiever denkt men over de mogelijkheden voor resocialisatie.

Als volgende stap werd onderzocht door welke variabelen regiemsevaluatie het best kan worden voorspeld. Dit bleken de variabele toekomstverwachtingen en verblijfsduur te zijn. Verblijfsduur vertoonde een negatieve bêta- waarde hetgeen impliceert dat gedetineerden een steeds negatiever houding ten aanzien van het regime ontwikkelen naar mate zij langer in detentie verblijuen.

In het model dat vervolgens werd gepostuleerd zijn beide opvattingsvariabelen Belang van resocialisatie en Scepsis opgenomen. En als onafhankelijke variabelen gelden opleiding, toekomst-verwachtingen, regiemsevaluatie, strafduur en verblijfsduur.

De relaties tussen de afhankelijke variabelen en de onafhankelijke variabelen werden door middel van de volgende vergelijkingen gepostuleerd en vervolgens in een 'run' getest met de methode van structurele vergelijkingen (EQS, Bentler, 1992).

Belang van resocialisatie $=$ Toekomstverwachtingen en Opleiding en Error Scepsis $=$ Regimesevaluatie en Toekomstverwachtingen en Strafduur en Error Regimesevaluatic $=$ Toekomstverwachtingen en Verblijfsduur en Error Toekomstverwachtingen $=$ Opleiding en Error

Er worden verschillende maten gebruikt om de 'fit' van het model uit te drukken. Als belangrijkste maat geldt de Chi-kwadraat. Als de bijbehorende statistische test niet significant verschilt van nul, dan kan het model als passend op de data worden beschouwd.

Naast de Chi-kwadraat wordt in deze studie de Comparative Fit Index gebruikt. Deze index kan variëren van 0 tot 1 . Een CFI van 1 geldt als een optimale fit.

In figuur 1 zien we de resultaten van de EQS -analyse grafisch weergegeven. Het model past goed, Chi kwadraat $=8.37$, df $=4, p=.078, \mathrm{CFI}=0.96$

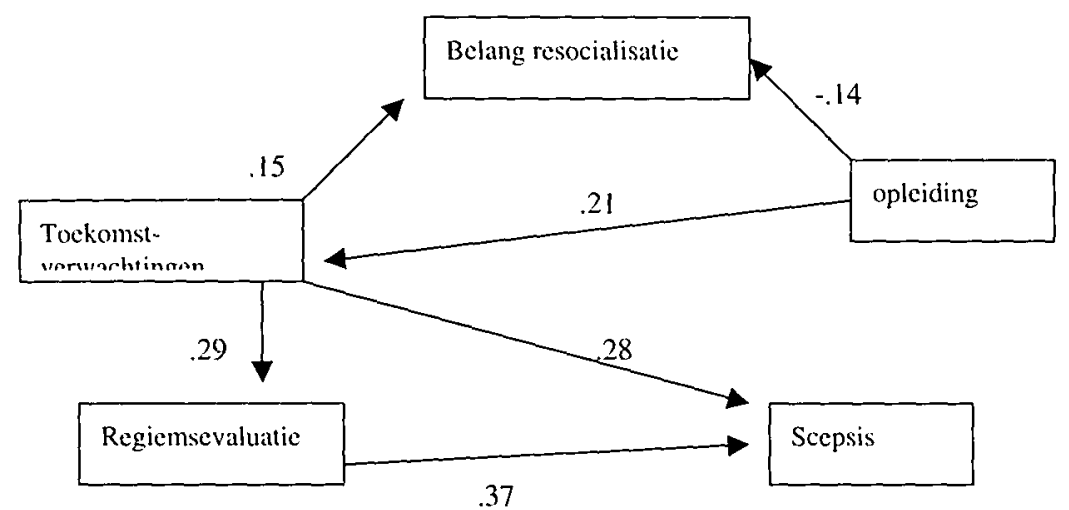

Chi-kwadraat $=8.37 . \mathrm{df}=4, p=.078$

CFI $=.096$

Figuur 1: Causale modellering met betrekking tot de opvattingen ten aanzien van resocialisatie

In het figuur zijn de error componenten weggelaten. De pijlen in de figuur duiden op de veronderstelde causale invloed. De waarden die de pijlen vergezellen zijn zogenaamde padcoëf- 
ficiënten. Zij zijn vergelijkbaar met bêta -gewichten en geven de sterkte van de invloed aan. Uit de figuur valt af te leiden dat het belang dat men aan resocialisatie toekent, wordt beïnvloed door toekomstverwachtingen en opleiding. De invloed van opleiding met een waarde van -.14 is negatief, hoe lager men is opgeleid des te meer belang kent men toe aan resocialisatie. Een positieve invloed van toekomstverwachtingen van .15 betekent dat hoe gunstiger men denkt over de toekomst des te meer belang hecht men aan resocialisatie. Opleiding heeft een directe positieve invloed (.21) op toekomstverwachtingen. Hoe hoger men is opgeleid, des te gunstiger zijn de verwachtingen omtrent de toekomst.

De sterkste positieve invloed op de opvattingen ten aanzien van resocialisatie in casu de variabele scepsis wordt uitgeoefend door regimesevaluatie(.37). Hoe meer men het regime op een positieve wijze beoordeelt des te meer mogelijkheden ziet men voor resocialisatie tijdens de detentie. Toekomstverwachtingen oefenen behalve op de waardering van het regime (.29) ook nog eens een directe, positieve invloed (.28) uit op de waargenomen mogelijkheden voor zelfherstel. Verblijfs-duur en strafduur ontbreken in de causale modellering. Een goed passend model bleek slechts te construeren na verwijdering van beide tijdsvariabelen. Het effect van deze duurvariabelen valt vermoedelijk samen met de variabele scepsis en regimesevaluatie.

Uit de regressie-analyse bleek overigens dat men gunstiger denkt over het regime en over de mogelijkheden voor zelfherstel tijdens een detentie naarmate respectievelijk de duur van het verblijf en van de straf korter is. En naarmate men langer in detentie verblijft wordt het oordeel over het regime negatiever.

Tenslotte dient zich hier de vraag aan naar de precieze status van de opvattingsvariabele Scepsis. Het EQS-model laat zien dat het hier gaat om een variabele die zowel door persoonskenmerken (Toekomstverwachtingen) als door de perceptie van de detentie-omgeving (Regimesevaluatie) wordt beinvloed. Vanuit theoretisch en methodologisch oogpunt is dit een vrij belangwekkend resultaat. Als, zoals wij stelden, de meest plausibele benadering van de verklaring van houdingen van gedetineerden een integratie-model is waarin omgevings- en persoonsgebonden factoren interacteren, dan lijken de resultaten van het EQS-model, vooral waar het de variabele Scepsis betreft, de juistheid van deze veronderstelling te bevestigen.

\subsubsection{Relaties tussen omgevingskenmerken en deelname aan de activiteiten}

In deze paragraaf wordt de relatie tussen omgevingskenmerken en deelname aan de activiteiten onderzocht. Uit tabel 13 blijkt dat de deelname aan het onderwijs, crea en hulpverlening een positieve samenhang vertoont met de beoordeling van het regime.

Tabel 13: Correlaties tussen deelname en omgevingskenmerken $(140<N<205)$

\begin{tabular}{lccccc}
\hline Omgevingskenmerken & Onderw & Crea & Hulp & Sport & Biblioth. \\
\hline 1. Regimesevaluatie & $.20^{* *}$ & .05 & $.14^{*}$ & $.15^{*}$ & .10 \\
2. Verblijfsduur & -.01 & .01 & .07 & .02 & $-.15^{*}$ \\
3. Strafduur & .06 & .04 & $.18^{*}$ & .01 & $-.15^{*}$ \\
4. Cont. gedetineerden & -.05 & $-.17^{*}$ & .01 & $-.20^{* *}$ & -.13 \\
\hline
\end{tabular}

$* \mathrm{p}<.05 ; * * \mathrm{p}<.01$

Hoe meer men het regime als gedetineerdengericht beoordeelt des te frequenter maakt men gebruik van deze activiteiten. Een meer ordegerichte beleving van het regime gaat gepaard met een minder frequente deelname aan de bovengenoemde activiteiten.

De mate waarin men gebruik maakt van de hulpverleningsvoorzieningen en de bibliotheek bleek 
te correleren met de verblijfsduur en strafduur. De samenhang is negatief bij het bibliotheek bezoek, hoe langer men al zit en hoe langer de opgelegde straf des te minder maakt men gebruik van de bibliotheekvoorzieningen. De correlatie van de hulpverleningscontacten met strafduur is positief. Hoe hoger de opgelegde straf des te meer contacten heeft men met de hulpverleningsinstanties.

Men neemt tenslotte significant minder frequent deel aan sport en crea naarmate men intensiever omgaat met mede-gedetineerden.

In tabel 13a wordt per detentiefase een overzicht gegeven van de gemiddelde scores op de deelname aan de activiteiten onderwijs, crea, sport en bibliotheek. Alleen het bibliotheekbezoek bleek gemiddelde scores op te leveren die significant verschillen per detentiefase. Gedetineerden in de begin- en eindfase van de detentie maken actiever gebruik van deze activiteiten dan gedetineerden in de middenfase. Het percentage gedetineerden dat geen enkel contact of een of meerdere contacten met hulpverleners had gedurende het afgelopen half jaar bleek per detentiefase niet significant te verschillen.

Tabel 13 a Gemiddelde deelname -scores voor begin-midden- en eindfase van de detentie

\begin{tabular}{llccc}
\hline Deelname & $\begin{array}{c}\text { HVB } \\
\text { Inr.Sitt.Inr.Roe.Inr.Gr } \\
\text { a }\end{array}$ & $\begin{array}{l}\text { Kortgestraft } \\
\text { Afd. B Sitt } \\
\text { Eindfase }\end{array}$ & $\begin{array}{l}\text { Langgestraft } \\
\text { Afd. C Sitt } \\
\text { Middenfase }\end{array}$ & $\begin{array}{c}\text { Langgestraft } \\
\text { Afd. D Sitt } \\
\text { Middenfase }\end{array}$ \\
\hline Onderwijs & 2.2 & 1.9 & 2.9 & 2.1 \\
Crea & 2.3 & 1.8 & 2.7 & 1.9 \\
Sport & 3.8 & 3.7 & 3.6 & 3.5 \\
Bibliotheek*** & 3.8 & 4.0 & 3.3 & 3.0 \\
\hline
\end{tabular}

$* * * \mathrm{p}<.001$

\subsubsection{De relaties tussen persoonskenmerken en de deelname aan activiteiten}

In tabel 14 worden de correlaties weergegeven van de persoonskenmerken met de deelname aan activiteiten.

Tabel 14: Correlaties tussen deelname en persoonsvariabelen $(135<\mathrm{N}<202)$

\begin{tabular}{lccccc}
\hline Persoonsvariabelen & Onderw & Crea & Hulp & Sport & Biblioth. \\
\hline 1. Leeftijd & -.06 & -.11 & .09 & $-.19 * *$ & -.11 \\
2. Opleiding & $.27 * *$ & .07 & .10 & .13 & $.27 * *$ \\
3. Werkervaring & -.01 & .02 & .13 & .03 & $.18 * *$ \\
4. Drugsgebruik & .05 & -.13 & .00 & -.11 & -.00 \\
5. Recidive & -.13 & .05 & -.11 & -.01 & -.09 \\
6. Toekomstverwacht. & $.20 * *$ & .09 & .02 & $.15 *$ & .11 \\
\hline
\end{tabular}

$* p<.05 ; * * p<.01$

De deelname aan het onderwijs vertoont een positieve correlatie met het opleidingsniveau, hoe hoger men is opgeleid des te vaker neemt men deel aan het onderwijs. Voorts blijkt dat hoe positiever men denkt over de toekomst des te frequenter maakt men gebruik van de onderwijs-faciliteiten. De deelname aan sport is duidelijk leeftijdsgebonden, hoe ouder men is des te minder vaak gaat men sporten. Ook bij de sport zien we een positieve samenhang met toekomstverwachtingen. Het bezoek aan de bibliotheek is frequenter naarmate men 
hoger is opgeleid. Tenslotte blijken gedetineerden dic voorafgaand aan de detentic over werk beschik-ten, vaker naar de bibliotheek te gaan.

\subsubsection{Relaties tussen programma-integriteit en deelname aan de activiteiten}

De deelname aan de activiteiten vertoont een aantal correlaties met de evaluatie van de randvoorwaarden (tabel 15).

Tabel 15: Correlaties tussen deelname en programma-integriteit $(54<\mathrm{N}<170)$

\begin{tabular}{lccccc}
\hline Programma-integriteit & Onderwijs & Crea & Hulpverl & Sport & Bibliotheek \\
1. Informatie & $.21 * *$ & .11 & .05 & .09 & .08 \\
2. Ondersteuning & .21 & $.27^{*}$ & .07 & .22 & .20 \\
3. Materiaal & $.21^{*}$ & .17 & .08 & .10 & $.20^{*}$ \\
\hline
\end{tabular}

$* p<.05: * * p<.01$

Meer frequente deelname alan het onderwijs hangt samen met een positiel oordeel over de informatieverstrekking. De deelname aan de crea hangt positief samen met de ervaren begeleiding en ondersteuning. Hoe beter de ondersteuning en begeleiding des te vaker maakt men gebruik van deze activiteit. Hoe slechter de ervaren begeleiding en ondersteuning, des te minder frequent makt men gebruik van deze activiteit.

Ook de kwaliteit van de voorzieningen op het gebied van materiaal en middelen beinvloedt in positieve zin de deelname aan de kunstzinnige vorming. Hoe beter de ervaren kwaliteit des te fre-quenter de deelname.

Deze samenhang met de crea activiteiten weerspiegelt voor een deel ook de specifieke problematiek met betrekking tot de randvoorwaarden die in vorige hoofdstukken reeds werd gesignaleerd.

Bij de crea-activiteiten speelt immers in de inrichtingen het probleem van een adequate continue begeleiding. Niet steeds is een consulent aanwezig en soms wordt crea begeleid door bewaarders die weinig affiniteit hebben met deze activiteit, hetgeen demotiverend kan werken op de deelnemers. Soms is er geen bewarend personeel om deze activiteit te begeleiden en verblijven bij voorbeeld kortgestrafte gedetineerde noodgedwongen op cel.

\section{Samenvattend}

De wijze waarop men de ongeving in casu het regime ervaart, oefent een invloed uit op de deelname aan een aantal activiteiten. Hoe negatiever men het regime beoordeelt des te minder vaak neemt men deel.

Hoe langer men zit en hoe langer men nog te gaan heeft, des te minder vaak bezoekt men de bibliotheek. Maar een positieve samenhang van verblijfsduur en strafduur met de deelname aan de activiteiten blijkt zich ook voor te doen bij de hulpverleningsactiviteiten. Met name blijkt dat men meer gebruik maakt van de hulpverlening naarmate de strafduur langer is.

Naarmate men hoger is opgeleid en men gunstiger denkt over de toekomst, des te frequenter neemt men deel aan het onderwijs. Bibliotheekbezoek en sport vertoonden evencens een samenhang met respectievelijk opleiding en leeftijd. Bibliotheekbezoek bleek tenslotte ook nog een samenhang te vertonen met het arbeidsverleden. De overige persoonsgebonden factoren bleken geen significante correlaties op te leveren ten aanzien van de deelname aan de activiteiten.

De wijze waarop de randvoorwaarden met betrekking tot de activiteiten zijn ingevuld blijkt bij een aantal activiteiten eveneens een samenhang te vertonen met de deelname. 


\subsubsection{Deelname aan de activiteiten en de modellering van de relaties met omgevings-en persoonsgebonden variabelen en programma- integriteitsvariabelen.}

Bij de deelname aan de activiteiten werd een regressie-analyse volgens de methode 'forward' uitgevoerd. Als vertrekpunt voor deze analyse golden de variabelen die op basis van de correlatie-analyses een significant verband vertoonden met de deelname aan de verschillende activiteiten. Bij deze regressie-analyse is de deelname aan verschillende activiteiten de athankelijke, te voorspellen variabele. De predictoren zijn de verschillende ongevingspersoonsgebonden en programma-integriteitsvariabelen. Daarnaast werd op basis van de correlatie-analyses besloten de opvattings-variabele Scepsis tevens als predictor in te voeren bij de activiteiten die gericht zijn op de voorbereiding van de terugkeer in de samenleving zoals onderwijs, hulpverlening en kunstzinnige vorming.

\section{Deelname onderwijs}

In de onderstaande tabel wordt voor het onderwijs een overzicht gegeven van de variabelen die voor wat betreft de deelname een significante voorspellende waarde hebben.

Tabel 16: Regressieanalyse Deelname aan onderwijs

\begin{tabular}{llll}
\hline Predictoren & info & opleiding & scepsis \\
& Significante & beta-waarden & \\
Deelname onderwijs & $.21^{* *}$ & $.23^{*}$ & $.27^{* *}$ \\
\hline
\end{tabular}

$\mathrm{R} 2=.21$ df $=3 \quad \mathrm{~F}=8.902 \quad \mathrm{p}=.000$

$* \mathrm{p}=<.05, * * \mathrm{p}=<.01, * * * \mathrm{p}=<.001$

De regressieberekening levert bij de onderwijsactiviteiten ten aanzien van de deelname het volgende resultaat op. Gezamenlijk verklaren de predictoren $21 \%$ van de variantie. Informatieverstrekking, Opleiding en de mate van Scepsis ten aanzien van de mogelijkheden voor zelfherstel leveren elk een onafhankelijke significante bijdrage aan de deelname aan het onderwijs. De variabele Scepsis draagt het meest bij aan de variantie (13\%). De beide overige factoren dragen elk $4 \%$ bij aan de verklaarde variantie. Het model is blijkens de p-waarde significant. Een combinatie van factoren voorspelt het beste de deelname aan het onderwijs. De factoren zijn direct of indirect afkomstig uit de drie hiervoor omschreven clusters. Informatieverstrekking is een aspect van programma-integriteit, opleiding behoort tot de persoonsgebonden variabelen en via scepsis beïnvloeden het regime en de toekomstverwachtingen als resp. omgevingsvariabele en persoonsgebonden variabele waarschijnlijk een indirecte invloed uit op de deelname. In modelvorm ziet het voorgaande er als volgt uit: 


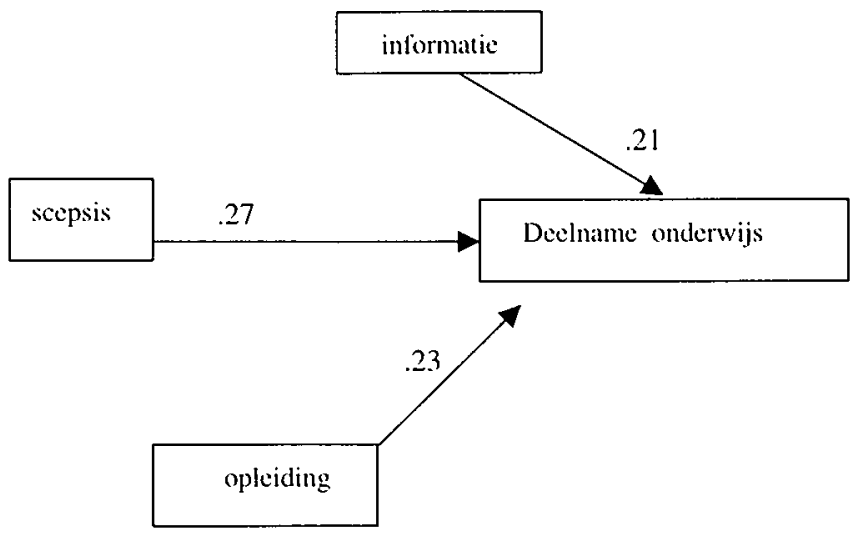

\section{Deelname crea}

$\mathrm{Na}$ regressie-analyse volgens de methode 'forward' resulteerde er voor de deelname aan de creaactiviteiten een model waarin de variabele scepsis, als enige variabele, een significante voorspellende waarde heeft.

Tabel 17: Regressieanalyse Deelname aan crea

\begin{tabular}{ll}
\hline Predictoren & scepsis \\
& Sign. beta-waarden \\
Deelname crea & $.55 * * *$ \\
\hline $\mathrm{R} 2=.30$ df $=1 \quad \mathrm{~F}=23.522 \quad \mathrm{p}=.000$ \\
$* \mathrm{p}=<.05, * * \mathrm{p}=<.01, * * * \mathrm{p}=<.001$
\end{tabular}

Scepis heeft een hoge significante beta-waarde en de R2 waarde van het model is eveneens aan de hoge kant. Scepsis verklaart $30 \%$ van de variantie. Ook hier kan men concluderen dat er via de variabele scepsis sprake is van een indirecte invloed van zowel omgevings-als persoonsgebonden variabelen. Scepsis is immers, zo hebben wij gezien, afhankelijk van toekomstverwachtingen en regimesevaluatie.

In modelvorm ziet een ander er aldus uit:

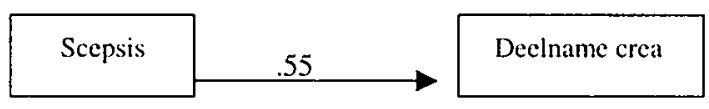

\section{Deelname sport}

De deelname aan de sport wordt het best voorspeld door een drietal persoonsgebonden variabelen: opleiding, leertijd en druggebruik. 
Tabel 18: Regressieanalyse Deeiname aan sport

\begin{tabular}{llll}
\hline Predictoren & leeftijd & opleiding & drugs \\
& Significante & beta-waarden & \\
& & & \\
Deelname sport & $-.19^{*}$ & $.23^{*}$ & $-.19^{*}$ \\
\hline
\end{tabular}

$R 2=.11$ df $=3 \quad F=5.243 \quad p=.002$

$* p=<.05, * * p=<.01, * * * p=<.001$

De waarden van de variabelen leeftijd en druggebruik zijn negatief, hetgeen erop duidt dat de deelname aan sport frequenter is bij druggebruik voorafgaand aan detentie en de deelname is minder frequent naarmate men ouder is. Hoe hoger men is opgeleid des te vaker neemt men deel aan sport. In modelvorm kan men dit als volgt samenvatten:

Opleiding is de variabele met de hoogste beta-waarde in het model. Gezamenlijk verklaren de variabelen $11 \%$ van de variantie, hetgeen niet bijzonder hoog is.

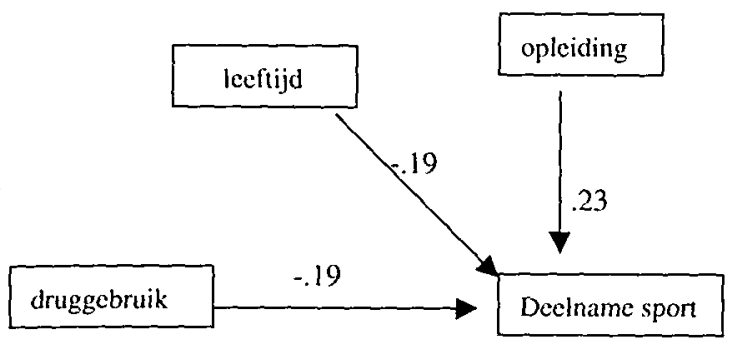

\section{Deelname bibliotheek}

$\mathrm{Na}$ regressie-analyse resulteerde er slechts één variabele die een significante bijdrage levert aan de voorspelling van het bibliotheekbezoek. Het betreft de persoonsgebonden variabele opleiding die $19 \%$ van de variantie verklaart. Hoe hoger men is opgeleid des te frequenter maakt men gebruik van de bibliotheek.

Tabel 19: Regressieanalyse Bezoek aan bibliotheek

Predictoren opleiding

Sign. beta-waarden

Bibliotheekbezoek .34****

$\mathrm{R} 2=.19 \quad \mathrm{df}=8 \quad \mathrm{~F}=2.587 \quad \mathrm{p}=0.14$
$* \mathrm{p}=<.05, * * \mathrm{p}=<.01, * * * \mathrm{p}=<.001$

De relatie tussen bibliotheekbezoek en opleiding ziet er in modelvorm aldus uit:

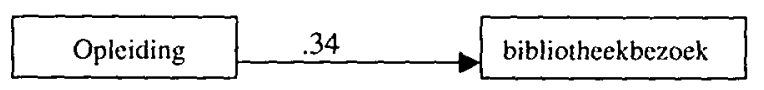




\section{Hulpverleningscontacten}

Regressie-analyse leverde bij de hulpverleningscontacten cen model op met een acceptabele pwaarde waarin één variabele een significante beta- waarden vertoont, nl. Scepsis. Echter de R2walarde is aan de lage kant.

Tabel 20: Regressieanalyse Hulpverleningscontacten

\begin{tabular}{ll}
\hline Predictoren & scepsis \\
& Sign, beta-waarden \\
Hulpverleningscontacten & $.23 * * *$ \\
\hline $\mathrm{R} 2=.056 \quad \mathrm{df}=1 \mathrm{~F}=12.082 \quad \mathrm{p}=.001$ \\
$* \mathrm{p}=<.05, *{ }^{*} \mathrm{p}=<.01, * * * \mathrm{p}=<.001$
\end{tabular}

Hoe meer mogelijkheden men voor zelfherstel waarneemt tijdens detentie des te meer contact men zoekt met de hulpverleningsinstanties binnen de inrichting.

In modelvorm kan dit aldus worden weergegeven:

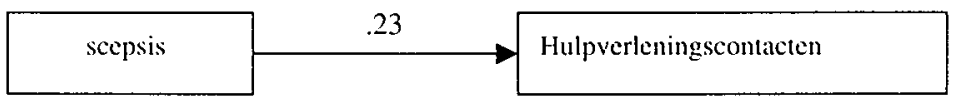

\section{Samenvattend}

Opvallend is dat bij drie van de vijf activiteiten de variabele scepsis een aanzienlijke voorspellende waarde heeft ten aanzien van de deelname. Opvattingen ten aanzien van resocialisatie in de zin van de mogelijkheden voor zelfherstel die men waarneemt tijdens detentie blijken dus een invloed te hebben op deelname aan activiteiten als onderwijs en crea en op de frequentie van de hulpver-leningscontacten. Het zijn kortom de activiteiten die bij uitstek zijn bedoeld om de terugkeer in de samenleving te bevorderen.

Opmerkelijk is ook de rol van de persoonsgebonden variabele Opleiding bij het bibliotheekbezoek, onderwijs en sport. Hoe hoger men is opgeleid, des te frequenter makt men gebruik van deze activiteiten.

Bij de correlatie-analyse resulteerde voor de sport alleen een significante samenhang met leeftijd, hoe jonger des te frequenter maakt men gebruik van deze activiteit. Een significante correlatie met druggebruik die men op basis van de onderzoeksliteratuur (van der Linden, 1981) zou mogen verwachten bleek te ontbreken. Uit de multipele- regressie komt echter wel een significante negatieve relatie tevoorschijn. Dit impliceert dat druggebruik gepaard gaat met een meer frequente deelname aan de sportactiviteiten. Het effect van deze variabele werd waarschijnlijk in de simpele correlaties versluierd door andere variabelen. Een verklaring voor de samenhang van druggebruik met sportbeoefening is waarschijnlijk dat verslaafde gedetineerden deze activiteit vooral gebruiken om hun verslaving en de bijbehorende abstinentieverschijnselen die tijdens detentie kunnen optreden, in enigerlei mate onder controle te krijgen.

Bij de sportbeoefening en het bibliotheekbezoek spelen uitsluitend persoonsgebonden variabelen een rol, zij het dat de totale verklaarde variantie aan de lage kant is. Bij deze activiteiten heeft één type variabele, de persoonsgebonden variabele een zekere exclusiviteit 
als het gaat om verklarende uitspraken. De variabelen met betrekking tot de programmaintegriteit spelen blijkens een enkele significante bêta- waarde van de variabele informatieverstrekking bij het onderwijs slechts een ondergeschikte rol. De invloed van de variabele 'scepsis'of de waargenomen mogelijkheden voor zelfherstel duidt op een indirect effect van zowel een omgevingsgebonden variabele regimesevaluatie en een persoonsgebonden variabele toekomstverwachtingen.

Toepassing van de methode van structurele vergelijkingen (EQS, Bentler, 1985) waarbij een gepostuleerd causaal model in een 'run' getest wordt, bleek bij elk van de deelname variabelen afzonderlijk niet te resulteren in een model met een acceptabele Comparative Fit-Index. Evenmin resulteerde een causaal model na introductie van de deelname-variabelen in het model dat bij de opvattingen met succes werd getest. Ook bij de belevingsvariabelen bleek na toepassing van de methode van structurele vergelijkingen de fit-index nict hoog genoeg. Derhalve werd besloten voor de deelname- en belevingsvariabelen te volstaan met een analyse op basis van regressiemodellen.

\subsubsection{Relaties tussen omgevingskenmerken en de beleving van de activiteiten.}

In de tabellen 21 en 22 zien we over de beleving van alle activiteiten een verband met de evaluatie van het regime. Bij de beleving van alle activiteiten behalve de beleving van de korte termijnaspecten van crea is het verband positief. Bij de meer detentie-situatie gebonden beleving van crea is sprake van een negatieve correlatie. Hoe meer men het regime als orde-gericht beleeft, des te meer is men geneigd die aspecten bij de crea te waarderen die samenhangen met het reduceren van de directe spanningen en ongemakken van het gedetineerd zijn.

Tabel 21: Correlaties tussen beleving en ongevingskenmerken $(71<\mathrm{N}<216)$

\begin{tabular}{lccc}
\hline Ongevingskenmerken & Onderwijs & Crea kort & Crea lang \\
1. Reginesevaluatie & $.21 * *$ & $-.30 * *$ & $.28 * *$ \\
2. Verbiijfsduur & $.23 * *$ & .02 & .13 \\
3. Strafduur & .17 & -.02 & .17 \\
4. Contact gedetineerden & -.14 & -.06 & -.00 \\
\hline
\end{tabular}

$* p<.05 ; * * p<.01$

Tabel 22: Correlaties tussen beleving en omgevingskenmerken $(71<N<216)$

\begin{tabular}{lcccc}
\hline Omgevingskenmerken & Hulp kort & Hulp lang & Arbeid & Vrije tijd \\
1. Regimesevaluatie & $.34^{* *}$ & $.35^{* *}$ & $.37^{* *}$ & $.33^{* *}$ \\
2. Verblijfsduur & -.01 & -.08 & -.06 & $-.29 * *$ \\
3. Strafduur & .08 & -.02 & .05 & $-.23 * *$ \\
4. Contact gedetineerden & -.09 & -.14 & -.01 & $-.73 * *$ \\
\hline
\end{tabular}

$* \mathrm{p}<.05: * * \mathrm{p}<.01$

Voor de beleving van activiteiten als onderwijs en hulpverlening en de beleving van de lange termijnaspecten van crea geldt: een meer gedetineerdengerichte beleving van het regime gaat gepaard met een groter belang of waarde die men hecht aan belevingsaspecten als persoonlijke groei en vooruitgang. En ook voor de activiteiten als arbeid en vrije tijdsbesteding geldt dat een meer positieve beleving van deze activiteiten gepaard gaat met een meer positieve, gedetineerdengerichte beleving van het regime. 
Verblijfsduur en strafduur vertoonden een negatieve correlatie met vrije tijdsbesteding, naarmate men minder lang in detentie verblijft, des te positiever is men over de vrije tijdsbesteding. Een positieve correlatie is voorts aanwezig tussen verblijfsduur en de beleving van de onderwijsactiviteiten. Naarmate men langer in detentie verblijft des te positiever wordt de beleving van de onderwijsactiviteiten.

Deze laatste samenhang wordt, zoals uit de ANOVA- analyses in hoofdstuk 6 bleek, waarschijnlijk veroorzaakt door een, sterk op activiteiten gerichte groep langgestraften voor wie onderwijs een cruciale rol vervult bij de zingeving van hun lange straftijd. Gedetineerden van deze afdeling (C-vleugel) scoren vergeleken bij de respondenten van andere afdelingen en uit andere inrichtingen gemiddeld het meest negatief op de schalen die de opvattingen meten over resocialisatie, maar in hun beleving van de onderwijsactiviteiten zijn zij het meest positief.

De beleving van de activiteiten vertoont met uitzondering van de vrije tijdsbesteding geen samenhang met contacten met medegedetineerden.

In tabel 22a worden de gemiddelde scores op de belevingsvariabelen vergeleken voor de verschil-lende fasen van de detentie. Tevredenheid met de vrije tijdsbesteding leverde een significant verschil op, hetgeen impliceert dat met name de gedetineerden die in de begin- en eindfase van de detentie verkeren meer tevreden zijn met de wijze waarop men de vrije tijd kan doorbrengen dan gedetineerden in de middenfase.

Tabel 22a Gemiddelde scores op belevingsschalen voor de begin- midden- en eindfase van de detentie

\begin{tabular}{lcccc}
\hline & $\begin{array}{c}\text { HVB } \\
\text { Inr. Sitt, Inr.Roe Inr.Gra } \\
\text { Beginfase }\end{array}$ & $\begin{array}{c}\text { Kortgestraft } \\
\text { Afd.B Inr.Sitt. } \\
\text { Eindfase }\end{array}$ & $\begin{array}{c}\text { Langgestraft } \\
\text { Afd.C Inr.Sitt. } \\
\text { Middenfase }\end{array}$ & $\begin{array}{l}\text { Langgestraft } \\
\text { Afd.D } \\
\text { Inr.Sitt } \\
\text { Middenfase }\end{array}$ \\
\hline $\begin{array}{l}\text { Beleving onderwijs } \\
\text { Beleving crea kort }\end{array}$ & 3.43 & 3.72 & 4.15 & 3.70 \\
$\begin{array}{l}\text { Beleving crea lang } \\
\text { Beleving hulpverlening }\end{array}$ & 2.78 & 2.90 & 2.34 & 2.14 \\
kort & 3.13 & 2.84 & 3.52 & 3.10 \\
Beleving hulpverlening & 3.26 & 3.02 & 3.14 & 2.68 \\
lang & 3.04 & & & 2.01 \\
Tevredenheid Arbeid & 2.06 & 2.78 & & 2.51 \\
Tevredenheid Vrije tijd** & 3.10 & 1.97 & 1.61 & 1.87 \\
\hline
\end{tabular}

$* * \mathrm{p}=<.01$

\subsubsection{De relatie tussen persoonskenmerken en de beleving van de activiteiten}

In tabel 23 en 24 is de samenhang weergegeven tussen de beleving van de activiteiten de verschil-lende persoonskenmerken. 
Tabel 23: Correlaties tussen beleving en persoonsvariabelen $(70<N<202)$

\begin{tabular}{lccc}
\hline Persoonsvariabelen & Onderwijs & Crea kort & Crea lang \\
\hline 1. Leeftijd & .08 & -.02 & .13 \\
2. Opleiding & -.02 & $-.26^{*}$ & .00 \\
3. Werkervaring & .10 & -.03 & $.36^{* *}$ \\
4. Drugsgebruik & .03 & -.05 & .16 \\
5. Recidive & .01 & .10 & -.02 \\
6. Toekomstverwachting & .18 & -.17 & .14 \\
\hline
\end{tabular}

${ }^{*} \mathrm{p}<.05 ;{ }^{* *} \mathrm{p}<.01-.19$

Tabel 24: Correlaties tussen beleving en persoonsvariabelen $(70<N<202)$

\begin{tabular}{llccc}
\hline Persoonsvariabelen & Hulp kort & Hulp lang & Arbeid & Vrije tijd \\
\hline 1. Lecftijd & -.10 & -.14 & -.08 & -.13 \\
2. Opleiding & -.00 & -.11 & .04 & -.15 \\
3. Werkervaring & $.19 *$ & .07 & $.18^{*}$ & .07 \\
4. Drugsgebruik & .06 & -.16 & $.16 *$ & -.07 \\
5. Recidive & -.13 & .00 & -.11 & -.01 \\
6. Toekomstverwachting & $.24 * *$ & .11 & .14 & $.23 * *$ \\
\hline
\end{tabular}

$* p<.05 ; * * p<.01$

De correlaties tussen de beleving van de activiteiten en de persoonskenmerken laten zien dat naar-mate men lager is opgeleid men meer waardering heeft voor de belevingsaspecten van de creatieve activiteiten die aan de detentie-situatie zijn gebonden. Dat wil zeggen de korte termijn aspecten. Het hebben van werk voorafgaand aan de detentie gaat gepaard met een hogere waardering van de belevingsaspecten van de creatieve activiteiten die gericht zijn op persoonlijke ontwikkeling. De belevingsaspecten bij de hulpverlening die gericht zijn op de detentie-situatie worden meer gewaar-deerd als men voorafgaand aan de detentie over werk beschikte en als men positiever over de toekomst denkt.

Respondenten die voorafgaand aan de detentie naar eigen zeggen geen drugs gebruikten en die over werk beschikten, geven blijk van meer tevredenheid over de arbeid.

Tenslotte blijkt dat naarmate men gunstiger verwachtingen heeft over de toekomst, men meer tevreden is over de mogelijkheden voor vrije tijdsbesteding.

\subsubsection{De relatie tussen kenmerken van programma-integriteit en de beleving van de activiteiten}

In de volgende tabellen wordt de relatie tussen informatieverstrekking, ondersteuning en begeleiding, materiaal en middelen en de beleving van de activiteiten weergegeven.

Tabel 25: Correlaties tussen beleving en programma-integriteit $(45<\mathrm{N}<175)$

\begin{tabular}{lccc}
\hline Programma-integriteit & Onderwijs & Crea kort & Crea lang \\
\hline 1. Informatie & $.32 * *$ & -.13 & $.24 *$ \\
2. Ondersteuning & $.59 * *$ & -.20 & $.33 *$ \\
3. Materiaal & $.56 * *$ & -.16 & $.43 * *$ \\
\hline
\end{tabular}

${ }^{*} \mathrm{p}<.05 ;{ }^{* *} \mathrm{p}<.01$ 
Tabel 26: Correlaties tussen beleving en programma-integriteit $(45<\mathrm{N}<175)$

\begin{tabular}{lcccc}
\hline Programma-integriteit & Hulp kort & Hulp lang & Arbeid & Vrije tijd \\
\hline 1. Informatie & $.25 * *$ & $.25 * *$ & $.31 * *$ & $.28 * *$ \\
2. Ondersteuning & $.53 * *$ & $.49 *$ & .15 & $.31 *$ \\
3. Materiaal & $.23 *$ & $.25 *$ & .15 & .16 \\
\hline
\end{tabular}

$* p<.05 ; * * p<.01$

Hoe positiever men is over de invulling van de randvoorwaarden op het punt van informatieverstrekking, begeleiding en ondersteuning en materiaal en middelen des te positiever beleeft men de activiteiten met name op het punt van de persoonlijke ontwikkeling. Deze samenhang doet zich voor bij onderwijs, crea en hulpverlening, zo blijkt uit bovenstaande tabel. Bij de hulpverlening blijken de belevingsaspecten dic op de detentie-situatie zijn gericht eveneens positief samen te hangen met de programma-integriteit.

Hoe positiever men is over de informatieverstrekking des te groter de tevredenheid over de arbeid en vrije tijdsbesteding. Hoe meer men is te spreken over de ondersteuning en begeleiding bij de activiteiten, des te meer tevreden is men tenslotte ook over de vrije tijdsbesteding.

\section{Samenvattend}

Op grond van de voorgaande correlationele analyse kan met betrekking tot de correlationele samenhang tussen de beleving en de omgevingsgebonden factoren het volgende worden vastgesteld. Het blijkt dat naarmate gedetineerden het regime in een meer restrictieve, ordegerichte en naar ik veronderstel ook negatieve zin beoordelen, de beleving van de activiteiten een minder positief op persoonlijke groei en ontwikkeling gericht karakter heeft. Omgekeerd geldt dat een meer positieve, gedetineerdengerichte beleving van het regime gepaard gaat met een meer positieve beleving van de activiteiten in termen van persoonlijke groei en vooruitgang. Bovendien blijkt bij de onderwijsactiviteiten een positief verband met de verblijfsduur. Hoe langer men in detentie verblijft des te positiever beleeft men de onderwijsactiviteiten.

De beleving van de activiteiten vertoont een aantal verbanden met persoonsgebonden achtergrond-factoren. De meest opmerkelijke is het verband tussen opleiding en de beleving van de crea. Hoe lager men is opgeleid des te meer heeft men de neiging deze activiteit te waarderen als een middel om de ongemakken en deprivatie van de detentie te reduceren. De belevingsaspecten die meer op persoonlijke groei zijn gericht vertonen een samenhang met werkervaring. Respondenten die voorafgaand aan de detentie over werk beschikten, geven blijk van een hogere waardering van de vormende aspecten van deze activiteit dan respondenten die niet over werk beschikten voordat zij werden gedetineerd. Werkervaring en toekomstverwachtingen vertoonden een positieve samen-hang met de beleving van de korte termijnaspecten van de hulpverlening.

De beleving van de activiteiten vertoont ten slotte ook een samenhang met de ervaren kwaliteit van de uitvoering van de activiteiten of wel de programma-integriteitsaspecten.

\subsubsection{De beleving van de activiteiten en de modellering van de relatie met de omgevings- en persoonsgebonden variabelen en variabelen van programma- integriteit}

De belevingsvariabelen waarbij respondenten voor activiteiten als onderwijs, crea, hulpverlening, arbeid en vrije tijdsbesteding hun waardering voor deze activiteiten konden aangeven met betrekking to aspecten als persoonlijke groei, toekomstige levenssituatie, en de directe 
detentieomstandigheden, werden onderworpen aan een regressie-analyse volgens de methode 'forward'. Als predictoren gelden bij deze bewerking weer de omgevingsvariabelen (regimescvaluatie, verblijfsduur, strafduur, en contacten met mede-gedetineerden), persoonsgebonden variabelen (drugsgebruik, recidive, leeftijd, toekomstverwachtingen, opleiding en werkervaring), programma-integriteitsvariabelen (materiaal en middelen, ondersteuning en begeleiding en informatieverstrekking) en de twee opvattingsvariabelen scepsis en belang van resocialisatie.

\section{De beleving van de onderwijsactiviteiten}

De regressie-analyse volgens de methode 'forward'voor de beleving van de onderwijsactiviteiten leverde een predictor op met een zeer hoge R2 waarde $\mathrm{nl}$. ondersteuning en begeleiding. Deze variabele alleen verklaart $44 \%$ van de variantie. Hoe beter de ervaren ondersteuning en begeleiding bij het onderwijs, des te positiever de beleving (tabel 27).

Tabel 27: Regressieanalyse Beleving onderwijs

\begin{tabular}{ll}
\hline predictoren & Ondersteuning en begeleiding \\
\hline & Significante beta-waarden \\
Beleving onderwijs & $.66^{* * *}$ \\
\hline
\end{tabular}

$R 2=44, \mathrm{df}=1 \quad F=22.336 \quad \mathrm{p}=.000$

$* \mathrm{p}=<.05, * * \mathrm{p}=<.01, * * * \mathrm{p}=<.001$

De beleving van onderwijs blijkt dus het best voorspeld te kunnen worden met een organisatiegebonden variabele als ervaren ondersteuning en begeleiding. We zien hier duidelijk hoe belangrijk programma-integriteit kan zijn voor de beleving van de activiteiten.

De relatie ziet er in figuurvorm als volgt uit:

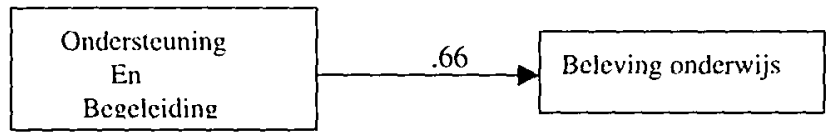

\section{Beleving van de kunstzinnige vorming}

Bij de regressie-analyse werd door middel van de methode 'forward'een tweetal predictoren aangewezen die de beleving van de korte termijn aspecten het best voorspellen .

Tabel 28: Regressieanalyse Beleving crea

\begin{tabular}{lll}
\hline predictoren & regimesevaluatie & Scepsis \\
\hline & Significante & beta-waarden \\
$\begin{array}{l}\text { Beleving crea } \\
\text { korte termij) }\end{array}$ & $-.28^{*}$ & $-.24^{*}$ \\
\hline
\end{tabular}

$R 2=.20 \quad d f=2 \quad F=10.266 p=.000$

${ }^{*} \mathrm{p}=<.05,{ }^{*} \mathrm{p}=<<.01,{ }^{* * *} \mathrm{p}=<.001$

Scepsis als belangrijkste factor bepaalt $15 \%$ van de variantie. De beta-waarde van deze predictor is negatief. Hoe minder kansen of mogelijkheden voor zelfherstel men waameemt, des te meer waarde kent men toe aan de belevingsaspecten van de kunstzinnige vorming die de 
ongemakken en spanningen van de detentie reduceren. Regimes-evaluatie verklaart $5 \%$ van de variantie. Ook hier is de bêta-waarde negatief. Hoe meer men het regime als depriverend en restrictief beschouwt, des te meer waardeert men de kunstzinnige vorming als een middel om de ongemakken en spanningen van de detentie te verminderen.

In modelvorm zien de relaties er als volgt uit:

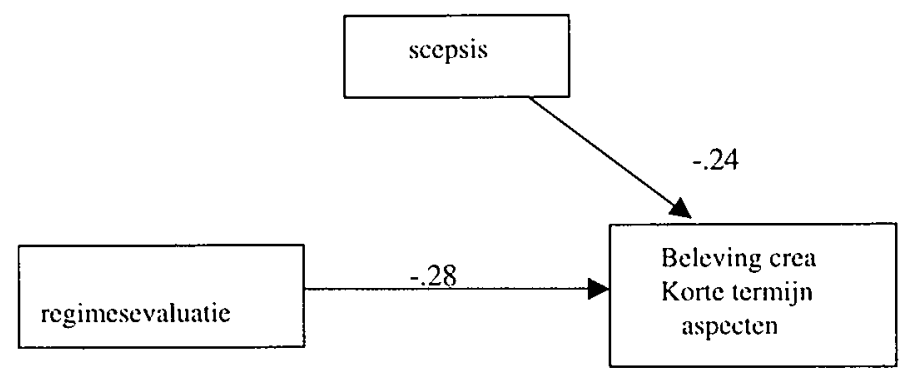

Op basis van het EQS-model dat voor de determinanten van de opvattingen ten aanzien van resocialisatie werd berekend kan men concluderen dat via de variabele scepsis de beleving van het regiem en toekomstverwachtingen indirect een rol spelen. Beleving van het regiem is de factor die de meeste invloed uitoefent op de opvattingsvariabele scepsis. Men kan voor wat betreft de beleving van de korte termijn aspecten van de kunstzinnige vorming er vanuit gaan dat het regime zowel een direct als indirect effect heeft. Het indirecte effect verloopt via de opvattingsvariabele scepsis.

De beleving van de lange termijn aspecten van de kunstzinnige vorming blijkt op basis van regressie-analyse het meest te worden beïnvloed door de variabelen materiaal en middelen, werkervaring en belang van resocialisatie.

Tabel 29: Regressieanalyse Beleving crea (lange termijn)

\begin{tabular}{llll}
\hline Predictoren & Materiaal en middelen & Werkervaring & belang van resocialisatie \\
\hline & Significante & beta-waarden & \\
Beleving crea & $.28^{* *}$ & $.25^{* *}$ & $.24^{*}$ \\
(lange termijn) & & \\
\hline
\end{tabular}

$\mathrm{R} 2=.26 \mathrm{df}=3 \quad \mathrm{~F}=7.946 . \mathrm{p}=.000$

${ }^{*} \mathrm{p}=<.05, * * \mathrm{p}=<.01, * * * \mathrm{p}=<.001$

De predictor materiaal en middelen verklaart $14 \%$ van de variantie. Werkervaring verklaart $6 \%$ en het belang van resocialisatie eveneens $6 \%$. Een en ander kan als volgt worden geïnterpreteerd. Hoe beter de ervaren kwaliteit van de ondersteuning op het gebied van materiaal en middelen des te meer waardering heeft men voor de belevingsaspecten op het gebied van de persoonlijke ontwikkeling. De predictor materiele voorzieningen laat zien dat een goede invulling van de randvoorwaarden een belangrijke invloed heeft op de beleving van de activiteiten.

Hoe meer belang men hecht aan resocialisatie, des te sterker wordt de beleving van de kunstzinnige vorming gekleurd door aspecten met betrekking tot de persoonlijke groei. Werkervaring vertoont een positieve samenhang hetgeen impliceert dat het hebben van werk voorafgaand aan de detentie gepaard gaat met meer waardering voor de belevingsaspecten die 
gerelateerd zijn aan persoonlijke groei. Samengevat in een figuur zien de relaties er aldus uit:

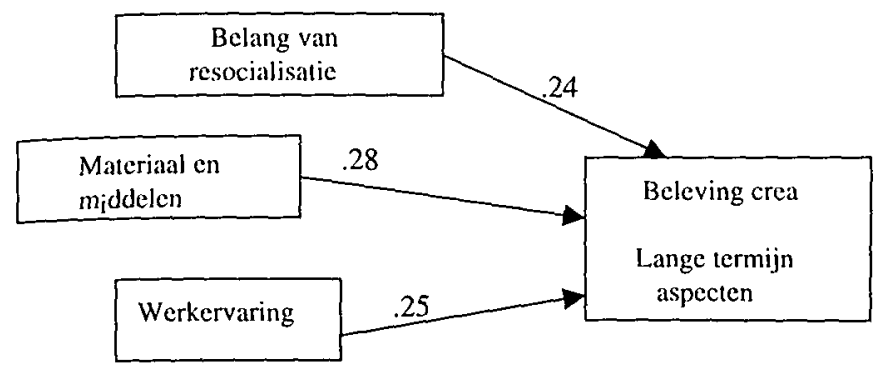

\section{Beleving van de hulpverleningscontacten}

Evenals bij de beleving van de kunstzinnige vorming werd de beleving van de hulpverleningscontacten gemeten via twee schalen die aspecten met betrekking tot persoonlijke groei en het hanteren van de detentiesituatie weergeven.

Kijken we naar de resultaten van de regressie-analyse volgens methode 'forward' met betrekking tot de beleving van de korte termijnaspecten van de hulpverlening dan blijken, ondersteuning en arbeidsverleden het meest van invloed op deze aspecten van de beleving,

Tabel 30: Regressieanalyse Beleving hulpverlening (korte termijn)

\begin{tabular}{lll}
\hline Predictoren & Werkervaring & Ondersteuning en begeleiding \\
\hline $\begin{array}{l}\text { Beleving hulpverlening } \\
\text { (korte termijn) }\end{array}$ & Significante & Beta-waarden \\
\hline
\end{tabular}

$R 2=.51 \mathrm{df}=2 \quad \mathrm{~F}=12.580 \quad \mathrm{p}=.000$

${ }^{*} \mathrm{p}=<.05, *{ }^{*} \mathrm{p}=<.01,{ }^{* * *} \mathrm{p}=<.001$

Ondersteuning en begeleiding neemt van de totale verklaarde variantie (51\%) het grootste deel voor zijn rekening (33\%), werksituatie voorafgaand aan de detentie verklaart $18 \%$ van de variantie.

Bij de beleving van de korte termijnaspecten van de hulpverlening zien we dat de mate waarin men waardering heeft voor de korte termijn aspecten van de hulpverleningscontacten in de eerste plaats wordt beïnvloed door de aard van de geboden ondersteuning en begeleiding. Het hebben van werk voorafgaand aan detentie is eveneens van invloed op de waardering van de korte termijn-aspecten van de beleving van de hulpverleningscontacten. Het hebben van een baan voorafgaand aan de detentie leidt blijkbaar tot een andere houding ten aanzien van de hulpverleningscontacten. Samengevat in modelvorm zien de relaties er aldus uit:

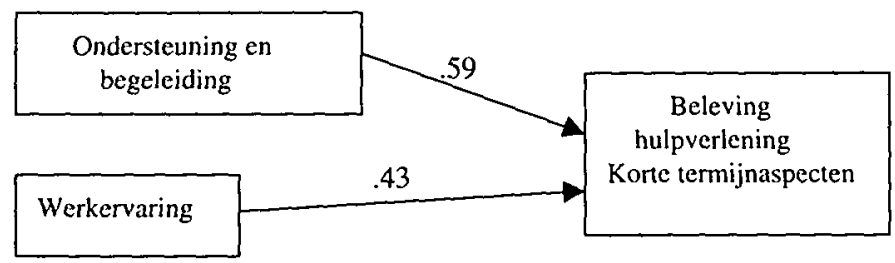


Na een regressie-analyse volgens de methode 'forward' met de lange termijn aspecten van de beleving van de hulpverleningscontacten als afhankelijke variabele en de verschillende clusters van achtergrondvariabelen als predictoren, bleven een drietal variabelen over die sterk van invloed zijn op de beleving van de lange termijnaspecten van de hulpverleningscontacten.

Tabel 31: Regressieanalyse Beleving hulpverlening (lange termijn)

\begin{tabular}{lccc}
\hline Predictoren & Belang resocialisatic & $\begin{array}{c}\text { Regiemsevaluatic } \\
\text { Significante }\end{array}$ & $\begin{array}{l}\text { Ondersteuning } \\
\text { en begeleiding } \\
\text { beta-watarden }\end{array}$ \\
$\begin{array}{l}\text { Beleving hulpverlening } \\
\text { (lange termijn) }\end{array}$ & $.51^{* * *}$ & $.39 * *$ & $.36^{* *}$ \\
\hline $\begin{array}{l}\mathrm{R} 2=.75 \mathrm{df}=3 \quad \mathrm{~F}=26.895 \mathrm{p}=.000 \\
* \mathrm{p}=<.05, * * \mathrm{p}=<.01 . * * * \mathrm{p}=<.001\end{array}$ & &
\end{tabular}

De hoogste significante bêta-waarde blijkı regimes-evaluatie op te leveren. Vervolgens blijkt ook de waarde die men toekent aan de resocialisatiedoelstelling een hoge significante bijdrage te leveren. Een significante bijdrage vertoont ook de ervaren ondersteuning en begeleiding.

De drie variabelen regimes-evaluatie, belang van resocialisatie en ondersteuning verklaren met een hoge significantie $(p=.000)$ gezamenlijk $75 \%$ van de variantie. Daarvan neemt regimesevaluatie $41 \%$ voor zijn rekening, belang van resocialisatie verklaart $23 \%$ en ondersteuning verklaart $11 \%$ van de variantie

De relatie met regimes-evaluatie betekent dat hoe positiever men het regime beoordeelt, des te meer waardering heeft men voor de belevingsaspecten van de hulpverlening die gericht zijn op de verbetering van de (toekomstige ) levenssituatie. Voor de twee overige variabelen geldt dat hoe meer belang men hecht aan resocialisatie en hoe meer men tevreden is met de geboden ondersteuning des te meer staat men open voor aspecten van de hulpverlening die zich richten op persoonlijke groei en zelfherstel. In modelvorm zien de relaties er aldus uit:

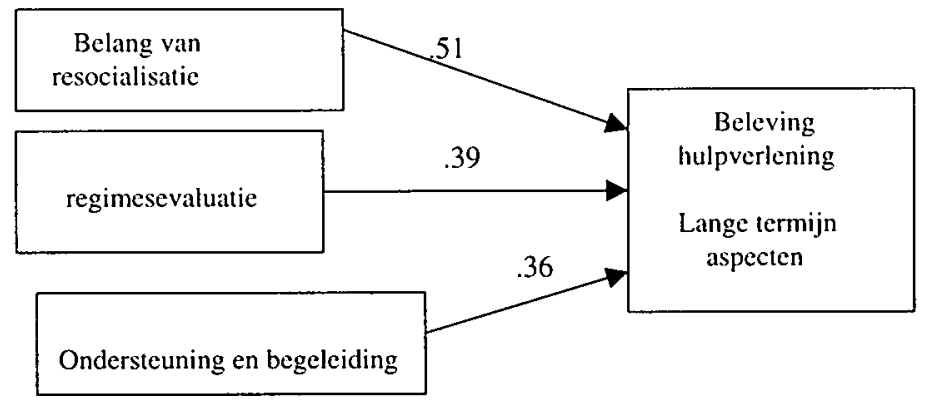

\section{Tevredenheid arbeid en vrije tijdsbesteding}

Uit een regressie-analyse met betrekking tot de beleving van de arbeid blijkt dat het regime de belangrijkste predictor is voor de waardering van de arbeid. 
Tabel 32: Regressieanalyse Tevredenheid arbeid

\begin{tabular}{lll}
\hline Predictoren & Regimesevaluatic & Belang van Resocialisatie \\
& Significante & beta-waarden \\
& $.17^{*}$ \\
\hline
\end{tabular}

$\mathrm{R} 2=16 \quad \mathrm{Df}=2 \mathrm{~F}=11.886 \mathrm{p}=.000$

$* \mathrm{p}=<.05, * * \mathrm{p}=<.01, * * * \mathrm{p}=<.001$

Hoe positiever men het regime beoordeelt, des te meer tevreden is men over de arbeid. Het belang van resocialisatie oefent, zij het in bescheiden mate een positief effect uit op de tevredenheid met de arbeid. Hoe groter het belang dat men hecht aan de voorbereiding van de tenugkeer in de samen-leving, des te positiever beoordeelt men de arbeid. In modelvorm zien de relaties er als volgt uit:

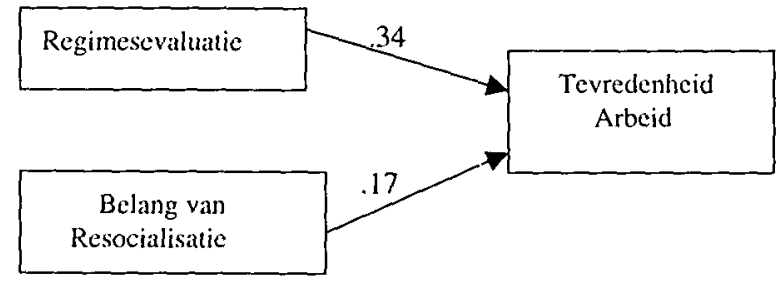

Bij de waardering van de mogelijkheden voor vrije tijdsbesteding buiten de reguliere activiteiten van het SKW zijn de variabelen scepsis en strafduur de belangrijkste predictoren.

Tabel 33: Regressicanalyse Tevredenheid vrijetijdsbesteding

\begin{tabular}{lll}
\hline Predictoren & Scepsis & Strafduur \\
\hline & Significante & beta-waarden \\
tevredenheid vrijetijdsbesteding & $.32^{* *}$ & $-.28^{* *}$ \\
\hline
\end{tabular}

$\mathrm{R} 2=.21 \quad \mathrm{~F}=11.294 \quad \mathrm{df}=2 \quad \mathrm{p}=000$

${ }^{*} \mathrm{p}=<.05,{ }^{*} \mathrm{p}=<.01,{ }^{* * *} \mathrm{p}=<.001$

Hoe meer kansen men voor zich zelf percipieen voor wat betreft het zelfherstel des te positiever beoordeelt men de mogelijkheden voor de vrije tijdsbesteding. Strafduur is negatief gerelateerd aan het oordeel over de vrije tijdsbesteding. Hoe langer de uit te zitten straf des te negatiever de houding ten aanzien van vrije tijdsbesteding. Dit laatste betekent wellicht dat het probleem van verveling voor langgestrafte gedetineerden een belangrijk gegeven van de detentie vormt. In modelvorm zien de relaties er aldus uit:

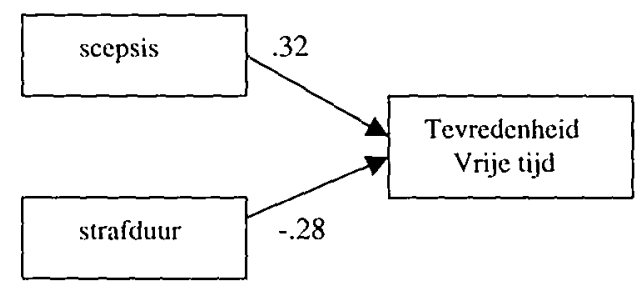




\section{Samenvattend}

Voor de beleving van de activiteiten levert de regressic-analyse als belangrijk resultaat op dat bij het merendeel van de activiteiten sprake is van een een invloed van zowel omgevingsgebonden variabelen als van variabelen die los staan van de omgeving Ook hier kan worden geconcludeerd dat de regressie-analyses een ondersteuning opleveren voor de integratieve benadering van dit onderzoek. De belevingsvariabelen worden in hun algemeenheid echter sterker bepaald door een omgevingsgebonden variabele als regimes-evaluatie of door situationele, organisatiegebonden variabelen met betrekking tot de programma-integriteit. Het is steeds dit type omgevings-of situatiegebonden variabelen dat de variantie van de belevingsvariabelen het best verklaart. De invloed van predictoren die onafhankelijk zijn van de detentie-omgeving of organisatic is duidelijk geringer en deze predictoren, namelijk arbeidsverleden en belang van resocialisatie hebben tevens een geringer aandeel in de verklaarde variantie.

De invloed van de omgevingsgebonden variabelen is bij de beleving van de activiteiten in vergelijking met de deelname aan de activiteiten veel duidelijker en sterker. Bij de deelname aan de activiteiten daarentegen is het directe effect van omgevingsgebonden predictoren, veel minder sterk aanwezig. De deelname aan de activiteiten kenmerkt zich eerder door een sterker direct effect van persoonsgebonden variabelen.

Opvallend is tenslotte ook de invloed van de opvattingsvariabelen op de deelname aan en beleving van de activiteiten. In het bijzonder bij de deelname aan de activiteiten die expliciet worden aangeboden ten behoeve van de voorbereiding van de terugkeer in de samenleving (onderwijs, hulpverlening, kunstzinnige vorming) valt de invloed van de waargenomen mogelijkheden voor zelfherstel op (Scepsis). Bij de beleving van deze activiteiten komt duidelijk de invloed van de andere opvattingsvariabele naar voren namelijk het toegekende belang van resocialisatie.

Vat men de resultaten van de voorgaande regressie van de houdingen ten aanzien van resocialisatie in een model samen dan ontstaat een beeld dat het eerder beschreven relatiemodel in het theoretisch gedeelte voor een belangrijk gedeelte ondersteunt. Bij de presentatie van dit integrale model wordt zoveel mogelijk de structurering van het onderzoeksmodel uit hoofdstuk 4 gevolgd.

De stippellijnen in het model geven aan dat het factoren en relaties betreft die niet expliciet werden getoetst maar hun aanwezigheid wordt verondersteld aanwezig te zijn. 


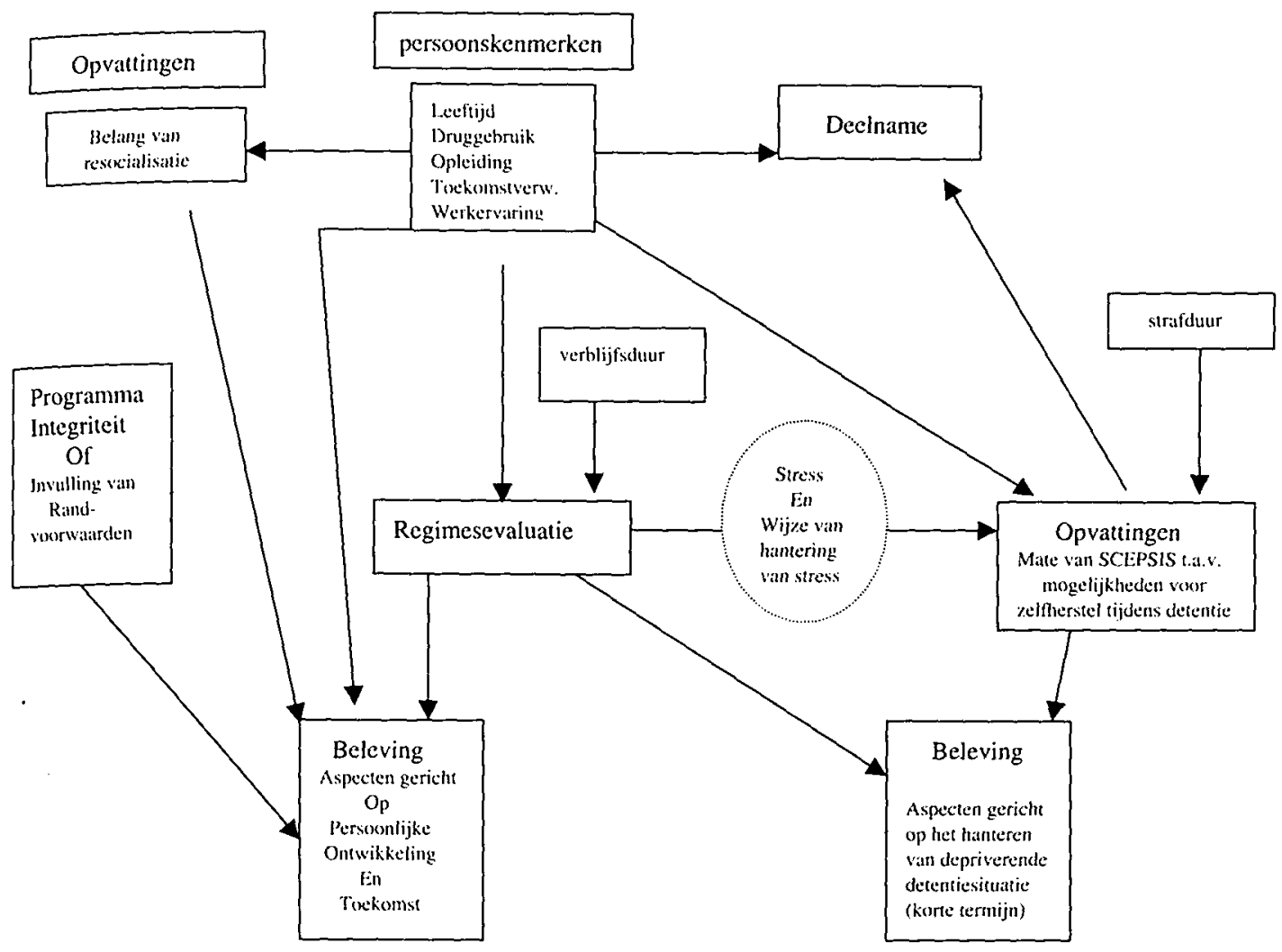

figuur 8. Relatiemodel: Relaties tussen houdingen ten aanzien van resocialisatie en achtergrondvariabelen

\subsection{Beantwoording van de verklarende onderzoeksvragen}

Aan het einde van hoofdstuk 4 werd een aantal verklarende vraagstellingen geformuleerd die als leidraad fungeren bij het onderzoek van de omgevings-en persoonsgebonden determinanten van de houdingen ten aanzien van resocialisatie. $\mathrm{Na}$ de analyses uit dit hoofdstuk kunnen deze vragen als volgt worden beantwoord.

De eerste deelvraag betreft de onderlinge relaties tussen opvattingen, deelname en beleving: Welke onderlinge relaties zijn er tussen opvattingen ten aanzien van resocialisatie, de beleving van en deelname aan de activiteiten?

De aard van de opvattingen heeft een bepaalde voorspellende waarde voor de deelname aan met name de ontwikkelingsactiviteiten en vervolgens ook voor de beleving van die activiteiten.

De deelname aan activiteiten die bij uitstek zijn bedoeld om de terugkeer in de samenleving voor te bereiden (onderwijs, kunstzinnige vorming en hulpverlening) wordt vooral beïnvloed door de opvattingen van gedetineerden over de kansen en mogelijkheden voor zelfherstel tijdens de 
detentie. Hoe meer kansen en mogelijkheden op het gebied van zelfherstel men waarneemt des te vaker neemt men deel.

De beleving van de activiteiten ondergat eveneens een invloed van de opvattingen. Het giat hier echter om de invloed van opvattingen in de zin van het belang dat men aan het resocialisatie-streven in het algemeen toekent. Het zijn met name de belevingsaspecten die betrekking hebben op de persoonlijke ontwikkeling en toekomstige levenssituatie die door deze opvattingsvariabele worden beïnvloed.

Opvallend is voorts dat de beleving van de activiteiten sterker in het teken statat van het bestrijden van de ongemakken en spanningen van de detentiesituatie naarmate men minder kansen en mogelijkheden voor zelfherstel tijdens de detentie ziet.

Op basis van correlationele analyses bleken deelname aan en beleving van de verschillende activiteiten ook onderling samen te hangen. Deze laatste verbanden suggereren de aanwezigheid van een sterke positieve gerichtheid op zinvolle bezigheden in het algemeen.

De tweede en derde onderzoeksvraag behandelen de invloed van een ongevingskenmerk als het regime en een reeks (tijds)variabelen die verbonden zijn met het prisonisatie-proces. Om precies te zijn luidde de tweede onderzoeksvraag:

Houdt een orde- dan wel een gedetineerdengerichte beleving ran het regime direct of indirect verband met de houdingen ten aanzien van resocialisatie?

De beleving van het regime heeft een directe invloed op de opvattingen in de zin van de waargenomen kansen mogelijkheden voor zelfherstel. Hoe meer men het regime beleeft in een positieve gedetineerdengerichte zin des te meer mogelijkheden voor zelfherstel neemt men waar. En meer ordegerichte beleving van het regime in restrictieve en negatieve zin gaat gepaard met de perceptie van minder mogelijkheden.

De invloed van het regime reikt verder dan de opvattingen. Er is zo, bleek uit de regressieanalyses een indirecte invloed op de deelname aan de activiteiten via de waargenomen mogelijkheden voor zelfherstel (Scepsis) en een directe invloed op de beleving van een aantal activiteiten. Een gedetineerdengerichte positieve beleving van het regime leidt indirect via de waargenomen mogelijkheden voor zelfherstel tot frequentere deelname en een negatieve beleving van het regime leidt indirect tot minder frequente deelname of geen deelname

Voor de directe invloed van het regime op de beleving van de activiteiten geldt het volgende. Bij de beleving van de lange termijnaspecten van de kunstzinnige vorming en de hulpverleningscontacten zien we een positieve relatie met de beleving van het regime. Hoe positiever men over het regime denkt, des te positiever beleeft men de lange termijn aspecten van deze activiteiten. Hoe negatiever men over het regime denkt, des te minder belang hecht men aan deze lange termijn aspecten die betrekking hebben op persoonlijke groei, ontwikkeling en verbetering in de levens-situatie.

Bij de beleving van de korte termijn aspecten van de beleving van de kunstzinnige vorming zien we een negatieve relatie met de beleving van het regime. Hoe negatiever men over het regime denkt des te hoger de waardering van de belevingsaspecten die te maken hebben met het vermijden of verminderen van de ongemakken en deprivatie van de detentie-situatie. In het vorige hoofdstuk bleek dat gedetineerden in een HVB-regime en kortgestraften deze korte termijnaspecten van de beleving van de kunstzinnige vorming gemiddeld meer waarderen dan langgestrafte gedetineerden. Regimes voor de HVB-gedetineerden en voor kortgestraften zijn veel restrictiever dan die voor langgestraften. Objectieve kenmerken van de omgeving beïnloeden hier, indirect via de beleving van het regime, de beleving van de kunstzinnige vorming. 
Deze bevindingen met betrekking tot de invloed van het regime leveren ondersteuning op voor het deprivatie-model waarbij wordt verondersteld dat de mate van omgevingsgebonden deprivatie tijdens de detentie direct van invloed is op de houdingen van gedetineerden.

Echter, de invloed van de detentie-omgeving op de houdingen van gedetineerden verloopt mogelijk door de aanwezigheid van een prisonisatie-proces tevens op meer complexe wijze.

Volgens de verklaringen van houdingen van gedetineerden op basis van het deprivatie-model, ontstaan oppositionele en negatieve houdingen van gedetineerden tevens door een aanpassing aan de normen en waarden van de gedetineerdencultuur. De pijnlijke consequenties van de detentie drijven de gedetineerde als het ware in de richting van een deviante gedetineerdencultuur die zich kenmerkt door oppositie ten aanzien van de conventionele waarden en normen van de officiële inrichtingscultuur. Een negatieve beleving van het regime en daarmee tevens een negatieve houding ten aanzien van resocialisatie kan tevens worden veroorzaakt dan wel worden versterkt door het prisonisatie-proces. Dat wil zeggen door een sterkere oriëntatie op de normen en waarden van een (deviante) gedetineerdencultuur. De rol van dit prisonisatie-proces wordt zichtbaar bij de beant-woording van de volgende onderzoeksvraag met betrekking tot de invloed van de tijdsvariabelen.

De derde onderzoeksvraag betreft de veronderstelde samenhang tussen de overige relevante factoren uit het deprivatie-model:

Vertonen verblijfsduur, strafduur; detentiefase en contacten met medegedetineerden een samenhang met de houdingen ten aanzien van resocialisatie?

Uit de correlationele analyses bleek een samenhang van de verblijfsduur en opgelegde strafduur met de houdingen ten aanzien van resocialisatie.

Naarnate men langer in detentie verblijft en de opgelegde strafduur hoger is, geeft men in sterkere mate blijk van scepsis ten aanzien van de mogelijkheden voor zelfherstel tijdens de detentie. Er bleek tevens een samenhang te zijn met de deelname aan en beleving van bepaalde activiteiten. Op één uitzondering na, namelijk de beleving van de onderwijsactiviteiten waren al deze correlaties negatief. Een negatieve correlatie duidt in dit geval op een afnemende belangstelling en op een minder positieve beleving .

Na causale modellering bij de opvattingen ten aanzien van resocialisatie en regressie-analyse bij de deelname en beleving van de activiteiten bleek de betekenis van verblijfdsduur en strafduur minder groot.

Bij de causale modellering die voor de opvattingen werd uitgevoerd bleek een betrouwbaar model slechts te construeren na verwijdering van variabelen als verblijfsduur en strafduur. Na deze aanvul-lende analyses blijkt het directe effect van de tijdsvariabelen van bescheiden aard te zijn. Het effect van strafduur en verblijfsduur lijkt op basis van de regressie-analyses vooral van indirecte aard te zijn, dat wil zeggen, zij verloopt via de variabelen regimesevaluatie en de waargenomen mogelijk-heden voor zelfherstel (Scepsis).

Men kan concluderen dat de gevonden relaties op grond van de correlationele- en regressieanalyses een tendens laat zien van meer negatieve houdingen naar mate men langer in detentie verblijft en de opgelegde strafduur hoger is. Men dient hier veeleer te spreken in termen van tendensen dan in termen van oorzaken.

Die tendens van meer negatieve houdingen ten aanzien van resocialisatie wordt overigens niet alleen maar zichtbaar op grond van resultaten van de correlationele en regressie-analyses.

De resultaten van de univariate variantie- analyses in hoofdstuk 6 waarbij werd getracht voor wat betreft de houdingen ten aanzien van resocialisatie mogelijke verschillen op te sporen tussen gedetineerden met een verschillende verblijfstitel (lang-kortgestraft, HVB) illustreert een zelfde 
tendens tot een negatiever opstelling naarmate men langer in detentie verblijft en de opgelegde strafduur hoger is. Zo bleek uit een vergelijking in de gevangenis te Sittard van de houdingen van langgestraften, kortgestraften en gedetineerden in een HVB-regime dat de meest negatieve opvattingen, de minst positieve beleving en de laagste participatiegraad voor de meeste activiteiten onder langgestraften werden aangetroffen.

Tulkens (1992, p.15) merkt over de betekenis van de factor tijd voor langgestraften het volgende op:

"Zij kampen echter met twee problemen. Ten eerste kunnen zij tijdens de detentie vaak (te) weinig aan hun toekomst doen. Ten tweede betekent toekomstgerichtheid in die situatie dat hun tijd extra lang duurt. Deze omstandigheden leiden er vaak toe, dat men zich voor de toekomst afsluit".

De tendens tot negativiteit bij afgestrafte gedetineerden die hetzij in mididen-of eindfase van de detentie verkeren, kent echter een aantal nuanceringen als men de detentiefase en de verschillen in houding tussen de twee afdelingen voor langgestraften in ogenschouw neemt.

Met betrekking tot de evaluatie van het regime, de opvattingen ten aanzien van resocialisatie, bibliotheekbezoek en tevredenheid met de vrije tijdsbesteding blijkt de groep respondenten i.c. de langgestraften die zich in de middenfase van de detentie bevindt, zich significant negatiever op te stellen. De kortgestraften die zich in de eindfase bevinden en de HVB -gedetineerden die in de beginfase verkeren vertonen een meer positieve houding. De U-vormige curve die Wheeler (1961) beschrijft met betrekking tot het aanpassingsproces aan de detentie en meer in het bijzonder, de aanpassing aan de gedetineerdencultuur, blijkt dus een parallel te hebben in de opvattingen ten aanzien van resocialisatie, de deelname aan en beleving van de activiteiten en de beoordeling van het regime. De negatieve tendens die zich onder de gedetineerden na verloop van tijd bij de houdingen ten aanzien van resocialisatie voordoet, is derhalve geen continue neerwaartse tendens. Aan het eind van de detentie is er sprake van een ombuiging in positieve richting.

De tweede nuancering van de negatieve tendens ontstaat als men de reeds eerder vermelde differentiatie voor de groep langgestrafte gedetineerden in ogenschouw neemt.

Een afdeling $\mathrm{C}$ waarop meer gemotiveerde gedetineerden worden geplaatst laat gemiddeld de hoogste deelname -graad bij activiteiten als onderwijs en crea zien. Deze groep is gemiddeld het meest negatief in de opvattingen over resocialisatie, maar tegelijkertijd gemiddeld het meest actief bij activiteiten als onderwijs en kunstzinnige vorming. Bovendien is de beleving van de onderwijsactiviteiten en van de lange termijnaspecten van de kunstzinnige vorming in de totale onderzoekspopulatie gemiddeld het meest positief bij deze groep langgestraften.

We zien dat als het om de deelname aan en beleving van de onderwijsactiviteiten en de kunstzinnige vorming van deze, meer gemotiveerde langgestrafte gedetineerden gaat, geen sprake is van een negatieve tendens die men op grond van de detentiefase en de strafduur zou mogen verwachten. Deze discrepantie verklaarden wij reeds eerder uit het feit dat het hier om een groep gedetineerden gaat die sterk op activiteiten zijn gericht en deze activiteiten vooral beschouwen als een middel on geestelijk in beweging te blijven en om zin te geven aan een langdurig verblijf in detentie. De houdingen van de groep afgestrafte gedetineerden die vanwege verslavings-en gedragsproblematiek op de andere D-vleugel voor langgestraften worden geplaatst, vertonen bij de deelname en beleving van de meeste activiteiten in het algemeen wel een negatieve tendens. De laagste gemiddelde scores op sommige deelname- en belevingsvariabelen in de onderzoeks-populatie worden bij deze groep aangetroffen. De meest negatieve beleving van het regime treffen we eveneens aan bij deze groep langgestraften.

Deze bevinding vormt een aanwijzing dat een invloed van de gedetineerdencultuur of van een 
prisonisatieproces vermoedelijk werkzaam is. $\mathrm{Bij}$ de langgestraften is een meer ordegerichte, negatieve beleving van het regime niet alleen maar een gevolg van de objectieve restricties in dat regime. Het regime kent juist meer vrijheden dan bij voorbeeld het regime in een HVB of op een kortgestrafte-afdeling. Naar alle waarschijnlijkheid is de meer negatieve beleving van het regime door de langgestraften een uitvloeisel van een sterkere orientatie op de normen en waarden van een gedetineerdencultuur.

De rol van de gedetineerdencultuur in dit verband is wellicht deze: de beleving van de gevangenschap als belastend en depriverend leidt na verloop van tijd tot een zich eerder wenden tot een oppositionele gedetineerdencultuur. Deze orientatie op een oppositionele gedetineerdencultuur leidt tot een sterkere beleving van het regime als ordegericht. En een orde-gerichte beleving van het regime dient men in deze studie immers voor een belangrijk deel te interpreteren als een beleving van het regime die sterker in het teken staat van een onderlinge afstand en wantrouwen tussen personeel en gedetineerden.

Vatten we het voorgaande samen dan kan worden vastgesteld dat de onderzoeksresultaten met betrekking tot de invloed van de deprivatievariabelen regimesevaluatie, verblijfsduur en strafduur op de houdingen ten aanzien van resocialisatie de werking van een prisonisatie-proces suggereren. De werking van dit proces wordt zichtbaar door een meer negatieve beleving van het regime door de langgestrafte gedetineerden die in de middenfase van de detentie verkeren. Een meer negatieve beleving van het regime komt immers inhoudelijk neer op een zich sterker afzetten tegen de officiële inrichtingscultuur. Hieruit zou men een vermoedelijk, sterker wordende binding met een oppositionele gedetineerdencultuur kunnen afleiden. Op zijn beurt kan die meer negatieve beleving van het regime, een negatieve invloed hebben op de opvattingen in de zin van de mogelijkheden voor zelfherstel.

Indirect, via de variabele scepsis heeft een negatieve beleving van het regime vervolgens weer een negatieve invloed op de deelname aan de activiteiten.

Voorts heeft de beleving van het regime ook een directe invloed op de beleving van de activiteiten. Hoe negatiever de beleving van het regime des te minder postief is de beleving van, althans, een aantal activiteiten

Contacten met medegedetineerden als variabele uit het deprivatie-model tenslotte, bleek na regressie-analyse geen predictor te zijn met een significante voorspellende waarde voor wat betreft de houdingen ten aanzien van resocialisatie. Wel bleek in hoofdstuk 6 na variantieanalyse dat langgestrafte gedetineerden significant meer intensieve contacten onderhielden met medegedeti-neerden dan de overige categorieën respondenten. In dit opzicht kan men spreken van een patroon dat hooguit duidt op de aanwezigheid van een prisonisatie-proces.

Onderzocht werd of bepaalde persoonsgebonden variabelen een samenhang vertonen met de houdingen ten aanzien van resocialisatie. De vierde onderzoeksvraag luidde:

Vertonen bepaalde persoonsgebonden variabelen een samenhang met houdingen ten aanzien van resocialisatie?

De onderzoeksresultaten laten een aantal duidelijke directe en indirecte verbanden zien tussen de houdingen ten aanzien van resocialisatie en bepaalde persoonsgebonden variabelen. $\mathrm{Bij}$ de deelname aan de activiteiten blijkt het opleidingsniveau een voorspellende waarde te hebben ten aanzien van de deelname aan onderwijs, bibliotheekbezoek en sport. Leeftijd en druggebruik gelden bij de sport als de overige variabelen met een voorspellende waarde. Een directe relatie van persoonsgebonden variabelen is verder aanwijsbaarbij de opvattingen ten aanzien van resocialisatie. Het belang dat men toekent aan de resocialisatie-doelstelling is hoger naarmate men beter is opgeleid en men gunstiger toekomstverwachtingen heeft. 
Gedetineerden zien meer mogelijkheden voor zelfherstel of resocialisatie tijdens detentie naarmate zij gunstiger toekomstverwachtingen hebben. De invloed van opleiding is hier van indirecte aard en verloopt namelijk via toekomstverwachtingen. Toekomstverwachtingen beinvloeden bovendien de beleving van het regime. Hoe gunstiger de toekomstverwachtingen des te positiever is de houding ten opzichte van het regime.

Het arbeidsverleden in de zin van het hebben van werk voorafgaand aan de detentie is van invloed op de belevingsaspecten bij de hulpverlening en de kunstzinnige vorming die betrekking hebben op de persoonlijke groei en de toekomstige levenssituatie. Gedetineerden die over werk beschikten voorafgaand aan de detentie, waarderen deze belevingsaspecten meer dan gedetineerden die niet over werk beschikten. De verklaring voor dit verband ligt misschien niet zozeer in het hebben van werk als zodanig, maar veeleer in de aanwezigheid van een achterliggende derde factor. Hierbij zou men kunnen denken aan positieve houdingen ten aanzien van conventionele normen en waarden die te maken hebben met 'vooruit willen komen in het leven', de tijd op een zinvolle, nuttige manier willen besteden, met het nastreven kortom van sociaal wenselijke doeleinden met legitieme middelen.

De rol van de persoonsgebonden variabelen dient zeker niet te worden gebagatelliseerd, zij spelen dus wel degelijk een rol. Heel duidelijk komt dit tot uiting bij een activiteit als onderwijs, die sterk in het teken staat van mogelijkheden voor persoonlijke groei. Het genoten opleidingsniveau oefent bij de deelname een sterk positief effect uit.

De geconstateerde, niet te verwaarlozen invloed van persoonsgebonden factoren en opleidingsniveau op de houdingen en gedrag inzake resocialisatie is van belang in het licht van de, in literatuur over resocialisatie veronderstelde aanwezigheid van selectiemechanismen. Selectie van gedetineerden voor resocialisatie-programma's wordt in de literatuur wel eens geassocieerd met een bewust of onbewust gehanteerde strategie van gevangenisfunctionarissen om alleen die gedetineerden toe te laten met een gunstige prognose omtrent recidive (een zogenaamd laag risicoprofiel), goed gedrag tijdens detentie, zonder een ernstige verslavingsproblematiek en met een vooruitzicht op een permanent legaal verblijf in het land van detentie. Het bezwaar dat tegen deze praktijk wordt aangevoerd, komt erop neer dat de voorzieningen niet terecht komen bij gedetineerden die deze het hardst nodig hebben. Men selecteert voornamelijk gedetineerden met eigenschappen die de kans op succes van het programma vergroten. Zo stelt Moerings (1990) dat binnen de gevangenis een soort onderlaag is ontstaan. Met name drugsverslaafden, buitenlandse gedetineerden en gedetineerden met gedragsstoomissen missen niet zelden de boot als het gaat om deelname aan faciliteiten op het gebied van resocialisatie en detentie-fasering.

En Zamble en Porporino (1991) constateren dat gedetineerden die als gevolg van gebrekkige coping-vaardigheden in de inrichting vaak probleemgevend gedrag ten toon spreiden, van deelname worden uitgesloten ten gunste van gedetineerden die de programma's eigenlijk niet echt hard nodig hebben. De resultaten van de voorliggende studie laten zien dat er een groep gedetineerden is die mede op grond van persoonsgebonden kenmerken als toekomstverwachtingen en opleiding zich wat positiever tegen het regime opstelt ${ }^{\prime}$. Men komt de

${ }^{1}$ Deze positieve opstelling van gedetineerden ten aanzien van het regime die voortvloeit uit predetentiefactoren, betekent overigens niet dat de beoordeling van het regime geheel en al het resultat is van deze factoren. De objectieve kenmerken van het regime beïnvloeden die beleving, zoals verondersteld, eveneens. Een aanwijzing in dit verband zijn met name de resultaten van de vergelijking van gemiddelde scores van de HVB-respondenten in de drie onderzochte inrichtingen in hoofdstuk 7. De waardering van het regime door gedetineerden in één van de onderzochte HVBinrichtingen is hoger dan van de HVB-respondenten in de overige inrichtingen. De meer 'positieve' HVB-inrichting laat tevers een gemiddeld hogere score zien op de waargenomen mogelijkheden voor zelfherstel (scepsis) in vergelijking met één van de andere inrichtingen met een vergelijkbaar HVB- 
inrichting reeds binnen met een wellicht wat meer coöperatieve en constructieve instelling. Deze groep richt zich vervolgens ook sterker op de activiteiten. Het lijkt een zichzelf selecterende groep te zijn. Het ligt voor de hand dat het bewarend personeel en de leden van de professionele staf op deze meer positieve instelling inspelen.

Men heeft belang bij programma's of activiteiten die worden bezocht door gemotiveerde deelnemers. Er is hier sprake van een soort wisselwerking en een gedeeld belang. Gedetineerden die op grond van bepaalde persoonlijke predisposities de detentie meer inhoud en zin willen geven, stellen zich actiever op. Het personeel ziet deze groep gemotiveerden graag komen ondat het prettig werken is en wellicht wat makkelijker resultaten worden geboekt. Het verschijnsel van een groep gedetineerden wier motivatie alleen al sterker is op grond van predisposities die min of meer los staan van de detentie wijst op de noodzaak van nader onderzoek naar de persoonsgebonden factoren die deze sterke motivatie beïnvloeden. Men kan hier behalve aaan het opleidingsniveau tevens denken aan cognitieve factoren als copingvaardigheden, locus of control en self-efficacy op grond waarvan men de geboden mogelijkheden en kansen daadwerkelijk in het eigen voordeel weet te gebruiken. Onderzoek naar de invloed van persoonsgebonden factoren kan tevens inzichten opleveren over de mogelijkheden om minder gemotiveerde gedetineerden te mobiliseren voor programma's gericht op zelfherstel.

Onderzocht werd of programma-integriteit van invloed is op de houdingen ten aanzien op resocialisatie. De vijfde onderzoeksvraag luidde in dit verband:

Houdt de programma-integriteit een direct dan wel indirect verband met de houdingen ten aanzien van resocialisatie?

De programma-integriteit houdt uitsluitend een direct verband met de beleving van en deelname aan de activiteiten. Slechts één activiteit, namelijk onderwijs wordt de deelname rechtstreeks beïnvloed door de kwaliteit van de informatie verstrekking. Hoe beter de voorlichting en informatie over deze activiteit des te frequenter de deelname. De invloed van programmaintegriteit komt het sterkst naar voren bij de beleving van de activiteiten. Hoe beter de ervaren kwaliteit van de ondersteuning en begeleiding, des te positiever de beleving van met name de belevingsaspecten die gericht zijn op persoonlijke groei en toekomstige levenssituatie. Voorts blijken bij de kunstzinnige vorming de faciliteiten in de zin van de ervaren kwaliteit van de geboden materialen en middelen een belangrijke factor te zijn. Opmerkelijk is hier dat de ervaren kwaliteit van de geboden ondersteuning en begeleiding geen rol van betekenis spelen. Met goede materialen en adequate faciliteiten kan men blijkbaar het plezier in en het gepercipieerde belang van de kunstzinnige vorming voor de persoonlijke ontwikkeling meer beïnvloeden dan met de kwaliteit van de ondersteuning. Het ligt ook eigenlijk wel voor de hand, zonder verf bijvoorbeeld is een proces van persoonlijke groei via zelfexpressie ook moeilijk op gang te brengen. En blijkens de geschreven commentaren en op grond van eigen observatie komt het in de praktijk daadwerkelijk voor dat zij wel naar de crea gaan maar dat zij vanwege allerlei organisatorische tekortkomingen niet over de benodigde materialen kunnen beschikken.

De waarde van programma-integriteit komt dus voornamelijk neer op een, wat men zou kunnen noemen, toegevoegde waarde. Verbetering van de programma-integriteit heeft waarschijnlijk maar een zeer beperkt effect op deelname. Hooguit via de informatie verstrekking kan men de

regime. Voorts blijkt de invloed van de objectieve restricties van het regime ook uit gemiddelde waardering van HVB-respondenten voor de belevingsaspecten die betrekking hebben op het reduceren van de ongemakken van de detentie, ook wel aangeduid als de korte termijn aspecten. Die waardering is in vergelijking met die van de langgestraften gemiddeld hoger. 
deelname van een activiteit als onderwijs rechtstreeks beinvloeden. Via programma-integriteit kan men echter wel de houdingen ten aanzien van resocialisatie in rechtstreekse zin beïnvloeden. De programma-integriteit en de ervaren kwaliteit ervan zijn immers vooral van invloed op de belevingsaspecten die te maken hebben met zelfverbetering, persoonlijke groei en de toekomstige levenssituatie.

In het theoretisch kader van dit onderzoek geldt als een belangrijk uitgangspunt dat omgevingsen persoonsgebonden variabelen en programma-integriteit, mogelijk een onderlinge samenhang direct of indirect van invloed zijn op de houdingen ten aanzien van resocialisatie. Een zesde onderzoeks-vraag die in dit verband werd gesteld, luidde als volgt:

Welke soort factoren leggen het meeste gewicht in de schaal bij de verklaring van de houdingen ten aanzien van resocialisatie?

In hoofdstuk 4 werd uitgegaan van de veronderstelling dat een adequate verklaring van houdingen ten aanzien van resocialisatie gebaseerd zou moeten zijn op een integraal verklaringsmodel waarin zowel persoons- en omgevingsgebonden variabelen een rol spelen. De resultaten van de analyses in dit hoofdstuk laten zien dat de aard en oorsprong van de houdingen ten aanzien van resocialisatie inderdaad voor een belangrijk deel kunnen worden verklaard door zowel persoons- als omgevings-gebonden variabelen. Zo zijn de mogelijkheden die men voor zelfherstel waarneemt (Scepsis) voor een deel afhankelijk van de omgeving, in het bijzonder van de beoordeling van het regime en voor een deel ook van een persoonsgebonden variabele als toekomstverwachtingen. De beleving van de omgeving, in de zin van het regime wordt niet alleen maar bepaald door de (objectieve) eigenschappen van de omgeving. De persoonsgebonden variabele toekomstverwachtingen en indirect ook het opleidingsniveau beïnvloeden de beleving van het regime eveneens. Hoe hoger men is opgeleid des te gunstiger denkt men over de toekomst. Hoe gunstiger de toekomst-verwachtingen des te positiever de houding ten opzichte van het regime.

De deelname aan en beleving van de activiteiten laat voor wat hun verklaring betreft voor het merendeel van de activiteiten een samengaan zien van zowel persoons-als omgevingsgebonden achtergrond-variabelen. Slechts bij het belang dat men aan resocialisatie toekent en de deelname aan de sport en het bibliotheekbezoek ontbreekt een dergelijke combinatie van omgevings-en persoonsgebonden variabelen. $\mathrm{Bij}$ deze afhankelijke variabelen bleken alleen predictoren van persoonlijke aard van invloed en speelde de omgeving geen aanwijsbare rol.

Uit de resultaten van de analyses in dit hoofdstuk zoals deze zijn samengevat in het model in figuur 8 blijken de houdingen ten aanzien van resocialisatie sterker te worden verklaard door factoren die omgevingsgebonden zijn. Vooral als men de programma-integriteit of de factoren in rand-voorwaardelijke sfeer eveneens als een, in essentie organisatie- en dus omgevingsgebonden factor beschouwt, dan komt de invloed van de omgeving vergeleken bij die van de persoonsgebonden 'import' variabelen toch wat sterker naar voren. In de aangetroffen verbanden is er bij de onafhankelijke variabelen weliswaar sprake van een samengaan van bijvoorbeeld regimesevaluatie of programma-integriteit met persoonsgebonden variabelen maar hierbij verklaart de perceptie van de omgeving steeds een groter deel van de variantie.

In dit verband dient nog eens te worden gewezen op de belangrijke invloed van de omgevingsvariabele regimesevaluatie bij de verklaring van de waargenomen mogelijkheden voor resocialisatie. De waargenomen mogelijkheden voor resocialisatie tijden de detentie blijken op hun beurt een cruciale variabele te zijn voor de deelname aan de activiteiten die dienstig zijn aan een proces van zelfherstel.

In het theoretische kader werd niet alleen uitgegaan van een integratie-model, het model werd 
vervolgens toegespitst in de vorm van een interactionistische benadering van houdingen ten aanzien van resocialisatie. Verondersteld werd op grond van met name een interactionistische perspectief dat de houdingen van gedetineerden ten aanzien van resocialisatie in essentie dienen te worden beschouwd als een reactie die de aanpassing vergemakkelijkt aan een omgeving die als depriverend en als belastend wordt ervaren.

Een belangrijke veronderstelling op basis van de interactionistische benadering is dat de relatie tussen de omgeving en het individu geen uni-directionele, deterministische relatie is. Verondersteld werd dat er sprake is van interpretatie van de omgeving die varieert al naargelang de eerdere ervaringen verwachtingen en doelstellingen van het individu.

Deze veronderstelling vindt ondersteuning in de onderzoeksresultaten. De beleving van het regime is direct afhankelijk van een persoonsgebonden variabele als toekomstverwachtingen en indirect van het opleidingsniveau en wordt dus niet alleen maar bepaald door de objectieve eigenschappen van de omgeving. Het interpretatie-aspect is duidelijk aanwezig.

De veronderstelling dat de houdingen ten aanzien van de activiteiten vooral dienen te worden beschouwd als een aanpassingsreactie op een, als depriverend en belastend ervaren detentieomgeving vindt in meer afgeleide vorm ondersteuning in de onderzoeksresultaten. In het kader van de onderzoeksvraag met betrekking tot de rol van stress en stresshantering wordt deze thematiek van de aanpassing aan de detentie-omgeving verder besproken.

Op grond van de onderzoeksresultaten met betrekking tot de persoonsgebonden variabelen kan men nu reeds vaststellen dat een verklaring van de houdingen enkel en alleen in termen van een aanpassingsreactie op een stressvolle omgeving maar ten dele opgaat. Daar waar het toegekende belang aan resocialisatie en de deelname aan een aantal activiteiten louter en alleen in directe zin worden beïnloed door persoongebonden variabelen wordt een dergelijk type verklaring gefalsifieerd. De omgevingscomponent is hier immers niet aanwijsbaar van invloed.

De laatste en zevende onderzoeksvraag luidde als volgt:

In hoeverre kunnen de houdingen ten aanzien van resocialisatie worden beschouwd als een bepaalde vorm van hanteringgedrag?

Om de stress als gevolg van het verblijf in detentie te hanteren en om zich aan de depriverende omstandigheden aan te passen gebruiken gedetineerden verschillende strategieën. Een van de strategieën is het creëren van een 'niche' waarbij activiteiten en het streven naar zelfverbetering centraal staan. De mate van bereidheid om deze strategie te volgen is min of meer belichaamd in de opvattingsvariabele Scepsis, de variabele die de mate aangeeft waarin men nog mogelijkheden voor zich zelf ziet om via (ontwikkelings) activiteiten iets te doen aan zelfverbetering.

Hoe minder mogelijkheden voor zelfherstel men voor zichzelf waarneemt, des te minder frequent de deelname aan ontwikkelingsactiviteiten en des te groter de kans dat men zijn toevlucht neemt tot andere strategieën om de depriverende en stressvolle omstandigheden van de detentie het hoofd te bieden. Hoe meer mogelijkheden men waarneemt voor zelfherstel des te frequenter neemt men deel aan de activiteiten die met name gericht zijn op het bevorderen van de terugkeer in de samenleving zoals onderwijs, hulpverlening en kunstzinnige vorming.

Een perceptie van weinig of geen mogelijkheden voor zelfherstel tijdens de detentie kan, zoals gezegd, gepaard gaan met het zoeken van andere strategieën. In het model zijn in dit verband de twee overige vormen van stresshantering namelijk heroriëntatie en vluchtgedrag opgenomen. Heroriëntatie impliceert in de detentiesituatie een zich afwenden van vergelijkingspatronen of dimensies die conventionele waarden belichamen als reactie op de deprivatie en vernederingen van de detentie. Men oriënteert zich vervolgens sterker op een wereld met (deviante of 
oppositionele) subculturele waarden en normen waarin men wel een positief zelfbeeld kan handhaven. Een sterkere mate van oriëntatic op de normen en waarden van de gedetineerdencultuur kan vervolgens gepaard gaan met een meer negatieve opstelling ten aanzien van resocialisatie. De, in dit onderzoek aangetoonde tendens tot meer negatieve houdingen ten aanzien van resocialisatie naamate men langer in detentie verbliff en men nog langer te gaan heeft, zou men kunnen interpreteren als een vorm van hantering van de depriverende detentie-omstandigheden die sterker in het teken staat van heroriëntatie en als een hanteringstrategie in de zin van vlucht- of vermijdingsgedrag .

Expliciete toetsing van de hypotheses met betrekking tot stress en 'coping' heeft in dit onderzoek niet plaatsgevonden. In impliciete, exploratieve zin kan men echter wel spreken van verbanden die duiden op de relevantie van de concepten stress en stresshantering.

In de eerste plaats dient hier te worden gewezen op de wijze van operationalisatie van de opvattingsvariabele 'waargenomen mogelijkheden voor zelfherstel' (Scepsis).

De verschillende items waarmee deze variabele werd gemeten weerspiegelen in zekere de verschillende vormen van hanteringgedrag zoals met name cen meer probleemgerichte aanpak ('ik beschouw mijn detentie vooral als een moment om mijn leven weer op orde te brengen'; 'ik vind mijn verblijf hier een goed moment on aan de toekomst te werken') en vluchtgedrag ('hoe langer ik hier zit des te somberder zie ik de toekomst'; 'werken an je toekomst tijdens detentie is zinloos'; 'mijn verblijf hier ontneemt je verder iedere zin om aan je toekomst te werken').

De perceptie van meer mogelijkheden voor zelfherstel vormt derhalve een indicatie voor een meer probleemgerichte hantering van de detentie-situatie en deze probleemgerichte hantering resulteert blijkens de analyses inderdaad in een meer frequente deelname aan de activiteiten. De perceptie van weinig of geen mogelijkheden voor zelfherstel resulteert mogelijk eerder in vermijdingsgedrag of heroriëntatie, in de zin van een sterkere betrokkenheid bij een gedetineerdensubcultuur als gevolg waarvan men niet of nauwelijks deelneemt aan de ontwikkelingsactiviteiten.

Het verband tussen de belevingsaspecten van de kunstzinnige vorming die gericht zijn op het vermijden van de deprivaties van de detentie enerzijds en regimes-evaluatie en scepsis anderzijds, vormen eveneens een mogelijke aanwijzing dat stress en hanteringgedrag een rol spelen. Hoe negatiever men het regime beleeft en hoe minder mogelijkheden voor zelfherstel men waarneemt, des te meer waardeert men de belevingsaspecten van de kunstzinnige vorming die de spanningen en ongemakken van de detentie reduceren. De beleving van de kunstzinnige vorming komt als gevolg van deze samenhang als het ware sterker in het teken te staan van vlucht-of vermijdingsgedrag. De ervaring van meer stress fungeert hier waarschijnlijk als interveniërende variabele.

Het belang van stress en stresshantering (of 'coping') bij de verklaring van de houdingen ten aanzien van resocialisatie wordt ook aannemelijk als men de geconstateerde negatieve tendens in de ontwikkeling van de houdingen ten aanzien van resocialisatie in ogenschouw neemt. De houdingen van gedetineerden in de begin- en eindfase van detentie vertonen een meer positief karakter als men ze vergelijkt met de houdingen van de langgestraften.

Een verklaring voor dit verschil wordt in de onderzoeksliteratuur veelal gezocht in de aan-of afwezigheid van de invloed van de gedetineerden(sub)cultuur. De meer positieve houding van de gedetineerden in de beginfase van de detentie brengt men doorgaans in verband met de afwezigheid van de invloed van de gedetineerdencultuur en een sterkere invloed van predetentie factoren.

In de eerste fase van de detentie zijn, aldus Wheeler (1961), gedetineerden nog sterk georiënteerd op de waarden, normen en gedragsvormen waarmee zij de gevangenis binnenkomen. Na gemiddeld zes maanden begint een proces van prisonisatie, waarbij men zich 
sterk richt op de informele gedetineerdencultuur en de gevangenencode. Aan het einde van de detentic ontrekt men zich hier weer aan en richt men zich weer meer op de normen en waarden van de buitenwereld.

Wheeler's verklaring voor de positieve houding aan het begin van de detentie oriënteert zich vooral op de sterkere binding met (conventionele) waarden en normen waarmee men bij aanvang van de detentie de gevangenis binnenkomt. De vraag is echter of gedetineerden bij binnenkomst in de inrichting nog wel die binding hebben. Betrokkenheid bij een criminele subcultuur buiten de inrichting die veelal kenmerkend is voor het ontstaan van crimineel gedrag suggereert juist dat die binding verzwakt of afwezig is. Uit het onderzoek van Kolstad (1996) blijkt dat het zelfbeeld van gedetineerden juist wordt bepaald door het gevoel dat zij in de vrije samenleving aan de rand van die samenleving leven. $\mathrm{Zij}$ hebben in ieder geval het gevoel dat zij niet meer bij die conventionele samenleving horen.

Een verklaring voor de meer positieve houding aan het begin van de detentie dient mijns inziens tevens rekening te houden met een fenomeen dat in empirische zin duidelijk is vastgesteld namelijk, de aanwezigheid van zeer hoge stress-niveaus aan het begin van de detentie.

Uit onderzoek naar stressverschijnselen onder gedetineerden blijken de stress-niveaus het hoogst te zijn gedurende de beginperiode van de detentie. Voorts blijkt uit de beschrijvende literatuur dat de schok en de vernedering van de gevangenschap bijzonder groot kunnen zijn en hun uitwerking op de psychische gesteldheid van de gedetineerde niet missen. Zo stelt Knol (1997, p. 270) dat het gedetineerd worden de herinnering aan een hele geschiedenis van misère, mislukking en ontsporing verhevigt. Hij spreekt hier van een crisissituatie die een confrontatie behelst. Een confrontatie met "grenzen aan de vrijheid, maar ook met grenzen aan de eigen mogelijkheden, aan de ontplooiing van zichzelf, aan persoonlijke relaties en sociale verbanden en aan de samenleving". Volgens $\mathrm{Knol}$ is er sprake van een chaos van gevoelens waarin men orde tracht te scheppen en waarbij een sterke behoefte is aan interpretatiekaders, waarvoor men aanklopt bij geestelijke verzorgers en leden van de professionele staf zoals onderwijzers, de psycholoog en geestelijke verzorgers. Uit mijn gesprekken met gedetineerden blijken ook gedetineerden zelf aan te geven dat de beginperiode van de detentie het zwaarst is. Juist gedurende deze periode lijkt men meer open te staan voor een drastische bezinning op het heden en verleden en de neiging om naar een meer probleemgerichte aanpak van de psycho-sociale problematiek te zoeken is gedurende deze periode wellicht sterker. Waarschijnlijk leidt dit (voor veel gedetineerden waarschijnlijk slechts tijdelijk) tot een minder sceptische en negatieve houding ten aanzien van pogingen tot zelfherstel. Ook Tulkens (1992) stelt dat veel gedetineerden zich waarschijnlijk voor hun detentie zich niet erg om de toekomst bekommerd hebben, door hun detentie wordt het perspectief van de toekomst niettemin belangrijker. De confrontatie met het gevangen worden gezet maakt doorgaans diepe indruk. Bij Serge (1977, p.32) vinden we hierover de volgende beschrijving:

"The first days are the worst. And in the first days the first hours. Here is man between these four walls. Alone; nothing around him. No event. No possibility of an event. Total inactivity.... Yesterday you had a thousand worries...the hours rushed by....you had newspapers.... Yesterday,....there were your woman.... Your friends.... and all at once : nothing... A runner, suddenly immobilized, experiences shock. So does a captive."

Zamble en Porporino (1988, p.89) lijken een gelijksoortige betekenis toe te kennen aan de beginperiode van de detentie als zij stellen dat:

"Misery is one of the best motivators, and the evidence indicates that emotional distress was strikingly high at the beginning of a prison term. The conditions we surveyed at the beginning of a prison term are 
sufficient to break up many old patterns,at least temporarely, to allow room for new ways of acting. Thus we see the shock of incarceration opening an window of opportunity".

Als men vanuit de coping-theorie positieve houdingen en gedrag in zake resocialisatie als een meer probleemgerichte reactie op de stressvolle omstandigheden beschouwt dan is de 'shock of incarceration' op grond van deze coping-theory een gebeurtenis die (tijdelijk) tot een oriëntatie op een meer probleemgerichte aanpak van de situatie zou kunnen leiden. In concreto betekent dit dat gedetineerden als gevolg van de 'shock of incarceration' met name aan de beginperiode minder sceptisch staan tegenover pogingen tot zelfherstel. Het voornemen om in de toekomst de zaken anders en beter aan te pakken fungeert binnen die stressvolle beginsituatie vooral als een geestelijk houvast of een strategie om orde in de chaos te scheppen.

In termen van het model waarin de relaties tussen houdingen ten aanzien van resocialisatie zijn getoetst zou men de vermoedelijk belangrijke rol van stress en stresshantering voor gedetineerden in de beginfase van de detentie als volgt kunnen omschrijven.

De 'shock of incarceration' of de 'schok van de vrijheidsbeneming' leidt tot meer stress. In combinatie met persoonsgebonden variabelen als toekomstverwachtingen (en indirect ook opleiding) leidt deze verhoogde stress tot een (tijdelijk) grotere ontvankelijkheid voor meer probleemgerichte vormen van stresshantering in de vorm van meer positieve houdingen ten aanzien van resocialisatie.

Stress als gevolg van de detentie-situatie leidt misschien niet alleen aan het begin van de detentie tot een (tijdelijk) grotere mate van ontvankelijkheid voor probleemgerichte pogingen tot zelfherstel, ook de spanningen die samenhangen met de deprivaties tijdens de middenfase worden door op activiteiten gerichte langgestrafte gedetineerden het hoofd geboden middels een hanteringsstrategie die een meer probleemgericht karakter draagt. Hoe de relatie met stress en stresshantering voor deze groep gedetineerden met de gemiddeld hoogste deelname en belevingsscores voor de onderwijsactiviteiten en de kunstzinnige vorming verloopt, is niet aangegeven in het model. Hun relatief frequente deelname en hoge belevingsscores bij activiteiten als onderwijs en kunstzinnige vorming suggereren echter wel de aanwezigheid van een 'niche' die sterk in het teken staat van activiteiten en die waarschijnlijk de aanpassing aan de specifieke (stressvolle) omstandigheden van een langdurige detentie vergemakkelijkt.

De betekenis van stress en hantering wordt, zoals gezegd, in dit onderzoek niet expliciet getoetst. Deze variabelen werden on exploratieve redenen in het onderzoeksmodel opgenomen. De onderzoeksresultaten laten in dit verband zien dat het zeker de moeite waard is de invloed van stress en stresshantering in vervolgonderzoek van houdingen van gedetineerden in expliciete zin te toetsen.

Een belangrijke uitkomst van dit onderzoek is immers dat stress en stresshantering als factoren met een veronderstelde invloed op de houdingen, zich bij de interpretatie van de resultaten op plausibele wijze laten inpassen.

Het is overigens verbazingwekkend dat de rol van het begrip stress en stresshantering in het onderzoek van aanpassingsprocessen in een gevangenisomgeving nooit eerder is onderzocht. Immers, stress-niveaus in gevangenissen zijn waarschijnlijk veel hoger dan in welke andere organisatie in deze samenleving.

Er wordt wel hier en daar gewezen op een, naar veronderstelling groot belang van deze factoren voor het aanpassingsproces, echter pogingen om de relevatie van deze factoren in empirische zin te toetsen zijn voor zover bekend nooit ondernomen. De integratie van stress en stresshantering in het model dat in dit onderzoek werd getoetst kan men dan ook beschouwen als een eerste (exploratieve) stap in deze richting. 


\subsection{Samenvatting en conclusies}

Reeds eerder in deze studie werd vastgesteld dat wetenschappelijke kennis van houdingen van gedetineerden ten aanzien van resocialisatie betrekkelijk gering is. In het bijzonder de vraag welke factoren nu van invloed zijn op die houdingen is eigenlijk nooit op systematische wijze beantwoord.

Een opvallend resultaat van de analyses uit dit hoofdstuk is de aanwijsbare systematiek of orde die aanwezig is in de relaties tussen de afhankelijke variabelen. De manier van denken over resocialisatie en de deelname aan en beleving van de verschillende activiteiten vertonen een aantal duidelijke, onderlinge relaties.

De deelname aan en beleving van regimesactiviteiten is uiteindelijk steeds in belangrijke mate te herleiden tot een bepaalde manier van denken of tot bepaalde cognities over de voorbereiding van de terugkeer in de samenleving.

Van belang is in de eerste plaats een bepaald geloof in de noodzaak en zinvolheid van pogingen tot zelfverbetering en van verbetering van gedetineerden in het algemeen. Zoals wij in hoofdstuk 6 zagen, is dat geloof bij de meeste gedetineerden wel aanwezig. Maar met een dergelijk geloof alleen is men er nog niet. Van belang voor het ondernemen van daadwerkelijke pogingen tot zelfherstel is in de tweede plaats een bepaalde mate van optimisme omtrent de feitelijke mogelijkheden daartoe in een detentie-situatie.

Echt optimistisch over de mogelijkheden voor zelfherstel zijn de meeste gedetineerden niet, men kan hun visie veeleer omschrijven als gematigd negatief. De resultaten van de analyses in dit hoofdstuk laten zien dat de mate waarin gedetineerden voor zich zelf kansen en mogelijkheden zien om aan het zelfherstel te werken, afhankelijk is van zowel factoren van persoonlijke aard als van omgevingsfactoren. Gedetineerden komen de inrichtingen binnen met bepaalde persoonlijke eigenschappen op grond waarvan zij zich in meerdere of mindere mate openstellen voor pogingen tot zelfherstel. Op grond van persoonsgebonden factoren als een hoger opleidingsniveau en een optimistische kijk op het toekomstig leven na ontslag schat men de aanwezige kansen en mogelijkheden gunstiger in. De waargenomen mogelijkheden voor zelfherstel worden echter tevens beïnvloed door de manier waarop men de detentie-omgeving, in casu, het regime beleeft. Hoe meer gedetineerden vinden dat in het regime sprake is van aandacht voor hun individuele behoeften en noden, van aanmoediging tot een zinvolle invulling van de detentie en van een bepaalde mate van vertrouwen tussen het bewarend personeel en gedetineerden, des te meer mogelijkheden voor zelfherstel nemen zij waar en des te actiever de houding waarmee $\mathrm{zij}$ zich vervolgens opstellen.

Hoe meer gedetineerden de indruk hebben dat dit niet het geval is en dat de nadruk in het regime ligt op gehoorzaamheid, discipline en op een afstandelijke en onpersoonlijke benadering, des te minder mogelijkheden voor zelfherstel nemen zij waar.

De manier waarop gedetineerden het regime beoordelen is overigens niet alleen afhankelijk van de objectief (restrictieve of liberale) eigenschappen van het regime. Persoonlijke factoren (toekomstverwachtingen en indirect ook het opleidingsniveau) zijn eveneens van invloed op de beleving van het regime. Er is in dit verband duidelijk sprake van een interpretatie-aspect.

Wat is nu precies de betekenis van de detentie-omgeving, in het bijzonder van de beleving van het regime, voor de waargenomen mogelijkheden voor zelfherstel? De betekenis van deze factor lijkt hier vooral van modererende aard te zijn. De inrichtingsorganisatie kan via de eigenschappen van het regime een bepaalde mate van motivatie, die gedetineerden reeds lijken te hebben op grond van bepaalde persoonlijke ( pre-detentie) factoren, versterken of 
afbreken. Met andere woorden, via het regime kan de inrichtingsorganisatie gedetineerden tot op zekere hoogte aanmoedigen of ontmoedigen in hun houdingen en gedrag ten aanzien van resocialisatie.

Tot op zekere hoogte staat met opzet in cursief gedrukt, want, zo geven de analyses aan, de houdingen lijken ook indirect te worden beïnvloed door een proces waarop men als inrichtingsorganisatie doorgaans minder greep heeft, namelijk het prisonisatie-proces.

Uit de analyses van dit hoofdstuk blijkt een duidelijke dynamiek in de houdingen van gedetineerden ten aanzien van resocialisatie. Deze dynamiek kan men op plausibele wijze onder meer relateren aan een prisonisatie-proces.

Naarmate men langer in detentie verblijft en men nog betrekkelijk ver verwijderd is van het ontslag uit detentie, ontwikkelt zich in de houdingen ten aanzien van resocialisatic een negatieve tendens. Gedetineerden lijken minder overtuigd van het belang van resocialisatie, men ziet minder mogelijkheden en kansen in dit opzicht en ook in de deelname en beleving van de activiteiten is, althans bij een deel van de langgestraften een neerwatartse trend te bespeuren. Voorts wordt ook het regime in meer negatieve, restrictieve zin beleefd, terwijl objectief, in de regelgeving van het regime, voor langgestraften juist sprake is van minder beperkingen in vergelijking met bijvoorbeeld de beginfase van de detentie in een HVB-regime.

Uit deze negatieve ontwikkeling in de houdingen van gedetineerden kan men de vermoedelijke werking van een prisonisatie-proces afleiden.

Dit proces werd als volgt beschreven. De lasten van een langdurig verblijf beginnen zwaarder te wegen en men hanteert de vernederende detentiesituatie door middel van een strategie van heroriëntatie. Men wendt zich af van vergelijkingspatronen die conventionele waarden en normen belichamen en keert zich vervolgens tot een gedetineerdensubcultuur met deviante of oppositionele waarden en normen waarbinnen men wel een positief zelfbeeld kan handhaven. Een bepaalde mate van oppositie die kenmerkend is voor de gedetineerdencultuur resulteert vervolgens in een perceptie van het regime die sterker in teken staat van verzet, van het vergroten van de afstand tot het personeel en van onderling wantrouwen. En een negatieve beleving van het regine heeft, naar werd verondersteld, weer repercussies voor de manier waarop men denkt over resocialisatie en voor de houding ten aanzien van de activiteiten.

De voorgaande beschrijving van het prisonisatie-proces plaatst de houdingen van gedetineerden ten aanzien van resocialisatie in essentie in het kader van een proces van aanpassing aan de detentie-omgeving. Een belangrijk resultaat van de analyses uit dit hoofdstuk is voorts dat de aanpassing aan een langdurige detentie niet voor alle gedetineerden gepaard gaat met een sterkere oriëntatie op een gedetineerdencultuur met alle negatieve gevolgen voor hun houdingen van dien. Er is tevens een tegengestelde trend te bespeuren bij een bepaalde groep langgestraften in de middenfase van de detentie die juist neerkomt op een zeer actieve deelname en zeer positieve beleving van met name ontwikkelingsactiviteiten als onderwijs en kunstzinnige vorming.

De deprivaties verbonden aan de detentie drijven bij wijze spreken niet iedereen in gelijke mate in de armen van een negatieve gedetineerdencultuur. Er zijn ook langgestraften die de deprivaties en spanningen van een langdurige detentie trachten te hanteren op een wijze die men zou kunnen omschrijven als meer probleemgericht en constructief. Men vlucht niet in passiviteit, isolement, druggebruik en afgeven op of ondermijnen van het systeem, maar men schept een niche waarbij men bij de beleving van de activiteiten sterk het accent legt op persoonlijke ontplooiing en ontwikkeling. Opvallend is dat deze groep langgestraften de activiteiten ook nauwelijks lijkt te gebruiken als een middel om de directe spanningen of 
ongemakken van het gedetineerd zijn te reduceren. Dit heeft deels te maken met de specifieke problematiek van het uitzitten van een langdurige detentie waarbij behoeften als het geestelijk in beweging blijven, het vinden van een bepaald (levens)doel en het handhaven van de eigen identiteit een belangrijke rol kunnen spelen. Deels hangt de voorkeur voor een meer constructieve invulling van een langdurige detentie ook samen met persoonlijke, individuele kenmerken van gedetineerden.

Bij de bespreking van de onderzoeksresultaten die een bepaalde dynamiek in de houdingen ten aanzien van resocialisatie laten zien, werd niet alleen de middenfase van de detentie onder de loep genomen. Ook de beginfase en de eindfase van de detentie kwamen aan de orde. In de literatuur veronderstelt men een dynamiek die verloopt volgens een U-vormige curve. De houdingen zijn aan het begin en einde van de detentie het meest positief en gedurende de middenfase het minst positief. Een dergelijke curve bleek na analyse ook bij de houdingen ten aanzien van resocialisatie aanwijsbaar, zij het niet in zuivere vorm. De houdingen van langgestrafte gedetineerde in de middenfase vertonen, zoals wij zagen, geen uniform negatief beeld.

$\mathrm{Bij}$ de verklaring van met name de meer positieve opvattingen in de beginfase van de detentie werd nader ingegaan op de specifieke problematiek van deze fase. Het begrip 'shock of incarceration'werd geintroduceerd en toegelicht van uit de stressvolle omstandigheden van de beginperiode van de detentic. Vervolgens werd de aard van de houdingen gerelateerd aan het begrip hanteringgedrag in het bijzonder aan een tijdelijke oriëntatie op meer probleemgerichte vormen van stresshantering.

Een belangrijk inzicht dat niet alleen deze maar ook de andere analyses met betrekking de omgevings-en persoonsgebonden determinanten van de houdingen ten aanzien van resocialisatie opleveren, is het volgende.

De visie waarin de aard van de houdingen ten aanzien van resocialisatie uitsluitend wordt verklaard vanuit de aanpassing aan een stressvolle, depriverende omgeving is onvolledig. Het aspect van aanpassing en stresshantering kunnen bij de verklaring van de aard van de houdingen weliswaar op vrij plausibele wijze worden ingepast, maar zij verklaren niet alles.

De verschijnselen die in deze studie met betrekking tot de houdingen van gedetineerden werden aangetroffen duiden steeds op een (interactie)effect van zowel persoons- als omgevingsgebonden factoren. Integratie van beide typen variabelen leidt tot een meer volledige en adequate verklaring van de gevonden verschijnelen.

Een laatste en zeker niet de minste conclusie die op grond van de analyse van de gegevens kan worden getrokken betreft de invloed van de omgevingsgebonden factoren. Vooral als men de programma-integriteit of de factoren in randvoorwaardelijke sfeer eveneens als een, in essentie omgevings- of situatiegebonden factor beschouwt, dan valt het overwicht, in termen van het grootste deel van de verklaarde variantie van de omgevingsgebonden factoren op.

In concreto betekent dit voor het beleid in de inrichting dat met name het regime en de factoren in randvoorwaardelijke sfeer als een belangrijk aangrijpingspunt kunnen fungeren voor de beïnvloeding van de houdingen van gedetineerden ten aanzien van resocialisatie. Beleid in inrichtingen ten aanzien van resocialisatie van gedetineerden ontbeert veelal een basis in de vorm van empirisch ondersteunde veronderstellingen. Besluitvorming met betrekking tot investeringen in zorg, gericht op de voorbereiding van de terugkeer in de samenleving, kan met de informatie die in dit hoofdstuk werd gepresenteerd in ieder geval worden voorzien van een wat steviger fundament in empirisch wetenschappelijke zin.

Met dit hoofdstuk is het beeld van het functioneren van het proces van zelfherstel voor wat 
betreft de houdingen van de gedetineerden afgerond.

Tenslotte, als er één belangrijk resultaat aan dit beeld kan worden verbonden is het wel dit: het laat zien dat een proces van zelfherstel in de context van een gevangenisomgeving een buitengewoon complex verschijnsel is, waarover wij in wetenschappelijke zin eigenlijk nog maar weinig weten. De penologische kennis staat hier nog volstrekt in de kinderschoenen.

Hoe het personeel in de inrichting als relevante actoren in het proces van zelfherstel en als vormgever van het regime tegen de resocialisatie-opdracht aankijkt, is een onderwerp dat in het volgende hoofdstuk in empirische zin wordt onderzocht. 


\title{
HOUDINGEN VAN HET PERSONEEL TEN AANZIEN VAN RESOCIALISATIE
}

\begin{abstract}
"Zolang personeel gevangenen slechts ziet als waardeloze brekebenen en non-valeurs, zal een zichzelf waarmakende voorspelling in werking treden en een antagonistische sfeer ontstaan. Als gevangenispersoneel gevangenen benadert als mensen die verantwoordelijkheid kunnen en willen dragen voor hun eigen toekomstige leven, kan een ontspannen klimaat van wederzijdse ondersteuning en samenwerking tot ontwikkeling komen." (Tulkens, 1999, p.96)
\end{abstract}

\section{$9.1 \quad$ Inleiding}

Sinds de introductie in de negentiende eeuw van de cellulaire gevangenis in West-Europa en Noord-Amerika heeft dit instituut een ontwikkeling doorgemaakt die men vooral dient te beschouwen in het licht van het denken over misdaad en straf. Naarmate in het denken over de vrijheidsbenemende sanctie in de loop van de twintigste eeuw steeds meer plaats werd ingeruimd voor andere doeleinden dan louter vergeldende, werden de taken van de gevangenis en het (bewarend) personeel uitgebreid en daarmee in zekere zin ook gecompliceerder.

Zo beperkte de taak van de bewaarder eind jaren veertig van de twintigste eeuw in een overwegend hiërarchisch penitentiair stelsel, zich voornamelijk tot bewaking en verzorging van gedetineerden door middel van een regime dat een sterk beroep deed op de handhaving van orde en tucht. Met de intrede van het resocialisatie-doel in het formele penitentiaire beleid in de decennia erna, wordt de taakstelling van de bewaarder of inrichtingswerker veel breder en meer complex. Bovendien krijgen specialisten op het gebied van hulpverlening, scholing en vorming een plaats in de penitentiaire organisatie.

Volgens de Nota Taak en Toekomst (1982) die men kan beschouwen als een beleidsmatige overgang van een gedifferentieerd penitentiair stelsel naar een autonoom stelsel (Kommer, 1991), omvatten de taken van de inrichtingswerker de bejegening, begeleiding en beveiliging. Onder bejegening dient men te verstaan de humane wijze van omgaan met gedetineerden. Begeleiding wordt omschreven als het daadwerkelijk bijdragen aan de verwezenlijking van de doeleinden van de detentie door gedetineerden individueel en groepsgewijs te stimuleren in hun bezigheden. En onder beveiliging kan men verstaan het voorkomen van ontvluchtingen en het bevorderen van een ordelijke gang van zaken.

In de Nederlandse inrichtingen wordt sindsdien op grond van de Nota Taak en Toekomst en een tweetal andere nota's uit de jaren tachtig (de Nota inzake een herziene Gestandaardiseerde Inrichtingsstructuur en de functie van Inrichtingswerker of wel de GIS-nota uit 1981; de Nota inzake het Regiemsactiviteiten-programma of wel de RAP-nota uit 1983) de 
bewaarder of penitentiair inrichtingswerker formeel een belangrijke taak gegeven bij de begeleiding en bejegening van de gedetineerden. Bij de uitvoering van het regimesactiviteiten-programma vervullen zij ten aanzien van activiteiten in de leef-ontwikkelings-en arbeidssector een centrale rol. Zij worden ingezet bij de begeleiding van kunstzinnige vorming, sport en recreatie. Volgens de GIS-nota levert de PIW-er een belangrijke bijdrage aan de voorbereiding van de terugkeer in de samenleving met name via de begeleidende en bejegenende taak.

Het realiseren van de beleidsmatige uitgangspunten van de nota Taak en Toekomst voor wat betreft de begeleidende en bejegenende taken van de inrichtingswerker is niet onverdeeld voorspoedig verlopen. Het zijn vooral de steeds weer terugkerende bezuinigingen geweest die het optimaal realiseren van de uitgangspunten van Taak en Toekomst al gauw belemmerden (Moerings, 1984).

Tien jaar na het verschijnen van Taak en Toekomst. als men in veel inrichtingen in de ontwikkelingssector met name bij activiteiten als onderwijs en kunstzinnige vorming nog volop worstelt met de adequate implementatie van de uitgangspunten van deze nota, begint men met de herijking van het vigerende beleid op grond van de Nola Werkzame Detentie (1994). De versobering van de regimes op basis van deze nota betekent in de praktijk een zekere mate van uitholling van de begeleidende en bejegende taken van de PIW-ers. Het aantal uren voor activiteiten op het gebied van scholing, hulpverlening, kunstzinnige vorming en ontspanning wordt in veel inrichtingen verminderd ten faveure van een standaardregime waarin de arbeid centraal staat. Begeleiding van activiteiten door PIW-ers in de ruime geest van de nota Taak en Toekomst wordt niet meer mogelijk en wenselijk geacht. In de periode rondom het verschijnen van de nota Werkzame Detentie in 1994 zien we bovendien in de media een toenemend aantal berichten verschijnen waarin onder meer ook gevangenispersoncel zich kritisch uitlaat over de zin van het activiteitenaanbod zoals dat totnogtoe op grond van de nota Taak en Toekomst werd gedaan. Men twijfelde met verwijzing naar de verzwaring van de gedetineerdenpopulatie aan de geschiktheid van de gedetineerden voor de verschillende vormende activiteiten en indirect, eigenlijk ook aan hun motivatie om de voorbereiding van de terugkeer in de samenleving serieus ter hand te nemen. Deze ontwikkeling halverwege de jaren negentig zou wellicht kunnen duiden op een verminderde steun van gevangenispersoneel in het penitentiaire veld voor de resocialisatie-gedachte. In 1993 schrijft Helgers in NRC-Handelsblad over deze bewaarders :

"Ik zie geen oude eerlijke boeven meer, zeggen de oudere gevangenisbewaarders. Dat klopt. Ze bestaan nauwelijks nog in onze gevangenissen. Maar het is wel deze categorie van "oude, eerlijke boeven" waarop ons beleid was afgestend. Een beleid gericht op humanisering van detentic, erop gericht om gedetineerden aan zo weinig mogelijk beperkingen te onderwerpen en gericht op verbetering en zelfs heropvoeding van de delinquent" (NRC-Handelsblad, maart 1993)

Hoe gevangenispersoneel in het bijzonder de bewaarder of PIW-er denkt over de zorg voor gedetineerden en over een detentiedoel als de voorbereiding van de terugkeer in de samenleving is, althans in Nederland, vrij zelden voorwerp van wetenschappelijk onderzoek geweest. Recent onderzoek is zeer schaars. Het laatste omvangrijke onderzoek onder PIW-ers werd halverwege de jaren tachtig verricht en concentreert zich vooral op de oorzaken van het ziekteverzuim onder PIW-ers (Kommer,1991). De lacune in de kennis van de houding van het gevangenispersoneel ten aanzien van resocialisatie vormt een eerste aanleiding voor onderzoek.

Onderzoek van de houdingen van gevangenispersoneel ontleent zoals ik in hoofdstuk 1 liet zien, zijn belang vooral aan het streven naar het behoud en ontwikkeling van een humane detentie waarin ruimte is voor sociale perspectieven van gedetineerden. Die ruimte, hoewel 
aan beperkingen onderhevig binnen een, in principe beveiligingsgerichte gevangenisorganisatie is de moeite van het verdedigen waard. Voor een dergelijk streven is echter kennis vereist van het resocialisatie-proces zoals zich dat tijdens de detentie voltrekt.

Zowel het gevangenispersoneel als gedetineerden interacteren in het proces van zelfherstel. De manier waarop beide partijen zich tijdens dit proces opstellen is van invloed op het verloop en de uitkomsten van het resocialisatie-proces. Door nict alleen gedetineerden maar ook het gevangenispersoneel te vragen naar hun beleving en opvattingen inzake resocialisatie ontstaat een meer volledig beeld van de wijze waarop in de penitentiaire inrichting gestalte wordt gegeven aan dit detentiedoel. Tevens verkrijgt men door een onderzoek van de houdingen van alle betrokken partijen een beter beeld van de determinanten van het psychosociale klimaat.

Een dergelijk klimaat is van groot belang voor een adequate zorg voor gedetineerden waarin rekening wordt gehouden met de schadelijke aspecten van de detentie en met de behoeften van gedetineerden aan maatschappelijk perspectief '. Het is evenwel onvoldoende duidelijk hoe het gevangenispersoneel feitelijk gestalte geeft aan de psycho-sociale kwaliteit van de gevangenisgemeenschap en met welke opvattingen en intenties dit gepaard gaat ${ }^{2}$. In het onderhavige onderzoek van de houdingen van het gevangenis zijn in dit verband de volgende onderzoeksvragen als uitgangspunt geformuleerd:

1.Op welke wijze denkt het gevangenispersoneel over de doelen van de vrijheidsstraf in het algemeen, en over resocialisatie als detentiedoel in het bijzonder?

Ten aanzien van de begeleidingstaak van de PIW-er in het bijzonder die waar het de creaactiviteiten betreft de luiden de onderzoeksvragen aldus:

2.Op welke wijze geeft de PIW-er in zijn handelen uitdrukking aan de verschillende detentieen regimesdoelstellingen?

3.Hoe beoordeelt de PIW-er de motivatie en motieven van gedetineerden voor deelname aan de activiteiten in het bijzonder de kunstzinnige vorming?

4. Welke verwachtingen heeft de PIW-er van de effecten die de activiteiten sorteren, in het bijzonder de activiteiten op het gebied van kunstzinnige vorming?

5.Welke relaties bestaan er tussen enerzijds bepaalde opvattingen over resocialisatie en anderzijds de manier van omgang van de PIW-er met gedetineerden, het oordeel over de randvoorwaarden en de effecten met betrekking tot de kunstzimige vorming?

\footnotetext{
'Wentink (1993) meent dat het psycho-sociale klimaat primair wordt bepaald door de houdingen van de medewerkers (management, afdelingshoofden, PIW-ers, werkmeesters) ten opzichte van het werk en de gedetineerden. Is deze houding overwegend negatief (gekleurd door cynisme en desillusie) dan is het klimaat in de inrichting eveneens overwegend negatief.

Zo concludeerde Grapendaal (1987) in zijn onderzoek naar de aanwezigheid van een gedetineerdensubcultuur in een drietal Nederlandse gevangenissen dat in vervolgonderzoek met name de invloed van specialisten als maatschappelijk werkers, geestelijke verzorgers, onderwijzers, sportinstructeurs op de gevangenisgemeenschap nader zou moeten worden onderzocht. Niet alleen het bewarend personeel drukt een belangrijk stempel op de organisatie en de kwaliteit van de detentie, ook specialisten en de directie spelen hier een belangrijke rol die in de onderzoeksliteratuur betrekkelijk onderbelicht is gebleven.
} 
6. Hoe denkt het personeel, betrokken bij de aitroering van de resocialisatieopdracht over de plaats van deze activiteiten in de organisatie, in het bijzonder over samenwerking. ondersteuning, plaats in het regimesactiviteitenprogramma, informatievoorziening, secundaire ondersteuning en waardering door collega's en leiding en materiaal en middelen?

Alvorens de resultaten van de enquête onder het gevangenispersoneel te bespreken wordt een overzicht gegeven van de relevante onderzoeksliteratuur.

\subsection{Houdingen van het personeel ten aanzien van resocialisatie: een literatuuroverzicht}

\subsubsection{PIW-ers en hun opvattingen over de resocialisatiedoelstelling}

$\mathrm{Bij}$ de introductie in de jaren zestig van de twintigste eeuw van het resocialisatie- of behandelingsdoel in de inrichtingsorganisatic constateerden sommige onderzoekers dat bewaarders veelal een taakopvatting hadden die niet strookte met het officiële beleid waarin van hen juist een meer gedetineerdengerichte houding werd gevraagd. Deze aanwezigheid van waarden en normen onder het uitvoerend personeel van gevangenissen die afwijken van het officiële beleid duidt men ook wel aan met het begrip "bewaarderssubcultuur".

De meeste studies laten zien dat als het gaat om bepaalde voorkeuren van bewaarders bij hun taakopvatting er sprake is van pluralisme. Zo vond Grapendaal (1987) onder het bewaarderscorps van dric Nederlandse inrichtingen grofweg gezegd drie stijlen van taakopvatting.

Een groep bewaarders legt in de taakopvatting de prioriteit vooral bij het leggen van persoonlijke relaties met gedetineerden. Deze groep heeft meer oog voor de problemen van gedetineerden en hanteert daarbij de regels en voorschriften op een soepele wijze. De werkstijl van deze categorie is meer gedetineerdengericht. Een tweede groep legt veel meer de nadruk op het handhaven van orde en rust in de inrichtingen. Men benadert de gedetineerden met een zekere mate van wantrouwen en de naleving van de regels en voorschriften staat voorop. Tenslotte is er nog een derde categorie bewarders die cen onverschillige houding aannemen. $\mathrm{Zij}$ leggen geen uitgesproken accenten in hun taakopvatting. In de praktijk worden de meer gedetineerdengerichte bewaarders aangeduid als de "Sinterklazen" en de meer ordegerichte bewaarders als de "Zwarte Pieten".

Andere onderzoekers (Kauffmann, 1988: Kommer, 1990) komen tot een vergelijkbare conclusie: er is sprake van verscheidenheid aan opvattingen. Dit neemt echter niet weg dat volgens sommigen (Kauffman,1988) een bepaalde taakopvatting, met name de antigedetineerdenhouding de boventoon kan voeren. Bij een dergelijke dominantie van een bepaalde takkopvatting hoeft er geenszins sprake te zijn van een meerderheid van het personeel. Een minderheid kan blijkbaar de toon zetten ook in de ogen van de andersdenkende collega's. In dit verband hanteert men in de onderzoeksliteratuur het begrip "pluralistic ignorance".

Dit begrip duidt op het feit dat bewaarders niet goed op de hoogte zijn van de verschillende opvattingen van hun collegae. De meer gedetineerdengerichte bewaarder denkt dat hij met enkele andere collegae volkomen alleen staat temidden van een meerderheid die weinig op heeft met gedetineerden. Terwijl de bewaarders met een sterke anti-gedetineerdengerichtc houding ervan uitgaan dat iedereen het met hen eens is. Blijkbaar is er onder bewaarders sprake van een discrepantie tussen privé-opvattingen en de opvattingen die men er op het werk, te midden van de collegae erop na houdt. 
Ofschcon men als individu in de privé-sfeer een meer gedetineerdengerichte houding toejuicht, gaat men er veelal toch vanuit dat collega-bewaarders in het algemeen een dergelijke houding afkeuren en dat zij veel meer werken vanuit een ordegerichte houding.

Een dergelijke vorm van 'pluralistic ignorance' houdt een collectieve, ordegerichte manier van interacteren in stand eenvoudig weg omdat men is bevreesd voor sancties van collegae. Bijgevolg is men sterk geneigd om in gezelschap van collegae een duidelijk ordegerichte houding te etaleren, terwijl men privé als individu er toch anders over denkt. (Cullen, 1989) Volgens Kommer (1991) is er onder Nederlandse bewaarders, althans aan het einde van de jaren tachtig van de twintigste eeuw, geen sprake van een bewaarderssubcultuur, noch van een 'pluralistic ignorance'. Er lijkt geen sprake van een, op grote schaal afwijzen van het overkoepelend beleid en men is goed op de hoogte van het feit dat er onder collegae verschillende opvattingen bestaan, zonder dat men zich daardoor geïsoleerd voelt.

Cullen et al. (1989) concluderen op grond van onderzoek uit de jaren zeventig en tachtig met betrekking tot de opvattingen van Amerikaanse bewaarders dat het populaire beeld van de bewaarder als een autoritaire functionaris die misvormd is door het werken in een inhumane omgeving, niet strookt met de feiten. Ook Cullen et al. concluderen dat er sprake is van pluralisme en dat bewaarders niet simpelweg kiezen voor een punitieve en ordegerichte opstelling zonder meer.

$\mathrm{Zij}$ achten het van belang de opvattingen van bijvoorbeeld bewaarders over resocialisatie, zelfs in een periode waarin resocialisatie als doelstelling van het penitentiaire beleid aan belang heeft ingeboet, te onderzoeken.

Zij gaan er immers op empirische gronden vanuit dat de resocialisatie-gedachte nog steeds aanhang heeft in kringen van beleidsfunctionarissen, het publiek en het gevangenispersoneel in het werkveld. Van een algehele verwerping van de resocialisatie-gedachte is, volgens Cullen et al. op basis van de empirische gegevens in ieder geval geen sprake. Integendeel, het grootste deel van de survey-data laat eerder het tegendeel zien. Zij concluderen voor wat betreft de opvattingen van het Amerikaanse publiek in de jaren zeventig en tachtig dat resocialisatie nog steeds als een belangrijke en nastrevenswaardige opdracht wordt gezien. En op grond van de bestaande onderzoeksliteratuur concluderen zij dat in het penitentiaire werkveld onder het personeel evenmin sprake is van een volledige verwerping van het resocialisatie-ideaal.

Het onderzoek dat Cullen et al. onder Amerikaans penitentiair inrichtingswerkers verrichtten, levert als belangrijkste conclusie op dat zij het beveiligingsdoel weliswaar als een zeer belangrijk onderdeel van hun taak zien, maar dat dit geenszins een negatieve houding impliceert ten aanzien van penitentiaire programma's die gedetineerden kansen op zelfherstel bieden. Bewaarders zien deze programma's en de resocialisatie-opdracht juist als een welkome gelegenheid om hun werk meer diepgang te geven.

Over het onderzoek van de opvattingen van bewaarders ten aanzien van resocialisatie merken zij verder nog op dat het aantal studies schaars is en dat zij methodologisch gezien een nogal rudimentair karakter dragen.

Zoals wij reeds in de inleiding opmerkten is het onduidelijk hoe Nederlands gevangenispersoneel in de jaren negentig over de resocialisatie-doelstelling denkt. Empirisch onderzoek in het bijzonder met betrekking tot de opvattingen van de Nederlandse bewaarders is niet voor handen. Derhalve is het zinvol om de opvattingen van bewaarders over de zin van de vrijheidsstraf in het algemeen en over de resocialisatie-opdracht als detentiedoel te onderzoeken.

In het kader van de geformuleerde onderzoeksvragen werd tevens de vraag gesteld wat het betekent voor het gevangenispersoneel een beveiligende taak te combineren met begelei- 
dende en bejegenende taken. In de volgende paragraal zal dit onderwerp aan de hand van de literatuur nader worden uitgewerkt.

\subsubsection{Detentiedoelen en de taakopvattingen van de PIW-er}

De vraag wat het betekent voor de organisatie van de penitentiaire inrichting en in het bijzonder voor het gevangenispersoneel, een beveiligende taak te combineren met een bejegeningstaak onder meer uit hoofde van de resocialisatie-opdracht, is met name in Amerikaanse studies van de penitentiaire organisatic voorwerp van onderzoek geweest. Wat deze organisatic-sociologische en psychologische studic van de gevangenisgemeenschap betreft, kan men in de Verenigde Staten spreken van een rijke traditie. Centraal binnen deze onderzoekstraditie staat de relatie tussen de organisatiedoelen en het functioneren van de inrichtingsorganisatie. Een belangrijk thema vormen de conflicten die ontstaan binnen de organisatie als de traditionele beveiligingstaak wordt gecombineerd met bejegenende taken. Conflicten in organisaties kunnen uiteindelijk een bedreiging vormen voor het functioneren van de organisatie en het persoonlijk welzijn van het personeel.

Vanuit cen meer theoretische benadering concludeert Cressey $(1959,1960)$ dat de moderne gevangenis wordt gekenmerkt door de aanwezigheid van een drietal hiërarchische systemen die gericht zijn op bewaking, dienstverlening aan gedetineerden en op het gebruik van hun arbeidskracht. Elk van deze systemen heeft een eigen wijze van benadering van gedetineerden en van onderlinge afstemming is veelal geen sprake. De positie van de bewaarder binnen de organisatie waarin de resocialisatie- of behandelingsgedachte eveneens een rol speelt, wordt veel complexer doordat bewaarders meer moeten doen dan louter bewaken. Zij moeten doorverwijzen naar hulpverleners of de professionals van de dienstverlening en zij treden ook op als een soort leke-hulpverlener, zij zullen zich immers ook bezig moeten houden met bejegenen en begeleiden. Volgens Cressey manifesteert de tegenstrijdighcid van de verschillende opdrachten zich bij uitstek in het werk van de bewaarders. Hij spreekt hier van een organisatorisch dilemma waarbij bewaarders over betrekkelijk weinig middelen beschikken om de gedetineerden te laten doen wat van hen wordt verwacht. Afwijken van de regels wordt vervolgens een belangrijk middel om macht over de gedetineerden te behouden. In Nederland heeft Zwezerijnen (1972) zich met hetzelfde onderwerp beziggehouden en hij concludeert dat bewaarders als gevolg van de introductie van de resocialisatie-opdracht steeds terughoudender worden in hun ongang met gedetineerden juist vanwege een verminderd vermogen om orde en veiligheid te garanderen. Onderzoek vanuit het perspectief van de gevangenis als organisatie werd voorts door auteurs als Zald (1962); Grusky (1959); Ohlin (1958); Street et al.(1966) verricht en hun conclusies zijn vergelijkbaar met die van Cressey.

In de loop van de jaren zeventig en tachtig ontwikkelt zich tevens cen onderzoekstroming die zich specifiek richt op de problemen die de bewaarder in de moderne gevangenisorganisatie ondervindt. In deze studies is het organisatieperspectief minder belangrijk, het accent ligt vooral op de vraag hoe bewaarders het werken in een gevangenis beleven (Blokland, 1974; Lombardo, 1981; Klofas en Toch, 1983; Kauffman,1988; Kommer. 1991). Een belangrijk thema in dit type onderzoek is de tegenstrijdigheid van de verschillende opdrachten aan het bewarend personeel en de eventueel daaruit voortvloeiende rolconflicten.

Als belangrijkste consequenties van een rolconflict worden in de literatuur genoemd terugtrekking, een passieve opstelling, het zich concentreren op slechts één taak en onverschilligheid. 
Het rolconflict met betrekking tot het dienstverlenende en beveiligende aspect van het werk is ook voor het onderwerp van de studie van belang. De actieve, begeleidende rol die bewaarders bij de begeleiding van crea-activiteiten hebben gekregen, kenmerkt zich wellicht ook door de aanwezigheid van een conflict tussen enerzijds de beveiligende en anderzijds de dienstverlenende en bejegenende rol.

Uit een tussentijds evaluaticonderzoek met betrekking tot de opleiding of kadertraining creatieve vaatrdigheden voor bewaarders door van Hooff en van Zeijl ( I984) blijkt echter dat PIW-ers bij het begeleiden van creatieve vaardigheden, die een bijdrage dienen te leveren aan de persoonlijke ontwikkeling van gedetineerden, geen conflicten crvaren tussen de beveiligende en bejegenende en begeleidende aspecten van hun werk. In de volgende paragraaf zal dil onderzoek nader worden besproken.

Op grond van bij voorbeeld studies als die van Kommer (1991) en Lombardo (1981) mag men concluderen dat in de praktische uitvoering van het werk voor de meeste PIW-ers de doelen wel degelijk verenigbaar zijn als zij daartoe maar de gelegenheid krijgen in de vorm van bij voorbeeld een grotere mate van autonomie. Uit de studic van Kommer blijkt overigens ook dat naarmate inrichtingswerkers ouder zijn, meer werkervaring hebben opgedaan en meer opleiding hebben gehad, hun houding ten aanzien van gedetineerden en van doelstellingen als resocialisatic en een humane tenuitvocrlegging, positiever zijn. Conflicten tussen de dienstverlenende taak en de heveiligingstakk worden alleen ervaren als gevolg van door de organisatie opgelegde beperkingen. Het uitvoeren van de beide taken als zodanig acht men dus wel mogelijk, echter de organisatic hindert de bewaarder als het ware bij een adequate taakvervulling

Zo schrijft Kommer het betrekkelijk hoge ziekteverzuim van de Nederlands PIW-ers vooral toe aan factoren die in de inrichtingsorganisatie besloten liggen namelijk, de onduidelijke positie van de bewaarder in de organisatie, gebrek aan autonomie en aan het ontbreken van goede communicatic. Kommer (p.318):

"Het probleem vanuit de optick van de PIW-er zit niet in de onverenigbaarheid van de strafdoelen maar in het feit dat de organisatiestructuur het hem onvoldoende mogelijk maakt om datgene te doen wat nodig is om die doelen to verenigen: "situationeel handelen vanuit vertrouwen in het eigen oordeel en kunnen."

Gelet op de uitkomsten van de hierboven besproken studies ligt het voor de hand eventueel door PIW-ers ervaren interne rolconflicten als belevingsaspect van hun taakuitoefening buiten beschouwing te laten. De resultaten van het onderzoek naar conflicten geeft veeleer aan dat de problemen zich concentreren rondom discrepanties tussen vermogens en middelen. In deze studie zullen wij volstaan met een onderzoek van de taakopvatting van de PIW-ers in meer beschrijvende zin door hen te vragen in welke mate orde-en gedetineerdengerichte aspecten in het eigen handelen aan de orde komen.

De discrepantic uussen vermogens en middelen zal in de volgende paragraaf als aspect van de begeleidende taak van de bewaarder aan de orde komen.

\subsubsection{De bewaarder als begeleider van activiteiten: de crea-bewaarder}

In de jaren tachtig resulteerden de veranderde eisen aan de tenuitvoerlegging van de gevangenisstraf in een verzwaring van de bewaardersfunctie.

Deze verzwaring hing samen met de volgende ontwikkelingen in het gevangeniswezen:

-een intensivering van de contacten tussen bewaarder en gedetineerden met name gelet op het tegengaan van detentieschade;

-de verminderde nadruk op regels en voorschriften die leidt tot situaties waarin een sterker beroep wordt gedaan op het eigen inzicht, oordeclsvermogen en initiatief van de bewaarder; 
-het minder handelbaar zijn van gedetineerden als gevolg van een sterker gevoelde tegenstelling tussen het leven in vrijheid en de vrijheidsberoving (nota Beleidsvraagstukken Gevangeniswezen, 1976, p.9);

-de verbeterde rechtspositie van de gedetineerden die voortvloeit uit het streven de tenuitvoerlegging humaan te laten zijn (Taak en Toekomst, p. 14);

-de intrede van met name externe deskundigen die gedetineerden qua faciliteiten meer te bieden hebben, hetgeen de bewaarder toch weer terugdringt in de positie van een pure toezichthouder terwijl het streven juist was de bewaarder een belangrijker plaats te geven in de begeleiding en bejegening (Taak en Toekomst, p.47);

-de verzwaring van de gedetineerdenpopulatie en capaciteitsproblemen.

In de nota's Taak en Toekomst, de Nota Inzake een herziene gestandaardiseerde Inrichtingsstructuur en de functie van Inrichtings werker (GIS -nota) en in de Nota inzake het Regimesactiviteitenprogramma (RAP-nota) wordt het beleid voor de jaren tachtig aangegeven. De GIS- nota schetst een model waarmee men een oplossing aandraagt voor de verzwaring van de bewaardersfunctie. Men voegt aan de traditionele beveiligingstaak de taken van bejegening en begeleiding toe. In het GIS-model neent de begeleidingstaak een belangrijke plaats in. De begeleiding wordt expliciet in verband gebracht met de voorbereiding van de terugkeer in de samenleving en de verwezenlijking van deze opdracht. De begeleiding draagt zowel een sociaal als een instrumenteel-technisch karakter. De bewaarder dient aan te sluiten bij de behoeften van de gedetineerden, hen te begeleiden bij het oplossen van hun problemen ten gevolge van het verblijf in de inrichting of hen daarvoor door te verwijzen, gedetineerden te sturen en eventueel te corrigeren in hun gedrag. Men gaat ervan uit dat de bewaarder instrumenteel- technisch in staat is bepaalde activiteiten voor te bereiden, uit te voeren en te begeleiden zodat hij bepaalde kennis en vaardigheden op de gedetineerden kan overbrengen. Voor het gevangeniswezen betekent deze grotere nadruk op de begeleidende taak van de bewaarder onder meer dat men minder externe deskundigen nodig heeft.

Voor de bewaarders betekent een en ander dat zij meer dan voorheen actief betrokken worden bij het activiteitenprogramma.

De uitbreiding en verdieping van de bewaardersfunctie via het GIS-model had tot gevolg dat er hogere eisen wat betreft kennis, vaardigheid en persoonlijkheid aan de bewaarders moesten worden gesteld, hetgeen weer consequenties had voor de opleiding van de bewaarder. De scholing werd verzorgd door de opleidingsorganisatie van het gevangeniswezen (toenmaals het CWOI of wel het Centraal Wervings-en Opleidings Instituut)

De inrichtingswerker kreeg in de eerste plaats een basisopleiding die moest garanderen dat de drie kerntaken op een adequate manier en in aansluiting op het in de inrichting bestaande regime werden uitgevoerd. Daarnaast kreeg de inrichtingswerker een aanvullende opleiding om de instrumenteel- technische activiteiten te kunnen begeleiden. Als de belangrijkste activiteiten die een specifieke instrumenteel-technische vaardigheid vereisen werd gekozen voor de sport en de kunstzinnige vorming.

Over deze kunstzinnige vorming merkt men in de Nota Taak en Toekomst dat creatieve handvaardigheid in alle inrichtingen een essentiële activiteit voor gedetineerden dient te zijn. Men baseert zich hierbij ondermeer op het uitgangspunt dat handvaardige activiteiten meer waardering vinden bij gedetineerden dan verbale activiteiten (zie ook het rapport "commissie Doelstelling en functie Huis van Bewaring, 1977) Het gevangeniswezen vond indertijd dat het aanbieden van creatieve activiteiten aan gedetineerden aansloot op de beleidsdoelstellingen zoals het tegengaan van schadelijke effecten van de detentie, het scheppen van ontplooiingsmogelijkheden en de voorbereiding van de terugkeer in de samenleving. 
In de tweede helft van de jaren tachtig gaat men binnen het gevangeniswezen aan de slag met de bijscholing van de bewaarders of inrichtingswerkers. Op het gebied van de kunstzinnige vorming wordt een cursus opgezet in samenwerking met de centra voor de kunstzinnige vorming in den lande. Het curriculum van de cursus wordt in samenwerking met het LOKV (Landelijke Ondersteuning Kunstzinnige Vorming) verder uitgebouwd en aangescherpt in het bijzonder op het punt van de vormingsdoelen. De bewaarder moest immers de activiteiten zo kunnen begeleiden dat de persoonlijkheidsontwikkeling van gedetineerden werd bevorderd. De vaardigheden van de bewaarder moesten het niveau van huisvlijtbegeleiding, dat sinds jaar en dag op beperkte schaal in de inrichtingen werd aangeboden, in ieder geval overstijgen. Vervolgens werden zeker tot halverwege de jaren negentig bewaarders opgeleid tot creabewaarders. Doel van deze cursus is de bewaarder niet zozeer om te vormen tot een professionele begeleider, maar hem/haar te scholen als een begeleider die met enig verstand van materialen en technieken en met een zekere didactische kennis in staat is zelfstandig een vormingsproces bij de gedetineerden op gang te brengen. De begeleiding van de kunstzinnige vorming door de PIW-er had daarnaast nog tot doel de relatie met de gedetineerden te verbeteren zodat men meer op voet van gelijkheid met elkaar kon omgaan. Hierbij ontleent de bewaarder zijn autoriteit niet aan het handhaven van de regels maar aan zijn persoonlijke vaardigheden. Tevens had men voor ogen de arbeidssatisfactie van het bewarend personeel te verbeteren.

Met de opleiding van de bewaarder tot crea-begeleider deed tegelijkertijd de crea-consulent zijn intrede in de inrichting. Docenten van de centra voor de kunstzinnige vorming die de crea-opleiding voor bewaarders verzorgden, gingen in de inrichtingen het vervolg op de basisopleiding Kunstzinnige Vorming voor bewaarders verzorgen. Doel was om in de tweede lijn de bewaarders te blijven begeleiden en bij te scholen in hun kunstzinnige en didactische vaardigheden.

Overziet men de jaarverslagen ${ }^{3}$ van de crea-consulenten vanaf het einde van de jaren tachtig tot en met de tweede helft van de jaren negentig dan kan men het volgende concluderen voor wat betreft de activiteitenbegeleiding en de rol van de crea-bewaarder in de inrichtingen.

In sommige inrichtingen en in sommige periodes, met name in de beginperiode toen er nog sprake was van een zeker elan en enthousiasme, wierp het voorgestane beleid zeker zijn vruchten af. Consulenten en bewaarders slaagden er inderdaad in de kunstzinnige vorming in de inrichtingen naar een hoger plan te tillen. Een blijvend effect van hun inspanningen is mijns inziens geweest dat men de drempel voor de introductie van de creatieve activiteiten in de gevangenis verlaagd heeft. Men heeft laten zien dat kunstzinnige vorming in de inrichting, mits de randvoorwaarden adequaat worden ingevuld, daadwerkelijk een waardevolle bijdrage kan leveren aan de detentiedoelen. Echter de voornemens zoals die in de jaren tachtig werden geformuleerd voor wat betreft de begeleidende rol van de bewaarder bij de kunstzinnige vorming blijken op grond van de jaarverslagen maar ten dele te zijn verwezenlijkt. De bijscholing en ondersteuning van de bewaarders door consulenten bleek al gauw, vanwege roostertechnische en financiële problemen, niet lang vol te houden. In de praktijk blijkt het toch uiterst moeilijk een groep bewaarders regelmatig vrij te stellen van hun andere taken om zich verder te bekwamen in het begeleiden van kunstzinnige vorming.

\footnotetext{
${ }^{3}$ Deze jaarverslagen zijn niet geplubiceerde, interne rapporten, die tot 1997 door de crea-consulenten werden opgesteld en werden toegestuurd aan de landelijke adviseur kunstzinnige vorming van de Dienst Justitiële Inrichtingen.
} 
Dat de doelstellingen van Taak en Tockomst en de GIS-nota voor wat betreft de begeleidende rol van de crea- bewaarder bij de kunstzinnige activiteiten wellicht wat te hoog gegrepen en, in zekere zin. ook vrij onduidelijk waren laat een evaluatieonderzoek zien dat in de aanloopperiode werd verricht door Van Hoofl en van Zeijl (1984).

Van Hooff en van Zeijl concluderen dat de diverse, bij het beleid betrokken instanties hun doeleinden voor het merendeel op een vrij hoog abstractieniveau formuleren. Men legt meer de nadruk op het bereiken van de als ideaal geziene eindsituatic dan op de manier waarop dic eindsituatie zou moeten worden bereikt.

Verder worden de effecten die men met de trainingen creatieve vaardigheden beoogt, onvoldoende uitgewerkt. Men blijft, wat de explicitering van de effecten betreft, steken in zeer globale begrippen zoals resocialisatie. relatieverbetering, het aanmoedigen van een open houding, creativiteitsontwikkeling e.d. Ook constateert men dat de centra die indertijd in een experimentele fase meewerkten aan de kadertrainingen voor bewaarders, geen systematisch uitgewerkte middelen hanteerden ter realisering van de beoogde effecten.

Hierbij dient echter te worden aangetekend dat in een later stadium, met name door inschakeling van het LOKV en het CWOl, de crea-opleiding qua opzet en beoogde middelen en doeleinden een zekere explicitering onderging. Niettemin kan men stellen dat dit euvel van weinig expliciet geformuleerde middelen en doeleinden naderhand toch steeds weer bleef terugkeren in de praktijk. In sommige inrichtingen beschouwt men meer huisvlijtachtige activiteiten zonder een vormend doel reeds als voldoende aan de mat voor de begeleidende taak van de bewaarder. In weer andere inrichtingen stelde men het juist op prijs dat huisvlijtachtige activiteiten zich meer gingen ontwikkelen in de richting van een activiteit waarbij de persoonlijke ontwikkeling van de gedetineerde aan bod kwam.

Van Hooff en van Zeijl concluderen na evaluatie van de beoogde effecten het volgende:

- Voor zover het doel van de crea-opleiding voor bewarders is een handvat aan te reiken teneinde hun bejegeningstaak meer inhoud te geven en wel door middel van intensiever contact met gedetineerden, sorteert het begeleiden van crea-activiteiten een positief effect.

- Voor zover het doel van de crea-activiteiten is bewaarders cen andersoortig gedrag aan te leren en verandering aan te brengen in de traditionele machtsongelijkheid tussen bewaarder en gedetineerde is er geen enkele aanwijzing dat de activiteiten dit doel naderbij brengen. Bewaarders lijken juist erop uit te zijn de afstand tussen hen en de gedetineerden te handhaven en men lijkt niet bereid de hun toegewezen autoriteit in te wisselen voor een meer op gelijkheid gebaseerde relatie. Interessant in dit opzicht is de bevinding dat bewaarders geen rolconflict ervaren tussen hun beveiligende en bejegenende laken op de ring en hun begeleidende taak op het gebied van kunstzinnige vorming

Men concludeert dat PIW-ers geen rolconflict ervaren omdat zij simpelweg alleen die leerdoelen onderschrijven en benadrukken die de traditionele machtsongelijke en op beveiliging gerichte rolverdeling instand houden. Bewaarders vermeden hun vormende en op de persoonlijke ontwikkeling van gedetineerden gerichte taak en concentreerden zich voornamelijk op ontspannend bezig zijn als doel van de activiteiten.

Een factor die belemmerend werkt op de bereidheid om aan de persoonlijkheidsontwikkeling van gedetineerden te werken, is dat zij daarbij bepaalde onderwerpen bespreekbaar mocten maken en daarover van gedachten moeten wisselen met gedetineerden. Van Hooff en van Zeijl stellen vervolgens dat men zich daarbij 'bloot' moet geven, iets van zichzelf moet laten zien. Het is daarbij moeilijk zich te verschuilen achter een bepaalde "deskundigheidsmacht", zoals dat wel mogelijk is bij bepaalde technische vaardigheden. De deskundigheid die voor het werken aan de persoonlijkheidsontwikkeling van gedetineerden noodzakelijk is, vraagt om een langdurige scholing op hoog niveau, aldus de onderzoekers. Men betwijfelt of de bewaarder de eerstaangewezen functionaris dient te zijn bij de persoonlijkheids- en creativi- 
teitsontwikkeling van de gedetineerde. Hiervoor is meer nodig dan het uitbreiden van didactische vaardigheden in de opleiding.

Uit de evaluatic van Van Hooff en van Zeijl blijkt dat het streven naar deskundigheidsmacht op het gebied van technische vaardigheden bij de crea-activiteiten daarentegen wel een belangrijke rol speelt.

Zij concluderen dat situaties waarin bewaarders verwachten dat gedetineerden het 'beter weten of kunnen' door hen als bedreigend worden ervaren. Deze situaties vormen aanleiding tot het herhaald verzock om meer materiaal en technische kennis. De bewaarders willen als begeleider status ontlenen aan een bepaalde deskundigheidsmacht in technisch, instrumentele zin. $\mathrm{Zij}$ wensen kortom vast te houden aan de traditionele zekerheden in hun rol als bewaarder.

Tenslotte constateren de onderzockers het volgende probleem op organisatorisch gebied.

De status van de crea-opleiding en de begeleidingstaak is volgens de bewaarders onduidelijk binnen het regime van de betrokken inrichtingen. Bewaarders uiten twijfels aan het belang dat er 'van bovenaf' wordt gehecht aan de cursussen en de financiële bereidheid om mee te werken aan oplossingen. Dergelijke problemen op het gebied van de positie binnen de organisatie en van een adequate invulling van de randvoorwaarden met name als het gaat om een voldoende begeleiding en bijscholing van de crea-bewaarder door professionele docenten, kan men beschouwen als zeer kenmerkend voor de praktijk van de kunstzinnige vorming binnen de inrichtingen zoals die zich na de jaren tachtig heeft ontwikkeld. Op basis van de jaarverslagen van de crea-consulenten kan men stellen dat de situatie in veel inrichtingen met betrekking tot de randvoorwaarden van bij- voorbeeld de kunstzinnige vorming en de begeleidersrol van de PIW-ers betrekkelijk problematisch is gebleven. Het is geen activiteit die structureel en formeel een duidelijke plaats volgens de oorspronkelijke uitgangspunten van het beleid binnen het regime heeft verworven.

Integendeel met de invoering van het beleid gebaseerd op Werkzame detentie is de positie van de kunstzinnige vorming binnen de inrichtingen steeds meer onder druk komen te staan. In sommige inrichtingen zijn de kunstzinnige activiteiten helemaal van het programma verdwenen, vrijwel nergens worden crea-bewaarders nog regelmatig ondersteund en begeleid door de crea-consulent. Thans is de praktijk in veel inrichtingen dat een professionele docent of consulent zelf de groepen begeleidt en de bewaarder met zijn crea-opleiding weer gewoon fungeert als toezichthouder. Voor zover bewaarders met een crea-opleiding nog de crea begeleiden, geldt in het algemeen dat deze begeleiding zeker niet steeds beantwoordt aan de, in de jaren tachtig gestelde vormende doelen. De veelal ontbrekende gelegenheid om door een consulent in dit opzicht te worden ondersteund en getraind maakt dat in veel situaties de crea al snel weer vervalt tot puur ontspannend bezig zijn op het niveau van huisvlijt. Voor zover het gestelde doel van de persoonlijkheidsontwikkeling in de crea-activiteiten werd verwezenlijkt in het afgelopen decennium, dan was dit steeds dankzij een intensieve ondersteuning van bewaarders door consulenten, hoofden SKW en inrichtingsdirecties die de oorspronkelijk doelstellingen hoog in het vaandel schreven.

Het hierboven besproken onderzoek van Van Hooff en van Zeijl is binnen het wetenschappelijk onderzoek van de gevangenis als een uniek onderzoek te beschouwen. Het is afgaande op de bestaande onderzoeksliteratuur eigenlijk de enige wetenschappelijke bron waarin de ervaringen van bewaarders met kunstzinnige vorming op een wetenschappelijke manier worden benaderd.

De vraag is echter in hoeverre de bevindingen uit de jaren tachtig nog actueel zijn. Een aantal conclusies met name die op het gebied van de weerstand van de bewaarders tegen de vormende doelen en de minder gunstige organisatorische condities waaronder men moet 
werken lijken aan actualiteit niets te hebben ingeboet. De problemen die kenmerkend waren voor de jaren tachtig, slepen zich voor het merendeel in het volgend decennium voort.

Toch lijkt het zinvol in de jaren negentig de mening van de bewaarders over de creaactiviteiten te onderzoeken.

In de eerste plaats om de recentelijk steeds vaker geuite veronderstelling dat de huidige gedetineerdenpopulatic minder ontvankelijk zou zijn voor het activiteitenaanbod nog eens te toetsen. Bewaarders zal dan ook worden gevraagd naar hun mening over de motieven en motivatie van gedetineerden waar het hun deelname aan de activiteiten betreft.

In de tweede plaats lijkt het zinvol ook in de jaren negentig de houdingen van bewaarders ten aanzien van de effecten van de kunstzinnige vorming en van de organisatorische inbedding van deze activiteit te onderzoeken. Dergelijk onderzoek is wellicht interessant vanwege de mogelijke aanwezigheid van een 'groeiproces' waardoor men in zijn algemeenheid toch positiever tegen deze activiteit aankijkt dan in de beginperiode van de jaren tachtig het geval was.

\subsection{Overig personeel: de professionele staf en de inrichtingsdirectie}

Het ligt voor de hand niet alleen de bewaarders als direct uitvoerenden een aantal vragen voor te leggen, ook medewerkers als crea-consulenten, onderwijzers, hoofden SKW en penitentiair reclasseringswerkers dienen te worden ondervraagd. De vragenlijst die aan hen zal worden voorgelegd zal in grote lijnen hetzelfde zijn als die voor bewaarders. Voorts is het belangrijk de leden van het management-team bij het onderzoek te betrekken, zij bepalen immers in globale zin het inrichtings-en organisatieklimaat. Hun visie op resocialisatie is derhalve relevant voor dit onderzoek. Hamm en Schrink (1989) merken over deze ondersteuning van resocialisatie-programma's door het leidinggevend personeel en door het organisatie-klimaat in het algemeen op dat, indien in de organisatie op het decentrale niveau ondersteuning ontbreekt, resocialisatie-programma's niet van de grond zullen komen, de officiële mandaten op het centrale niveau ten spijt.

In de volgende twee paragrafen zal de rol van de externe deskundigen en van de leiding binnen de inrichtingsorganisatie worden behandeld in het bijzonder in relatie tot de resocialisatie-opdracht.

\subsubsection{De professionele staf}

Functionarissen als hulpverleners, onderwijzers, geestelijk verzorgers, crea-consulenten, sportinstructeurs, de psycholoog, psychiater en het medisch personeel brengt men in de literatuur ook wel samen onder het begrip professionele staf. In de huidige organisatie vallen deze verschillende functiegroepen hetzij geheel of gedeeltelijk onder de leiding van de directie van de inrichting. Bij functionarissen zoals de reclasseringswerkers, de arts of psychiater en geestelijk verzorgers blijft de rol van de directie beperkt tot een beheersmatige. Voor de inhoudelijke verantwoordelijkheid is bij deze functies sprake van een onafhankelijke positie. Een dergelijke positie is van belang voor een adequate taakuitoefening die veelal het opbouwen van een vertrouwensrelatie impliceert. Een dergelijke vertrouwensrelatie betekent dat men als hulpverlener niet verplicht is inhoudelijke informatie over cliënten aan de directie te verstrekken. Het betekent tevens dat de gedetineerden de mogelijkheid hebben om in de hulpverleningscontacten vrijuit over hun problemen te spreken zonder de vrees dat deze ter ore komen van de directie.

In de literatuur over de gevangenisorganisatie is de tamelijk onafhankelijke positie van de professionele staf een steeds weer terugkerend thema. Zo vinden we bij auteurs als Cressey 
(1959) en Zald (1962) de constatering dat de professionals uit wat Cressey noemt de behandelingshierachic een ideologie erop nahouden die afwijkt van die van de bewakingshierarchie of die van de arbeidssector.

Cressey vat de eisen die de behandelingsgedachte of de dienstverlenende houding, die kenmerkend is voor de professionals, als volgt samen:

- de organisatie mag de gedetineerden geen leed toebrengen;

- de gedetineerde moet worden beschouwd als een autonoom individu;

- men dient rekening te houden met de individuele mogelijkheden en behoeften van de gedetineerden, er moet gelegenheid zijn tot geestelijke groei;

- gedetineerden moeten de gelegenheid krijgen om bepaalde keuzen te maken, hun vrijheid mag niet te veel worden ingeperkt;

- gedetineerden moeten kansen krijgen om hun maatschappelijke positie te verbeteren via scholing, vorming en werk.

Zald (1962) gaat ervan uit dat alle penitentiaire inrichtingen zich op een continuum bevinden met als extremen beveiliging en behandeling. De conflicten tussen de verschillende functiegroepen die belast zijn met beveiliging, bejegening en behandeling vertonen een samenhang met de positie van de inrichting op het continuum. In een meer op beveiliging gerichte organisatie is de kans op conflicten tussen enerzijds professionals uit de behandelingshierachie en anderzijds het personeel belast met beveiliging vrij groot. In een inrichting die zich meer orienteert op de behandelingsgedachte breken vaak conflicten uit tussen de professionals onderling. Blijkbaar heeft elke groep toch de wens om zijn eigen kijk op de organisatie en op de gedetineerde als de meest prominente te laten gelden.

In de praktijk van de gevangenis zien we vrijwel nooit dat de behandelingsgedachte tot uitgangspunt van de organisatie wordt gekozen. Immers volgens Cressey zou dit resulteren in een onwerkbare situatie: alles wordt afhankelijk gesteld van de individuele motivatie van gedetineerden. In de praktijk zien we dat ten einde de tenuitvoerlegging in een ongestoorde context te laten verlopen elke penitentiaire organisatie, in casu de gevangenis, het niet kan stellen zonder beveiliging, routine en een zekere bedrijfsmatigheid. Omdat de gevangenis van nature een dwanginstituut ontsnapt men niet aan deze noodzaak van reglementering, discipline en controle. De bestuursvorm van de gevangenis blijft daarom in wezen bureaucratisch van aard. En juist vanwege deze bureaucratische aard blijven, volgens de meeste onderzoekers, pogingen tot zelfherstel steeds een secundaire aangelegenheid. Patterson (1988, p.218) vat het dilemma die de introductie van verschillende detentiedoelen voor de organisatie oplevert als volgt samen:

"Specialists, with the expertise and professional training, are limited in the provision of services because of the bureaucratic nature of the prison. Prisons run on routine, but the specialist demands more flexibilty to facilitate the success of his programme. Change in routine upsets the general prison staff who cling rigidly to normal practice set out in rules and regulations. The prison adminstrator is thus caught in the crossfire between philosophical commitments and goal routine."

Zolang men in de gevangenisorganisatie verschillende doelen tracht te verwezenlijken blijven volgens Patterson de tegenstellingen tussen beveiligen en bejegenen of tussen zorg en dwang, een bedreiging voor een adequate invulling van dienstverlenende taken.

In het Nederlandse gevangeniswezen wordt gestreefd naar een evenwichtige realisering van de verschillende doeleinden middels hun integratie op organisatieniveau. De functionele specialisatie waarbij verschillende hiërarchieën los van elkaar de bijbehorende doelstellingen trachten te verwezenlijken, wordt sinds het midden van de jaren tachtig gezien als een onwenselijke koers. Om een gevangenisorganisatie te scheppen die daadwerkelijk humaan, zo veel mogelijk schadevrij en resocialisatiebevorderend werkt heeft men gekozen voor een 
verbreding en verdieping van de bewatadersfunctic, en voor een beter overleg lussen de leden van de professionele staf (hulpverleners, onderwijzers, psycholoog en geestelijke raadslieden) en de PIW-ers. Men zou kunnen zeggen dat op grond van het beleid van de nota Taak en Toekomst (1982) de organisatie van de inrichting vanwege dit streven naar doelintegratie, zich heel voorzichtig is gaan ontwikkelen in de richting van een professioneclbureaucratische bestuursvorm met als belangrijk speerpunt de deskundigheidsbevordering of professionalisering van de inrichtingswerker die tevens een grotere autonomie en flexibiliteit in zijn taakuitoefening dient te hanteren. Zo constateert Hoogenboom (1991, p.93) voor wat betreft de samenwerking tussen de inrichtingswerkers en de hulpverleners:

"Ook ik heb in de liatste jaren een verschuiving zien optreden in de wijze waarop inrichtingswerkers aankijken tegen en samenwerken met andere functionarissen. Een alantal jaren geleden wats het wantrouwen tegen hulpverleners groot: ze werden gezien als functionarissen die de traditionele machtspositie van bewaarders ondermijnden. Er was sprake van wederzijdse verkettering."

De jaren negentig kan men beschouwen als een periode walarin deze ontwikkeling, waarover Kommer in 1991 opmerkt dat zij nog maar zeer moeizaam verloopt, min of meer in de kiem wordt gesmoord. Een van de kerntaken van de penitentiaire organisatic namelijk, het scheppen van cen kwalitatief goed psycho-sociaal klimaat, tevens een belangrijk aspect van de zingeving van de organisatic, is door de regimesversobering op basis van Werkzame Detentie in een gevarenzone terechtgekomen (Knol, 1998). Uit de reeds eerder in hoofdstuk I besproken evaluaties van het nieuwe beleid blijkt hoe zorgtaken juist door een krappe programmering als gevolg van een hernieuwd primaat van de gevangenisarbeid en door een tendens tot bezuiniging op de personeelsbezetting steeds meer onder druk zijn komen te staan.

Een en ander laat zien hoe kwetsbaar de positie van met name de dienstverlenende hiërarchie in feite is gebleven. Alle voomemens tot het scheppen van een kwalitatief goed psychosociaal klimaat, de professionalisering van de inrichtingswerker en doelintegratie ten spijt, het lijkt erop dat de klok weer wordt teruggedraaid en dat de tenuitvoerlegging van vrijheidsbeneming, zoals Wiewel (1994) stelt, weer geworden is wat het ooit al was: 'uitzitten'.

In het licht van deze ontwikkelingen is het van belang de mening van de professionele staf in casu de penitentiair reclasseringswerkers, de onderwijzers en de crea-consulenten te peilen.

Die mening is tot op heden weinig in beeld gebracht. Voor het eerst sinds de jaren tachtig is er onlangs een belangrijke studie verschenen waarin onder meer de mening van de reclasseringswerkers over straffen en resocialiseren aan de orde komt (Schuyt en Kommer, 1998). Uit deze studie blijkt dat reclasseringswerkers over het algemeen geen dilemma ervaren bij de dubbele taak van dienstverlening aan justitie en hulpverlening aan de cliënt. De meeste reclasseringswerkers beschouwen de taken als complementair.

Het imago van een softe instelling ten aanzien van delinquenten blijkt bij de meerderheid van de reclasseringswerkers te ontbreken. Men heeft een realistische kijk op de straf en haar normbevestigende functie in de samenleving. Straffen mag, doch strenger straffen wordt als weinig effectief gezien. Straffen met een resocialiserende, corrigerende functie worden als veelbelovender beschouwd. Voor het voorkomen van recidive is naar de mening van de meeste reclasseringswerkers een pedagogische straf, gericht op zelfontplooiing, op zelfinzicht en zelf-confrontatie nodig. Op materieel gebied acht men als 'beste' oplossing voor de resocialisatie van de cliënt het richten van de inspanningen op werk, huisvesting en saneren van schulden en verbetering van de financiële situatie. Op immatericel vlak noemt men het vergroten van de sociale binding met de samenleving, sociale vaardigheden, het leren nemen 
van cigen verantwoordelijkheid, scholing, e.d. De houding van de hedendaagse reclasseringswerker komt uit de studie van Schuyt en Kommer te voorschijn als een, in essentie idealistische houding met een realistische kijk op de mogelijkheden van cliënt van de reclasseringswerkers zell en van de reclassering als organisatic.

\subsubsection{De leiding van de inrichting}

Een belangrijk deel van het werk van de leiding van de inrichting of wel tegenwoordig het management-team genoemd. kan men omschrijven als voorwaardenscheppend. Deze voorwaardenscheppende werkzaamheden worden gekenmerkt door een zekere afstand ten opzichte van het personeel op de werkvlocr (PIW-crs, werkmeesters, professionele staf) Hiërarchisch gesproken bevinden zich tussen het personeel op de werkvloer en de directie nog een aantal andere niveaus. De voorwaardenscheppende werkzaamheden van de leiding van de inrichting richten zich op het expliciteren van (overkoepelende) beleidsdoelstellingen (beleid) en het zeker stellen van de uitvoering ervan (beheer).

Ter realisering van het voorgestane beleid van Taak en Toekomst koos men in de jaren lachtig voor een gewijzigde relatic tussen de inrichtingsorganisatic en de centrale directie. De voorgestane ontwikkelingen van Taak en Toekomst konden slechts verwezenlijkt worden door de inrichtingsdirecties meer beleidsruimte te geven. Men streefde naar een zekere mate van verzelfstandiging van inrichtingen (ook wel deconcentratie). Deze verzelfstandiging werd verder vorm gegeven met wat men aanduidde als de Beleidsplanoperatie. Iedere inrichting moest een beleidsplan maken dat centraal werd getoetst aan de hand van een algemeen beleidskader. Een goedgekeurd belcidsplan werd gehanteerd als een soort contract tussen de centrale directie en de inrichting (Dhondt, 1991). Dhondt constateert dat in de loop der jaren tachtig een aantal duidelijke veranderingen is opgetreden in de centrale sturing. Aan beleidsplannen werd steeds minder aandacht besteed. In plaats van beleid werden thema's als beheer en doelmatigheid de richtinggevende. Deconcentratie werd in de loop van de jaren tachtig onder invloed van de capaciteitstekorten steeds meer een middel tot verbetering van het beheer. Centrale sturing vond steeds meer plaats op basis van standaardisering van resultaten. Deze ontwikkeling levert volgens sommigen (Dhondt,1991) in feite een primaat van het beheer op.

Kommer (1991 p.287) wijst in het begin van de jaren negentig op hetzelfde gevaar:

"Of vooral de positieve gevolgen (van een gewijzigde organisatiestructuur. PN) dwz. een mogelijkheid tot grotere autonomie op uitvoerend niveau dan wel de negaticve (een overheersing van aandacht voor beheersaspecten) de overhand zullen krijgen valt nog moeilijk te zeggen. Somber stemt echter de gedachte dat uiteindelijk beheer een stuk gemakkelijker (want concreter en beter te verantwoorden) is dan beleid (waarvoor immers een visie nodig is, en het vermogen mensen te enthousiasmeren), en dat ook in de maatschappij in het algemeen de tendens vooral lijkt te gaan in de richting van zakelijkheid en efficiëntie, onder gelijktijdig verlies van geloofwardigheid van ideologicën."

In het bijzonder waar het on beleid gaat rust op de schouders van de leiding van de inrichting de taak van de zingeving van de organisatie. Van der Zande (1991) merkt hierover op dat de leiderschapsstijl in de organisatie in dit opzichı ondersteunend maar vooral ook visionerend en enthousiasmerend zou moeten zijn. De manager als leider zal vooral de zingever binnen de betrekkelijk 'zinloze' dienstverleningssituatie van de penitentiaire inrichting moeten zijn. Wentink (1993) wijst op het gevaar dat de zingeving van de organisatie steeds minder wordt gekleurd door het streven naar een gunstig psycho-sociaal detentieklimaat en door pedagogische overwegingen, ten gunste van een zingeving die veel meer in het teken staat van een bewaars-en beheersstructuur. 
Historisch gezien is in het Nederlandse gevangeniswezen de autonomie van de inrichtingsdirectie bij de vormgeving van het beleid en de strategie van de inrichtingsorganisatie, van vrij recente aard. Zeker tot halverwege de jaren zeventig was de vrije beleidsruimte van de leiding van de inrichting zeer beperkt, gevangenisdirecteuren voerden een regime volgens strakke voorschriften van het departement. De gevangenisdirecteur fungeerde vooral als beheerder van de inrichting. Geleidelijk aan kregen gevangenisdirecties meer discretionaire bevoegdheden op het gebied van regimesvoering met name als gevolg van de introductie van de interne differentiatie. In de loop van de jaren tachtig en negentig krijgt deze ontwikkeling van een decentrale autonomie steeds meer vorm en wel op dusdanige wijze dat de inrichtingen een belangrijke invloed kunnen uitoefenen op de wijze van implementatie van het beleid, met alle gevolgen voor het regime van dien. De autonomie van de inrichtingen is dermate groot dat er zelfs verschillen in regimesvoering bij voorbeeld op het gebied van maatschappelijke integratie ontstaan tussen inrichtingen met een gelijke bestemming. Inrichtingen hebben wat het regime betreft unieke kenmerken gekregen. Volgens Boin (1995) is er feitelijk zelfs geen sprake meer van algemeen gedeelde en ondersteunde kernwaarden in de penitentiaire inrichtingen.

In het kader van deze ontwikkeling rijzen er een aantal belangrijke kwesties.

In de eerste plaats voor wat de gezagsverhouding tussen het departement en het decentrale niveau betreft. De toenemende publicitaire en politieke druk op het gevangeniswezen en de verhoogde kwetsbaarheid van de inrichtingen gaf in de loop van de jaren negentig althans binnen de visie van de departementale leiding reden tot direct ingrijpen in het penitentiaire veld. De behoefte aan een grotere mate van sturing vanuit een centraal niveau diende zich aan en kreeg met name gestalte in de beleidsuitgangspunten van de nota Werkzame Detentie. Door de relatief autonome positie van de inrichtingen stonden de nieuwe beleidsaanpassingen op gespannen voet met de beperkte sturingsmogelijkheden. Op het departement percipieerde men, als reactie op de problemen waarmee men in het gevangeniswezen te maken kreeg (ontsnappingen, veranderde gevangenispopulatie, cellentekort, bezuinigingen), een noodzaak tot centraal ingrijpen waartoe men, aldus Boin, feitelijk niet meer in staat was. Immers de historisch gegroeide gezagsverhoudingen tussen het centraal niveau en het decentraal niveau maakten dat gedetailleerde controle over het regime op verzet bij de inrichtingen in het veld stuitte en de nodige spanningen in de gezagsverhoudingen teweegbracht. Een proces van herijking van de balans tussen controle en autonomie lijkt zich derhalve in de tweede helft van de jaren negentig te hebben ingezet. Men kan hier in navolging van Boin spreken van een bestuurlijk stelsel in transformatie, waarbij deels sprake lijkt te zijn van een poging van het departement om nieuwe waarden te institutionaliseren in een decentrale omgeving die inmiddels sterk gehecht is aan een traditie van noninterventie en autonomie.

De spanning tussen het centrale niveau en het decentrale penitentiaire veld roept in de tweede plaats de vraag op naar de inhoud en oorsprong van de kernwaarden.

Zo stelt Boin (1995) dat het een belangrijke vraag is of er sprake is van centraal opgelegde kernwaarden dan wel van een institutionaliseringsproces van kernwaarden dat zich vooral op het decentrale niveau voltrekt.

De praktijk van het gevangeniswezen laat zien dat inrichtingsdirecties zich weliswaar oriënteren op de centraal geformuleerde uitgangspunten of kernwaarden, echter de mate waarin men zich speelruimte permitteert bij de uitvoering, resulteert over het geheel van de inrichtingen genomen in een veelvoud van varianten op de centrale uitgangspunten. De recente departementale evaluaties van het beleid gebaseerd op Werkzame Detentie illustreren dit gegeven heel duidelijk. Het voornemen om inrichtingen in gedetailleerde de wijze van 
uitvoering voor te schrijven heeft men reeds laten varen en men erkent dat er sprake is van Werkzane Detentie 'eigen stijl'. Zo zijn er inrichtingen waar de zorg voor een goed psychosociaal klimaat hoog in het vaandel staat en waar men juist daardoor veel minder recht in de leer is voor wat betreft de uitgangspunten van de nota Werkzame Detentie. Er zijn ook inrichtingen waarin men het accent vooral is gaan leggen op het doelmatigheidstreven van de nota Werkzame Detentie, hetgeen dan leidt tot flinke bezuinigingen bij voorbeeld op het gebied van maatschappelijke integratie-activiteiten. De recente ontwikkelingen op bestuurlijk niveau laten in ieder geval een ding zien: het is voor de beleidsmakers op het centrale niveau toch niet oninteressant te weten wat er leeft onder het uitvoerend personeel op de werkvloer. Dit is een eerste voorwaarde indien men bepaalde nieuwe waarden wenst te institutionaliseren of indien men, zoals het toenmalige hoofd DJI tijdens de doop van Werkzame Detentie het formuleerde, een cultuuromslag wenst te bewerkstelligen. In het geval van een sterke traditie van autonomie op decentraal niveau ligt het vervolgens voor de hand de formulering van nieuwe kernwaarden mede te baseren op een grondige kennis van de visies en ervaring van het (leidinggevend) personeel die met de uitvoering van het beleid worden belast. Empirisch onderzoek van deze visies is totnogtoe nauwelijks verricht.

Een recente inventarisatie van de visies van gevangenisdirecties op het beleid en beheer van de inrichtingsorganisatie vinden wij Boin (1998, p.88-92). Boin onderscheidt in de jaren negentig grofweg drie soorten visies op het beleid en beheer van de gevangenis: een visie in liberale, beperkte en gemengde ('mixed bag') zin.

De aanhangers van de liberale visie onderschrijven het denkbeeld dat de detentie, naast een beveiligende en bewarende functie, ook een functic vervult op het gebied van het zelfherstel van gedetineerden. De detentie moet een menselijk gezicht behouden en meer inhouden dan louter opsluiten en onschadelijkmaken. Gedetineerden worden in essentie gezien als 'verliezers'. Hun criminele levensstijl is geen kwestie van een bewuste vrije keuze, men wordt door de omstandigheden ertoe gedreven. Binnen deze visie is het dan ook belangrijk gedetineerden 'iets mee te geven', bij voorbeeld in de vorm van educatie en sociale vaardigheden, waarvan zij later in de vrije samenleving profijt kunnen hebben.

De aanhangers van de beperkte visie zien weinig heil in een aanbod van voorzieningen dat gericht is op de verbetering van gedetineerden. $\mathrm{Zij}$ zien criminaliteit in essentie als een bewuste, rationele en calculerende keuze van de dader. Daders kiezen min of meer voor een criminele carrière. Binnen deze enge of beperkte visie worden gedetineerden als onverbeterlijk gezien. Als de ouders, de school en de samenleving er al niet in slagen deze mensen te verbeteren, waarom zou dat in de gevangenis dan wel lukken? De aanhangers van deze beperkte visie zien als belangrijkste taak van de gevangenis de beveiliging van de samenleving. De tenuitvoerlegging moet weliswaar aan humane maatstaven beantwoorden, maar dit impliceert geenszins een breed aanbod van resocialiserende voorzieningen. Die voorzieningen zijn slechts voorbehouden aan gedetineerden die blijk geven van motivatie en goed gedrag. Het bijbrengen van discipline en van normbesef wordt als een belangrijke taak van het personeel gezien.

De gemengde visie wordt gekenmerkt door een nadruk op beheer. Er ontbreekt een uitgesproken visie op de oorzaken van criminaliteit en op de bejegening van gedetineerden. Men volstaat met het zo goed mogelijk uitvoering geven aan alle, centraal voorgeschreven detentiedoelen. Een variant op deze beheersmatige visie, betreft een puur bedrijfsmatige visie op de penitentiaire organisatie. Een visie op het detentiebeleid ontbreekt, men legt de nadruk op een zo efficiënt mogelijk beheer van de organisatic. 
In de onderhavige studie zal de leiding van de inrichting met name worden gevraagd naar hun meningen over de resocialisatiedoclstelling en over de betekenis die de activiteiten in hum visie hebben voor de gedetineerden en de organisatic.

\subsection{Opzet en uitvoering van het onderzoek onder het personeel}

\subsubsection{Dataverzameling}

De respondentengroep uit het gedeelte van deze studie dat zich richt op de houdingen van het personeel bestaat uit PIW-ers, onderwijzers, penitentiair reclasseringswerkers en leden van het management-taam werkzatam in de drie inrichtingen die reeds eerder in Hoofdstuk 5 werden beschreven.

Uit de literatuur (Kommer.1991. Grapendaal.1987) blijkt dat het benaderen van gevangenispersoneel, in het bijzonder bewarend personeel, beslist geen eenvoudige zaak is.

Dit kan te maken hebben met de moeilijke bereikbalarheid van respondenten als gevolg van telkens wisselend personeel dat immers in continue-dienst werkt. Daarnatast kunnen problemen bij de dataverzameling samenhangen met een bepalalde mate van desinteresse, wantrouwen en ongeloof in het nut van het onderzock. Om dergelijke problemen bij de dataverzameling te omzeilen wordt ook wel gebruik gemaakt van een schriftelijke benadering en ondervraging via de post. Een dergelijke werkwijze leidt echter veelal tot een te lage respons onder PIW-ers (Grapendaal, 1987).

De dataverzamelingsmethode waarvoor in dit onderzock aanvankelijk werd gekozen wals verspreiding en beantwoording van vragenlijsten voor PIW-ers tijdens het team-overleg. Hieraan vooraf ging uiteraard een bricf watrin het personeel werd geinformeerd omtrent het onderzoek en om medewerking werd gevraagd. Helaas bleck dit plan in twee inrichtingen niet tot de gewenste resultaten te leiden. In een inrichting weigerde een afdelingshoofd medewerking aan dit plan om de cenvoudige reden dat hij resocialisatic van gedetinecrden -flauwekul vond. Naar zijn mening was als gevolg van Werkzame Detentie de resocialisaticdoelstelling afgeschatt. detentic werd volgens hem voortatan weer gewoon 'tuchten'. Ik besloot daarom de PIW-ers in deze inrichting niet via het team-overleg te benaderen, maar hen zoveel mogelijk tijdens hun dienst te benaderen om vervolgens afspraken te maken over het inleveren en ophalen van de vragen-formulieren.

In de andere inrichting kregen PIW-ers de vragenlijsten uitgereikt via het afdelingshoofd. Via het afdelingshoofd werden ingevulde formulieren geretourneerd. In deze inrichting was de respons zeer laag. Hiervoor was ik reeds gewaarschuwd door een van de leden van het management-team. Volgens haar waren de PIW-ers de laatste tijd als gevolg van andere. recent uitgevoerde enquêtes een beetjc 'enquête-moe' geworden.

In de derde inrichting werden de zaken geheel anders aangepakt in vergelijking met de andere twee inrichtingen. Hier kregen de afdelingshoofden eenvoudigweg de opdracht van een lid van het management-team om de PIW-ers tijdens het team-overleg de vragenformulieren te laten invullen, uiteraard op basis van vrijwilligheid. De respons onder PIW-ers was in deze inrichting dan ook aanmerkelijk beter. De strategie van dataverzameling die hier werd gevolgd is mijns inziens de enig werkelijk effectieve als het gaat om het verkrijgen van een goede respons.

De dataverzameling onder de overige personeelsleden verliep in grote lijnen als volgt. Deze personeelsleden werden in de inrichting waar ik zelf werkzaam ben. eerst benaderd via een brief met informatie over het onderzoek. Vervolgens benaderde ik hen persoonlijk om een vragenformulier uit te reiken en om afspraken te maken over het retourneren van de 
formulieren. In de andere twee inrichtingen verliep de verspreiding en het retourneren van de enquêteformulieren hetzij persoonlijk, hetzij via het Hoofd SKW of het postvak.

\subsubsection{Respons}

In de drie inrichtingen werden 187 PIW-ers benaderd. Het voltallige PIW-ers-corps werd niet benaderd. In één inrichting werd alleen het bewarend personecl van de afdelingen waar de gedelineerden-enquête werd gehouden benaderd. Van de totale groep PIW-ers die werd benaderd retoumecrden 58 respondenten een brujkbaar enquête-formulier. Dit is een respons van $31 \%$ hetgeen aan de lage kant is. Bij schriftelijke enquêtes onder bewarend personeel is een lage respons overigens een bekend fenomeen. Zo bereikt Kommer in zijn onderzoek (1991) onder PIW-ers een response percentage van 39\%.

De generalisecrbaarheid van het onderzock onder de PJW-ers wordt beperkt doordat van hen geen persoonskenmerken werden vastgelegd. Vergelijking op bepaalde kenmerken van de response-groep met de totale onderzoekspopulatie bleef achterwege omdat de randvoorwaarden van het onderzoek in dit opzicht aan beperkingen onderhevig waren. De randvoorwaarden van dit onderzoek waren van dusdanige aard dat een vergelijking op bij voorbeeld persoonskenmerken van de respondenten met de persoonskenmerken van de totale onderzoeksgroep geen haalbare kaart bleek. Met name het raadplegen van de personeelsadministratie ten behoeve van een dergelijke vergelijking zou een te omvangrijke, en nalar het zich liet aanzien voor de inrichtingsorganisatie, een te ingrijpend onderdeel van het onder\%oek worden.

De respons van de onderwijzers was zeer goed te noemen, van de onderwijzers reageerde over de dric inrichtingen iedereen. Van de aangeschreven twee crea-consulenten retourneerde cen consulent cen vragen lijst. De penitentiair reclasseringswerkers vertoonden eveneens een goede respons. In twee inrichtingen werden ook de leden van het managementteam benaderd voor medewerking aan het onderzoek, doch in totaal retourneerden slechts twee directieleden een ingevulde vragenlijst. Men dient deze studie onder de leden van de professionele staf en inrichtingsdirectie vooral te zien als een exploratieve studie waarbij zowel gebruik word gemaakt van resultaten uit een schriftelijke enquête en in beperkte mate ook van materiaal verzameld op grond van oriënterende interviews met betrokken personeelsleden.

In de onderstaande tabel 1 worden de gegevens over de respons samengevat in aantallen.

In de tabel zien we dat de PIW-ers 61 vragenformulieren retourneerden, drie formulieren waren op niet bruikbare wijze ingevuld, zodat de gegevens van 58 respondenten werden gebruikt De overige respondenten zowel van het dienstvak PIW, als van de andere personeelsgeledingen vulden een bruikbaar formulier in. Waar in de tabel geen cijfers zijn geplaatst doch streepjes. betekent dit dat de desbetreffende personeelsgeleding niet werd benaderd voor medewerking aan de enquête. De reden hiervoor was van praktische aard, in casu tijdnood. De aanduiding NVT heeft betrekking op het feit dat de crea-consulent in de desbetreffende inrichting zelf het onderzock uitvoerde. 
Tabel 1. Responsgegevens

\begin{tabular}{|c|c|c|c|c|c|c|c|c|c|}
\hline & \multicolumn{3}{|c|}{ Sittard } & \multicolumn{3}{|c|}{ Rocrmond } & \multicolumn{2}{|c|}{ Grave } & \multirow[b]{2}{*}{ Totall } \\
\hline & Respons & $\begin{array}{l}\text { Non- } \\
\text { respons }\end{array}$ & Totaal & Respons & $\begin{array}{l}\text { Non- } \\
\text { respons }\end{array}$ & Totial & Respons & $\begin{array}{l}\text { Non- } \\
\text { respons }\end{array}$ & \\
\hline PIW & 24 & 60 & 85 & 30 & 30 & 60 & 7 & 36 & 42 \\
\hline Onderwijzers & 3 & 0 & 3 & 1 & 0 & 1 & 3 & 0 & 3 \\
\hline PRW & 2 & 1 & 3 & - & - & - & 3 & 1 & 4 \\
\hline $\begin{array}{l}\text { Crea- } \\
\text { consulent }\end{array}$ & nvi & nvt & nvt & 0 & 1 & 1 & 1 & () & 1 \\
\hline Management & 2 & 2 & 4 & - & - & - & 0 & 5 & 5 \\
\hline
\end{tabular}

\subsubsection{Methode van onderzoek}

Als methode van onderzoek werd primair gebruikt gemaakt van vragenlijsten met voornamelijk uitspraken en antwoordcategorieën die variëren van "l mee eens tot en met 5 mee oneens".

Gelet op de randvoorwaarden met betrekking tijd en geld bleck dit de meest alangewezen methode om aan voldoende informatie te komen over de houdingen van het personeel.

De keuze voor de vragenlijsten berust, met name als het gaat om de houdingen van het bewarend personeel, op de behoefte aan het systematiseren van bestaande kennis. Het leek mij zinvol de exploratie van individuele ervaringen van het personeel die in de oriënterende fase van het onderzoek (onder meer ook in het kader van een stage-onderzoek van een HBOstagiaire) plaatsvond, aan te vullen met een meer systematische en kwantitatieve aanpak.

De vragenlijst voor het personeel volgt voor wat betreft de opvattingen ten aanzien van de resocialisatiedoelstelling, de randvoorwaarden waaronder men de werkzaamheden verricht, en de waargenomen effecten van met name de kunstzinnige activiteiten in grote lijnen dezelfde aspecten als in de gedetineerdenenquête, teneinde vergelijkingen met de houdingen van gedetineerden en tussen de verschillende functiegroepen onderling waar nodig mogelijk te maken. Met het oog op een bewerking van de data met een correlationele analyse en een variantie-analyse (ANOVA-analyse) werd een aantal schalen geconstrueerd, waarvan in de volgende paragraaf een overzicht wordt gegeven. Bij de constructie van deze schalen werd evenals bij het onderzoek onder gedetineerden gebruik gemaakt van de principale componentenanalyse en van de reliability-analyse. Voor een meer uitgebreide beschrijving van deze analyse- technieken wordt de lezer verwezen naar Hoofdstuk 5.

\subsubsection{Meetinstrumenten}

\subsubsection{Opvattingen over resocialisatie}

In eerste instantie werd voor deze schaal een tiental items geformuleerd met betrekking tot de zinvolheid of zinloosheid van de resocialisatie-opdracht.

De items werden zodanig gekozen dat de in hoofdstuk 1 beschreven verschillen in benadering van de resocialisatie-opdracht werden gereflecteerd. Het betreft hier enerzijds een visie waarin de "Nothing Works" ideologie naar voren komt en waarbij het doorslaggevende criterium voor beoordeling van de zin of het nut van de resocialisatie-doelstelling de geringe of ontbrekende speciaal -preventieve effecten in termen van recidive- reductie is. De redeneertrant bij dit type benadering komt in het kort gezegd op het volgende neer: resocialisatie werkt niet, immers gedetineerden zijn niet te verbeteren, zij recidiveren toch, dus resocialisatie is niet zinvol of nodig. 
Anderzijds is er een manier van benaderen die onder meer door Conrad (1981) werd beschreven als tamelijk kenmerkend voor het gevangenispersoneel, namelijk, een benadering waarbij recidive cen ondergeschikte rol speelt. Men kijkt vooral naar de positieve effecten die resocialiserende voorzieningen tijdens de detentie op gedetineerden hebben. Men bekommert zich niet om tockomstige gedragsveranderingen in de zin van een verminderde recidive, wellicht ondat men beseft dat deze vanuit een detentiesituatie moeilijk zijn te beïnvloeden. Men oriënteent zich meer op de gunstige effecten op de persoonlijke ontwikkeling en op constructieve, genormalisecrde en humane verhoudingen tijdens de detentie.

Het verschil tussen beide visies kan men nader omschrijven aan de hand van de begrippen die wij in Hoofdstuk 2 behandelden. De definitie van het begrip resocialisatie, zo blijkt uit dit hoofdstuk, vertoont verschillen al naar gelang de aard van de athankelijke variabele of het nagestreefde doel of effect.

Beschouwt men recidive-vermindering als het enige criterium of doel van de interventies dan spreekt men van cen opvatting van resocialisatie in "enge zin". Beschouwt men ook andere doelen (humanisering van de detentie) dan recidive-vermindering als zinvol en legitiem, zoals het zich beter weten te handhaven en een groter psychisch welbevinden, dan spreekt men van een definitie van resocialisatic in ruime zin. De items die wij formuleerden volgens de beide bovengenoemde visies reflecteren indirect ook het onderscheid tussen opvattingen van resocialisatie in enge zin en ruime zin.

De volgende items reflecteren de opvatting van resocialisatie in enge zin waarbij ontbrekende gunstige effecten in de zin van recidive-vermindering of een geringe gemotiveerdheid van gedetineerden een reden zijn om de resocialisatie-gedachte als weinig zinvol te beschouwen:

De schaal Resocialisatie in enge zin

-gedetineerden zijn niet te resocialiseren dus kan men resocialisatie matar beter afschaffen:

-begeleiding van gedetineerden tijdens en na hun detentic heeft weinig zin, met de meesten loopt het loch weer verkeerd at:

-het aantal gedetineerden dat echt gemotiveerd is voor resocialisatie is te klein om er nog langer mee door te gaan:

-resocialisatic van gedetineerden vind ik niet nodig. het belangrijkste is dat zij zich tijdens hun detentie rustig en ordelijk gedragen:

Vervolgens werden items geformuleerd die de opvatting van resocialisatie in ruime zin reflecteren:

De schaal Resocialisatie in ruime zin

-gedetineerden moet je niet alleen matar straffen ze moeten ook de kans krijgen om aan een betere toekomst te werken:

-met resocialisatic voorkom je in ieder geval dat gedetineerden nog gevaarlijker in de samenleving terugkeren dan zij al waren:

-voorzieningen ten behoeve van resocialisatie moet je a anbieden ook al vervallen de meeste gedetineerden weer in dezelfde fouten:

- van de activiteiten leren gedetineerden altijd iets ook al is het niet genoeg om later op het rechte pad le blijven:

-hoe meer hulp en steun voor gedetineerden des te beter zullen zij zich later redden:

-zonder hulp en steun tijdens detentic ziet de tockomst er voor gedetineerden nog veel slechter uit:

Een aspect dat in de formulering van deze items naar voren komt is de waardering van de resocialisatie-gedachte los van het geringe speciaal- preventieve effect in termen van recidive na detentie. Andere doeleinden zoals het zich beter weten te redden na detentie, persoonlijke 
groei tijdens de detentic of doeleinden met en ethische normatieve, humane strekking liggen in de formulering van deze items besloten

De items die een opvatting van resocialisatic in enge zin representeren bleken na lactoranalyse en reliability analyse een schaal te vormen met cen alpha waarde van .79 . Dit is de opvattingsschaal "Resocialisatie in enge $z i n "$. De itcms die een rume interpretatic van de resocialisatie weerspiegelen vormen eveneens een schaal met een alpha -walarde van .76. Dit is de opvattingsschaal "Resocialisatie in ruime zin"

Hoe hoger men scoort op deze twee schalen des te sterker beoordeelt men de resocialisatic doelstelling hetzij in enge. hetzij in ruime zin.

\subsubsection{Opvattingen over de zin van de vrijheidsbeneming in het algemeen}

Opvaltingen over resocialisatic in enge of ruime zin zoals gedelinieerd in dit onderzock hebben vooral betrekking op resocialisatie als stratdoel op executicf nivcau, het niveau waarop de straf daadwerkelijk ten uitvoer wordt gelegd. Vegter (1984, p.29) onderscheidt naast dit type strafdoel nog twee andere, namelijk het strafdoel op het applicatieve niveau en legislatieve niveau. Het applicatieve niveau betreft de doelen die worden nagestreefd met het opleggen van een vrijheidsstraf aan een schuldig bevondene. Het legislatieve niveau heeft betrekking op de doelen die men nastreeft met het in de wet opnemen van een vrijheidsstraf. Om meer zicht te krijgen op de aard van de opvattingen van het personeel over de resocialisatie-doelstelling werd eveneens cen aantal uitspraken voorgelegd over resocialisatic als strafdoel op applicatief niveau. Een vijftal gronden of doeleinden van de strafoplegging in de vorm van een vrijheidsbeneming werden voorgelegd: vergelding, beveiliging van de samenleving, voorkomen van eigenrichting, generale preventic en resocialisatie. De vijf doelen werden als volgt verwoord:

Het opsluiten van wetsovertreders heeft zin:

1 omdat zij moeten boeten voor wat zij misdaan hebben:

2. omdat de samenleving moet worden beschermd tegen gevaarlijke daders

3. omdat moet worden voorkomen dat het publick wrak neemt op daders;

4. omdat moet worden voorkomen dat andere mensen het misschien ook gaan doen;

5. om wetsovertreders weer op het rechte pad te brengen.

Respondenten werd verzocht elk doel in volgorde van belangrijkheid een cijfer te geven.

\subsubsection{Scepsis ten aanzien van de gevangenis als resocialiserend instituut}

Evenals aan gedetineerden werd aan het personeel gevraagd aan te geven inhoeverre men de detentie een geschikt moment vindt om aan de tockomst te werken. Hicrtoe werden de volgende items geformuleerd:

\section{De schaal Scepsis}

-zich goed voorbereiden op de toekomst daar komen gedetineerden nauwelijks aan toe in de bajes;

-van gevangenisstraf worden de meeste gedetineerden eerder slechter dan beter;

-hoe langer gedetineerden hier zitten des te negatiever denken zij over de toekomst:

-met een verblijf in de gevangenis krijgt men de meeste gedetineerden niet op het rechte pad:

-de gevangenis vind ik een ongeschikte omgeving om aan de toekomst te werken".

Ook deze items vormden een schaal Scepsis met een alpha-waarde van 66.

Hoe hoger men scoort op deze schaal des te sceptischer is men ten aanzien van de mogelijkheden om tijdens het verblijf in de gevangenis de terugkeer in de samenleving voor te bereiden. 


\subsubsection{Activiteiten}

Niet alle activiteiten hebben een duidelijke relatie tot de voorbereiding van de terugkeer in de samenleving. Het zijn bij uitstek activiteiten als onderwijs, kunstzinnige vorming, hulpverlening die in verband kunnen worden gebracht met de resocialisatie-doelstelling. Als het gatat on onderdelen uit het activitcitenprogramma als arbeid, recreatie, sport, bibliotheekbezoek en geestelijke verzorging dan is een relatie met de resocialisatiedoelstelling minder expliciet. Deze activiteiten kunnen niettemin toch een belangrijke functie vervullen uit hoofde van andere doelstellingen zoals cen humane, ongestoorde tenuitvoerlegging en het beperken van detentieschade.

Voorts dient men in dit verband met de mogelijkheid rekening te houden dat een deel van de personeelsleden de resocialisatie-gedachte niet ondersteunt maar toch een positieve houding heeft ten aanzien van hel aanbod van activiteiten, bij voorbeeld om humane en beheersmatige redenen of ter vermindering van detentieschade. Om een indruk te krijgen van de houdingen van het personeel ten aanzien van de activiteiten werden een aantal items voorgelegd waarin de zinvolheid van de activiteiten niet alleen vanuit het oogpunt van de resocialisatiedoelstelling aan de orde komt maar ook vanuit de andere detentie-of regimesdoelstellingen.

Deze uitspraken bleken een schal Activiteiten te vormen met een alpha-waarde van .70

De schalal Activiteiten

-bij ecn humane bejegeningvan gedetineerden horen zinvolle activiteiten;

-activiteiten vind ik belangrijk voor een goede omgang tussen gedetineerden en personeel;

-van activiteiten leren gedetineerden altijd iets, ook al is het niet genoeg om het rechte pad te blijven;

-zinvolle activiteiten hebben denk ik een gunstig effect op het toekomstig functioneren van gedetineerden:

-activiteiten vind ik onmisbaar voor een rustige en ontspannen sfeer in de inrichting:

Hoe hoger de score op deze schaal Activiteiten, des te positiever de effecten die men toekent aan het aanbod van activiteiten.

\subsubsection{De gepercipieerde motieven en motivatie van gedetineerden}

Ten aanzien van de motivatic en motieven van gedetineerden zoals die door het personeel worden walargenomen bij activiteiten als de kunstzinnige vorming en sport werden een aantal items opgenomen. Factor-analyse en reliability -analyse resulteerden hier in twee schalen. De schal Motivatie bestaande uit vijf items leverde een alpha op van .57.

De schatal Motivatie

-Gedetineerden zijn over het algemeen gemakkelijk te motiveren voor de deelname aan de sport:

-Gedetineerden die naar de crea gatan zijn doorgaans goed gemotiveerd:

-Gedetineerden die gaan sporten doen dat doorgaans wel fanatiek:

-Gedetincerden zijn over het algemeen gemakkelijk meet te krijgen voor crea;

- Hier hoef je niet te zeuren om wat sporters bij elkaar te krijgen:

De items die de gepercipieerde motieven voor deelname aan de kunstzinnige vorming representeren, hebben betrekking op korte termijn overwegingen als niet op cel te hoeven zitten, verveling verdrijven, opzoeken van gezelligheid en motieven gericht op de persoonlijke ontwikkeling zoals "gedetineerden gaan naar de crea om iets nieuws te leren".

De analyses leverden uiteindelijk een schaal Motieven op waarin alleen de molieven die betrekking hebben op het reduceren van de directe ongemakken van de detentie-situatie 
overblijven (alpha .82) Hoe hoger de scores op deze schaal des te meer is men van mening dat de genoemde aspecten van vermijdingsgedrag een rol spelen.

De schaal Motieven

-Gedetineerden gaan naar de crea als ze zich vervelen;

-Gedetineerden gaan vooral voor de gezelligheid naar de crea:

Gedetineerden zien crea eigenlijk alleen maar als een manier om de tijd kapot te krijgen;

-De belangrijkste reden voor gedetineerden om naar de crea te gaan is om van de afdeling af te zijn;

\subsubsection{De waargenomen effecten van de kunstzinnige vorming}

Aan de kunstzinnige vorming worden blijkens reeds eerder besproken beleidsnotities een aantal effecten toegekend op het gebied van de persoonlijke en sociale ontwikkeling. Tevens acht men deze activiteit bevorderlijk voor de wijze waarop gedetineerden omgaan met de detentie-situatie. Te denken valt hier aan effecten als het tegengaan van verveling (RAPnota, 1983), de mogelijkheid de spanningen te reduceren door het aanbieden van een creatieve uitlaatklep en het bevorderen van een rustige en constructieve houding ten aanzien van de detentie Men zou deze laatste effecten ook wel kunnen beschouwen als het beter hanteren van de spanningen verbonden aan de detentiesituatie, dus als een vorm van coping.

De items met betrekking tot de effecten van de kunstzinnige vorming bleken inderdaad een drietal schalen te vormen, zodat kan worden gesproken van drie verschillende dimensies.

\subsubsection{Persoonlijke ontwikkeling.}

De items die deze aspecten representeren benadrukken de ontwikkeling van de creatieve vermogens, het versterken van zelfvertrouwen, het handiger worden in het hanteren van materialen en technieken. Na analyse resulteerde een schaal Persoonlijke ontwikkeling met vijf items met een alpha-waarde van .81 . Hoe hoger de score op deze schaal des te sterker is men ervan overtuigd dat genoemde effecten zich bij gedetineerden voordoen

\section{De schaal Persoonlijke ontwikkeling}

Door crea-activiteiten:

-krijgen gedetineerden meer vertrouwen in hun eigen capaciteiten;

-ontwikkelen gedetineerden hun creatieve vermogens;

-krijgen gedetineerden meer handigheid in het werken met diverse materialen en technieken;

-leren gedetineerden nuttige en bruikbare dingen maken;

-geven gedetineerden een creatieve vorm aan hun ideeen;

\subsubsection{Sociale ontwikkeling}

Ook ten aanzien van de aspecten verbonden met de sociale ontwikkeling kon een schaal Sociale ontwikkeling worden geconstrueerd met vijf items die een betere omgang (in de zin van het verkrijgen van meer respect en meer begrip) ten opzichte van het bewarend personeel en tussen gedetineerden onderling benadrukken. De alpha -waarde van deze schaal is .82 
De schaal Sociale ontwikkeling

Door crea-activiteiten:

-krijgen gedetineerden meer begrip voor je taak als PIW-er;

-heb je als begeleidend PIW-er een beter contact met gedetineerden;

-waarderen /respecteren gedetineerden andere meer;

-krijgen gedetineerden meer waardering voor het werk van PIW-ers;

-gaan gedetineerden in het algemeen prettiger met elkaar om;

\subsubsection{Hantering van de detentiesituatie door gedetineerden}

De effecten die het personeel hier kreeg voorgelegd in de vorm van een vijftal items benadrukken aspecten als het minder lastig zijn, het uiten van problemen op een meer creatieve manier, het zich goed kunnen ontspannen en zich minder vervelen, het makkelijker handhaven van de orde op de afdeling. Hier resulteerde uiteindelijk een schaal Hantering met een alpha-waarde van .56

Hoe hoger de score op deze schaal des te sterker is men van mening dat de genoemde effecten optreden.

De schaal Hantering

Door crea-activiteiten:

-zijn gedetineerden minder lastig;

-vervelen gedetineerden zich minder;

-leren gedetineerden hun problemen meer creatief te uiten;

-handhaaf je als PIW-er makkelijker de orde op de ring;

-kunnen gedetineerden zich goed ontspannen;

\subsubsection{De kunstzinnige vorming en programma- integriteit.}

De items die de programma integriteit of randvoorwaarden van de kunstzinnige vorming weerspiegelen konden worden onderverdeeld in een viertal schalen: Informatie (alpha.67), Ondersteuning (alpha, .60), Plaats in het dagprogramma (alpha, .74) en Afstemming (alpha, .80)

Hoe hoger de score op deze integriteitsschalen des te meer tevreden is men over de invulling van de verschillende randvoorwaarden.

De schaal Informatie

- Voor gedetineerden is het voldoende duidelijk wanneer zij kunnen deelnemen aan de crea;

- Het is voor gedetineerden duidelijk wat zij bij de crea kunnen gaan doen;

-Als ik de crea moet begeleiden weet ik van tevoren wat gedetineerden kunnen gaan doen;

De schaal Ondersteuning

-Collegae waarderen het als je de crea begeleidt;

-In het overleg van de afdeling komt de crea voldoende aan de orde;

-Je krijgt hier voldoende ondersteuning in je werk als begeleider van crea-activiteiten;

-De werksfeer in deze inrichting is over het algemeen wel stimulerend voor mijn werk als crea-PIWer;

De schaal afstemming

-Wat gedetineerden bij de crea kunnen doen vind ik voldoende gevarieerd;

-gedetineerden kunnen bij de crea iets doen wat zij leuk vinden; 
De schatal Platats in het dagprogramma

-De tijden waarop gedetineerden van mijn afdeling naar de crea kunnen vind ik gunstig:

-Er is voldoende tijd voor crea vrijgematakt in het dagprogramma:

-Er is voldoende tijd voor PIW-ers om de sport voor te bereiden;

-De tijden waarop gedetincerden hier natar de sport kunnen vind ik gunstig:

-Er is in het dagprogramma voldoende tijd vrijgemalakt voor sport:

\subsubsection{Taakopvatting: orde-versus gedetineerdengerichtheid}

De items die een meer orde-cq gedetineerdengerichte houding in het eigen handelen weerspiegelen leverden twee schalen op.

De schaal die de ordegerichte aspecten weerspiegelt bestatat uit vijf items. Deze schaal (Orde) heeft een alpha- walarde van .58.

Hoe hoger de score op beide schalen des te meer geeft men blijk van hetzij een meer ordegerichte hetzij cen meer gedetineerdengerichte opstelling

De schalal Orde

-van gedetineerden verwacht ik dat zij zonder tegensputteren doen wat ik zeg:

-in mijn werk met gedetineerden richt ik mij voomamelijk op het handhaven van orde en rust;

-ik probeer zoveel mogelijk afstand te bewaren in mijn omgang met gedetineerden:

-in mijn werk richt ik mij voornamelijk op het in acht nemen van de lecfregels:

-ik ben altijd op mijn hoede voor gedetineerden die vriendelijk zijn;

De schaal Gedetineerdengerichtheid met de gedetineerdengerichte items leverde cen alpha waarde op van 79 .

De schaal Gedetineerdengerichtheid

-de meeste voldoening van mijn werk met gedetineerden heb ik als ik iemand heb kunnen helpen;

-als ik tijd heb probeer ik een persoonlijk gesprek te voeren met gedetineerden;

-ik probeer rekening te houden met de verschillende wensen en behoelten van gedetinecrden:

-ik moedig gedetineerden aan zoveel mogelijk van hun detentic te maken:

-gedetineerden die in de put zitten geef ik extra alandacht:

\subsection{Resultaten van de enquête onder het personeel}

\subsubsection{Houdingen van de PIW-ers: de opvattingen over de resocialisatie-doelstelling}

In het vorige hoofdstuk werd naar aanleiding van de recente ontwikkelingen in het gevangeniswezen gewezen op de gevolgen van een verdere versobering van de regimes in het bijzonder voor wat betreft de bejegenende en begeleidende taken van de PIW-er.

Deze paragraaf wordt ingeleid met het verhaal van een oudere PIW-er die na 25 dienstjaren de gevangenisdeur voorgoed achter zich dicht trekt.

Het is een buitengewoon illustratief verhaal waarin vanuit het perspectief van een PIW-er de ontwikkelingen van de laatste decennia de revue passeren.

"Ik ben in 1975 bij het gevangeniswezen gaan werken maar dat was toen toch heel anders werken in die tijd. Je mocht bij wijze van spreken nog niet eens gewoon praten met een gedetineerde. Je moest echt afstand houden. Eigenlijk deed je niet meer dan sleutelen. Gelukkig voor mij kwam daar gauw verandering in want anders had $i k$ het niet zo lang volgehouden. Je kreeg als bewaarder zo tegen het einde van de jaren zeventig toch al veel meer mogelijkheden. Je kon wat meer activiteiten galan doen met gedetineerden, je mocht ook meer initiatieven nemen. En na verloop van tijd kregen we ook wat 
meer extsal scholing. Ik kreeg toen echt plezier in mijn werk. Er is toen een tijd geweest dat er niet op de centen werd gekeken, er stonden bakken geld klaar voor allerlei dingen. Je had toen nog het idee dat er groei en ontwikkeling in je werk zat. Op een gegeven moment kon je een extra opleiding krijgen voor de crea en voor de sport. Als je die cursussen deed kon je uiteindelijk in schaal zes komen. Nou, daar wilde iedereen wel aan meedoen. Jammer voor mij zat ik er toen niet bij, er werden zo'n veertig man voor uitgekozen. Dat heb ik toen toch rot gevonden, vooral omdat ik al initiatieven had genomen met sport. Toen eind jaren tachtig deze inrichting werd gebouwd, ben ik hier gaan werken, gewoon omdat je hier meer kansen had. ledereen kreeg hier de crea-opleiding on de sportopleiding en je kon vervolgens meteen door naar schaal zes. Niet dat ik dat ik nou zo zat te azen op dat ene schatilije hoor, want de sport heb ik altijd hartstikke leuk gevonden om dat te begeleiden. Dat was vergeleken met vroeger toch een enorme verbetering. Je kreeg eigenlijk op een simpele manier een veel beter contact met die jongens door een partijtje voetbal te organiseren en door gewoon zelf mee te doen. Dat w'als vroeger gewoon ondenkbaar.

In het begin was hier iedereen nog heel enthousiast, iedereen had wel zin om aan de slag te gaan.. Maar dat gevoel is nu helental weg, je merkt het aan alles, het loopt voor geen meter meer. Ik ben echt blij dat ik er volgend jaar uit kan, de rek is eruit. We zijn weer terug bij af en je moet maar eens opletten, nog even en we zijn weer gewoon cipier. Sommige collega's maakt het gewoon niks uit dat ze op het latatst eigenlijk niet veel anders meer aan het doen zijn dan gewoon "sleutelen". Maar voor mij is dat niks. Je hebt nergens tijd meer voor. alles is zo krap ingedeeld en met steeds minder mensen moet je steeds meer gaan doen. Het is alleen maar bezuinigen, bezuinigen en nog eens bezuinigen. Die heren daarboven in het voorgebouw die hebben nergens last van. Ze schuiven de problemen gewoon door naar beneden, ze zien ons gewoon niet stam. Je moet eens boven in die kantoorunits kijken. al die plaatsvervangende unitdirecteuren, unitdirecteuren, managementassistenten. Laten ze daar eerst maar eens gaan snijden. Kijk, ze bedenken steeds weer iets nieuws en op papier klopt het allemaal wel, maar als wij ermee aan de slag moeten klopt het voor geen meter. En dat gaat zo maar door jaar in jaar uit, elk half jaar een nieuw programma en volgens mij worden ze steeds slechter. Je wordt gewoon moe van al die veranderingen. En misschien komt dat wel doordat ik al wat langer meeloop, maar mijn collegac die een stuk jonger zijn krijgen er ook genoeg van. Het ene plan is nog niet eens goed uitgevoerd of het wordt al weer geschrapt voor een nieuw plan.

Neem nou die Werkzame Detentie, met die arbeid, dat kan toch nooit goed gaan. Je ziet het toch zelf hier op die arbeidszalen. Voor vijf tientjes per week gaat een gedetineerde zich toch nooit uit de naad werken. De meeste gaan natuurlijk wel naar de arbeid on niet op cel te hoeven zitten, maar werken zoals in een bedrijf buiten dat zie je hier gewoon niet. En werk is er ook niet genoeg. Ze zitten daar soms gewoon te kaarten! Weet je wie het nu moeilijk hebben? De werkmeesters en het hoofd arbeid, die worden opgejatad van boven af, die moeten werk binnen halen wat niet echt makkelijk is en ze moeten die gasten opjagen die er helemaal geen zin in hebben, nee, .... het werkt allemaal voor geen meter.

Eerst was het resocialisatie en nou heet het tegenwoordig maatschappelijke integratie. Dan stellen ze cen dure trajectbegeleider aan om anderhalve gedetineerde per jaar maatschappelijk te integreren. Dat is gewoon flauwekul. Ik zeg altijd maar diegenen die echt gemotiveerd zijn om hier nooit meer terug te komen die hoef je niet te helpen die blijven gewoon weg en redden zich zelf wel".

De collegae van deze PIW-er die bereid waren het enquêteformulier in te vullen denken blijkens de uitkomsten in meerderheid in positieve zin over de resocialisatie-doelstelling.

Meer dan de helft is het oneens met de uitspraak dat gedetineerden onverbeterlijk zijn en daarom eigenlijk geen resocialisatie nodig hebben.

Een ruime meerderheid $(60 \%)$ vind dat de resocialisatie-doelstelling nodig is omdat detentie meer inhoudt dan het zich ordelijk en rustig gedragen van gedetineerden

Het feit dat het merendeel van de gedetineerden na detentie toch weer recidiveert, is voor een zeer ruime meerderheid $(78 \%)$ geen reden om deze resocialiserende voorzieningen maar af te schaffen.

Men denkt evenmin dat het aantal gedetineerden dat echt gemotiveerd is voor resocialisatie te klein is om er nog langer mee door te gaan $(61 \%)$. 
De frequentie-verdelingen op deze vier uitspraken van de schalal Opvattingen in Enge zin laten zien dat een meerderheid van de PIW-ers een visie in enge zin op de resocialisatieopdracht niet onderschrijft.

Kijken we naar de frequentieverdelingen bij de items die de schaal Opvattingen in Ruime zin reflecteren dan blijkt het volgende.

Een meerderheid $(76 \%)$ vindt dat je gedetineerden niet alleen maar moet straffen, ze verdienen naar hun mening ook een kans om aan een betere toekomst te werken.

Een groep van iets meer dan $40 \%$ is het niet eens met de uitspraak dat je met resocialisatie in ieder geval voorkomt dat gedetineerden nog gevaarlijker in de samenleving terugkeren dan zij al waren. Een bijna even grote groep, namelijk $38 \%$ denkt dat dit nuttige effect wel optreedt

Een meerderheid $(55 \%)$ vindt dat begeleiding tijdens en na de detentie zinvol is, ook al loopt het met de meesten toch weer verkecrd af.

Een meerderheid $45 \%$ onderschrijft niet de gedachte dat als je de hulp en steun tijdens detentie uitbreidt gedetineerden zich later beter zullen redden. Ongeveer eenderde van de respondenten $(29 \%)$ denkt echter wel dat met meer hulp en steun gedetineerden zich beter weten te redden.

Een percentage van $68 \%$ van de respondenten is van mening dat gedetineerden altijd profijt hebben van de voorzieningen ook al is dat niet genoeg om op het rechte pad te blijven. De toekomst zou er zonder hulp en steun tijdens detentie volgens $64 \%$ nog veel slechter uitzien. De frequentieverdelingen tonen aan dat de meerderheid van de PIW-ers een ruime opvatting van resocialisatie aanhangen en een enge opvatting verwerpt.

Over de mogelijkheden om de terugkeer in de samenleving voor te bereiden tijdens de detentie denken de ondervraagde PIW-ers het volgende.

Een meerderheid $(55 \%)$ vindt dat gedetineerden nauwelijks aan een goede voorbereiding van de detentie toekomen in de gevangenis.

Bijna de helft van de PIW-ers $(48 \%)$ denkt dat gevangenisstraf ecrder een slechte invloed heeft op de meeste gedetineerden dan een goede. Tegelijkertijd is er een kwart van de respondenten die het niet eens zijn met deze stelling.

Driekwart van de respondenten meent dat men gedetineerden met een verblijf in de gevangenis niet op het rechte pad krijgt. Bovendien is naar de mening van $44 \%$ van de respondenten het gevolg van een verblijf in detentie dat gedetineerden steeds negatiever gaan denken over de toekomst. Bijna een derde $(27 \%)$ denkt dat dit niet het geval is.

Een derde van de respondenten vindt de gevangenis een ongeschikte omgeving om aan de toekomst te werken, terwijl de helft $(50 \%)$ dat niet vindt. Een meerderheid is zich weliswaar bewust van de beperkingen van de gevangenis op het gebied van resocialisatie, maar die beperkingen acht men blijkbaar niet van dien aard dat men het werken aan de toekomst als geheel onmogelijk of als zinloos beschouwt.

\subsubsection{Meningen van PIW-ers over de zin van vrijheidsbenemende sancties}

Aan de PIW-ers werd een vijftal mogelijke redenen voor het opsluiten van wetsovertreders voorgelegd. De bescherming van de samenleving acht men de meest zinvolle reden om wetsovertreders op te sluiten. Op de tweede plaats komt de vergeldingsdoelstelling. Afschrikking van derden of generale preventie vindt men vervolgens de beste reden. Speciale preventie of resocialisatie en voorkomen van eigenrichting komen respectievelijk op de vierde en vijfde plaats. 
Blijkbaar acht men de resocialisatiedoelstelling opgevat als het streven om de wetsovertreder via een vrijheidsbeneming weer op het rechte pad te brengen een weinig zinvolle rechtvaardiging van de vrijheidsbeneming.

Deze bevindingen vormen een interessant contrast met de bevindingen uit de vorige paragraaf die aangeven dat PIW-ers in meerderheid niet afwijzend staan tegenover resocialisatie als detentiedoel op executief niveau. Men beschouwt blijkbaar de resocialisatiedoelstelling op het applicatieve niveau geen goede rechtvaardiging van de vrijheidsbeneming, toch vindt een meerderheid dat voorzieningen dic kansen en mogelijkheden voor zelfverbetering tijdens de detentie bieden, zinvol zijn. Men koestert in meerderheid weliswaar niet de verwachting dat men gedetineerden met deze voorzieningen op het rechte pad krijgt, men is zich terdege bewust van de beperkingen van het instituut gevangenis. Maar die beperkingen acht men niet van dien aard dat het werken aan de toekomst als een zinloze, overbodige activiteit wordt gezien.

In het denken over resocialisatie spelen speciaal preventieve overwegingen of bezwaren met betrekking tot een gering effect qua recidive-reductie dus blijkbaar geen gewichtige rol bij het merendeel van de PIW-ers.

Als we vervolgens kijken naar hun houding ten aanzien van de activiteiten in het algemeen dan komt het zojuist geschetste beeld nog sterker tot uiting.

\subsubsection{Meningen van PIW-ers over de activiteiten in het algemeen}

Een ruime meerderheid van de PIW-ers $(68 \%)$ is het eens met de uitspraak: "van de activiteiten leren gedetineerden altijd iets, ook al is het niet genoeg om later op het rechte pad te blijven". Een ruime meerderheid $(64 \%)$ denkt dat zinvolle activiteiten een gunstig effect op het toekomstig functioneren van gedetineerden hebben. Blijkbaar hanteert men het perspectief van "alle beetjes helpen" en derhalve opteert men eerder voor een ruime opvatting van de resocialisatie-doelstelling.

En meer dan $90 \%$ van de respondenten vindt dat zinvolle activiteiten onmisbaar zijn voor een humane bejegening. Een zeer ruime meerderheid $(87 \%)$ is van mening dat activiteiten onmisbaar zijn voor een rustige en ontspannen sfeer in de inrichting en ruim $70 \%$ denkt bovendien dat de activiteiten belangrijk zijn voor een goede omgang tussen personeel en gedetineerden

Overzien we de voorgaande resultaten over de opvattingen van het bewarend personeel ten aanzien van de resocialisatie-gedachte dan blijkt men de resocialisatie-gedachte zeker niet in de meer bevlogen en idealistische zin te omarmen. Men is vrij realistisch en erkent dat men de gedetineerde met de bestaande voorzieningen op het gebied van maatschappelijke integratie in de gevangenis allén niet op het rechte pad krijgt. Noch ziet men het verbeteringsideaal in het algemeen als een goede reden om wetsovertreders op te sluiten. PIW-ers lijken meer te kiezen voor een opvatting waarbij de activiteiten gericht op maatschappelijke integratie niet zozeer worden gerechtvaardigd of ondersteund vanuit een verbeteringsideaal maar veeleer vanuit de gedachte dat een humane tenuitvoerlegging meer inhoudt dan simpel opbergen en bewaken. $\mathrm{Zij}$ beschouwen de resocialisatie-gedachte en de bijbehorende activiteiten als dienstig aan genormaliseerde betrekkingen en een constructief klimaat waarin men zinvol bezig is en ledigheid uit den boze is. Het feit dat men met de (resocialiserende) activiteiten de meeste gedetineerden niet op het rechte pad krijgt, lijkt in de perceptie van het merendeel van het bewarend personeel geen rol van betekenis te spelen bij hun houding ten aanzien van resocialisatie. Blijkbaar is het verminderen van recidive als eindresultaat van de intramurale interventies geen doorslaggevend aspect van hun visie op resocialisatie. Wellicht beschouwt men het verminderen van recidive als een doel dat in een later stadium, in de post-detentiefase, met de inzet van de gedetineerde en andere instanties 
zijn beslag moet krijgen. Het nut van de activiteiten voor een eventueel resocialisatie-proces wordt immers veel meer geinterpreteerd in termen van een bijdrage of 'alle beetjes helpen'. Voorts lijken bewaarders de activiteiten niet louter te waarderen als een middel om rust en orde te scheppen, men waardeert de activiteiten tevens om een bepaalde meerwaarde ten aanzien van humaniteit en zingeving van de detentic.

In de onderzoeksliteratuur wordt de geringe aandacht in de inrichtingen voor specialalpreventieve doeleinden in de zin van recidive-reductie onderkend.

Denkers (1976) noemt op grond van een analyse van het gevangeniswezen in de jaren zeventig een aantal eigenlijke of werkelijke doeleinden (te onderscheiden van de officiële doelstelling, waaronder resocialisatie) van het gevangeniswezen zoals vergelding, humanisering ter vermindering van vergelding en detentieschade en humanisering als een middel ter handhaving van de orde en rust. Volgens Denkers zijn er talloze andere werkelijke of 'unstated goals' die mede de besluitvorming bepalen. In aard en sterkte variëren zij van land tot land en van gevangenis tot gevangenis. Recidive -vermindering als doel van voorzieningen gericht op resocialisatie spelen aldus Denkers geen rol van belang. Speciaalpreventieve doelstellingen als eigenlijke doelstelling van het gevangeniswezen spelen hooguit een rol voor zover word getracht recidive -vermeerdering te voorkomen. Zo speelde in de jaren zeventig van de twintigste eeuw recidive-vermindering bij open gestichten, die juist bedoeld waren on de resocialisatie te bevorderen, in de optie van de verantwoordelijke strafrechtsfunctionarissen geen rol van betekenis. Men streefde er hooguit naar te voorkomen dat gedetineerden er slechter uitkwamen dan zij er waren ingekomen. Het criterium van doelmatigheid van de verschillende detentievormen is, zo concludeert Denkers in de jaren zeventig, kennelijk niet de relatief geringere recidive.

Conrad (1981, p.1722 en 1723) beschrijft het perspectiel van het penitentiaire werkveld in het bijzonder van de inrichtingsdirectie zelfs als: "immediate concerns that blot out any thought of recidivism as a criterion of their succes of what they are doing." En verder merkt Conrad op: "What an administrator needs to know about a program is not the rate of recidivism at the end, but such immediately practical questions as its costs, the number of prisoners volunteering to participate, and ist effectiveness in achicving immediate aims."

Ook Logan en Gaes (1993) veronderstellen dat de docleinden die men met activiteitenprogramma's in de inrichtingen nastreeft niet zozeer zijn gericht op recidive- reductic, maar veeleer op het scheppen van een klimaat dat een humaan, constructief, veilig en ordelijk karakter draagt.

Sommige auteurs menen dat deze geringe aandacht in de inrichtingen voor daadwerkelijke gedragsveranderende effecten vooral te wijten is aan het vasthouden aan het orde- en rustprincipe (zie bij voorbeeld Melk,1985).

Zetten we de bovengenoemde onderzoeksresultaten af tegen deze veronderstellingen in de literatuur dan zien we dat het hierin geschetste beeld door onze gegevens in grote lijnen wordt bevestigd. Bewaarders ondersteunen de resocialisatiegedachte vooral om humane redenen. Bovendien neemt men, als het om de middelen van resocialisatie of wel de activiteiten gaat, gunstige effecten waar, die niet alleen betrekking hebben op een rustige en ontspannen sfeer in de inrichting, maar ook op aspecten als groei in de persoonlijke en sociale ontwikkeling.

Een groei die in hun visie weliswaar niet toereikend is om later niet meer te recidiveren, maar die niettemin als zinvol wordt ervaren.

Het feit dat de meeste respondenten de activiteiten niet alleen waarderen om hun bijdrage aan een rustige gang van zaken in de inrichting maar ook andere, minder beheersmatige of 
praktische functies onderkennen, duidt erop dat de resocialisatie-doelstelling en de bijbehorende activiteiten een zingevende, positieve rol vervullen voor een substantieel deel van het personeel. Men onderkent een duidelijke meerwaarde van de middelen doelstellingen van resocialisatie die verder reikt dan puur beheersmatige overwegingen.

Men lijkt de activiteiten ook te waarderen als een fenomeen dat een positief tegenwicht biedt in een omgeving die doorgaans gekleurd wordt door negatieve gebeurtenissen en ervaringen. Welbeschouwd ligt dit ook wel voor de hand want de resocialisatie-doelstelling is binnen het complex van doelstellingen van de detentie bij uitstek de enige doelstelling met een evidente positieve betekenis, in de zin van de mogelijkheid van persoonlijke groei. Detentie wordt in de beleving van degene die haar ondergaan veelal gekenmerkt door een gevoel van een zekere machteloosheid en achteruitgang in de zin van detentieschade. De gedetineerde voelt zich letterlijk en figuurlijk vastgezet en hij of zij heeft het idee dat men geen kant meer op kan. De resocialisatiedoelstelling, sterker nog dan de andere doelstellingen zoals humaniteit in de zin van minder vergelding en beperken van detentieschade, die juist een negatief vertrekpunt hebben in de zin van het reduceren van leed, lijkt hier met de belofte van groei en vooruitgang een noodzakelijke en uniek tegenwicht in positieve zin te bieden. Resocialisatie biedt de mogelijkheid voor zowel het personeel als gedetineerden het werk of verblijf in een, in essentie destructieve, negatieve omgeving zin te geven. De positieve houdingen ten aanzien van de resocialisatie-doelstelling en de aangewende middelen dienen mijns inziens vooral in het licht van deze positieve zingevende waarde te worden verklaard. Het personeel heeft blijkbaar toch behoefte aan een stuk geloof om te kunnen werken met gedetineerden.

In de studie van Denkers (1976, p.241) treffen we in dit verband een buitengewoon illustratief citaat aan van een hoofd Gevangeniswezen in de jaren zeventig, een citaat dat naar mijn mening eigenlijk nog niets aan actualiteit heeft ingeboet:

"Ik vind wel dat je, als hoofd van het gevangeniswezen, je twijfels voor een deel zelf moet verwerken, en ze maar niet moet door geven tot aan de laagste bewaarder toe. Die man moet namelijk iedere dag met die gedetineerde omgaan. Dus als je die niet een stuk geloof schenkt, dat hij op die plaats vruchtbaar kan werken, en iets kan betekenen voor die vent waarmee hij een paar jaar moet optrekken... als je al je eigen twijfels doorgeeft, geef je iets door dat hij, op dat niveau, niet dragen kan."

Ook nu nog is naar mijn mening dit laatste aspect van belang. Blijkbaar heeft de bewaarder op de werkvloer en in zijn dagelijkse werk toch behoefte aan een bepaalde mate van zingeving en blijkens de resultaten van deze studie speelt de resocialisatiegedachte, opgevat in ruime zin, hierbij nog steeds een belangrijke rol.

Men zou dit geloof in de resocialisatie-doelstelling ook kunnen zien als een soort oneigenlijk gebruik van de doelstelling. Men klampt zich vast aan een doelstelling niet zozeer vanwege een geloof in de intrinsieke waarde van die doelstelling, maar meer om zichzelf het idee of gevoel te geven dat men nog enigszins zinvol werk aan het verrichten is. Een dergelijke interpretatie bezit wellicht enige plausibiliteit. Echter, de wijze waarop bewaarders de middelen en doelstellingen van resocialisatie beschouwen vertoont in het licht van die zingeving van het werk toch ook een verrassende mate van realisme. Dit realisme is vermoedelijk het gevolg van een goede inschatting van de complexiteit van een proces van zelfherstel en van de beperkte mogelijkheden die de gevangenis voor het proces van zelfherstel kan bieden. Men koestert immers geen hooggespannen verwachtingen als het om het voorkomen van recidive gaat noch klampt men zich vast aan een onbereikbaar verbeteringsideaal. Wel koestert men in meerderheid de gedachte dat iedere vorm van persoonlijke groei of zelfherstel of pogingen daartoe tijdens de detentie opzichzelf, los van de eventuele effecten op toekomstig regelovertredend gedrag, waardevol zijn. Hiermee geeft het 
bewarend personeel blijk van het vermogen om het oorspronkelijke hooggespannen verbeteringsideaal als het ware te transformeren tot een meer, op de beperkte leest van de gevangenis geschoeide, realistische en genuanceerde versie. Een beter oog voor nuances heeft men doordat men dagelijks, midden in het primaire proces op de werkvloer staat. Men zit met de neus boven op de problemen die delinquenten hebben en vervolgens ziet men ook hoe moeilijk het is hieraan iets te doen. Vanuit dit perspectief beschouwt men iedere verbetering en stap vooruit in houding en gedrag van de gedetineerde als cen moeizaam veroverde, maar zeer waardevolle overwinning.

\subsubsection{De PIW-ers en hun visie op de begeleiding van de activiteiten}

In dezelfde periode waarin de schriftelijke enquête werd gehouden onder de PIW-ers werd door een stagiaire van een HBO-opleiding sociaal-pedagogisch hulpverlening een stageonderzoek gehouden naar het functioneren van de crea-activiteiten in een van de onderzochte inrichtingen.

In het kader van dit stage onderzoek werden interviews gehouden met een achttal PIW-ers. Tevens werd een aantal oriënterende gesprekken gevoerd ter voorbereiding van dit stageonderzoek. Uit deze gesprekken en interviews komt onder meer naar voren een groep PIWers naar voren die zeer gemotiveerd is voor de begeleidende taak als crea-PIW-er. Zij vonden dat de tijden voor de crea in het algemeen te kort waren en dat men wel frequenter als begeleider wilde worden ingezet bij de crea-activiteiten.

Voorts bleek deze groep zijn best te doen de gedetineerden te motiveren en te voorzien van informatie over de crea-activiteiten. Volgens het verslag van de stagiaire is er ook een groep ongemotiveerde PIW-ers die het liefst helemaal niet werden ingezet bij de crea. Zij zien zich zelf puur als bewaker of beveiliger ondanks hun crea-opleiding. Voor deze groep verloopt het contact met de gedetineerden tijdens de crea niet anders dan op de afdeling. Het lijkt erop of deze groep zich voor wat hun begeleidende en bejegende taken zoveel mogelijk afsluit. In het stageverslag komen we ten aanzien van deze ongemotiveerde groep nog de volgende passage tegen:

"de ongemotiveerde groep PIW-ers zien het in principe als onmogelijk een gedetineerde te resocialiseren wanneer ze hem tevens moeten opsluiten." (p.32)

Ten aanzien van de gemotiveerde PIW-ers constateert men in het stage-onderzoek dat zij een duidelijke meerwaarde van de crea voor de contacten met de gedetineerden zien, deze contacten worden volgens hen diepgaander en lastige gedetineerden worden mede daardoor beheersbaarder. Uit de interviews met de gedetineerden door de stagiaire blijkt een dergelijk gunstig effect op de contacten tussen personeel en gedetineerden eveneens. In het verslag staat hierover het volgende vermeld:

"de gedetineerden geven wel aan dat ze het fijner vinden wanneer een PIW-er zelf meedoet met de activiteiten. Er heerst dan een andere sfeer dan op de vleugel. Er ontstaan dan ook andere gespreksthema's. Als een PIW-er zich echt opstelt als toezichthouder, als bewaker, dan komt ook bij de crea de meer gespannen sfeer van de vleugel terug."(p.29)

Een van deze PIW-ers zegt het volgende:

"De waarde van de crea wordt duidelijk onderschat. Het is niet alleen maar domweg iets maken met je handen. Je bent als PIW-er bezig een sfeer te scheppen om de gedetineerden zichzelf zoveel mogelijk te laten ontplooien. Dit komt ook de beheersbaarheid alleen maar ten goede." (p.32) 
Voorts geven de meer gemotiveerde PIW-ers aan dat gedetineerden door de crea stabieler worden, hun gedrag wordt er positief door beïnloed. Deze groep benadrukt ook dat crea vooral een middel is om bepaalde doelen te bereiken zoals het versterken van een gevoel van eigenwaarde en een meer stabiele opstelling bij de gedetineerden.

Wat de organisatie van de kunstzinnige vorming van de crea betreft hadden zowel de meer gemotiveerde als de ongemotiveerde bewaarders een eensluidende mening. De ondersteuning van de crea-consulent zou voor elk crea-moment moeten gelden teneinde de begeleiding beter te laten verlopen. Voorts is men van mening dat bij de crea-begeleiding eigenlijk alleen maar gemotiveerde PIW-ers moeten worden ingezet. De ongemotiveerde groep bleek geen behoefte te hebben aan bijscholingsmomenten, voorbereidingstijd noch structureel overleg. Deze groep gaf te kennen dat men de basisopleiding tot crea-bewaarder op zich zelf al een corvee vond.

Ten aanzien van de gegevens uit dit stage-verslag dient te worden opgemerkt dat het slechts om de mening van een zeer kleine groep PIW-ers ging uit een inrichting en op grond van dit meer kwalitatieve materiaal is generaliseren naar een grotere groep PIW-ers niet mogelijk. Toch zien we in de uitkomsten van de schriftelijke enquête onder een groep van 59 PIW-ers over drie inrichtingen een aspect dat in het stageverslag naar voren kwam namelijk, de aanwezigheid van een kleine groep PIW-ers met een zeer positieve houding ten aanzien van de kunstzinnige vorming terugkomen. In het bijzonder als het gaat om de inschatting van de motieven van gedetineerden voor deelname aan de crea is er een kleine groep van PIW-ers die in deze motieven meer ontdekken dan louter de behoefte om niet op cel te hoeven te zitten.

In de schriftelijke enquête voor de inrichtingswerkers werd een aantal items opgenomen die betrekking hebben op de begeleiding van de activiteiten in het bijzonder de kunstzinnige activiteiten en de sportactiviteiten. Omdat halverwege de jaren negentig in toenemende mate ook door functionarissen uit het gevangeniswezen de motivatie en geschiktheid van de huidige gedetineerdenpopulatie voor het toenmaals heersende niveau van voorzieningen in twijfel werd getrokken, werden derhalve ook items voorgelegd met betrekking tot de motivatie en motieven van gedetineerden voor hun deelname aan activiteiten als kunstzinnige vorming en sport. Juist deze twee activiteiten werden uitgekozen omdat het bij uitstek de activiteiten zijn waarbij de PIW-er een belangrijke taak heeft als begeleider en als zodanig een goed beeld krijgt van de motieven en motivatie van de gedetineerden.

\subsubsection{PIW-ers en hun mening over de motieven en motivatie van gedetineerden}

Een zeer ruime meerderheid $(90 \%)$ vindt dat gedetineerden makkelijk te motiveren zijn voor deelname aan de sportactiviteiten. Over het gemak waarmee men gedetineerden kan motiveren voor de crea-activiteiten is men minder eenduidig positief. Een kwart van de respondenten denkt niet dat gedetineerden zo gemakkelijk te motiveren zijn voor crea. Bijna een derde $(28 \%)$ heeft hier geen uitgesproken mening over. Bijna de helft $(48 \%)$ denkt echter dat gedetineerden wel gemakkelijk zijn te motiveren voor deze activiteit. Eveneens een ruime meerderheid $(70 \%)$ vindt dat gedetineerden die naar de crea gaan over een goede motivatie beschikken. Over de motivatie van de sporters is $92 \%$ zeer goed te spreken.

Verslavingsproblematiek is volgens een meerderheid (54\%) een factor waardoor gedetineerden moeilijker zijn te motiveren voor deelname aan de activiteiten. Meer dan een kwart $(26 \%)$ denkt dat verslavingsproblemen het motiveren van gedetineerden voor de activiteiten niet in de weg staan. Dit item viel overigens weg bij de constructie van de schaal Motivatie. De frequentieverdelingen op dit item worden echter wel vermeld vanwege het vermeende grote belang van drugsverslaving voor de motivatie voor activiteiten. 
De motieven die men voor deelname aan de crea-activiteiten toekent, worden in de perceptie van de PIW-ers nogal sterk gekleurd door de behoefte de directe spanningen en ongemakken van het gedetineerd zijn te verminderen. Zo is $58 \%$ van mening dat de belangrijkste reden voor gedetineerden om naar de crea te gaan betrekking heeft op de behoefte van de afdeling weg te zijn. Echter, $32 \%$ is het hiermee niet eens. Verveling verdrijven en het zocken van gezelligheid en het kapot zien te krijgen van de tijd is eveneens voor cen meerderheid van de respondenten een belangrijk motief van gedetineerden voor deelname alan de creaactiviteiten. Ook bij deze items zien we een kleine minderheid van ongeveer een derde van de respondenten die vindt dat deze motieven niet doorslaggevend zijn

Hierbij dient men zich wel te realiseren dat het merendeel van de respondenten werkzaam was op een HVB afdeling en zoals uit de gedetineerdenenquete blijkt, in een HVB regime spelen vanwege het restrictieve karakter van dit regime motieven die de directe ongemakken van de detentie reduceren een sterkere rol.

Tevens dient men zich te realiseren dat onder het bewarend personeel de gedachte dat gedetineerden voornamelijk aan activiteiten declnemen om vanachter de deur vandaan te zijn' een vast onderdeel is van hun repertoire aan uitspraken over gedetineerden. Naar mijn stellige indruk is het een soort opvatting die bij de bewalarderscultuur lijkt te horen. Als creaconsulent was het een van de eerste meest opvallende waarschuwingen die ik van bewaarders te horen kreeg, "maak je geen illusies, zij komen alleen maar naar de crea om nict op die cel te hoeven zitten." Zelfs het feit dat bewaarders met eigen ogen kunnen waarnemen hoe gedetineerden ondanks deze reële behoefte om niet op de cel te hoeven zitten, toch sericus iets gaan leren bij de kunstzinnige vorming doet niets af aan de hardnekkigheid van deze opvatting. Wel zien we, evenals in de uitkomsten van het eerder vermelde stage-onderzoek dat er een kleine groep PIW-ers met een vermoedelijk uitgesproken positieve houding tegenover crea-activiteiten. $\mathrm{Zij}$ laten zich aan de standaardopvattingen omtrent de opportunistisch motieven van gedetineerden niets gelegen liggen. Zij hebben blijkbaar een hogere pet op van de motieven van gedetineerden en zijn het niet eens met de welhaast tot cliché geworden opvattingen dat gedetineerden voornamelijk voor crea kiezen om de vanachter de deur te zijn of om de tijd kapot te krijgen of puur om de gezelligheid. Vanuit hun grotere betrokkenheid bij de kunstzinnige vorming hebben deze bewaarders wellicht ook een meer positieve en voor een deel wellicht ook een realistischer kijk op de motieven van gedetineerden.

Uit het volgende gedeelte van de enquête blijkt dat PIW-ers in meerderheid, ondanks hun vrij eenzijdige kijk op de motieven van gedetineerden toch wel oog hebben voor de gunstige effecten op het gebied van de persoonlijke en sociale ontwikkeling. Blijkbaar gaat men ervan uit dat de motieven van gedetineerden om aan de kunstzinnige vorming deel te nemen weliswaar sterk worden bepaald door de ongemakken van de detentie, niettemin beschouwt men eventuele gunstige effecten voor de persoonlijke ontwikkeling en levenssituatie als cen nuttige en wel degelijke aanwezige bijkomstigheid van de activiteiten.

\subsubsection{PIW-ers over de waargenomen effecten van de crea-activiteiten}

De gevonden frequenties laten zien dat het bewarend personeel in meerderheid toch die aspecten die te maken hebben met de persoonlijke ontwikkeling wel degelijk waarneemt.

Een meerderheid $(52 \%)$ vindt dat gedetineerden door de crea-activiteiten meer vertrouwen krijgen in hun eigen capaciteiten en $58 \%$ denkt dat gedetineerden hun creatieve vermogens ontwikkelen. De meeste PIW-ers constateren ook dat gedetineerden meer handigheid in het hanteren van materialen en technieken $(68 \%)$ verwerven en op een creatieve manier vormgeven aan hun ideeën $(62 \%)$. Een minderheid van PIW-ers met een negatieve of 
onverschillige houding ten aanzien van de kunstzinnige vorming ontkent dat de genoemde leereffecten optreden of heeft hierover geen uitgesproken mening.

Naast de effecten op de persoonlijke ontwikkeling van de gedetineerde werd de PIW-ers tevens cen aantal mogelijke effecten voorgelegd die betrekking hebben op de sociale ontwikkeling. Zo vindt $44 \%$ niet dat gedetineerden door deelname aan de crea-activiteiten meer begrip krijgen voor de taak van PIW-crs, $36 \%$ heeft hier geen uitgesproken mening over en $20 \%$ vindt dat dit effect wel optreedt.

Een ruime meerderheid denkt als PIW-er bovendien een beter contact te krijgen met de gedetineerden $(86 \%)$ als gevolg van de begeleiding van de crea-activiteiten.

Nog geen vijfde (18\%) denkt dat een effect van crea is dat gedetineerden meer respect voor elkaar of voor anderen krijgen. De overige respondenten zijn het hicrmee niet eens (34\%) of hebben geen uitgesproken mening hierover.

Een derde denkt dat gedetineerden als gevolg van crea-activiteiten preltiger met elkaar omgaan en $18 \%$ ziet cen dergelijk effect niet.

De effecten die te maken hebben met de dagelijkse. ordentelijke en rustige gang van zaken (de schaal Hamtering) en verwijzen naar de manier waarop gedetineerden de detentiesituatie hanteren, latat het volgende beeld zien.

Meer dan de helft (52\%) vindt dat doordat gedetineerden meedoen aan een activiteit als crea minder lastig zijn en een zelfde percentage gelooft dat men zich door deelname aan de crea minder verveelt.

Van de respondenten vindt $70 \%$ dat gedetineerden zich door de kunstzinnige vorming goed kunnen ontspannen.

Een kwart is van mening dat gedetineerden door crea hun problemen op een meer creatieve manier leren uiten, terwijl $46 \%$ dit effect niet waarneemt

Een derde gelooft dat er ook een gunstig effect is op het handhaven van de orde op de afdeling, maar $40 \%$ denkt dat niet het geval is.

Tenslotte werd aan bewalarders middels twee items gevraagd wat het effect van de begeleiding van de crea is op hun arbeidssatisfactie. Deze items behoren overigens niet tot de schaal Hantering.

De helft $(50 \%)$ vindt dat je door begeleiding van crea-activietiten meer plezier krijgt in je werk, maar een vijfde van de respondenten vindt dat dit nict het geval is. Ruim een kwart gelooft dat mede door de begeleiding van de crea-activiteiten je als PIW-er je werk beter aan kan, een derde heeft hier geen mening over en ruim $42 \%$ is het hiermee oneens.

Overzien we de mening van de PIW-ers over de effecten van de crea-activiteiten dan blijkt men over de effecten op het gebied van de persoonlijke ontwikkeling het meest positief te zijn. De overige twee dimensies laten een minder eenduidig positief beeld zien. Opvallend is dat als het gaat om de sociale ontwikkeling, een ruime meerderheid de activiteiten vanuit het oogpunt van een betere omgang met gedetineerden zeer waardeert en tevens ziet een meerderheid een gunstig effect in de zin van een betere aanpassing aan de detentie door minder probleemgevend gedrag.

\subsubsection{PIW-ers over de randvoorwaarden van de activiteiten}

Over de aspecten met betrekking tot de programma-integriteit als frequentie van de begeleiding, de plaats in het dagprogramma, informatieverstrekking aan gedetineerden, voorbereidingstijd, ondersteuning door collegae en leiding, samenwerking met en ondersteu- 
ning door de crea- consulent, deskundigheidsbevordereing en afstemming van de activiteiten op de behoeften van gedetineerden werd de respondenten een aantal uitspraken voorgelegd.

Aan de PIW-ers werd gevraagd met welke frequentic zij als begeleider bij de crea-activiteiten aanwezig zijn. Het blijkt dat slechts $2 \%$ zegt heel vaak de creat te begeleiden. Vervolgens geeft ruim $18 \%$ aan valak naar de crea te gaan en de overgrote meerderheid $(40 \%)$ treedt slechts af en toe op als begeleider. Ruim $38 \%$ komt zelden of nooit als crea-begeleider in actie. De meeste bewaarders $(65 \%)$ vinden dat zij vaak genoeg aan de beurt komen en $34 \%$ is van mening dat men binnen het huidige rooster niet voldoende aan de beurt komt voor begeleiding van de crea.

In een van de inrichtingen is de crea-consulent vrijwel altijd bij de crea-activiteiten anwezig en deze neemt als het om de begeleiding galat, het voortouw. De PIW-ers die eveneens bij de crea worden ingezet, komen hierdoor in hum begeleidende taak niet echt meer tot hun recht. De meeste PIW-ers vervalten weer in hun toezichthoudende rol, ondanks het feit dat men over een crea-opleiding voor PIW-ers beschikt. De helft van de respondenten in deze inrichting is het eens met deze gang van zaken, de andere helft is het hiermee echter niet eens.

Deze manier van werken in deze inrichting is een gevolg van het feit dat in deze inrichting nog nooit structureel momenten zijn geschapen om, met de ondersteuning van de consulent in de tweede lijn, de PIW-ers daadwerkelijk hun oorspronkelijke begeleidende taak naar behoren te laten vervullen.

De PIW-ers in deze inrichting beschouwen dit in meerderheid als een duidelijk gemis (79\%). Ondanks de ontbrekende randvoorwaarden wordt er volgens $45 \%$ met de consulent meestal tijdens de crea over bepaalde zaken toch nog overleg gevoerd. Een meerderheid (54\%) zegt nooit met de consulent overleg te voeren over de gang van zaken bij de kunstzinnige vorming.

Over de tijden waarop de gedetineerden van de afdeling van de betrokken respondenten naar de crea kunnen gaan is een derde ontevreden. De helft vindt de tijden gunstig gekozen.

Over de hoeveelheid tijd die gedetineerden krijgen om zich met creatieve activiteiten bezig te houden, is de groep respondenten verdeeld. Vier op de tien PIW-ers vindt de tijd voldoende echter eveneens vier op de tien bewaarders vindt de tijd te kort. Over het moment waarop men naar de sport kan gaan, is men aanmerkelijk meer tevreden $(68 \%)$, en over de hoeveelheid tijd eveneens $(58 \%)$.

Ruim $53 \%$ vindt dat men onvoldoende tijd krijgt om de crea voor te bereiden en bijna $28 \%$ vindt dat de voorbereidingstijd voldoende is.

Over de waardering door collegae als men vaak de crea begeleidt is $34 \%$ tevreden, echter een kwart denkt niet dat collegae het waarderen als je de crea vaak begeleidt.

Slechts $18 \%$ is van mening dat de crea voldoende aan de orde komt in het afdelingsoverleg. Een meerderheid van $56 \%$ vindt dat dit onvoldoende gebeurt.

De helft is ontevreden over de ondersteuning door de leiding in het werk als crea-bewaarder. Slechts een vijfde van de respondenten is hierover tevreden. De werksfeer in de inrichting vindt een kwart $(25 \%)$ wel stimulerend als het gaat on de begeleidende taak bij de crea. Ruim $37 \%$ heeft hierover geen mening en eveneens $37 \%$ vindt de werksfeer niet stimulerend. Ruim de helft van de PIW-ers vindt zijn kennis en vaardigheden ontoereikend voor cen goede begeleiding van de crea-activiteiten. Over materialen en gereedschappen is $46 \%$ van de PIWers ontevreden en een derde vindt dat een en ander in orde is. Iets meer dan de helft vindt de crea-ruimte niet goed onderhouden. 
Ruim 68\% denkt dat gedetineerden voldoende duidelijkheid krijgen omtrent het tijdstip van de crea-activiteiten en eveneens een ruime meerderheid vindt dat de activiteiten voldoende zijn afgestemd op de behoeften van de gedetineerden Over de informatie omtrent de inhoud van de crea-activiteiten alan gedetineerden is vier op de tien respondenten tevreden en ruim cen derde is hicrover niet tevreden.

Tenslotte probect 45\% van de PIW-ers gedetincerden altijd aan te moedigen om naar de crea te gaan, maar een kwart zegt dit nooit te doen.

Overzien we frequentieverdelingen met betrekking tot de verschillende aspecten van programna-integriteit bij de activiteiten dan blijkt men het meest ontevreden over de ondersteuning bij deze activiteiten. Zoals wij bij de bespreking van de literatuur zagen, was dit blijkens de uitkomsten van het onderzoek van Van Hooff en van Zeijl (1984), ook al een belangrijke klacht. Men heeft blijkbaar nog steeds niet het gevoel dat men in zijn of haar bezigheden als crea-bewaarder voldoende gestimuleerd of ondersteund wordt door de leiding van de inrichting. Men ervaart bovendien in meerderheid het ontbreken van begeleiding en ondersteuning door de consulent als een gemis.

\subsubsection{PIW-ers en hun visie op de omgang met gedetineerden.}

In de gedetineerden-enquête werd de beleving van het regime geoperationaliseerd door middel van items die betrekking hebben op de dagelijkse contacten tussen gedetineerden en bewarend personeel. Voor deze wijze van operationalisatie werd gekozen omdat op grond van de onderzoeksliteratuur blijkt dat de contacten tussen gedetineerden en bewarend personeel in belangrijke mate bepalend zijn voor de wijze waarop gedetineerden het regime in zijn totaliteit beoordelen. (Van der Linden, 1981 en Grapendaal,1987)

In de studies van van der Linden en Grapendaal wordt de interactie tussen het bewarend personeel en gedetineerden geoperationaliseerd door middel van items die een meer ordegericht handelen versus een meer gedetineerdengericht handelen weerspiegelen

De ordegerichte aspecten in de beleving van het regime door gedetineerden hebben betrekking op de mate van wantrouwen ten opzichte van het personeel, de gepercipieerde mate van regelhandhaving en de onderlinge afstand tussen personeel en gedetineerden. De gedetineerden-gerichte aspecten van het regime hebben betrekking op de ervaren ondersteuning bij problemen en de mate van persoonlijke aandacht en vertrouwen.

Als belangrijkste resultaat uit de gedetineerden-enquête kwam naar voren dat over de gehele populatie genomen de gedetineerden het regime als gematigd ordegericht beschouwen, echter wordt naar de inrichtingen afzonderlijk gekeken dan blijken er significante verschillen in de evaluatie van het regime te zijn. Zo ervaren gedetineerden in één inrichting het regime op een meer gedetineerdengerichte wijze. De regimesevaluatie blijkt na de correlationele -en regressieanalyse een belangrijke invloed te hebben op de door gedetineerden waargenomen mogelijkheden voor zelfherstel tijdens detentie.

De bijdrage die het bewarend personeel middels zijn optreden tegenover gedetineerden aan het ervaren detentieklimaat en het proces van zelfherstel levert is derhalve een factor die de moeite van het onderzoeken waard is.

In de volgende paragraaf wordt verslag gedaan van dit optreden vanuit het perspectief van het bewarend personeel zelf. Uitspraken over orde- en gedetineerdengerichte aspecten van het eigen optreden tegenover gedetineerden werden voorgelegd aan het personeel teneinde een indruk te krijgen in welke mate men waarde hecht aan de handhaving van de orde, in welke mate men zich in zijn handelen richt op de behoeften en problemen van gedetineerden en in welke mate men de nadruk legt op afstand en wantrouwen ten opzichte van de gedetineerden. 
De items werden zoveel mogelijk in de dezelfde rin geformuleerd als bij de gedetineerdenenquête teneinde een vergelijking tussen de houdingen van het personeel en gedetineerden mogelijk te maken waar het de aard valn de onderlinge contacten betreft.

\subsubsection{Houdingen van PIW-ers ten aanzien van een orde-gerichte taakopvatting}

$V$ an de bewalarders verwacht $40 \%$ dat gedetineerden zonder tegensputteren doen wat men zegt. Bijna een kwart van de bewaarders verwacht dit niet en $36 \%$ heeft hier geen uitgesproken mening over.

Een veel duidelijker meerderheid tekent zich af bij de uitspraak: "ik richt mij in mijn werk voornamelijk op het handhaven van orde en rust." Ruim $62 \%$ van de respondenten is het eens of enigszins met de us uitspratak eens.

Vier op de tien bewaarders geeft aan dat men zoveel mogelijk afstand probeert te bewaren in de omgang met gedetineerden. Een bijna even groot deel namelijk $36 \%$ doet dit naar eigen zeggen niet.

Zich voornamelijk richten op het in acht nemen valn de lectregels wordt door $37 \%$ als een belangrijk aspect van het werk gezien. Voor een vijfde van de respondenten is zulks niet het geval en een meerderheid van bijna $40 \%$ heef hier geen uitgesproken mening over.

Op zijn hoede voor gedetineerden die vriendelijk zijn is $35 \%$ en $31 \%$ is dat niet. Een derde van de respondenten neemt hier een neutraal standpunt in.

Uit de frequenties blijkt dat een meer ordegericht optreden nadrukkelijk geen belangrijke rol speelt in de takopvatting van een kleine minderheid. De meerderheid van de respondenten stelt zich nadrukkelijk orde-gericht op of neemt een meer neutrale positie in. Typerend voor de taakopvatting van de meerderheid van de respondenten is echter wel het feit dat men zegt zich bij de taakuitoefening voornamelijk te richten op het handhaven van orde en rust.

\subsubsection{Houdingen van PIW-ers ten aanzien van een gedetineerdengerichte taak- opvatting}

Kijken we naar de items die een meer gedetineerdengericht optreden weergeven in het eigen handelen dan zien we toch een beeld waarbij zich een duidelijke meerderheid met een positieve houding aftekent.

Een ruime meerderheid $(69 \%)$ geeft te kennen dat men de meeste voldoening bij het werken met gedetineerden heeft als men iemand heeft kunnen helpen.

Een zeer ruime meerderheid $(85 \%)$ probeert als men daartoe de gelegenheid heeft een persoonlijk gesprek te voeren met gedetineerden.

De meeste bewaarders $(60 \%)$ proberen rekening te houden met de verschillende behoeften in wensen van de gedetineerden. Men tracht ook in meerderheid gedetineerden aan te moedigen iets van hun detentie te maken $(78 \%)$.

Als gedetineerden in de put zitten, geeft een ruime meerderheid van $81 \%$ aan dat men dic persoon extra aandacht geeft.

Het is op grond van de frequentieverdelingen ten aanzien van de gedetineerdengerichte aspecten van het handelen in ieder geval mogelijk te concluderen dat de respondenten uit deze enquête in hun omgang met gedetineerden een gedetineerdengerichte houding aan de dag leggen. Echter extrapoleren naar de totale populatie bewaarders uit de onderzochte inrichtingen is niet mogelijk vanwege de betrekkelijk geringe respons en vanwege de onduidelijke status van de representativiteit van het deel van de populatie dat werd ondervraagd. Met de mogelijkheid van een zekere mate van selectiviteit onder de respondenten, dat wil zeggen een oververtegenwoordiging van het meer gedetincerdengerichte en meer op resocialisatie gerichte type bewarder, dient men rekening te houden. 
Zet men de frequentieverdelingen zoals die werden aangetroffen bij de ordegerichte-aspecten van de taakopvatting af tegen die van de gedetineerden-gerichte takopvatting dan kan men het volgende concluderen.

Een minderheid van de respondenten verwerpt steeds nadrukkelijk een ordegerichte benadering van gedetineerden. Deze minderheid heeft naar alle waarschijnlijkheid ook een uitgesproken gedetineerdengerichte houding. Kijken we echter naar de frequentieverdelingen bij de gedetinecrdengerichte aspecten van het handelen dan tekent zich hier een grote meerderheid af die een dergelijk optreden in het eigen handelen toelaat. Een deel van die meerderheid onderschrijft behalve de ordegerichte aspecten, vermoedelijk ook de gedetineerdengerichte aspecten van de bewaarderstaak en probeert in de omgang met gedetineerden beide taakaspecten te combineren.

Deze bevinding duidt er wellicht op dat de verschillen in taakopvatting tussen bewaarders, bijvoorbeeld tot uiting komend in het bekende verschil tussen de" Zwarte Pieten en Sinterklazen", in de jaren negentig niet meer zo scherp is. Het is heel goed mogelijk dat met name dalt deel van de bewaarders dat bij de ordegerichte aspecten van het handelen een positieve of neutrale houding aanneemt, tevens in staat en bereid is de typisch bejegenende, op de behoeften van de gedetineerden afgestemde aspecten in het eigen handelen toe te laten. Men kan in ieder geval vaststellen dat als het om de gedetineerdengerichte omgang betreft, het percentage dat een ambivalente of negatieve houding aanneemt een kleine minderheid vormt. Een en ander duidt wellicht op de werking van een voortschrijdend proces van professionalisering waarin bewalarders steeds beter in staat zijn om de verschillende aspecten van hun werk te integreren. De, totnogtoe veronderstelde tegenstelling tussen de Zwarte Pieten en de Sinterklazen die men in het onderzoek uit de jaren tachtig nog in alle hevigheid aantreft. is wellicht wat minder scherp geworden. Immers de jaren tachtig gelden binnen het gevangeniswezen toch vooral als een periode van overgang van een meer beveiligende op orde en tucht ingestelde bewaardersfunctie naar cen tevens op begeleiding en bejegening gerichte functie van inrichtingswerker.

Bulten (1991) merkt in dit verband op dat in het werk van de PIW-er sprake is van een ambivalentie tussen enerzijds agressieve impulsen voortvlociend uit een beveiligende taak en anderzijds positieve gevoelens voortvloeiend uit de zorgtaken. Volgens Bulten wordt deze ambivalentie onder PIW-ers niet zelden afgeweerd door een zgn. "splijtingsmechanisme" waardoor cen intrapsychisch organisatieconflict wordt vermeden. Men scheidt eenvoudig weg de agressieve aspecten van het werk van de idealistische. Op macroniveau leidt dit afwecrmechanisme in de organisatie tot verschillende groepen zoals de Sinterklazen en de Zwarte Pieten, de socio`s en de macho`s en de depri`s en de positivo`s. Bulten wijst op het gevalar dat de ene groep PIW-ers zich sterk identificeen met de gedetineerde als slachtoffer, terwijl de andere groep PIW-ers continu moet bewijzen dat de groep gedetineerden volstrekt anders is dan zij zelf zijn. Lukt het een organisatie niet om met deze tegenstrijdige tendensen om te gaan dan worden deze veelal door middel van splijting vermeden en op de lange baan geschoven. De bevindingen uit deze studie met betrekking tot de orde-cq-gedetineerdengerichte houdingen van PIW-ers laten zien dat aan het eind van de jaren negentig wellicht toch sprake is van een voortschrijdende professionalisering waardoor PIW-ers in hun werk beter ongaan met de bovengenoemde ambivalentic in hun taakuitoefening.

Men zou het volgende kunnen concluderen: bewaarders zijn in meerderheid bereid gedetineerdengerichte aspecten in hun handelen toe to laten, tegelijkertijd houdt men oog voor de ordegerichte aspecten van de omgang met gedetineerden. Bewaarders die in hun 
handelen getuigen van een uitgesproken ordegerichte of gedetineerdengerichte manier van werken en daarmee beantwoorden aan het klassieke onderscheid tussen Sinterklazen en Zwarte Pieten, lijken elk afzonderlijk als groep een kleine minderheid binnen de onderzochte populatic te vormen.

Vergelijken we tenslotte de houdingen van de bewaarders met die van de gedetineerden op het punt van de orde-en gedetineerdengerichte aspecten van de interacties dan blijft men toch zitten met een behoorlijke discrepantie. De mate van gedetineerdengerichtheid die we bij de bewaarders aantreffen correspondeert niet echt sterk met de mate waarin gedetineerden een dergelijke houding waarnemen. Afgaande op de houding van de bewaarders zouden gedetineerden bij nader inzien veel positiever moeten zijn. Een aantal factoren spelen hier mogelijk een rol.

Bewaarders doen zich mogelijk om redenen van sociale wenselijkheid positiever voor dan zij in feite zijn. Bewaarders willen wel de nadruk leggen op een meer gedetineerdengericht handelen in hun omgang met gedetineerden, maar zij krijgen door de verhoogde werkdruk onvoldoende gelegenheid hiertoe. $\mathrm{Zij}$ beperken zich noodgedwongen daarom tot de meest noodzakelijke beveiligende en ordehandhavende aspecten van hun taak.

De bewaarderstaak brengt in de praktijk van het dagelijkse leven in een gevangenis nu eenmaal bepaalde ordegerichte elementen met zich mee die door gedetineerden doorgaans als negatief worden ervaren ( $V$ an der Linden, 1981). Dergelijke negatieve ervaringen blijven nu eenmaal langer hangen in de hoofden van gedetineerden en drukken een zwaarder stempel op de beleving van de omgang met het bewarend personeel. Positieve ervaringen als gevolg van een meer gedetineerdegerichte bejegening vallen als het ware weg tegen de ordegerichte aspecten van de omgang die meestal gepaard gaan met ergernis en frustraties.

Tenslotte, de helft van de respondenten onder de bewaarders is afkomstig uit de inrichting te Roermond en zoals we uit de vergelijkingen tussen de inrichtingen op de variabele regimesevaluatie in de gedetineerden-enquête zagen, ervaren de gedetineerden in deze inrichting het regime als gemiddeld het meest gedetineerdengericht. Dit duidt wellicht op een taakopvatting van het bewarend personeel in deze inrichting die in vergelijking met het personeel uit de twee overige inrichtingen wat meer gedetineerdengericht is. Het feit dat de bewaarders uit Roermond een groot deel van de onderzochte populatie uitmaken, kan leiden tot vertekening. In een van de volgende paragrafen zal een vergelijking tussen inrichtingen voor wat de verschillen in taakopvatting van PIW-ers betreft, hierover opheldering verschaffen.

\subsection{Relaties tussen de opvattingen van PIW-ers over resocialisatie en hun houdingen ten aanzien van de taakuitoefening en activiteiten}

Evenals bij de gedetineerden-enquête is een belangrijke veronderstelling bij het onderzoek onder het bewarend personeel dat de manier van denken over resocialisatie in belangrijke mate bepalend is voor de wijze waarop men zich bij de concretisering van de verschillende (resocialiserende) doelen opstelt.

Om deze veronderstelling empirisch te toetsen werd op basis van de schaalconstructies een correlationele analyse uitgevoerd.

De eerste relatie die werd onderzocht betrof de samenhang tussen de opvattingen over resocialisatie in enge en ruime zin met een orde-dan wel meer gedetineerdengerichte taakopvatting. Tevens werd de relatie met de variabele Scepsis onderzocht. Deze variabele meet de mate waarin men vindt dat de detentie voldoende mogelijkheden biedt en een geschikt moment is voor pogingen tot zelfverbetering.

In tabel 2 zijn de correlaties in een matrix weergegeven. 
Tabel 2 : correlaties tussen opvattingen ten aanzien van resocialisatie en de taakopvatting

\begin{tabular}{llllll}
\hline & 1 & 2 & 3 & 4 & \multicolumn{1}{c}{5} \\
\hline $\begin{array}{l}\text { 1.Opvatting resocialisatie } \\
\text { (enge zin) }\end{array}$ & 1.00 & $-.49^{* *}$ & $.29^{* *}$ & -.26 & -.09 \\
$\begin{array}{l}\text { 2. Opvatting resocialisatie } \\
\text { (ruime zin) }\end{array}$ & & 1.00 & .11 & $.59^{*}$ & $.33^{*}$ \\
$\begin{array}{l}\text { 3. Ordegericht } \\
\begin{array}{l}\text { 4. Gedetineerdengericht } \\
\text { 5. Scepsis }\end{array}\end{array}$ & & 1.00 & -.05 & .08 \\
\hline
\end{tabular}

${ }^{*} \mathrm{p}=<.05 * * \mathrm{p}=<.01$

De correlatie-matrix in tabel 2 laat in de eerste plaats een negatieve correlatie zien tussen de beide opvattingsvariabelen. Hoe meer men kiest voor een enge opvatting van de resocialisatie-gedachte, waarbij men zoals wij zagen de zinvolheid alleen beoordeelt op basis van een (vermeende geringe) speciaal preventie werking in termen van recidive en of (geringe) motivatie van gedetineerden, des te minder is men geneigd de resocialisatie-doelstelling te waarderen om andere effecten dan uitsluitend (falende) recidive-vermindering.

Hoe meer men de resocialisalie-doelstelling in enge zin beoordeelt des te meer neigt men naar een ordegerichte taakopvatting waarbij men, zoals wij zagen, zich meer richt op regelhandhaving en het op afstand houden van gedetineerden.

Hoe meer men in ruime zin over de resocialisatie-opdracht denkt des te meer is men geneigd tot een gedetineerdengerichte opstelling ten aanzien van gedetineerden. Dit impliceert dat men rekening houdt met wensen en behoeften van gedetineerden, hen eerder aanmoedigt iets van hun detentie te maken en bereid is gedetineerden te ondersteunen als het gaat om het benutten van kansen en mogelijkheden voor zelfherstel.

Tenslotte laat de matrix zien dat Scepsis of de waargenomen mogelijkheden voor resocialisatie van gedetineerden tijdens detentie negatiever worden ingeschat naarmate men in meer ruime zin denkt over resocialisatie en naar mate men blijk geeft van een meer gedetineerdengerichte opstelling.

\subsection{Relaties tussen opvattingen van PIW-ers over resocialisatie en hun houding ten aanzien van de activiteiten en hun effecten}

De manier waarop men denkt over resocialisatie weerspiegelt zich niet alleen in de wijze waarop men zich als bewaarder bij de taakuitoefening opstelt of in de wijze waarop men de mogelijkheden voor resocialisatie tijdens detentie inschat. De correlatie-matrix in tabel 3 laat zien dat de aard van de opvattingen ook een samenhang vertoont met de manier waarop men tegen de activiteiten en hun effecten op de gedetineerden aankijkt. De effecten betreffen die van een activiteit als kunstzinnige vorming. 
Tabel 3: correlaties tussen opvattingen ten aanzien van resocialisatie en de houding ten alanzien van de activiteiten en hun effecten

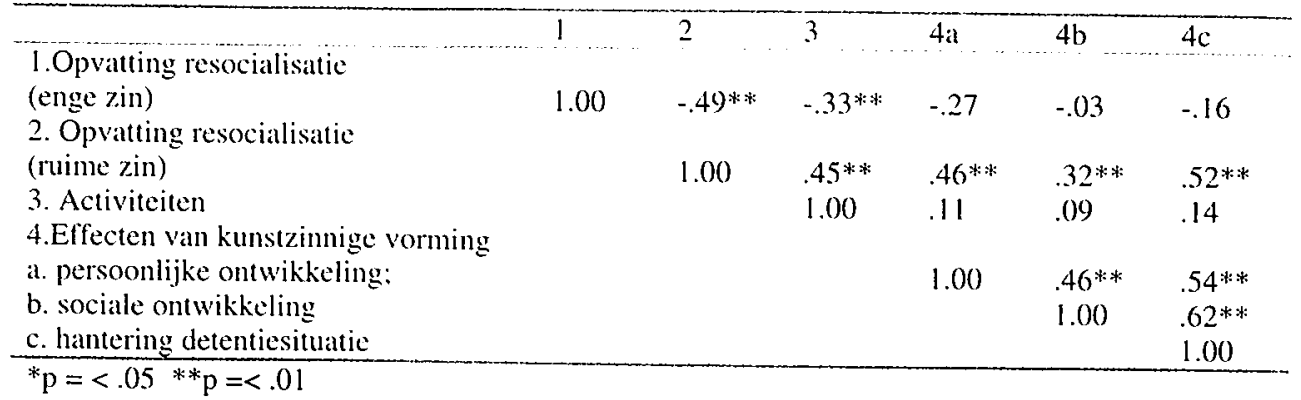

Een opvatting van resocialisatie in enge zin gat significant gepaard met cen meer negatieve houding ten aanzien van de zinvolheid van activiteiten in het algemeen. In cen van de vorige paragrafen werd toegelicht dat het bij de ervaren zinvolheid van de activiteiten niet alleen maar gaat om een bepaald effect op toekomstig normoverschrijdend gedrag maar vooral ook om een reeks andere beoogde effecten, zoals een humaan, genormaliseerd en constructief detentieklimaat.

Een ruime opvatting van resocialisatie gaat gepaard met een positief oordeel over de zinvolheid van de activiteiten voor de detentieomgeving in het algemeen.

En hoe sterker men een opvatting van resocialisatie in ruime zin erop nahoudt, des te hoger schat men de effecten in van persoonlijke en sociale aard van een activiteit als kunstzinnige vorming. De functie van de activiteit als uitlaatklep en als middel om een rustige en ordentelijke gang van zaken te bewerkstelligen (hantering detentiesituatie) wordt eveneens hoger gewaardeerd door respondenten die in meer ruime zin over de resocialisatie-opdracht denken. Nagegaan werd of een meer ordegerichte taakopvatting dan wel een meer gedetineerdengerichte taakopvatting van PIW-ers samenhangt met de beoordeling van de activiteiten en het effect van de kunstzinnige vorming. Tevens werd de variabele Scepsis gerelateerd aan het oordeel over de activiteiten en de effecten van de kunstzinnige vorming.

Tabel 4 geeft de desbetreffende relaties weer en laat zien dat naarmate PIW-crs zich meer gedetineerdengericht opstellen, zij positiever oordelen over de activiteiten en de effecten van de kunstzinnige vorming.

Tabel 4: Relaties tussen taakopvatting. scepsis en de houding ten aanzien van de activiteiten en hun effecten

\begin{tabular}{llllllll}
\hline & 1 & 2 & 3 & 4 & $5 \mathrm{a}$ & $5 \mathrm{~b}$ & $5 \mathrm{c}$ \\
\hline 1. Ordegericht & 1.00 & -.05 & .08 & -.13 & .12 & .11 & .12 \\
2. Gedetineerdengericht & & 1.00 & $.46^{* *}$ & $.48^{* *}$ & $.42^{* *}$ & $.30^{*}$ & $.47^{* *}$ \\
3. Scepsis & & & 1.00 & .15 & .16 & .04 & .23 \\
4. Activiteiten & & & 1.00 & .11 & .09 & .14 \\
$\begin{array}{l}\text { 5. Effecten van kunstzinnige vorming } \\
\text { a.persoonlijke ontwikkeling; }\end{array}$ & & & & & & \\
b.sociale ontwikkeling & & & & 1.00 & $.46^{* *}$ & $.54^{* *}$ \\
c. hantering detentiesituatie & & & & & 1.00 & $.62^{* *}$ \\
\hline $\mathrm{p}=<.05 * * \mathrm{p}=<.01$ & & & & & & & \\
\hline
\end{tabular}


Opvaltingen over de motivatie en motieven van gedetineerden ten aanzien van de activiteiten vertoonden slechts een enkele correlatie met het oordeel over de effecten van de kunstzinnige vorming. Naarmate men gunstiger denkt over de motivatie van de gedetineerden voor de activiteiten, des te hoger slaat men het effect aan van de kunstzinnige vorming op het bevorderen van een rustige en constructieve gang van zaken.

\subsection{Relaties tussen opvattingen over resocialisatie, taakopvatting en scepsis enerzijds en het oordeel over randvoorwaardelijke aspecten anderzijds}

De PIW-ers werd gevraagd naar hun oordeel over een aantal randvoorwaardelijke aspecten met betrekking tot de kunstzinnige vorming. Het gaat hier om aspecten als de afstemming van de inhoud van de activiteiten op de behoeften van de gedetineerden. de plaats in het dagprogramma, de informatieverstrekking en de ondersteuning van de PIW-er als begeleider van de activiteiten.

$\mathrm{Na}$ correlationele-analyse (tabel 5) blijkt het oordeel over deze integriteitsaspecten wel een hoge onderlinge samenhang te vertonen maar eigenlijk nauwelijks met opvattingsvariabelen. De crvaren mate van ondersteuning bij de taak als crea-bewaarder is hoger naarmate men in meer ruime zin over resocialisatie denkt. De tevredenheid over de informatieverstrekking aan gedetineerden omtrent de kunstzinnige vorming is hoger naarmate men een opvatting van resocialisatic in meer enge zin huldigt.

Tabel 5: Relaties tussen opvattingen ten aanzien van resocialisatic, taakopvatting en scepsis enerzijds en het oordeel over randvoorwaardelijke aspecten anderzijds.

\begin{tabular}{|c|c|c|c|c|c|c|c|c|c|}
\hline & 1 & 2 & 3 & 4 & 5 & 6 & 7 & 8 & 9 \\
\hline 1. Afstemming & 1.00 & $.32^{*}$ & $.29^{*}$ & .25 & .05 & .22 & .14 & .21 & .08 \\
\hline 2. Informatie & & 1.00 & $.48^{* *}$ & $.52 * *$ & $.18 *$ & .23 & .22 & -.02 & -.04 \\
\hline 3. Ondersteuning & & & 1.00 & $.46 * *$ & -.04 & $.38 * *$ & .22 & .03 & -.01 \\
\hline 4. Plaats in dagprogramma & & & & 1.00 & -.05 & .23 & .28 & .03 & -.12 \\
\hline 5. Opvatting resoc. (enge $z$ in) & & & & & 1.00 & $.49 * *$ & $.29 *$ & -.26 & -.09 \\
\hline 6. Opvatting resoc. (rume zin) & & & & & & 1.00 & .11 & $.59 *$ & $.33^{*}$ \\
\hline 7. Ordegericht & & & & & & & 1.00 & -.05 & .08 \\
\hline 8.Gedetineerdengericht & & & & & & & & 1.00 & $.64 * *$ \\
\hline 9.Scepsis & & & & & & & & & 1.00 \\
\hline
\end{tabular}

$* \mathrm{p}=<.05 * * \mathrm{p}=<.01$

\section{Samenvattend}

Resumeren we de belangrijkste resultaten van de correlationele analyse dan kan het volgende worden vastgesteld.

De opvattingen van de PIW-ers over resocialisatie vertonen een samenhang met de manier waarop zij de activiteiten en de effecten van de kunstzinnige vorming op bijvoorbeeld de persoonlijke en sociale ontwikkeling van de gedetineerden beoordelen. Hoe sterker men van mening is dat inspanningen ten behoeve van resocialisatie ook om andere redenen dan louter recidive-vermindering zinvol en nuttig kunnen zijn, des te positiever denkt men over de activiteiten. Een dergelijke opvatting over resocialisatie in ruime zin gaat eveneens gepaard met een grotere bereidheid zich in meer gedetineerdengerichte zin op te stellen bij de uitoefening van de bejegenende taken 
Aanhangers van een opvatting van resocialisatie in enge zin, waarbij het falen in termen van recidive-vermindering het belangrijkste beoordelingscriterium is, geven vaker blijk van een ordegerichte houding in de omgang met gedetineerden en van een negatief oordeel over de activiteiten.

De correlaties lijken te wijzen op de aanwezigheid van een positieve of negatieve basishouding in het algemeen. Het is, met name als het gaat om een negatieve houding ten aanzien van de resocialisatie-doclstelling voorstelbaar dat men toch om humane redenen of om redenen van een schadebeperkende detentie, of omwille van de orde en rust de activiteiten als zinvol beschouwt. Dit lijkt echter niet het geval te zijn, hoe negatiever de opvatting over de resocialisatie-doelstelling des te negatiever is men over activiteiten voor gedetineerden in het algemeen.

Deze verbanden wijzen enerzijds op de aanwezigheid van groep PIW-ers met een negatieve houding tegenover pogingen om gedetineerden, vanuit het perspectief van een humane, schadebeperkende en kansenbiedende bejegening, tegemoet te komen.

Anderzijds wijzen deze verbanden op de aanwezigheid van een groep bewaarders die een dergelijke bejegening ondersteunt en daarbij tevens vanuit een meer gedetineerdengerichte taakopvatting te werk gaat.

De groep bewaarders met een negatieve houding ten aanzien van resocialisatie lijkt, op basis van de frequentieverdelingen, een kleine minderheid. Het overgrote deel van de respondenten stelt zich afwijzend of neutraal op tegenover een eenzijdig afstandelijke en ordegerichte benadering. Een meerderheid ondersteunt de resocialisatie-gedachte en eveneens een meerderheid denkt in gunstige zin over de activiteiten in hun algemeenheid. Uit de frequentieverdelingen blijkt in dit verband dat de meeste respondenten zowel orde- als gedetineerdengerichte aspecten in hun handelen proberen te verenigen.

Tenslotte, hoe ruimer men denkt over de resocialisatie-doelstelling en hoe meer men blijk geeft van een gedetineerdengerichte taakopvatting des te kritischer is men over de mogelijkheden voor zelfverbetering binnen de muren van de gevangenis. Wellicht leidt een sterker geloof in de waarde van de resocialisatie-doelstelling en een gedetineerdengerichte opstelling tot een grotere betrokkenheid en naar het zich laat aanzien, tevens tot een scherper oog als het gaat om de beperkingen van het instituut.

\subsection{Verschillen in houdingen van bewaarders tussen inrichtingen: een vergelijking van gemiddelde scores}

Uit de enquête onder gedetineerden bleek een significant verschil tussen inrichtingen in de manier waarop gedetineerden het regime beoordelen. Voor een deel lijken deze verschillen te herleiden tot de inrichtingscultuur die in meerdere of mindere mate een gedetineerdengericht of ordegericht karakter heeft. Deze en andere aspecten van inrichtingsklimaat zijn wellicht ook terug te vinden in de houdingen van de PIW-ers. Houdingen van PIW-ers ten aanzien van resocialisatie en de activiteiten werden daarom over de drie inrichtingen vergeleken. De resultaten van deze vergelijkingen dienen met het nodige voorbehoud te worden benaderd. Het aantal respondenten in een inrichting te Grave is bijzonder laag $(N=7)$, hetgeen consequenties heeft voor de geldigheid die men aan de uitkomsten van de analyse toekent. $\mathrm{Bij}$ de vergelijking dient men derhalve niet al te veel betekenis toe te kennen aan significantie-niveaus. Men mag op basis van de verschillen in gemiddelde scores geen al te stellige conclusies trekken. In de onderstaande tabellen wordt een overzicht gerepresenteerd van de gemiddelde scores op de diverse schalen. 
Tabel 6: gemiddelde scores: opvattingschalen resocialisatie PIW voor drie inrichtingen

\begin{tabular}{|c|c|c|c|c|c|c|c|c|c|}
\hline & \multicolumn{3}{|c|}{ Inr. Sittard } & \multicolumn{3}{|c|}{ Inr. Roermond } & \multicolumn{3}{|c|}{ Inr. Grave } \\
\hline Schaal opvattingen & Score & $n$ & sd & Score & $n$ & sd & Score & $\mathrm{n}$ & sd \\
\hline Resocialisatic (eng) & 2.64 & 23 & .95 & 2.46 & 23 & 1.00 & 1.50 & 7 & 1.50 \\
\hline Resocialisatie (ruim) & 3.33 & 23 & .74 & 3.62 & 24 & .80 & 3.76 & 7 & .28 \\
\hline
\end{tabular}

Resocialisatie in enge zin: $\mathrm{F}=4.10, \mathrm{df}=2, \mathrm{p}=<.05$

Resocialisatie in ruime zin: $\mathrm{F}=.98, \mathrm{df}=2, \mathrm{p}=.38$

Vergelijking van de wijze waarop PIW-ers in de drie inrichtingen denken over resocialisatie laat een tendens tot een sterkere nadruk in de inrichting te Sittard zien op opvattingen in enge zin. De gemiddelde score voor de opvattingen in ruime zin laat zien dat deze in Sittard in vergelijking met de overige inrichtingen minder sterk aanwezig is.

Tabel 7: gemiddelde scores op de taakopvattingsschalen PIW voor drie inrichtingen

Inr. Sittard

Inr. Roermond

Inr. Grave

\begin{tabular}{|c|c|c|c|c|c|c|c|c|c|}
\hline Schaal Taakopvatting & Score & $\mathrm{n}$ & $\mathrm{sd}$ & Score & $n$ & sd & Score & $\mathbf{n}$ & sd \\
\hline Ordegericht & 3.11 & 23 & .54 & 3.34 & 23 & .78 & 2.62 & 7 & .58 \\
\hline Gedetineerdengericht & 3.38 & 23 & .53 & 4.20 & 24 & .89 & 4.28 & 7 & .47 \\
\hline
\end{tabular}

Ordegericht: $F=3.16, \mathrm{df}=2, \mathrm{p}=.05$

Gedetineerdengericht: $F=1.92, \mathrm{df}=2, \mathrm{p}=.15$

Uit de bovenstaande tabel blijkt dat een ordegerichte taakopvatting gemiddeld het meest wordt onderschreven door PIW-ers in Roermond, tegelijkertijd is dit ook de inrichting waar een gedetineerdengerichte taakopvatting het handelen van de PIW-ers gemiddeld het meest bepaalt. De laagste score voor een gedetineerdengerichte bejegening wordt gevonden in de inrichting te Sittard. De verschillen tussen de inrichting te Roermond en de inrichting te Sittard zijn hier aanzienlijk

Tabel 8: gemiddelde scores : schaal Activiteiten en Scepsis PIW voor drie inrichtingen

\begin{tabular}{|c|c|c|c|c|c|c|c|c|c|}
\hline & \multicolumn{3}{|c|}{ Inr. Sittard } & \multicolumn{3}{|c|}{ Inr. Roermond } & \multicolumn{2}{|c|}{ Inr. Grave } & \\
\hline Schaal & Score & $\mathrm{n}$ & sd & Score & $\mathrm{n}$ & sd & Score & $\mathrm{n}$ & sd \\
\hline Activiteiten & 3.63 & 23 & .44 & 3.70 & 24 & .53 & 3.65 & 7 & .35 \\
\hline Scepsis & 3.21 & 23 & .78 & 3.48 & 24 & .70 & 3.28 & 7 & 1.05 \\
\hline
\end{tabular}

Activiteiten; $F=.11, \mathrm{df}=2, \mathrm{p}=.89$

Scepsis; $F=.69, \mathrm{df}=2, \mathrm{p}=.50$

Ook bij de houding ten aanzien van de zinvolheid van de activiteiten en de mate van scepsis ten aanzien van de gevangenis als resocialiserend instituut scoort de inrichting te Roermond, zoals in tabel 8 te zien is, weer wat hoger dan de overige twee inrichtingen. Bewaarders in deze inrichting achten de activiteiten gemiddeld zinvoller dan de bewaarders in de overige twee inrichtingen, tegelijkertijd is men ook kritischer ten aanzien van de gevangenis als een geschikt instituut voor de verwezenlijking van de resocialisatie-opdracht. 
De scores op de schalen die de houding ten aanzien van de motieven, motivatie, de effecten van de kunstzinnige activiteiten en de randvoorwalardelijke aspecten van de kunstzinnige vorming werden alleen vergeleken voor de imichting te Sittard en te Roermond. De reden voor het hier weglaten van de inrichting te Grave is dat op twee van de vier onderzochte afdelingen de kunstzinnige vorming niet aan gedetineerden werd aangeboden. Bovendien werd op cen afdeling (VBA) de kunstzinnige vorming uitsluitend door een professionele docent begeleid.

Uit tabel 9 blijkt dat PIW-ers in de inrichting te Roermond de motieven van gedetineerden voor deelname aan de kunstzinnige activiteiten sterker in het teken stellen van vermijdingsgedrag of het tegengaan van de directe ongemakken van de detentie dan de PIW-ers in Sittard. Het oordeel over de motivatie verschilt niet noemenswardig tussen de respondenten in beide inrichtingen.

Een verklaring voor het eerste verschil hangt wellicht samen met het regine. De inrichting te Roermond kent enkel een HVB-regime dat gepaard gaat met meer restricties dan een regime voor langgestraften in de inrichting te Sittard. De hoogte van de gemiddelde score op de schaal Motivatie laat zien dat PIW-ers in beide inrichtingen de motivatie van gedetineerden voor activiteiten als sport en kunstzinnige vorming hoog inschatten.

Tabel 9: gemiddelde scores op de schalen Motieven en Motivatie (PIW) voor twee inrichtingen

Inr. Sittard

Inr. Roermond

\begin{tabular}{|c|c|c|c|c|c|c|}
\hline Schaal & Score & $\vec{n}$ & $\mathrm{sd}$ & Score & $n$ & $\mathrm{sd}$ \\
\hline Motieven & 3.16 & 24 & 1.16 & 3.45 & 26 & 1.00 \\
\hline Motivatie & 4.10 & 24 & .57 & 4.10 & 26 & .53 \\
\hline
\end{tabular}

Motieven: $F=.86 . \mathrm{df}=1, \mathrm{p}=.35$

Motivatie: $F=.000 \mathrm{df}=1, \mathrm{p}=.99$

Vergelijking van de gemiddelde scores op de waargenomen effecten van de kunstzinnige activiteiten laten geen opzienbarende verschillen zien. Voor twee van de drie effecten scoren de PIW-ers in de inrichting te Roermond wat hoger.

Uit de resultaten van de gedetineerden-enquête bleek dat waar het de randvoorwatarden van de kunstzinnige vorming betreft, de inrichting te Roemond in vergelijking met de overige twee inrichtingen een wat minder gunstig beeld vertoont. Op grond hiervan zou men in vergelijking met de andere inrichting(en) tevens een minder gunstig oordeel over bijvoorbeeld de ervaren mate van ondersteuning mogen verwachten. De gemiddelde scores laten na vergelijking met de inrichting te Sittard inderdaad een dergelijk beeld zien. Op twee van de overige randvoorwaardelijke aspecten zijn de PIW-ers in Roermond weer meer tevreden dan de PIW-ers in Sittard. Over de plaats van de kunstzinnige vorming in het dagprogramma is men in gelijke mate tevreden. 
Tabel 10: gemiddelde scores op de schalen met betrekking tot de waargenomen effecten van de activiteiten (PIW) voor twee inrichtingen

Inr. Sittard

\begin{tabular}{lcccccc}
\hline Schat & Score & $n$ & sd & Score & $n$ & sd \\
Persoonlijke ontw. & 3.50 & 25 & .65 & 3.48 & 26 & .88 \\
Sociale ontwikkeling & 2.82 & 24 & .87 & 3.10 & 26 & .73 \\
Hantering detentiesituatic & 3.06 & 23 & .65 & 3.36 & 26 & .59 \\
\hline
\end{tabular}

Persoonlijke ont $w .: F=.005, \mathrm{~d} f=1 . \mathrm{p}=.94$

Sociale ontwikkeling: $F=1.45$. $\mathrm{d} f=1, p=.23$

Hantering: $F=2.83, \mathrm{~d} f=1, p=.099$

Tabel 11: gemiddelde scores randvoorwaardelijke aspecten kunstzinnge vorming (PIW) voor twee inrichtingen

$$
\text { Inr. Sittard Inr. Roermond }
$$

\begin{tabular}{|c|c|c|c|c|c|c|}
\hline Schaal & Score & $\mathrm{n}$ & sd & Score & $\mathrm{n}$ & sd \\
\hline Afstemming & 2.28 & 23 & 1.23 & 3.62 & 25 & 1.03 \\
\hline Informatieverstrekking & 3.02 & 23 & .95 & 3.24 & 23 & 1.23 \\
\hline Ondersteuning & 2.70 & 23 & .72 & 2.56 & 25 & .85 \\
\hline Plaats in het dagprogramma & 3.30 & 22 & 1.19 & 3.30 & 24 & .79 \\
\hline
\end{tabular}

Afstemming: $F=5.84, \mathrm{df}=1, \mathrm{p}=<.05$

Informatie: $F=.44, \mathrm{df}=1, \mathrm{p}=.50$

Ondersteuning; $F=39, \mathrm{df}=1, \mathrm{p}=.53$

Plaats:, $F=.00, \mathrm{df}=1, \mathrm{p}=.99$

De voorgalande vergelijking voor de inrichtingen van gemiddelde scores op de verschillende houdingsschalen toont een vrij helder beeld. De houdingen van PIW-ers in de inrichting te Roermond zijn overwegend positiever dan die van hun collegae in de andere inrichtingen.

Opvattingen in enge zin ten aanzien van de resocialisatie-opdracht zijn gemiddeld het sterkst in de inrichting te Sittard. Deze inrichting laat tevens de laagste gemiddelde scores zien als het gaat om een gedetineerden-gerichte bejegening van gedetineerden en om een ruime opvatting ten aanzien van de resocialisatie-doelstelling. De hoogste score op deze laatste variabele wordt aangetroffen onder de PIW-ers te Roermond

Tevens worden gemiddeld de hoogste scores voor ordegerichtheid en gedetineerdengerichtheid onder de PIW-ers te Roermond aangetroffen. Dit is een interessant resultaat in het licht van de conclusies die werden getrokken op basis van de frequentie-verdelingen op de schalen orde- en gedetineerdengerichtheid. Een belangrijke conclusie hier was immers dat de meeste bewaarders als gevolg van een voortschrijdende professionalisering zowel ordegerichte- en gedetineerdengerichte aspecten van hun taak in hun omgang met gedetineerden trachten te verenigen. De hogere scores op de beide schalen met betrekking tot de takopvatting van de PIW-ers in Roermond duiden wellicht op een grotere bereidheid of vermogen van het bewarend personeel in deze inrichting om beide taakaspecten te combineren.

Uit het literatuuronderzoek blijkt dat oudere bewaarders beter instaat zijn de verschillende doelen van de detentie in hun handelen te verenigen. De gemiddelde leeftijd van het bewaarderscorps in Roermond is hoger dan in beide andere inrichting.

Op grond van de voorgaande vergelijking van de houdingen van het bewarend personeel in de drie inrichtingen werden verschillen in de houdingen gevonden. Echter, aan de gevonden verschillen tussen de houdingen van de PIW-ers mag men met name vanwege het 
betrekkelijk geringe aantal respondenten geen al te verstrekkende conclusies verbinden. De voorgaande variantie-analyse geeft op zijn best aanleiding tot bepaalde vermoedens die door vervolgonderzoek onder een groter aantal respondenten nader geverifieerd zouden moeten worden.

\subsection{Resultaten van de enquête onder de leden van de professionele staf en inrichtingsdirectie}

Uit de paragraaf waarin de methode van onderzoek werd besproken kwam naar voren dat aan de enquête onder onderwijzers, penitentiair reclasseringswerkers en leden van het managementteam slechts een klein aantal respondenten meewerkten. Dit was voor een deel het gevolg van het feit dat het aantal in deze functies werkzame personen in een penitentiaire inrichting in vergelijking met het dienstvak PIW nu eenmaal laag is. Gelet op het aantal werkzame onderwijzers vormt het aantal van 7 respondenten een maximale respons. De respons van penitentiair reclasseringswerkers en van de leden van het management-team kan men gelet op het aantal in deze functies werkzame personen bestempelen als redelijk De respons op de enquêteformulieren gericht aan de leden van het management-team die werden verspreid in twee van de drie inrichtingen is met een aantal van twee geretourneerde enquêteformulieren laag te noemen.

Het geringe aantal respondenten heeft gevolgen voor de wijze waarop de verkregen data geanalyseerd dienen te worden. Immers bij een laag aantal respondenten bestaat het gevaar dat correlaties kunstmatig hoog worden, en de verschillen tussen gemiddelde scores niet of nauwelijks significant blijken te zijn. Vergelijkingen tussen de scores van de leden van de professionele staf en leden van het management-team onderling lijkt vanwege de kans op vertekening van het onderzoeksmateriaal derhalve weinig zinvol. Daarom zal met betrekking tot de houdingen van deze functiegroepen worden volstaan met een weergave van de gevonden frequentieverdelingen en reacties op een aantal open vragen. De leden van de professionele staf en het management-team krijgen zoveel mogelijk dezelfde uitspraken voorgelegd als de PIW-ers en gedetineerden. Die uitspraken hebben betrekking op de opvattingen over de resocialisatie-doelstelling in enge en ruime zin, de visie op het doel van het straffen in het algemeen, de waargenomen effecten van het onderwijs op gedetineerden en de randvoorwaardelijke aspecten van het werk.

\subsubsection{Houdingen van onderwijzers, penitentiair reclasseringswerkers en leden van het management-team: de opvattingen over strafdoelen en de resocialisatie- doelstelling}

Als belangrijkste doelen van het bestraffen van wetsovertreders zien de respondenten de vergeldingsdoelstelling. Op de tweede plaats komt de beveiliging of bescherming van de samenleving en speciale preventie geformuleerd als het weer op het rechte pad brengen van wetsovertreders, komt op de derde plaats. Op de vierde en vijfde plaats komen respectievelijk de generale preventie en het voorkomen van eigenrichting.

Over de resocialisatiedoelstelling als detentiedoel denken zowel onderwijzers als penitentiair inrichtingswerkers zeer positief. Men hangt vrijwel unaniem een ruime opvatting van de resocialisatie-doelstelling aan. Opvattingen in enge zin over de resocialisatie-doelstelling lijken nauwelijks aanhang te vinden onder onderwijzers en penitentiair reclasseringswerkers. Zo is bijna $86 \%$ van de respondenten het niet eens met de uitspraak dat gedetineerden niet zijn te resocialiseren en dat men daarom resocialisatie maar beter kan afschaffen. 
Wat betreft de reacties van de twee leden van het management van een inrichting die aan de enquête meewerkten bleek zich een opmerkelijk verschil voor te doen. De reacties van het ene directielid tendeerden in de richting van een ruime opvatting van de resocialisatiegedachte, terwijl de reacties van het andere lid meer in de richting gingen van een enge opvatting van de resocialisatie. Zo vindt deze laatste respondent niet dat zinvolle activiteiten een gunstig effect hebben op het toekomstig functioneren van gedetineerden, hij vindt het bieden van kansen aan gedetineerden een te softe benadering voor de huidige gedetineerdenpopulatie en is voorstander van de gedachte de resocialisatie-doelstelling maar af te schaffen omdat gedetineerden eenvoudigweg niet te resocialiseren zijn. Wel acht deze respondent de activiteiten zinvol voor het bevorderen van een goed klimaat in de inrichting en beschouwt hij de detentie wel als cen geschikt moment om het leven een andere wending te geven. De activiteiten beschouwt deze respondent over het algemeen als te vrijblijvend. In deze opvatting staat hij niet alleen, op de totale groep (dus leden van de professionele staf en management-team tezamen) vormt het percentage respondenten dat eveneens die mening is toegedaan een meerderheid $(57 \%)$.

\subsubsection{Onderwijzers en penitentiair inrichtingswerkers over de effecten van hun werk}

Aan de onderwijzers werd een aantal uitspraken over de waargenomen effecten van het onderwijs op gedetineerden voorgelegd.

De helft van de onderwijzers denkt dat door het volgen van onderwijs gedetineerden beter weten wat voor soort werk of opleiding zij na detentie willen volgen. Ruim een derde van de onderwijzers heeft hier geen duidelijke mening over en $16 \%$ denkt dat dit effect niet optreedt. Ruim $85 \%$ van de onderwijzers meent dat gedetineerden tijdens het volgen van onderwijs meer plezier in het studeren krijgen.

Dat gedetineerden door het volgen van onderwijs makkelijker werk vinden wordt door $42 \%$ onderschreven. Eveneens $42 \%$ heeft hier geen uitgesproken mening over en $14 \%$ denkt dat dit niet het geval is.

Het gunstig effect van het onderwijs op het zelfbeeld wordt door alle respondenten onderkend. Een percentage van $71 \%$ is van mening dat gedetineerden door het volgen van onderwijs zich later, in de vrije maatschappij beter weten te redden.

Ruim $85 \%$ vindt dat de onderwijs-activiteiten het vertrouwen van de gedetineerden in hun eigen kunnen versterken.

Volgens ruim $71 \%$ heeft het volgen van onderwijs als effect dat gedetineerden positiever over hun toekomst denken. Een op de drie onderwijzers denkt dat door het volgen van onderwijs de detentie voor de gedetineerden minder zwaar wordt. Het overgrote deel van de respondenten heeft hierover echter geen uitgesproken mening en $14 \%$ meent dat het volgen van onderwijs op de ervaren zwaarte van de detentie geen effect heeft.

De uitspraken die aan onderwijzers werden voorgelegd zijn behoudens enige wijzigingen in de formulering verder hetzelfde als die in de enquête aan de gedetineerden werden voorgelegd. Opvallend is dat de reacties van de onderwijzers een patroon vertonen dat een zekere overeenkomst vertoont met de meningen van gedetineerden over de effecten van het onderwijs.

Over de gunstige effecten van het onderwijs in de zin van het versterken van het zelfvertrouwen, het verkrijgen van een positief zelfbeeld of een duidelijker beeld met betrekking tot beroepskeuze en opleiding zijn de leerkrachten evenals de gedetineerden in hun antwoorden tamelijk eenduidig. Gaat het echter over de effecten van het onderwijs op de toekomstige levenssituatie, in het bijzonder in de zin van het makkelijker vinden van betaald werk, dan is er sprake van een minder positief antwoordpatroon en een zekere verdeeldheid. 
Door middel van de gesprekken in de oriëntaticfase met penitentiair reclasseringswerkers werd voldoende informatie vergaard omtrent hun visic op het effect van hun inspanningen ten behoeve van de gedetineerden. Besloten werd derhalve hierover geen uitspraken in de schriftelijke enquête op te nemen.

De reclasseringswerkers zijn als het gaat om gedetineerden die in de beginfase van de detentie verkeren of kortgestraft zijn vooral bezig met materiële hulpvragen op het gebied van huisvesting, uitkering, contacten met familie e.d.

Hoe langer gedetineerden gestraft zijn, des te meer verschuift het accent naar immateriële aspecten van de hulpverlening.

Een zeer belangrijk aspect van de hulpverleningsrelatie is het opbouwen van een zekere emotionele rust waarbij de cliënt weer een zeker gevoel van zelfwaardering terugkrijgt. Men werkt eerst aan het ontstaan van een vertrouwensbasis. Recidive-vermindering speelt bij het werk van de hulpverleners geen prominente rol. Bewust van de veelal complexe psychosociale problematiek en het langdurige moeizame karakter van cen proces van zelfherstel stelt men zich voor wat de te bereiken effecten betreft. bescheiden op. Men denkt meer in termen van kleine stappen vooruit met name in de zin van het opgang brengen van cen proces van zelfherstel.

\subsubsection{Onderwijzers en penitentiair reclasseringswerkers over de randvoorwaarden van hun werk}

Op de uitspraak "in deze organisatie word ik gewaardeerd in mijn werk" antwoordt 66\% bevestigend. Een derde heeft hierover geen uitgesproken mening of is het niet eens met deze uitspraak. Driekwart van de respondenten is tevreden met de ondersteuning door de directe chef. En $83 \%$ zegt plezier te hebben in zijn werk.

Over het overleg van de onderwijsafdeling met de verschillende gedetinecrdenafdelingen of vleugels is een minderheid van de onderwijzers niet tevreden. En ruim $85 \%$ is dat wel. Over het overleg tussen het onderwijs en instellingen buiten de inrichting is een kwart niet tevreden. Een percentage van $41 \%$ is hierover wel tevreden. Een derde heeft hierover geen mening.

Over het overleg binnen de eigen afdeling is een meerderheid van $55 \%$ tevreden.

Ontevreden is een ruime meerderheid $(67 \%)$ van de reclasseringswerkers en onderwijsgevenden over de tijden waarop de activiteiten platsvinden. Een nog groter percentage $(75 \%)$ is ontevreden over de hoeveclheid tijd die in het dagprogramma is vrij gemakt voor de activiteiten. Ruim eenderde is ontevreden over de mate van ondersteuning door de leiding van de inrichting in de werkzaamheden en $41 \%$ heeft hierover geen mening.

De helft van de respondenten geeft aan de werksfeer in de inrichting niet stimulerend te vinden voor het te verrichten werk en $75 \%$ denkt niet dat de leiding van de inrichting goed op de hoogte is omtrent het door de respondenten verrichte werk.

De respondenten kregen ook de gelegenheid om middels een open vraag aan te geven wat naar hun mening de belangrijkste problemen zijn waarmee zij in hun werkzaamheden to maken krijgen. De reacties op deze open vraag zijn dermate informatief dat wij zij hier zo volledig mogelijk zullen representeren.

Een probleem dat door de PRW-ers wordt genoemd is de aanwezigheid van tegenstrijdige belangen:

"Voor de reclassering staat de persoon en zijn resocialisatie centraal. maar voor het gevangeniswezen: rust. orde en veiligheid." 
Een PRW-er formuleerde het als: "Er is sprake van onbekendheid met elkaars werkterrein: er is nog steeds een tegenstelling tussen beveiliging en hulpvertening."

Door drie van de vijf PRW-ers wordt dit probleem als eerste genoemd.

Een volgend probleem dat vrijwel alle PRW-ers noemen zijn de bezuinigingen op de beschikbare middelen om de doelen van de reclassering te verwezenlijken:

"Er is sprake van een toenemende afbouw en versobering van de mogelijkheden bij het gevangenisweren. Dit heeft niet alleen duidelijke gevolgen voor de gedetineerden, zij krijgen immers minder aandacht. maar ook voor de organisatic en inhoud van het penitentiair reclasseringswerk".

Men signaleert steeds minder mogelijkheden om de gedetineerden te bereiken.

De toename van het aantal buitenlandse, psychisch gestoorde en verslaafde gedetineerden wordt als een belangrijk probleem gezien. Een respondent merkt op dat er nauwelijks mogelijkheden zijn om met deze groepen te werken en een andere respondent meent dat de problematick van deze groepen het bereiken van maatschappelijke integratie extra moeilijk maakt.

Verder worden samenwerkingsproblemen genoemd in het bijzonder met betrekking tot de zgn. "buitenreclassering":

"De buiten reclassering is alleen bereid iets te doen voor gedetineerden die in een inrichting verblijven die binnen het ressort van hun bureau ligt."

En verder merkt een respondent op:

"Van de rechasseringswerkers in de gevangenis wordt verwacht dat zij hulpverlening verstrekken, matr als wij vervolgens om informatic over een client aankloppen bij de buitenreclassering dan blijft men nogal eens in gebreke".

Ook de kwaliteit van de nazorg wordt genoemd als een belangrijk probleem:

"Gedetineerden zonder huisvesting hebben nauwelijks medewerking van woningbouwverenigingen bij hun pogingen om na detentie onderdak te vinden".

"Medewerking van de samenleving om detentieschade te beperken is erg beperkt en erg afhankelijk van de economie (denk bij voorbeeld aan het stopzetten van bijzondere bijstand ten behoeve van doorbetaling van een huurwoning tijdens de preventieve fase van de detentie). Ondanks het feit dat de schuldvraag van een verdachte nog niet beantwoord is ontstat er in de preventieve fase toch al veel sociale schade (in de vorm van het kwijtraken van een woning, verlies van werk en inkomen, verstoorde relaties). Een en ander kan een terugkeer in de samenleving onevenredig zwaar maken".

De commentaren die het onderwijzend personeel geeft op de open vraag naar de belangrijkste problematiek kan men grofweg verdelen in onderwijskundige, regimaire, organisatorische en persoonlijke problemen.

Met betrekking tot het regime noemt men de invoering van het standaardregime dat tot een minimaal en onvoldoende aanbod leidt. Gedetineerden zijn moeilijker te bereiken. Het regime geeft geen ruimte meer voor gedetineerden die extra aandacht behoeven en flexibele oproeptijden ontbreken. Een respondent merkt op dat er sprake zou moeten zijn van een cvenwichtige en gelijke positie van de activiteiten zodat op grond hiervan de onderwijsactiviteiten een betere plaats in het dagprogramma verwerven. 
Op onderwijskundig gebied constateert men het probleem van de grote verschillen tussen de kandidaten. Als gevolg hiervan is men veel tijd kwijt met het peilen van de onderwijshiaten in de vorm van het afnemen van toetsen. Er is voorts sprake van een constante instroom van kandidaten op verschillende momenten hetgeen een goede programmering en verwezenlijken van programmadoelen bemoeilijkt. Voorts noemt men de wisselende motivatie en moeilijke persoonlijkheidsstructuur van de kandidaten als een probleem dat het geven van onderwijs aan deze doelgroep extra zwaar maakt. Een respondent noemt de hospitalisering als de oorzaak van de vele "ups en downs" van de kandidaten

Op het persoonlijk vlak noemt men als probleem dat er doorlopend twijfels zijn omtrent het effect van de inspanningen die men verricht. De moeilijke meetbaarheid van de effecten en de omstandigheid dat veel effecten van indirecte aard zijn, leiden tot onzekerheid. Tenslotte wordt als bron van onzekerheid genoemd het feit dat men als een soort duizendpoot zeer veel vakken moet doceren waarvoor men eigenlijk niet goed is opgeleid zoals bij voorbeeld boekhouden, computervaardigheden en algemene ondernemersvaardigheden.

Een probleem dat in de enquêteformulieren van de onderwijzers terugkomt en ook uit de antwoorden op de gesloten items over de randvoorwaarden blijkt, is het permanente gevoel dat men niet serieus wordt genomen door de organisatie. Men spreekt hier over de ambivalente houding van het overige inrichtingspersoneel tegenover het onderwijs, het ontbreken van invloed op de organisatie, onvoldoende inzicht in de besluitvorming die repercussies heeft voor het onderwijs, het ontbreken van directe feedback of een luisterend oor van de zijde van het managementteam, een moeizaam verlopend overleg met de overige afdelingen van de inrichting als gevolg van te lange kanalen, een directe chef of hoofd SKW die onvoldoende opkomt voor de belangen van de afdeling en een gebrekkige voorlichting over educatie en vorming naar de rest van de inrichtingsorganisatie toe.

De problemen die door de twee respondenten van het management-team worden genoemd hebben betrekking op de schaarse middelen (geld) en de coördinatie tussen de verschillende disciplines. Een van deze respondenten verwoordt het perspectief van de leiding van de inrichting als het om bepaalde problemen gaat heel duidelijk:

"Je moet detentie als een gegeven beschouwen en niet zoals het PRW en ook het onderwijs doen, samen met de gedetineerde tegen het systeem gaan knokken".

Deze respondent benadrukt vooral het aspect van de aanpassing van de gedetineerde aan de detentie en hij beschouwt de ontwikkelingsactiviteiten blijkbaar als belangrijke instrumenten daartoe.

Een van de collega-directeuren van deze respondent benadrukt in een interview, verricht in het kader van het reeds eerder genoemde HBO-stageonderzoek, vooral de budgettaire aspecten van het aanbod van bij voorbeeld een activiteit als kunstzinnige vorming. Opvallend is dat deze respondent voor wat betreft de zinvolheid van deze activiteit voornamelijk doeleinden noemt als afleiding en ontspanning.

"Crea is op zich, dus los van de gevangenis, een geschikte activiteit. Het kan dienen als vrije tijdsbesteding of als afleiding. Maar als je de crea plaatst binnen de gevangenis dan zal het altijd op een van de laatste plaatsen komen. Als wij, als directie, geld moeten vragen aan Den Haag omdat het budget op is, dan zegt Den Haag ook dat we moeten stoppen met activiteiten als crea of muziek. De opleiding van de PIW-ers heeft veel geld gekost, de crea-consulent kost geld en dat terwijl wij het niet hoeven aan te bieden. Wij zijn dus al heel soepel." 
Verder wordt nog het probleem van de samenwerking genoemd binnen de reclassering. Volgens een van de leden van het managementteam opereren het CAD en het PRW als eilandjes, hetgeen een goede samenwerking bemoeilijkt.

\subsection{Samenvatting en conclusies}

De respondenten onder de bewaardersgroep ondersteunen in meerderheid de resocialisatiegedachte. Ondanks het feit dat zij denken dat de intramurale voorzieningen op het gebied van resocialisatic nict toereikend zijn om gedetineerden weer op het rechte pad te brengen, vindt men die inspanningen toch waardevol. Zij hanteren derhalve een ruime opvatting van de resocialisatie-doelstelling. Deze ruime opvatting impliceert een visie waarbij de zinvolheid en effectiviteit van de intramurale inspanningen veeleer wordt gedefinieerd in termen van het op gang brengen of ondersteunen van een proces van persoonlijke groei. De (geringe) effectiviteit in termen van het voorkomen of verminderen van recidive vormt dus geen reden om resocialisatie als detentiedoel te verwerpen.

$\mathrm{Zij}$ denken niet zozeer in termen van recidive-vermindering maar veeleer in termen van een het leveren van een bijdrage aan een proces van zelfherstel.

Verder waarderen PIW-ers de voorzieningen gericht op resocialisatie tevens om humane en beheersmatige reden. Men acht de voorzieningen dienstig aan een tenuitvoerlegging in een humane en constructieve sfeer, waarbij deze voor het personeel en gedetineerden een positief zingevend element vertegenwoordigen in een, overwegend als pijnlijk en negatief ervaren situatie.

Ook de leden van de professionele staf zoals de onderwijzers en penitentiair reclasseringswerkers, denken overwegend positief over de resocialisatie-gedachte. Het verbeteringsideaal wordt door deze groep respondenten als rechtvaardiging voor de vrijheidsbeneming zelfs iets belangrijker geacht dan de respondenten onder de PIW-ers.

De PIW-ers en de leden van de professionele staf onderkennen het gegeven dat de gevangenisomgeving een adequate voorbereiding van de terugkeer in de samenleving in de weg kan staan. Toch acht men ondanks de negatieve aspecten van een verblijf in de gevangenis pogingen tot zelfherstel mogelijk en zinvol.

Deze resultaten bevestigen de veronderstellingen van een aantal auteurs zoals Denkers (1976), Conrad (1981) en Logan en Gaes, (1989) waarin een relatief geringere recidive als resultaat van de intramurale voorzieningen van ondergeschikte betekenis is voor de houdingen van het personeel ten aanzien van de resocialisatie-doelstelling. Recidive-reductie speelt hooguit een zeer indirecte rol naast veel belangrijkere overwegingen die betrekking hebben op een zinvolle humane en constructieve tenuitvoerlegging van de gevangenisstraf.

De resultaten laten zien dat de overwegend ondersteunende houding van PIW-ers ten aanzien van de resocialisatiegedachte zich ook weerspiegelt in hun opvattingen over de omgang met gedetineerden. In de takkopvatting beperken zij zich niet tot louter ordegerichte aspecten, zij laten ook gedetineerdengerichte aspecten in het handelen toe. Een kleine minderheid baseert het cigen handelen voornamelijk op een ordegerichte of louter gedetineerdengerichte benadering van gedetineerden.

Deze resultaten zijn vergelijkbaar met de onderzoeksresultaten van Kommer (1990) die geen aanwijzingen vond voor het bestaan van een sterk anti-gedetineerdengerichte bewaarderscultuur in een vorm zoals die door Kauffman (1988) werd aangetroffen in Amerikaanse gevangenissen. Kommer stelt dat het gangbare beeld wordt gekenmerkt door PIW-ers die in woord en daad niet anti-gedetineerdengericht waren. Dat neemt niet weg dat er wel een kleine minderheid aanwezig is die, aldus Kommer, een sterk negatieve instelling ten opzichte 
van gedetineerden heeft en die afwijkt van het normale beeld. Kommers gegevens werden verzameld halverwege de jaren tachtig en wij kunnen derhalve concluderen dat de houding van bewaarders in de jaren negentig niet noemenswaardig is veranderd. Het uit de literatuur van de jaren tachtig bekende onderscheid tussen Zwarte Pieten, neutralen en Sinterklazen is nog wel in bepaalde mate herkenbaar. Maar van scherpe of verscherpte tegenstellingen tussen de ordegerichte of gedetineerdengerichte bewaarders lijkt geen sprake. Bewalarders met een zeer uitgesproken orde- of gedetineerdengerichte houding vormen nog stecds cen minderheid. Een veranderde, meer ordegerichte opstelling ten aanzien van gedetineerden als gevolg van bij voorbeeld een verharding van de gedetineerdenpopulatie, lijkt bij een mecrderheid van de PIW-ers niet te hebben plaatsgevonden.

Een en ander wijst op een daadwerkelijk effect van een voortschrijdende professionalisering van de bewaarder en op het feit dat de officiële normen en doelstellingen zoals dic in Taak en Toekomst (1982) zijn geformuleerd voor de PIW-er nog steeds worden onderschreven.

PIW-ers denken, zo blijkt verder uit de onderzoeksresultaten, in het algemeen gunstig over de motivatie van gedetineerden voor activiteiten als sportbeoefening en kunstzinnige vorming. De ondervraagde groep PIW-ers constateert wel dat als gevolg van verslavingsproblematiek gedetineerden over het algemeen moeilijker zijn te motiveren. Echter, de suggestie van sommige gevangenisfunctionarissen halverwege de jaren negentig dat het activiteitenaanbod niet meer zou passen bij een moeilijker, minder gemotiveerde en verharde populatie, wordt door het onderhavige onderzoek niet bevestigd. De bevindingen ten alazien van de opvattingen van bewalarders over resocialisatie laten overigens een zelfde soort conclusie zien: een meerderheid denkt niet dat het aambieden van resocialiserende voorzieningen een te softe benadering is voor de huidige gedetineerdenpopulatie.

De motieven van gedetineerden voor deelname aan kunstzinnige vorming worden in de visic van de PIW-ers weliswar sterk bepaald door de behoefte de ongemakken van de detentie te reduceren, echter men sluit de aanwezigheid van 'hogere' motieven gericht op de persoonlijke ontwikkeling niet uit.

Als aan PIW-ers verder wordt gevraagd welke effecten de kunstzinnige vorming heeft op de gedetineerden, dan zien we bij effecten op de persoonlijke ontwikkeling het meest eenduidige positieve beeld. Een meerderheid van de respondenten denkt dat alle effecten daadwerkelijk optreden. Bij de effecten op de sociale ontwikkeling is het beeld minder eenduidig, echter één effect springt er in positieve zin tuit, namelijk een beter onderling contact tussen bewaarders en gedetineerden. Ook als het om de aanpassing aan de detentiesituatie gaat, ziet een meerderheid een positief effect in de zin van minder probleemgevend gedrag.

$\mathrm{Bij}$ de randvoorwaardelijke aspecten van de activiteitenbegeleiding, in het bijzonder die van de kunstzinnige vorming vallen de volgende resultaten op.

Een zeer ruime meerderheid is ontevreden met het feit dat structureel geen plaats in het rooster is voor een regelmatige bijscholing en ondersteuning door een consulent en dat er geen voorbereidingstijd voor de crea-PIW-ers is ingepland. Een meerderheid acht de eigen kennis en vaardigheden om als crea-bewaarder op te treden ontoereikend en vindt dat deze activiteit onvoldoende aan bod komt in het afdelingsoverleg. Over de ondersteuning door de leiding in het werk als crea-begeleider is eveneens een meerderheid niet tevreden. De mening over de plaats in het dagprogramma van de kunstzinnige vorming in het bijzonder de beschikbare hoeveelheid tijd en het tijdstip is wat minder negatief. Alleen over de informatieverstrekking aan gedetineerden over de crea, is een overgrote meerderheid tevreden. 
Dezelfde ontevredenheid over de randvoorwaarden van de activiteiten, met name over de ondersteuning vanuit het kader en de organisatie in het algemeen, doet zich voor bij de leden van de professionele staf.

Een en ander wijst erop dat de activiteiten die gericht zijn op de voorbereiding van de terugkeer in de samenleving binnen het regime en het beleid van de inrichting een vrij onzekere en kwetsbare positie innemen. Een soortgelijke conclusie werd reeds in de jaren tachtig getrokken,door van Hooff en van Zeijl (1984) met betrekking tot de kunstzinnige vorming. De resultaten van deze studie laten zien dat het beeld in de jaren negentig niet veel anders is.

Met deze bevindingen raken we, als het om de gevangenis en intramurale interventies gaat, een fundamenteel, steeds terugkerend probleem: speciaal preventieve doeleinden dienen onder betrekkelijk ongunstige condities verwezenlijkt te worden.

Volgens Tulkens (1988) is dit een probleem dat in de aard van de gevangenis besloten is. Naar zijn mening is dit probleem uiteindelijk te herleiden tot een fundamentele onverenigbaarheid van de beveiligingsdoelstelling met speciaalpreventieve doelstellingen gericht op het bevorderen van zelfherstel. Tulkens (ibid., p.15): "Deze eigenschappen, bedrijfsmatigheid en beveiliging, versterken elkaar en maken de gevangenis tot een systeem waarin speciaal preventieve doeleinden van zelfherstel niet of zeer beperkt zijn te realiseren."

Kommer (1991) gat in zijn onderzoek naar onder meer de oorzaken van een verminderde welbevinden van PIW-ers nader in op de kwestie van de ogenschijnlijke onverenigbaarheid van de detentiedoelstellingen. Vanuit een organisatiesociologische benadering waarbij zowel het micro- als het macroniveau van de organisatie aan bod komen, werpt hij een toch wat minder fatalistisch licht op deze kwestie. Konmer's studie laat zien dat een verminderd welbevinden uiteindelijk te herleiden is tot factoren met betrekking tot de inhoud van het werk (onzekerheid in de interacties met gedetineerden en slecht functionerende teams) en tot een zekere spanning tussen de doelstellingen van de organisatie (onder meer tot uiting komend door een gebrek aan ondersteuning door de leiding van de inrichting). Deze factoren blijken echter niet te herleiden tot een fundamentele onverenigbaarheid van de doeleinden.

Vanuit de optiek van de PIW-er blijkt uit het onderzoek van Kommer immers op microniveau geen onverenigbaarheid van de strafdoelen. In de praktische uitvoering van het werk achten de meeste PIW-ers verschillende doeleinden wel degelijk verenigbaar mits hen daartoe de gelegenheid wordt geboden. De resultaten van dit onderzoek naar de houdingen van PIW-ers laten een soortgelijke conclusie toe. Men keert zich niet af van speciaal-preventieve doeleinden, integendeel een meerderheid van de PIW-ers tracht ze in de omgang met de gedetineerden te verenigen met het beveiligingsdoel.

Het probleem, aldus Kommer, ligt in de inhoud van het werk, maar de oplossing ligt in de organisatiestructuur die dient te worden afgestemd op de inhoud van het werk teneinde de problemen die daarmee samenhangen zoveel mogelijk op te lossen. De organisatie dient met andere woorden het personeel de mogelijkheid te bieden om datgene te doen wat nodig is om die verschillende doelen te verenigen. En voor Kommer is dat met betrekking tot de PIW-ers een situationeel handelen vanuit vertrouwen in eigen oordeel en kunnen. Kommer heeft voornamelijk het functioneren van de PIW-ers onderzocht. Het functioneren van de professionele staf bleef in zijn studie buiten beschouwing.

De problemen van de leden van de professionele staf en van de bewaarders, zo blijkt uit de onderhavige studie, hangen vooral samen met de organisatic. Als PRW-ers aangeven dat als gevolg van de invoering van Werkzame Detentie de bereikbaarheid van de gedetineerden een steeds groter probleem vormt, dan is dat een aanwijzing voor het feit dat de organisatie onvoldoende gelegenheid biedt de reclasseringstaak op een adequate manier te vervullen. 
Men kan derhalve stellen dat de problemen van de professionele staf en van PIW-ers bij de uitvoering van hun bejegenende en resocialiserende taak te herleiden zijn tot een gebrekkige afstemming van de organisatiestructuur op de inhoud van het werk.

Een organisatiestructuur die slechts een afspiegeling is van het feit dat het werk moeilijk of niet verenigbare doelen heeft, is niet de juiste en moet worden vervangen door een die de mogelijkheid biedt die doelen op de werkvloer te verenigen.

Vanuit deze benadering is het mogelijk een minder fatalistisch beeld van de vermeende onverenigbaarheid van de detentiedoelen te schetsen. $\mathrm{Er}$ is in het werk weliswaar steeds sprake van een spanning tussen verschillende doelstellingen, maar dat neemt niet weg dat men zich wel degelijk kan en moet bezig houden met de voorwaarden waaraan de organisatie dient te voldoen wil men de verschillende, ogenschijnlijk onverenigbare doelstellingen op de werkvloer realiseerbaar maken.

In dit verband is ook een ander resultaat van het onderzoek relevant, namelijk de verschillen in houdingen van PIW-ers ten aanzien van de resocialisatieopdracht die de vergelijking tussen de inrichtingen opleverde. Deze verschillen kunnen wellicht voor een deel worden herleid tot een verschil in inrichtingsklimaat.

In een van de onderzochte inrichtingen tendeert het klimaat naar een zekere onverschilligheid bij de PIW-ers ten aanzien van de verschillende taken. Onverschilligheid en terugtrekking, zo laat ook Kommer (1991) zien, kan bij PIW-ers worden aangemerkt als een vorm van copinggedrag dat de stress als gevolg van het werk reduceert.

De voorgaande analyse leidt tot de volgende veronderstelling:

de mate waarin de organisatie van de inrichting erin slaagt de organisatiestructuur af te stemmen op de verschillende taken van het personeel en de inhoud van het werk is van betekenis voor de wijze waarop het personeel deze taken opvat. Hoe slechter de afstemming van de organisatiestructuur des te groter de kans op een negatieve cultuur waarin het personeel op een negatieve of onverschillige manier tegen de verschillende taken aankijkt.

De mate waarin men de organisatiestructuur op de inhoud van het werk kan afstemmen, wordt voor een deel bepaald door externe omstandigheden waarop men weinig invloed kan uitoefenen, zoals bijvoorbeeld opgelegde bezuinigingen of beleidsveranderingen.

Voor een deel echter heeft de mate van afstemming van de organisatiestructuur ook te maken met interne factoren waarop men wel invloed heeft, zoals duidelijkheid over de strategie van de organisatie (of wel de visie op langere termijn), over de aanwezigheid van een heldere, eenvormige en gedeelde visie ten aanzien van het belang van niet alleen beveiligende en beheersmatige taken maar ook van bejegenende taken uit hoofde van de resocialisatieopdracht. Andere intern beïnvloedbare factoren zijn het vermogen te enthousiasmeren en te motiveren, aandacht voor de identificatie en binding met de organisatie, de kwaliteit van het werkoverleg, de aanwezigheid van een duidelijke en open communicatie en controle op het nakomen van afspraken en het uitvoeren van besluiten.

De slotstelling van dit hoofdstuk luidt dan ook dat er voor inrichtingsdirecties op het gebied van de structuur van de organisatie nog genoeg uitdagingen zijn om de kwaliteit van het primaire proces te verbeteren. Deze uitdaging, zo blijkt uit dit onderzoek, geldt ook voor het primaire proces dat betrekking heeft op de zorg in verband met de terugkeer in de samenleving. Dit uitgangspunt lijkt mij veel bemoedigender en op empirische gronden ook beter te verdedigen dan de meer fatalistische visie dat de doelstellingen in het bijzonder speciaal-preventieve nu eenmaal niet of nauwelijks verwezenlijkt kunnen worden vanwege de fundamentele onverenigbaarheid met doeleinden als bedrijfsmatigheid en beveiliging. De verwezenlijking van op zelfherstel gerichte bedoelingen moet het binnen de inrichtingsorganisatie en binnen de penitentiaire organisatie als geheel weliswaar steeds opnemen tegen 
concurrerende doeleinden. Dit noopt zoals ook in de samenvatting en conclusies van hoofdstuk 2 bleek, tot een zekere bescheidenheid ten aanzien van de ambities die men in de context van de gevangenis met resocialisatic nastreeft. Het gevangeniswezen kan echter wel streven naar een optimale ruimte voor sociale perspectieven van gedetineerden binnen de inrichtingsorganisatic. Een goede basis voor een dergelijk streven blijkt feitelijk aanwezig te zijn in de vorm van de positieve houding van het uitvoerend personeel ten aanzien van het resocialisatie-streven. De houding van het personeel is in essentie nog steeds dat in de sfeer van de tenuitvoerlegging punitieve doelen en resocialiserende elkaar niet hoeven uit te sluiten maar elkaar veronderstellen. Die houding is wellicht idealistisch getint voor zover impliciet de humane, ethisch normatieve betekenis van het resocialisatie-beginsel lijkt te worden erkend. Die houding draagt een realistisch karakter voor zover men de effectiviteit van penitentiaire interventies vooral definieert in termen van het leggen van een basis voor een proces van zelfherstel en van een bijdrage aan een schadebeperkende, constructieve en humane tenuitvoerlegging van de gevangenisstraf. 


\title{
SAMENVATTING EN CONCLUSIES
}

\author{
"Ik hoop zo lang mogelijk buiten te blijuen" \\ (uitspraak van gedetinecrde bij ontslag uit detentie)
}

\subsection{Inleiding}

In het inleidende hoofdstuk van dit boek werd een lacune geconstateerd in de wetenschappelijke kennis over de aard en oorsprong van de houdingen van zowel gedetimeerden en gevangenispersoneel ten aanzien van resocialisatic.

In het verlengde hiervan werd beargumenteerd dat de betrekkelijk geringe kennis van deze houdingen vanuit een ethisch-normatieve, penologische en organisationele optiek een probleem vormt dat de moeite van het onderzoeken waard is.

De noodzaak en het belang van vermeerdering van de wetenschappelijke kennis van houdingen van gedetineerden en gevangenispersoneel ten aanzien van de resocialisatie-opdracht vormde de aanleiding voor het onderzoek waarvan in dit boek verslag is gedaan.

Het doel van het onderzoek is inzicht te krijgen in de wijze waarop gedetineerden en gevangenispersoneel het resocialisatiedoel en de bijbehorende activiteiten ten behoeve van de terugkeer in de samenleving beoordelen.

Tevens is als doel gesteld inzicht te verkrijgen in de persoons-en omgevingsgebonden factoren die de houdingen van gedetineerden ten aanzien van resocialisatie beïnvloeden.

De doelstellingen van het onderzoek zijn samengevat in een algemene probleemstelling:

Wat houdt het streven natr resocialisatie in het Nederlandse gevangeniswezen precies in, hoe beoordelen gedetineerden en personeel dit streven en door welke factoren wordt hun oordeel beinvloed?

In dit laatste hoofdstuk wordt de balans van het onderzoek opgemaakt aan de hand van de verschillende onderzoeksvragen en de antwoorden die daarop werden verkregen.

In dit hoofdstuk wordt verder het methodologisch en theoretische kader dat is gehanteerd om de verschillende vragen te beantwoorden, op zijn waarde beoordeeld. Het hoofdstuk wordt afgesloten met een beschouwing over de (toekomstige) betekenis van de resocialisatieopdracht voor het gevangeniswezen en met een aantal aanbevelingen. De indeling in een ethisch normatieve, instrumentele en organisationele optiek geldt hierbij als leidraad. 


\subsection{Samenvatting en conclusies van het onderzoek onder gedetineerden}

In hoofdstuk 1 werd de probleemstelling uitgesplitst in een zestal beschrijvende vraagstellingen, waarvan de eerste twee vragen werden beantwoord in hoofdstuk 2 . Deze vragen luiden:

1. Wat houdt het begrip resocialisatie precies in?

2. Op welke wijze heeft men totnogtoe in het Nederlandse gevangeniswezen gestalte gegeven aan het resocialisatiedoel?

Hoofdstuk 2 begon met een verheldering en operationele definitic van het begrip resocialisatie. Het reeds ecrder in hoofdstuk 1 geformuleerde onderscheid tussen het resocialisatiedoel in intrinsieke en instrumentele zin fungeerde hierbij als vertrekpunt. Het resocialisatiedoel in intrinsieke zin betreft de wettelijk (art.2 lid 2 Penitentiaire Beginselenwet, 1999) vastgelegde opdracht aan het gevangeniswezen de tenuitvoerlegging van de vrijheidsstraf zoveel mogelijk dienstbaar te maken aan de voorbereiding van de terugkeer in de samenleving. Vanuit een ethisch normatieve optiek beoogt dit wettelijk resocialisaticbeginsel primair de rechtsbescherming van onveroordeelde en veroordeelde gedetineerden. Het benadrukt de gedachte dat gedetineerden door een gerechtelijke vrijheidsbeneming niet volledig buiten de samenleving worden gesteld. Het punitieve doel van de gerechtelijke vrijheidsbeneming veronderstelt in het Nederlandse strafrecht dus tevens de aanwezigheid van het resocialisatiedoel.

De concrete uitvoering van de resocialisatieopdracht door het Nederlandse gevangeniswezen verwijst naar het resocialisatiedoel in instrumentele zin. Bij het verwezenlijken van dit doel gaat het om de beïnvloeding van houdingen en gedrag van justitiabelen. Voorkómen of verminderen van toekomstig crimineel gedrag is het meest bekende en gangbare doel dat men met resocialisatie als speciaal preventief instrument van de strafrechtspleging nastreeft. Andere vormen van beïnloeding van het gedrag of de houdingen van justitiabelen betreffen het bewerkstelligen van een grotere sociale redzaamheid, een groter welbevinden en groei in psycho-sociaal, educatief opzicht. Resocialisatie kan al naar gelang het nagestreefde doel op een ruime of meer beperkte of enge wijze worden geïnterpreteerd. Bij de definitie van resocialisatie in enge zin wordt recidive-vermindering als het voornaamste doel van resocialisatie beschouwd. Zowel bij de doelen die men met resocialisatie nastreeft als de middelen waarmee men deze doeleinden tracht te verwezenlijken zijn, al naar gelang het heersende penitentiaire klimaat, in de loop der tijd de accenten steeds op een verschillende manier gelegd.

Bij de beantwoording van de tweede onderzoeksvraag naar de wijze waarop in het Nederlandse gevangeniswezen in de loop der tijd gestalte is gegeven aan het streven naar verbetering of resocialisatie van gedetineerden komen deze wisselende accenten duidelijk aan het licht.

\subsubsection{Resocialisatie in historisch perspectief}

De verbinding tussen de gerechtelijke vrijheidsbeneming en het streven naar verbetering van gedetineerden krijgt in West-Europa en de Verenigde Staten in de eerste helft van de negentiende eeuw steeds duidelijker vorm. Met het verdwijnen van de lijf-en doodstraffen en het uitgroeien van de vrijheidsbeneming tot de belangrijkste sanctievorm deed tevens het streven naar zedelijke verbetering van gedetineerden als nevendoel van die vrijheidsbeneming zijn intrede. 
De introductie van het verbeteringsstreven wordt door auteurs als Franke (1990) en Garland (1990) in verband gebracht met de werking van een omvangrijk civilisatieproces in de Westerse cultuur. Een cruciaal aspect in dit civilisatie-proces is een toenemende gevoeligheid voor het (gevangenis)leed van de 'gevallen' mens.

Ter rechtvaardiging van dit leed waren afschrikking, vergelding en wraak alléén niet langer aanvaardbaar. Die doeleinden werden steeds meer in verband gebracht met primitieve driften. De zedelijke verbetering van gedetineerden werd vervolgens als nevendoel aan de gevangenisstraf verbonden. Om die zedelijke verbetering te bereiken achtte men de gemeenschappelijke opsluiting van gedetineerden in de huizen van correctie ongeschikt. De verbetering van het verdorven innerlijk diende te geschieden in de strikte eenzaamheid van de cellulaire opsluiting. Gevangenen werden weliswaar nog steeds uit hoofde van vergelding en wraak opgesloten, maar door dat in de vorm van de eenzame cellulaire afzondering te doen, werd naar men veronderstelde, tevens hun zedelijke verbetering bevorderd.

Aan het eind van de negentiende eeuw en het begin van de twintigste eeuw ontstaan er andere denkbeelden omtrent straffen en verbeteren. De denkbeelden van de Nieuwe Richting in het strafrecht en de opkomst van de criminologie als nieuwe wetenschap legden de basis voor de resocialisatie-gedachte in moderne zin. Verbetering van gedetineerden wordt een speciaal preventief doel van de straf dat betrekking heeft op het toekomstig sociaal functioneren van de dader. De straf diende meer in te houden dan louter vereffening van het door de dader aangerichte kwaad. De zin van de straf werd tevens gezocht in een te verwachten nuttig effect op dader en samenleving. Criminaliteit werd immers niet meer gezien als het resultaat van een vrij wilsbesluit maar als een vorm van gedrag waartoe de dader krachtens sociale, psychische en erfelijke tekorten werd gedetermineerd. Na de Eerste Wereldoorlog sprak men ook niet meer over zedelijke verbetering maar over opvoeding van gedetineerden. Die opvoeding behelsde de omvorming van de anti-of a-sociale persoon van de dader tot iemand die na zijn detentie beter is toegerust voor het leven in de vrije maatschappij. Het rigide karakter van het cellulaire stelsel werd met het oog op deze opvoedingsgedachte enigszins doorbroken.

In beleidsmatige en wettelijke zin krijgt het streven naar een beter toekomstig sociaal functioneren van de (ex) gedetineerde op serieuze wijze gestalte na 1945. Het resocialisatiebeginsel krijgt een wettelijke basis en het cellulaire stelsel wordt afgeschaft.

Socialisering van de gevangenisstraf en de daarmee gepaard gaande humanisering en liberalisering van het gevangenisregime worden als belangrijke voorwaarden beschouwd voor het realiseren van de resocialisatie-gedachte. Feitelijk komt resocialisatie in de naoorlogse periode neer op humanisering van de detentiesituatie en niet zozeer op het stelselmatig nastreven van blijvende gedragsveranderingen bij gedetineerden. Van een serieus streven naar recidive-vermindering als doel van resocialisatie is maar ten dele sprake.

Het uitblijven van substantiële recidive-vermindering is in de jaren zeventig en tachtig van de twintigste eeuw een belangrijke reden voor het gevangeniswezen om in beleidsmatige zin minder aandacht te besteden aan resocialisatie. In de jaren tachtig verschuift bovendien de aandacht in het strafrechtelijk beleid steeds meer naar punitieve en beheersmatige doeleinden. In de jaren negentig is resocialisatie geen hoofddoel meer van het penitentiaire beleid. De belangrijkste hoofddoelen zijn dan veiligheid, menswaardigheid en doelmatigheid. De wettelijke resocialisatieopdracht wordt in de nieuwe Penitentiaire Beginselenwet (1999) overigens wel gehandhaafd. Uitvoering geven aan deze opdracht is echter geen speerpunt van het beleid meer. 
De selectieve praktijk van het resocialisatie-streven in de jaren negentig vormt een afspiegeling van de ondergeschikte betekenis van deze doelstelling. Slechts een kleine groep kansrijke en gemotiveerde gedetineerden kan aanspraken maken op programma's waarin bijzondere aandacht is voor hun terugkeer in de samenleving. Voor het overgrote deel van de gedetineerden verwacht men niet dat dergelijke bijzondere matschappelijke integratieprogramma's voldoende rendement opleveren in termen van recidive-vermindering. Voor deze groep gedetineerden die als minder gemotiveerd wordt beschouwd, is op zijn best een beperkt aanbod van educatieve activiteiten en psycho-sociale hulpverlening aanwezig. De basis van dit aanbod ligt voomamelijk in de wettelijke bepalingen van de Penitentiaire Beginselenwet en niet zozeer in de uitgangspunten van het penitentiaire beleid van de nola Werkzame Detentie.

Na bijna twee eeuwen straften en resocialiseren kan men concluderen dat van het ideal om gedetineerden om te vormen tot oppassende burgers die niet meer recidiveren, in ideologische en beleidsmatige zin weinig meer over is.

Resocialisatie is aan het einde van de twintigste eeuw noch in instrumentele, noch in intrinsieke zin een belangrijke doelstelling van het penitentiair beleid. Het is een vrij kwetsbare doelstelling gebleken.

Die kwetsbaarheid van de resocialisatiedoelstelling wordt mede veroorzaakt door het feit dat in de strafrechtelijke besluitvorming het resocialisatiedoel zowel in intrinsieke als in instrumentele zin het steeds moet opnemen tegen andere, concurrerende doelen waaraan evenzeer recht moet worden gedaan.

Ondanks deze inherente beperkingen bij de realisering van het resocialisatiedoel kan de tenuitvoerlegging van de gevangenisstraf het niet zonder dit doel stellen. Een gevangenisstraf die geen perspectieven meer biedt voor gedetineerden glijdt immers af naar een niveau dat op gespannen voet staat met humane en rechtsbeschermende principes. Met name het wegvallen van het geloof in resocialisatie als instrument van criminele politiek maakt dat de aanwezigheid en het voortbestaan van de resocialisatie-gedachte in het strafrechtelijk systeem, in sterkere mate afhankelijk is geworden van de erkenning van haar humane en normatieve strekking.

De erkenning en benadrukking van de ethische en rechtsbeschermende betekenis van het resocialisatiebeginsel betekent overigens niet dat voorzieningen die gedetincerden een sociaal perspectief bieden, hun fundament louter ontlenen aan gevoelens van solidariteit of charitatieve motieven. Het betreft hier een fundament dat tevens inherent is aan de rechtstaat waarin bepaalde beginselen van rechtsbescherming van justitiabelen zijn vastgelegd.

De benadrukking van het ethisch normatieve fundament van de resocialisatie-gedachte sluit het nastreven van utilitaire, instrumentele doeleinden bovendien niet uit. Resocialiserende voorzieningen die men in beginsel om humane, normatieve en niet rationele overwegingen aanbiedt, kunnen een nuttige functie vervullen voor de persoonlijke ontwikkeling van de gedetineerde, de voorbereiding tijdens de detentie op extra-murale vervolgvoorzieningen die uiteindelijk kunnen resulteren in verminderde recidive en het scheppen van een schadebeperkend, constructief en humaan detentieklimaat.

\subsubsection{De instrumenten ten behoeve van resocialisatie}

In hoofdstuk 2 werden tevens de belangrijkste instrumenten beschreven die in het Nederlandse gevangeniswezen ter realisering van het resocialisatiedoel worden gehanteerd. Deze beschrijving aan de hand van wetenschappelijke bronnen, rapporten en nota's werd in empirische zin aangevuld met een beschrijving in hoofdstuk 5 van het concrete aanbod van activiteiten in de drie onderzochte inrichtingen. 
De onderwijsactiviteiten, de kunstzinnige vorming, de hulpverlenings-contacten en de arbeid werden in hoofdstuk 2 als belangrijkste instrumenten in meer uitgebreide zin beschreven naar hun inhoud en naar hun organisatorische en juridische context. Tevens werd ingegaan op het karakter van maatschappelijke integratieprogramma's en het recentelijk ingevoerde penitentiaire programma. Van beide typen programma kan worden gezegd dat zij als instrument afwijken van de manier waarop resocialiserende voorzieningen sinds jaar en dag in Nederlandse worden aangeboden. Met name bij de maatschappelijke integratie programma's heeft de interventie qua opzet, selecticcriteria en begeleiding een veel doelgerichter en meer systematisch karakter. De methode van individuele trajectbegeleiding waarbij gedetineerden vanuit de inrichting naar een betaalde arbeidsplaats of bepaalde vormen van extramurale zorg voorzieningen worden toegeleid en de multi-disciplinaire aanpak die hierbij tevens wordt gehanteerd, betekenen een verbetering ten opzichte van voorgaande decennia.

Deze maatschappelijke integratie-programma's liggen echter buiten het bereik van het merendeel van de gedetineerden.

Ten tijde van de afname van de enquête uit deze studie verkeerden de maatschappelijke integratie-programma's in een beginfase. Tijdens deze periode werd ook in een van de onderzochte inrichtingen een begin gemaakt met de opzet van cen maatschappelijk integratieprogramma. De gedetineerden die in deze studie werden ondervraagd maakten derhalve (nog) geen gebruik van deze bijzondere regimaire voorzieningen op het gebied van maatschappelijke integratie. Het aanbod van educatieve activiteiten en hulpverlening verliep derhalve voor de ondervraagde respondenten op een wijze zoals die sinds jaar en dag in de Nederlandse inrichtingen gebruikelijk was.

De algemene conclusic uit deze beschrijvingen is dat het aanbod van de verschillende activiteiten en de begeleiding van de gedetineerden op een weinig doelgerichte manier plaatsvindt. De overkoepelende doelstellingen die in de verschillende beleidsnota's zijn geformuleerd voor de activiteiten zijn zeer divers, breed en weinig operationeel geformuleerd. Kijkt men vervolgens op het niveau van de inrichting dan zien we dat het aanbod van de activiteiten weliswar volgens bepaalde programma-beschrijvingen of leerplannen verloopt, echter dit lijkt voor wat betreft de concrete begeleiding van gedetineerden niet steeds te resulteren in een planmatige aanpak over een langere periode. De begeleiding op het gebied van onderwijs en hulpverlening wordt voor het merendeel van de deelnemers eerder gekenmerkt door een ad-hoc karakter dan door planmatigheid.

Er wordt in het penitentiair onderwijs wel gewerkt met leerplannen en met een bepaald, daarop gebaseerd onderwijsprogramma, echter aan de concrete begeleiding van de gedetineerden ligt over het algemeen geen begeleidingsplan ten grondslag dat zich over een wat langere periode uitstrekt.

$\mathrm{Bij}$ het onderwijs is er een kleine minderheid die in een bepaald vak cen diploma heeft behaald, maar veelal onduidelijk blijft de bijdrage van dit resultaat aan de maatschappelijke integratie van de gedetineerde.

Voor een deel is het weinig doelgerichte karakter inherent aan de detentie-situatic, het einde van de detentie is vaak nog lang niet in zicht en het leggen van een directe relatie tussen de activiteiten tijdens detentie en het leven na detentie is daarom een aspect dat niet veel aandacht krijgt. Voorts kunnen acute problemen als direct gevolg van de detentie, de boventoon voeren.

Niettemin is het van belang reeds in een zo vroeg mogelijk stadium van de detentie de voorbereiding van de terugkeer bij voorbeeld in de vorm van een detentieplan expliciet aan de orde te stellen. Een detentieplan kan hierbij als een belangrijk houvast of structurerend 
instrument fungeren waarmee de activiteiten expliciet in verband worden gebracht met het einddoel.

Wat dus feitelijk tijdens de uitvoering van de activiteiten veelal ontbreekt, is een samenhangend eenduidig kader waarin wordt aangegeven op welke wijze de verschillende activiteiten zoals onderwijs, hulpverlening, kunstzinnige vorming en arbeid worden verondersteld bij te dragen aan een proces van zelfherstel. Die bijdrage blijft veelal onuitgesproken. De impliciete basisfilosofie lijkt nog steeds sterk te zijn gebaseerd op de gedachte dat een aanbod zonder meer cen gunstig effect heeft op een proces van zelfherstel. De mate van integriteit van de interventies of activiteiten (dat wil zeggen dat de interventie wordt uitgevoerd zoals bedoeld in theorie en ontwerp) kan men derhalve als zwak omschrijven. Dit geldt a fortiori voor resocialiserende voorzieningen zoals onderwijs en hulpverlening die aan gedetineerden in een standaardregime worden aangeboden. In de geschreven commentaren uit de enquête voor de gedetineerden wordt, zij het in andere bewoordingen, door een aantal respondenten aan dit probleem van de geringe doelgerichtheid en onvoldoende mate van programma-integriteit gerefereerd.

Sommige respondenten onder het personeel en onder de gedetineerden benadrukken in het $\mathrm{kwalitatieve}$ onderzoeksmateriaal dat er nauwelijks sprake is van een adequate voorbereiding op de terugkeer in de samenleving. Voorts wordt het ontbreken van adequate vervolgzorg als een belangrijke oorzaak gezien voor de terugval in criminaliteit.

Uit de jaarverslagen, nota's en rapporten blijkt dal de programma-integriteit in negatieve zin wordt beïnvloed door problemen van organisatorische aard. Randvoorwaardelijke aspecten die in onvoldoende mate zijn ingevuld kunnen de implementatie van de nagestreefde doelstellingen danig hinderen. In de drie onderzochte inrichtingen bleek ook uit de oriënterende gesprekken met de medewerkers van de onderwijsafdeling, penitentiair reclasseringswerkers en PIW-ers dat de invulling van de randvoorwaarden op een aantal punten niet adequaat is. De organisatorische problemen die werden genoemd zijn aanzienlijk: de nieuwe roosters als gevolg van Werkzame Detentic die resulteren in minder tijd voor de activiteiten, een verminderde bereikbaarheid van de gedetineerden voor de hulpverleners, geen onderwijs meer tijdens arbeidstijd voor gedetineerden in een standaardregime, geen ruimte voor deskundigheidsbevordering van crea-PIWers, gelijktijdige planning van bezoek met de kunstzinnige activiteiten, een verhoogde werkdruk voor PIW-ers, de ervaring van een geringe ondersteuning vanuit de leiding, geen begeleiding door een professionele creadocent, gebrekkige of ontbrekende materialen etc.

Aan deze randvoorwaardelijke aspecten en de visies van gedetineerden en personeel hierop, wordt bij de bespreking van de overige onderzoeksresultaten in een van de volgende paragrafen verder aandacht besteed.

De derde onderzoeksvraag die voortvloeit uit het beschrijvende deel van de probleemstelling luidt:

Hoe denken gedetineerden en personeel over de resocialisatie-doelstelling?

Bij de beantwoording van deze vraag en de volgende onderzoeksvraag zal worden volstaan met de bespreking van de onderzoeksresultaten die betrekking hebben op de houdingen van gedetineerden. De resultaten met betrekking tot de houdingen van het personeel zullen elders in deze slotbeschouwing afzonderlijk worden besproken. 


\subsubsection{De opvattingen van gedetineerden over resocialisatie}

Naspeuringen in de onderzoeksliteratuur leveren, blijkens het verslag dat daarvan werd gedaan in hoofdstuk 3, weinig studies op waarin men op een systematische, empirische manier de opvattingen van gedetineerden ten aanzien van de resocialisatie-doelstelling onderzoekt. Men treft voornamelijk veronderstellingen aan, al dan niet gebaseerd op impressies.

Zo veronderstelt men in de nota Werkzame Detentie op grond van een peiling onder personeel in drie representatieve inrichtingen dat een meerderheid van de gedetineerden niet of nauwelijks bereid is iets van de detentie te maken.

De resultaten van het empirisch onderzoek, zoals beschreven in hoofdstuk 6, leveren waar het de opvattingen van gedetineerden ten aanzien van resocialisatie betreft, een complexer en meer genuanceerd beeld op dan wordt verondersteld op grond van de bovengenoemde peiling van de Dienst Justitiële Inrichtingen.

Een grote meerderheid van de gedetineerden denkt positief over de resocialisatie-doelstelling als zodanig. Gedetineerden vinden dat zij in beginsel een nieuwe kans moeten krijgen op een beter leven na detentie. Blijkbaar beschouwen zij resocialisatie als een streven dat hen in humaan en emancipatoir opzicht min of meer toekomt. Het bieden van zoveel mogelijk hulp en steun wordt door hen beschouwd als een belangrijke voorwaarde voor een beter leven na detentie. Elke vorm van hulp en steun wordt in principe als welkom beschouwd. Gedetineerden schrijven het feit dat velen van hen na detentie weer in hun oude fouten vervallen, toe aan een gebrek aan hulp en steun. Het resocialisatiedoel is voor hen in essentie een doel dat hun (toekomstige) belangen dient. Deze houding weerspiegelt in zekere zin het negatieve beeld dat gedetineerden van hun eigen positie hebben als uitgesloten, achtergesteld en hulpbehoevend.

Gedetineerden zijn in meerderheid overtuigd van het belang van het resocialisatiedoel als zodanig, maar ten aanzien van resocialisatie, opgevat als de mogelijkheden om tijdens de detentie aan het zelfherstel te werken is de meerderheid van de gedetineerden gematigd negatief. Men is kritisch over de omstandigheden waaronder men het zelfherstel dient te bewerkstelligen en men vindt de detentie eigenlijk geen goed moment om aan de toekomst te werken. Dit betekent geenszins dat de toekomst geen belangrijk onderwerp in het leven van de meeste gedetineerden is, noch dat men verdere pogingen om tijdens de detentie aan een betere toekomst te werken als zinloos beschouwt. Een meerderheid acht dergelijke pogingen voor zichzelf als wel degelijk zinvol.

Een kleine minderheid van ongeveer eenvijfde deel beschouwt resocialisatie in de gevangenis als betrekkelijk zinloos en legt een uitgesproken negatieve houding aan de dag ten aanzien van de gevangenis als resocialiserend instituut.

Een substantiële minderheid van ruim eenderde deel van de respondenten is niet van plan de moed te laten zakken en voelt zich door de detentie-omstandigheden niet gehinderd in zijn pogingen tot zelfherstel. Deze groep gedetineerden is minder kritisch over de detentieomstandigheden en toont een grotere mate van bereidheid om te werken aan de toekomst. Deze groep vertoont overeenkomsten met de categorie gedetineerden die Irwin (1980) aanduidt met het begrip 'gleaners' .

Werken aan de toekomst tijdens een detentie vinden de meeste gedetineerden moeilijk doch niet zinloos. Blijkbaar beschouwen zij de resocialisatie in de gevangenis niet als een volstrekt hopeloze of een bij voorbaat vruchtenloze onderneming.

De constatering in de beleidsnota Werkzame Detentie dat een meerderheid niet of nauwelijks bereid is iets te maken van de detentie kan men op grond van de onderzoeksresultaten als volgt bijstellen. 
Een belangrijk bezwaar tegen deze, in de nota Werkzame Detentic geuite veronderstelling, betreft de suggestie dat de meerderheid van de gedetineerden ook afwijzend zou statu tegenover de resocialisatie-gedachte als zodanig.

Dit onderzoek laat zien, dat men geenszins negatief denkt over de resocialisatie-doelstelling als zodanig. noch dat een toekomstig leven zonder criminaliteit een onderwerp is dat de meerderheid van de gedetineerden niet bezighoudt noch dat men pogingen tot zellherstel zonder meer als nutteloos verwerpt. Gedetineerden zijn in meerderheid echter wel kritisch of gematigd negatief ten aanzien van de mogelijkheden voor zelfherstel tijdens detentie. Die negatieve houding is bovendien niet van enige realiteitszin ontbloot. De beperkingen zijn voor een deel inherent ain de detentiesituatie.

De discrepantie tussen wat Cloward (1969) noemt "aspirations for rehabilitation and expectations of achievement" of wat Tulkens (1988) noemt op "zelfherstel gerichte bedoelingen en de feitelijke mogelijkheden om deze te realiseren" lijkt tot op zekere hoogte in de natuur van de penitentiaire inrichting besloten te liggen.

Tevens dient men zich te realiseren dat werken alan een toekomstig maatschappelijk perspectief in een situatie waarin de maatschappelijke realiteit afwezig is, vaak een tamelijk abstract en ver verwijderd doel blijft.

De vierde onderzoeksvraag die behoort tot het beschrijvende deel van de probleemstelling luidt:

Op welke wije zijn gedetineerden en (personeel) betrokken bij de activiteiten gericht op de voorbereiding van de terugkeer in de samenleving?

\subsubsection{De deelname van gedetineerden aan de activiteiten}

De bevindingen ten aanzien van de opvattingen van gedetineerden ten aanzien van resocialisatie, zo bleek in hoofdstuk 6, worden in zekere zin weerspiegeld in de resultaten met betrekking tot de participatic van gedetineerden in de activiteiten die specifiek zijn bedoeld om de terugkeer in de samenleving voor te bereiden.

Activiteiten als onderwijs en kunstzinnige vorming worden in meerdere of mindere mate bezocht door bijna de helft van de gedetineerden die werden ondervraagd. Iets meer dan een kwart van de gedetineerden bezoekt deze activiteiten vaak of heel vaak. Bij de hulpverleningsactiviteiten ligt de contact- frequentie iets hoger, omdat met name de dienstverlening door het BSD veelal praktische zaken betreft die door veel gedetineerden als zeer belangrijk worden ervaren (verlof, strafonderbreking, overplaatsing e.d.). Ruin driekwart van de gedetineerden meldt een of meerdere contacten met medewerkers van het BSD, PRW, Geestelijke Verzorging en psycholoog/psychiater gedurende het afgelopen half jaar. Zeer hoge deelname-cijfers worden gevonden bij de sportbeoefening en het bibliotheekbezoek.

Een vergelijking van de deelname aan de activiteiten met gegevens van onderzoek uit de jaren tachtig (Grapendaal et al., 1985) levert als belangrijkste conclusie op dat de participatiegraad van gedetineerden uit het onderhavige onderzoek van een vergelijkbaar niveau is of, bij sommige activiteiten, hoger is dan in de jaren tachtig. De regelmatig, in de eerste helft van de jaren negentig, geuite twijfel aan de geschiktheid en motivatie van de huidige gedetineerdenpopulatie voor het activiteitenaanbod zoals gebaseerd op het beleid van de jaren tachtig, heeft derhalve geen grond in het gevonden patroon van deelname aan de activiteiten.

De vijfde onderzoeksvraag luidt:

Op welke wijze beleven gedetineerden (en personeel) de verschillende activiteiten gericht op de voorbereiding van de terugkeer in de samenleving? 


\subsubsection{De beleving van de activiteiten}

De veelvuldig geuite veronderstelling dat gedetineerden als resocialiserend bedoelde activiteiten in een penitentiaire setting voornamelijk gebruiken om de spanningen en ongemakken van een depriverende en vernederende detentiesituatie te verminderen, is een veronderstelling die blijkens de onderzoeksliteratuur nauwelijks in empirische zin is onderzocht.

De enkele studies die voor wat de beleving van de verschillende regiemsactiviteiten betreft wel empirische evidentie verschaffen, nuanceren deze veronderstelling. Ook de resultaten van dit onderzoek zoals gepresenteerd in hoofdstuk 6 geven aanleiding tot bijstelling van de veronderstelling dat de beleving van de activiteiten voornamelijk in het teken staat van het reduceren van de ongemakken van de detentie.

Het karakter van de beleving van activiteiten als onderwijs, kunstzinnige vorming en hulpverlening blijkt het basale niveau van louter stress-reductie of vermijdingsgedrag ('avoidance posture') te ontstijgen.

Behoeften van een hogere orde zoals die aan zelfverwerkelijking, zelfexpressie, zelfbevestiging, zelfcontrole, en cognitieve ontwikkeling, behoeften kortom waarbij doeleinden als persoonlijke groei en verandering van levensstijl voorop staan, spelen voor gedetineerden eveneens een belangrijke rol. De resultaten laten zien dat de beleving van met name de ontwikkelingsactiviteiten als onderwijs, hulpverlening en kunstzinnige vorming een veel heterogener karakter heeft dan totnogtoe werd verondersteld. Vermijdingsgedrag of het verminderen van de ongemakken van de detentie blijkt op grond van het onderzoek slechts één van de motieven waardoor de beleving van de activiteiten wordt gekleurd. Bij sommige activiteiten zoals het onderwijs blijkt vermijdingsgedrag slechts voor een kleine minderheid van de gedetineerden een rol te spelen. Bij de kunstzinnige vorming spelen detentie-situatie gebonden motieven zoals het niet 'op cel hoeven zitten in de beleving van bijna de helft van de respondenten een rol, maar dit betekent niet dat men de activiteiten voomamelijk beleeft als een middel on de tijd door te komen. De functie die deze activiteit voor de persoonlijke ontwikkeling kan hebben, wordt evenzeer gewaardeerd door een meerderheid van de deelnemers.

Kunstzinnige vorming is voor de meeste deelnemers geen vrijblijvende activiteit die men louter gebruikt on de ongemakken van de detentie te verzachten.

De beleving van de hulpverleningscontacten blijkt sterker in het teken te staan van de directe problemen als gevolg van de detentie-situatie dan van de behoefte aan persoonlijke groei en verandering in de toekomstige levenssituatie. De resultaten duiden erop dat men eigenlijk niet toekomt aan een echte hulpvraag waarbij de psychosociale problematiek op een meer fundamentele wijze aan de orde komt. De aard van de hulpverleningscontacten beperkt zich vooral tot de directe gevolgen van de detentie-situatie. Volgens sommige auteurs hangt een en ander samen met een inkapseling van de hulpverleningscontacten in het 'orde- en rustprincipe' (Melk,1985,1993), ook wel door deze auteur aangeduid als de 'ritssluiting-problematiek'. Melk behandelt het orde- en rustprincipe als een kenmerk op het niveau van de organisatie en wel als een aspect van de gevangenisstructuur. Vervolgens hanteert hij het 'orde-en rust' principe als cen factor die houdingen en gedrag op het niveau van het individu op een eenzijdige manier, (vanuit het perspectief van de organisatie) determineert. De houding van gedetineerden en personeel ten aanzien van de hulpverleningscontacten komt als gevolg van de grote nadruk in het gevangenissysteem op het handhaven van orde en rust, geheel in het teken te staan van een beperkte hulpvraag.

De resultaten van dit onderzoek laten echter zien dat de beleving van de hulpverleningscontacten zowel in het teken staat van de deprivatie van de detentiesituatie als van 
aspecten met betrekking tot persoonlijke groei en de toekomstige levenssituatie, zij het dat de detentie-omstandigheden iets meer gewicht in de schaal leggen.

Deze grotere rol van de detentiesituatie in de beleving van de hulpverleningscontacten lijkt bovendien niet louter het resultaat van een inkapseling in het orde-en rustprincipe.

Een opvallend aspect van de resultaten met betrekking tot de beleving van de activiteiten die specifiek bedoeld zijn als voorzieningen ter voorbereiding van de terugkeer in de samenleving vormt de houding ten aanzien van de mogelijke effecten van de activiteiten op de toekomstige levens- en werksituatie. Over deze effecten is men over het algemeen lang niet zo positief en uitgesproken als over de aspecten die te maken hebben met de persoonlijke groei. De geringe mate van programma-integriteit en doelgerichtheid van de activiteiten speelt hierbij mogelijk een rol. Bovendien is het toekomstige nut van de activiteiten voor veel gedetineerden een aspect dat bij uitstek in een detentiesituatie nogal ver weg ligt en betrekkelijk vaag blijft.

De houding van de gedetineerden ten opzichte van de arbeid is ronduit negatief te noemen. Een meerderheid vindt de arbeid eentonig en heeft er geen plezier in. Bijna de helft vindt niet dat men bij de arbeid nuttige dingen leert en driekwart van de gedetineerden denkt niet door de arbeid makkelijker werk te vinden. Deze gegevens zijn, gelet op de uitgangspunten van de nota Werkzame Detentie niet bepaald bemoedigend te noemen. De nota koestert zo bleek eerder in hoofdstuk 2 bepaalde verwachtingen over de resocialiserende werking van de arbeid. Men verwacht een gunstig effect van het dagelijks verrichten van werk op de verdere levensloop.

Palmer (1994) constateert in een overzicht van de effectiviteit (in termen van vermindering van recidive) van verschillende typen interventies bij delinquenten dat training van arbeidsvaardigheden overwegend effectief is als zij deel uit maakt van een bredere, multi-modale aanpak. Van belang voor de effectiviteit is blijkens Palmer's studie een interventie waarbij een bepaalde theorie en ontwerp worden gehanteerd die vervolgens op een adequate manier worden geïmplementeerd. Het is duidelijk dat de arbeid, zoals nu aan het merendeel van de gedetineerden aangeboden, niet aan dergelijke voorwaarden voldoet. Ook bij de arbeid ziet men de gedachte of beter gezegd, de hoop dat van een aanbod van arbeid zonder meer een resocialiserende werking uitgaat.

De bevindingen met betrekking tot de beleving van activiteiten als onderwijs en kunstzinnige vorming laten zien dat zij vooral een gunstig effect hebben op psychische eigenschappen als zelfvertrouwen, het herwinnen van zelfrespect en een gevoel van eigenwaarde. Gedetineerden zijn trots op hun prestaties en ontdekken dat zij meer capaciteiten in huis hebben dan zij aanvankelijk dachten. Voorts krijgt men meer plezier in studie en vorming. Aansluiten op de capaciteiten en uitgaan van wat gedetineerden wel kunnen presteren en waar ze goed in zijn is volgens Schuyt (1998) een factor die van belang is voor het succes van interventies. Schuyt constateert dat bij de diagnose ten behoeve van het reïntegratieproces meestal wordt gelet op tekortkomingen en niet op capaciteiten. "De vraag, aldus Schuyt (p. 241), of (...) het glas half vol is of half leeg, wordt systematisch beantwoord in het nadeel van de cliënten." Activiteiten als onderwijs en kunstzinnige vorming blijken deze tendens juist te doorbreken en bewijzen in dit opzicht tevens hun nuttige en ondersteunende functie voor het reintegratie-proces.

De zesde onderzoeksvraag van beschrijvende aard luidt:

In welke mate is er sprake van verschillen tussen houdingen van gedetineerden ten aanzien van resocialisatie als een onderscheid word gemaakt naar inrichting, regime en afdeling? 


\subsubsection{Verschillen in houding tussen inrichtingen en afdelingen}

De beschrijving van de houdingen van gedetineerden ten aanzien van resocialisatie per inrichting, en afdeling gaf een eerste indruk van de mogelijke betekenis van omgevingsgebonden factoren op een hoger abstractieniveau zoals het inrichtings- of afdelingsklimaat, organisationele, randvoorwaardelijke, regimaire aspecten en de kenmerken van de verschillende deelpopulaties.

De vergelijking tussen de inrichtingen levert als belangrijk resultaat op dat de waargenomen (significante) verschillen tussen inrichtingen en afdelingen in houdingen ten aanzien van resocialisatie, vooral lijken samen te hangen met de kenmerken van de gedetineerden en met het afdelingsklimaat en de invulling van randvoorwaarden van de activiteiten. De invloed van een regime van beperkte gemeenschap lijkt met name bij de manier waarop de HVBgedetineerden en kort-gestraften de kunstzinnige vorming beleven, een belangrijke rol te spelen. Omgevingsgebonden factoren blijken dus van invloed op de houdingen ten aanzien van resocialisatie.

De beoordeling van het regime door gedetineerden die in de drie onderzochte inrichtingen onder vergelijkbare omstandigheden (i.c. een HVB-afdeling) verbleven, bleek verschillen op te leveren, maar deze waren niet significant. Het meest positief over het regime waren gedetineerden in een huis van bewaring waar men het standaardregime nog niet had ingevoerd. Het verschil in de beoordeling van het regime bleek wel significant bij vergelijking van de gemiddelde scores per inrichting. Dit verschil lijkt vooral samen te hangen met de kenmerken van gedetineerden en niet zozeer met het inrichtingsklimaat.

De volgende vraagstelling voor het verklarende deel van het onderzoek luidt:

Welke persoons- en omgevingsgebonden factoren zijn, eventueel in onderlinge samenhang, van invloed op de houdingen van gedetineerden ten aanzien van de voorbereiding van de terugkeer in de samenleving?

De manier waarop gedetineerden over de resocialisatie-doelstelling als zodanig en de mogelijkheden voor resocialisatie tijdens de detentie denken, blijkt binnen het geheel van onderling gerelateerde factoren als een belangrijk vertrekpunt of basis te fungeren. De aard van de opvattingen heeft een aanzienlijke voorspellende waarde voor de deelname aan en beleving van de activiteiten.

\subsubsection{Determinanten van de opvattingen over resocialisatie}

Het belang dat men toekent aan de resocialisatie-doelstelling als zodanig is afhankelijk van pre-detentie factoren als opleidingsniveau en toekomstverwachtingen. Hoe lager het opleidingsniveau des te groter het belang dat men toekent aan de resocialisatiedoelstelling als zodanig. Dit verband ondersteunt de verklaring die werd gegeven van de overwegend positieve opvattingen van gedetineerden over het belang van resocialisatie. Die opvattingen vormen in zekere zin een afspiegeling van het beeld dat gedetineerden hebben van hun eigen positie als hulpbehoevend en achtergesteld.

De mogelijkheden die men voor het zelfherstel waarneemt, worden eveneens direct beinvloed door een pre-detentiefactor als toekomstverwachtingen. Echter, het sterkst wordt de mate waarin men nog mogelijkheden ziet om aan het zelfherstel tijdens detentie te werken, beïnvloed door de beleving van het regime Hoe meer men het regime ervaart als restrictief en ordegericht des te minder mogelijkheden voor zelfherstel neemt men waar. Hoe meer men het regime op een gedetineerdengerichte, positieve manier beleeft des te meer mogelijkheden voor zelfherstel neemt men waar. De beleving van het regime is niet alleen maar het resultaat van eigenschappen van de objectieve omgeving in de zin van het beleid, inrichtingsideologie 
en inrichtingsklimaat. Het oordeel over het regime is tevens afhankelijk van persoonsgebonden factoren die men van buitenaf in de inrichting meeneemt, zoals toekomstverwachtingen en indirect ook het opleidingsniveau. Er lijkt dus in een bepaalde mate sprake van een bepaalde positieve of negatieve instelling waarmee gedetineerden de inrichting binnenkomen. Die houding is medebepalend voor de manier walarop men zich opstelt tegenover het regime en indirect daarmee ook voor de bereidheid om aan de toekomst te werken.

\subsubsection{Determinanten van de deelname aan de activiteiten}

De mate waarin men nog mogelijkheden voor zelfherstel waarneemt, is voor de declname aan activiteiten die programmatisch gezien expliciet gerelateerd zijn aan de voorbereiding van de terugkeer in de samenleving (onderwijs, kunstzinnige vorming en hulpverlening), de meest bepalende dan wel de enige factor van belang. Aangezien de mate waarin men nog mogelijkheden ziet voor zeltherstel wordt beinvloed door pre-detentiefactoren en een omgevingsfactor als het regime, zijn de determinanten van de deelname aan de ontwikkelingsactiviteiten indirect van zowel persoons- als omgevingsgebonden aard. De deelname aan de sport en het bibliotheekbezoek worden uitsluitend bepaald door persoonsgebonden variabelen als opleiding, druggebruik en leeftijd.

De bevinding dat er vermoedelijk een groep gedetineerden is die op grond van persoonsgebonden factoren de inrichting binnenkomt met een meer coöperatieve en constructieve houding en mede op grond daarvan actiever gebruik maakt van de voorzieningen gericht op resocialisatie duidt op de alanwezigheid van een selectieproces. Er is een patroon dat erop duidt dat juist de meer kansrijke en hoger opgeleide gedetineerden met een redelijk optimistische kijk op de toekomst intensiever gebruik maken van die voorzieningen. De minder kansrijke lager opgeleide gedetineerden die overigens wel van het belang van resocialisatie overtuigd zijn, stellen zich minder actief op. Hun instelling is minder coöperatief en positief, zij hebben sterker de neiging om zich af te zetten tegen het regime en bovendien zien zij vanwege een somberder kijk op de toekomst minder mogelijkheden voor zelfherstel. Het verschijnsel dat vooral de 'goede'gevallen gebruik maken van de programma's gericht op reïntegratie staat bekend onder de naam 'creaming', of ook wel het afromingsverschijnsel (Schuyt, 1998, p.237). In de gevangenis lijkt dit verschijnsel of patroon spontaan, dat wil zeggen zonder een nadrukkelijke invloed van het handelen van bewaarders of leden van de professionele staf, op te treden.

\subsubsection{De determinanten van de beleving}

$\mathrm{Bij}$ de beleving van de activiteiten is er voor wat betreft de determinanten sprake van een invloed van de opvattingen ten aanzien van resocialisatie, persoonsgebonden variabelen en omgevingsgebonden variabelen als het regime en de programma-integriteit (ook wel de randvoorwaardelijke aspecten genoemd).

De invloed van de programma-integriteit of de kwaliteit van de implementatie komt het sterkst naar voren bij de belevingsaspecten die gericht zijn op persoonlijke groei en de (toekomstige) levenssituatie. Belangrijkste factor bij de beleving van de onderwijsactiviteiten is de kwaliteit van de geboden ondersteuning en begeleiding. Faciliteiten in materiële zin beïnvloeden naast factoren als het belang dat men toekent aan resocialisatie en het arbeidsverleden het sterkst de beleving van die aspecten van de kunstzinnige vorming die gerelateerd zijn aan de persoonlijke groei. De beleving van de hulpverleningsactiviteiten wordt waar het aan persoonlijke groei en detentie-situatie gerelateerde aspecten betreft eveneens beïnvloed door de ervaren ondersteuning en begeleiding. Naast deze randvoor- 
watardelijke aspecten zijn de opvattingen ten aanzien van resocialisatie en een omgevingsvariabele als het regime de meest invloedrijke factoren.

Binnen het geheel van de onderzochte determinanten van de houdingen van gedetineerden ten aanzien van doelstellingen en middelen van resocialisatie voeren de variabelen die aan de ongeving, respectievelijk de organisatie gebonden zijn, de boventoon.

De persoonsgebonden variabelen laten een minder geprononceerde, meer indirecte samenhang zien.

\subsubsection{De rol van prisonisatie}

Houdingen ten aanzien van resocialisatie worden negatiever naarmate de tijd dat men in detentie verblijft, verstrijkt. De negatieve invloed van een prisonisatie-proces, in casu, van een sterkere binding van de gedetineerden met een oppositionele gedetineerdencultuur op de houdingen ten aanzien van resocialisatie is in het algemeen het sterkst tijdens de middenfase van de detentie. De begin- en eindfase van de detentie worden gekenmerkt door meer positieve houdingen en bevestigen daarmee de bevindingen uit de onderzoeksliteratuur. De resultaten van dit onderzoek laten verder zien dat het prisonisatie-proces niet voor alle langgestrafte gedetineerden een zelfde uniforme, negatieve invloed op de houdingen uitoefent. Dit onderzoek toont dat de invloed van een oppositionele gedetineerdencultuur een gedifferentieerd karakter draagt. Er is immers ook een groep langgestraften met weliswaar meer negatieve opvattingen ten aanzien van resocialisatie, maar deze laat zich daardoor niet hinderen als het gaat om een zeer frequente deelname aan en zeer positieve beleving van activiteiten als kunstzinnige vorming en onderwijs. Zij lijken zich door een meer positieve houding ten aanzien van de activiteiten te onttrekken aan de invloed van de gedetineerdencultuur en de activiteiten vooral te gebruiken als een 'niche 'waarin men de langdurige detentie op een meer zinvolle, actieve en constructieve wijze het hoofd tracht te bieden.

\subsubsection{De rol van stress en stresshantering}

Ten aanzien van stress en (stress)hanteringgedrag als een factor waarvan het effect overigens niet in expliciete zin werd getoetst in dit onderzoek, kan men in tentatieve en exploratieve zin concluderen dat een aantal gevonden verbanden duiden op een mogelijk effect van deze factoren.

Zo blijkt onder gedetineerden die in de beginfase van de detentie verkeren, de waardering voor de belevingsaspecten van de kunstzinnige vorming die in het teken staan van vermijdingsgedrag (of vluchtgedrag) het hoogst te zijn. En vermijdings- of vluchtgedrag kan men beschouwen als een vorm van hanteringsgedrag. De rol van stress wordt hier des te aannemelijker als men zich realiseert dat de beginfase in het algemeen geldt als een moeilijke situatie voor gedetineerden. Bovendien gaat deze situatie ook nog eens gepaard gaat met een plaatsing onder de tamelijk restrictieve omstandigheden van een HVB-regime. Gedetineerden in een dergelijk regime brengen sinds de invoering van een standaardregime in 1995 aanmerkelijk meer uren door op hun cel.

De hoge waardering van de belevingsaspecten die gerelateerd zijn aan de depriverende eigenschappen van de detentie vertoont ook een duidelijk samenhang met een negatieve beoordeling van het regime. De invloed van het stressvolle karakter van de zgn. 'shock of incarceration' aan het begin van een detentie lijkt hier plausibel.

De wijze waarop men stress in de detentiesituatie hanteert kan op grond van bepaalde situationele factoren en predisposities van persoonlijke aard verschillen vertonen. Naast vermijdingsgedrag kan een reactie op stress de vorm aannemen van en meer probleemgerichte strategie of een strategie in de vorm van heroriëntatie. Het is, blijkens de 
onderzoeksliteratuur heel goed mogelijk dat men gebruik maakt van meerdere hanteringstrategieën tegelijk om bepaalde problemen het hoofd te bieden.

Een hoog stress-level tijdens de beginfase van de detentie hoeft niet alleen maar te resulteren in vluchtgedrag. Een reactie in de vorm van een grotere mate van ontvankelijkheid voor een meer probleemgerichte hanteringsstrategie is eveneens voorstelbaar. Als gevolg daarvan kan er sprake zijn van een (tijdelijk) grotere ontvankelijkheid voor, op zelfherstel gerichte bedoelingen. De bevinding dat de opvattingen ten aanzien van resocialisatie van gedetineerden in de beginfase van de detentie gemiddeld veel positiever zijn dan die van gedetineerden in de middenfase kan, zo werd betoogd, wellicht tevens worden verklaard vanuit het aanmerkelijk meer stressvolle karakter van de beginfase van de detentie. Deze stressvolle situatie impliceert een confrontatie met de eigen grenzen en mogelijkheden. En vermoedelijk leidt dit tot een tijdelijk, sterkere drang om, orde, zekerheid en houvast te scheppen in een chaotische levenssituatie.

Heroriëntatie als hanteringgedrag van een stressvolle, vernederende detentie werd in verband gebracht met een sterkere oriëntatie op een negatieve gedetineerdencultuur tijdens de middenfase van de detentie. Heroriëntatie is gericht op het handhaven van een positief zelfbeeld door middel van diverse cognitieve strategieën, zoals het zoeken van andere vergelijkingspersonen of vergelijkingsdimensies en het vergroten van de afstand tot bestaande vergelijkingspersonen. Vertaald naar de detentiesituatie betekent heroriëntatie dat men zijn status of positief zelfbeeld niet meer handhaaft door een oriëntatie op een officiële inrichtingscultuur met conventionele normen en waarden, maar door een oriëntatie op een (deviante) oppositionele gedetineerdencultuur.

In dit opzicht heeft stress via heroriëntatie op een gedetineerdencultuur vermoedelijk een indirecte (negatieve) invloed op de houdingen, in casu, de opvattingen ten aanzien van resocialisatie. Voor langgestraften is heroriëntatie en vluchtgedrag één van de mogelijke opties om de deprivaties en stress als gevolg van een detentie te hanteren. De specifieke problemen van een langdurige detentie worden ook bestreden door een actieve en meer probleemgerichte houding die gepaard gaat met een intensief gebruik van de activiteiten.

Samengevat komen de bevindingen met betrekking tot het verklarend deel van de probleemstelling op het volgende neer.

Gedetineerden die de inrichting binnenkomen zijn reeds op grond van pre-detentiefactoren in meerdere of mindere mate gemotiveerd voor op resocialisatie of zelfherstel gerichte bedoelingen. Vervolgens hebben ook de omstandigheden van de beginfase van de detentie met als belangrijk aspect 'de shock of incarceration', vermoedelijk voor een substantieel gedeelte van de gedetineerden een (tijdelijk) positief effect op de houdingen en het gedrag inzake resocialisatie. Naarmate de tijd verstrijkt ebt dit effect van de beginperiode weg, het stress-niveau wordt lager, en is men eenmaal afgestraft, dan wordt een tendens waarneembaar van minder positieve houdingen ten aanzien van resocialisatie. De invloed van een negatieve, oppositionele gedetineerdencultuur doet zich hier gelden, zij het niet op een wijze die voor alle gedetineerden hetzelfde is. Er is sprake van een gedifferentieerd effect.

De houdingen worden bepaald door zowel factoren van persoonlijke als van omgevingsgebonden aard. De aard van de houdingen dient men te beschouwen als het product van een complexe interactie tussen beide typen factoren. De omgevingsgebonden factoren zoals het regime, het effect van een gedetineerdencultuur en de programma-integriteit zijn geen factoren die de houdingen van gedetineerden ten aanzien van resocialisatie volledig determineren. De veronderstelling dat een, als depriverend ervaren gevangenisomgeving het ontstaan van positieve houdingen van gedetineerden ten aanzien van resocialisatie verhindert en hooguit resulteert in een onrealistisch schijnoptimisme omtrent de toekomst, is wat al te 
eenzijdig. De gevangenis-omgeving heeft weliswaar een aanwijsbare negatieve invloed op de houdingen ten aanzien van resocialisatie die met het voortschrijden van de detentie sterker wordt, maar dit betekent niet dat de pogingen die gedetineerden ondernemen om iets aan hun positie te verbeteren van generlei waarde of betekenis zouden zijn.

De opvattingen ten aanzien van resocialisatie zijn aan het begin van de detentie positiever en lijken te berusten op een behoefte aan serieuze bezinning op en verandering van de levenssituatie. De beleving van de activiteiten als onderwijs, kunstzinnige vorming en in mindere mate de hulpverlening blijkt duidelijk in het teken te staan van een behoefte aan persoonlijke groei. Langgestrafte gedetineerden grijpen de activiteiten aan als een mogelijkheid on zin aan hun langdurig verblijf te geven. Er zijn kortom tal van positieve, substantiële effecten aanwijsbaar van voorzieningen gericht op resocialisatie.

De vraag die men in dit verband kan stellen is of en in welke mate het mogelijk is de houdingen van gedetineerden ten aanzien van resocialisatie tijdens een detentie te beïnloeden. De meeste gedetineerden zien het belang van resocialisatie in, echter de waargenomen mogelijkheden voor zelfherstel zijn cruciaal voor een actieve en ondernemende houding ten aanzien van resocialisatje. Die waargenomen mogelijkheden kan men vermoedelijk ten dele beïnvloeden door een accentuering van gedetineerdengerichte eigenschappen van het regime. En met een adequate invulling van de randvoorwaarden kan men vooral de beleving van de activiteiten in positieve zin beînvloeden. Via deze factoren waarvan een modererende invloed lijkt uit te gaan kan men bepaalde houdingen of de motivatie van gedetineerden versterken. Een dergelijk streven is echter aan bepaalde grenzen gebonden. Kansarme gedetineerden met een lage opleiding en een pessimistische kijk op de toekomst vertonen tevens een sterkere neiging zich af te zetten tegen het regime. Ondanks het feit dat zij het belang van resocialisatie en van hulp en steun met het oog op hun toekomst inzien, blijven zij steken in een betrekkelijk negatieve en passieve houding. $\mathrm{Zij}$ willen misschien wel, maar tegelijkertijd lijkt er sprake te zijn van een niet kunnen. Om deze groep tc activeren lijkt het gebruikmaken van de modererende invloed van het regime en de adequate invulling van de randvoorwaarden ontoereikend. Om de motivatie van deze groep te versterken zijn waarschijnlijk ingrijpender stimulansen in de vorm van speciale, intensieve programma's noodzakelijk. Helaas is het huidige beleid ten aanzien van deze passieve, 'moeilijker' groep gedetineerden juist op een versobering van de voorzieningen gericht. Dit onderzoek laat zien dat de houding van deze groep gedetineerden niet louter berust op onwil maar tcvens op onvermogen.

\subsection{Samenvatting en conclusies van het onderzoek onder het personeel}

In hoofdstuk 9 werden de resultaten gepresenteerd van het onderzoek naar de houdingen van het personeel in de drie onderzochte inrichtingen. Onderzocht werd hoe PIW-ers, leden van de professionele staf en van het management-team denken over de resocialisatie-opdracht en de verwezenlijking ervan op het niveau van de inrichting.

Uit het onderzoek kwam naar voren dat de respondenten onder de bewaarders in meerderheid de resocialisatie-gedachte ondersteunen, ondanks het feit dat men geen overwegend gunstige effecten van de inspanningen verwacht in termen van recidive-vermindering. Zij opteren derhalve voor een opvatting van resocialisatie in ruime zin waarbij de gepercipieerde waarde of zinvolheid van dit doel niet uitsluitend wordt gekoppeld aan het succes in termen van recidive. 
De ondervraagde leden van de professionele staf dat wil zeggen reclasseringswerkers, onderwijzers, crea-consulenten hanteren eveneens een opvatting van resocialisatic in ruime zin.

De response onder de leden van het management-team was te laag om ten aanzien van hun opvattingen in meer algemene zin uitspraken te doen.

Zowel PIW-ers als leden van de professionele staf onderkennen in meerderheid het gegeven dat de gevangenisomgeving een adequate voorbereiding van de terugkeer in de samenleving in de weg kan staan. Malar ook deze visie op de gevangenisomgeving vormt voor het personeel geen beletsel om pogingen tot zelfherstel toch zinvol en mogelijk te achten.

PIW-ers denken in meer algemene zin positief over activiteiten voor gedetineerden. Zij waarderen het gehele scala aan activiteiten als een instrument om de gevangenisstraf op een humane, constructieve en zinvolle manier ten uitvoer te leggen.

Aan de interventie binnen de penitentiaire setting koppelt men in meer impliciete zin een doel als het opgang brengen van een proces van zeltherstel en het ondersteunen van een proces van persoonlijke groei. Recidive-reductie speelt in hun visie geen zwaarwegende rol. Deze onderzoeksresultaten bevestigen de, in de onderzoeksliterattur geuite, maar nooit eerder in empirische zin getoetste veronderstellingen ontrent de vermeend ondergeschikte betekenis van recidive-reductie in de opvattingen van het gevangenispersoneel.

Het gevonden beeld met betrekking tot de opvattingen van de PIW-ers ten aanzien van resocialisatie weerspiegelt zich tevens in hun takopvattingen. Een gedetineerdengerichte taakopvatting speelt een duidelijke rol naast de meer ordegerichte aspecten van het werken met gedetineerden. Het is slechts een kleine minderheid die zich in de omgang met de gedetineerden hetzij uitgesproken ordegericht, hetzij gedetineerdengericht opstelt.

PIW-ers denken over het algemeen niet dat voorzieningen gericht op resocialisatie niet meer passen bij het karakter van de huidige gedetineerdenpopulatie die, naar wordt verondersteld, een verzwaring heeft ondergaan in het afgelopen decennium. Een meerderheid vindt niet dat het kansen bieden aan gedetineerden in het kader van resocialisatie een te softe benadering is voor de huidige gedetineerdenpopulatie. Men denkt positief over de motivatie van gedetineerden waar het de regimesactiviteiten betreft. Wel erkent men de negatieve invloed van een toegenomen drugsverslaving op de houdingen van gedetineerden.

De motieven die men aan gedetineerden voor deelname aan de kunstzinnige vorming toeschrijft stelt men nogal sterk in het teken van het tegengaan van de spanningen en ongemakken van de detentie-situatie. Men neemt tegelijkertijd een aantal gunstige effecten waar voor de persoonlijke en sociale ontwikkeling van gedetineerden en voor het inrichtingsklimaat.

De meest negatieve houdingen van PIW-ers en leden van de professionele staf hebben betrekking op de ervaren ondersteuning vanuit de leiding en de organisatic als geheel. Een meerderheid van de respondenten bleek hierover ontevreden. De resultaten duiden erop dat men bij de begeleiding van de activiteiten vooral problemen ervaart in randvoorwaardelijke en organisationele sfeer.

Het personeel dat in uitvoerende zin bezig is met de resocialisatie-opdracht heeft niet de indruk dat dit onderdeel van de detentie grote prioriteit heeft bij de leiding. De geringe respons onder de leden van het management-team vormt in dit opzicht tevens een indicatie. De reacties van één van de twee leden van het management-team die een ingevuld formulier retourneerden wijzen bovendien in de richting van een beheersmatige visie op de activiteiten als een middel dat vooral de aanpassing van de gedetineerden aan de detentiesituatie dient te bevorderen. 
Een interpretatic van deze randvoorwaardelijke problemen dient mede te worden gezocht in een organisatiestructuur die onvoldoende is afgestemd op de inhoud van het werk en niet alleen in de notie van een fundamentele onverenigbaarheid van de detentie-doelen.

De resultaten van de enquête onder het personeel dienen met het nodige voorbehoud te worden benaderd, het betreft een onderzoek onder een betrekkelijk klein aantal respondenten, waarvan de mate van representativiteit niet is vastgesteld. Met het generaliseren van de uitkomsten natr een grotere groep personeelsleden dient men derhalve voorzichtig te zijn.

\subsection{Wetenschappelijke relevantie van het gekozen theoretisch en methodologisch kader}

Een vraag die in deze paragraaf wordt beantwoord betreft de wetenschappelijke relevantie van het gekozen theoretisch en methodologisch kader.

In de inleiding werd het belang toegelicht van een meer procesevaluatieve benadering van de voorzieningen in de penitentiaire inrichting ten behoeve van resocialisatie. De resultaten van het onderzoek verschaffen nieuwe inzichten die zonder dit proces-evaluatieve perspectief niet verkregen hadden kunnen worden.

Het gekozen theoretisch perspectief van een integratie-model toegespitst in de vorm van een interactionistische benadering van houdingen ten aanzien van resocialisatie bleek een geschikt kader om een verklaring te bieden voor de aard en oorsprong van de houdingen ten aanzien van resocialisatie.

De aard en oorsprong van de houdingen bleek inderdaad het best te kunnen worden verklaard vanuit een integratiemodel van zowel persoons- als omgevingsgebonden variabelen. Beide typen variabelen bleken zowel onafhankelijk als in onderlinge samenhang de houdingen te beïnvloeden.

Kern van de interactionistische benadering is de veronderstelling dat de relatie tussen houdingen en gedrag van gedetineerden enerzijds en de (depriverende) detentie-omgeving en de persoonsgebonden variabelen anderzijds, geen uni-directionele deterministische relatie veronderstelt, maar een relatie impliceert waarin sprake is van een interpretatie van de omgeving die verschillen vertoont al naar gelang de eerdere ervaringen, verwachtingen en doelstellingen van het individu.

De gevonden relaties tussen houdingen en achtergrondvariabelen laten zien dat de houdingen ten aanzien van resocialisatie voor zover zij door de omgeving worden beïnvloed, inderdaad de functie hebben van een middel dat de aanpassing aan de detentiesituatie vergemakkelijkt. Het transactionele karakter van de interactie tussen het individu en de detentie-omgeving blijkı aanwezig. Echter de houdingen ten aanzien van resocialisatie staan, blijkens de onderzoeksresultaten, niet alleen maar in het teken van een aanpassingsreactie aan een depriverende en stressvolle omgeving. Persoonsgebonden determinanten blijken een direct of indirect effect te hebben op de houdingen ten aanzien van resocialisatie. De directe effecten zijn onafhankelijk van de omgeving. In dit opzicht levert dit onderzoek een aanvulling of nuancering op de benadering van andere onderzoekers (Toch, 1977) waarin de houdingen ten aanzien van resocialisatic voornamelijk als een aanpassingsreactie op de omgeving worden gezien. Met name bij een positieve beleving van de activiteiten in termen van persoonlijke groei ziet men dit (neven)-effect van de persoonsgebonden achtergrondvariabelen optreden.

Als een logische consequentie van de veronderstelling dat houdingen voor een deel ook in het teken staan van een aanpassingsreactie aan een (depriverende) detentieomgeving werden de begrippen stress en stresshantering om exploratieve redenen in het verklarend onder- 
zoeksmodel opgenomen. $\mathrm{Bij}$ de interpretatic van de onderzoeksresultaten bleek de aanwezigheid of rol van deze factoren zeer plausibel. Een belangrijk resultaat van het onderzoek is dat er goede redenen zijn om in vervolgonderzoek de rol van stress en stresshantering in meer expliciete zin te onderzoeken.

Tenslotte heeft dit onderzoek laten zien dat de bezwaren van een aantal onderzoekers tegen de gangbare benadering van prisonisatie-processen, gegrond zijn. Een alternatieve benadering waarbij men het begrip prisonisatie als een 'attitudinal factor' introduceert en deze vervolgens in combinatie met andere omgevings- en persoonsgebonden variabelen in verband brengt met specifieke vormen van gedrag blijkt inderdaad veel meer inzicht te geven in de verschillende reacties op de detentie. De belangrijkste bijdrage van het onderzoek aan het prisonisatieonderzoek is in dit opzicht als volgt te formuleren:

Aanpassingsreacties in termen van prisonisatic blijken veel minder uniform en meer gedifferentieerd juist door de houdingen ten aanzien van resocialisatie in verband te brengen met een combinatie van aan prisonisatie gerelateerde factoren en omgevings- en persoonsgebonden variabelen.

\subsection{Slotbeschouwing: mogelijkheden en beperkingen van resocialisatie}

In het inleidende hoofdstuk werd in het kader van de aanleiding en achtergrond van het onderzoek het resocialisatie-streven uit een drietal invalshoeken aan een beschouwing onderworpen. Er werd een onderscheid gemaakt in een ethisch normatieve, (penologisch) instrumentele en organisationele optiek. De relevantie van het onderzoek werd vervolgens vanuit deze optiek toegelicht. In deze slotbeschouwing wordt aan de hand van de onderzoeksresultaten nagegaan welke betekenis men in het huidige tijdsbestek aan de resocialisatie-gedachte kan toekennen. De gehanteerde driedeling in een ethisch-normatieve, instrumentele en organisationele optiek keert in dit slothoofdstuk als leidraad voor een slotbeschouwing en een reeks aanbevelingen weer terug.

\subsubsection{Resocialisatie als aspect van een humaan detentiebeleid}

De situatie waarin gedetineerden verkeren voordat $\mathrm{zij}$ in een gevangenis terechtkomen kenmerkt zich in veel gevallen reeds door een bepaalde mate van maatschappelijke uitsluiting. De factoren die bij deze uitsluiting behoren zijn langdurige werkloosheid, een lage of afgebroken opleiding, een verbrokkelde en onregelmatige beroepsloopbaan, onstabiele relaties en onvolledige gezinssituaties. Gevangenisstraf versterkt dit proces van uitsluiting nog eens extra. In het wettelijk resocialisatiebeginsel komt de gedachte tot uitdrukking dat dit proces van uitsluiting tijdens de detentie zoveel mogelijk dient te worden voorkomen. De gedachte is dat gedetineerden in beginsel deel blijven hebben aan de samenleving en dat zij tijdens die detentie niet van die samenleving mogen vervreemden. Bij een humane detentie horen ook kansen op een toekomstig maatschappelijk perspectief en volgens de interpretatie van Kelk (1993, (1), p.34), impliceert dit tevens een versterking van de autonomie van de gedetineerde. Het gaat in essentie, om wat Kelk (1993, (2), p.196) noemt, een strafrecht met een menselijk gezicht waarin aandacht is voor de individuele noden en behoeften en dat het individu nieuwe kansen geeft. Kelk noemt een dergelijk strafrecht van grote maatschappelijke betekenis.

Dit onderzoek laat zien dat er onder gedetineerden een reële behoefte aan sociaal perspectief is. Gedetineerden wijzen resocialisatie niet af, integendeel, zij zijn overtuigd van het belang van deze doelstelling. Tegelijkertijd laat dit onderzoek zien hoe moeilijk het is om in een detentiesituatie zicht te krijgen op een betere toekomst. $\mathrm{Zij}$ vinden op hun weg naar 
zelfherstel tal van hindernissen die hun oorsprong vinden in persoons-en omgevingsgebonden factoren. Ondanks die hindernissen zijn de inspanningen die zowel gedetineerden als gevangenispersoneel ten behoeve van een proces van zelfherstel niet zonder zin of betekenis. Gedetineerden blijken, zoals zij zelf aangeven daadwerkelijk vruchten te plukken van voorzieningen op het gebied van educatie en hulpverlening. Die vruchten hebben niet alleen maar betrekking op de behoefte de detentie zo gemakkelijk mogelijk door te komen. Vanujt het perspectief van de persoonlijke groei, het ontdekken van de eigen capaciteiten is er sprake van een duidelijk effect van de activiteiten. Activiteiten waarbij de persoonlijke ontwikkeling centraal staat vervullen voor een substantieel gedeelte van de gedetineerden een belangrijke functie. Zowel uit het kwantitatieve als het kwalitatieve materiaal blijkt dat activiteiten als onderwijs en kunstzinnige vorming de gedetineerden de mogelijkheid geven zichzelf te hervinden in een moeilijke detentiesituatie. Via resocialiserende activiteiten schept men in de gevangenisomgeving als het ware weer kansen en mogelijkheden voor zingeving aan het bestaan. Het is juist hier dat het menselijke humane gezicht van het strafrecht zich openbaart. Het onderzoeksmateriaal illustreert deze humanitaire werking van de resocialisatie-gedachte binnen de context van de gevangenis. Het toont aan dat alleen al om humane, ethische redenen het de moeite waard is en blijft om kansen en mogelijkheden te bieden aan gedetineerden. Maar zoals wij reeds in het inleidende hoofdstuk opmerkten, voor het strafrechtelijk systeem is het onmogelijk resocialisatie enkel en alleen in het teken te zetten van humane en rechtsbeschermende overwegingen. Aan de vraag wat het oplevert en wat men ervoor terugkrijgt in termen van een bijdrage aan een proces van zelfherstel kan men niet voorbij gaan. De instrumentele en organisationele aspecten behoeven evenzeer aandacht. In de volgende paragrafen zullen de onderzoeksresultaten worden belicht vanuit deze instrumentele en organisationele aspecten van het resocialisatie-streven.

\subsubsection{Integratie van de intramurale en extramurale zorg}

Een van de inzichten die het effectiviteitonderzoek van resocialisatie in de afgelopen twintig jaar heeft opgeleverd is dat het teweegbrengen van blijvende gedragsveranderingen bij delinquenten veel minder eenvoudig is dan men in de bloeiperiode van het resocialisatieideaal veronderstelde. Tal van factoren zijn van invloed op het succes van interventies. Om met deze interventies zelf te beginnen: een eerste voorwaarde is een deugdelijke opzet en uitvoering. Die was, zo bleek uit de reacties op de studie van Martinson (1974), van een dermate lage kwaliteit dat zijn conclusie dat 'niets werkt' op zijn minst voorbarig was. Sindsdien is er vooruitgang geboekt in de wetenschappelijke kennis omtrent kwaliteitsaspecten als de theoretische basis van programma's, de afstemming op de kenmerken van dader (het zgn. responsiviteitsprincipe) en setting, de intensiteit (het zgn. risicoprincipe) en het moment van de interventie, programma-integriteit en effectcriteria. Maar ook al is aan deze kwaliteitseisen in optimale zin voldaan, dan nog is succes niet verzekerd.

Gunstige effecten die tijdens een detentie worden bereikt, blijken vaak van korte duur te zijn. Een belangrijke oorzaak hiervoor is het ontbreken van adequate opvang na detentie. Schuyt (1998, p.240) merkt hierover op:

"Als er niet is gezorgd voor huisvesting, geld en de allereerste noodzakelijke levensbehoeften of voor de terugkeer naar familie, vrienden of een andere welkome omgeving, dan zien ex-gedetineerden vaak geen kans om zich zelfstandig door nieuwe moeilijkheden heen te slaan. Voor hen begint op dat moment (....) de straf na de straf."

De terugkeer en sociale integratie in de samenleving is een fase in het reintegratieproces die wordt gekenmerkt door specifieke hindernissen zoals de straf na de straf in de vorm van 
negatieve reacties van de samenleving, gebrek aan opvang en begeleiding na detentie. Cruciaal in deze fase van rehabilitatie is het weer (her)vinden van binding met de gemeenschap. Niet alleen de hulp in de vorm van nazorg door de professionele deskundigen is hier van belang, ook de gemeenschap dient een vitale rol te spelen bij de sociale integratie van de ex-gedetineerde in de post-detentie fase (Schuyt, 1998, p.236 e.v.).

Een proces van zelfherstel en sociale integratie is dus complex en langdurig van aard en nog niet ten einde met het verlaten van de gevangenis. Na deze intramurale fase volgt een extramurale fase waarin nazorg en steun van de gemeenschap nodig zijn om daadwerkelijke sociale integratie te bewerkstelligen. Deze combinatie van een penitentiaire interventie met nazorg duidt men ook wel aan als de geïntegreerde aanpak.

Deze visie op het resocialisatie-proces als een meer omvangrijk proces dat vraagt on een detentie-overstijgend traject naar maatschappelijk herstel heeft consequenties voor de beoordeling van de doelmatigheid van penitentiaire interventies.

\subsubsection{Naar een juiste beoordeling van doelmatigheid van penitentiaire interventies}

De effecten in termen van recidive zijn binnen een integrale visie op het resocialisatieproces idealiter een uitkomst van een gezamenlijke inspanning en verantwoordelijkheid van alle betrokken partijen en niet alleen maar van de gevangenis. Binnen een dergelijke brede visie op resocialisatie krijgt de penitentiaire interventie de hoedanigheid van bijdrage, schakel of deelinterventie binnen een bij voorkeur duidelijk en gestructureerd opgezet traject van (langdurig) zelfherstel dat zich uitstrekt over de verschillende fasen van de detentie en de postdetentie-fase. De doelnatigheid van de penitentiaire (deel)interventie wordt binnen deze integrale visie tevens afhankelijk gesteld van de aanwezigheid van detentie-overstijgende trajecten.

Het ligt bij deze benadering minder voor de hand het falen of slagen van de inspanningen in termen van recidive-vermindering enkel en alleen te verbinden met de kwaliteit van de inspanningen die in de penitentiaire setting worden geleverd.

De verantwoordelijkheid voor het eindresultaat in de zin van daadwerkelijke rehabilitatie wordt gedragen door alle bij het traject betrokken partijen, inclusief de instanties voor vervolgzorg en- 'last but not least'- de samenleving. Binnen deze integrale benadering is het mogelijk de intramurale inspanningen te beoordelen op een wijze die recht doet aan de mogelijkheden en beperkingen van de gevangenis. Die beoordeling van de bijdrage van de gevangenis aan het resocialisatie-proces zal in de eerste plaats in het teken komen te staan van de vraag inhoeverre de intramurale voorzieningen een doelmatige basis of vertrekpunt opleveren voor de vervolgvoorzieningen in de extramurale fase. Die vraag impliceert in eerste instantie een evaluatie van de directe effecten van de penitentiaire interventie. De vraag naar de bijdrage aan recidive-vermindering dient vervolgens in tweede instantie te worden beantwoord na afloop van de extramurale fase. Volgens de integrale benadering ligt het voor de hand de inspanningen van alle betrokken instanties te verbinden met het eindresultaat in termen van recidive.

De belangrijkste vraag die in het kader van de effectiviteit van penitentiaire interventies gesteld dient te worden is in welke mate de gevangenis erin slaagt een doelmatige basis te leggen voor een proces van zelfherstel. Want uit dit onderzoek blijkt dat resocialisatie in een detentiesituatie veelal niet meer maar ook niet minder inhoudt dan het opgang brengen en versterken van een proces van zelfherstel. Gelet op de omstandigheden waaronder het proces van zelfherstel plaatsvindt en gezien de complexiteit van dit proces is het onrealistisch te verwachten dat men gedetineerden tijdens de detentie reeds kan klaarstomen voor een misdaadvrije toekomst. Uit dit onderzoek blijkt dat gedetineerden en personeelsleden dic rechtstreeks betrokken zijn bij het vormgeven van de resocialisatie-opdracht, dergelijke 
verwachtingen ook niet hebben. En dat is niet het gevolg van een gepercipieerde onverenigbaarheid van detentie-doelen en een negatieve visie op resocialisatie maar veeleer het gevolg van een specifieke kijk op en ervaringskennis van het proces van zelfherstel. Men beoordeelt het reïntegratieproces in termen van het boeken van kleine stappen van vooruitgang in een vaak langdurig traject van zelfherstel. De interventies beschouwt men vooral als een schakel in een proces van persoonlijke groei en niet als een ingreep waarvan de waarde of zinvolheid louter staat of valt met de uitkomsten in termen van recidive.

Een dergelijke visie op de intramurale inspanningen als 'halffabrikaat' (van den Hurk, 1998, p.192) lijkt vooral geworteld in een meer realistische kijk op en inschatting van de mogelijkheden en onmogelijkheden van de detentie waar het om het bewerkstelligen van gedragsveranderingen gaat. Wat hierbij opvalt, is een overwegend positieve houding van zowel gedetineerden als personeel ten aanzien van de resocialisatie-doelstelling. Men verwerpt resocialisatie in de gevangenis als zodanig niet. Hulp en ondersteuning ten behoeve van het zelfherstel tijdens detentie worden als waardevol en zinvol ervaren ook al is het toekomstig effect ervan niet direct duidelijk.

De hiervoor geschetste benadering van de instrumentele aspecten van het resocialisatiestreven die blijkens de onderzoeksresultaten ook hun grond in de empirie vinden levert wellicht een bijdrage tot een realistisch denkklimaat waarin interventies in een detentiesetting niet louter als vruchtenloze ineffectieve pogingen tot criminaliteitsbestrijding worden gezien, maar als een onderdeel van een multi-modaal en integraal antwoord op de complexe problematiek van delinquenten.

Een dergelijke benadering van interventies in een detentiesetting opent ook perspectieven voor een meer rationele en empirisch gefundeerde benadering van de mogelijkheden voor zelfherstel in de detentiesituatie.

De boven geschetste benadering kan een stimulans en rechtvaardiging vormen om een, op zich zelf zinvol aanbod een specifieker en meer doelgericht karakter te geven en in te passen in het kader van een bredere interventie. Wat dit laatste betreft ligt hier tevens een taak voor de penologische wetenschap, die zich decennialang al te eenzijdig heeft gericht op de recidive-uitkomsten en de procesmatige kanten heeft verwaarloosd.

Het hedendaagse aanbod in Nederlandse penitentiaire inrichtingen van voorzieningen gericht op zelfherstel berust ook veel te weinig op de huidige wetenschappelijke inzichten omtrent de kwaliteit en effectiviteit van penitentiaire interventies. Het merendeel van de gedetineerden dat onderwijs volgt of gebruik maakt van de hulpverlening doet dit op een weinig systematische en doelgerichte wijze. Het uitgangspunt is nog steeds dat het aanbod van activiteiten zonder meer een resocialiserend effect heeft. Van een systematische inventarisatie van de problemen van gedetineerden die recidive-gerelateerd zijn en het vervolgens formuleren van een multi-modale integrale interventie met een detentie-overstijgend traject is geen sprake. Met de vooruitgang die personeel en gedetineerden in het proces van zelfherstel boeken, wordt te weinig gedaan. Men slaagt er niet in de op zich zelf waardevolle resultaten vanuit het oogpunt van doelmatigheid een bepaalde meerwaarde te geven omdat een systematische, integrale en doelgerichte aanpak ontbreekt.

De wetenschappelijke relevantie van dit onderzoek voor de penologie is dat, althans voor het Nederlandse gevangeniswezen, vanuit een procesmatige benadering voor het eerst de dynamiek en de systematiek in het geheel van relaties tussen houdingen ten aanzien van resocialisatie en de detentiesetting op empirisch wetenschappelijke wijze is verkend en vastgesteld. Met het onderzoek is voor het eerst een stap gemaakt in de richting van een empirisch wetenschappelijke benadering van een terrein waarover men zich totnogtoe voornamelijk uitliet in termen van niet getoetste veronderstellingen en vermoedens. 
In de volgende paragraaf worden een aantal aanbevelingen geformuleerd met betrekking tot de programma-inhoudelijke, randvoorwaardelijke en organisatorische aspecten van de huidige voorzieningen op het gebied van resocialisatie. De resultaten van het voorliggende onderzoek worden hierbij zoveel mogelijk betrokken.

\subsubsection{Het belang van een multi-modale aanpak}

In hoofdstuk 1 bleek uit de studie van Martinson (1974) dat er in niet één type interventie is aan te wijzen die in overwegende mate dat wil zeggen, in twee derde of meer van de afzonderlijke interventies tot een belangrijke afname van recidive leidt. Twintig jaar later constateert Palmer (1994) dat een dergelijk panacee nog steeds niet voor handen is. Een combinatie van verschillende interventie-vormen lijkt bovendien veelbelovender. Van een dergelijke gecombineerde of multi-modale aanpak is in de Nederlandse resocialisatie-praktijk maar zeer ten dele sprake te zijn.

In Nederlandse inrichtingen kan het overgrote deel van de gedetineerden die buiten de speciale maatschappelijke integratie-projecten vallen, een enkel uurtje per week deelnemen aan de verschillende vormen van educatie of een gesprek voeren met de hulpverleners.

De materiele en immateriële problematiek van Nederlandse gedetineerden wordt in de contacten met de hulpverleners voornamelijk benaderd met één vorm van begeleiding, namelijk 'casework'. Hulpverlener en cliënt bouwen hierbij een ondersteunende relatie op waarin naar de oorzaken van het delinquente gedrag wordt gezocht.

Deze begeleiding en eventueel therapie in het kader van hulpverlening wordt bovendien aangeboden als afzonderlijk activiteit. Een combinatie met educatie in een bepaald detentieof begeleidingsplan ontbreekt veelal. Uit het oogpunt van recidive-vermindering is dit niet bijzonder effectief, zo blijkt uit het effectiviteitonderzoek (Bol,1995, Palmer,1994). Uit het effectiveitonderzoek blijkt dat een combinatie van elementen als scholing en therapie tot een coherent geheel, meer succes oplevert.

De complexe problematiek van delinquenten vraagt blijkbaar om complexe multi-modale interventies.

Van dit laatste is in Nederlandse inrichtingen, behoudens in sommige bijzondere programma's eigenlijk geen sprake. Onderwijs en hulpverlening doen een aanbod dat min of meer los staat van elkaar. Bovendien wordt het aan het initiatief van de gedetineerde overgelaten of hij of zij van zowel educatie als hulpverlening of slechts van een van deze beide activiteiten gebruik maakt. Een brede gecombineerde en onderling samenhangende aanpak die betrekking heeft op alle probleemgebieden ook wel aangeduid als de multi-modale aanpak, ontbreekt. Clustering van scholing en hulpverlening binnen een coherente, integrale aanpak verdient derhalve aanbeveling.

\subsubsection{Aanpak van criminogene factoren}

Uit het onderhavige onderzoek bleek dat de beleving van de hulpverleningscontacten door gedetineerden sterker in het teken stonden van de directe, negatieve gevolgen van de detentiesituatie dan van aspecten als persoonlijke groei en verandering van de (toekomstige) levenssituatie. Het krijgen van meer inzicht in de oorzaken van de verschillende problemen die zij hebben, werd slechts door een minderheid van de gedetineerden als een belangrijk effect genoemd.

Aan een diagnose van de problemen, kenmerken en omstandigheden die leiden tot delinquent gedrag komt men in de hulpverleningscontacten blijkbaar in onvoldoende mate toe. Een expliciete visie op criminogeen geachte factoren ook wel aangeduid als de theoretische of conceptuele basis van de interventie, wordt niet of nauwelijks ontwikkeld. Een dergelijke visie is volgens Antonowicz en Ross (1994) echter cruciaal voor het succes van interventies. 
Het verdient derhalve aanbeveling interventies aan te bieden die in de eerste plaats gebaseerd zijn op empirisch degelijk onderbouwde en klinisch relevante theorieën over crimineel gedrag.

\subsubsection{Het belang van (vroegtijdige) cognitief/gedragsgerichte interventies}

Uit het effectiviteitonderzoek (Palmer, 1994; Bol,1995; Antonowicz en Ross, 1994) komt naar voren dat het type interventie waarin cognitieve en gedragsgerichte elementen worden gecombineerd, vergeleken met andere combinaties, tamelijk veelbelovend en overwegend effectief is. Succesvolle interventies blijken in vergelijking met niet succesvolle interventies (bijvoorbeeld volgens een afschrikkings-of psycho-dynamisch model) veel vaker cognitieve en gedragsgerichte elementen te bevatten.

Gedragsgerichte interventies zijn gebaseerd op leertheoretische principes, waarbij bekrachtiging van gedrag wordt nagestreefd. Gedragsgerichte interventies zijn vooral effectief als men cognitieve elementen toevoegt. Gebleken is dat gedetineerden het best reageren op leertheoretische principes van interpersoonlijke invloed, vaardigheids-ontwikkeling en cognitieve verandering. Binnen het domein van cognitieve/gedragsgerichte interventies worden genoemd:

-training van scholing en arbeidsvaardigheden;

-training van interpersoonlijke vaardigheden (empathie, sociale vaardigheden);

-morele opvoeding;

Training in cognitieve vaardigheden richt zich onder meer op het zelfbeeld, verwachtingen, waarden en op de vraag hoe men tegen het leven aan kijkt. Ze zijn dus tevens gericht op het bevorderen van inzicht en het beïnvloeden van de cognitieve stijl of het denken van delinquenten. (Ross Fabiano en Ewles, 1990). Uitgangspunt bij cognitief/gedragsmatige interventies is het confronteren van delinquenten met hun delict, hun motieven en de ontwikkeling van een andere denkstijl en gedragspatronen.

De bevinding in de onderhavige studie dat gedetineerden aan het begin van de detentie (tijdelijk) een grotere motivatie tonen voor pogingen tot zelfherstel, vormt in het licht van het belang van cognitieve interventies een interessant aangrijpingspunt voor de verbetering van het huidige voorzieningen aanbod.

De grotere ontvankelijkheid van gedetineerden in de beginfase van de detentie voor zelfherstel werd voor een deel verklaard uit de specifieke stressvolle omstandigheden van de beginperiode (de zgn. 'shock of incarceration'). De schok en vernedering van de gevangenschap kan men eigenlijk beschouwen als een soort crisissituatie. In deze situatie wordt men (tijdelijk) sterker geconfronteerd met de hele eigen geschiedenis van misere, mislukking en ontsporing. Tijdelijk gaat deze fase van de detentie gepaard met een sterkere mate van bezinning op het eigen verleden, heden en toekomst. Men loopt tegen de grenzen aan van de eigen vrijheid, mogelijkheden, persoonlijke relaties en sociale verbanden.

Een dergelijke periode van grotere ontvankelijkheid voor bezinning op de eigen levenssituatie lijkt daarom bij uitstek geschikt voor het aanbieden van cognitieve interventies.

Cognitieve interventies dienen derhalve zo vroeg mogelijk te worden aangeboden.

Ook andere onderzoekers (Zamble en Porporino, 1990) komen tot de conclusie dat (cognitieve) interventies zo vroeg mogelijk moeten beginnen omdat de aanvankelijk sterkere motivatie een goed basis biedt voor gedragsveranderingen. Doel van de interventies in de beginfase en in de middenfase zou het versterken en consolideren van de motivatie moeten zijn, zodat een fundament ontstaat voor latere interventies. De eindfase leent zich bij uitstek voor de voorbereiding op vervolgvoorzieningen.

Ook om een aantal andere redenen kan vroegtijdige interventie via cognitieve trainingen mogelijk effectief zijn. 
In Nederlandse gevangenissen worden gedetineerden eigenlijk zelden met hun delict en hun eigen gedrag geconfronteerd. Schuldverwerking en het versterken van de gewetensfunctie zijn cruciaal voor het verwerven van zelfinzicht en voor het zelfherstel. Van een multimodale, gestructureerde aanpak van criminogene factoren als antisociale attitudes, cognities, geringe zelfcontrole, geringe sociale vaardigheden is in het algemeen geen sprake.

Voor de meeste gedetineerden breekt na de beginfase van de detentie vermoedelijk een fase aan van ontkenning en verdringing van de psychosociale problematiek, van gevoelens van leegte. zinloosheid en verzet met name als de invloed van een antisociale gedetineerdencultuur sterker wordt. De mogelijkheden voor interventies die zich richten op het versterken en consolideren van motivatie voor zelfverbetering worden dan aanmerkelijk minder.

Vroegtijdige interventies zijn verder van belang omdat, blijkens de gegevens van de Dienst Justitiële Inrichtingen, tweederde van de langgestraften de geplande route via de detentiefasering niet doorloopt. Men zit de straf geheel uit in een gesloten gevangenis, van een detentieroute via plaatsing in een halfopen of open setting is geen sprake (Justitiekrant, 2811-97). Om deze groep tijdens de detentie toch nog enige voorbereiding op de terugkeer in de samenleving te bieden kunnen vroegtijdige, effectieve cognitieve interventies uitkomst bieden.

\subsubsection{Resocialisatie tijdens voorlopige hechtenis}

Het gesignaleerde belang van een vroegtijdige interventic tijdens de detentie staat op gespannen voet met het restrictieve regime dat in de huizen van bewaring tijdens de voorlopige hechtenis wordt gevoerd. Mogelijkheden voor resocialisatie zijn in dit regime minimaal. Gelet op de soms lange duur van de voorlopige hechtenis en op het feit dat zich in het huis van bewaring reeds veroordeelde gedetineerden bevinden die het laatste gedeelte van een korte onvoorwaardelijke vrijheidsstraf uitzitten, is dit vanuit oogpunt van het maatschappelijk herstel van gedetineerden een onwenselijke situatie. De behoefte aan hulp en steun is juist in deze fase van de detentie bijzonder groot. Tegelijkertijd is voor gedetineerden in een huis van bewaring het stelsel van minimale beperkingen van toepassing. Bovendien is het resocialisatie-ideaal door de PBW ook van toepassing verklaard op de vrijheidsbenemende maatregel van voorlopige hechtenis. Het lijkt dus hoog tijd te zijn dat de bestaande restricties in de huizen van bewaring zo veel mogelijk worden weggenomen teneinde de kansen en mogelijkheden van gedetineerden op zelfherstel te vergroten. In het bijzonder voor gedetineerden die in aansluiting op een voorlopige hechtenis een korte vrijheidsstraf in een huis van bewaring uitzitten lijken de omstandigheden voor penitentiaire interventies met een extramuraal vervolg gunstig. Van een negatieve invloed van een gedetineerdencultuur zoals die $\mathrm{min}$ of meer waarneembaar is op afdelingen voor langgestraften, is in een HVB-setting veel minder sprake. Bovendien kan er aansluiting worden gezocht op een grotere motivatie voor zelfherstel gedurende de beginfase van de detentie. In dit verband kan worden gewezen op het onderzoek van Janssen (1999) naar de werking van de korte vrijheidsstraf waarin de onderzoekster pleit voor een verder onderzoek naar de specifieke behoeften en mogelijkheden van deze categorie gedetineerden op het gebied van maatschappelijke integratie.

\subsubsection{Motivatie}

De bevinding dat gedetineerden over het algemeen gematigd negatief zijn ten aanzien van de mogelijkheden voor zelfherstel tijdens een detentie impliceert geenszins dat men negatief denkt over de resocialisatie-doelstelling als zodanig.

In het recente penitentiaire beleid van Werkzame Detentie gaat men volledig aan dit laatste aspect van de houdingen van gedetineerden voorbij. Voorts gaat men voorbij aan het gegeven 
dat een bepaalde mate van scepsis ten aanzien van de mogelijkheden voor zelfherstel inherent is aan de detentiesituatic of de omstandigheden van het gedetineerd zijn in het algemeen. Men wekt hierdoor impliciet de suggestie dat ongemotiveerdheid van gedetineerden voornamelijk een kwestie is van onwil en niet tevens van een zekere mate van onvermogen. Vervolgens wordt $80 \%$ van de gedetineerden op grond van deze veronderstelling uitgesloten van een zorg voor de voorbereiding van de terugkeer in de samenleving die naar de geldende matstaven van de penologie als adequat mag worden beschouwd.

Waarschijnlijk behoort de groep gedetineerden die minder kansen voor zelfherstel waarneemt voor een belangrijk deel ook tot de categoric hoog-riskante delinquenten, waarbij de kans op terugval zeer groot is. Men keert bij gebrek aan adequate zorg waarschijnlijk even gevaarlijk zo niet gevaarlijker in de samenleving terug dan men al was, met alle verdere materiële en immateriële schade als gevolg van terugval van dien.

Neemt men de tevens de conclusie uit evaluatie-onderzoek in ogenschouw waaruit blijkt dat ongemotiveerde delinquenten het qua recidive niet slechter doen dan gemotiveerde delinquenten (Antonowicz en Ross, 1994) en dat meer intensieve interventies gericht op minder gemotiveerde gedetineerden met een hoog risicoprofiel in termen van recidivevermindering even effectief of zelfs meer effectief zijn dan intensieve interventies bij gemotiveerde gedetineerden met een laag risico-profiel (Antonowicz en Ross, 1994; Andrews et al 1990), dan verdient het aanbeveling de bestaande praktijk van een verlaagd voorzieningenniveau van vermeend ongemotiveerde gedetineerden te heroverwegen. Op grond van het effectiviteitscriterium zijn er dus geen reden om programma's slechts aan te bieden aan degenen die gemotiveerd zijn.

De (impliciete) visie in het recente beleid op de molivatie van gedetineerden als een tamelijk onveranderlijke grootheid die blijkens de uitsluiting van (extra) zorg van het merendeel van de gedetineerden niet de moeite van het beïnvloeden waard is, wordt bovendien door de resultaten van dit onderzoek weerlegd.

Het regime blijkt een belangrijke factor te zijn bij de verklaring van de aard van de houdingen van gedetineerden ten aanzien van resocialisatie. Het karakter van het regime kan de houdingen in positieve of negatieve zin beinvloeden. Derhalve ligt hier een belangrijk aangrijpingspunt voor het beleid om de motivatie van gedetineerden te versterken. Echter, het scheppen van een regime en inrichtingsklimaat dat positieve houdingen van gedetineerden ten aanzien van resocialisatie stimuleert, is uit het oogpunt van de intensiteit en doelgerichtheid van interventies niet toereikend. Een belangrijk aanknopingspunt ter verbetering van de bestaande resocialisatie-praktijk ligt vooral ook besloten in de programmatische aspecten van het aanbod op het gebied van educatie en hulpverlening.

Het bestaande aanbod van educatie en kunstzinnige vorming wordt door gedetineerden vooral gewaardeerd om hun mogelijkheden voor persoonlijke groei en verbetering van hun (toekomstige) levenssituatie. In dit opzicht zijn de activiteiten effectief omdat zij voorzien in en aansluiten op de behoeften van gedetineerden. Tegelijkertijd zijn deze activiteiten in de ogen van de meerderheid van de gedetineerden te weinig doelgericht. Verbetering van de manier waarop (conceptuele basis, assessment, afstemming op de behoeften en capaciteiten, multimodale geöntegreerde aanpak, cognitief gedragsmatig karakter, nazorg) en de kwantiteit (duur en aantal contacten of nomenten) waarmee men deze activiteiten aanbiedt kan de motivatie van gedetineerden mogelijk versterken.

\subsubsection{Resocialisatie en de psycho-sociale kwaliteit van de detentie}

Detentie gaat voor alle gedetineerden in meerdere of mindere mate gepaard met het prijsgeven van de eigen identiteit, eigen initiatief en autonomie. On deze en tal van andere redenen is de detenticomgeving een schadelijke omgeving. In het licht van de schadelijkheid 
van een detentie voor het individu spreekt het bijna voor zich dat men uiterste terughoudendheid betracht bij het gebruik van de vrijheidsbenemende sanctie. En indien deze sanctie toch wordt toegepast, dient de tenuitvoerlegging humaan en schadebeperkend te zijn. Gedetineerdenzorg is in de eerste plaats gericht op het beperken van de schade als gevolg van het verblijf in een penitentiaire inrichting. De zorg is daarnaast in positieve zin gericht op het bevorderen van persoonlijke groei en van (sociale) perspectieven. Een verbetering van de positie van de gedetineerden behoort dus tevens tot de doeleinden van de gedetineerdenzorg. De voorzieningen gericht op resocialisatie vervullen, zo laat dit onderzoek zien, een belangrijke functie bij het verwezenlijken van deze doeleinden. Activiteiten als kunstzinnige vorming, hulpverlening en onderwijs bieden gedetineerden de gelegenheid om de directe spanningen en deprivaties van de detentie te verminderen. Via activiteiten als onderwijs en kunstzinnige vorming vinden gedetineerden een uitlaatklep, afwisseling en ontspanning. Bovendien vergemakkelijken activiteiten de aanpassing aan de depriverende detentieomgeving voor gedetineerden met een sterke behoefte aan afwisseling en bezig zijn. Aanpassing aan een depriverende detentieomgeving blijkt bij de vormende activiteiten en de hulpverleningscontacten in de beleving van de gedetineerde niet de enige functie te zijn. Deze activiteiten voorzien ook in een behoefte aan persoonlijke groei en perspectief. Men kan hier ook spreken van een behoefte aan zingeving van het eigen leven en aan het handhaven of versterken van autonomie. Het betreft hier pogingen om weer greep op het eigen leven te krijgen. Die pogingen staan min of meer los van de directe deprivaties van de detentieomgeving en van het streven de detentie zo gemakkelijk mogelijk en schadevrij door te komen. Zij dragen overigens wel in meer indirecte en globale zin bij aan het beperken van de detentieschade. Vanuit het perspectief van de psycho-sociale kwaliteit van de detentie vervullen educatieve activiteiten, hulpverlening en het regime een belangrijke functie. Deze voorzieningen lijken zowel in de perceptie van het personeel als gedetineerden een belangrijk positief element te vertegenwoordigen in een omgeving die toch al sterk doortrokken is van negatieve betekenissen. De activiteiten scheppen in het inrichtingsklimaat een ruimte voor gedetineerden waarin aandacht mogelijk is voor persoonlijke ontwikkeling en bezinning op de toekomstige levenssituatie. Een dergelijke ruimte waarin niet alleen maar wordt gereageerd op hun tekorten maar tevens op hun capaciteiten en potenties van gedetineerden, ontbreekt veelal in hun leven in de vrije maatschappij. Alleen al vanuit deze optiek verdient het aanbeveling het regimesactiviteitenprogramma als instrument voor een gunstig klimaat psycho-sociaal klimaat voor gedetineerdenzorg in ere te houden en te verbeteren.

\subsubsection{De invloed van de gedetineerdencultuur}

De onderzoeksresultaten laten zien dat het in een gevangenisgemeenschap moeilijk is gemotiveerd te blijven voor bedoelingen die gericht zijn op zelfherstel. Met name in de fase van de detentie waarin het moment van terugkeer in de samenleving ver weg ligt, krijgt het denken van gedetineerden over een beter maatschappelijk perspectief een negatiever karakter. De lasten van het gevangenisleven beginnen zwaarder te wegen en de invloed van de gedetineerdencultuur doet zich hier gelden. Dit betekent echter niet dat alle langgestrafte gedetineerden zich in de middenfase van de detentie passiever en negatiever opstellen ten aanzien van de activiteiten. $\mathrm{Er}$ is een groep langgestrafte gedetineerden die blijkens hun positieve beleving van en frequente deelname aan educatieve bezigheden een sterke behoefte aan zinvolle bezigheden aan de dag legt. Het streven om niet af te stompen en geestelijk in beweging te blijven, het handhaven van een positief zelfbeeld, de persoonlijke identiteit en autonomie zijn belangrijke behoeften waarin de educatieve voorzieningen voorzien. De schadebeperkende en humane functie van de activiteiten voor langgestrafte gedetineerden wordt hier manifest. Langgestraften kampen overigens wel met het probleem van verveling. 
Uit mijn persoonlijke ervaringen met het werken van langgestraften blijkt dat zij op dit punt ook zelf positieve initiatieven ontplooien. Zij komen regelmatig zelf met projecten waarin kunstzinnige vorming wordt gekoppeld aan een goed doel, projecten waarvoor ik vervolgens zelf de praktische uitvoering in de inrichting organiseer. Bij een substantieel gedeelte van deze groep gedetineerden is er sprake van een zeer positieve en constructieve houding, waarop men als inrichtingsorganisatie zoveel mogelijk dient aan te sluiten. Helaas is, gelet op manifeste probleem van de verveling, van dit laatste in onvoldoende mate sprake.

In overzichtstudies van het effectiviteitonderzoek concludeert men dat de aanwezigheid van een negatieve gedetineerdencultuur in een detentiesetting geen contra-indicatie hoeft te vormen voor de implementatie van een succesvolle interventie. Voorwaarde is vooral dat deelnemers aan een interventie binnen detentie zoveel mogelijk worden afgeschermd van een overwegend antisociale gedetineerdencultuur (Antonowicz en Ross, 1994)

Een en ander betekent niet dat men gedetineerden die blijk geven van een geringe of verminderde motivatie voor wat betreft een adequate voorbereiding van de terugkeer in de samenleving aan hun lot moet overlaten. Het gevaar bestaat immers dat men afdelingen kweekt die het etiket van vergaarbak van hopeloze gevallen krijgen. Juist deze groepen gedetineerden die veelal gebukt gaan onder een ernstige verslavingsproblematiek en een gebrek aan sociale en cognitieve vaardigheden vormen een uitdaging op het gebied van interventies. Voor deze groepen zou men specifieke programma's kunnen ontwikkelen.

\subsubsection{Verbetering van randvoorwaarden in de organisatie}

Veel minder eenduidig positief zijn de houdingen van gedetineerden en personeel over de afstemming van de detentiesituatie en de organisatie op het streven naar zelfverbetering. Men noemt vooral problemen in randvoorwaardelijk sfeer die betrekking hebben op ondersteuning en begeleiding en de beperkte hoeveelheid tijd in het dagprogramma Bijna de helft van gedetineerden is ontevreden over de geboden ondersteuning bij problemen. Het personeel mist vooral ondersteuning van de leiding bij de uitvoering van de begeleidende taken.

Voor een deel kunnen deze problemen in indirecte zin worden herleid tot de optimaliserende aard van de strafrechtelijke besluitvorming. Behalve resocialisatie dienen op het niveau van de tenuitvoerlegging andere conflicterende doeleinden te worden nagestreefd. Die doeleinden kunnen van organisationele aard zijn (bezuiniging en rekening houden met een kritische buitenwacht) of betrekking hebben op beveiliging, (handhaven van orde en rust) en vergelding. De noodzaak van een gelijktijdig nastreven van deze overige doeleinden impliceert dat de resocialisatiedoel maar ten dele kan worden gerealiseerd. Een dergelijke optiek speelt echter in de opvattingen van het uitvoerend personeel geen dominante rol. Men acht de aanwezigheid van het resocialisatiedoel verenigbaar met het beveiligingsdoel.

Voor een belangrijk deel zijn deze problemen een te vermijden gevolg van een inadequate organisatiestructuur. In dit opzicht gaat het om vragen als de kwaliteit van het beleid, de communicatie, de organisatie van de zingeving en de visie op de bejegening van de gedetineerden.

Uit het onderzoek bleek bij voorbeeld een belangrijk verschil in visie tussen de leiding van verschillende inrichtingen op een activiteit als kunstzinnige vorming. In de ene inrichting beschouwt men bijvoorbeeld kunstzinnige vorming als een soort luxe, een extraatje voor gedetineerden. In budgettaire, culinaire termen duidt men dit in deze inrichting aan met de term 'overschep'.

In de andere inrichting neemt men deze activiteit serieuzer gelet op de goed ingevulde randvoorwaarden en beschouwt men de activiteit blijkbaar als een belangrijk onderdeel van het instrumentarium waarmee men het klimaat in de inrichting en de houdingen van gedetineerden kan beïnvloeden. 
Deze verschillen in benadering kan men ook interpreteren als een verschil in rationaliteit waarmee men de voorzieningen voor gedetineerden benadert. In de enc inrichting neigt men naar een meer traditionele ordegerichte, intuitieve benadering op grond waarvan men gedetineerden niet te veel in de watten wenst te leggen. In de andere inrichting denkt men meer in termen van doelrationaliteit.

De optimaliseringproblemeı die op het macroniveau een rol spelen leggen de verhoudingen op het (micro)niveau van de inrichting geenszins vast volgens een deterministisch patroon. De verhoudingen en ontwikkelingen op het macroniveau van het strafrechtelijk systeem structureren uiteraard wel de wijze waarop op het microniveau aan het primaire proces gestalte wordt gegeven. Matar binnen deze structuur blijft de mogelijkheid open van geheel eigen interpretaties van en visies op de vereiste kwaliteit van de uitvoering van de resocialisatie-opdracht.

De interpretaties die in dit onderzoek onder het uitvoerend personeel werden aangetroffen vertegenwoordigen in overwegende mate een positieve en liberale visie op de resocialisatieopdracht. Het belang van voorzieningen gericht op de voorbereiding van de terugkeer in de samenleving en van het regimesactiviteiten-programma in het algemeen, wordt onderschreven. Dit belang wordt door het bewarend personecl niet alleen maar gerelateerd aan beheersmatige overwegingen zoals een ongestoorde en rustige gang van zaken in de inrichting.

In de ogen van het personeel houdt detentie meer in dan een louter bewarende en beveiligende functie.

Hun houding staat, ondanks de verlegging van de accenten van het beleid van Werkzame Detentie naar een restrictieve, meer punitieve en vergeldende benadering van de tenuitvoerlegging van de gevangenisstraf. nog steeds mede in het teken van humanisering van de detentie en in het verlengde daarvan, het bieden van kansen en mogelijkheden op een beter maatschappelijk perspectief voor gedetineerden.'

Het verdient aanbeveling deze houding van het gevangenispersoneel te beschouwen als een teken van kracht en van aanwezig potentieel in de organisatie dat men dient te benutten om een detentie met een menselijk gezicht te behouden en in kwalitatief opzicht verder gestalte te geven.

Met betrekking tot dit laatste kan men de volgende aanbevelingen doen voor het in de toekomst te voeren beleid.

\subsection{Aanbevelingen}

1. Elke detentie zou moeten beginnen met een inventarisatie van de materiële en immateriëlc behoeften op het gebied van maatschappelijk herstel en van de capaciteiten van de individuele gedetineerde. Aan de hand hiervan dient een detentieplan te worden opgesteld waarin de tijd die men in detentie doorbrengt mede wordt gestructureerd door

\footnotetext{
'Van Stokkom (1999. p.54) merkt in dit verband op: "De deskundigen in het justitiële veld vormen samen een sterke pragmatische gemeenschap waarin ervaringskennis en matatwerk de toon aangeven. Deze gemeenschap kent haar eigen inzichten en werkwijzen, haar eigen dynamiek en Eigengesetzlichkeit. waarop voorstanders van bedrijfsmatige efficiëntie en stroomlijning weinig greep lijken te hebben. Men werkt er nuchter en realistisch aan herstel, 'graden van vrijheid'en reïntegratie van daders."
} 
begeleidingsinhoudelijke aspecten op het gebied van scholing, cognitieve/gedragsgerichte interventie en materiële hulpverlening (huisvesting, schuldsanering en werk).

2. In het detentieplan dient in een zo vroeg mogelijk stadium aansluiting te worden gezocht op vormen van extramurale zorg. Het detentieplan dient bij voorkeur in het teken te staan van een detentie-overstijgend traject.

3. De criteria van doelmatigheid van de interventies zullen veel meer, dan nu het geval is, expliciet moeten worden vastgelegd. Die criteria dienen te zijn gebaseerd op overkoepelende kwaliteitsdefinities. In dit verband verdient het instellen van onafhankelijke inspecties de voorkeur. Ontwikkeling van kwaliteitscriteria dient door gevangenispersoneel niet alleen te worden gezien als een controlemiddel van departementswege, het is tevens een middel om de betekenis en waarde van hun inspanningen zichtbaar te maken.

4. Er dient regelmatig onderzoek te worden verricht naar de inspanningen die zowel gedetineerden als personeel op het gebied van zelfherstel leveren. Dergelijk onderzoek dient niet eenzijdig gericht te zijn op de tekortkomingen van de interventies. Ook de humane betekenis van deze inspanningen en de geboekte vooruitgang dienen te worden benadrukt en aan een breed publiek ter kennis te worden gesteld. Het geduld, de inzet en vasthoudendheid waarmee gedetineerden en personeel in een betrekkelijk onvriendelijke en negatieve setting toch nog vooruitgang weten te boeken, mag best worden getoond en is iets waarop men trots mag zijn.

5. Verbetering van de kwaliteit van resocialisatie-programma's dient niet alleen afhankelijk te worden gesteld van de kwantiteit van het betrokken personeel maar ook van de kwaliteit van het personeel. Ondersteuning in de vorm van deskundigheidsbevordering dient te worden uitgebreid

6. Gelet op het veelbelovend karakter van cognitieve interventies verdient het aanbeveling de mogelijke bijdrage van de geestelijke verzorging aan dergelijke interventies aan een nader onderzoek te onderwerpen.

7. Penitentiair Inrichtingswerkers zouden in het kader van een mentorschap voor gedetineerden stelselmatig en intensiever dienen te worden betrokken bij de begeleiding in het kader van maatschappelijk herstel

8. De inspanningen van het penitentiair reclasseringswerk dienen zich over alle fasen van de detentie uit te strekken. Hun inspanningen dienen niet beperkt te blijven tot de kansrijke gedetineerden die zich aan het einde van hun detentie bevinden.

9. Het verdient in het kader van de begeleiding na detentie aanbeveling dat de voorwaardelijke invrijheidsstelling waarbij reclasseringstoezicht als voorwaarde geldt, weer wordt ingevoerd.

10. Beveiliging in de zin van het handhaven van orde en rust stelt grenzen aan het streven naar maatschappelijk herstel in een detentiesituatie. Dit betekent echter niet dat het beveiligingsdoel steeds als het belangrijkste uitgangspunt van de detentie dient te worden gehanteerd. Het dient waar mogelijk flexibel te worden toegepast ten behoeve van het maatschappelijk herstel. De perceptie van gedetineerden van het regime als gematigd orde- 
gericht duidt op de noodz meer gedetineerden-gericl

11. Het aandeel in de buitenlandse culturele acht

tot verbetering van het inrichtingsklimaat in de richting van een rakter.

Ise gedetineerdenpopulatie van gedetineerden met een oedraagt nu reeds om en nabij de helft van de populatie. Meer intensieve vormen vat. snterventie gericht op maatschappelijke integratie dient bij deze groep in de eerste plaats rekening te houden met de kansen op een legaal verblijf in Nederland. Ten aanzien van buitenlandse gedetineerden van wie bij voorbaat al vaststaat dat zij hun verblijf in Nederland na detentie niet op een legale wijze kunnen voortzetten, dient noodgedwongen te worden volstaan met minder intensieve, interventie-vormen.

Ook voor deze groep gedetineerden dienen penitentiaire interventies zinvol te zijn, al was het alleen maar met het oog op de niet denkbeeldige kans dat zij hun verblijf na detentie op illegale wijze voortzetten.

12. Het verdient aanbeveling het (toekomstige) centrale overkoepelende beleid ten aanzien van resocialisatie in sterkere mate te baseren op de percepties van de betrokkenen in het werkveld. Bundeling van krachten en het ontwikkelen van een coherente gedeelde visie op resoualisatie is in tijden van een beperkt krediet bij politiek en publiek te verkiezen boven twrespa!+ । fragmentatie. De wettelijk gegeven resocialisatie-opdracht zou bij een dergelijke visie als u.tgangspunt moeten gelden. Die visie dient te worden geformuleerd voor alle gedetineerden die in meerdere of mindere mate blijk geven van behoeften en noden op het gebied van resocialisatie

13. Men zou de gemeenschap of de samenleving die als maar blijft vragen on een strenger optreden tegen criminaliteit wat vaker moeten wijzen op zijn medeverantwoordelijkheid voor de reïntegratie en rehabilitatie van gedetineerden voor wie, juist als gevolg van deze roep om strengere en langduriger straffen, de terugkeer in de samenleving aanmerkelijk moeizamer verloopt.

\section{Tot besluit}

$\mathrm{Na}$ de voorgaande beschouwing kan men vaststellen dat er tal van geldige redenen zijn om de resocialisatie-opdracht weer als een belangrijk detentiedoel temidden van de andere doeleinden op de agenda te plaatsen. Uitgangspunt hierbij is geen onrealistisch streven naar de wedergeboorte van het resocialisatie-ideaal zoals dat de gemoederen in de jaren zestig en zeventig bezighield. Uitgangspunt is daarentegen een realistische en in empirisch, wetenschappelijke zin gefundeerde waardering van de resocialisatie-opdracht. Aldus ontstaat ruimte voor een benadering waarin resocialisatie in de gevangenis wordt beschouwd als een mogelijk, zinvolle en humane reactie op delinquentie en niet als een opdracht die gelet op de recidivecijfers al bij voorbaat gedoemd is te mislukken. Het afrekenen van de inspanningen op het gebied van maatschappelijke integratie binnen een penitentiaire setting op recidivecijfers alleen en het vervolgens in twijfel trekken van het nut van deze inspanningen is een weinig heilzame weg. Een dergelijke weg is allerminst heilzaam als men zich realiseert dat het de voedingsbodem kan zijn van een beleid dat gericht is op het 'opsluiten van gedetineerden zonder meer'. De gevangenis als instituut heeft, zo laat dit onderzoek zien, in potentie veel meer in huis dan een louter bewarende functie. Een geloof in de humanitaire waarde van het resocialisatiestreven is onder gedetineerden en personeel aanwezig, tegelijkertijd is men realistisch ten aanzien van datgene wat de gevangenis gedetineerden te 
bieden heeft op het gebied van resocialisatie en reïntegr? resocialisatie-gedachte ligt besloten in de mate waarin het gev? bijdrage aan de terugkeer van gedetineerden in de samenlevin normatieve en instrumentele vruchten van dit streven $v$ maken.

Deze vruchten dienen niet te worden aangewend ter rechtvaardiging van het gebruik van de vrijheidsbenemende sanctie. De gevangenisstraf en het instituut gevangenis is en blijft in het kader van het strafrechtelijk ingrijpen een reactie die zo veel mogelijk achterwege dient te worden gelaten. Het ware wenselijk als wij het in de toekomst zonder de gevangenis konden stellen. Echter, zo lang de samenleving in zijn reactie op criminaliteit zijn toevlucht zoekt tot dit instituut, blijft het van belang om ons, met dit weinig gelukkige en schadelijke instituut bezig houden. Het is betrekkelijk gemakkelijk op veilige afstand te blijven roepen dat het instituut gevangenis niet deugt en resocialisatie niet werkt, het is daarentegen veel moeilijker te voorkomen dat juist door het gebruik van dit instituut, gedetineerden als non-valeurs nog verder buiten de samenleving worden gesteld. Van dit laatste krijgt vroeg of laat niet alleen de gedetineerde maar ook de samenleving de rekening gepresenteerd. 


\section{Summary}

According to Dutch legislation , ?rison Act, 1953; Penitentiary Principles Act, 1999) the enforcement of imprisor: aent should not be exclusively aimed at punishing the offender. Imprisonment should atiso be oriented at the re-integration of the detainee into society. To realise this goal of rehabilitation Dutch prisoners are offered services in the field of education and psycho-social assistance. Prisoners are not obliged to make use of these services. Preparing for the future mainly depends on the prisoners own initiative or attitude. In addition the attitude of tt prison personnel plays an important role. Their task is to encourage and assist prisoners who are willing to prepare for the future.

The attitudes of both prisoners and the prison personnel towards rehabilitation are the central theme of this study. This study aims at describing and explaining their attitudes. More specifically, this studies examines the process of re-integration from the perspective of the participants opinic is and experience.

Chapter 1 clarifies the reasons for studying rehabilitation from this particular perspective. It is argued that from an normative, penological and organisational point of view there are ample reasons for studying the attitudes of prisoners and prison personnel towards rehabilitation.

The reason for studying the attitudes of prisoners and personnel in more detail is certainly not an unrealistic belief in the possible renaissance of the rehabilitation ideal. In the view of the author, reintegration programmes which offer opportunities to offenders are still worth to be examined, because imprisonment in accordance with humane standards cannot do without these programmes. Moreover rehabilitation may perform a very important counterbalancing, positive function in an essentially detrimental and negative environment. It may reduce the harmful effects of imprisonment and prevent the degeneration of imprisonment to mere warehousing practices. The importance of a humane, least harmful treatment and an adequate, purposive care for prisoners presupposes rational, scientific knowledge about the prisoners' needs, attitudes and the organisational context of this care.

From the point of view of penology there is another important argument for studying the attitudes of prisoners and personnel towards rehabilitation.

In penology there is of course a large body of evaluation research about the effectiveness of rehabilitation programmes. In most studies however the process-evaluative aspect is lacking. As to what really happens as regards the attitudes of the participants during the intervention period, most studies show what may be called a black-box character. They use outcomemeasures that cannot be connected to a process. More specifically, important information about what happens during the correctional programme with regard to offender characteristics and attitudes, adequate implementation or programme integrity, and organisational and staff characteristics have been neglected. Information resulting from such a processevaluative approach is considered essential to account for the expected and unexpected successes and failures. An evidence-based approach regarding the process of rehabilitation during incarceration, which examines the nature and sources of attitudes toward rehabilitation, may clarify the meaning of rehabilitation for prisoners, prison personnel and the prison organisation. This type of knowledge may contribute to our knowledge of the role which rehabilitative activities play in the prisoner's adjustment to prison life and in their lives in general. Knowledge of the individual and environmental background factors which possibly affect the implementation of correctional programmes may be used to improve their effectiveness. Finally this knowledge may clarify the proper place of correctional 
programmes within the whole process of re-integration which ideally should contirue after release with additional guidance. Furthermore, an examil dtion of prisoners' and personnel's attitudes toward rehabilitative activities may clarify the issue of receptivity for rehabilitation which according to sceptical arguments is rather low or diminished.

This chapter concludes with the following questions:

1. What is the meaning of the concept of rehabilitation?

2. In what way the idea of correction and rehabilitation of prisoners veloped in the Dutch prison system?

3. What are the opinions of inmates and prison personnel toward rehabilto partis a goal of detention?

4. How do inmates and prison personnel perceive their engagement in activities which are beneficial to their return into society, that is education individual counselling and creative activities?

5. What is the frequency of inmates' engagement in the institution's programme of activities?

6. What is the relationship between inmates' opinion, perceived value and degree of participation?

Everyone who works or lives for any length of time in a prison knows that inmates, in spite of the same uniformly restrictive environmental characteristics, show different reactions to imprisonment. Some react with apathy and withdrawal. Others develop more co-operative or rebellious behaviour styles. Obviously the restrictive conditions of confinement are not so powerful as to determine uniform behavioural effects. Neither individual characteristics nor dispositions are so predominant as to determine behaviour across environmental conditions. Behaviour or attitudes of prisoners can be explained only by considering both the situation and the ways the person reacts. This interactional perspective of studying external and internal factors which may affect different attitudes toward rehabilitation is reflected in the following question:

7. What is the relationship between attitudes on the one hand and environmental and individual characteristics on the other hand?

Chapter 2 describes how from the early part of the $19^{\text {th }}$ century until the present era the idea of reforming or rehabilitating offenders evolved in the Dutch prison system. It describes how in the early part of the $19^{\text {th }}$ century the extended use of imprisonment was accompanied by a growing popularity of the idea of turning prisoners into honest citizens. Retribution of an offence and deterrence were more and more seen as important, though inadequate goals of custodial punishment. A growing extension of sympathy to the offender resulted in the introduction of the more 'civilised' subsidiary goal of rehabilitation. In the $19^{\text {lh }}$ century the rehabilitation of the prisoner was seen to be come about as a result of his personal change. Isolation and strict confinement within the four walls of his cell were considered as beneficial to his moral improvement. He was removed from adverse influences; contact with other prisoners was kept to a minimum. The ultimate goal was achieving repentance, hence the emphasis on religion and the work of the chaplain.

At the end of the $19^{\text {th }}$ century the sciences of criminology, penology, sociology and psychiatry came to the fore and this led to a focus on the offender rather than on the offence, on the criminal rather than the crime. The notion of rehabilitation in a pseudo-medical sense was invented. It created a new class of so called delinquents who were categorised as 
moitatt; and socially disadvantaged persons. Punishment, in particular the use of custodial punishment, became increasingly ustified by the notion of controlling and reducing the crime rate and of protecting society against crime. Preventing future criminal conduct by eradicating the roots of the social and mental illnesses of the offender became an important goal of imprisonment. With this rather paternalistic notion of reform which essentially tries to impose an internal change on a human being from outside, the modern $20^{\text {th }}$ century notion of rehabilitation $\boldsymbol{\lambda}$ as bors.

Chapter $2 \mathrm{~d} / \mathrm{d}$, $\mathrm{f} ; \mathrm{s}$, $\mathrm{w}$ this paternalistic and humanitarian notion of rehabilitation or resocialisat

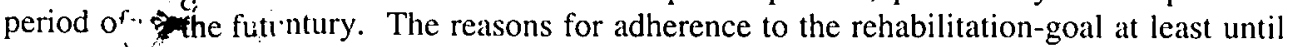
the beginis..s of lli 1980s in the Dutch penal system are strongly based on humane concerns iiiud on the supposed normalising effect of rehabilitation programmes on the prison environment. Rerabilitation in Dutch penal policy implied in particular a practice of humanised prison- zgimes rather than a practice of purposive recidivism-reduction by specific treatment programmes. Chapter 2 also describes the waning of the rehabilitation principle in penal policy during the 1980 s and the rise of a new realism during the last decade of the $20^{\text {th }}$ century.

Finally a historical and juridical description is given of the activities which are perceived to be beneficial to the re-integration of prisoners, that is education, creative activities, individual counse...ing and prison labour. The character of these rehabilitative services is rather non directive and incoherent. The mere supply of activities is supposed to have a beneficial effect on the re-integration of offenders. However, in the case of special re-integration programmes offered to only a small minority of highly motivated offenders a more coherent, specific and systematically planned approach is chosen.

First of all Chapter 3 offers a review of the theoretical research on the concept of attitude. Next the focus is in particular on studies of attitudes of detainees toward the goal of rehabilitation. Research on this subject is relatively scarce. Empirical research which uniquely gathers detailed information about attitudes of Dutch prisoners toward rehabilitation is lacking. The common view in Dutch penology of inmates' attitudes toward rehabilitative efforts is strongly based on interpretations of the deprivation model. Participation of detainees and their attitudes toward the activities are mainly interpreted in the light of the pains of imprisonment. Activities originally meant to be conducive to an effectual return in society, are supposed to be transformed to a remedy for the painful circumstances of incarceration. Moreover activities are supposed to lose their initial rehabilitative aims in favour of becoming an institutional management tool for keeping order and peace. However an empirical basis for the assumptions is lacking.

Particularly on the basis of foreign, mainly Anglo-American research, inmates' attitudes toward rehabilitation may be operationalised as opinions about the goal of rehabilitation as such, and about rehabilitation explicitly related to the context of an incarceration. Attitudes may also be operationalised in the sense of the perception of the activities they are engaged in. Those perceptions may relate to basic and higher needs. Short -term basic needs refer to avoiding or reducing the depressing aspects of confinement like stimulus-deprivation, release of energy, boredom, isolation, coping with stress and so on. Higher needs refer to personal growth, self-actualisation and future life opportunities.

In Chapter 4 the relationship between attitudes on the one hand and personal and environmental background variables on the other hand is examined on the basis of literature. Relevant variables are distinguished and integrated in an interactionist research model which 
refers to the conditions of imprisonment and the way individuals perceive and adapt to these institutional conditions.

The role of rehabilitative activities in the process of adaptation are discussed.

Subjects like the prison as a people-changing organisation, jrisonisation, stress, coping-styles and programme-integrity are examined on the basis of literature. This chapter is concluded with a number of specific research questions about the relationship between the inmates attitudes toward rehabilitation and environmental and personal back \& round variables.

Chapter 5 discusses the design and methods of the study. In 1996 aduit male prisoners of three penitentiaries in the south -east region of the Netherlands were asked to participate in an attitude survey. Two prisons uniquely housed detainees on remand and oine prison housed both detainees on remand and detainees sentenced to a short or a long prison term. A questionnaire with 140 items, in a Dutch and French version, was distributed among the population of the three prisons. Out of the total number of 496 poten al respondents 75 persons were eliminated for reason of absence (transport, over-work, illness, total illiteracy, inadequate command of a West European language, isolation or mental health problems). From the remaining 421 detainees, 226 filled in the questionnaire, which means a response rate of $54 \%$. For prisons a response rate of $54 \%$ is a good result, as much low'er results are not uncommon in the field of correction. A governmental survey in 1992 regarding the detention climate in one of the prisons of our survey revealed exactly the same response-rate. The main reason for using the survey technique refers to gaining insight in the occurrence of certain attitudes toward rehabilitation among a larger group of detainees. This quantitative approach toward attitudes is rather exceptional in penological research. In most studies about attitudes toward rehabilitation mainly qualitative data are gathered among small numbers of respondents. In this study more qualitative data resulting from interviews with inmates and prison personnel were gathered during the explorative period.

One question to consider is whether the respondents of this study were representative of the general population of inmates in the Netherlands. Therefore the background characteristics of the respondents were compared with those of the population in general by using information from the Central Bureau of Statistics and the Policy Information Department of the Dutch prison service. The survey sample is fairly representative for the general population of prisoners in the Netherlands.

To assess the samples attitudes about rehabilitation we included two scales measuring support for rehabilitation, and scales measuring the perception of education, creative activities, individual counselling, recreational activities and prison labour. Since a purpose of this study was to explore the extent to which environmental conditions and individual characteristics are sources of the prisoners' orientations toward rehabilitation, several scales measuring these background variables were also included. Variables such as the perception of the prison regime, future expectations and programme integrity were measured through multiple items. Some of these scales were derived from measures used in previous studies. Data were collected on level of educational attainment, age, marital status, drug abuse, previous incarceration, employment status, ethnic background and length of stay and length of sentence.

Chapter 5 is concluded with a short impression of the organisation and circumstances of life in the selected penitentiaries

Chapter 6,7 and 8 describe the results of the investigation of the nature and sources of the inmates' attitudes toward rehabilitation. 
The opinion: "inmates' towat " goà of rehabilitation as such are predominantly positive. Rehabilitation, a principle of mane detention which offers opportunities for a better future is strong1. 'orsed.

A majority agree. the view that the more support detainees receive during incarceration, the better they wil. in themselves later in society. Any support is considered useful and welcome. Their orien. it loward rehabilitation may be rather summarised by the statement "Anything Works". The view of Nothing Works in rehabilitation is clearly not a popular one among prisoners. Th:s particular view of prisoners on the goal of rehabilitation seems to be rather strongly coloil.ed by the perception of their own position as needy and disadvantaged.

However, a strong , idorsement of the goal of rehabilitation as such does not imply equally strong attempts to ...prove one's situation. Responses on the second opinion-scale measuring the perceived opportunities for change during detention reveal that a minority (nearly $40 \%$ ) is very optimistic c pportunities for reform during incarceration. The attitude of the majority of the re adents towards opportunities for change during detention might be described as moderately negative. Although they are concerned about their future and although attempts 'it improving one's situation are not rejected as entirely meaningless, they are rather scent: and pessimistic about the possibility to improve one's situation during detention. In : $z \wedge$, improving one's situation is considered meaningful but difficult. Also here the prisoners rientation toward rehabilitation differ from the rather popular view of the prison as a complete failure with regard to rehabilitation. Although attempts at improvement during detention may be far from adequate in preventing future criminal behaviour, these attempts still represent valuable steps of personal growth in the perception of the majority of the prisoners.

These cognitive patterns in the opinions of prisoners about the rehabilitation goal are reflected more or less in their participation in the institution 's programme of activities, especially the educational and creative activities. Approximately one third of the respondents admits to participating very often in those activities. About one fifth admits to participating now and then or rarely. Over $50 \%$ had no contact with education or creative activities at all. Almost three quarter of the respondents mention one or more contacts with services in the field of social assistance, probation service, pastoral care and mental health.

The results regarding the prisoners' perception of the activities they are engaged in indicate that the common view of uniquely opportunistic or negative perceptions influenced by deprivation is a rather one-sided view. Avoiding the depressing aspects of confinement like boredom, being out of the cell and reducing tensions played an important role for a minority of the inmates who are involved in education $(20 \%)$ and creative activities $(31 \%)$. For the majority of the respondents education has a positive impact on personal growth aspects such as cognitive interest, improving skills, self confidence, self-knowledge and optimism about the future. A large majority $(88 \%)$ believes education in itself to be a positive and useful activity. However when asked for perceptions of more specific impact on future socioeconomic status the percentage of positive attitudes is lower (46\%)

Creative activities are valued by a majority of the respondents for such reasons as learning something for the joy of learning and opportunities for self-actualisation and self -expression. Perceptions of the services in the field of social work, such as probation service show the considerable impact of de depressing or stressful aspects of being incarcerated. Although a majority considers social work contacts as probably useful for the future, only one third explicitly values these contacts for their personal development, solution of psycho-social problems and a future law -abiding life. In their contacts with social workers the majority of the respondents however stresses the sounding board function, establishing emotional 
stability and solving practical problems relating to th incarcerated.

srect consequer $s$ of being

Furthermore in Chapter 6 the attitudes of prisoners towarc ehabilitation : three prisons housing the sample population. Comparison of avera suggest the influence of the environment in the sense of the organisa'

impared for the iggregate scores ilmate.

Chapter 7 en 8 deal with the description and analysis of the defelw rants of the prisoners' attitudes toward rehabilitation.

The research-model and the research questions formulated in Chapter 4 rrovide the basis for the analysis of the determinants. First of all the analysis clearly show: the presence of a structure in the relationships between the way respondents think about re ${ }^{\prime}$ bilitation and their participation and evaluation with regard to the programme activities. Brieit summarised: the more positive one thinks about rehabilitation the more frequent one participates and the more positive the appreciation of the activities.

Cognitions about rehabilitation, especially the appraisal of opporturin. " for improvement during a detention is the most influential determinant of the participation in activities which are particularly beneficial for the reintegration, that is education, creative activities and individual counselling. Moreover, the perceived importance of the rehabilita ${ }^{-\eta} \eta$ goal as such exerts an influence on the prisoners evaluation of these activities, especially ie aspects of personal growth and advancement.

The importance one attributes to the rehabilitation goal is uniquely influenced by personal factors such as the level of educational attainment and future expectations.

The appreciation of the opportunities for rehabilitation turns out to be directly influenced by both personal and environmental background factors, such as future expectations and the evaluation of the prison regime. An indirect influence is exerted by the level of educational attainment. However, the most influential determinant for the appreciation of the opportunities for rehabilitation is the evaluation of the prison regime. The way prisoners evaluate the regime however is not uniquely the product of situational factors, that is the objective, liberal or restrictive characteristics of the regime. Personal, pre-institutional background factors such as future expectations and educational attainment also determine the way prisoners perceive the regime.

This combination of determinants of personal and environmental origin is equally characteristic for the explanation of the degree of involvement in activities and the way prisoners evaluate the activities with respect to their basic and higher needs. The perception of the regime and of the quality of the implementation of the institutions programme (the so called programme integrity factors) are the most influential determinants of the prisoners evaluation of rehabilitative activities.

The analysis reveals another remarkable pattern, namely the influence of a time variable, that is the time served in prison. The longer one remains in prison the more negative one becomes about rehabilitation. Prisoners during the middle-phase of their incarceration show a tendency of least positive attitudes. The influence of a prisonisation-process seems plausible, although this influence is not uniformly negative for all long term prisoners. Remarkably, of the sample population the most active prisoners with the most positive evaluation of educational and creative activities were found on a special wing for motivated and activity-oriented inmates sentenced to a long prison term. Although their thinking about rehabilitation was rather negative, they placed high value on the personal growth aspects of the activities. For them coping with long-term imprisonment probably meant staying active, sane and avoiding institutionalisation. In contrast, less motivated long term prisoners who were also housed on a special wing and who often struggled with drug-addiction and behavioural problems, showed 
the most negative attitudes toward rehabilitation. Their adjustment to imprisonment meant the predominant use of lower level $\mathrm{m}$ des of coping behaviour. The nature of their attitudes suggest the negative influence $c$. a opposing inmate-subculture and the predominant use of reactions with resentment, apathy "u escape in drug-abuse.

The most positive thinking about : thilitation however is found among detainees on remand who are at the beginni of their prison term. An interpretation of the positive attitudes toward the opportunitie. are at the beginning of shabilitation among a substantial part of the respondents who arceration should focus on the characteristics of this beginning period. It is a well $\mathrm{k}$ : $n$ the fï not only in research but also in the daily practice of prison life, that the event of be ss seriowerated means a moment of crisis and emotional distress in the life of the individual :srizes. In literature this situation is called the 'shock of incarceration'. It is a situation which is often experienced as shocking and humiliating. The prisoner is confronted agairi with his personal history of failure and rejection. He faces a lot of fundamental questions about his (future)life, his social relations and his place in the world. As a reaction many prisoners feel a strong urge to put some order in their life. They are looking for a frame of reference, a hold in their disturbed and ruined lives. Under these circumstances the intention to live a law -abiding life in the future and to change for the better is easilv'made. As Zamble and Porporino (1989) succinctly state: "misery is one of the ber notivators". There may even be a genuine insight that changing one's life is the only c left. Therefore it is not surprising that especially at the beginning of an incarceration de ees favour the idea of rehabilitation. Possibly this period of distress temporarily incites son. inmates to a more effective higher level mode of coping and to a higher amenability for change.

The findings of chapter 6,7 and 8 suggest a modification of the current view of the prisoners' attitudes toward rehabilitation. The nature and source of their attitudes do not point to an uniformly negative opportunistic and negative character, nor to a predominant negative influence of the pains of imprisonment. Although their attitudes bear a clear mark of their adaptation to the painful circumstances of incarceration, explanation of their attitudes by a indigenous-origins model does not speak for itself. Personal background factors which refer to a direct-importation model also play a role. The research-model which essentially refers to an integration of both an indigenous and importation model turns out to be a more plausible model for the explanation of the prisoners' attitudes toward rehabilitation. Finally the role of the personal background factors should not be underestimated. Prisoners' cognitions, especially the way they estimate their opportunities for change are in part the product of individual characteristics which are independent of factors in the prison environment. They enter the prison with predispositions which are already more or less favourable for their orientation towards self-improvement. This is what might be called motivation. This particularly implies that each intervention by means of the institutions programme of rehabilitation amounts to reinforcing or encouraging an already existing amenability to change. A low amenability to change presupposes a more intensive modification of the prison-environment. In the case of the sample population of whom over $50 \%$ of the respondents stayed rather passive, a more supportive regime will probably not sufficiently activate them. More intensive encouragement by means of special programmes directed at cognitions with respect to self-improvement and higher level modes of coping behaviour will be required.

In Chapter 9 the literature regarding the correctional orientation of the prison personnel is discussed. In addition the design and results of the attitude-survey among the prison 
personnel are presented. The level of prison guards', teachers' and probation officers' support for rehabilitative ideology is remarkably high, especi; ly when one considers the past decade's assault on the treatment ideal by politicians, $r$ ninal justice policy- makers, and academic criminologists. Although prison guards see mair laining order as a core feature of their role they also believe in the potential of prison proor mes directed at the rehabilitation of offenders. Although both prison guards and members of the pre ' ional staff believe that prisoners will not be changed in law-abiding citizens by the inst; they highly value those activities. Remarkably this appreciation. pragmatic and managerial arguments. Although prison gua beneficial for a constructive and orderly enforcement of impri. services are also valued for their contribution to a process : pursunal growth and , programme activities, iniquely grounded in countive: der the activities advancement. Both guards and members of the professionat staff embrace a rather liberal view of rehabilitation. Poor outcomes in recidivism are irrelevant for the - ison personnel's orientation towards rehabilitation. Irrespective of these poor outcomes thev hold a positive view on rehabilitation. All this points to a view in which the appreciatior of the first and often small steps in a complex and difficult process of self-improvement p'ay an important role. It implicitly points to a humane and realistic view on rehabilitation. A humane prison presupposes a new chance for those who are in need of it and effective rehabilitition includes efforts which go beyond the realm of a single correctional intervention.

In Chapter 10 the main findings of the study are summarised and final conclusions . recommendations are presented.

In the concluding remarks the meaning of the rehabilitation goal for the present era is examined in the context of the results of the study. As in the introductory chapter a normative, penological and organisational point of view serve as a guideline.

The results of the study clearly indicate that from a normative, humane point of view rehabilitation is a rewarding principle. The way prisoners perceive rehabilitation and its related activities reveal an important function of this goal. Rehabilitative activities enable them to discover the possibility of personal growth that is of positive and new values in a rather hopeless situation. It offers a new chance to those who sincerely try to move from the bottom of the social barrel. This possibility for self-improvement is the very basis of hope. In offering instead of denying the possibility of hope the penal system reveals its humane and moral intent. The attitudes of prisoners reveal the viability of rehabilitation as a principle which emphasise the humane treatment and protection of offenders against total social exclusion.

Also from an organisational point of view in particular from the penal policy of an adequate care which limits the harmful effects of detention the results of this study emphasise the value of rehabilitation. Rehabilitation and its related activities perform a positive function in an essentially negative and detrimental environment. By mobilising capacities and personal growth of the inmates it offers a counterbalance for attacks on the personal autonomy of the prisoner by the prison system. Briefly summarised, rehabilitation contributes to the psychosocial quality of the detention -climate by offering a positive modus for adaptation to an environment which may be harmful.

From a penological point of view the findings of this study offer a valuable contribution to the research on the effectiveness of rehabilitation programmes. By analysing the determinants of the attitudes of prisoners toward rehabilitation we got to the core of the matter. Prisoners' motivation for rehabilitation show a clear relationship with cognitions about the possibilities for changing one's life. If we want to mobilise prisoners in favour of rehabilitation and keep them motivated and well-armed against the negativism of prisonisation, programmes should 
focus on cognitions and coping abilitic.s. Creating more liberal and supporting prison-regimes will probably be not enough. The : ;ults of the study show the importance of the timing of correctional intervention. If motivat, on for change is highest at the beginning of a term one should capitalise on this opportinity. In institutional practice however restrictions with respect to adequate rehabilitative services are highest during the beginning of a term. And with this we touch an important weakness of the Dutch practice of rehabilitation, that is its apparent lack of purposiven. ss with respect to the reintegration of the majority of offenders. In spite of the praiseworthy intention of creating a supportive and humane regime and of supplying services: the field of education and probation, the current Dutch practice of rehabilitation reve serious shortcomings in the field of the quality of programmatic and non-programmati, peits.: Chapter 10 offers recommendations for the development of a more rational and ifective practice of rehabilitation.

Finally an important conclusion is that the nature and sources of the attitudes of prisoners and prison personnel suggest a potential which is worth to be taken seriously. As it is shown in this chapter putting this potential down by referring to poor outcome measures or to the notorious 'Nothing Works' adagium is untenable from a scientific, humane and normative point of view. A realistic and evidence- based view on rehabilitation and its proper role for penal policy is formulated. 


\section{Literatuur}

Adams, K., K. J. Bennetl, T. J. Flanagan, J. W. Marquart, S. J. vuvelier, E. Fritsch, J. Gerber, D. R. Longmire, \& V. S. Burton, Jr. (1994). A large-scale Multidimensional test of the effect of education programs on offenders' behavior. The Prison J....nal, Vol. 74, No. 4, December, p. 433-449

Ajzen, I. (1993). Attitude Theory and the Attitude-Behavior Relation.In: Krebs, D. \& Schmidt, P., (eds.), New Directions in Attitude Measturement. Berlijn, de Gruyter

Akers R.. N. S. Hayner \& W. Gruninger (1977). Prisonization in five countı., type of prison and inmate characteristics. Criminology, jrg. 16, No. 4. p.527-554

Alpert, G. P. (1979). Patterns of change in prisonization: a longitudinal analysis. 'riminal Justice and Behavior, No. 6. p.159-174

Andrews D. A.. L. Zinger, R. D. Hoge, J. Bonta, P. Gendreau \& F.T. Cullen (1990) (1). Does correctional treatment work? A clinically relevant and psychologically informed meta-analyses. Criminology. Vol. 28, No. 3, p.369-404

Andrews. D. A., J. Bonta \& R. D. Hoge (1990) (2). Classification for effective rehabilitation. Criminal Justice and Behavior, Vol. 17, No. 1. March, p.19-52.

Antonowicz, D. H. \& Ross, R. (1994). Essential Components of Succesful Rehabilitation Programs for Offenders. International Journal of Offender Therapy and Comparative Criminology, Vol. 38, No. 2, p.97-105.

Atchley, R. C. \& M. P. McCabe (1968). Socialization in correctional communities: a replic.:tion. American Sociological Review, jrg. 33, p.774-785.

Bentler. P. M. (1992). EQS Structural Equations Progran Manuel. Los Angeles: University of California.

Berghuis, A. C. (1981). De Sprang, evaluatie van een bijzonder regiem in een jeugdhuis van bewaring. 's Gravenhage: Staatsuitgeverij

Berghuis, A. C. \& J. J. A. Essers (1986). Criminaliteitsbestrijding en publieke opinie. Tijdschrift voor Criminologie, jrg. 28, p.159-179.

Berk. B. B. (1966). Organizational goals and inmates' organization. American Journal of Sociology, $7 /$ (March). p. 522-534.

Besier, E. J. (1986). Honderd jaar gerangenisarbeid. In: Vrijheidsstraf, van de nood een deugd maken?' 's Gravenhage: Ministerie van Justitie, Directie Gevangeniswezen

De Beer, A. P. G., \& G. J. Ploeg (1994). Een reclassering op vernieuwde leest. Justitiële verkenningen, afl. 4, p. 9-21.

Blokland, L. J. (1974). Werken achter Tralies: een onderzoek naar de positie van bewaarders in 33 Nederlandse strafinrichtingen. Arendonk: Albora.

Boin. A. (1995). Het gevangeniswezen: naar een nieuwe balans tussen centrale controle en autonomie van inrichtingen. Sancties, afl. 3, p.147-162.

Boin. A. (1998). Contrasts in Leadership, (Dissertatie) Delft: Eburon Publishers.

Boin. A. (1999). Bezuinigen met behoud van kwaliteit? Justitiele verkenningen, jrg. 25, nr. 1, p.24-34

Bol, M. W. (1995). Gedragsbeünloeding door strafrechtelijk ingrijpen. Een literatuurstudic. Arnhem: Gouda Quint.

Boshier, R. (1983). Education Inside: Motives for Participation In Prison Education Programmes. Vancouver, British Columbia: British Columbia University.

Bowker, L. H. (1977). Prison Subcultures. Lexington: Lexington Books.

Brand- Koolen, M. J. M. \& J. J. Overwater (1985). Reclasseringshulp onder spanning. Justitiële Verkenningen, Reclasseringsnummer, p.5-47.

Brand-Koolen, M. J. M. (1997). Twee decennia reclassering. Proces, nr. 6, p. 111-114.

Brouwers, M. \& M. Sampiemon (1988). Vrouwen in detentie. 's Gravenhage, Ministerie van Justitie / WODC. 
Bukstel, L. H. \& P. R. Kilmann 1900). Psychological effects of imprisonment on confined individuals. Psychological Revien, 88 , p.469-493.

Bulten, B. H. (1991). De borderline-si', 'nutu als metafoor voor de beschrijving van de penitentiaire organisatie.Sancties, afl.2, p.78

Burns, G. (1998). A Perspective on Policy and Practice in the re-integration of offenders.European Journal on Criminal Po!ir . Research, Vol. 6, No. 2, p.171-183.

Caminada, H. P.G. M. (1973). Het PTK-evaluatieonderzoek.Nijmegen: Schippers.

Conrad, J. P. (1981). A lost ideal, a new hope: the way toward effective correctional treatment. The Journal of Crimunal Law \& Criminology, Vol. 72, No. 4, p.1699-1735.

Clemmer, D. (1940,1 . The Prison Community. New York: Holt, Rinehart and Winston.

Cloward, R. A. (196\%. . scial Control in the Prison. In: L. Hazelrigg, (ed.), Prison within Society. Garden City: D. Jleday

Cressey, D. (1959). Contradictory directives in complex organizations: the case of the prison. In: Hazeirigg L. (ed.), Prison within Society. Garden City: Doubleday.

Cressey, D. (1960). Limitations on Organization of Treatment in the Modern Prison. In: Theoretical Studies in the Social Organization of the Prison. New York: Social Science Research Council.

Cullen F.T. \& $\mathrm{Y}$ `. Gilbert (1982). Reaffirming Rehabilitation. Cincinnati: Anderson Publishing.

Cullen, F. T., E.Lutze, B. G. Link \& N.T. Wolfe (1989). The Correctional Orientation of Prison Guards: J Officers Support Rehabilitation? Federal Probation, nr.l, Maart, p.33- 42.

Denkers, F. A. C. M. (1976). Criminologie en Beleid. Nijmegen: Dekker \& van de Vegt.

$\checkmark$ Derks, F. C. H. (1991). Resocialiseren-reclasseren-rehabiliteren.Proces, m.10, oktober, p.273-285.

Dhondt, J. (1989). Psycho-Sociale kwaliteitsbewaking binnen het gevangeniswezen in ontwikkeling. In: Psycho-sociale kwaliteit van de detentie. ‘s-Gravenhage: Ministerie van Justitie.

.ondt, J. (1991). Gevangeniswezen: de ene deconcentratie is de andere niet. Sancties, jrg. 2, $\mathrm{mr} .2$, p.65-67.

Dhondt, J. (1993). Taak en Toekomst op z'n kop?'Sancties, af7. 3, p.143 - 147.

Dijksterhuis, F. P. H. (1973). De Gevangenis Bankenbos II. Assen: Van Gorcum.

Elting, L. (1994). Werkzame Detentie.Justitiële verkenningen, jrg. 20, nr.2, p.84-94.

Emmerik, J. L. van (1983). Behandeling als straf, of straf als behandeling? Justitiële verkenningen, $n r .4$, p.5-48.

Faine, J. R. (1973). A self-consistency approach to prisonization. Sociological Quarterly, No.4, p.576588.

Feld, B. C. (1981). A comparative analysis of organizational structure and inmate subcultures in institutions for juvenile offenders. Crime and delinquency, jrg. 27, No.3, p.336-363.

Fiselier, J. (1969). Open gesticht en recidive. Nijmegen: Criminologisch Instituut.

Fiselier, J. (1998) (1). Lang leve de reclassering. Sancties, afl. 4, p.205- 209.

Fiselier, J. (1998) (2). Krijgt de delinquent de straf die hij verdient? In : K. Schuyt \& M. Kommer, Niet bij straf alleen. Amsterdam.

Flanagan, Th. J. (1983). Correlates of institutional misconduct among state prisoners: a research note. Criminology, jrg. 21, nr.1, p.29-39.

Folkman, S., R. S. Lazarus, C. Dunkel- Schetter, R. J. Gruen \& A. De Longis (1986). Dynamics of a stressfull encounter: cognitive appraisal, coping, and encounter outcomes. Journal of Personality and Social Psychology, 50, p. 992-1003.

Franke, H. (1990). Twee eeuwen gevangen. Utrecht: Het Spectrum

Franke, H. (1991). De golfslag van het gevangeniswezen. Sancties, afl. 6, p.345- 357.

Garabedian, P.C. (1963). Social roles and processes of socialization in the prison community. Social Problems, 11, p.139-152.

Garabedian, P. C. (1964). Social roles in a correctional community. Joumal of Criminal Law, Criminology and Police Science, 55, p.235-247. 
Garland. D. (1990). Punishment and Modern Society: A Study 'n Social Theory. Oxford: University Press.

Gendreau, P. \& R. R. Ross (1979). Effective Correctional Tre nent: Bibliotherapy for Cynics. Crime and Delinquency, 25, p.463-489.

Gendreau, P. (1996). The principles of effective interventions with offenders. In: A.T. Hartland (Ed.), Choosing correctional options that work: Defining the t tand evaluating the supply. California: Sage publications.

Glover, J.W., \& E. W. Lotze (1989). Prison Schooling: Who Gets Educated? Journal of Correctional Edacation 40. No.3, p.108-114.

Goffman, E. (1961). Asylums: Essays on the Social Situation of mental Pationts and Other Inmates. Anchor: Garden City, NJ.

Grapendaal, M., B. v.d. Linden \& A. Rook (1985). Regiem in ontwikkeling. . ' avenhage: Ministerie van Justitie / WODC.

Grapendaal, M. (1987). In dynamisch evenwicht. 's Gravenhage: Ministerie van Justitie / WODC.

Grizzle, G.A. \& A.D. Witte (1980). Criminal Justice Evaluation Techniques: Methods Other than Random Assignment. In: M. W. Klein \& K.S. Teilmann (Eds.), Handbook of Criminal Justice Evaluation. Beverly Hills: Sage Publications.

Grusky, O. (1959). Role Conflict in Organization: A Study of Prison Camp r^icials. In : L. Hazelrigg (ed.), Prison within Society, Garden City: Doubleday.

Haan, W. J. M. de (1990). The Politics of Redress: Crime, Punishment and Penal Abolition. London: Unwin Hyman.

Haen Marshall, I. (1994). Zet ze maar achter tralies. In: NRC-Handelsblad ,8-9-1994.

Hamm, M. S. \& J. L. Schrink (1989). The conditions of effective implementation. Criminal Justice and Behavior, Vol.16, No.2, June, p. 166-182.

Hart, A.C.'t (1993). Totale instituties en het totalitaire. Arnhem: Gouda Quint.

Hawkins, G. (1976). The Prison: Policy and Practice. Chicago: University of Chicago Press.

Helgers, H. (1993). Gevangenisbewaarders hebben heimwee naar 'oude eerlijke boef'.In: NRCHandelsblad, maart 1993.

Hepburn, J. R., \& J.R. Stratton (1977). Total institutions and inmate self-esteem.British Journal of Criminology 14: p.150-157.

Herbschleb, M.D. \& F.Zorge (1992). Hoe zit het met de kwaliteit van de detentie in de Geerhorst? 'sGravenhage: Ministerie van Justitie, D. en J., Beleidsinformatie.

Hoeven van der Th. (1986). Beeldende vorming, een jonge loot. In: Vrijheidstraf, van de nood een deugd maken? p. 93-107. 's Gravenhage, Ministerie van Justitie, Directie Gevangeniswezen

Hooff van, M.D.M. \& R. M. van Zeijl (1984). Tussentijds evaluatie-onderzoek Kadertrainingen creatieve vaardigheden. Leiden: vakgroep Sociale Psychologie.

Hoogenboom, F. J. M. (1991). De penitentiaire inrichtingswerker, een echte professional? Sancties, jrg. 2, $m$ r.2, p. $91-101$.

Hurk, A. A.van den (1998). Tussen de helpende en harde hand (Diss.).Katholieke Universiteit Nijmegen.

Innes, C. A. (1993). Recent public opinions in the United States toward punishment and corrections. The Prison Journal, jrg.73, nr.2, p. 221-136.

Irwin, J., \& D. Cressey (1962). Thieves, convicts, and the inmate culture. Social Problems, 10, p.142155.

Irwin, J. (1970). The Felon. Englewood Cliffs: Prentice Hall.

Irwin, J. (1980). Prisons in Turmoil. Boston: Little Brown.

Ittelson, W. H., H. M. Proshansky, L. C. Rivlin \& G. H. Winkel (1974). An Introduction to Environmental Psychology. New York: Holt, Rinehart \& Winston.

Jacobs, J., (1976). Stratification and conflict among prison imates. Journal of Criminal Law and Criminology, 66, p.476-482. 
Janse de Jonge J. A. (1991). Om de persoon san de dader. (Diss.). Arnhem: Gouda Quint.

Janssen, J. (1999). Laat maar zitten: Een exploratief onderack nadr de werking lan de korte rrijheidsstraf (Diss.) Groningen: Rijksuniverstiteit Groningen.

Jensen, G. F. \& D. Jones (1976). Perspectives in immate culture: a study of women in prison. Social forces $54:$ p.590-603.

Jonge, G. de (1994). Strafwerk: over de arbeidsverhouding unssen gedetineerden en Justitie. (Diss.). Breda: Uitgeverij Papieren Tijger.

Jonge. G. de (1995). De rol van de arbeid in het nieuwe standaardregime. Sancties, aff.2. p.71-76.

Jonge - de, R. Verpalen \& H. Creemers (1999). Bajesboek: Handboek roor gedetineerden en ter be. $\quad$ resestelden. Breda: Uitgeverij Papicren Tijger.

Junger- 1. . ', Verniewwing en behoudzucht in het strafrecht: de ontwikkeling van alternatieve. if de celstraf. Justitiele verkenningen, jrg. 20, m.2, p.22-48 .

Kauffman, K. (1988'. Prison Officers and their World. Cambridge: Harvard University Press.

Kelk. C. (1993) (1). Kort begrip van het detentierecht. Nijmegen: Ars Aequi Libri. 3e druk.

Kelk. C. (1993) (2): Het gevangeniswezen in de gevarenzone?' Delikt en Delinkwent. 23, Af1.3, p.195202.

Kelk, C. (1993) 3). Het grote belang van een goed gestructureerde en rijke detentiefasering. Sancties, af7.2. p.69-82.

Kelk, C. (1998). De reclassering van gedetineerden. Delikt en Delinkwem, 28 , af7.5 p.421-426.

Kleber. R. J. (1982). Stressbenaderingen in de psychologie. Deventer: van Lochun Slaterus.

Klofas, J. \& H. Toch (1983). The Guard Subculture Myth. Joumal of Research in Crime and Delinquency, $19, n r .2$, p.238-254.

Knol, R. (1997). Pastorat binnen Werkzame Detentie. Sancties, af7.5. p.269- 284.

Kolstad. A. (1996). Imprisonment as Rehabilitation: Offenders' assessment of why it does not work. Joumal of Criminal Justice, Vol.24, No.4, p.323-335.

Kommer, M. (1991). De gevangenis als werkplek, (Diss.). Arnhem: Gouda Quint.

\Konink M. de \& P. Schepers (1998). De publieke opinie over resocialisatie van misdadigers. Tijdschrift voor Criminologie,afl.3 p.257-273.

Krisberg, B. (1980). Utility of Process Evaluation: Crime and Delinquency Programs. In: M. W. Klein and K. S. Teilmann (eds.), Handbook of Criminal Justice Evaluation. Beverly Hills: Sage.

Kuitenbrouwer, F. (1993). Reclassering in het verdomhoekje. In: NRC-Handelsblad, 18-9-1993.

Lazarus, R. S. \& R. Launier (1978). Stress related transactions between person and environment. In: L.A. Pervis \& M. Lewis (Eds.) Perspectives in interactional psychology. New York: Plenum Press.

Linden. B. van der (1981). Middellanggestrafien; een vergelijking ran twee gevangenisregiems. 'sGravenhage: Ministerie van Justitie / WODC.

Logan, C. H. \& G. G. Gaes (1993). Meta-analysis and the rehabilitation of punishment. Justice Quarterly, Vol.10. No.2, June, p. 245-264.

Lombardo, L.X. (1981). Guards Imprisoned: Correctional Officers at Work. New York: Elsevier North Holland.

Lösel, F. (1996). Changing patterns in the use of prisons: an evidence-based perspective. European Journal On Criminal Policy and Research, Vol.4. No.3, p. 108-128.

Love, G. D. (1991). Considerations of the Inmate Locus of Control for Effective Instructional Leadership. Journal of Correctional Education .42(1): p.36-41.

Martin, S. E., L. B. Sechrest \& R. Redner (1981). New Directions in the Rehabilitation of Criminal Offenders. Washington: National Academic Press.

Martinson, R. (1984). What Works?- Questions and Answers about Prison Reform. Public Interest. Spring, p.22-54.

Melk, G. D. (1985). Resocialisatie in de gevangenis.Delikt en Delinkwent, 15 afl.8. p.749-766. 
Melk, G. D. (1993). Is resocialisatic in de gevangenis mogelijk? Delikt en Delinkwent, 23, aft.8, p.780-792.

Miller, S., \& S. Dinit\% (1973). Measuring institutional impact,a follow-up.Criminology, 11, p.417426.

Moerings, L.M.(1978). De gevangenis uit, de maatschappij in. De gevangenis en haar betekenis voor de sociale kontakten van ex-gedetineerden. (Diss.) Alphen aan den Rijn: Samsom.

Moerings, L. M. (1984). Recente ontwikkelingen in gevangeniswezen.Delikt en Delinkwent, 14, afl. 3, p. $220-236$.

Moerings, L M. (1990). Detentie: een schadevrij onderkomen?Proces, nr.3, p.57-63.

Moerings, L. M.(1992). Totale institutie. Tijdschrift voor Criminologie, nr. 1, p.58-61.

Moerings, L. M. (1993). De sleutelpositie van de gevangenisdirecteur. In: J. A. J- : je, L. M.
Moerings, A. van Vliet (Eds.). Bimnen de steen van dit bestaan. Arnhem: Gr zumnt.

Ohlin, L. E. (1958). The reduction of Role-conflict in Institutional Staff. In: Hazeirigg L. (ed.) Prison within Society. Garden City: Doubleday.

Otte, M. (1997). Taakstraffen en reclassering nieuwe stijl.Sancties, afl. 2, pp.83-95.

Palmer, T. (1975). Martinson revisited. Journal of research in crime and delinqu.ncy, jrg. 12, july, p.133-152.

Palmer, T. (1991). The effectiveness of intervention: recent trends and current issues. Crime and Delinquency, vol.37, no.3, july, p.330-346.

Palmer, T. (1994). A profile of correctional effectiveness and new directions for research. New York: State University of New York Press

Parker, E. A. (1990). The Social-Psychological Impact of a College Education on the Prison Inmate. Journal of Correctional Education, 41, nr. 3, p.140-146.

Parsons, M. \& M. Langenbach (1993). The Reasons Inmates Indicate they Praticipate in Prison Education Programs: Another look at Boshier's PEPS. Journal of Correctional Education, 44, (1), p.38-41.

Patterson, W. (1988). Changing Philosophies and Prison Management. Australian and New Zealand Journal of Criminology, 21, p.214-227.

Poole, E. D., R. M. Regoli \& Ch. W. Thomas (1980). The measurement of of inmate social role types: an assessment. Journal of Criminal Law and Criminology, 71 : p. 317-324.

Pugh, D.N. (1993). The effects of problem Solving Abilty and and Locus of Control on Prisoner Adjustment. International journal of Offender therapy and Comparative Criminology, 37, $n$ r.2, p.163-176.

Quay, H.C. (1977). The three faces of evaluation.Criminal Justice and Behavior, Vol.4, No.4, p.341355.

Rijksen, R. (1958). Meningen van gedetineerden over de strafrechtspleging. Assen: Van Gorcum.

Rijksen, R. (1967). Vijf jaar tot levenslang, langgestraften in de gevangenis te Breda. Alphen aan de Rijn: Samsom.

Rijsman, J. (1981). Sociale motivatie, In : J.M.F. Jaspars \& R. van der Vlist ( Red.), Sociale Psychologie in Nederland. Deel 1: Het individu. Deventer: Van Lochum Slaterus.

Rood-Pijpers, E. B. M., (1988). Mensen over misdaad en straf (Diss.).Arnhem: Gouda Quint.

Rood-Pijpers, E. B. M. \& L. Combrink-Kuiters (1991). Gelet op de reclassering. Arnhem: Gouda Quint.

Rook, A. (1983). Subculturen in penitentiaire inrichtingen.Justitiële verkenningen, nr.10, p.5- 39.

Ross, R. R., E. A. Fabiano \& C. D. Ewles (1988). Reasoning and Rehabilitation. International Journal on Offender Therapy and Comparative Criminology, 32, p.29-36.

Ryan, T.A. (1991). Literacy Training and Reintegration of Offenders. Forum on Corrections, 3, no.1, p. 17-23.

Schwartz, B. (1971). Pre-institutional vs. situational influence in a correctional community. Journal of 
Criminal Law, Criminology, and Police Science, 62: p.530-545.

Schuyt, K. (1998). Binding en perspectief: de toekomst van de reclassering. In: Schuyt, K \& M. Kommer (Eds.). Niet bij straf alleen. Amsterdam: University Press.

Sechrest, L., S. O. White \& E. D. Brown (1979). The Rehabilitation of Criminal Offenders Problems and Prospects. Washington: National Academy of Sciences.

Schrag C. (1961). Some foundations for a theory of corrections. In: D. Cressey (ed.), The prison : Studies in Institutional Organization an Change. NewYork: Holt, Rinehart and Winston.

Serge, V. (1977). Men in p son. London: Writers and Readers Publishing Cooperative.

Speldenbrink, B. (1994). Reclassering nieuwe stijl, te veel doel, te weinig middel.Justitiële Verkenningen, afl, p.63-71.

Spickenheuer, J. L. P 984). Het reclasseringswerk: visies van clienten en maatschappelijk werkers op het hulpverle

Steenhuis, D.W. (19'p xijden onder invloed. Assen: Van Gorcum.

Stokkom, B.A.M. v: , 1999). Pragmatisch sanctiebeleid.Justitële Verkenningen, jrg. 25, nr.6, p.4156.

Street, D., R.Vinter and Ch. Perrow (1966). Organization for Treatment. New York: Free Press.

Van Swaaningen, R. \& G.de Jonge (1995). The Dutch Prison System and Penal Policy in the 1990s: from Humanitaria: Paternalism to Penal Business Management. In: V.Ruggiero, M.Ryan \& J. Sim (eds.), Western European Penal Systems. A critical Anatomy. London: Sage Publications.

Sykes, G. M. 1 1958). The society of captive. Princeton: Princeton university press.

Sykes ¿., S.L. Messinger (1960). The inmate social system.In: R. Cloward et al. (eds.), It retical Studies in Social Organization of the Prison. New York: Social Science Research council.

ittle, C. R. (1972). Institutional living and self-esteem. Social Problems, 20, p. 65-77.

Thomas, Ch.W., (1977) Theoretical perspectives on prisonization: a comparison of the importation ans deprivation models. Journal of Criminal Law and Criminology, 68; p.135-145.

Thomas, Ch. W. \& S.C. Foster (1972). Prisonization in the inmate contraculture. Social Problems, jrg. 20,nr. 2, p.229-239.

Thomas, Ch. W. \& E. D. Poole (1975). The consequences of incompatible goal structures in correctional settings.International Journal of Criminology and Penology 3: p.27-42.

Thomas,Ch.W. \& D. M. Petersen (1977). Prison organization and immate subcultures. Indianapolis: Bobbs-Merrill.

Thomas, Ch. W. , D. M. Petersen \& R. M. Zingraff, (1978). Structural and social psychological correlates of prisonization. Criminology, jrg. 16, nr.3, november, p.383-393.

Thomas Ch. W. \& M. T. Zingraff (1976). Organizational structure as a determinant of prisonization. Pacific Sociological Review 19: p.98-116.

Toch, H. (1977). Living in Prison: The Ecology of Survival. New York: Macmillan.

Tootoonchi, A. (1993). College education in prison: The inmates 'perspectives. Federal Probation, 57, No.4, p. 34-40.

Troyer, J. C. \& D.E. Frease (1975). Attitude change in a western Canadian penitentiary. Canadian Journal of Criminology and corrections 7; p.250-262.

Tulkens, J.J.J (1988). Graden van Vrijheid, oratie. Arnhem: Gouda Quint.

Tulkens, J.J.J. (1991). Vanuit het oogpunt van de gevangene. In: Th.van Veen en G. van Essen, Sanctietoepassing: een nieuwe ordening. Opstellen aangeboden aan G.H. Veringa, Amhem: Gouda Quint.

Tulkens, J.J.J.(1992). Straftijd: toegemeten en uitgezeten. Justiriele verkenningen, afl.3, p.8-31.

Tulkens, J.J.J. (1994). Koersen of laveren; over de nieuwe vrijheidsstraf en haar hindernissen. Sancties, afl.4, p.238-251.

Tulkens, J.J.J. (1999) Gevangenissen in de 21 ste eeuw. Justitiële Verkenningen,jrg. 25,nr.l, p.87-98

Vegter, P.C. (1984). Gevangenisstelsels. Justitiele verkenningen, nr.10, p.29-43. 
Vegter, P.C., (1989). Vormen van detentie, (Diss.). Arnhem: Gouda Quint.

Vegter, P.C., (1990). Deconcentratie: enkele voorwaarden en gevolgen. Sancties, afl.4, p.189-193.

Verhagen, J.J.L.M. (1999). Het Nederlandse gevangeniswezen, uitgebreid en ingeschikt. Justitiële verkenningen, jrg. 25 inr.l, p. 9- 24.

Veringa, G.H., (1964). Het gevangeniswezen in de branding, openbare les. Nijmegen: Dekker \& van de Vegt.

Veringa, G.H., (1966). Integratie van strafrechtelijk beleid. Nijmegen: Dekker \& van de Vegt.

Veringa, G.H., (1990), Ons een zorg. Sancties, af7.4, p.204-210.

Van Voorhis, P. (1987). Correctional Effectiveness: The High Cost of .gnoring Success. Federal Probation, Maart, p. 56-63.

Wellford, C. (1967). Factors associalted with adoption of the inmate coc socializtion. Journal of Criminal law, Criminology and Policie Science,

study of normative ग.197-203.

Wentink, P.P.L.J. (1993). Vastgelopen jeugd; onderzoek ,opvoeding en beh. :ling in de justitiële jeugdinrichtingen. Sancties, af7.3, p.157-167.

Winfree, L.T., G.L. Mays, J.E. Crowley \& B.J. Peat, (1994). Drug History and Prisonization; Toward understanding Variations in Inmate Institutional Adaptations. International Journal of Offender Therapy and Comparative Criminology, 38, (4), p.281-296.

Warren, M.Q. (1977). Correctional treatment and coercion: The differential effectiveness perspective. Criminal Justice and Behaviour, 4, p.335-376.

Wiewel, P. G. (1994). Onwerkbare detentie. Sancties, afl.1, p.8-21.

Whittington, J. (1994). Lifers, long-term prisoners and education. Prison Service Journu $\wedge .96$, nov., p.49-51.

Winters, C. A. (1995). Inmate opinions toward education and participation in prison educa. programmes. The Police Journal, 68, No.1, p.39-50.

Wright, K. N. (1991). A study of individual,environmental, and interactive effcts in explaining adjustment to prison. Justice Quarterly, Vol.8, No.2, June, p.217-243.

Zald, M. (1962). Power Balance and Staff Conflict in Correctional Institutions. In: L. Hazelrigg (ed.), Prison within Society. Garden City: Doubleday.

Zande van der, R. (1991). Stuurmanskunst in penitentiaire inrichtingen. Sancties, jrg.2, nr.2, p.102108.

Zamble, E. \& F.J. Porporino (1988). Coping, behavior and adaptation in prison inmates. New York: Springer.

Zamble, E. \& F.J. Porporino (1990). Coping,Imprisonment and Rehabilitation. Criminal Justice and behavior, Vol.J7, No.1, March, p.53-70.

Zingraff, M.T. (1975). Prisonization as an inhibitor of effective resocialization.Criminology, 13, nr.3, november, p.366-389.

Zingraff, M.T. (1980). Inmate assimilation; a comparison of male and female delinquents. Criminal Justice and Behavior, 7: p. 275-292.

Van Zutphen J.G.J. (1986). Penitentiair ondenvijs vroeger en nu. In: Vrijheidsstraf, Van de nood een deugd maken?' 's Gravenhage: Ministerie van Justitie, Directie Gevangeniswezen.

Zwering, A. (1989). Vrouwen in detentie.Nemesis, 2.p.48-54.

Zwezerijnen, J.J.A. (1972). Dwang en Vertrouwen. Alphen aan de Rijn: Samsom. 


\section{Rapporten, nota's en verslagen}

Commissie Fick (1947). Rapport v" « commissie voor de verdere uitbouw van het gevangeniswezen. 'sGravenhage: Minio" yan J. ,tie, Staatsdrukkerij

Commissie s'Jacob (19 appor. van de commissie voor de bouwkundige voorzieningen vam het gevangenisweze; "„ederlandse gevangenissen en haar noodzakelijke verbeteringen. 's Gravenhage: Minist van Justitie/ Staatsdrukkerij.

Gevangenisnota (1964). . Nederlandse gevangeniswezen; nota over het Nederlandse gevangeniswezen aangeboden doori Minister van Justitie aan de Tweede Kamer der Staten-Generaal. 's Gravenhage: Staatsdrukkerij-e, "itgeverijbedrijf.

Nota Beleidsvraagstukkèn Gevangeniswezen (1976). 's Gravenhage, kamerstuken, TK-14 102, nrs. 1-2.

Commissie van Hatt $\eta$ (1977). Rapport van de commissie doelstelling en functie huis van bewaring. 'sGravenhage: 1 ' listerie van Justitie, Staatsuitgeverij.

GIS-nota (1981). Nc :i inzake een herziene Gestandaardiseerde Inrichtingsstructuur en de funktie van de Inrichtingswerkèr. 's Gravenhage: Ministerie van Justitie/ DGW

Nota Taak en Toekomst van het Nederlandse Gevangeniswezen (1982). 's Gravenhage: kamerstukken, TK, 17539,nrs. I-2.

RAP-Nota (1983) Vota inzake de ontwikkeling van een Regiems Activiteiten Programma (concept). 'sGravenhage: Ministerie van Justitie, DGW.

Nota Werkza'ie Detentie (1994). 's Gravenhage, kamerstukken, TK 1993-1994, nrs. 10-11.

Rapport van de projectgroepen, 2e fase Werkzame Detentie, aangeboden an de Tweede kamer (1997). 'sGravenhage: DJI.

Raamleerplan Penitentiair Ondenvijs (1987). Amersfoort: Studiecentrum Volwasseneneducatie/ .nisterie van Justitie, DGW.

L'it de bak, aan de bak? Beroepsgerichte educatie en detentie (1987). Amersfoort: Studiecentrum 'olwasseneneducatie/ Ministerie van Justitie, DGW.

witie Kunstzinnige Vonning (1993). Utrecht: DGW/ LOKV.

Jaanverslag van Adviseurs Sociaal-cultureel werk (1992). 's Gravenhage: Ministerie van Justitie, DGW.

Gemotiveerd Kiezen, strategisch meerjarenplan Reclassering Nederland (1996-1999) (1996). Den Bosch: Reclassering Nederland.

Blauwdruk "De reclassering in breder perspectief" (1993). Den Bosch: Reclassering Nederland.

Reclasseringsregeling (1995). Den Bosch: Reclassering Nederland.

Gevangenisstatistiek (1995). Voorburg: Centraal Bureau voor de Statistiek.

Yearbook of Correctional Education (1993). Correctional Education Association / Center for the Study of Correctional Education. San Bernardino: California State University.

Gedetineerden weer aan het werk: Rapport nummer l, (1998). Crossraods /Europees partnerschap. London: NACRO Information service.

Penitentiaire beginselenwet (1999). Wetsgeschiedenis van Wetsvoorstel 24 263. In: Dossierkennis. Deventer: Kluwer.

Crea in de gevangenis in de knel? Verslag van een stage Sociaal Pedagogische Hulpverlening in PI De Geerhorst, Gulikers, R. (1996) . 


\section{Curriculum Vitae}

Peter Nelissen werd op 17 juli 1954 geboren te Vlissinger, $\mathrm{Va}$ : 1971 studeerde hij rechten aan de Katholiek Universitei Nijn behaalde hij zijn doctoraal examen in de vrije studierichting Cri: Tijdens zijn rechtenstudie begon hij tevens aan een opleiding schilo aan de Academie voor Beeldende Kunsten te Arnhem. $\mathrm{Na}$ afrondin $n_{i}$ vervolgde hij deze opleiding die hij in 1985 voltooide. Na een korte pe opleiding is hij vanaf 1989 werkzaam als beeldend kunstenaar, docent dexamen HBS-A in In november 1978 ologie en Strafrecht. a, tekenen en grafiek n zijn rechtenstudie gogisch didactische in het Centrum voor

de Kunsten te Roermond en als consulent kunstzinnige vorming bij het gevangeniswezen. Deze laatste werkzaamheden verrichtte hij ten behoeve van een drietal $\mathrm{i}$ chtingen in Zuiden Midden-Limburg. Hij publiceerde over resocialisatie en verrichtte vens een evaluatieonderzoek van maatschappelijke integratie ten behoeve van P.I de Geel.1, orst en de Dienst Justitiële Inrichtingen.

In 1999 startte hij Nelissen Onderzoek- \& Adviesbureau te Maastricht.

Hij is getrouwd met Marie-Louise Schreurs en zij hebben drie kinderen. 


\section{Bijlage 1 Factoranalyse van opvattingen}

- Als gedetineerde moet je de kans krijgen om je voor te bereiden op de

Factor toekomst

- Met de meeste gedetineerden $s$ het, als ze vrij zijn, toch weer fout omdat ze te weinig worcien $g_{-a t o l p e n}$

- Hoe meer hulp en stev _. etineerden krijgen des te beter zij zich later zullen redden.

- Ik gebruik mijn sura

- Je moet tijdens je st

ooral om mijn leven weer op orde te brengen. jd al het mogelijke doen voor een betere toekomst. toekomst tijdens je straftijd is zinloos.

- Werken aan een be

genis ontneent je alle zin om je net je toekonst

Het zitten in eer,
bezig te houden.

- Ik vind mijn vrr! lijf hier een goed moment om mijn leven een betere wending te ge

- Activiteiten 7 : beetje bezig ı. aden.

- Hoe mijn leven ina de bajes uit gaat zien houdt mijn nu weinig bezig.

- Je goed voorberi iren op de toekomst, daar kom je in de bajes nauwelijks aan toe.

- Op je toekomst heb je als gedetineerde weinig invloed.

- Door revangenisstraf gaat het eerder slechter dan beter met je.

- Hoe ianger ik hier zit des te somberder zie ik mijn toekomst.

Eigenwararde

Verklaarde variantie

$\mathrm{n}$ de gevangenis alleen maar om de gedetineerden een

.390 of cel af te zijn.

- Ik vind het niet zo belangrijk wat ik bij crea doe, als ik de tijd maar on krijg.

- Ik ga naar de crea als ik mij verveel.

- Iets nieuws leren bij de crea vind ik niet zo belangrijk.

$-.408$

- Ik ga vooral naar de crea voor de gezelligheid.

- Bij de crea heb je het gevoel dat je je tijd nuttig besteedt.

- $\quad$ Bij de crea krijg je steeds meer plezier in het maken van dingen.

- $\quad$ Bij de crea ben ik een stuk handiger geworden in het hanteren van materialen en technieken.

- Bij de crea heb ik ontdekt meer te kunnen dan ik eigenlijk dacht.

- Na mijn vrijlating wil ik verder gaan met een cursus creatieve activiteiten.

- Door de crea denk ik na mijn vrijlating minder moeite te hebben met vrije tijdsbesteding. 


\section{Stellingen behorend bij het proefschrift van P.uh. Nelissen, Resocialisatie en Detentie}

1. Tot op heden wordt de Nederlandse praktijk van resocialisatie niet zozeer gekenmerkt door een doelgerichte voorbereidin ? uc terugkeer in de samenleving als wel door cen streven naar een verm. shappelijking of humanisering van de detentiesituatie. (Dit proefschrift)

2. De stelling dat resocialisatie niet tot vermindering van crin ncle recidive leidt, is vanuit wetenschappelijk oogpunt onhoudbaar. (Dit, chrift)

3. De veranderingsgezindheid van daders dient men niet te or schatten, na het twintigste levensjaar nemen criminele activiteiten sterk ir . mvang af.

4. De marginale rol van criminologisch en penologisch onderzoek aan Nederlandse universiteiten staat in geen verhouding tot het belang ' $\_$de overheid en de bevolking heden ten dage toekennen aan maatschappel jke veiligheid.

5. Aangezien de motivatie van gedetineerden de sleutelvariabele voor een succesvolle resocialisatie is, zijn de resultaten van dit proefschrift op zijn minst bemoedigend. (Dit proefschrift)

6. Diepgang en tijdloosheid in wetenschappen en kunsten zijn het gevolg van een fascinatie met het raadsel van ons bestaan; oppervlakkige en modieuze producten daarentegen vloeien voort uit het louter nastreven van persoonlijk belang.

7. Dankzij de verwerping van de regels van de klassieke kunst en de nadruk op vernieuwing in de moderne kunst kan men heden ten dage het knoeien met verf een stuk gemakkelijker laten doorgaan voor het beoefenen van Schone Kunsten.

8. Er zijn slechts drie soorten wetenschappers, zij die kunnen rekenen en zij die niet kunnen rekenen. (Variant op een Vlaamse spreuk) 